\title{
IMPLEMENTAÇÃO DAS DECISÕES DO SISTEMA DE SOLUÇÃO DE CONTROVÉRSIAS DA OMC E MECANISMOS DE EFETIVAÇÃO NO DIREITO BRASILEIRO
}

Tese de Doutorado

Professor Orientador: Wagner Menezes

FACULDADE DE DIREITO

UNIVERSIDADE DE SÃO PAULO 


\section{IMPLEMENTAÇÃO DAS DECISÕES DO SISTEMA DE SOLUÇÃO DE CONTROVÉRSIAS DA OMC E MECANISMOS DE EFETIVAÇÃO NO DIREITO BRASILEIRO}

Tese apresentada à Faculdade de Direito da Universidade de São Paulo para obtenção do título de Doutora em Direito

Área de Concentração: Direito Internacional e Comparado

Orientador: Professor Associado Wagner Menezes 
CAPUCIO, Camilla. Implementação das Decisões do Sistema de Solução de Controvérsias da OMC e Mecanismos de Efetivação no Direito Brasileiro. Tese apresentada à Faculdade de Direito da Universidade de São Paulo para obtenção do título de Doutora em Direito.

Aprovado em:

Banca Examinadora

Prof. Dr.

Instituição:

Julgamento:

Assinatura:

Prof. Dr.

Instituição:

Julgamento:

Assinatura:

Prof. Dr.

Instituição:

Julgamento:

Assinatura:

Prof. Dr.

Instituição:

Julgamento:

Assinatura:

Prof. Dr. Instituição:

Julgamento: Assinatura: 
A meus pais, Maria do Socorro de Mello Capucio e Carlos Eduardo Capucio, por todos os ensinamentos a mim e a meus irmãos, sobre aquele conhecimento que os livros não ensinam: do amor e da vida. 


\section{AGRADECIMENTOS}

Este trabalho é fruto dos estudos do período entre 2012 e 2014, como aluna do doutorado em Direito Internacional na Faculdade de Direito do Largo São Francisco, da Universidade de São Paulo. Estes foram anos de intensa pesquisa, reflexão, questionamentos e descobertas: uma jornada feita de incontáveis passos. Muitas pessoas me ajudaram a vislumbrar, reestruturar e concretizar a realização desses passos, e por isso expresso minha gratidão...

Agradeço ao meu orientador Professor Wagner Menezes, por fazer deste doutorado não somente um título, mas uma verdadeira e inesquecível experiência de vida. Seu comprometimento acadêmico e entusiasmo contagiante na divulgação do Direito Internacional são fonte de inspiração e aprendizado. Obrigada por me conduzir neste difícil, mas sem dúvida gratificante, processo onde sonhos, quando acompanhados de muito trabalho, podem se concretizar.

Agradeço ao Professor Roberto Luiz Silva, pela confiança e orientação desde a graduação. Agradeço além: pelo incentivo na evolução, na ousadia, na travessia.

Agradeço ao Professor Paulo Borba Casella, cujos valiosos, aprofundados e instigantes ensinamentos, além de me acompanharem durante os anos em que estive no Largo, se fizeram especialmente importantes na etapa de qualificação.

Agradeço ao Professor Umberto Celli Junior, pelos relevantes apontamentos feitos ao trabalho na fase de qualificação, e pela generosa abertura e rica oportunidade de refletir sobre as complexidades do Comércio Internacional durante os encontros na disciplina de Pós-Graduação.

Agradeço ao Professor Alberto do Amaral Júnior, pela oportunidade de participar de suas alentadas disciplinas na Pós-Graduação, e pelo desafio afável à problematização de perspectivas, metodologias e conceitos do Direito Internacional.

Agradeço ao Professor André de Carvalho Ramos, pela abertura a novas e necessárias temáticas de estudo no Direito Internacional, e pelo incentivo ao enfrentamento dessas vertentes pelos alunos da Pós-Graduação.

Agradeço aos funcionários de diversos setores da Faculdade, responsáveis por garantir as condições para que o espetáculo do conhecimento ali aconteça, todos os dias. Em especial, expresso meu agradecimento às funcionárias do DIN, por toda sua solicitude.

Agradeço aos colegas e amigos do Núcleo de Estudos em Tribunais Internacionais (NETIUSP), pelo compartilhamento dos desafios e pelas reflexões desenvolvidas nas pesquisas, eventos e reuniões do grupo.

Agradeço aos colegas desta jornada e amigos que conheci na Sanfran, geração de promissores internacionalistas - Jean Ditzz, Carla Dantas, Raphael Vasconcelos, Carolina 
Claro, Luiz Phillipe de Oliveira, Daniela Bucci, Andreia Costa, André Lasmar, etc. Nossas trocas nas disciplinas e nossos cafés durante os intervalos me instigaram à pesquisa e me incentivaram a continuar. Dentre eles, não posso deixar de registrar meu agradecimento especial ao Rafael Santos Morais e a Sibele Lopes.

Obrigada Rafa, por ter sido o meu verdadeiro anjo da guarda durante estes anos de doutorado. Por seu apoio, sua amizade, sua doação e sua sinceridade.

Obrigada Sibele, por ser um exemplo de superação. Por toda a sua sensibilidade, doçura e bondade.

Agradeço à Dani, por ter me acolhido em sua casa sempre de braços e coração abertos.

Agradeço especialmente à Laura, Luigi e Breno: por terem sido minha família paulistana. Por todo o amor e carinho com que sempre me receberam.

Agradeço à Isolda, por me apoiar desde o início, e em especial pelas dicas tecnológicas.

Agradeço aos demais amigos e amigas, pela torcida e pela compreensão de que esta jornada exigia um necessário distanciamento.

Agradeço aos colegas professores da UNA, pelo incentivo e pela gentileza, especialmente nos últimos meses, quando meu único assunto era esta tese.

Agradeço aos meus alunos, por me permitirem, a cada dia, a certeza de que tenho a dádiva de amar aquilo que faço, e de que - apesar de tudo - a carreira acadêmica vale a pena.

Agradeço às famílias Mello e Capucio, por todo o pensamento positivo e o incentivo na finalização deste projeto.

Agradeço aos meus "padrinhos", Sandra e José Maria, dentre tantos outros motivos, pela acolhedora e, sobretudo, carinhosa presença durante o difícil período de escrita deste trabalho.

Agradeço aos meus pais e a meus irmãos, Ariadne, Cadu e Marcello, por torcerem, me apoiarem e se orgulharem de mim, mesmo sem entender exatamente o que eu estava fazendo.

Agradeço ao Beto, companheiro desta e de outras caminhadas. Por me apoiar sempre, e por estar ao meu lado, mesmo nos momentos mais difíceis. Este trabalho também é seu!

Agradeço a Deus, por um ciclo que se fecha, e por outros que virão... 


\section{A verdade dividida}

A porta da verdade estava aberta

mas só deixava passar

meia pessoa de cada vez.

Assim não era possivel atingir toda a verdade,

porque a meia pessoa que entrava

só conseguia o perfil de meia verdade.

E sua segunda metade

voltava igualmente com meio perfil.

E os meios perfis não coincidiam.

Arrebentaram a porta. Derrubaram a porta.

Chegaram ao lugar luminoso

onde a verdade esplendia os seus fogos.

Era dividida em duas metades

diferentes uma da outra.

Chegou-se a discutir qual a metade mais bela.

Nenhuma das duas era perfeitamente bela.

E era preciso optar. Cada um optou

conforme seu capricho, sua ilusão, sua miopia.

(Carlos Drummond de Andrade)

"Um Estado Democrático de Direito tem necessário apreço ao cumprimento das leis e ao funcionamento das instituições. No plano internacional, o Brasil zela, portanto, pelo estrito cumprimento de suas obrigações internacionais. $O$ respeito aos compromissos do País na área comercial deve, portanto, orientar a elaboração de políticas públicas."

(AZEVEDO, Roberto Carvalho de. Prefácio. In: BENJAMIN, Daniela Arruda. (Org). O Sistema de Solução de Controvérsias da OMC: uma perspectiva brasileira. Brasília: FUNAG, 2013. p. 30.) 


\title{
RESUMO
}

\section{CAPUCIO, Camilla. Implementação das Decisões do Sistema de Solução de} Controvérsias da OMC e Mecanismos de Efetivação no Direito Brasileiro. 2014. 391 f. Tese (Doutorado) - Faculdade de Direito, Universidade de São Paulo, São Paulo, 2014.

\begin{abstract}
A presente Tese de Doutorado tem como objetivo analisar os mecanismos de implementação das decisões do Sistema de Solução de Controvérsias da OMC, consideradas como decisões adjudicatórias internacionais, na busca pelo incremento de efetividade desse sistema, e com a finalidade de proposição de um modelo para tal implementação no sistema jurídico brasileiro. O estudo adota uma abordagem dialética entre a dimensão teórica e a dimensão empírica de seu objeto, na investigação acerca das condições nas quais o Sistema de Solução de Controvérsias gera seus efeitos nos membros da OMC, bem como dos sujeitos e processos envolvidos nessa dinâmica transnormativa. A partir da análise empírica dos casos nos quais o Brasil atuou como demandante, demandado e terceira parte no Sistema de Solução de Controvérsias da OMC, e do exame da implementação por parte de seus principais usuários, a pesquisa desenvolve constatações sobre a diversidade dos mecanismos de implementação e dos efeitos jurídicos das decisões desse sistema de resolução de litígios nos diferentes ordenamentos. O trabalho procura enfrentar as complexidades de seu objeto no contexto normativo-institucional brasileiro, avaliando o tratamento casuístico, difuso e informal conferido à temática da implementação das decisões do Sistema de Solução de Controvérsias da OMC no Brasil, e confirmando a hipótese da necessidade e conveniência do estabelecimento de um marco normativo geral que institucionalize e legitime a escolha relacionada ao meio de implementação dessa decisão.
\end{abstract}

Palavras-Chave: Organização Mundial do Comércio (OMC); Sistema Multilateral de Comércio; Sistema de Solução de Controvérsias; Implementação; Decisões Adjudicatórias Internacionais. 


\begin{abstract}
CAPUCIO, Camilla. Implementation of the Decisions of the WTO's Dispute Settlement System and Enforcement Mechanisms in Brazilian Law. 2014. 391 f. Tese (Doutorado) - Faculdade de Direito, Universidade de São Paulo, São Paulo, 2014.

This Thesis aims to analyze the mechanisms for implementing the decisions of WTO's Dispute Settlement System, considered as international adjudicatory decisions, in the search for increasing effectiveness of this system, and in order to propose a model for implementation in the Brazilian legal system. The study adopts a dialectical approach between the theoretical dimension and the empirical dimension of its object, in the investigation of the conditions in which the Dispute Settlement System generates its effects on members of the WTO, as well as the subjects and processes involved in this transnormative dynamic. From the empirical analysis of cases in which Brazil served as plaintiff, defendant and third party in the WTO's Dispute Settlement System, and the review of the implementation by their main users, this research reveals findings about the diversity of implementation mechanisms and of legal effects of the decisions of this dispute resolution system in various jurisdictions. The thesis seeks to address the complexities of its object in the brazilian legal-institutional context, evaluating the casuistic, diffuse and informal treatment given to the implementation of the decisions of the WTO's Dispute Settlement System decisions, and confirming the hypothesis of necessity and advisability of establishing a general normative framework that institutionalizes and legitimizes the choices related to the measures for implementing these decisions.
\end{abstract}

Key Words: World Trade Organization (WTO), Multilateral Trading System; Dispute Settlement System; Implementation; International Adjudicatory Decisions. 


\section{RIASSUNTO}

\section{CAPUCIO, Camilla. Implementazione delle decisioni del Sistema di Risoluzione delle}

Controversie dell'OMC e meccanismi responsabili nel Diritto Brasiliano. $391 \mathrm{f}$. Tese

(Doutorado) - Faculdade de Direito, Universidade de São Paulo, São Paulo, 2014.

Questa tesi si propone di analizzare i meccanismi d'implementazione delle decisioni del Sistema di Risoluzione delle Controversie dell'OMC, considerate come decisioni aggiudicative internazionali, alla ricerca di una più ampia efficacia di questo sistema, e al fine di proporre un modello per l'implementazione nel sistema giuridico brasiliano. Lo studio adotta un approccio dialettico tra la dimensione teorica e la dimensione empirica del suo oggetto, nello studio delle condizioni in cui il Sistema di Risoluzione delle Controversie genera i suoi effetti sui membri dell'OMC, nonché dei soggetti e processi coinvolti in questa dinamica transnormativa. Dall'analisi empirica dei casi in cui il Brasile ha attuato come attore, convenuto e terzo nel sistema di risoluzione delle controversie dell'OMC, e dell'esame dell'implementazione dai loro principal utenti, sono stati sviluppatti i risultati della ricerca sulla diversità dei meccanismi di implementazione e degli effetti giuridici delle decisioni di questo sistema di risoluzione delle controversie in varie giurisdizioni. Il lavoro cerca di affrontare le complessità del suo oggetto nel contesto giuridico-istituzionale brasiliano, esaminando il trattamento casistico e informale dato alla questione dell'implementazione delle decisioni del Sistema di Risoluzione delle Controversie dell'OMC in Brasile, e confermando l'ipotesi della necessità e l'opportunità di stabilire un quadro normativo generale che istituzionalizzi e legittimi la scelta per dei mezzi di implementazione di tali decisioni.

Parole chiave: Organizzazione Mondiale del Commercio (OMC); Sistema Commerciale Multilaterale; Sistema di Risoluzione delle Controversie; Implementazione; Decisioni Aggiudicative Internazionali. 


\section{LISTA DE SIGLAS E ABREVIATURAS}

AAD

ADPF

ASMC

CACEX

CAMEX

$\mathrm{CF} / 88$

$\mathrm{CIDH}$

CIJ

CGC

CVDT

ESC

EUA

GATT/

GATT 1947

GATS 1994

GATS

GIPI

GT

ITC

MDIC

MF

MRE

OIC

OMA

$\mathrm{OMC}$

OSC

PROEX

STF

STJ

TRIMs

TBT

TRIPS

TJUE/TJCE

$\mathrm{UE} / \mathrm{CE}$

URAA

USTR
Acordo sobre a Implementação do Artigo VI (Acordo Antidumping)

Arguição de Descumprimento de Preceito Fundamental

Acordo sobre Subsídios e Medidas Compensatórias

Carteira de Comércio Exterior

Câmara de Comércio Exterior

Constituição da República Federativa do Brasil de 1988

Corte Interamericana de Direitos Humanos

Corte Internacional de Justiça

Coordenação-Geral de Contenciosos

Convenção de Viena sobre o Direito dos Tratados de 1969

Entendimento relativo às Normas e Procedimentos sobre Solução de Controvérsias

Estados Unidos da América

Acordo Geral sobre Tarifas e Comércio, assinado em 30 de outubro de 1947

Acordo Geral sobre Tarifas e Comércio (Anexo do Acordo da OMC)

Acordo Geral sobre o Comércio de Serviços

Grupo Interministerial em Propriedade Intelectual

Grupo de Trabalho

International Trade Commission (Comissão dos EUA para o Comércio Internacional)

Ministério do Desenvolvimento, Indústria e Comércio Exterior

Ministério da Fazenda

Ministério das Relações Exteriores

Organização Internacional do Comércio

Organização Mundial de Aduanas

Organização Mundial do Comércio

Órgão de Solução de Controvérsias

Programa de Financiamento à Exportação

Supremo Tribunal Federal

Superior Tribunal de Justiça

Acordo sobre Medidas de Investimento Relacionadas ao Comércio

Acordo sobre Barreiras Técnicas ao Comércio

Acordo sobre Aspectos dos Direitos de Propriedade Intelectual

Tribunal de Justiça da União Europeia / Tribunal de Justiça das Comunidades Europeias

União Europeia/ Comunidades Europeias

Uruguay Round Agreements Act

United States Trade Representative (Representante dos EUA para o Comércio) 


\section{SUMÁRIO}

INTRODUÇÃO ................................................................................. 16

1 COMÉRCIO E DIREITO INTERNACIONAL: ANÁLISE SISTÊMICA....................................................................................................... 22

1.1 Direito Internacional: Aspectos Fáticos, Valorativos e Normativos........ 22

1.2 Juridificação e Jurisdicionalização do Comércio Internacional................ 24

$1.3 \quad$ As Mudanças de Paradigma do Direito Internacional.............................. 26

1.3.1 O Paradigma Constitucionalista do Direito Internacional....................... 32

1.3.2 O Constitucionalismo e a OMC .............................................................. 38

1.4 Direito Internacional Contemporâneo e Sistema: a Perspectiva Sistêmica do Direito Internacional..................................................... 41

1.5 A OMC e o Direito Internacional Público............................................. 45

1.5.1 A OMC como um "Subsistema" Aberto do Direito Internacional

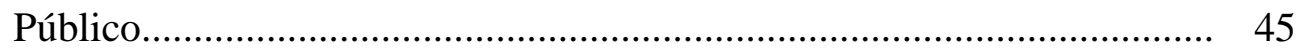

1.5.2 A Perspectiva de Comunitarização da OMC .............................................. 47

1.5.3 A OMC e a Convenção de Viena sobre o Direito dos Tratados............... 50

1.6 A Dimensão Jurídica da OMC e o Sistema de Solução de Controvérsias no Cenário Contemporâneo................................................................... 56

2 O SISTEMA DE SOLUÇÃO DE CONTROVÉRSIAS DA OMC E A NATUREZA JURÍDICA DE SUAS DECISÕES.............................. 60

2.1 O Sistema de Solução de Controvérsias da OMC................................. 60

2.1.1 Evolução Histórica da Solução de Controvérsias no Sistema Multilateral: do GATT à OMC ......................................................... 60

2.1.2 O "Novo" Sistema de Solução de Controvérsias Alcançado na Rodada

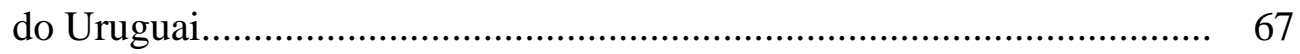

2.1.3 Componentes do Sistema................................................................ 75 
2.1.3.1 Instância Política............................................................................... $\quad 75$

2.1.3.2 Instâncias Adjudicatórias............................................................... 80

2.1.4 Especificidades do Sistema de Solução de Controvérsias........................ 85

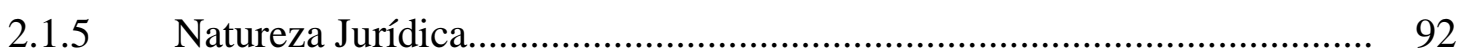

2.2 O Procedimento do Sistema de Solução de Controvérsias........................ 95

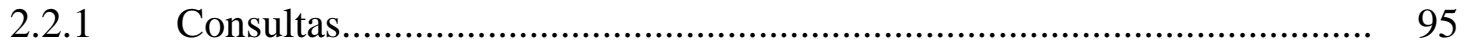

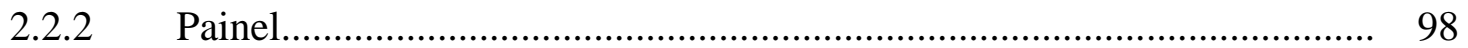

2.2.3 Apelação................................................................................... 102

2.2.4 Implementação e Execução................................................................. 104

2.2.5 Compensação e Retaliação................................................................... 105

2.3 Outros Meios de Solução de Controvérsias............................................. 108

2.3.1 Bons Ofícios, Conciliação e Mediação..................................................... 108

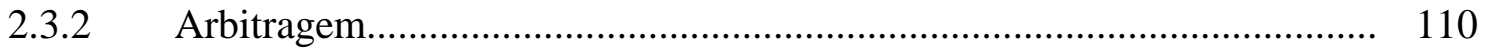

$2.4 \quad$ Detalhamento Conceitual.................................................................. 111

2.5 Características das Decisões do Sistema de Solução de Controvérsias da

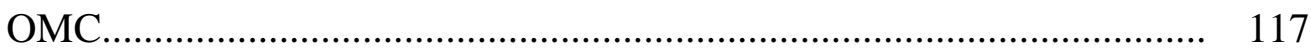

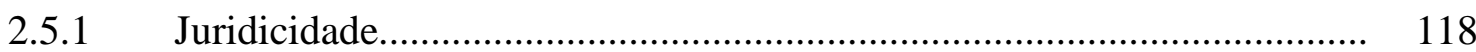

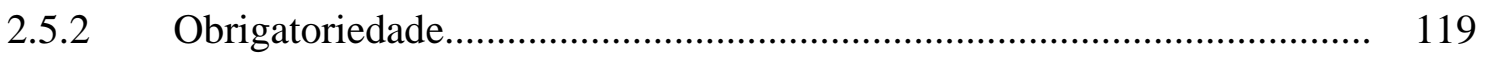

2.5.3 (In)determinabilidade ........................................................................ 123

3 IMPLEMENTAÇÃO DAS DECISÕES DO SISTEMA DE SOLUÇÃO DE CONTROVÉRSIAS DA OMC: ANÁlISE DE CASOS.

3.1 Comentários Iniciais sobre a Implementação das Decisões..................... 131

3.2 Comentários Iniciais sobre a Participação do Brasil no Sistema de Solução de Controvérsias da OMC........................................................... 133

3.3 Comentários sobre o Recorte Adotado na Análise................................... 137

3.4 A Implementação das Decisões do Sistema de Solução de Controvérsias pelo Brasil..................................................................... 141

3.4.1 Análise Preliminar e Definição dos Casos a Serem Examinados............. 142

3.4.2 Caso DS46: Brazil - Export Financing Programme for Aircraft........... 143

3.4.3 Caso DS332: Brazil - Measures Affecting Imports of Retreaded Tyres.. 149 
3.4.4 Observações.

3.5 A Implementação das Decisões do Sistema de Solução de Controvérsias nos Casos em que o Brasil Foi Demandante.

3.5.1 Análise Preliminar e Escolha dos Casos a Serem Examinados................ 166

3.5.2 Caso DS219: European Communities - Anti-Dumping Duties on Malleable Cast Iron Tube or Pipe Fittings from Brazil

3.5.3 Caso DS269: European Communities - Customs Classification of Frozen Boneless Chicken Cuts

3.6 A Implementação das Decisões do Sistema de Solução de Controvérsias nos Casos em que o Brasil Atuou como Terceira Parte.... 180

3.6.1 Análise preliminar e escolha dos casos a serem examinados................... 182

3.6.2 Caso DS362: China - Measures Affecting the Protection and Enforcement of Intellectual Property Rights.

3.6.3 Caso DS381: United States - Measures Concerning the Importation, Marketing and Sale of Tuna and Tuna Products.....

3.6.4 Observações.

4.1 Aspectos Relevantes da Implementação

4.2 Breve Exame da Implementação por Outros Membros.

4.2.1 Estados Unidos da América 198

4.2.2 União Europeia (UE/CE) 208

4.2.3 Japão. 223

4.2.4 China. 224

4.3 Considerações sobre os Efeitos da Decisão do Sistema de Solução de Controvérsias e os Mecanismos Nacionais de Implementação. 228

4.4 Considerações sobre as Variáveis Envolvidas na Implementação. 234 
5.1 O Contexto da Implementação das Decisões de Tribunais Internacionais no Brasil....

5.2 O Status Jurídico dos Acordos da OMC e das Decisões do Sistema de Solução de Controvérsias no Ordenamento Jurídico Brasileiro.

5.3 Mecanismos Nacionais de Efetivação Existentes na Sistemática Brasileira. 257

5.4 A Relação entre as Instituições Nacionais. 267

5.5 As Especificidades do Objeto em Questão. 279

5.6 Direito Internacional, Direito Interno e Política na Implementação das Decisões do Sistema de Solução de Controvérsias.

5.7 Proposição de Modelo para o Direito Brasileiro.

5.7.1 Da Necessidade e das Vantagens do Estabelecimento de um Marco Normativo para Implementação das Decisões do Sistema de Solução de Controvérsias no Brasil.

5.7.2 Proposição de Adoção de Marco Normativo Geral. 297

CONCLUSÃO.

REFERÊNCIAS BIBLIOGRÁFICAS.

Livros 306

Capítulos de Livros. 310

Cursos da Academia de Direito Internacional de Haia. 317

Artigos, Revistas e Periódicos. 319

Teses e Dissertações.

Lista Cronológica de Casos de Tribunais Nacionais. 333

Brasil. 333

Estados Unidos da América. 334

Lista Cronológica de Casos do TJUE/TJCE. 335

Lista Cronológica de Casos da CIJ. 336

Lista Cronológica de Casos da CIDH.

Lista Cronológica de Casos do Mecanismo de Solução de Controvérsias do MERCOSUL 
Lista Cronológica de Casos do Sistema de Solução de Controvérsias da OMC.

Bases de Dados e Páginas Eletrônicas.

APÊNDICES

APÊNDICE A - PARTICIPAÇÃO DO BRASIL COMO DEMANDADO NO SISTEMA DE SOLUÇÃO DE CONTROVÉRSIAS DA OMC.

APÊNDICE B - BREVE DESCRIÇÃO DOS CASOS EM QUE O BRASIL ATUOU COMO DEMANDADO NO SISTEMA DE SOLUÇÃO DE CONTROVÉRSIAS DA OMC

APÊNDICE C - PARTICIPAÇÃO DO BRASIL COMO DEMANDANTE NO SISTEMA DE SOLUÇÃO DE CONTROVÉRSIAS DA OMC..

APÊNDICE D - BREVE DESCRIÇÃO DOS CASOS EM QUE O BRASIL ATUOU COMO DEMANDANTE NO SISTEMA DE SOLUÇÃO DE CONTROVÉRSIAS DA OMC.

APÊNDICE E - PARTICIPAÇÃO DO BRASIL COMO TERCEIRA PARTE NO SISTEMA DE SOLUÇÃO DE CONTROVÉRSIAS DA OMC......

APÊNDICE F - BREVE DESCRIÇÃO DOS CASOS EM QUE O BRASIL ATUOU COMO TERCEIRA PARTE NO SISTEMA DE SOLUÇÃO DE CONTROVÉRSIAS DA OMC 


\section{INTRODUÇÃO}

O Direito Internacional, como fruto da sociedade internacional, tem se desenvolvido rumo a uma maior institucionalização, inclusive por meio da criação de instâncias adjudicatórias, órgãos responsáveis pela solução pacífica e jurídica dos litígios, por meio da aplicação das normas internacionais. Simultaneamente, a normatividade internacional tem se expandido, de modo a abarcar novas temáticas, remodelando a relação entre os Estados e os demais sujeitos da sociedade internacional contemporânea.

De maneira correlata, a intensificação das relações comerciais internacionais observada nas últimas décadas, e a percepção da imbrincada relação entre os diferentes participantes do comércio internacional, levaram a uma expansão do escopo das normas do sistema multilateral de comércio, e a sua maior institucionalização. A criação do Sistema de Solução de Controvérsias da Organização Mundial do Comércio, com diferenças marcantes em face da solução de litígios no GATT, consubstanciou essa tendência à institucionalização do Direito Internacional na seara das relações comerciais.

Com a frequente utilização do Sistema de Solução de Controvérsias da Organização Mundial do Comércio como mecanismo de resolução de litígios comerciais, tendo em conta também a diversidade de matérias sob seu exame e a complexidade jurídicainstitucional no interior dos Estados, é notável a necessidade de estudos sobre o modo de concretização de suas decisões pelos membros.

As análises de efetividade do Sistema de Solução de Controvérsias da Organização Mundial do Comércio comumente apresentam um amplo índice de cumprimento de suas decisões, conferindo relevo às estatísticas de cumprimento e às possibilidades de aplicação de medidas compensatórias e/ou retaliação. Contudo, essas análises - com frequência - não buscam adentrar nas condições deste "cumprimento", ou seja, investigar como se deram as ações envolvidas na fase de implementação.

Isto se confirma na escassez de investigações doutrinárias e análises sobre os procedimentos e mecanismos dos respectivos ordenamentos jurídicos internos para implementação das decisões do Sistema de Solução de Controvérsias da Organização 
Mundial do Comércio. Como se verificará na análise preliminar sobre a concretização destas decisões no Brasil, nos Estados Unidos da América, na União Europeia, no Japão e na China, poucas informações estão disponíveis sobre a perspectiva procedimental e sistêmica dessa implementação.

Nesse quadro, uma análise mais detida, adentrando na percepção qualitativa do cumprimento, por meio da verificação do trâmite interno para implementação das decisões do Sistema de Solução de Controvérsias da Organização Mundial do Comércio e da participação das instituições nacionais, se faz necessária. A pesquisa da real implementação das decisões é também requisito indispensável à reflexão sobre a efetividade desse mecanismo de resolução de litígios, se tomarmos a efetividade como o cumprimento do comando jurídico emanado da autoridade legitimamente constituída. Nesse sentido, a análise empírica da implementação das decisões do Sistema de Solução de Controvérsias da Organização Mundial do Comércio e do seu respectivo trâmite interno é tema urgente, uma vez que esse sistema é crescentemente buscado como modo de pacificar conflitos entre os Estados da sociedade internacional.

Para além da justificativa acadêmica, a relevância do tema analisado é explícita, sob os aspectos econômico, jurídico e social. A implementação efetiva das decisões desse Sistema de Solução de Controvérsias alcança seus efeitos concretos nas economias, sociedades e indivíduos do "mundo real". Por força do encurtamento das distâncias e da moderna configuração das cadeias produtivas, ao influenciar a previsibilidade, a transparência, a segurança jurídica e a justiça das relações econômicas internacionais, referida implementação tem a potencialidade de afetar setores inteiros das economias nacionais, bem como os balanços comerciais dos Estados e, em última análise, o bem-estar econômico e social dos indivíduos.

Nessa direção, a relevância desta pesquisa se intensifica ainda mais, na medida em que o Sistema de Solução de Controvérsias da Organização Mundial do Comércio e sua interpretação das situações fáticas a ele submetidas têm abarcado temas outros, e não apenas hermeticamente o comércio internacional. O Sistema de Solução de Controvérsias tem crescentemente se deparado com casos envolvendo questões relacionadas à proteção do meio ambiente, à proteção da saúde humana, e aos direitos humanos, o que reforça a necessidade de investigação de sua real efetividade nos espaços internos e o desenvolvimento de instrumentos que a aprimorem. 
A pesquisa realizada buscará tratar de uma série de questionamentos, muitos deles de tessitura extremamente aberta, e cuja problematização não tem sido suficientemente realizada pela doutrina, tais como: Qual o contexto normativo-axiológico do Sistema de Solução de Controvérsias da Organização Mundial do Comércio na atualidade? Como este sistema de solução de litígios se insere no Direito Internacional? Qual a sua natureza jurídica e de suas decisões? Suas decisões são jurídicas e obrigatórias aos membros? Como se operacionaliza a implementação das decisões do Sistema de Solução de Controvérsias da Organização Mundial do Comércio? As decisões desse sistema podem ser invocadas pelos sujeitos nos judiciários nacionais? Como tem se dado a implementação das decisões no Brasil? Quais são os instrumentos de implementação, e quem os operacionaliza? Como as instituições nacionais interagem nas escolhas relacionadas à implementação? As medidas de implementação são parte da política externa ou constituem política pública? Esta implementação ocorre com transparência, e está sujeita a algum tipo de controle?

As transformações observadas pela sociedade internacional nas últimas décadas, bem como seus reflexos evidenciados na conformação do Direito Internacional contemporâneo, exigem uma nova abordagem dos métodos aplicados à pesquisa científica nesta seara. Se por um lado a pesquisa em Direito Internacional exige uma abordagem metodológica própria, que leve em consideração as especificidades da disciplina, por outro, se deve ultrapassar a perspectiva que reduz a metodologia da pesquisa jurídica à dimensão teórica, ignorando as demais esferas que compõem o objeto tridimensional dessa ciência.

Dadas as especificidades do Direito Internacional face aos outros ramos da ciência jurídica, que por sua natureza oferecem desafios metodológicos adicionais, os potenciais benefícios de procedimentos empíricos são expressivos, como instrumentos capazes de revelar aspectos do fenômeno jurídico internacional ainda pouco conhecidos, que podem ser úteis ao refinamento de construções teóricas, permitindo uma análise mais graduada da ordem jurídica internacional.

Em contraponto ao modelo metodológico jurídico tradicional, que tendia a presumir - ao invés de examinar - a (in)eficácia do Direito Internacional, ignorando nuances relevantes, tem surgido nas últimas décadas uma nova geração de pesquisas, que se preocupa com a verificação empírica da relevância normativa do Direito Internacional, e com o desenho de mecanismos internos, transnacionais e globais para sua concreção. 
É nesta abordagem que se insere esta investigação. Em busca da apreensão empírica da efetividade e alcance de institutos do Direito Internacional, assume especial relevância a investigação acerca das condições nas quais o Direito Internacional gera seus efeitos, bem como dos sujeitos e processos aí envolvidos.

Adentrando no plano metodológico eleito para o presente trabalho, este se utiliza da pesquisa de métodos múltiplos (multi-method research), pela compreensão de que tal abordagem permite uma visão mais sistematizada do fenômeno que se busca observar. Assim, serão utilizados, de modo associado, procedimentos de pesquisa direcionados à leitura, interação e contagem da realidade sob análise.

Em um momento inicial, a leitura do objeto ocorre a partir da análise da moldura teórica da pesquisa, bem como das manifestações constantes de documentos oficiais das disputas no Sistema de Solução de Controvérsias. A interação, por sua vez, se concretiza no estudo aprofundado de casos, selecionados a partir do procedimento anterior, com foco na implementação da decisão nesses casos. A contagem, por fim, é realizada na filtragem da base de dados de disputas da Organização Mundial do Comércio.

Isso pois a dimensão empírica da pesquisa, aliada a uma moldura teóricoconceitual, é capaz de auxiliar na compreensão das "bases internas" do Direito Internacional. É certo que esta investigação exige uma ruptura com a assunção do Estado como agente unitário na sociedade internacional, abrindo espaço para a percepção da existência de uma variedade de agentes econômicos individuais - tais como importadores, fornecedores, distribuidores e consumidores - que participam da comunidade do comércio internacional e são influenciadas pela implementação das decisões do Sistema de Solução de Controvérsias da Organização Mundial do Comércio.

Assim, não se pode ignorar, na busca pela incorporação de procedimentos empíricos ao plano metodológico deste trabalho, a relação dialética entre ambas as dimensões da pesquisa. Em uma direção, a dimensão empírica objetiva revelar aspectos reais inalcançados pela abstração teórica, construindo conhecimento que pode se projetar em refinamento, reflexão e até revisão do arcabouço teórico. Na direção oposta, contudo, a dimensão empírica da pesquisa somente é possível a partir da moldura teórica do estudo, responsável pelo recorte metodológico, e pela escolha própria da amostragem e dos procedimentos metodológicos mais adequados. 
Esta pesquisa se desenvolverá por meio de cinco capítulos, assim denominados: (1) Comércio e Direito Internacional: Análise Sistêmica; (2) O Sistema de Solução de Controvérsias da OMC e a Natureza Jurídica de suas Decisões; (3) Implementação das Decisões do Sistema de Solução de Controvérsias da OMC: Análise de Casos; (4) Implementação das Decisões do Sistema de Solução de Controvérsias da OMC: Procedimento, Mecanismos e Variáveis; e (5) Proposição para um Modelo Brasileiro.

O primeiro capítulo objetivará situar o sistema multilateral de comércio no contexto do sistema jurídico internacional, explicitando a necessária relação entre a Organização Mundial do Comércio e o Direito Internacional Público, em sua formulação contemporânea. Essa contextualização da Organização Mundial do Comércio e de seu corpus juris como parte do sistema jurídico internacional de modo mais amplo é de relevância fulcral à aplicação de fontes e métodos desta pesquisa, vez que não se exclui a aplicação de doutrinas e mecanismos inicialmente formulados para a implementação de decisões internacionais ligadas a outros ramos do Direito Internacional como possibilidades para o fortalecimento da implementação das decisões do Sistema de Solução de Controvérsias no Brasil.

O segundo capítulo buscará contextualizar, caracterizar e analisar o Sistema de Solução de Controvérsias da Organização Mundial do Comércio e as suas decisões, delineando um necessário refinamento conceitual e explicitando as possíveis etapas e resultados de uma controvérsia neste mecanismo. Será também apresentado o quadro normativo que requer a implementação das decisões e prevê as consequências do nãocumprimento. Esse capítulo é de clara relevância para o objeto de estudo, ao explorar a base normativa-institucional que sustenta a solução de litígios no sistema multilateral de comércio, sendo essencial ao desenvolvimento das análises e reflexões apresentadas nos capítulos seguintes.

O terceiro e o quarto capítulos, em continuidade ao exame realizado no capítulo que lhes precede, serão responsáveis pela análise empírica da implementação das decisões do Sistema de Solução de Controvérsias da Organização Mundial do Comércio, sob a perspectiva dos mecanismos e procedimentos nacionais para sua concretização. No terceiro capítulo, a partir do resultado da análise qualitativa preliminar, sob a perspectiva dos interesses brasileiros nesse sistema de resolução de litígios, serão selecionados casos que estarão sujeitos ao procedimento metodológico do estudo de caso, capaz de evidenciar 
apontamentos sobre a prática da implementação e seus mecanismos. O quarto capítulo, por sua vez, apresentará procedimentos internos de implementação de alguns dos principais usuários do Sistema de Solução de Controvérsias da Organização Mundial do Comércio, cujo exame é de substancial pertinência ao objeto deste estudo.

O quinto capítulo, por fim, conjuga as percepções colhidas nos capítulos precedentes, traduzindo-as à realidade normativa-institucional brasileira. Assim, após a explicitação da dimensão axiológica da temática - realizada pelo primeiro capítulo -, a análise de sua dimensão normativa - realizada pelo segundo capítulo -, e o exame de sua dimensão fática - realizada pelo terceiro e pelo quarto capítulos -, cumpre ao quinto capítulo apresentar propostas para um modelo brasileiro.

A presente pesquisa se depara, como se observa, com diversos desafios. O primeiro deles é a multiplicidade de percepções acerca da solução de controvérsias na Organização Mundial do Comércio e sua inserção no sistema jurídico internacional, o que exigiu uma contextualização teórica e um refinamento conceitual, essenciais ao desenvolvimento dos demais questionamentos.

Outro desafio é a naturalização de análises estritamente políticas ou econômicas deste objeto, em abandono à perspectiva jurídica que necessariamente deve permear a temática multidisciplinar. Observa-se, também, o desafio da correlação entre os aspectos de especificidade e generalidade, e como se projetam nas medidas dos casos concretos e nos mecanismos nacionais de implementação, bem como nas suas variáveis implícitas. Por fim, a análise da prática brasileira apresenta desafios adicionais à pesquisa, ao evidenciar novas complexidades e aspectos pouco explorados pela doutrina e jurisprudência nacionais.

Para além destes desafios, ou mesmo devido à existência deles, o estudo da implementação concreta das decisões do Sistema de Solução de Controvérsias da Organização Mundial do Comércio se apresenta como uma das temáticas mais ricas do Direito Internacional contemporâneo, ao evidenciar a correlação transnormativa entre o sistema multilateral de comércio e os respectivos ordenamentos jurídicos nacionais na busca por relações comerciais com menos distorções - e, por isso, mais justas. Este estudo convida à reflexão sobre a configuração atual da implementação das decisões do Sistema de Solução de Controvérsias da Organização Mundial do Comércio, buscando oferecer alternativas para o seu aprimoramento no Brasil. 


\section{COMÉRCIO E DIREITO INTERNACIONAL: ANÁLISE SISTÊMICA}

\subsection{Direito Internacional: Aspectos Fáticos, Valorativos e Normativos}

O Direito Internacional, embora com processos, características, sujeitos e estruturas próprias e diferenciadas do fenômeno jurídico interno, é Direito em seu sentido primeiro, de regulação social, de harmonização de condutas, e de preservação de um conjunto de valores compartilhados pela sociedade internacional e, portanto, é constituído por meio de indivíduos, organizações, instituições e das interações entre eles.

O Direito, como compreendido pela corrente tridimensionalista erigida no Brasil por Miguel ReALE, é fenômeno cuja complexidade abarca necessariamente três dimensões: o fato, o valor, e a norma. ${ }^{1}$ Essa concepção se diferencia das concepções unidimensionalistas, ou acaba por integrá-las, ao objetivar alcançar uma visão totalizante do fenômeno jurídico.

A utilidade e a propriedade desta teoria não passaram desapercebidas aos internacionalistas. Ao contrário, CELSO LAFER é um de seus discípulos, tendo aplicado as categorias do tridimensionalismo à sua visão do fenômeno jurídico internacional. ${ }^{2}$ VICENTE MAROTTA RANGEL também aplica a teoria tridimensionalista, observando sua relevância como forma de aproximar o Direito Internacional das Relações Internacionais, conferindo especial atenção à sua premente aplicabilidade no contexto da América Latina. ${ }^{3}$ José ANTÔNIO PASTOR RIDRUERo é outro autor dentre o rol dos teóricos do Direito

1 Cf. REALE, Miguel. Fundamentos do direito: contribuição ao estudo da formação da natureza e da validade da ordem jurídica positiva. São Paulo: Revista dos Tribunais, 1940 (sobretudo o capítulo final intitulado "ato, valor e norma"). Cf. REALE, Miguel. Teoria tridimensional do direito. 5. ed. São Paulo: Saraiva, 1994. cap. II.

2 LAFER, Celso. Miguel Reale (1910-2006) - uma homenagem. Revista USP, n.70, p. 110-119, jul./ago. 2006.

3 RANGEL, Vicente Marotta. Direito internacional e relações internacionais: a teoria tridimensional no contexto brasileiro. In: Teorias de relaciones internacionales y de derecho internacional en America Latina. Caracas: 1989. p. 462-483. 
Internacional que conferiram relevo à esta perspectiva, ao destacar a necessidade de considerar estes três "mundos" no estudo da disciplina. ${ }^{4}$

O presente trabalho tem a concepção tridimensionalista como um de seus pressupostos, ao entender que a pesquisa jurídica deve necessariamente se preocupar com as três facetas de seu objeto. ${ }^{5}$ Aplicada à pesquisa em Direito Internacional, tal teoria constitui embasamento para a compreensão de seu objeto como um sistema jurídico que não pode ignorar a realidade concreta, mas que tem na busca da concreção de valores, o quilate de interpretação da dimensão normativa e institucional presente na ordem internacional.

Assim, ao analisarmos os mecanismos e a participação das instituições nacionais na implementação de decisões internacionais - e em especial de decisões do Sistema de Solução de Controvérsias da Organização Mundial do Comércio (OMC), objeto deste estudo - não podemos ignorar as dimensões fática, normativa e axiológica do Direito Internacional e de sua relação com as instituições do Direito Interno dos Estados. ${ }^{6}$

Se num aspecto descritivo, o Direito Internacional é fruto de uma sociedade internacional pregressa, pelo aspecto prescritivo ele é vetor de construção da sociedade internacional futura, representando por um lado a estabilidade, por outro a transformação social. Nesta constante evolução, tem-se que as aceleradas transformações sofridas pela sociedade internacional contemporânea rompem com a lógica de divisão estanque entre o interno/doméstico/nacional e o internacional/global/mundial, exigindo uma reengenharia dos conceitos e análises aplicados à disciplina, como se busca brevemente explicitar.

4 Pastor Rudriejo incluiu as três dimensões no título de seu curso da Academia de Direito Internacional da Haia, explicitando ab initio sua perspectiva: "J'ai évoqué tout au long de cette introduction trois mondes : primo, le monde des normes; secundo, le monde des faits : et tertio, le monde des valeurs. Autrement dit, j'ai fait référence à trois plans, le plan juridique, le plan sociologique et le plan axiologique. De là, à mon avis, la nécessité de se servir d'une triple approche, tant pour la recherche que pour l'enseignement du droit international, à savoir une approche juridique, une approche sociologique et une approche axiologique. De là, aussi, le sous-titre que j'ai donné à ce cours : normes, faits et valeurs. [...] Autrement dit, nous ne devons pas nous contenter de l'étude de la norme. De la norme, nous devons descendre au monde des faits, premièrement, et nous élever au monde des valeurs, deuxièmement". PASTOR RIDRUEJO, José Antonio. Le droit international à la veille du vingt et unième siècle: normes, faits et valeurs. Cours général de droit international public. Recueil des cours, vol. 274, p. 9-308, 1998. p. 37-38.

5 REALE, Miguel. Filosofia do Direito. São Paulo: Saraiva, 2002. p. 513.

6 Reafirma-se como critério de efetividade a participação das instituições internas na execução, aplicação e implementação do Direito Internacional. Cf. CASELLA, Paulo Borba. Fundamentos e Perspectivas do Direito Internacional pós-Moderno. Revista da Faculdade de Direito da Universidade de São Paulo, p. 433-466, jan./dez 2006. p. 433. 


\subsection{Juridificação e Jurisdicionalização do Comércio Internacional}

Em um contexto de "adensamento de juridicidade" das relações internacionais e de institucionalização crescente do Direito Internacional, ${ }^{7}$ observa-se na realidade atual aspectos como a internacionalização de áreas e temas antes de exclusivo domínio dos Estados, e a interconexão transnormativa entre as esferas interna e internacional do fenômeno jurídico, de modo a transcender as concepções clássicas de relação entre elas. ${ }^{8}$

Os fenômenos de juridificação e de jurisdicionalização ${ }^{9}$ observados na sociedade internacional tem se manifestado, respectivamente, através da construção de normas e mecanismos jurídicos de regulamentação das relações entre os sujeitos, e da instituição de Tribunais Internacionais, novas instâncias de aplicação e formulação do Direito Internacional na contemporaneidade. ${ }^{10}$

O comércio internacional, enquanto ramo profundamente influenciado pela força globalizante, se apresentou como terreno fértil ao desenvolvimento destes fenômenos. ${ }^{11} \mathrm{~A}$ constituição do sistema multilateral de comércio em suas origens e sua evolução é ilustração disso, sendo certo que a passagem do regime jurídico do GATT à OMC se deu em resposta às novas exigências e anseios da sociedade internacional, ${ }^{12}$ tais como as

7 LAFER, Celso. A OMC e a regulamentação do comércio internacional: uma visão brasileira. Porto Alegre: Livraria do Advogado, 1998. p. 123-125. LAFER, Celso. O Sistema de Solução de Controvérsias da Organização Mundial do Comércio. In: CASELLA, Paulo Borba; MERCADANTE, Araminta de (coord.). Guerra comercial ou integração mundial pelo comércio?: a OMC e o Brasil. São Paulo: LTr, 1998, p. 729-755. p. 748.

8 MENEZES, Wagner. Ordem Global e Transnormatividade. Ijuí: Ed. Unijuí, 2005.

9 TRINDADE, Antônio Augusto Cançado. International law for humankind: towards a new jus gentium (II). General course on public international law. Recueil des cours, vol. 317, p. 9-312, 2005. Em especial, capítulo XXV, p. 183.

10 MENEZES, Wagner. A Jurisdicionalização do Direito Internacional: Conflitos de Competência entre Tribunais Internacionais, sua prevenção e resolução. 2011. 513 f. Tese (Livre Docência em Direito) Faculdade de Direito, Universidade de São Paulo, São Paulo. p. 150. MENEZES, Wagner. Tribunais Internacionais: Jurisdição e Competência. São Paulo: Saraiva, 2013.

11 Em relação à $\mathrm{OMC}$, Elaini Cristina Gonzaga Silva utiliza em sua dissertação de mestrado o termo "juridicização" com sentido aproximado, se referindo ao fenômeno "que conduz ao estabelecimento de um ordenamento jurídico por meio da introdução de normas secundárias e afirmação de normas primárias". SILVA, Elaini Cristina Gonzaga da. Juridicização das Relações Internacionais e Solução de Controvérsias: Análise do Sistema Multilateral de Comércio. 2007. 225 f. Dissertação (Mestrado em Direito) - Faculdade de Direito, Universidade de São Paulo, São Paulo, 2007. p. 29.

12 AMARAL JÚNIOR, Alberto do. A Solução de Controvérsias na OMC. São Paulo: Atlas, 2008. p. 
demandas por segurança jurídica e cooperação com fins ao desenvolvimento, como nortes ao comércio internacional. ${ }^{13}$

É exatamente essa busca plurisubjetiva no Direito Internacional pela discussão, construção, e efetivação de mecanismos que melhor equacionem os diferentes interesses do comércio internacional, bem como que instituam o respeito ao império do direito (rule of law) que está na base do multilateralismo econômico, que tem como arcabouço histórico o GATT e como moldura institucional a OMC. ${ }^{14} 15$

A OMC configura-se como principal organização internacional contemporânea responsável pela coordenação e desenvolvimento das relações comerciais internacionais. A Organização assume, pois, papel central no Direito Internacional Econômico, vez que funciona, simultaneamente, como organização supervisora das regras já acordadas e das obrigações assumidas pelos membros, e como foro de contínua negociação destas e de novas regras. ${ }^{161718}$

No cerne do sistema multilateral de comércio está o Sistema de Solução de Controvérsias da OMC, ${ }^{19}$ que embora possua arquitetura única, pelo aspecto especial de seus procedimentos e das relações entre as instâncias que o compõem, é sistema de natureza adjudicatória, de competência exclusiva face à ampla gama de temas sob guarida dos Acordos da Organização.

A centralidade que a OMC e seu Sistema de Solução de Controvérsias tem assumido na realidade internacional exige que este estudo parta de uma breve reflexão acerca dos paradigmas do Direito Internacional, com o intuito primordial de evidenciar a matriz teórica que recairá sob as análises desta tese.

97-100.

13 Para um histórico do GATT, e sobre suas limitações em garantir o desenvolvimento aos países "subdesenvolvidos", Cf: LAFER, Celso. O Gatt, a Cláusula de Nação mais favorecida e a América Latina. Boletim da Sociedade Brasileira de Direito Internacional, n. 55/60, p. 133-151, 1972-1974. p. 134-136.

14 JACKSON, Jonh $\mathrm{H}$. The Jurisprudence of GATT and the WTO. Cambridge: Cambridge University Press, 2000. p. 8-9.

15 CARREAU, Dominique; JUILLARD, Patrick. Droit International Économique. Paris: Editions Dalloz, 2007. p. 47-48.

16 THORSTENSEN, Vera. OMC- Organização Mundial do Comércio: As Regras do Comércio Internacional e a Nova Rodada de Negociações Multilaterais. 2a ed. São Paulo: Aduaneiras, 2001. p. 27.

17 BARRAL, Welber. De Bretton Woods a Doha. In: BARRAL, Welber (Org). O Brasil e a OMC. $2^{\mathrm{a}}$ ed. Curitiba: Juruá, 2006. p. 9-26.

18 SILVA, Roberto Luiz. Direito econômico internacional e direito comunitário. Belo Horizonte: Del Rey, 1995. p. 103-104.

19 BARRAL, Welber; PRAZERES, Tatiana. Solução de Controvérsias. In: BARRAL, Welber (Org). O Brasil e a OMC. 2a ed., 5a tir. Curitiba: Juruá, 2006, p. 27-46. p. 27-46. 


\subsection{As Mudanças de Paradigma do Direito Internacional}

Analisaremos diferentes paradigmas do Direito Internacional, com o objetivo de reconhecer que o novo paradigma que se impõe na ordem jurídica internacional exige a participação das instituições internas, imiscuídas com os valores internacionais, em reafirmação da consciência comunitária e dos interesses da coletividade internacional, além do desenvolvimento de uma interpretação sistêmica, integradora e constitucionalista.

Não se pretende fazer um histórico do Direito Internacional - o que exigiria um espaço consideravelmente maior que esta seção - assim como não foi esse o objetivo dos autores citados. O intuito é analisar a evolução do Direito Internacional de modo a evidenciar mudanças de paradigmas que ocorreram, e sustentar a compreensão da constitucionalização como o paradigma contemporâneo do Direito Internacional, para então tratar de suas consequências para a regulamentação do comércio internacional.

São recorrentes na literatura os diagnósticos de transformação da realidade internacional, bem como de sua próxima relação com mudanças profundas no Direito Internacional. Neste sentido, MARK ZACHER destacou que estar-se-ia enfrentando a queda do paradigma da ordem westfaliana, e a ascensão de uma nova arquitetura regulatória mundial. ${ }^{20}$ Em uma ordem mundial em modificação, os Estados se tornam interconectados em uma rede de interdependências, e a esse quadro se adiciona como novidade a consciência dos povos sobre seu futuro comum, reconhecendo-se uns aos outros como parte da humanidade. ${ }^{21}$

Desde a década de setenta, ReDley Bull antecipa uma ideia semelhante de evolução e mudança de paradigma, embora com emprego de outro vocabulário, através da

20 ZACHER, Mark. The Decaying pillars of the Westphalian temple: Implications for International Order and Governance. In: ROSENAU, James; CZEMPIEAL, Ernst-Otto. Governance, Order and Change in World Politics. Cambridge University Press, 1992, p. 58-101.

21 ZACHER, Mark. The Decaying pillars of the Westphalian temple: Implications for International Order and Governance. In: ROSENAU, James; CZEMPIEAL, Ernst-Otto. Governance, Order and Change in World Politics. Cambridge University Press, 1992, p. 58-101. p. 101. 
clássica distinção entre ordem internacional e ordem global. Em suma, a última, focada na humanidade como um todo, é mais ampla, mais fundamental, mais primordial, e moralmente prioritária que a ordem internacional, reguladora do paradigma de relação entre os Estados. A figura do Estado perde a primazia, com o conceito de ordem global, e se torna um caminho para atingir valores globais e interesses comuns. ${ }^{22}$

Essas noções permanecem atuais, diante de mudanças que se aprofundaram nas últimas décadas, gerando efeitos não apenas nas relações internacionais, mas inclusive na estrutura do Direito Internacional.

Em seu curso geral de Direito Internacional da Academia de Direito Internacional de Haia, Christian TOMUSChAT trata da complexidade crescente da ordem jurídica internacional, como vetor de evolução do Direito Internacional e passagem de um paradigma a outro. $\mathrm{O}$ autor identifica quatro estágios nesta linha evolutiva: (a) em suas origens, o Direito Internacional como um direito de coexistência; (b) no segundo estágio, o Direito Internacional como um direito de cooperação; (c) no terceiro estágio, o Direito Internacional como um plano abrangente para a vida social; e (d) no quarto estágio, o Direito Internacional no bojo de uma comunidade internacional. ${ }^{23}$

O autor parte dos estágios explicitados por WoLFGANG FRIEDMANN, ${ }^{24}$ que em seu estudo chamava atenção para as transformações profundas na sociedade internacional, principalmente desde a criação da Carta das Nações Unidas, que teriam engendrado a passagem de um direito de coexistência entre os Estados, para um paradigma de cooperação mais amplo.

Nessa análise, o estágio de coexistência descreve o Direito Internacional como um direito limitado a governar as relações entre os Estados, e consequentemente concebido como necessário apenas para limitados propósitos. Reinava, pois, a distinção firme de ratione materiae entre o Direito Internacional e o direito interno dos Estados, sendo que o primeiro tinha como funções essenciais a delimitação de competências estatais, a partir da

\footnotetext{
22 Nas palavras do autor: "If international order does have value, this can only be because it is instrumental to the goal of order in human society as a whole." BULL, Hedley. The Anarchical Society: A Study of Order in World Politics. $3^{\text {rd }}$ ed. Basingstoke; New York: Palgrave, 2002. p. 21.

23 TOMUSCHAT, Christian. International law: ensuring the survival of mankind on the eve of a new century. General course on public international law. Recueil des cours, vol. 281, p. 9-438, 1999. p. 56-90.

24 FRIEDMANN, Wolfgang. The Changing Structure of International Law, New York: Columbia University Press, 1964.
} 
territorialidade, e a preservação da existência e independência dos Estados. ${ }^{25}$

No segundo estágio, a era de cooperação se inaugura com o fim da primeira guerra mundial e a criação da Liga das Nações, cujo objetivo primário era promover a cooperação, com fins de alcançar a paz e segurança internacionais. A criação de uma estrutura institucional de âmbito global, acompanhada de um aparato normativo, era o primeiro passo na superação da clássica teoria da igualdade soberana.

Inaugurado, então, o impulso de cooperação entre os Estados com o objetivo de lidar com os desafios em comum enfrentados pela humanidade, expandiu-se pelas mais diversas áreas à medida que novos desafios de natureza transnacional eram descobertos, o que resultou na institucionalização e fortalecimento do Direito Internacional como meio de alcançar objetivos maiores da humanidade. Neste estágio, marcado pela criação e evolução do "Sistema ONU", se desenvolveu a ideia de que certos temas - não somente ligados à paz e segurança internacionais, mas também o desenvolvimento econômico, a autodeterminação dos povos, os refugiados e os recursos ambientais - são de responsabilidade coletiva da comunidade internacional. ${ }^{26}$

Assim, o desenvolvimento progressivo do Direito Internacional o levou a uma nova etapa, marcada pela significativa diminuição do espaço de soberania dos Estados, vez que ligados a uma rede crescente de compromissos jurídicos em áreas como os direitos humanos, a democracia nos governos internos, e metas de bem-estar dos indivíduos e de boa governança. Neste sentido, conforme a interdependência entre os Estados se intensifica e os compromissos que afetam a vida dos cidadãos se adensam, os Estados são vinculados profundamente por essas obrigações.

Há, desse modo, uma rearquitetura do Direito Internacional, que passa de um conjunto de regras que guiavam os Estados em suas relações entre si, a significar um corpus juris multifacetado que permeia todos os aspectos da vida humana. Esse desenvolvimento observado na terceira fase, contudo, se deu através de diferentes instrumentos, com papel destacado da soft law, que tende paulatinamente a se

25 TOMUSCHAT, Christian. International law: ensuring the survival of mankind on the eve of a new century. General course on public international law. Recueil des cours, vol. 281, p. 9-438, 1999. p. 56-59.

26 TOMUSCHAT, Christian. International law: ensuring the survival of mankind on the eve of a new century. General course on public international law. Recueil des cours, vol. 281, p. 9-438, 1999. p. 59-63. 
"endurecer". 27

Merece destaque o fato de que os novos compromissos assumidos pelo Direito Internacional são cada vez mais complexos, exigindo uma lógica diferente de implementação, que significa, em nossa interpretação, uma tradução dessas regras para a normatividade interna, pelos poderes estatais, de modo a gerar a produção de seus efeitos nas relações verticais, horizontais e transnacionais.

TOMUSCHAT parece, então, sugerir um quarto paradigma, de certo modo em complementação ao terceiro paradigma, que estaria ainda em desenvolvimento às vésperas da virada do milênio. Este paradigma, do Direito Internacional para a comunidade internacional, se caracteriza pela hierarquização de valores na ordem jurídica internacional, pela proteção dos interesses comunitários, e pela institucionalização de instrumentos coletivos protetivos, significando, portanto, a tradução normativa do conceito de comunidade internacional. ${ }^{28}$

De maneira correlata, BRUNO SIMMA enuncia a evolução do Direito Internacional clássico para o contemporâneo como a passagem de um sistema jurídico de caráter bilateral ${ }^{29}$ para uma perspectiva focada no interesse comunitário. ${ }^{30}$ Assim, estaria em curso uma evolução da compreensão do sistema jurídico internacional, distanciando-se de

27 TOMUSCHAT, Christian. International law: ensuring the survival of mankind on the eve of a new century. General course on public international law. Recueil des cours, vol. 281, p. 9-438, 1999. p. 63-72.

28 Nas palavras do autor: " [...] it would be wrong to assume that States as a mere juxtaposition of individual units constitute the international community. Rather, the concept denotes an overarching system which embodies a common interest of all States and, indirectly, of mankind." TOMUSCHAT, Christian. Obligations Arising for States without or against Their Will. Recueil des cours, vol. 241, p. 195-374, 1993. p. 227.

29 Segundo o conceito do autor: "[...] let me explain in some more detail what I have in mind in characterizing traditional international law as being essentially 'bilateral-minded': basically, international legal obligations existed, and still exist, at the level of relations between States individually. In other words, international law does not generally oblige States to adopt a certain conduct in the absolute, urbi et orbi, as it were, but only in relation to the particular State or States (or other international legal persons) to which a specific obligation under treaty or customary law is owed. This constellation led Alfred Verdross to speak of the 'relative' character of international law. I myself prefer the term 'bilateralist' because I consider it more illustrative and less prone to misunderstandings than the adjectives 'relative' or 'relational' "SIMMA, Bruno. From bilateralism to community interest in international law. Recueil des cours, vol. 250, p. 217-384, 1994. p. 230.

$30 \quad$ O interesse comunitário se coloca como antítese ao conceito de bilateralismo explicitado supra. "The antithesis of the bilateralism thus described consists of the assertion of community interest in the development of international law in a different direction, as it were. A first, very tentative, definition of "community interest" could perceive it as a consensus according to which respect for certain fundamental values is not to be left to the free disposition of States individually or inter se but is recognized and sanctioned by international law as a matter of concern to all States". SIMMA, Bruno. From bilateralism to community interest in international law. Recueil des cours, vol. 250, p. 217-384, 1994. p. 233. 
uma lógica de direitos e obrigações correlativas entre os Estados, e aproximando-se da consciência de interesses da comunidade internacional. ${ }^{31}$

Esta evolução tem levado a uma crescente institucionalização e organização da sociedade internacional, como resultado da necessidade de encontrar novas soluções para os novos problemas. Tal amadurecimento da ordem jurídica internacional promove profundas transformações na natureza do Direito Internacional, e urge por mecanismos de participação dos diferentes sujeitos, neste contexto de "comunitarização" e "publicização" das relações jurídicas internacionais. ${ }^{32}$

$\mathrm{O}$ autor destaca diversas facetas da realidade internacional que o levaram a reconhecer que o surgimento da consciência destes interesses comunitários não provocou uma completa inversão da lógica das relações internacionais, havendo uma coexistência e interação entre ambos os paradigmas no sistema jurídico internacional. ${ }^{33} 3435$ A ideia de comunidade internacional, contudo, desempenha relevante função ideológica, ao destacar

31 Para uma visão distinta do estágio atual de evolução do Direito Internacional, Cf: “Thus, the change from a State-centric international society to a global community with radically reduced significance of States will probably take far more time than is expected by those who have advocated the decline or retreat of States, or the high cause of global market economy or global civil society. The fundamentally State-centric character of the international or global society will likely persist in the twenty-first century. The sovereign States system, whose fundamental principle is the mutual recognition of the supremacy of territorial sovereignty of States in managing human affairs, will remain as the most important organizational and managing principle of the entire humanity in the world." YASUAKI, Onuma. A Transcivilizational Perspective on International Law. Questioning Prevalent Cognitive Frameworks in the Emerging Multi-Polar and Multi-Civilizational World of the Twenty-First Century. Recueil des cours, vol. 342, p. 77-418, 2010. p. 101-102.

32 Desta forma, ensina Bruno Simma: "In fact, international law has been moving in this direction for some decades now. The rapidly increasing international concern with human rights, the environment, the global commons, the spread of nuclear weapons, and economic interdependence, to name just a few obvious examples, amply illustrates that there is a worldwide social consciousness at work today that “communalizes" and "publicizes" international relations far beyond the traditional rituals of governmental interaction" SIMMA, Bruno. From bilateralism to community interest in international law. Recueil des cours, vol. 250, p. 217-384, 1994. p. 234.

33 SIMMA, Bruno. From bilateralism to community interest in international law. Recueil des cours, vol. 250, p. 217-384, 1994. P. 248.

34 Também neste sentido, Cf: "The constitutional system set up for the international community in the United Nations Charter is of course far from being perfect. It has only a limited capacity to enforce compliance with its basic rules. This, however, should not detract our attention from the fact that we live in an international legal system rather different from the one existing before 1945." FROWEIN, Jochen A. Reactions by Not Directly Affected States to Breaches of Public International Law. Recueil des cours, vol. 248. p. 349-445, 1994. p. 358.

$35 \quad$ No mesmo sentido, Cf: “[...] the legal protection of international community interests was the result of a gradual and, at first, almost imperceptible general trend. [...] Yet another interesting feature of this phenomenon is that the protection of community interests in international law has been effected through the adaptation, not the abandonment, of existing legal regimes. The new concepts, while being revolutionary in their substance, have been formulated in such a way as to fit into well-known legal frameworks." VILLALPANDO, Santiago. The Legal Dimension of the International Community: How Community Interests Are Protected in International Law? European Journal of International Law, vol. 21, n. 2, p. 387419, 2010. p. 407-409. 
que as regras construídas e as decisões tomadas pelos agentes estatais impactam na vida de seres humanos, devendo-se ainda buscar a construção de capacidade normativainstitucional para a concretização dessa noção. ${ }^{36} 37$

Na busca pelo paradigma "pós-moderno" do sistema internacional, ao proclamar pelos fundamentos do Direito Internacional pós-moderno, PAUlo Borba CASELLA explicita que este seria o embasamento para uma "ordenação teleologicamente humana do mundo". ${ }^{38}$ Assim, o autor indica:

\begin{abstract}
Terminados os dias da concepção estatizante e uniformizadora do Direito Internacional, que se pautava pelas normas de coexistência entre os Estados e somente entre eles se reconhecia a condição de sujeito, para ver instalado o direito internacional pós-moderno: dividido entre o anseio de construção da cooperação, com alguns laivos de implementação de patamar tendente à integração, em contextos específicos, de coesão econômica e de compartilhamento de valores, que permita superar algumas das dicotomias mais gritantes do direito internacional, como a sobrevivência da pretensão da exclusividade dos papéis estatais, no plano do direito e das relações internacionais, quando mais e mais se veem a emergência e a atuação dos agentes não estatais. ${ }^{39}$
\end{abstract}

Observa-se, portanto, o momento de transição pelo qual passa o Direito Internacional. ${ }^{40} \mathrm{~A}$ medida em que se complexiza, o Direito Internacional se

36 Assim destaca-se mais um ensinamento de Bruno Simma: "Thus, the term "international community" constantly reminds the representatives of States that it is less the Governments themselves that will be affected in their existence through successes or failures in the realization of community interests, but rather concrete human beings about whose basic needs, health, life or death, governmental decisions are being made. However, in the last instance, of course, what will be decisive is not the use of the term "international community" as such, as a mere combination of words, but rather con-crete institutions, principles and rules through which commitment to the interests common to humankind can be activated". SIMMA, Bruno. From bilateralism to community interest in international law. Recueil des cours, vol. 250, p. 217-384, 1994. p. 248.

37 Também em sentido correlato, Pierre Marie Dupuy identifica a comunidade internacional como "ficção jurídica" e como "imperativo categórico", funções da noção na ordem jurídica internacional: " $L a$ fiction juridique de la "communauté internationale» est le moyen technique de promotion de la visée philosophique de diplomates et d'hommes politiques qui font souvent du Kant [...] '.Cf: DUPUY, PierreMarie. L'unité de l'ordre juridique international: cours général de droit international public. Recueil des cours, vol. 297, p. 9-489, 2002. p. 267.

38 CASELLA, Paulo Borba. Direito Internacional Pós-moderno e a revisão dos modelos institucional e normativo. In: CASELLA, Paulo Borba. BRIC- Brasil, Rússia, Índia, China e África do Sul: uma perspectiva de cooperação internacional. São Paulo: Atlas, 2011, p. 113-137. p. 121.

39 CASELLA, Paulo Borba. Direito Internacional Pós-moderno e a revisão dos modelos institucional e normativo. In: CASELLA, Paulo Borba. BRIC- Brasil, Rússia, Índia, China e África do Sul: uma perspectiva de cooperação internacional. São Paulo: Atlas, 2011, p. 113-137. p. 120.

$40 \quad$ Assim postula o autor: "Ante as mutações verificadas na nova realidade, é preciso alcançar nova regulação internacional. De fundamentos mais amplos, para assegurar os resultados adequados dessa construção do direito internacional pós-moderno”. CASELLA, Paulo Borba. Direito Internacional Pós- 
institucionaliza e se hierarquiza, provocando também uma hibridização com o direito interno, além de uma tendência a abarcar o ser humano como seu sujeito central. $\mathrm{O}$ paradigma contemporâneo da sociedade internacional exige, pois, uma nova formulação do gerenciamento dos conflitos, de modo a integrar os diferentes setores do Estado em respeito ao "international rule of law". ${ }^{41}$

A organização do Direito Internacional a partir da centralização do indivíduo exige que o Direito Internacional seja traduzido em estruturas, instituições e mecanismos também internos, de modo a abarcar níveis de normatividade e governança que alcancem o cidadão. Este quadro demanda, pois, uma reestruturação da ordem jurídica internacional na qual os efeitos do Direito Internacional sejam concretizados em face dos indivíduos.

\subsubsection{O Paradigma Constitucionalista do Direito Internacional}

Embora a concepção de constituição no Direito Internacional não seja recente, ${ }^{42}$ a sua aplicação tem sido desenvolvida pela doutrina nas últimas décadas, como um paradigma de substituição à ordem internacional estatocêntrica, e em contraposição à

moderno e a revisão dos modelos institucional e normativo. In: CASELLA, Paulo Borba. BRIC- Brasil, Rússia, Índia, China e África do Sul: uma perspectiva de cooperação internacional. São Paulo: Atlas, 2011, p. 113-137. p. 126.

41 Em outro texto, Paulo Borba Casella reforça esta necessidade: “A conclusão se põe no sentido de que os Estados precisam estar sujeitos, no âmbito externo, a sistemas de pesos e contrapesos, ou à institucionalização de sistema normativo que lhes limite o alcance da esfera de discricionariedade. Na medida em que os mecanismos institucionais instaurem Estado de Direito"no âmbito internacional, pode-se ter evolução semelhante ao alcançado nas ordens internas, mediante a institucionalização das garantias constitucionais internas. [...]" CASELLA, Paulo Borba. Fundamentos e Perspectivas do Direito Internacional pós-Moderno. Revista da Faculdade de Direito da Universidade de São Paulo, p. 433-466, jan./dez. 2006. p. 441.

42 Segundo Bruno Simma, a primeira aplicação do termo ao Direito Internacional foi feita em 1926, por Alfred Verdross, na obra "Die Verfassung der Völkerrechtsgemeinschaft" (VERDROSS, Alfred. Die Verfassung der Völkerrechtsgemeinschaft, Vienna and Berlin, Springer, 1926.): “According to Verdross, the term "constitution" denotes the norms which regulate the basic order of a community, that is, its structure, organization and allocation of competences. For Verdross, writing in 1926, the existence of a universal international law grounded in and held together by the basic norm of pacta sunt servanda justified the use of the term "constitution", even in absence of a written document." SIMMA, Bruno. From bilateralism to community interest in international law. Recueil des cours, vol. 250, p. 217-384, 1994. p. 260. 
corrente fragmentária, revisitando, assim, a unidade e a coerência como pilares do sistema jurídico internacional. $^{43}$

Desde os primórdios do uso do termo ao Direito Internacional, o vocábulo vem associado a diversos sentidos correlatos, tais como: (i) as normas basilares que regulam a relação entre os sujeitos na ordem internacional universal; $44 \quad 45$ (ii) os princípios fundamentais de caráter costumeiro responsáveis pela determinação de competências e funções na comunidade internacional; ${ }^{46}$ (iii) a limitação ao soberanismo dos Estados na ordem jurídica internacional; ${ }^{47}$ (iv) a estrutura normativa-institucional de um "Estado

43 Nesta perspectiva de oposição ao paradigma fragmentário, Cf: VAN AAKEN, Anne. Defragmentation of Public International Law Through Interpretation: A Methodological Proposal. Indiana Journal of Global Legal Studies, vol. 16, pp. 483-512, 2009. COHEN, Harlan Grant. From Fragmentation to Constitutionalization. Pacific McGeorge Center for Global Business and Development Law Journal, vol. 25, p. 381-394, 2012.

44 Conforme a visão de Alfred Verdross: "La conception universaliste de la superordination du droit des gens se trouve aussi dans la doctrine et la pratique anglo-saxonne de ces temps; c'est l'ancien sens de l'adage bien connu " international law is a part of common law. »Car le sens original de cette formule est tel que le droit des gens doit etre applique, meme s'il est en contratradiction avec le droit national, parce que le droit international forme la constitution mondiale de laquelle dependent tous les Etats civilisesi." (grifo nosso). VERDROSS, Alfred. Le fondement du droit international. Recueil des cours, vol. 16, p. 247-323, 1927. p. 314.

45 De modo correlate, o Christian Tomuschat explicita: "Given the developments triggered by the UN Charter, today a community model of international society would seem to come closer to reality than any time before in history. According to this interpretation, States live, as from their birth, within a legal framework of a limited number of basic rules which determines their basic rights and obligations with or without their will, leaving them, however, sufficient room for self-responsible action within the openings of that legal edifice. One may call this framework, from which every State receives its legal entitlement to be respected as a sovereign entity, the constitution of international society or, preferably, the constitution of the international community, community being a term suitable to indicate a closer union than between members of a society." TOMUSCHAT, Christian. Obligations Arising for States without or against Their Will. Recueil des cours, vol. 241, p. 195-374, 1993. p. 210-11.

46 Scelle intitula a segunda parte de seu curso como "Technique Constitutionnelle du Droit des Gens", na qual afirma: "Au stade interétatique, au contraire, les principes constitutionnels demeurent à l'état de coutume, même si l'on peut en rencontrer l'expression dans des textes conventionnels : le traité joue en ce cas le rôle d'un élément coutumier. Il n'y a qu'une chose qui soit impos-sible, c'est l'absence de règles constitutives ou constitution-nelles. L'instinct seul des sujets de droit, membres de la Société internationale, suffit à les déterminer, car le senti-ment de la nécessité entraîne l'obéissance commune à la règle qui en découle implicitement. [...] Contenu du droit constitutionnnel international. - Que contient cet ensemble normatif? D'abord et nécessairement une détermination des compétences des sujets de droit, notamment des gouvernants. [...]" SCELLE, Georges. Règles générales du droit de la paix. Recueil des cours, vol. 46, p. 327-703, 1933. p. 422.

$47 \quad$ Nas palavras do autor: "[...] Nevertheless, the developments which have taken place during the past half-century in the organisation and composition of the international community and in the law regarding the use of force, have made a substantial impact upon the constitutional foundations of the international legal order. Whether international law can now properly be regarded as "law with a constitution" may be controversial, for text-books still for the most part tend to treat international organisation as a superstructure upon international law rather than as the constitutional framework of the international community. Some of the impact of international organisation upon international law has only made itself felt gradually and almost insensibly, so that we probably do not appreciate the full extent of changes that have already taken place. Even so, the complex of world organisations which exists to-day, and the law which surrounds them, seem to contain some elements at least of a world constitution; a constitution defective in many respects and very different in kind from that of a State, but nevertheless a form of constitution. True, general international law has not yet been properly integrated within this constitutional framework, and much 
mundial"; ${ }^{48}$ e (v) a cogência de instrumentos e estruturas formais como a Carta das Nações Unidas. ${ }^{49} 50$

Embora com diferentes nuances capturadas por cada autor, a perspectiva traz implícita a crença no Direito Internacional como um instrumento universalizante de transformação positiva da realidade internacional e de concretização de valores e interesses comunitários.

Mesmo diante da dificuldade de conceituação de vocábulos como "constituição", “constitucionalização" e “constitucionalismo” em suas acepções ligadas ao fenômeno jurídico internacional, dada a multiplicidade de autores que oferecem conceitos próprios, ainda que muitas vezes sobrepostos, se torna necessário buscar precisar esses termos, no seu uso por parte de alguns doutrinadores.

Uma das estudiosas no tema na contemporaneidade, ANNE PETERS, entende que o “constitucionalismo global" é uma agenda que busca a aplicação de princípios

progress has yet to be made before we can speak with confidence of international law having a constitution. But the constitutional framework of international law provided by international organisation is now so important that in the opinion of the present writer it must be given a prominent place in any analysis of the general principles of international law." WALDOCK, Humphrey. General course on public international law. Recueil des cours, vol. 106, p. 1-251, 1962. p. 7-8.

48 "[...] The task [the draftsmen of an International Bill of Rights] is no less than one of the international codification, in both its consolidating and its legislative sense, or the major constitutional law of mankind-a sphere in which the science of jurisprudence and politics converge in a most acute form." LAUTERPACHT, Hersch. The international protection of human rights. Recueil des cours, vol. 70, p. 1108, 1947. p. 89-90. “[...] S'ils sont des juristes, ils n'ont pas besoin d'attacher une importance excessive à l'argument banal qu'une fédération mondiale mettrait fin au droit international, en le transformant en droit constitutionnel de l'Etat mondial. Il n'en serait pas nécessairement ainsi: le changement qui en résulterait serait surtout une question de terminologie. En tout cas, si le résultat est souhaitable à d'au- tres points de vue, la disparition formelle de la science du droit international est indifférente." LAUTERPACHT, Hersch. Règles générales du droit de la paix. Recueil des cours, vol. 62, pp. 95-422, 1937. p. 411.

49 Na visão de Georg Schwarzenberger: "In an international community in the strict sociological meaning of the term, the overriding character of the interests of the whole- the constitutional law of the community - would be self-understood, and suitable reservations of international public policy in individual treaties could be taken for granted. Within the framework of a world society organised on the confederate pattern in the United Nations and its Specialised Agencies, the priority of the "higher" law of these international quasi-orders is less absolute. The matter is regulated by the rules of international law governing the conflict of treaties". SCHWARZENBERGER, Georg. The principles and standards of international economic law. Recueil des cours, vol. 117, p. 1-98, 1966. p. 47. "[...] the 'constitution of the organized community of Nations' within the framework of the United Nations, another attempt on the same pattern of a world confederation, must still be treated as being sub judice." SCHWARZENBERGER, Georg. The fundamental principles of international law. Recueil des cours, vol. 87, p. 191-385, 1955. p. 207.

$50 \quad$ Em perspectiva semelhante: "Why may we speak of a constitutional structure? While international law developed as a system of co-ordination among States based on the sovereign will of those agreeing on a treaty or forming a rule of customary international law, the Security Council now has the mandate to decide against the will of the State concerned, at least as long as that State remains a Member of the United Nations. [...] However, even for countries who have not become Members, and there are very few indeed, the constitution of the world community which we find enshrined in the United Nations Charter is not without considerable importance." FROWEIN, Jochen A. Reactions by Not Directly Affected States to Breaches of Public International Law. Recueil des cours, vol. 248, p. 349-445, 1994. p. 356. 
constitucionais na esfera jurídica, e a "constitucionalização" consistiria na emergência de aspectos constitucionais no Direito Internacional, como instrumento hermenêutico e como via de reforçar sua legitimidade, efetividade e justiça. ${ }^{51}$

Juntamente com KLAUS ARMIGEON, a autora afirma, em outra oportunidade, que se poderia denominar "constituição internacional" o núcleo das normas mais importantes que regulam a atividade política na comunidade global. Entretanto, os autores preferem a expressão "Direito constitucional global", por entenderem que o termo "constituição" poderia trazer concepções ligadas ao fenômeno jurídico interno, não sendo de todo adequado uma simples "tradução" do conceito no direito interno para o Direito internacional. $^{52}$

Assim, não se trata simplesmente de transpassar o conceito de "constituição" à uma escala superior, é necessário estudar o fenômeno em suas características próprias no ambiente global, em suas dimensões descritiva e prescritiva. ${ }^{53} 54$

Neste quadro teórico, “constitucionalização" indicaria a emergência de aspectos constitucionais na ordem jurídica internacional, sendo um processo que engendra um "reforço de normatividade" na ordem global. ${ }^{55}$

51 PETERS, Anne. The merits of global Constitutionalism. Indiana Journal of Global Legal Studies, vol. 16, p. 397-411, 2009. p. 397.

$52 \quad$ Nas palavras dos autores: "However, an international or global constitution cannot be gained by simply scaling up a typical state constitution. We must be aware of the problems of translation. This is one reason why we prefer the term "constitutional law" to "constitution." We seek to highlight that this body of law is not codified in one single document, but is dispersed in various treaties, soft law texts, and customary law. In particular, the U.N. Charter is not the World Constitution. Global constitutional law is a subset of international rules and principles which are so important that they deserve the label "constitutional". PETERS, Anne; ARMINGEON, Klaus. Introduction-Global Constitutionalism from an Interdisciplinary Perspective. Indiana Journal of Global Legal Studies, vol. 16, p. 385-395, 2009. p. 387.

53 Conforme explicitam os autores em outro trecho: "Constitutionalism asks for a legitimate constitution. This strand of thought cannot simply be transplanted to the international level, and one must beware of false domestic analogies. Global constitutionalism is constitutionalism 'in a new key.' We employ the term 'global constitutionalism' in order to characterize an academic and political agenda which identifies and advocates the application of constitutionalist principles, such as the rule of law, checks and balances, human rights protection, and possibly democracy, in the international legal sphere in order to improve the effectiveness and the fairness of the international legal order. Therefore, global constitutionalism has both descriptive and prescriptive elements. It does not merely claim to describe some features of the status quo of international relations, but also seeks to provide arguments for their further development in a specific direction." PETERS, Anne; ARMINGEON, Klaus. Introduction-Global Constitutionalism from an Interdisciplinary Perspective. Indiana Journal of Global Legal Studies, vol. 16, p. 385-395, 2009. p. 389.

54 Como exemplo de uma visão contrária, que parte da constituição interna (norte-americana) para reconhecê-la em organizações constitucionais, Cf: McGINNIS, John O. MOVSESIAN, Mark L. The World Trade Constitution. Harvard Law Review, vol. 114, Issue 2, p. 511-605, dec. 2000.

55 Assim, constitucionalização global significaria: “[...] a catchword for the continuing, but not linear, process of the gradual emergence and deliberate creation of constitutionalist elements in the international 
$\mathrm{Na}$ busca de um conceito interdisciplinar, esses autores destacam que sob as lentes do jurista, uma leitura constitucional da ordem jurídica internacional é um instrumento hermenêutico não diferente daqueles com os quais está habituado. Sob a perspectiva do cientista político, por sua vez, se percebe a necessidade de uma verificação empírica de uma "efetiva constituição" para além da falácia de políticos e, ${ }^{56}$ portanto, através de instituições e processos globais que reafirmem a normatividade do conceito.

LUIGI FERRAJOLli, por sua vez, conecta o conceito de "constitucionalismo" no Direito Internacional à implementação do império do direito na ordem jurídica internacional, como um sistema hierárquico de normas e princípios axiológicos, reconhecendo uma conexão direta com a noção de tottus orbis empregada por FRANCISCO DE VICTORIA. 5758

Uma definição similar é dada por PIERRE-MARIE DUPUY, englobando uma dimensão material, como um conjunto de princípios jurídicos de importância primária para a sociedade internacional, e uma dimensão institucional, através da designação de órgãos e definição de suas competências. ${ }^{59}$

Percebe-se, portanto, que o uso restrito da palavra "constituição" reservado unicamente ao soberanismo estatal, que não encontraria poder superior, não reflete a realidade atual. Neste sentido, também JOHN JACKSON adota um conceito amplo de “constituição”, de modo a também abarcar o fenômeno jurídico internacional. ${ }^{60}$

legal order by political and judicial actors, bolstered by an academic discourse in which these elements are identified and further developed." PETERS, Anne; ARMINGEON, Klaus. Introduction-Global Constitutionalism from an Interdisciplinary Perspective. Indiana Journal of Global Legal Studies, vol. 16, p. 385-395, 2009. p. 389-90.

56 PETERS, Anne; ARMINGEON, Klaus. Introduction-Global Constitutionalism from an Interdisciplinary Perspective. Indiana Journal of Global Legal Studies, vol. 16, p. 385-395, 2009. p. 386. 57 FERRAJOLI, Luigi. A soberania no mundo moderno: Nascimento e crise do Estado Nacional. São Paulo: Martins Fontes, 2002. p. 53.

58 Para uma análise mais detalhada do conceito de totus orbis em Francisco de Vitória, Cf: RANGEL, Vicente Marotta. Francisco de Vitoria y el Federalismo Internacional. In: MANGAS MARTÍN, Araceli. La Escuela de Salamanca y el Derecho Internacional en America: del Passado al Futuro. Salamanca: Asociacion Espanola de Professores de Derecho Internacional, 1993, p. 205-214.

59 DUPUY, Pierre-Marie. The Constitutional Dimension of the Charter of the United Nations Revisited. In: BOGDANDY, Armin von; WOLFRUM, Rüdiger (eds.). Max Planck Yearbook of United Nations Law, vol. 1, p. 1-32, 1997. p.3.

60 E assim, Jackson usa a expressão “[...] to embrace a variety of "constitution” authorities, using a variety (and often a large number) of instruments and traditional practices and experiences which have some impact on the views of constituents of an entity concerning the permissible procedures and behaviors involved in the process of governing." JACKSON, John. Sovereignty, the WTO and Changing Fundamentals of International Law. New York: Cambridge University Press, 2006. p. 222. 
O termo "constitucionalismo", em sua concepção, se aplica a diversos níveis de governança, e o autor identifica quatro usos diversos para o termo: (i) aplicado ao Estadonação que possui uma constituição formal; (ii) relativo ao conteúdo material normativo, ligado à proteção dos direitos humanos e à democracia, (iii) usado para descrever o desenvolvimento de uma organização internacional ou transnacional; e (iv) aplicado para descrever o processo evolutivo de criação e aplicação de normas relativas ao sistema do Direito Internacional como um todo, de modo a desafiar o seu caráter soberanista. ${ }^{61}$

Esse quarto sentido, que o autor busca desenvolver, tem grande relevância para o sistema jurídico internacional, e se aplica à busca por novos fundamentos do Direito Internacional:

\begin{abstract}
Quanto ao quarto tipo de definição mencionado acima, o termo pode significar e endossar uma abordagem global para o "redesenho" dos fundamentos do direito internacional (incluindo do direito econômico internacional e do direito institucional internacional). Poderia ser a rubrica com um sabor de aprovação e promessa, para cobrir estudos necessários, atuais e mais profundos, e atividades destinadas a examinar a "gestalt" do sistema jurídico internacional. "Constitucionalismo", portanto, pode ser uma boa abordagem para o desenvolvimento de substitutos para as muitas perplexidades existentes e os desafios para o sistema internacional global. (grifo nosso) ${ }^{62}$
\end{abstract}

Desse modo, "constitucionalismo" é uma perspectiva que, se desenvolvida com a devida reflexão, discussão e diálogo com a prática, poderia substituir as noções problemáticas de soberania e consenso na formação do Direito Internacional por outros fundamentos, constituídos como alicerces de um novo paradigma. ${ }^{63}$ Além disso, esta perspectiva reforça a necessidade de desenvolver parâmetros de legitimidade, democracia, transparência e accountability ao Direito Internacional e às instituições internacionais. ${ }^{64}$

61 JACKSON, John. Sovereignty, the WTO and Changing Fundamentals of International Law. New York: Cambridge University Press, 2006. p. 223-224.

62 Tradução livre do original em língua inglesa: "As to the fourth definition type mentioned above, the term could signify and endorse an overall approach to "redesigning" the fundamentals of international law (including international economic law and international institutional law). It could be the rubric with a flavor of approval and promise, to cover present and further necessary study and activity designed to examine the "gestalt" of the international legal system. "Constitutionalism" thus may be a good approach to developing replacements or substitutes for the many existing perplexities and challenges to the overall international system." JACKSON, John. Sovereignty, the WTO and Changing Fundamentals of International Law. New York: Cambridge University Press, 2006. p. 224.

63 JACKSON, John. Sovereignty, the WTO and Changing Fundamentals of International Law. New York: Cambridge University Press, 2006. p. 224-225.

64 JACKSON, John. Sovereignty, the WTO and Changing Fundamentals of International Law. 


\subsubsection{O Constitucionalismo e a OMC}

A perspectiva do constitucionalismo é uma concepção também aplicada por parte da doutrina à OMC. ${ }^{65}$ Segundo diagnóstico de JEFFREY DUNOFF, a maior parte dos autores aplica esta noção no contexto do sistema multilateral de comércio para se referir: (a) à arquitetura institucional da OMC; (b) ao processo de mediação judicial entre valores conflitantes; e (c) à primazia de um conjunto de compromissos normativos. ${ }^{66}$

Inserido na aplicação do conceito à arquitetura institucional na OMC, JOHN JACKSON descreve a passagem da abordagem "power-oriented", em direção à abordagem "rule-oriented", ${ }^{67}$ fenômeno ao qual nos referimos anteriormente, que CELSO LAFER denominou de "adensamento de juridicidade", e foi materializado com a passagem do GATT à OMC.

A segunda e dominante corrente destaca o sistema de solução de controvérsias da OMC como o motor de seu constitucionalismo, e neste sentido DEBORAH CASS, afirma que

New York: Cambridge University Press, 2006. p. 227.

65 TRACHTMAN, Joel P. The Constitutions of the WTO. European Journal of International Law, vol. 17, n. 3, p. 623-646, 2006.

$66 \mathrm{O}$ autor faz um diagnóstico dos principais sentidos conferidos ao constitucionalismo à OMC, embora tenha perspectiva crítica e contrária à de aplicação do constitucionalismo à OMC, Cf: "International legal scholarship, particularly trade scholarship, is preoccupied with questions of constitutionalism. However, neither WTO texts nor practice suggest that the WTO is a constitutional entity. The disjunction between scholarship and practice is puzzling: Why would scholars debate the WTO's (non-existent) constitutional features? [...]" DUNOFF, Jeffrey L. Constitutional Conceits: The WTO's 'Constitution' and the Discipline of International Law. European Journal of International Law, vol. 17, n. 3, p. 647-675, 2006. p. 647. DUNOFF, Jeffrey L. Why Constitutionalism Now? Text, Context and the Historical Contingency of Ideas. Journal of International Law and International Relations, vol. 1, p. 191-211, 2004-2005.

67 Embora sempre tenha reforçado a relevância desta passagem, nota-se certa uma evolução na concepção de "constitucionalismo" ligado à OMC pelo autor, no decorrer das seguintes obras: JACKSON, Jonh H. The Jurisprudence of GATT and the WTO. Cambridge: Cambridge University Press, 2000. JACKSON, John H. The World Trade Organization: Constitution and Jurisprudence. London: Royal Institute of International Affairs, 1998. JACKSON, John H. The WTO "Constitution" and Proposed Reform: Seven "Mantras" Revisited. Journal of International Economic Law, vol. 4, p. 67-78, 2001. JACKSON, John H. The Great 1994 Sovereignty Debate: United States Acceptance and Implementation of the Uruguay Round Results. Columbia Journal of Transnational Law, vol. 36, p. 157-188, 1998. JACKSON, John. Sovereignty, the WTO and Changing Fundamentals of International Law. New York: Cambridge University Press, 2006. 
o Órgão de Apelação da OMC "é a força dinâmica por trás da construção constitucional em virtude da sua capacidade de geração de normas e estruturas constitucionais durante a resolução de disputas. " 6869

Inserido na última corrente, ERNST-ULRICH PETERSMANN reconhece no constitucionalismo a eleição de valores normativos primários e hierarquizados, que constituem e limitam o poder dos governos e os direitos dos cidadãos. Em um sentido mais profundo, a constitucionalização da OMC envolve a sua submissão aos direitos humanos fundamentais, e aos princípios de justiça internacional. ${ }^{70}$

Na realidade, em sua obra é possível identificar o constitucionalismo na OMC como fenômeno que engloba também os dois sentidos citados, ligados à concretização do rule of law por meio do Sistema de Solução de Controvérsias. ${ }^{71}$ Contudo, o autor vai além

68 Tradução livre do original em língua inglesa: "is the dynamic force behind constitution building by virtue of its capacity to generate constitutional norms and structures during dispute resolution." CASS, Deborah Z. The "Constitutionalization" of International Trade Law: Judicial Norm-Generation as the Engine of Constitutional Development in International Trade'. European Journal of International Law, vol. 12, p. 39-75, 2001. p. 42.

69 Em uma posição contrária, Leonor Clodovil nega a existência de referido fenômeno: “ $A$ OMC é um sistema basicamente contratual e intergovernamental, que não tem natureza constitucional em nenhum sentido. O papel dos julgadores na OMC é contratual, diferentemente do papel atribuído a um juiz nacional pela constituição, consistindo em um exame mecânico sobre a concordância da ação do Membro com as obrigações que ele assumiu." CLODOVIL, Leonor Augusta Giovine. O Interesse Público no Antidumping. 2009. 345 f. Tese (Doutorado em Direito) - Faculdade de Direito, Universidade de São Paulo, São Paulo. p. 295.

70 Ernst-Ulrich Petersmann possui uma farta produção bibliográfica nesta temática. Embora outros artigos tenham sido também mencionados em outras notas da tese, destaca-se alguns dos trabalhos do autor que exploram esta relação: PETERSMANN, Ernst-Ulrich. How to Constitutionalize International Law and Foreign Policy for the Benefit of Civil Society? Michigan Journal of International Law, vol. 20, p. 1-30, 1998. p. 13. PETERSMANN, Ernst-Ulrich. Human Rights, International Economic Law and Constitutional Justice: A Rejoinder. European Journal of International Law, vol. 19, issue 5, p. 955-960, 2008. PETERSMANN, Ernst-Ulrich. Multilevel Judicial Governance as Guardian of the Constitutional Unity of International Economic Law. Loyola of Los Angeles International and Comparative Law Review, vol. 30, Issue 3, p. 367-418, 2008. PETERSMANN, Ernst-Ulrich. The WTO Constitution and Human Rights. Journal of International Economic Law, vol. 3, p. 19-25, 2000. Ernst-Ulrich Petersmann. Legal, Economic and Political Objectives of National and International Competition Policies: Constitutional Functions of WTO "Linking Principles" for Trade and Competition. New England Law Review, vol. 34, p. 145-162, 1999.

71 Nesse sentido: "Since the establishment of a GATT Legal Office in 1983, the progressive transformation of the multilevel GATT dispute settlement system into a compulsory worldwide jurisdiction for the settlement of trade disputes through panel, appellate, arbitration, and domestic judicial procedures continues to promote constitutional 'checks and balances' between the political and judicial branches of multilevel trade governance. [...]" PETERSMANN, Ernst-Ulrich. Multilevel Governance Problems of the World Trading System beyond the WTO Conference at Bali 2013. Journal of International Economic Law, vol. 17, p. 233-270, 2014. p. 247. 
dos sentidos mencionados, ao reconhecer expressamente a correlação entre o sistema multilateral de comércio e a realização de valores ligados aos direitos humanos. ${ }^{72}$

Assim, o Sistema de Solução de Controvérsias desempenha um papel essencial na passagem de uma inadequada perspectiva "hobesiana" do Direito Internacional - como instrumento de coexistência entre os Estados - rumo à construção de um "Direito Internacional da Integração". ${ }^{73}$ Por outro lado, embora existente e necessário, o constitucionalismo relacionado à OMC estaria limitado pelas concepções obtusas dos membros da Organização, que estariam em violação à disciplina multilateral ao restringir e coibir mecanismos de transparência e accountability em aspectos democráticos e judiciais. 74

Assim, a perspectiva do constitucionalismo aplicada à OMC, embora sujeita ao subjetivismo de sentidos conferidos pelos autores, é noção que retoma a ligação das regras comerciais com o Direito Internacional como um todo. Diferentemente de uma visão negativista e maniqueísta que tradicionalmente se aplicava a tal ramo do Direito Internacional, ${ }^{75}$ por meio desta perspectiva passa-se a vislumbrar uma relação de pertencimento entre o sistema multilateral de comércio e o sistema jurídico internacional

72 Assim explicita o autor em um de seus diversos artigos sobre o tema: "WTO law already serves 'constitutional functions': it protects freedom and non-discrimination across frontiers far beyond the unilateral domestic guarantees in all 135 WTO member states. By ensuring legally binding dispute settlement rulings and appellate review within short time-limits, the compulsory WTO dispute settlement system promotes rule of law more effectively than any other worldwide treaty system. The WTO Agreement asserts legal supremacy over the more than 20 worldwide trade agreements listed in the WTO Annexes. It also provides a legal framework for the periodic negotiation of new WTO Agreements. [...] If the WTO Agreement can be linked to a 'constitution', would the legitimacy, democratic acceptability, and legal consistency of WTO law not benefit from including additional constitutional safeguards such as human rights?" PETERSMANN, Ernst-Ulrich. The WTO Constitution and Human Rights. Journal of International Economic Law, vol. 3, p. 19-25, 2000.

73 PETERSMANN, Ernst-Ulrich. From the Hobbesian International Law of Coexistence to Modern Integration Law: The WTO Dispute Settlement System, Journal of International Economic Law, vol. 1, issue 2, p. 175-198, 1998.

74 PETERSMANN, Ernst-Ulrich. Multilevel Governance Problems of the World Trading System beyond the WTO Conference at Bali 2013. Journal of International Economic Law, vol. 17, p. 233-270, 2014. p. 248.

75 A exemplo, confira-se o posicionamento de Celso Duvivier de Albuquerque Mello: “[...] As perspectivas que vemos para o Direito Internacional Econômico é que ele é um direito visando a legalizar a exploração dos países pobres pelos ricos. Repetimos, é um ramo do Direito Internacional Público que perdeu a noção de justiça essencial a todo Direito. Ele é o lado negro do Direito Internacional Público. [...]" MELLO, Celso Duvivier de Albuquerque. Perspectivas do Direito Internacional Econômico. In: CASELLA, Paulo Borba; MERCADANTE, Araminta de (coord.). Guerra comercial ou integração mundial pelo comércio?: a OMC e o Brasil. São Paulo: LTr, 1998, p. 70-93. p. 93. 
como um todo, ${ }^{76}$ na busca pela concretização das funções mais amplas da normatividade internacional.

\subsection{Direito Internacional Contemporâneo e Sistema: a Perspectiva Sistêmica do Direito Internacional}

As transformações observadas nas últimas décadas e suas consequências processos e eventos como a globalização/mundialização, a criação de Organizações Internacionais, a internacionalização dos direitos humanos, a construção do sistema multilateral de comércio, denotam a influência do Direito Internacional em todos os ramos do direito interno e sua presença em praticamente todas as dimensões das sociedades.

Entretanto, esses mesmos processos e eventos que demonstram a institucionalização, o fortalecimento, e a expansão do Direito Internacional trouxeram fenômenos como a sua especialização e a jurisdicionalização, que contemporaneamente levam alguns acadêmicos a duvidarem da unidade e coerência do Direito Internacional e, portanto, de sua configuração como um sistema.

Em sua contraposição, a corrente doutrinária de perspectiva sistêmica do Direito Internacional se fortalece na evolução e continuidade de diversos autores desta posição, como passamos a brevemente explicitar.

Em estudos sobre a história semântica do termo sistema, MÁRIO G. LOSANO explicita que no grego clássico o termo tinha seus diversos significados conectados à ideia de agregação, e por isso usado em referência à ordem do mundo, seja ela ligada à

76 Assim conclui Joel Trachtman: "Yet we must also recognize that the WTO constitution is itself but a part of a broader structure for the global system. [...] Rather, it is necessary to examine the WTO constitution in the context of the general public international law system, and in relation to the other components of that system. Indeed, the general public interna- tional law system, including its subsystems, must be evaluated in constitutional terms." TRACHTMAN, Joel P. The Constitutions of the WTO. European Journal of International Law, vol. 17, n. 3, p. 623-646, 2006. p. 624. 
sociedade ou ao cosmos. ${ }^{77}$ Esse termo abstrato foi posteriormente recepcionado com dificuldades pelo latim, língua inclinada ao concreto, que tendeu a substituir o termo dos textos gregos por metáforas originadas da arquitetura e explicitadas pelos termos construere e structura. É essa a explicação, segundo o autor, para o entrelaçamento do significado semântico dos termos sistema e estrutura, que embora com particularidades, tem a função de designar uma natural tendência do jurista, que concebe sua disciplina como uma totalidade sistemática, ligada à ordem e harmonia. ${ }^{78} 79$

A presença dessa tentativa de sistematização passou evolutivamente de uma preocupação intuitiva a um desenvolvimento teórico e técnico desencadeado pelo pensamento de filósofos e, posteriormente, de juristas.

Em seu curso geral da Academia da Direito Internacional de Haia, GEORgE ABSAAB esclarece que a conceituação dos sistemas e dos ordenamentos jurídicos, a prescindir do foco na norma em si, é reação face às teorias de JONH AUSTIN e da escola alemã, resultantes do endeusamento do Estado, e que priorizaram a sanção como definição do Direito, tendo como consequência a negação radical da existência do Direito Internacional como Direito. Para Austin, o Direito Internacional se tratava de uma "moralidade positiva", enquanto a escola alemã o interpretava como um braço ou ramo do direito interno, à semelhança do Direito Internacional Privado. Assim, as teorias (i) da escola normativista (KELSEN); (ii) da escola institucionalista (RENAUD, ROMANO); e (iii) da escola de Oxford (HART), seriam reações àquele entendimento, e tentativas de analisar as facetas da noção de ordenamento e de sistema jurídico. ${ }^{80} 81$

A teoria pura do direito de HANS KELSEN se propunha a eliminar do direito os elementos não jurídicos e a abstrair a estrutura das normas de seu conteúdo substancial,

77 LOSANO, Mario G. Sistema e estrutura no direito. Volume I: das origens à escola histórica. São Paulo: Editora WMF Martins Fontes, 2008. p. 3.

78 Como explicita o autor: “[...] esses termos não são usados simultaneamente em todas as línguas, mas tiveram diversos exitos: são as facetas historicamente condicionadas de um componente constante do pensamento humano, principalmente ocidental, em geral, e do pensamento jurídico em particular." LOSANO, Mario G. Sistema e estrutura no direito. Volume I: das origens à escola histórica. São Paulo: Editora WMF Martins Fontes, 2008. p. 5.

79 Para uma visão da relação entre sistema e estrutura, Cf: FERRAZ JUNIOR Tércio Sampaio. Introdução ao Estudo do Direito: técnica, decisão, dominação. $6^{\mathrm{a}}$ ed. São Paulo: Atlas, 2011. p. 145.

80 ABI-SAAB, George. Cours Général de Droit International Public. Recueil des Cours, vol. 207, p. 9-463, 1987. p. 107.

81 Pierre-Marie Dupuy também retoma em seu curso estas mesmas três escolas como concepções de ordem jurídica, a partir das quais discute a unidade do sistema jurídico internacional. Cf: DUPUY, PierreMarie. L'unité de l'ordre juridique international: cours général de droit international public (2000). Recueil des cours, vol. 297, pp. 9-489, 2002. p. 67-76. 
para estudá-las como partes articuladas do ordenamento jurídico. Segundo KELSEN, a validade da norma se relaciona ao pertencimento e à coerência da norma com o ordenamento jurídico. $\mathrm{O}$ autor traçou uma estrutura piramidal para retratar o ordenamento jurídico, na qual as normas inferiores buscam sua condição de validade e existência nas normas superiores, o que culmina na norma fundamental. ${ }^{82}$ A grundnorm seria, pois, a base ideológica de legitimidade e aceitação social do ordenamento jurídico, mas em sendo uma norma hipotética, se coloca como um recurso lógico para conferir completude e fechamento ao sistema jurídico analisado em abstrato.

No entendimento de SANTI Romano, por sua vez, a essência do Direito não estaria na norma, mas nas instituições, pois a primeira seria incapaz de explicar a unidade e identidade própria do sistema em si, e as últimas seriam capazes de dar efeito às primeiras. Somente as instituições confeririam ao sistema jurídico a objetividade e a sanção, características distintivas do Direito, segundo o autor, e das quais a norma individualmente seria esvaziada. O Direito e as instituições seriam, pois, manifestação ou expressão da realidade e da unidade de um corpo social, e a ordem social e a ordem jurídica seriam ambas dimensões da mesma sociedade. ${ }^{83}$ Embora reconheça o valor de sua perspectiva holística, focada na relação entre sociedade e sistema jurídico, GEORGES ABI-SAAB critica a minimização excessiva do papel da norma no ordenamento jurídico na perspectiva de ROMANO, vez que seriam elas garantidoras da própria coerência e integração lógica do sistema, bem como do arcabouço institucional. ${ }^{84}$

A teoria de HART, por sua vez, oferece uma terceira concepção de sistema jurídico: um conjunto composto por regras primárias e regras secundárias. As regras primárias prescrevem comportamentos, as regras secundárias regem a estrutura, função e modalidades das regras primárias e de organização do próprio sistema. As regras secundárias se dividem em: (a) regras de reconhecimento, pelas quais o sistema jurídico reconhece aquelas regras que lhe pertencem; (b) regras de mudança, que tratam do nascimento, modificação e desaparecimento das regras; e (c) regras de adjudicação, que tratam da aplicação de regras gerais a situações concretas e das sanções. ${ }^{85}$

82 KELSEN, Hans. Teoria pura do direito. 7a ed. São Paulo: Editora WMF Martins Fontes, 2006.

83 ROMANO, Santi. O ordenamento jurídico. Florianópolis: Boiteux, 2008.

84 ABI-SAAB, George. Cours Général de Droit International Public. Recueil des Cours, vol. 207, p. 9-463, 1987. p. 107.

85 HART, Herbert Lionel Adolphus. O Conceito de Direito. São Paulo: Editora WMF Martins Fontes, 2009. 
Por fim, trazemos à discussão a perspectiva de NORBERTO BOBBIO sobre o ordenamento jurídico, que em muito influencia a ciência jurídica contemporânea, e se apresenta como tentativa de releitura da teoria de KELSEN, inegavelmente influenciada pelo pensamento de ROMANO, e projetada para além da concepção de HART.

Se inicialmente BoBBIO dá um passo atrás ao conceituar o ordenamento jurídico simplesmente como "um conjunto de normas", ${ }^{86}$ que pressuporia como única condição a existência de mais de uma norma, o autor vai além ao analisar os elementos que conectam essas normas participantes do sistema entre si. Terá espaço, portanto, em sua visão, as facetas da (a) unidade; (b) coerência e (c) completude do sistema.

Assim, um ordenamento normativo se apresenta como unitário quando deriva de fontes, que por sua vez emanam do mesmo núcleo justificador dessas normas, a norma fundamental à qual todas as fontes podem ser remontadas. Sendo somente unitário, o ordenamento jurídico não se caracterizaria propriamente como sistema, pois esse pressupõe adicionalmente a coerência, para que resulte em uma "unidade sistemática". ${ }^{87}$

O autor toma, pois, o sentido de sistema como um todo no qual não podem existir normas incompatíveis. A coerência deriva não da inexistência fática de conflito entre as normas, mas da eleição de critérios para a solução dessas antinomias, de modo a manter a justiça do sistema. ${ }^{88}$ Por fim, remetendo-nos à noção de completude, BOBBIO a explicita como característica do sistema jurídico pela qual o juiz pode nele encontrar norma para solucionar qualquer caso.

Transpondo essa noção de sistema ao Direito Internacional, reafirmamos a existência de um sistema jurídico internacional, que tem a sua unidade e coerência garantidas pela aplicação de critérios de solução de incongruências, nos quais assumem

86 BOBBIO, Norberto. Teoria do Ordenamento Jurídico. $6^{\text {a }}$ ed. Brasília: Editora Universidade de Brasília, 1995. p. 31.

87 Nas palavras do autor: “Entendemos por sistema uma totalidade ordenada, um conjunto de entes entre os quais existe uma certa ordem. Para que se possa falar de uma ordem, é necessário que os entes que a constituem não estejam somente em relacionamento de coerência entre si. Quando nos perguntamos se um ordenamento constitui um sistema, nos perguntamos se as normas que o compõem estão num relacionamento de coerência entre si, e em que condições é possível essa relação." BOBBIO, Norberto. Teoria do Ordenamento Jurídico. 6a ed. Brasília: Editora Universidade de Brasília, 1995. p 71.

88 BOBBIO, Norberto. Teoria do Ordenamento Jurídico. $6^{\text {a }}$ ed. Brasília: Editora Universidade de Brasília, 1995. p. 113. 
especial relevância os princípios, enquanto vetores axiológicos e integradores, fios condutores, linhas mestras dos valores fundantes da sociedade internacional. ${ }^{89}$

A completude do sistema jurídico internacional, por sua vez, se concretiza através da atividade de interpretação pelo juiz, que se torna responsável por integrar os diferentes preceitos normativos apreendidos pelas fontes do Direito Internacional, e diante de um caso concreto, oferecer a solução que esteja em harmonia com este sistema.

\subsection{A OMC e o Direito Internacional Público}

Evidenciada a perspectiva sistêmica do Direito Internacional, cumpre adentrar nas relações entre a Organização Mundial do Comércio e o Direito Internacional Público, com fins de situar a OMC como um subsistema originado do sistema jurídico internacional, e que com ele guarda próximas relações.

\subsubsection{A OMC como um "Subsistema" Aberto do Direito Internacional Público}

Diante da percepção de inexistência de "regimes autocontidos" 90 no Direito

89 Destaca-se, contudo, o papel dos princípios como atualizadores do sistema jurídico internacional. Neste sentido: "É certo, por isso, que não se pode ter uma visão equivocada dos princípios como pilares, ou valores imutáveis do Direito Internacional Público, posto que eles foram se traduzindo de acordo com o amadurecimento da sociedade internacional, em razão da dinamização das relações internacionais, bem como pelo ambiente onde essas relações foram se desenvolvendo. Assim, existe, por assim dizer, uma multiplicidade de princípios, mesmo no Direito Internacional, de acordo com suas sub-ramificações, em consonância com o modelo de relação que é desenvolvido pelos Estados, ou mesmo como um ponto de vista do operador do Direito, ao invocar ou aplicar discricionariamente sua perspectiva sobre princípios. ” p. 200. MENEZES, Wagner. Direito Internacional da América Latina. Curitiba: Juruá, 2007.

90 Embora muito criticada, a expressão foi explicitada pela CIJ no caso United States Diplomatic and Consular Staff in Tehran, no qual a Corte considerou "the rules of diplomatic law" e "the principles of inviolability of the person of diplomatic agents and the premises of diplomatic missions" como detentores desta natureza. 
Internacional, em forte crítica a esta nomenclatura, ${ }^{91}$ vez que todos os subsistemas buscam sua origem e legitimidade no Direito Internacional Público, chega-se à concepção da OMC como um subsistema aberto do Direito Internacional Público.

A nomenclatura subsistema é preferível à expressão "regime", pois indica uma relação de pertencimento face ao sistema do qual se origina. A caracterização "aberto", por sua vez, em contraposição à ideia de limite ou contenção, indica que o subsistema encontra-se em constante fluxo e é influenciado por regras e princípios, oriundos de outros subsistemas e do Direito Internacional Público em especial.

Neste sentido, GABRIELlE MARCEAU afirma que, embora o direito da OMC seja um subsistema específico dentro do Direito Internacional e, portanto, possua regras e princípios próprios, suas disposições devem ser interpretadas em consistência com o Direito Internacional, inclusive com os direitos humanos. ${ }^{92}$

É também nesta linha o entendimento de JoOST PAWELYN, que considera o Direito da OMC como um dos ramos do Direito Internacional Público e, ${ }^{93}$ buscando uma posição conciliadora entre a fragmentação e a unidade do sistema jurídico internacional, interpreta o Direito Internacional como um universo de ilhas interconectadas. ${ }^{94}$

O sistema multilateral de comércio, contudo, desempenha um papel especial no Direito Internacional Público, não apenas sendo um produto mas também um vetor da evolução do sistema jurídico internacional. ${ }^{95}$ Isso pois a OMC fortalece a coerência do

91 Esta foi uma das principais conclusões resultante dos estudos da Comissão de Direito Internacional da ONU na temática da fragmentação: "The main conclusion from the Commission's earlier debates was that neither the Commission nor the Special Rapporteurs - nor any of the cases regularly discussed in this connection - implied that the special rules would be fully isolated from general international law. 318. The Chairman suggested that in fact the term "self-contained regime" was a misnomer in the sense that no set of rules - whether in the narrower or the broader sense - was isolated from general law. He doubted whether such isolation was even possible: a regime can receive (or fail to receive) legally binding force ("validity") only by reference to (valid and binding) rules or principles outside it. [...] Chairman observed that in none of the existing treaty-regimes was the application of general international law excluded. On the contrary, the treaty bodies made constant use of general international law." United Nations. International Law Commission. Report on the work of its fifty-sixth session (3 mai./4 jun.; 5 jul./6 aug. 2004) General Assembly Official Records, Fifty-ninth Session. Supplement No. 10 (A/59/10). para. 317/321. Disponível em: <http://untreaty.un.org/ilc//reports/2004/2004report.htm> Acesso em: 25 mar. 2013.

92 MARCEAU, Gabrielle. WTO Dispute Settlement and Human Rights. European Journal of International Law, vol. 13, p. 753-814, 2002. p. 756.

93 PAUWELYN, Joost. Conflict of Norms in Public International Law: How WTO Relates to other Rules of International Law. New York: Cambridge University Press. 2003. p. 25.

94 PAUWELYN, Joost. Bridging Fragmentation and Unity: International Law as a universe of Interconnected Islands. Michigan Journal of International Law, vol. 25, p. 903-916, 2003-2004.

95 LAMY, Pascal. The Place of the WTO and its Law in the International Legal Order. European Journal of International Law, vol. 17, n. 5, p. 969-984, 2006. p. 970. 
sistema jurídico internacional como um todo, contribuindo para sua "comunitarização", 96 como se passa a analisar brevemente.

\subsubsection{A Perspectiva de Comunitarização da OMC}

Se por um lado, a OMC funciona como um fórum de negociação, em aplicação do paradigma de "tradicional" do Direito Internacional de cooperação, por outro a sofisticação do Sistema de Solução de Controvérsias pode indicar características de uma organização de integração, em um paradigma contemporâneo do Direito Internacional. ${ }^{97}$

Em um segundo sentido, a perspectiva comunitária também é aplicada à OMC para conceituá-la como uma "comunidade" de direito (Gemeinschaf), ${ }^{98}$ em análise sociológica de sua constituição, como paradigma substitutivo à perspectiva racionalista. Ambos os sentidos se interconectam. Nesta nova abordagem teórica da OMC, os principais atores do quadro analítico do comércio internacional não são os Estados, ${ }^{99}$ mas a variedade de agentes econômicos individuais - tais como importadores, fornecedores, distribuidores, consumidores, etc. - que participam da comunidade do comércio internacional. ${ }^{100101}$ Neste

96 Nas palavras de Pascal Lamy: "The greater the coherence within the international legal order, the stronger the international 'community'. In this sense the WTO is an engine, a motor energizing the international legal order. This is, in my view, the place and role of the WTO and its legal order in the international legal order: a catalyst for international mutual respect towards international coherence and even for increased global governance, which I believe is needed if we want the world we live in to become less violent, be that social, political, economic or environmental violence." LAMY, Pascal. The Place of the WTO and its Law in the International Legal Order. European Journal of International Law, vol. 17, n. 5, p. 969-984, 2006. p. 984.

97 LAMY, Pascal. The Place of the WTO and its Law in the International Legal Order. European Journal of International Law, vol. 17, n. 5, p. 969-984, 2006. p. 970.

98 CHO, Sungjoon. Beyond Rationality: A Sociological Construction of the World Trade Organization. Virginia Journal of International Law, vol. 52, p. 321-354, 2011-2012. p. 321.

99 É necessário destacar que o termo é utilizado nesta e em outras sentenças para designar os Estados como unidades básicas da sociedade internacional e participantes da $\mathrm{OMC}$, contudo não somente Estados são aceitos como membros da $\mathrm{OMC}$, que está aberta também à acessão de "territórios aduaneiros". Neste sentido esclarece a primeira das notas explicativas do Acordo Constitutivo da OMC "Entende-se que os termos 'país' e 'países' tais como utilizados no presente Acordo e nos Acordos Multilaterais de Comércio incluem quaisquer territórios aduaneiros autônomos dos membros da OMC." Caso único é o da União Europeia, por sua vez, é membro da OMC em status independente de seus Estados membros, como explica-se adiante.

100 CHO, Sungjoon. Beyond Rationality: A Sociological Construction of the World Trade Organization. Virginia Journal of International Law. Vol. 52, p. 321, 2011-2012. p. 343.

101 MANN, Erika. A Parliamentary Dimension to the WTO: More than Just a Vision. Reforming the 
viés, a OMC abarca expectativas dos múltiplos integrantes da comunidade, que possuem objetivos compartilhados na manutenção e respeito ao sistema.

Neste quadro analítico, assumem relevância especial as discussões sobre o Sistema de Solução de Controvérsias da OMC e a responsabilidade internacional no contexto multilateral, vez que há na doutrina a percepção de que o elemento de presunção de interesse econômico ou jurídico na instauração de procedimentos de solução de controvérsias simbolizaria a confirmação da hipótese de comunitarização da OMC. ${ }^{102}$

Isso é, o fato de cada membro ser capaz de acionar a responsabilização por violação da normativa multilateral ainda que não tenha interesse direto ou pessoal, explicita a existência de um interesse "comunitário" ou interesse "sistêmico" no respeito à legalidade. 103 Essa faceta de institucionalização da responsabilidade internacional no sistema multilateral de comércio simbolizaria uma primazia do respeito ao direito em substituição à lógica de reparação, em valorização aos interesses comuns. ${ }^{104}$

Em ambos os sentidos, a perspectiva comunitária simboliza a passagem da compreensão da OMC em uma lógica contratual e interestatal clássica para uma interpretação das "dimensões constitucionais" do sistema multilateral de comércio, em face aos agentes econômicos individuais integrantes da comunidade do comércio internacional, e como parte do sistema jurídico internacional em um sentido mais amplo. ${ }^{105}$

World Trading System. In: PETERSMANN, Ernst- Ulrich. Reforming the World Trading System. Legitimacy, Efficiency and Democratic Governance. Oxford: Oxford University Press, 2005, p. 421-428. p. 421.

102 Embora seja crescente esta interpretação, há também ceticismo em relação à extensão do significado desta presunção. Neste sentido, Alberto do Amaral Junior afirma "Na conjuntura atual, o prejuízo indireto decorrente de um interesse sistêmico não permite ao membro exercer o papel de ministério público nem lhe faculta propor uma espécie de actio popularis para a defesa do interesse público na OMC." AMARAL JUNIOR, Alberto do. A Solução de Controvérsias na OMC. São Paulo: Atlas, 2008. p. 107.

103 LAFER, Celso. A OMC e a regulamentação do comércio internacional: uma visão brasileira. Porto Alegre: Livraria do Advogado, 1998. p. 134

104 "An important, and in many ways innovative, feature of this system is the presumption of legal and economic interest in bringing proceedings, which confirms the hypothesis of a 'communitization' of WTO law: each Member State can enforce WTO law whether or not it has a direct and personal interest - in the interests, so to speak, of the 'community of states parties'. [...]" LAMY, Pascal. The Place of the WTO and its Law in the International Legal Order. European Journal of International Law, vol. 17, n. 5, p. 969-984, 2006. p. 976.

105 PETERSMANN, Ernst-Ulrich. Multi-Level Judicial Trade Governance without Justice? On the Role of Domestic Courts in the WTO Legal and Dispute Settlement System. European University Institute, Department of Law, EUI Working Paper LAW, n. 2006/44. p. 8. PETERSMANN, Ernst-Ulrich. Multilevel Judicial Governance of International Trade Requires a Common Conception of Rule of Law and Justice. Journal of International Economic Law, vol. 10, p. 529-551, 2007. 
A comparação com a evolução do ordenamento jurídico comunitário europeu é oportuna, e não escapa a diversos doutrinadores, ${ }^{106}$ que buscam na União Europeia preciosas lições para o futuro do Direito Internacional. ${ }^{107}$ Assim como o atual Tribunal de Justiça da União Europeia (TJUE) ${ }^{108}$ foi essencial no desenvolvimento da ordem jurídica comunitária - ${ }^{109}$ transformando tratados originariamente intergovernamentais, através de interpretações constitucionais centradas no cidadão, em instrumentos constitucionais de proteção da comunidade e dos direitos individuais - é possível que o Sistema de Solução de Controvérsias desempenhe papel central na comunitarização da OMC. ${ }^{110}$

Nos Acordos Regionais de Comércio, a promoção de segurança nas relações econômicas internacionais através de mecanismos de solução de controvérsias é um de seus elementos essenciais. No entanto, em contraste com o Direito Comunitário, o Direito

106 SLAUGHTER, Anne-Marie. BURKE-WHITE, William. Future of International Law Is Domestic (or, the European Way of Law). Harvard International Law Journal, vol. 47, p. 327-352, 2006. HSUEH, Ching-wen. Direct Effect, WTO Compliance Mechanism and the Protection for Individuals: Lessons Learned from the EC. Asian Journal of WTO \& International Health Law and Policy, vol. 4, issue 2, p. 521-556, sep. 2009. PETERSMANN, Ernst-Ulrich. From the Hobbesian International Law of Coexistence to Modern Integration Law: The WTO Dispute Settlement System, Journal of International Economic Law, vol. 1, issue 2, p. 175-198, 1998. PETERSMANN, Ernst-Ulrich Multilevel Judicial Governance as Guardian of the Constitutional Unity of International Economic Law. Loyola of Los Angeles International and Comparative Law Review, vol. 30, Issue 3, p. 367-418, 2008. PETERSMANN, Ernst-Ulrich. PETERSMANN, Ernst-Ulrich. The Future of the WTO: From Authoritarian Mercantilism to Multilevel Governance for the Benefit of Citizens. Asian Journal of WTO \& International Health Law and Policy, vol. 6 , issue 1, p. 45-80, $\mathrm{mar} / 2011$.

107 Embora não se tenha o objetivo de discutir as causas e o alcance da crise econômica com a qual tem se deparado a União Europeia, é relevante destacar que tal crise não desabona o significativo desenvolvimento normativo-institucional do ordenamento jurídico comunitário, com características ímpares como: primazia do direito comunitário, direta aplicabilidade, acesso ao sistema jurisdicional e aplicação de direitos e garantias supranacionais. Deste modo, a crise não abala a capacidade desta ordem jurídica de oferecer modelos de mecanismos e instrumentos bem sucedidos, especialmente no que tange à lógica diferenciada de relação entre o Direito Internacional (comunitário) e o direito interno dos Estados membros.

108 Referimo-nos ao Tribunal de Justiça da União Europeia (TJUE) como o órgão jurisdicional principal da atual União Europeia. Sua configuração modificou-se com o passar do tempo, assim como sua nomenclatura, uma vez que era anteriormente designado Tribunal de Justiça das Comunidades Europeias (TJCE). Não faremos diferenciação precisa entre eles, e pela compreensão de continuidade, nos referimos também por meio da sigla TJUE/TJCE.

109 Cita-se jurisprudência paradigmática neste sentido, como por exemplo: Caso Van den et Loos, no qual TJUE reconheceu a Comunidade como constitutiva de uma "Nova Ordem Jurídica" de direito internacional, " [...] pelo fato de os Estados terem limitado seus direitos soberanos, ainda que em áreas limitadas, e os sujeitos que lhe estão subordinados não constituem somente os Estados-membros, mas também seus nacionais" Van Gend en Loos v. Administratie der Belastingen (Rec.1963, p.1), Case 26/62, 05 fev. 1963. p. 3. Também é relevante a posição explicitada no caso Costa-E.N.E.L: "Ao criar uma comunidade de duração ilimitada, detentora de suas próprias instituições, sua própria personalidade, sua própria capacidade e capacidade de representação no plano internacional e, particularmente, poderes reais oriundos de uma limitação de soberania ou uma transferência de poderes dos Estados para a comunidade, os Estados Membros limitaram seus poderes, ainda que em áreas limitadas, e criaram um corpo de direito que subordina tanto seus nacionais quanto os próprios Estados." Costa / E.N.E.L. (Rec.1964, p.585), Case 6/64, 15 jul. 1964. p. 1141.

110 PETERSMANN, Ernst-Ulrich. De-Fragmentation of International Economic Law through Constitutional Interpretation and Adjudication with Due Respect for Reasonable Disagreement. Loyola University Chicago International Law Review, vol. 6, issue 1, p. 209-248, 2008-2009. 
Internacional emanado da OMC é classicamente compreendido como fonte de direitos e obrigações entre Estados, em desconsideração a direitos individuais. ${ }^{111}$ Essa perspectiva pode ser superada, por meio da interpretação constitucional, conforme explicitada supra.

Desse modo, ERnSt-UlRich PETERSMANn destaca que a realização dos objetivos mais amplos do sistema multilateral e de seu sistema de solução de controvérsia, relacionados à segurança e previsibilidade, só pode se dar em plenitude sob uma perspectiva focada no cidadão, a partir de reformas que promovam uma governança

coerente entre este Sistema de Solução de Controvérsias e os órgãos domésticos. ${ }^{112}$ Ademais, as obrigações dos membros da OMC não podem ser interpretadas descontextualizadas de obrigações prescritas na Carta da ONU, tais como o respeito à justiça e observância dos direitos humanos e liberdades fundamentais.

\subsubsection{A OMC e a Convenção de Viena sobre o Direito dos Tratados}

A relação entre a OMC e a Convenção de Viena sobre o Direito dos Tratados (CVDT) se apresenta sob duas principais dimensões: ${ }^{113}$ (i) a aplicação dos métodos previstos da CVDT; ${ }^{114}$ na atividade interpretativa dos painéis e do Órgão de Apelação do

111 PETERSMANN, Ernst-Ulrich. Multi-Level Judicial Trade Governance without Justice? On the Role of Domestic Courts in the WTO Legal and Dispute Settlement System. European University Institute, Department of Law, EUI Working Paper LAW, n. 2006/44. p. 9.

112 PETERSMANN, Ernst-Ulrich. Multi-Level Judicial Trade Governance without Justice? On the Role of Domestic Courts in the WTO Legal and Dispute Settlement System. European University Institute, Department of Law, EUI Working Paper LAW, n. 2006/44. p. 12.

113 Outras dimensões podem ser vislumbradas, a depender do objetivo e do enfoque da análise. Por exemplo: "An exploration of what is involved in the principle behind Article 31(3)(c) will enable the elaboration of an outline approach to interpretation which will: (a) reinstate the central role of customary, or general, international law in the interpretation of treaties; $(b)$ locate the relevance of other conventional international law in this process; and (c) shed new light on the position of treaties in the progressive development of international law over time (the so-called problem of 'intertemporality')." MCLACHLAN, Campbell. Principle of Systemic Integration And Article 31(3)(C) of The Vienna Convention. International and Comparative Law Quarterly, vol. 54, p. 279-319, 2005. p. 281-2.

114 Sobre os métodos de interpretação de tratados previstos na CVDT, Cf: LUPI, André Lipp Pinto Bastos. Comentários ao Artigo 31. In: SALIBA, Aziz Tuffi (Org.) Direito dos Tratados: Comentários à Convenção de Viena sobre o Direito dos Tratados (1969). Belo Horizonte: Arraes Editores, 2011, p. 223-238. 
Sistema de Solução de Controvérsias; e (ii) a aplicação da CVDT como base normativa de reforço da obrigatoriedade das decisões do Sistema de Solução de Controvérsias da OMC.

No que tange à primeira dimensão, há a percepção de que por força do artigo 3.2 do Entendimento relativo às Normas e Procedimentos sobre Solução de Controvérsias da OMC, ${ }^{115}$ conjugado com o artigo 31(3)(c) da CVDT, os membros presumidamente aceitaram o efeito vinculante e a aplicação do Direito internacional às regras da OMC. ${ }^{116}$ 117

Assim, o princípio da interpretação sistêmica consagrado na CVDT ${ }^{118}$ é a porta de entrada para a utilização do Direito Internacional Público na atividade interpretativa empreendida pelos painéis e pelo Órgão de Apelação em sua análise jurídica das controvérsias, e a ponte entre o Direito da OMC e o restante do sistema jurídico internacional.

De fato, os painéis e o Órgão de Apelação já aplicaram referido dispositivo da CVDT em diversas oportunidades, ${ }^{119}$ afirmando que o GATT - e consequentemente os

115 Entendimento Relativo às Normas e Procedimentos sobre Solução de Controvérsias. Versão oficial em português segundo o decreto n. 1.355, de 30 dez. 1994, que promulga a Ata Final que Incorpora os Resultados da Rodada Uruguai de Negociações Comerciais Multilaterais do GATT. "O sistema de solução de controvérsia da OMC é elemento essencial para trazer segurança e previsibilidade ao sistema multilateral de comércio. Os Membros reconhecem que esse sistema é útil para preservar direitos e obrigações dos Membros dentro dos parâmetros dos acordos abrangidos e para esclarecer as disposições vigentes dos referidos acordos em conformidade com as normas correntes de interpretação do direito internacional público. As recomendações e decisões do OSC não poderão promover o aumento ou a diminuição dos direitos e obrigações definidos nos acordos abrangidos."

116 Como Joost Pauwelyn destaca: "[...] the jurisdiction of WTO panels is limited. The applicable law before them is not." PAUWELYN, Joost. The Role of Public International Law in the WTO: How Far Can We Go? American Journal of International Law, vol. 95, p. 535-578, 2001. p. 566.

117 Nas palavras de Peter Kuyper: "Não pode haver muita dúvida de que os autores desta provisão [Artigo 3.2 do ESC] pretendiam que esta fosse uma referência indireta aos Princípios dos Artigos 31 e 32 da Convenção de Viena, mas que a Convenção em si não poderia ser referida, pois vários futuros membros da OMC não são parte nela (por exemplo, Estados Unidos) ou não podem vir a ser parte (por exemplo, a Comunidade Europeia)." KUYPER, Peter J. O Direito do GATT com um Campo Especial do Direito Internacional: Ignorância, Refinamentos Posteriores ou um Sistema Autocontinente de Direito Internacional? In: CASELLA, Paulo Borba; MERCADANTE, Araminta de (coord.). Guerra comercial ou integração mundial pelo comércio?: a OMC e o Brasil. São Paulo: LTr, 1998, p. 15-49. p. 20.

118 Segundo o autor, trata-se de um princípio geral de interpretação dos tratados, o princípio da integração sistêmica, de valor fundante e constitucional no sistema jurídico internacional: "However, it is submitted that the principle is not to be dismissed as a mere truism. Rather, it has the status of a constitutional norm within the international legal system. In this role, it serves a function analogous to that of a master-key in a large building.[...]" MCLACHLAN, Campbell. Principle of Systemic Integration And Article 31(3)(C) of The Vienna Convention. International and Comparative Law Quarterly, vol. 54, p. 279-319, 2005. p. 281-282.

119 Para uma análise empírica desta questão, em comparação a outros Tribunais Internacionais, Cf: CHARNEY, Jonathan I. Is international law threatened by multiple international tribunals? Recueil des cours, vol. 271, p. 101-382, 1998. p. 145-153. 
Acordos da OMC - "não deve ser lido em isolamento clínico do direito internacional público". 120

No tocante à segunda dimensão desta relação, refere-se ao fato de que o cumprimento das regras da OMC e das decisões de seu Sistema de Solução de Controvérsias, é obrigatório aos seus membros, por força da aplicação da CVDT.

Isto pois a obrigatoriedade das normas multilaterais e das decisões do Sistema de Solução de Controvérsias da OMC se baseia no Acordo Constitutivo da OMC e em seus anexos - em especial no Entendimento relativo às Normas e Procedimentos sobre Solução de Controvérsias - tratados internacionais em seu primeiro sentido. ${ }^{121} 122$

Assim explicita CELSO LAFER, sobre a obrigatoriedade de seu cumprimento:

\begin{abstract}
A primeira observação a ser feita sobre o sistema de solução de controvérsias da OMC é a de que, enquanto expressão de codificação e desenvolvimento progressivo e em contraste com o sistema do GATT, não é mero fruto de prática e interpretação. É uma obrigação, de outra hierarquia jurídica, uma vez que contemplada pelo próprio tratado constitutivo da OMC, e, enquanto tal, obriga a todos os Estados-membros e deve ser cumprida de boa-fé" (cf. Convenção de Viena sobre o Direito dos Tratados- art. 26). Em outras palavras, é parte do quadro constitutivo de uma nova organização - ela própria dotada de subjetividade internacional especializada, distinta da de seus membros -, o que não acontecia com o GATT que era de natureza contratual. Com efeito, ex vi do art. II do Acordo de Marrakesh, que trata do objeto e alcance da OMC - o Anexo 2, que é o "Dispute Settlement Understanding" é parte integrante dos compromissos dos Estados-membros. 123
\end{abstract}

120 Tradução livre do original em língua inglesa: "[...] is not to be read in clinical isolation from public international law." WTO. Appellate Body Report, United States - Standards for Reformulated and Conventional. WT/DS2/AB/R, 29 abr. 1996. para. 16.

121 Convenção de Viena sobre o Direito dos Tratados. Versão oficial em português segundo o decreto n. 7.030, 14 dez. 2009, que promulga a Convenção de Viena sobre o Direito dos Tratados, concluída em 23 de maio de 1969, com reserva aos Artigos 25 e 66. "Artigo 2 Expressões Empregadas 1. Para os fins da presente Convenção: a) "tratado" significa um acordo internacional concluído por escrito entre Estados e regido pelo Direito Internacional, quer conste de um instrumento único, quer de dois ou mais instrumentos conexos, qualquer que seja sua denominação específica [...]"

122 Sobre as motivações pelas quais o instrumento não foi denominado "tratado": "O Acordo da OMC contém todos os elementos de um tratado, no sentido de ato mais solene, regulador de assuntos da mais alta relevância para os Estados signatários. Não podia ser expressamente caracterizado como tratado, contudo, pela razão simples, mas incontornável, de que um dos principais participantes das negociações, o mais influente, isoladamente, os Estados Unidos da América, estava cerceado pelas próprias disposições constitucionais. [...]" PRATES, Alcides G. R. Comentários sobre o Acordo Constitutivo da OMC. In: CASELLA, Paulo Borba; MERCADANTE, Araminta de (coord.). Guerra comercial ou integração mundial pelo comércio?: a OMC e o Brasil. São Paulo: LTr, 1998, p. 94-124. p. 95.

123 LAFER, Celso. A OMC e a regulamentação do comércio internacional: uma visão brasileira. Porto Alegre: Livraria do Advogado, 1998. p. 123-125. LAFER, Celso. O Sistema de Solução de Controvérsias da Organização Mundial do Comércio. In: CASELLA, Paulo Borba; MERCADANTE, Araminta de (coord.). Guerra comercial ou integração mundial pelo comércio?: a OMC e o Brasil. São 
A CVDT, aplicando-se também a tratados constitutivos de Organizações Internacionais e a tratados adotados no âmbito de uma Organização Internacional por força de seu artigo $5^{\circ},{ }^{124}{ }^{125}$ codifica o princípio basilar do Direito Internacional pacta sunt servanda. ${ }^{126}$ Assim é que o artigo 26 prevê que os tratados internacionais obrigam as partes, que devem cumpri-los de boa-fé. ${ }^{127} 128$

O princípio foi aplicado em diversas oportunidades pelo Sistema de Solução de Controvérsias da OMC. No caso Argentina - Measures Affecting Imports of Footwear, Textiles, Apparel and Other Items, o painel menciona, em referência à solução de controvérsias, que: “[...] deve assumir que os membros da OMC irão desempenhar as suas obrigações do tratado de boa-fé, uma vez que são obrigados a fazê-lo pelo Acordo da OMC e pelo direito internacional." 129130

De modo correlato, o Órgão de Apelação explicitou no caso European Communities - Trade Description of Sardines:

Paulo: LTr, 1998, p. 729-755. p. 744.

124 Convenção de Viena sobre o Direito dos Tratados. Versão oficial em português segundo o decreto n. 7.030, 14 dez. 2009, que promulga a Convenção de Viena sobre o Direito dos Tratados, concluída em 23 de maio de 1969, com reserva aos Artigos 25 e 66. "Artigo 5 Tratados Constitutivos de Organizações Internacionais e Tratados Adotados no Âmbito de uma Organização Internacional- A presente Convenção aplica-se a todo tratado que seja o instrumento constitutivo de uma organização internacional e a todo tratado adotado no âmbito de uma organização internacional, sem prejuizo de quaisquer normas relevantes da organização."

125 Para um comentário das negociações e aprovação deste artigo, Cf: RIBEIRO, Manuel de Almeida. Comentários ao Artigo 5. In: SALIBA, Aziz Tuffi (Org.) Direito dos Tratados: Comentários à Convenção de Viena sobre o Direito dos Tratados (1969). Belo Horizonte: Arraes Editores, 2011, p. 24-26.

126 Sobre uma análise do princípio pacta sunt servanda como grundnorm do Direito Internacional em Kelsen, críticas e reformulações, Cf: CÂMARA FILHO, José Sette. Hans Kelsen e a teoria pura do Direito Internacional. Boletim da Sociedade Brasileira de Direito Internacional, n. 8, p. 70-91, jul./dez. 1948.

127 Convenção de Viena sobre o Direito dos Tratados. Versão oficial em português segundo o decreto n. 7.030, 14 dez. 2009, que promulga a Convenção de Viena sobre o Direito dos Tratados, concluída em 23 de maio de 1969, com reserva aos Artigos 25 e 66. "Artigo 26 Pacta sunt servanda - Todo tratado em vigor obriga as partes e deve ser cumprido por elas de boa fé."

128 MACEDO, Paulo Emílio Vauthier Borges de. Comentários ao Artigo 26. In: SALIBA, Aziz Tuffi (Org.) Direito dos Tratados: Comentários à Convenção de Viena sobre o Direito dos Tratados (1969). Belo Horizonte: Arraes Editores, 2011, p. 182-189.

129 Tradução livre do original em língua inglesa: “[...] must assume that WTO Members will perform their treaty obligations in good faith, as they are required to do by the WTO Agreement and by international law." WTO. Panel Report, Argentina - Measures Affecting Imports of Footwear, Textiles, Apparel and Other Items. WT/DS56/R, 25 nov. 1997. para. 6.14.

130 No tocante à obrigatoriedade de cumprir as decisões, segundo a ordem jurídica internacional, é interessante observar que em 1948 Eduardo Theiler já reconhecia a concretização de decisões internacionais como dever dos Estados: "Executar as decisões e recomendações dos órgãos internacionais é outro dever que resulta da qualidade de membro da comunidade internacional." THEILER, Eduardo. Os direitos e deveres internacionais dos Estados. Boletim da Sociedade Brasileira de Direito Internacional, n. 8, p. 5769, 1948. p. 63. 
Devemos presumir que os membros da OMC irão cumprir suas obrigações decorrentes de tratados de boa-fé, conforme exigido pelo princípio do pacta sunt servanda articulado no artigo 26 da Convenção de Viena. E, sempre na solução de controvérsias, cada membro da OMC deve assumir a boa-fé de todos os outros membros. 131

\section{O Órgão de Apelação retoma a questão na controvérsia United States - Continued}

Dumping and Subsidy Offset Act of 2000:

[A] execução dos tratados também é regida pela boa-fé. Assim, o artigo 26 da Convenção de Viena, intitulado pacta sunt servanda, ao qual vários apelantes se refere em suas alegações, estabelece que '[c]ada tratado em vigor obriga as partes a e deve ser cumprido por elas de boa-fé.' [...] Este princípio, ao mesmo tempo um princípio geral de direito e um princípio geral de direito internacional, controla o exercício de direitos por parte dos Estados 132

Relevante destacar, ainda, o desenvolvimento da aplicação do princípio ao sistema multilateral do comércio, explicitado pelo painel no caso Canada/United States Continued Suspension of Obligations in the EC-Hormones Dispute:

Somos da opinião de que o princípio da boa-fé pode ser analisado principalmente em relação às seguintes categorias:

(a) conduta de boa-fé em um procedimento de solução de controvérsias;

(b) boa-fé substantiva, ou seja, no que diz respeito às obrigações substanciais de um Estado;

(c) a boa fé no processo de interpretação (artigo 31 da Convenção de Viena sobre o Direito dos Tratados). ${ }^{133}$

131 Tradução livre do original em língua inglesa: "We must assume that Members of the WTO will abide by their treaty obligations in good faith, as required by the principle of pacta sunt servanda articulated in Article 26 of the Vienna Convention. And, always in dispute settlement, every Member of the WTO must assume the good faith of every other Member." WTO. Appellate Body Report, European Communities Trade Description of Sardines. WT/DS231/AB/R, 29 set. 2002. para. 278.

132 Tradução livre do original em língua inglesa: "[The] performance of treaties is also governed by good faith. Hence, Article 26 of the Vienna Convention, entitled Pacta Sunt Servanda, to which several appellees referred in their submissions, provides that '[e]very treaty in force is binding upon the parties to it and must be performed by them in good faith.' [...] This principle, at once a general principle of law and a general principle of international law, controls the exercise of rights by states." WTO. Appellate Body Report, United States - Continued Dumping and Subsidy Offset Act of 2000. WT/DS217/AB/R, WT/DS234/AB/R, 16 jan. 2003. para. 296-299.

133 Tradução livre do original em língua inglesa: "We are of the view that the principle of good faith could be analysed mainly in respect of the following categories: (a) good faith conduct in a dispute settlement procedure; (b) substantive good faith, i.e. with respect to the substantive obligations of a State; (c) good faith in the interpretation process (Article 31 of the Vienna Convention on the Law of Treaties)". WTO. 
Ademais, o artigo 27 da CVDT explicita que o direito interno dos Estados não é justificativa para o inadimplemento de um tratado, ${ }^{134} 135136$ por meio do qual reitera-se a ideia de que cabe a cada um dos membros da OMC o desenvolvimento de procedimentos, mecanismos e instituições internas capazes de promover o cumprimento com as obrigações decorrentes dos Acordos da OMC, dentre elas a de implementação das decisões de seu Sistema de Solução de Controvérsias.

A jurisprudência do Sistema de Solução de Controvérsias da OMC é também farta de decisões aplicando este artigo da CVDT. Cite-se, por exemplo, a disputa Brazil Export Financing Programme for Aircraft, na qual o painel, decidindo sobre a continuidade do cumprimento de obrigações contratuais assumidas internamente, contrárias à decisão do Órgão de Apelação, afirmou: “ [...] De todo modo, lembramos que, nos termos do artigo 27 da Convenção de Viena sobre o Direito dos Tratados, uma parte em um tratado não pode invocar as disposições de seu direito interno para justificar o inadimplemento de um tratado." 137

De modo correlato, no caso Mexico - Measures Affecting Telecommunications Services:

[...]De acordo com o princípio estabelecido no artigo 27 da Convenção de Viena, uma exigência imposta por um Membro ao abrigo do seu direito interno em relação a um grande fornecedor não pode unilateralmente corroer os seus

Panel Reports, United States/Canada-Continued Suspension of Obligations in the EC - Hormones Dispute, WT/DS320/R, WT/DS321/R, 31 mar. 2008. para. 7.313

134 Convenção de Viena sobre o Direito dos Tratados. Versão oficial em português segundo o decreto n. 7.030, $14 \mathrm{dez}$. 2009, que promulga a Convenção de Viena sobre o Direito dos Tratados, concluída em 23 de maio de 1969, com reserva aos Artigos 25 e 66. "Artigo 27 Direito Interno e Observância de Tratados Uma parte não pode invocar as disposições de seu direito interno para justificar o inadimplemento de um tratado. Esta regra não prejudica o artigo 46."

135 MACEDO, Paulo Emílio Vauthier Borges de. Comentários ao Artigo 27. In: SALIBA, Aziz Tuffi (Org.) Direito dos Tratados: Comentários à Convenção de Viena sobre o Direito dos Tratados (1969). Belo Horizonte: Arraes Editores, 2011, p. 191-197.

136 Em relação à "exceção" prevista pelo artigo 46, e aos parâmetros para interpretá-la, Cf: SALIBA, Aziz Tuffi; AUGUSTIN, Bruno Herwig Rocha. Comentários ao Artigo 46. In: SALIBA, Aziz Tuffi (Org.) Direito dos Tratados: Comentários à Convenção de Viena sobre o Direito dos Tratados (1969). Belo Horizonte: Arraes Editores, 2011, p. 372-404.

137 Tradução livre do original em língua inglesa: "In any event, we recall that, under Article 27 of the Vienna Convention on the Law of Treaties, a party to a treaty may not invoke the provisions of its internal law as justification for its failure to perform a treaty.” WTO. Panel Report, Brazil - Export Financing Programme for Aircraft - Recourse by Canada to Article 21.5 of the DSU. WT/DS46/RW, 26 jul. 2001. nota 23. 
compromissos internacionais assumidos em suas listas de concessões em face de outros membros da OMC [...] 138

Aos argumentos de que membros da OMC não são signatários da Convenção de Viena do Direito dos Tratados, notadamente os EUA e a UE/CE, afirma-se que é de amplo conhecimento o caráter costumeiro adquirido por certas disposições da CVDT, não exigindo-se a sua ratificação para que seja cogente aos membros da sociedade internacional, entendimento inclusive já explicitado pelo Órgão de Apelação. ${ }^{139} 140$

\subsection{A Dimensão Jurídica da OMC e o Sistema de Solução de Controvérsias no Cenário Contemporâneo}

A OMC representa uma organização única no cenário contemporâneo, atuando como um veículo para a evolução do Direito Internacional, e para a progressiva transformação da sociedade internacional em uma verdadeira comunidade global. ${ }^{141}$ Essa organização assume especial relevância, pois é capaz de demonstrar níveis crescentes de governabilidade global.

138 Tradução livre do original em língua inglesa: "In accordance with the principle established in Article 27 of the Vienna Convention, a requirement imposed by a Member under its internal law on a major supplier cannot unilaterally erode its international commitments made in its schedule to other WTO Members". WTO. Panel Report, Mexico - Measures Affecting Telecommunications Services. WT/DS204/R, 2 abr. 2004. para. 7.244.

139 Nas palavras dos autores: "The universal application of the provisions of the VCLT to international trade law is problematic, as some WTO Members, including United States, are not parties. However, the Appellate Body in Japan-Taxes implicitly resolved any uncertainty about its application to non-partied by declaring that the VCLT represents a codification of customary international law and is therefore binding on all States." CAMERON, James; GRAY, Kevin R. Principles of International Law in the WTO Dispute Settlement Body. International and Comparative Law Quarterly, vol. 50, p. 249-298, 2001. p. 254.

140 Conforme ensina Welber Barral: "[...] a Convenção de Viena vem sendo utilizada como grande parâmetro para a solução das controvérsias na OMC, mesmo quando envolvendo Membros que não são partes da Convenção de Viena, como é o caso do Brasil e dos EUA. Esta prática nunca foi contestada por qualquer Membro da OMC, o que leva a crer que a convenção de Viena foi entendida como materializando regras consuetudinárias de interpretação de tratados internacionais, regras que, portanto, são obrigatórias para todos os Membros." BARRAL, Welber. Solução de Controvérsias na Organização Mundial do Comércio. Brasília: Fundação Alexandre de Gusmão, 2007. p. 67.

141 LAMY, Pascal. The Place of the WTO and its Law in the International Legal Order. European Journal of International Law, vol. 17, n. 5, p. 969-984, 2006. p. 975. 
Durante as últimas seis décadas, o sistema GATT-OMC se consolidou como foro para interação, comunicação, e negociação em matérias relacionadas ao comércio pelos Estados, enquanto representantes de diversos interesses de seus setores nacionais. A conversão das expectativas de seus membros em compromissos jurídicos é o resultado deste processo de negociação, na busca por objetivos compartilhados, tais como o livre comércio e o desenvolvimento. ${ }^{142} 143$

Para além da esfera política de exercício diplomático da negociação, notadamente presente em seus procedimentos, a dimensão jurídica da OMC - sua esfera de adjudicação traz ao sistema multilateral de comércio elementos de previsibilidade e estabilidade. ${ }^{144} \mathrm{O}$ sistema multilateral de comércio é, portanto, organizado em torno de regras jurídicas e de um mecanismo de solução de controvérsias com exclusividade de interpretação de seus Acordos. ${ }^{145}$

Além da produção de efeitos concretos especificamente nas economias e sociedades nacionais dos membros envolvidos em uma determinada controvérsia, a relevância do Sistema de Solução de Controvérsias se expande. Isso pois a função de interpretação das regras multilaterais e o papel normativo de sua jurisprudência exercem influência sob as políticas comerciais dos Estados em médio e longo prazo. ${ }^{146}$

Isto é, embora a princípio a solução de um determinado caso seja apenas cogente para as partes em litígios, inexistindo o princípio do stare decisis, ${ }^{147}$ a jurisprudência

142 CHO, Sungjoon. Beyond Rationality: A Sociological Construction of the World Trade Organization. Virginia Journal of International Law, vol. 52, p. 321-354, 2011-2012. p. 343.

143 Acerca da relação entre comércio e a promoção do desenvolvimento, refere-se ao trabalho de Welber Barral: "Este artigo prefere, aristotelicamente, a terceira postura: o comércio internacional nem é a causa exclusiva das mazelas dos paises pobre, nem serve como mecanismo único de desenvolvimento. [...] o comércio internacional pode ser um instrumento estratégico para o desenvolvimento. O sucesso de sua utilização, entretanto, dependerá de fatores institucionais e sociais que não são inerentes nem derivados das práticas comerciais." BARRAL, Welber. A Influência do Comércio Internacional no Processo de Desenvolvimento. In: BARRAL, Welber; PIMENTEL, Luiz Otávio (Org.). Comércio Internacional e Desenvolvimento. Florianópolis: Fundação Boiteaux, 2006, p. 11-35. p. 12

$144 \quad$ Nas palavras do autor: "Ao final, a avaliação do sistema de solução de controvérsias da OMC permite concluir que este sistema trouxe um maior grau de previsibilidade e estabilidade das relações econômicas internacionais. Prova disto é que o OSC é hoje o mecanismo internacional que mais recebe reclamações, chegando a três centenas nos últimos oito anos. E isto mesmo reconhecendo-se que o sistema não é perfeitamente justo - qual tribunal o é? - e que as regras de discriminação positiva em favor dos paises em desenvolvimento são, acima de tudo, retóricas. " BARRAL, Welber. Solução de Controvérsias na Organização Mundial do Comércio. Brasília: FUNAG, 2007. p. 82.

145 AMARAL JUNIOR, Alberto do. A Solução de Controvérsias na OMC. São Paulo: Atlas, 2008.

146 AZEVEDO, Roberto Carvalho de. Prefácio. In: BENJAMIN, Daniela Arruda. (Org). O Sistema de Solução de Controvérsias da OMC: uma perspectiva brasileira. Brasília : FUNAG, 2013, p. 23-30. p. 26.

147 Há certa discussão doutrinaria acerca da noção de precedente no Sistema de Solução de Controvérsias da OMC. Embora a literalidade dos dispositivos do Entendimento afaste a aplicação do 
construída de modo consistente pelo Órgão de Apelação tem garantido não só a previsibilidade na interpretação do corpus juris da OMC, ${ }^{148}$ mas inclusive o seu desenvolvimento em face da inércia na construção de novos consensos negociais. ${ }^{149}$

O Sistema de Solução de Controvérsias da OMC, portanto, no exercício de seu controle de legalidade, fortalece a unidade, o equilíbrio e a estabilidade do sistema multilateral de comércio. ${ }^{150}$ Ademais, no cenário contemporâneo sua relevância se expande, na medida em que temas não diretamente comerciais - como meio ambiente e direitos humanos - são crescentemente objeto de sua apreciação, havendo expectativas de uma parcela da sociedade internacional no enfrentamento dessas questões, no intuito de aproveitamento do sistema já consolidado também para a pacificação de temas "sensíveis" da realidade internacional.

De fato, resta cada dia mais difícil afirmar o caráter exclusivamente interestatal da solução de controvérsias na OMC, tendo em vista a multiplicidade de interesses envolvidos nas decisões, ${ }^{151}$ e a pluralidade de temas sob análise dos painéis e do Órgão de Apelação.

princípio do stare decisis neste sistema, é geral a percepção de que na prática os relatórios tendem a seguir as interpretações anteriormente formuladas. Acerca deste debate, das vantagens de um reconhecimento formal do precedente vinculante, e das formas pelas quais este reconhecimento pode se dar, Cf: BAHALA, Raj. The Myth about Stare Decisis and International Trade Law (Part One of a Trilogy). American University International Law Review, vol. 14, p. 845-956, 1998-1999. BAHALA, Raj. The Power Of The Past: Towards de Jure Stare Decisis In WTO Adjudication (Part Three of a Trilogy). George Washington International Law Review, vol. 33, p. 873-978, 2000-2001.

148 Refere-se à posição explicitada por Alberto do Amaral Junior: "Transposto o princípio do uso do precedente para a OMC, o observador percebe sem dificuldade que os painéis e o Órgão de Apelação não se vinculam às decisões passadas, ainda que os fatos guardem entre si profunda similitude. As manifestações dos painéis e do Órgão de Apelação, nos limites de uma controvérsia, não equivalem a decisões de alcance geral sobre o significado de uma regra, com poderes para irradiar efeitos que atinjam a interpretação de outras controvérsias. Os relatórios adotados não configuram práticas subsequentes indicativas do sentido atribuído a um dispositivo particular. Ainda que não vinculem diretamente os painéis, os relatórios do Órgão de Apelação têm peso incontestável nas decisões por ele proferidas. Em geral, os painelistas resistem em se distanciar dos argumentos que prevaleceram em julgamentos passados, pois sabem que, a menos que haja fortes razões em sentido contrário, o relatório será revisto pelo Órgão de Apelação". AMARAL JUNIOR, Alberto do. A Solução de Controvérsias na OMC. São Paulo: Atlas, 2008. p. 101.

149 A esse respeito, relevante a reflexão de Piet Eeckout sobre a tendência de fortalecimento da função adjudicativa para a construção de compromissos no Direito Internacional Econômico, fenômeno observado em relação à OMC: "In sum, more collective action may be required, in particular at a global level. However, it is increasingly difficult to create new multilateral commitments. This means that the burden of developing international economic law (and, dare one say it, policy) is shifting towards another branch of global governance, the adjudicative branch. The WTO created a most effective, compulsory system of dispute settlement, whose success in terms of use cannot just be attributed to the stalling of WTO negotiations. [...] Clearly, in international economic law, the first decade of this century is marked by the rise of the adjudicative branch." EECKOUT, Piet. The Scales of Trade-Reflections on the Growth and Functions of the WTO Adjudicative Branch. Journal of International Economic Law, vol. 13, p. 3-26, 2010. p. 5.

150 AMARAL JUNIOR, Alberto do. A Solução de Controvérsias na OMC. São Paulo: Atlas, 2008. p.

102 .

151 AMARAl JUNIOR, Alberto do. A Solução de Controvérsias na OMC. São Paulo: Atlas, 2008. p. 
A constatação dessa nova posição do Sistema de Solução de Controvérsias da OMC exige, pois, o desenvolvimento de mecanismos e instrumentos internos de implementação transparente das decisões do sistema, levando em conta o amplo espectro dos sujeitos interessados em sua concreção. ${ }^{152}$

104.

152 Em um sentido mais amplo, o autor clama pelo desenvolvimento desses mecanismos de controle pelos indivíduos da concretização da normatividade advinda da OMC: "The exclusion of citizens, civil society, and parliaments from UN and WTO decision- making processes, and the inadequate accountability of intergovernmental UN and WTO rule-making vis-'a-vis adversely affected citizens, entail governance failures, for instance in the sense of governmental neglect of human rights, general consumer welfare, and democratic accountability that are nowhere mentioned in WTO law. The impunity of many governments for violating international law for the benefit of powerful interest groups (e.g. by redistributing income among domestic citizens through illegal distortions of trade and competition to the detriment of national con-sumer welfare) illustrates 'disconnected governance' and accountability gaps calling for stronger constitutional, democratic, and judicial remedies of adversely affected citizens." PETERSMANN, Ernst-Ulrich. Multilevel Governance Problems of the World Trading System beyond the WTO Conference at Bali 2013. Journal of International Economic Law, vol. 17, p. 233-270, 2014. p. 259. 


\section{O SISTEMA DE SOLUÇÃO DE CONTROVÉRSIAS DA OMC E A NATUREZA JURÍDICA DE SUAS DECISÕES}

\subsection{O Sistema de Solução de Controvérsias da OMC}

Com o objetivo de localizá-lo na sistemática mais ampla dos órgãos adjudicatórios internacionais, sem, contudo, ignorar suas especificidades, cumpre a este capítulo explicitar a evolução, os componentes, as características e o procedimento do Sistema de Solução de Controvérsias da OMC.

\subsubsection{Evolução Histórica da Solução de Controvérsias no Sistema Multilateral de Comércio: do GATT à OMC}

Com o colapso da economia mundial no período que seguiu a grande depressão, restou evidente a necessidade de novas instituições que promovessem, simultaneamente, a liberalização e a regulamentação do comércio internacional. A Conferência de Bretton Woods foi responsável pela inauguração desta nova era, com a criação de instituições fundamentais para a recuperação da economia mundial: o Banco Internacional para Reconstrução e Desenvolvimento (BIRD), o Fundo Monetário Internacional (FMI) e o projeto de criação da Organização Internacional do Comércio (OIC).

Diante do fracasso da OIC, resultante da recusa de ratificação da Carta de Havana pelo Congresso norte-americano, o Acordo Geral de Tarifas e Comércio (GATT, sigla de General Agreement on Tariffs and Trade) - projetado em 1947 para funcionar como uma 
regulamentação temporária, no lapso até a entrada em vigor da Carta constitutiva da OIC "teve que preencher o buraco nas relações internacionais". 153

Assim, não se pode olvidar que o GATT foi projetado como um acordo comercial, e não como uma verdadeira organização internacional, embora tenha sobrevivido surpreendentemente aos seus obstáculos, e se desenvolvido devido ao impulso contextual do fracasso da constituição da OIC. ${ }^{154}$ A despeito da falta de arcabouço institucional e de apoio financeiro, do seu caráter provisório e de sua abordagem contratualista, o GATT se tornou o principal instrumento de regulamentação do comércio internacional, por aproximadamente cinco décadas, até a criação da Organização Mundial do Comércio. ${ }^{155}$

Contudo, inobstante o inesperado êxito do GATT, a partir da década de 1980 houve percepção da necessidade e oportunidade de rearquitetura do sistema das regras do comércio internacional, tendo em conta sinais de seu esgotamento e o surgimento de crescentes complexidades nas relações comerciais internacionais. ${ }^{156}$ No intuito de satisfazer a novas necessidades e proclamas da sociedade internacional, iniciou-se em 1986 a Rodada do Uruguai, ciclo de negociações comerciais multilaterais que incluiu temas diversos como serviços, investimentos e propriedade intelectual, tendo como resultado a criação da Organização Mundial do Comércio. ${ }^{157} 158159$

153 Tradução livre do original em língua inglesa: "[...] when the ITO failed to come into being, the GATT had to fill the gap in international relations". JACKSON, Jonh H. The Jurisprudence of GATT and the WTO. Cambridge: Cambridge University Press, 2000. p. 23.

$154 \quad$ No mesmo sentido: "As the central institution of the world trading régime GATT was structurally quite deficient. GATT was, in a sense, an accident." McRAE, Donald M. The contribution of international trade law to the development of international law. Recueil des cours, vol. 260, p. 99-238, 1996. p. 177.

155 Sobre as características do GATT, e suas deficiências, Cf: SACERDOTI, Giorgio. A Transformação do GATT na Organização Mundial do Comércio. In: CASELLA, Paulo Borba; MERCADANTE, Araminta de (coord.). Guerra comercial ou integração mundial pelo comércio?: a OMC e o Brasil. São Paulo: LTr, 1998, p. 50-69. p. 52-55.

156 MOTA, Pedro Infante. O Sistema GATT/OMC: Introdução Histórica e Princípios Fundamentais. Coimbra: Almedina, 2005. p. 27.

157 Segundo descreve Alcides Prates: "O processo de negociação que levou ao seu estabelecimento surpreendeu pela rapidez. A Declaração de Punta del Este, que lançou a Rodada do Uruguai, em 1986, não continha referência à criação de uma organização. Apenas em 1990 começa-se a falar do assunto na Rodada. Há incertezas de quem foi o primeiro proponente deste novo avatar da Organização Internacional do Comércio, ou OIC, concebida formalmente na Conferência da Havana, encerrada em março de1948. [...] O Professor John Jackson, dos Estados Unidos, é citado como mentor acadêmico da proposta que, finalmente, ainda que com alterações profundas, veio a ser aprovada." PRATES, Alcides G. R. Comentários sobre o Acordo Constitutivo da OMC. In: CASELLA, Paulo Borba; MERCADANTE, Araminta de (coord.). Guerra comercial ou integração mundial pelo comércio?: a OMC e o Brasil. São Paulo: LTr, 1998, p. 94124. p. 94.

158 THORSTENSEN, Vera. OMC - Organização Mundial do Comércio: As Regras do Comércio Internacional e a Nova Rodada de Negociações Multilaterais. $2^{\mathrm{a}}$ ed. São Paulo: Aduaneiras, 2001. p. 27.

159 Para um histórico das rodadas de negociações do GATT, que resultaram na criação da OMC, Cf: SILVA, Roberto Luiz. Direito Econômico Internacional e Direito Comunitário. Belo Horizonte: Del Rey, 
Em um relevante incremento de institucionalidade e juridicidade, a OMC surge, desse modo, como continuidade jurídica do GATT, incorporando uma notável herança de suas decisões, procedimentos e práticas costumeiras. ${ }^{160}$ A criação de uma complexa organização internacional engendrou, portanto, profundas mudanças em algumas esferas do sistema do comércio internacional, e uma das mais relevantes foi a reformulação de seu mecanismo de solução de controvérsias. ${ }^{161}$

Como fruto de seu contexto, o GATT guardava características de sua origem, que contrastavam com a realidade do comércio internacional então estabelecida, tornando evidentes as suas limitações na oferta de soluções às controvérsias comerciais, que crescentemente foram se acirrando. Exatamente em função do papel de regulamentação provisória que lhe incumbiria, a solução de controvérsias não era uma preocupação manifestada no texto do GATT. ${ }^{162}$

De fato, no tocante à solução de disputas, havia no GATT apenas dois dispositivos correlatos - o artigo XXII e o artigo XXIII - uma vez que a carta da OIC era o instrumento que previa com mais detalhes a solução de controvérsias que funcionaria no âmbito daquela organização. ${ }^{163}$

O artigo XXII ${ }^{164}$ previa as consultas entre as partes contratantes - fase que também naquele contexto foi erigida a pré-requisito para se invocar a solução de controvérsias. Em

1995. Sobre seus resultados, p. 104-105.

160 Artigo XVI:I. Acordo Constitutivo da Organização Mundial do Comércio. Versão oficial em português segundo o decreto n. 1.355, de 30 dez. 1994, que promulga a Ata Final que Incorpora os Resultados da Rodada Uruguai de Negociações Comerciais Multilaterais do GATT.

161 Nas palavras de Celso Lafer: "O sistema de solução de controvérsias da OMC adensou a sua juridicidade, reduzindo a sua dimensão diplomática - caracterizada pelo controle político dos Estadosmembros no encaminhamento das soluções - através da multiplicação das normas secundárias que regem a organização e o funcionamento do sistema. (...) " LAFER, Celso. O Sistema de Solução de Controvérsias da Organização Mundial do Comércio. In: CASELLA, Paulo Borba; MERCADANTE, Araminta de (coord.). Guerra comercial ou integração mundial pelo comércio?: a OMC e o Brasil. São Paulo: LTr, 1998, p. 729-755. p. 748.

162 Assim explicita Pierre Pescatore: "Whoever speaks of dispute settlement in GATT must start from nearly nothing. The General Agreement does not mention dispute settlement, nor does it institute any articulate machinery for such purpose. Everything in this field had to be created ex nihilo by necessity and by experience." PESCATORE, Pierre. The GATT Dispute Settlement Mechanism: Its Present Situation and its Prospects. Journal of International Arbitration, vol. 10, issue 1, p. 27-42, 1993. p. 27.

163 A solução de controvérsia prevista na Carta de Havana incluía procedimento ligado à consultas, à arbitragem, com papel ativo do Conselho Executivo e inclusive possibilidade de remeter pedido de opinião consultiva à CIJ. Cf, Capítulo VIII (Settlement of Differences) da Carta de Havana.

164 Artigo XXII. Acordo Constitutivo da Organização Mundial do Comércio. Versão oficial em português segundo o decreto n. 1.355, de 30 dez. 1994, que promulga a Ata Final que Incorpora os Resultados da Rodada Uruguai de Negociações Comerciais Multilaterais do GATT. "CONSULTAS 1. Cada Parte Contratante examinará com compreensão as representações que the sejam encaminhadas por qualquer outra Parte Contratante e deverá se prestar a consultas a respeito daquelas representações, desde 
seu segundo parágrafo o dispositivo menciona, ainda, a possibilidade de entendimentos com as demais partes contratantes acerca da conduta questionada, sendo esse artigo a consubstanciação do estímulo à negociação para solucionar as controvérsias.

O artigo XXIII ${ }^{165}$ do GATT, por sua vez, era a pedra angular da solução de controvérsias que se desenvolveu nas décadas seguintes. ${ }^{166}$ Sob o título de "proteção de concessões e vantagens", previa a possibilidade de investigação, pelas partes contratantes, de determinada conduta objeto de representação, podendo estas inclusive dirigir recomendações e autorizar a suspenção de certas obrigações resultantes do Acordo.

Ademais desses dispositivos, cuja linguagem deixava a solução de controvérsias a cargo das próprias partes contratantes, as regras procedimentais foram sendo desenvolvidas

que elas digam respeito a questões relativas à aplicação do presente Acordo. 2. As Partes Contratantes poderão, a pedido de uma das Partes Contratantes, entrar em entendimentos com uma ou várias Partes Contratantes sobre questões para as quais a solução satisfatória não poderia ser alcançada através das consultas previstas no parágrafo primeiro."

165 Artigo XXIII. Acordo Constitutivo da Organização Mundial do Comércio. Versão ofícial em português segundo o decreto n. 1.355, de 30 dez. 1994, que promulga a Ata Final que Incorpora os Resultados da Rodada Uruguai de Negociações Comerciais Multilaterais do GATT. "PROTEÇÃO DE CONCESSÕES E VANTAGENS 1. No caso de uma Parte Contratante considerar que uma vantagem qualquer resultante para ela, direta ou indiretamente, do presente Acordo, está sendo anulada ou reduzida, ou que um dos objetivos do Acordo está sendo dificultado, em consequência: (a) do não cumprimento por outra das Partes Contratantes dos compromissos pela mesma assumidos em virtude do presente Acordo; (b) da aplicação por outra das Partes Contratantes de uma medida, contrária ou não às disposições do presente Acordo; ou (c) da existência de qualquer outra situação, dita Parte Contratante, a fim de obter solução satisfatória para a questão, poderá dirigir representações ou propostas por escrito à outra ou outras Partes Contratantes que lhe parecerem interessadas. Qualquer Parte Contratante, por essa forma interpelada, examinará, com boa vontade, as representações ou propostas que lhe tenham sido dirigidas. 2. Se as Partes Contratantes interessadas não chegarem a um Acordo satisfatório dentro de um prazo razoável, ou se a dificuldade for uma das previstas no $\$ 1$ (c) deste artigo, a questão poderá ser submetida às Partes Contratantes. As Partes Contratantes iniciarão, sem demora, uma investigação sobre qualquer assunto que lhes seja submetido e, se julgarem conveniente, dirigirão recomendações especiais e apropriadas às partes Contratantes que julguem interessadas, ou baixarão normas sobre a questão. As Partes Contratantes, quando acharem necessário, poderão efetuar consultas com as outras Partes Contratantes, com o Conselho Econômico e Social das Nações Unidas e com qualquer outra organização intergovernamental competente. Se elas consideram que as circunstâncias são suficientemente graves para justificar uma tal medida, poderão autorizar uma ou várias Partes Contratantes a suspender, com respeito a tal outra ou tais outras Partes Contratantes, a aplicação de qualquer concessão ou outra obrigação resultantes do Acordo geral cuja suspensão justificada elas examinarão, levando em conta as circunstâncias. Se uma tal concessão ou outra obrigação, for efetivamente suspensa com respeito a uma Parte Contratante, será permitido à referida Parte Contratante, no prazo de 60 dias, a contar da data da aplicação desta suspensão, notificar por escrito ao Secretário Executivo das Partes Contratantes, sua intenção de denunciar o Acordo geral; esta denúncia se efetuará ao término do prazo de 60 dias, contados a partir da data em que o Secretário executivo das Partes Contratantes tiver recebido a aludida notificação."

166 Assim explicita Ronald McRae: "The GATT dispute settlement process was not created; it evolved. [...]" McRAE, Donald M. The contribution of international trade law to the development of international law. Recueil des cours, vol. 260, p. 99-238, 1996. p. 118. 
pela prática ao longo dos anos, sendo posteriormente codificadas por meio de decisões e entendimentos de solução de controvérsias concluídos pelas então partes contratantes. ${ }^{167}$

Inicialmente, diante da inexistência de previsão de normas e procedimentos prescritos, as partes tratavam das disputas em suas reuniões regulares. Logo em seguida, passaram a ser constituídos "grupos de trabalho" para tratar das controvérsias, e estes eram compostos por representantes das próprias partes contratantes. Na década de 50, contudo, operacionalizou-se uma pertinente transição, quando passou a ter lugar a prática de utilização de painéis para a análise dos litígios. ${ }^{168}$ Os painéis eram formados por indivíduos independentes, em sua capacidade como especialistas, que não guardavam relação de representatividade com as respectivas partes contratantes. ${ }^{169}$

Assim, no desenvolvimento da solução de controvérsias no GATT, passou-se de um modelo absolutamente negocial, pelo qual a análise era realizada pelas próprias partes contratantes, para uma análise mais objetiva e neutra, pois desempenhada por terceiros, painelistas ${ }^{170}$ especializados nos temas do comércio internacional. ${ }^{171}$

Além do amplo poder das partes contratantes, que inicialmente manejavam a solução do litígio, identifica-se outros dois aspectos notadamente relevantes da solução de litígios no GATT: o fato de o procedimento frequentemente se basear em acusação de anulação ou redução de vantagens previstas no Acordo, ${ }^{172}$ não necessariamente havendo uma violação de uma obrigação; e o poder concedido às partes contratantes, para, em

167 Destaque para o documento "Understanding Regarding Notification, Consultation, Dispute Settlement and Surveillance," adotado pelas partes em nov. 1979, como resultado da Rodada de Tóquio. Jackson comenta que embora o status legal desse e de outros entendimentos resultantes dessa rodada não seja claro, o documento influenciou largamente a solução de controvérsias desde então e até a constituição da OMC, podendo ser considerada uma interpretação definitiva do Acordo do GATT, consistindo em um arcabouço constitucional do manejo dos procedimentos após o GATT.

168 JACKSON, John H.; DAVEY, William J.; SYKES JR., Alan O. Legal Problems of International Economic Relations. Cases, Materials and Text. 4a ed. St. Paul: West Group, 2002. p. 257

169 JACKSON, John. Sovereignty, the WTO and Changing Fundamentals of International Law. New York: Cambridge University Press, 2006. p. 141.

170 Adota-se o termo "painelistas" em referência aos membros dos painéis. O vocábulo oficial como constante da versão em português do ESC seria "membro do Grupo Especial". Os autores mais ligados à prática do Sistema de Solução de Controvérsias da OMC, contudo, adotaram os termos "painelistas" e "painéis", em referência aos termos em língua inglesa "panelist" e "panels".

171 JACKSON, Jonh $\mathrm{H}$. The Jurisprudence of GATT and the WTO. Cambridge: Cambridge University Press, 2000. p. 125. JACKSON, John. Sovereignty, the WTO and Changing Fundamentals of International Law. New York: Cambridge University Press, 2006. p. 141.

172 "Nullification or impairment" é a expressão original em inglês, usada com frequência na doutrina. Os termos anulação e redução estão em conformidade com a versão oficial em português do GATT 1947. Também é possível traduzí-la como "anulação e redução não-violatórias". 
determinadas circunstâncias, suspender obrigações previstas no GATT. ${ }^{173}$ Ambas as dimensões merecem um breve comentário.

O elemento de anulação ou redução de vantagens esperadas pelo Acordo permitiu, nas primeiras décadas do GATT, o surgimento de procedimentos sem que se comprovasse uma efetiva violação dos dispositivos legais. ${ }^{174} 175$ Em toda a sua ambiguidade, a expressão foi interpretada no início do GATT como ligada à noção abstratamente negocial de expectativas razoáveis nascidas do Acordo. Isto é, em casos de não-violação das regras do GATT, havia uma análise das legítimas expectativas oriundas do Acordo, e uma tentativa de reequilibrar as vantagens obtidas pelas partes contratantes. ${ }^{176}$

No que tange ao poder concedido às partes para, em determinadas circunstâncias, autorizar a suspensão de obrigações previstas no GATT, por meio de retaliação, retorsão ou rebalanceamento de vantagens, esta autorização - que se dava por maioria - ocorreu em apenas um caso, o que não impediu que houvesse medidas retaliatórias sem esta referida chancela. $^{177} 178$

São marcantes, ainda, na solução de controvérsias do GATT a ausência de controle de interpretação normativa realizada pelos diferentes painéis, estabelecidos de maneira $a d$ hoc, e a improbabilidade prática de adoção dos relatórios das disputas - tendo em vista que a exigência do consenso entre as Partes contratantes era obstaculizada pela parte

173 JACKSON, John. Sovereignty, the WTO and Changing Fundamentals of International Law. New York: Cambridge University Press, 2006. p. 138.

174 Para uma análise da "anulação e redução não-violatórias" em relação à responsabilidade internacional, e sua interpretação jurisprudencial nas últimas décadas do GATT, Cf: SACERDOTI, Giorgio. A Transformação do GATT na Organização Mundial do Comércio. In: CASELLA, Paulo Borba; MERCADANTE, Araminta de (coord.). Guerra comercial ou integração mundial pelo comércio?: a OMC e o Brasil. São Paulo: LTr, 1998, p. 50-69.

175 JACKSON, John. Sovereignty, the WTO and Changing Fundamentals of International Law. New York: Cambridge University Press, 2006. p. 139.

$176 \mathrm{O}$ autor reconhece na noção de "nullification or impairment" uma perspectiva pragmática que caracterizava a fase inicial do GATT. "Many of the early GATT's legal interpretations were written in a form which purposefully failed to make clear whether the suggested result was a legal requirement or merely a piece of friendly advice. The ambiguity seemed to make no difference. The judgment that a member was not behaving in accord with community norms seemed to be the main ingredient of what compulsion there was, and compliance would usually follow, sooner or later, without particular emphasis on obligation 'per se'." HUDEC, Robert E. GATT or GABB? - The Future Design of the General Agreement on Tariffs and Trade. Yale Law Journal, vol. 80, n. 7, p. 1299-1387, jun. 1971. p. 1340-1341.

177 Para maiores detalhes e análises sobre estes casos, Cf: JACKSON, John. Sovereignty, the WTO and Changing Fundamentals of International Law. New York: Cambridge University Press, 2006. p. 140. 178 Celso Lafer destacava à época, a impossibilidade de benefício desse mecanismo aos países subdesenvolvidos: "Os países subdesenvolvidos [...] não tem [...] condições de acionar o mecanismo de solução de controvérsias para remediar esta situação, uma vez que os poderes de retalização (sic) de que dispõem são diminutos." LAFER, Celso. O Gatt, a Cláusula de Nação mais favorecida e a América Latina. Boletim da Sociedade Brasileira de Direito Internacional, n. 55/60, p. 133-151, 1972-1974. p. 150. 
demandada. ${ }^{179}$ Acerca deste último traço marcante, JOHN JACKSON explicita o previsível mecanismo de bloqueio:

\begin{abstract}
Com efeito, o procedimento que contava com o consenso significava que a nação que "perdia" no painel, e poderia ser obrigada a seguir as obrigações estabelecidas pelo painel, podia "bloquear" a ação do Conselho, ao levantar objeções ao consenso. Assim, a parte vencida na disputa poderia evitar as consequências de sua derrota. Este "bloqueio" foi considerado como sendo o defeito mais relevante no processo de solução de controvérsias do GATT ${ }^{180}$
\end{abstract}

Assim, a solução de controvérsias do GATT apresentava diversos problemas, principalmente devido à sua história e origem. São visíveis as seguintes falhas: (i) a linguagem vaga dos artigos, que levou a imprecisões sobre o procedimento e seus objetivos; (ii) o poder de supervisão do procedimento pelas partes era pouco definido, tendo a prática levado à adoção do consenso para diversos dos temas; (iii) o mecanismo de bloqueio da constituição de painéis e da adoção dos relatórios; (iv) e a existência de diversos procedimentos, que levavam a uma fragmentação da solução da controvérsia. ${ }^{181}$

Alguns desses problemas foram equacionados com a constituição da OMC, que desempenhou uma clara evolução da temática da solução de litígios, ao estabelecer um sistema de solução de litígios unificado, em relação aos Acordos que foram resultado da Rodada do Uruguai. ${ }^{182} 183$

179 JACKSON, Jonh H. The Jurisprudence of GATT and the WTO. Cambridge: Cambridge University Press, 2000. p. 124.

180 Tradução livre do original em língua inglesa: "In effect, the procedure which relied on consensus meant that the nation which "lost" in the panel, and might otherwise be obligated to follow the panel obligations, could "block" the Council action by raising objections to the consensus. Thus, the losing party to the dispute could avoid the consequences of its defeat. This "blocking" was deemed to be the most significant defect in the GATT DS process." JACKSON, John. Sovereignty, the WTO and Changing Fundamentals of International Law. New York: Cambridge University Press, 2006. p. 141.

181 JACKSON, John. Sovereignty, the WTO and Changing Fundamentals of International Law. New York: Cambridge University Press, 2006. p. 143-144.

182 Na rodada de Tóquio houve a inclusão de mecanismos de solução de controvérsias nos Códigos então concluídos, suscitando inclusive um forum shopping. Neste sentido, foi de grande relevância a adoção de um sistema de solução de litígios unificado. MAROTTA RANGEL, Vicente. Marraqueche 94 e os Dois GATT: Breve Apresentação. In: CASELLA, Paulo Borba; MERCADANTE, Araminta de (coord.). Guerra comercial ou integração mundial pelo comércio?: a OMC e o Brasil. São Paulo: LTr, 1998, p. 126-136. p. 131.

183 No mesmo sentido: "[...] o Dispute Settlement Understanding, para fazer frente ao risco de fragmentação, trazido pela dispersão dos diversos Códigos da Rodada Tóquio - cada um tendo o seu sistema próprio, o que ensejava o fórum-shopping-representou a criação de um sistema único da OMC" LAFER, Celso. O Sistema de Solução de Controvérsias da Organização Mundial do Comércio. In: CASELLA, Paulo Borba; MERCADANTE, Araminta de (coord.). Guerra comercial ou integração 
Restou prejudicado o mecanismo de bloqueio, um dos mais graves entraves à solução de controvérsias do GATT, havendo, a partir de então, além do expresso direito dos membros de iniciar um procedimento de solução de litígios, o estabelecimento da regra do consenso reverso para adoção do relatório do painel, como será melhor explicitado adiante. $^{184}$

\subsubsection{O "Novo" Sistema de Solução de Controvérsias Alcançado na Rodada do Uruguai}

A criação do Sistema de Solução de Controvérsias da OMC engendrou uma rearquitetura das engrenagens da solução de litígios no sistema multilateral de comércio, em consolidação à perspectiva legalista. $\mathrm{O}$ embate entre a perspectiva legalista ("ruleoriented") da solução de controvérsias no sistema multilateral de comércio e a perspectiva pragmática, de primazia do elemento político ("power-oriented”), foi marcante durante a evolução do GATT. ${ }^{185} 186187$ Nesta contraposição, a primeira visão - que havia logrado

mundial pelo comércio?: a OMC e o Brasil. São Paulo: LTr, 1998, p. 729-755. p. 745.

184 Subitem 2.1.3.1.

185 Jackson classifica esta dicotomia como o embate entre um sistema "rule-oriented" $\mathrm{x}$ "power oriented". Cf: "A power-oriented system might involve various power-oriented bargaining chips, and in even older days, military bargaining chips or military actions. Contrast this with today's notion (and certainly at least 50 percent of the notion of the original GATT DS system) of building jurisprudential predictability and leveling the playing field for parties of different wealth and power structures." JACKSON, John. Sovereignty, the WTO and Changing Fundamentals of International Law. New York: Cambridge University Press, 2006. p. 146.

186 Hudec classifica a mesma dicotomia como um embate entre as perspectivas legalista x pragmática. Também ilustra a dicotomia como a tensão entre GATT x GABB. O autor esclarece que a utilização da expressão GABB (General Agreement on Better Bargaining) é uma ferramenta para caracterizar as críticas à visão legalista do sistema que tinha lugar quando da redação do trabalho. GABB é uma proposta ilusória de uma instituição alternativa, radicalmente pragmática, que operaria sem regras substantivas. "The issue, of course, is not an all-or-nothing choice between GATT and GABB, for it is unlikely that either point of view would be carried to absolute extremes in practice. But the issue is of that general dimension. Unless governments decide, fairly soon, to make a major effort to save the old GATT code, the pressures of a changing world will leave no choice but to commit the major part of GATT's work to GABB-type procedures." HUDEC, Robert E. GATT or GABB? - The Future Design of the General Agreement on Tariffs and Trade. Yale Law Journal, vol. 80, n. 7, p. 1299-1387, jun. 1971. p. 1301.

187 Como descreve Celso Lafer: "Em parte, esta tendência [negocial da solução de controvérsias do GATT] resulta do fato que o GATT, nos termos do princípio da reciprocidade contido no seu preâmbulo, almeja enquadrar-se, dentro da estrutura daquilo que Friedmann qualifica de Direito Internacional de 
êxito mais significativo nas últimas décadas do GATT - se cristalizou com o redesenho da solução de litígios. 188189190

Assim, com o surgimento da OMC, a solução de controvérsias foi oportunamente sistematizada em um acordo específico, o Entendimento Relativo às Normas e Procedimentos sobre Solução de Controvérsias (ESC), que delineia um Sistema de Solução de Controvérsias mais complexo, coeso e completo. Esta dimensão assume relevância vital para a organização, que tem na sua administração uma de suas funções erigidas pelo Acordo Constitutivo da OMC. ${ }^{191}$

Ademais, a submissão ao Sistema de Solução de Controvérsias, com competência exclusiva e universal no âmbito dos acordos multilaterais de comércio, tornou-se obrigatória a todos os membros da OMC, através do denominado "single undertaking". 192 Por meio desta nova abordagem, o Acordo Constitutivo da OMC prevê, em seu artigo II:2, que o ESC, tal qual os demais anexos, é parte integrante desse acordo, sendo obrigatório a todos os Membros. ${ }^{193}$

Cooperação, onde o vínculo entre as partes resultam de valores e interesses em comum. [...] A ideia era aplicar um "direito" dentro de um espectro de preocupações substantivas, não necessariamente limitado à distinção entre o "legal" e o "não-legal", através de procedimentos de negociações diplomáticas. [...]" LAFER, Celso. O Gatt, a Cláusula de Nação mais favorecida e a América Latina. Boletim da Sociedade Brasileira de Direito Internacional, n. 55/60, p. 133-151, 1972-1974. p. 146-147.

188 Retoma-se a ideia de "adensamento de juridicidade". LAFER, Celso. A OMC e a regulamentação do comércio internacional: uma visão brasileira. Porto Alegre: Livraria do Advogado, 1998. p. 123-125. LAFER, Celso. O Sistema de Solução de Controvérsias da Organização Mundial do Comércio. In: CASELLA, Paulo Borba; MERCADANTE, Araminta de (coord.). Guerra comercial ou integração mundial pelo comércio?: a OMC e o Brasil. São Paulo: LTr, 1998, p. 729-755. p. 748.

189 Assim também entendem os autores: "The advent of the WTO dispute resolution system suggest that the process of settling trade disputes has become judicialised. [...] In fact, the move to a more juridical"or 'rule-oriented' approach preceded the emergence of the WTO, and has simply been extended." CAMERON, James; GRAY, Kevin R. Principles of International Law in the WTO Dispute Settlement Body. International and Comparative Law Quarterly, vol. 50, p. 249-298, 2001. p. 249.

190 Para uma visão diferente dessa evolução, argumentando que desde o início há uma indissociável interação entre direito e política, em oposição à visão geral de "legalização", Cf: PAUWELYN, Joost. The Transformation of World Trade. Michingan Law Review, vol. 104, p. 1-66, 2005-2006.

191 Artigo III: 1-5. Acordo Constitutivo da Organização Mundial do Comércio. Versão oficial em português segundo o decreto n. 1.355, de 30 dez. 1994, que promulga a Ata Final que Incorpora os Resultados da Rodada Uruguai de Negociações Comerciais Multilaterais do GATT.

192 Assim explica Alcides Prates: "Por força deste dispositivo, materializou-se, no plano jurídico, o 'princípio da globalidade' (single undertaking), uma das linhas mestras das negociações da Rodada do Uruguai, ao menos na interpretação que faziam daquele princípio os principais participantes desenvolvidos. [...] Assim, já não existem sistemas diferenciados, como passara a ocorrer no GATT [...]." PRATES, Alcides G. R. Comentários sobre o Acordo Constitutivo da OMC. In: CASELLA, Paulo Borba; MERCADANTE, Araminta de (coord.). Guerra comercial ou integração mundial pelo comércio?: a OMC e o Brasil. São Paulo: LTr, 1998, p. 94-124. p. 97.

193 Artigo II:2. Acordo Constitutivo da Organização Mundial do Comércio. Versão oficial em português segundo o decreto n. 1.355, de 30 dez. 1994, que promulga a Ata Final que Incorpora os Resultados da Rodada Uruguai de Negociações Comerciais Multilaterais do GATT. "Escopo da OMC 2. Os 
A nova regra de aceite unificado de todos os acordos multilaterais, em contraposição às obrigações fragmentadas no "GATT à la carte" 194195 embora seja objeto de duras críticas sob a perspectiva dos países em desenvolvimento, ${ }^{196}$ foi um instrumento que garantiu a submissão da quase totalidade dos Estados da sociedade internacional a um Sistema de Solução de Controvérsias com ampla abrangência material. ${ }^{197}$

A criação do Órgão de Apelação, como uma instância de revisão e controle de legalidade dos relatórios dos painéis foi inovação diretamente ligada ao incremento de juridicidade do Sistema de Solução de Controvérsias. Merecem destaque, ainda, a inclusão de prazos especificados para as diferentes etapas do processo de solução de controvérsias, e a instituição da regra do consenso reverso. ${ }^{198}$ Esta última, que será analisada detalhadamente, engendra a adoção automática - ou quase automática - dos relatórios, sendo base para a caracterização deste sistema como adjudicatório e jurisdicional.

acordos e os instrumentos legais conexos incluidos nos anexos 1, 2 e 3 (denominados a seguir "Acordos Comerciais Multilaterais") formam parte integrante do presente acordo e obrigam a todos os Membros"

194 Assim explica Vicente Marotta Rangel: "[...] ineficácia do ordenamento emanado da Rodada de Tóquio, insusceptivel de reestabelecer o regime jurídico unitário do GATT, o qual vinha sendo diversificado em função de quarto pontos a saber: 1) domínios não-tarifários; 2) categorias de produtos; 3) categorias de países; 4) desdobramentos de regimes de exceção (embora todos contemplados, em seus núcleos iniciais, no Acordo Geral. O Secretariado do GATT havia identificado mais de duzentos instrumentos jurídicos integrantes desse ordenamento. Ao final da rodada, aos países se permitia aceitar os resultados adotados em uma base seletiva, ‘à la carte’. [...]” MAROTTA RANGEL, Vicente. Marraqueche 94 e os Dois GATT: Breve Apresentação. In: CASELLA, Paulo Borba; MERCADANTE, Araminta de (coord.). Guerra comercial ou integração mundial pelo comércio?: a OMC e o Brasil. São Paulo: LTr, 1998, p. 126-136. p. 131.

195 PETERSMANN, Ernst-Ulrich. The GATT/WTO Dispute Settlement System: International Law, International Organizations and Dispute Settlement. London: Kluwer Law International, 1997. p. 178.

196 Sobre as dificuldades de implementação do pacote de acordos, que oneraram os países em desenvolvimento, Cf: FINGER, Michael J. Implementing the Uruguay Round Agreements: Problems for Developing Countries. Initiative for Policy Dialogue. Network paper. Columbia University, 2001. Disponível em: <http://policydialogue.org/files/publications/Implementing_Uruguay_Round_Finger.pdf $>$ Acesso em: $20 \mathrm{dez} .2013$.

197 Sobre as vantagens e desvantagens da negociação em conjunto dos Acordos, Cf: "The "package" approach to trade negotiations has clear disadvantages. Like a convoy of ships, a big negotiation covering a range of subjects takes time to assemble and, once on the move, can only progress at the pace of its slowest element. Its agenda is usually overloaded; it is easily held hostage to doubts or delays in a key participating country. Nevertheless, the Uruguay Round showed that such a negotiation can finally achieve impressive results on a large number of highly controversial issues which, tackled individually and without the political impetus of a broader enterprise, would probably not have been resolved. (...)." CROOME, John. Reshaping

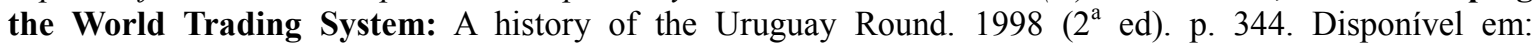
$<$ http://www.hse.ru/data/2011/12/05/1271919456/Reshaping\%202_e.pdf> Acesso em: 12 fev. 2014.

198 O autor cita ambas as inovações como concretização do "adensamento de juridicidade", com destaque para a constituição do Órgão de Apelação: “[...] essa segunda instância- quase única no Direito Internacional Público- reforça, pela sua função, o componente da juridicidade do sistema de solução de controvérsias da OMC." LAFER, Celso. O Sistema de Solução de Controvérsias da Organização Mundial do Comércio. In: CASELLA, Paulo Borba; MERCADANTE, Araminta de (coord.). Guerra comercial ou integração mundial pelo comércio?: a OMC e o Brasil. São Paulo: LTr, 1998, p. 729-755. p. 746. 
Em seu artigo I:1, o ESC especifica que seu âmbito de aplicação se destina: (i) às controvérsias pleiteadas conforme as disposições sobre consultas e solução de controvérsias dos "acordos abrangidos"; e (ii) às consultas e solução de controvérsias relativas aos direitos ou obrigações dos membros mencionados no Acordo Constitutivo da OMC e do próprio ESC.

Dentre os acordos abrangidos, mencionados no Apêndice 1 do ESC, temos na realidade menção à totalidade dos acordos desta Organização, em ampla definição da competência rationae materiae, segundo a sua estrutura de anexos: (i) o Acordo Constitutivo da Organização Mundial de Comércio; (ii) os Acordos Comerciais Multilaterais: GATT 1994 (Anexo 1 A) ${ }^{199}$; GATS (Anexo 1 B), TRIPS (Anexo 1 C), Entendimento Relativo às Normas e Procedimentos sobre Solução de Controvérsias (Anexo 2); (iii) Acordos Comerciais Plurilaterais: Acordo sobre o Comércio de Aeronaves Civis, Acordo sobre Compras Governamentais, Acordo Internacional de Produtos Lácteos; e Acordo Internacional de Carne Bovina (Anexo 4). ${ }^{200}$

Adicionalmente ao conjunto de regras e procedimentos previstos no ESC, cada um dos Acordos abrangidos mencionados supra contém regras e procedimentos especiais ou adicionais sobre solução de controvérsias oriundas do respectivo Acordo. Tais regras e procedimentos especiais ou adicionais, listados no Apêndice 2 do ESC, ${ }^{201}$ tem primazia na

199 Constam como parte integrante do Anexo 1A, formalmente, não apenas o GATT 1994, mas também os seguintes Acordos/Entendimentos: Nota Interpretativa ao Anexo 1A; Entendimento sobre a Interpretação do Artigo II 1(b); Entendimento sobre a Interpretação do Artigo XVII; Entendimento sobre as Disposições Relativas a Balanço de Pagamentos; Entendimento sobre a Interpretação do Artigo XXIV; Entendimento sobre Derrogações (Waivers) de Obrigações; Entendimento sobre a Interpretação do Artigo XXVIII; Protocolo de Marraqueche; Acordo sobre Agricultura; Acordo sobre a Aplicação de Medidas Sanitárias e Fitossanitárias; Acordo sobre Têxteis e Vestuário; Acordo sobre Barreiras Técnicas ao Comércio; Acordo sobre Medidas de Investimento Relacionadas ao Comércio (TRIMS); Acordo sobre a Implementação do Artigo VI (Antidumping); Acordo sobre a Implementação do Artigo VII (Valoração Aduaneira); Acordo sobre Inspeção Pré-Embarque; Acordo sobre Regras de Origem; Acordo sobre Procedimentos para o Licenciamento de Importações; Acordo sobre Subsídios e Medidas Compensatórias; Acordo sobre Salvaguardas.

200 Para os Acordos Plurilaterais há ressalva relevante, que merece destaque: “A aplicação do presente Entendimento aos Acordos Comerciais Plurilaterais dependerá da adoção, pelas partes do Acordo em questão, de uma decisão na qual se estabeleçam as condições de aplicação do Entendimento ao referido Acordo, com inclusão das possíveis normas ou procedimentos especiais ou adicionais para fins de sua inclusão no Apêndice 2, conforme notificado ao OSC." Apêndice 1 - Acordos Abrangidos pelo Entendimento. Entendimento Relativo às Normas e Procedimentos sobre Solução de Controvérsias. Versão oficial em português segundo o decreto n. 1.355, de 30 dez. 1994, que promulga a Ata Final que Incorpora os Resultados da Rodada Uruguai de Negociações Comerciais Multilaterais do GATT.

201 "Apêndice 2 Normas e Procedimentos Especiais ou Adicionais Contidos nos Acordos Abrangidos. Acordo sobre a Aplicação de Medidas Sanitárias e Fitossanitárias: Artigo 11.2; Acordo sobre Têxteis e Vestuário: Artigos 2.14, 2.21, 4.4, 5.2, 5.4, 5.6, 6.9, 6.10, 6.11, 8.1 a 8.12; Acordo sobre Barreiras Técnicas ao Comércio: Artigos 14.2 a 14.4, Anexo 2; Acordo sobre a Implementação do Artigo VI do GATT 1994: Artigos 17.4 a 17.7; Acordo sobre a Implementação do Artigo VII do GATT 1994: Artigos 19.3 a 19.5, Anexo 
aplicação, em caso se conflitos com os ditames gerais para a solução de litígios desenhados pelo Entendimento. ${ }^{202}$

No que tange ao âmbito temporal de aplicação das normas previstas no Entendimentos, a sua incidência foi limitada aos novos procedimentos iniciados após a data de entrada em vigor do Acordo Constitutivo da OMC, sendo que os casos então em andamento seriam regidos pelas normas e procedimentos vigentes na sistemática do GATT. ${ }^{203}$

Ademais, aos países em desenvolvimento que apresentem uma demanda em face de um membro desenvolvido, resguarda-se o gozo dos direitos constantes da Decisão de 5 de abril de 1966 (BISD 14S/20), havendo primazia destas regras sob os procedimentos dos artigos 4, 5, 6 e 12 do Entendimento. ${ }^{204}$

A relevância central deste sistema de solução de litígios é enunciada no ESC, ao reconhecê-lo como essencial para a previsibilidade e segurança do sistema multilateral de comércio. ${ }^{205}$ A primazia jurídica e a exclusividade do Sistema de Solução de Controvérsias em relação aos sistemas alternativos de solução de litígios fora da OMC são outros destaques desse instrumento. ${ }^{206} 207$

II.2.f, 3, 9, 21; Acordo sobre Subsídios e Medidas Compensatórias: Artigos 4.2 a 4.12, 6.6, 7.2 a 7.10, 8.5, Nota 35, 24.4, 27.7, Anexo V; Acordo sobre Subsidios e Medidas Compensatórias: Acordo 4.2 a 4.12, 6.6, 7.2 a 7.10, 8.5, Nota 35, 24.4, 27.7, Anexo V; Acordo Geral sobre o Comércio de Serviços: Artigos XXII:3, XXIII:3; Anexo sobre Serviços Financeiros: Artigo 4; Anexo sobre Serviços de Transporte Aéreo: Artigo 4; Decisão Relativa a Certos Procedimentos de Solução de Controvérsias para o GATS: Artigos 1 a 5." Entendimento Relativo às Normas e Procedimentos sobre Solução de Controvérsias. Versão oficial em português segundo o decreto n. 1.355, de 30 dez. 1994, que promulga a Ata Final que Incorpora os Resultados da Rodada Uruguai de Negociações Comerciais Multilaterais do GATT.

202 Artigo 1.2. Entendimento Relativo às Normas e Procedimentos sobre Solução de Controvérsias. Versão oficial em português segundo o decreto n. 1.355, de 30 dez. 1994, que promulga a Ata Final que Incorpora os Resultados da Rodada Uruguai de Negociações Comerciais Multilaterais do GATT.

203 Artigo 4.11. Entendimento Relativo às Normas e Procedimentos sobre Solução de Controvérsias. Versão oficial em português segundo o decreto n. 1.355, de 30 dez. 1994, que promulga a Ata Final que Incorpora os Resultados da Rodada Uruguai de Negociações Comerciais Multilaterais do GATT.

204 Artigo 4.12. Entendimento Relativo às Normas e Procedimentos sobre Solução de Controvérsias. Versão oficial em português segundo o decreto n. 1.355, de 30 dez. 1994, que promulga a Ata Final que Incorpora os Resultados da Rodada Uruguai de Negociações Comerciais Multilaterais do GATT.

205 Artigo 4.2 e nota de rodapé n. 1. Entendimento Relativo às Normas e Procedimentos sobre Solução de Controvérsias. Versão oficial em português segundo o decreto n. 1.355, de 30 dez. 1994, que promulga a Ata Final que Incorpora os Resultados da Rodada Uruguai de Negociações Comerciais Multilaterais do GATT.

206 Artigo 23. Entendimento Relativo às Normas e Procedimentos sobre Solução de Controvérsias. Versão oficial em português segundo o decreto n. 1.355, de 30 dez. 1994, que promulga a Ata Final que Incorpora os Resultados da Rodada Uruguai de Negociações Comerciais Multilaterais do GATT.

207 PETERSMANN, Ernst-Ulrich. The GATT/WTO Dispute Settlement System: International Law, International Organizations and Dispute Settlement. London: Kluwer Law International, 1997. p. 179. 
Em análise também dos objetivos implícitos do Sistema de Solução de Controvérsias da OMC, JOHN JACKSON reconhece diversos objetivos, dentre os quais destacamos os seguintes: (i) solucionar de maneira amigável as controvérsias, de modo a reduzir as tensões internacionais e os respectivos conflitos; (ii) desfazer danos causados pelo membro demandado, corrigindo as lesões provocadas por sua conduta; (iii) solucionar as controvérsias de maneira eficiente; ${ }^{208}$ (iv) completar as lacunas normativas e esclarecer as ambiguidades do texto dos acordos; (v) construir uma base de precedentes, no intuito de promover previsibilidade e segurança; ${ }^{209}$ (vi) garantir o cumprimento das obrigações dos acordos, bem como das decisões do Sistema de Solução de Controvérsias; (vii) reequilibrar as vantagens percebidas pelos membros a partir dos acordos; (viii) corrigir assimetrias de poder das relações econômicas interacionais; (ix) facultar aos membros o acesso a um procedimento adjudicatório com garantias básicas; (x) promover julgamentos fundamentados, que possam auxiliar na aceitabilidade pública do sistema multilateral de comércio. $^{210}$

As funções do Sistema de Solução de Controvérsias expressas no Entendimento se assentam: (a) na preservação de direitos e obrigações dos membros, tendo em vista os parâmetros dos acordos abrangidos; e (b) no esclarecimento das disposições vigentes dos referidos acordos, conforme as normas de interpretação do Direito Internacional Público.

208 Artigo 3.3. "É essencial para o funcionamento eficaz da OMC e para a manutenção de equilibrio adequado entre os direitos e as obrigações dos Membros a pronta solução das situações em que um Membro considere que quaisquer beneficios resultantes, direta ou indiretamente, dos acordos abrangidos tenham sofrido restrições por medidas adotadas por outro Membro." Entendimento Relativo às Normas e Procedimentos sobre Solução de Controvérsias. Versão oficial em português segundo o decreto n. 1.355, de 30 dez. 1994, que promulga a Ata Final que Incorpora os Resultados da Rodada Uruguai de Negociações Comerciais Multilaterais do GATT.

209 Artigo 3.2. "O sistema de solução de controvérsia da OMC é elemento essencial para trazer segurança e previsibilidade ao sistema multilateral de comércio. Os Membros reconhecem que esse sistema é útil para preservar direitos e obrigações dos Membros dentro dos parâmetros dos acordos abrangidos e para esclarecer as disposições vigentes dos referidos acordos em conformidade com as normas correntes de interpretação do direito internacional público. As recomendações e decisões do OSC não poderão promover o aumento ou a diminuição dos direitos e obrigações definidos nos acordos abrangidos." Entendimento Relativo às Normas e Procedimentos sobre Solução de Controvérsias. Versão oficial em português segundo o decreto n. 1.355, de 30 dez. 1994, que promulga a Ata Final que Incorpora os Resultados da Rodada Uruguai de Negociações Comerciais Multilaterais do GATT.

210 JACKSON, John. Sovereignty, the WTO and Changing Fundamentals of International Law. New York: Cambridge University Press, 2006. p. 147-151.

211 Artigo 4.3. Entendimento Relativo às Normas e Procedimentos sobre Solução de Controvérsias. Versão oficial em português segundo o decreto n. 1.355, de 30 dez. 1994, que promulga a Ata Final que Incorpora os Resultados da Rodada Uruguai de Negociações Comerciais Multilaterais do GATT. 
Em relação a essa primeira função, fica clara na linguagem dos artigos do ESC a preocupação com a conservação dos direitos e deveres acordados pelos membros, havendo o cuidado em enunciar que as recomendações e decisões não poderiam afetar o equilíbrio entre estes direitos e obrigações como presentes nos acordos, estando as instâncias adjudicatórias impedidas de aumentá-los ou diminuí-los. ${ }^{212}$ Este dispositivo enfatiza a primazia do direito e a abordagem legalista do sistema, que será explorada adiante. ${ }^{213}$

Nesse diapasão, e sempre limitadas pelo respeito ao equilíbrio adequado entre direitos e obrigações insculpidos pelos acordos, ${ }^{214}$ as recomendações e decisões formuladas pelo OSC tem o objetivo de alcançar uma solução satisfatória para as situações nas quais um dos membros da organização considere que seus direitos estão restringidos por medidas adotadas por outro membro. ${ }^{215}$

Ademais, sendo o objeto do sistema de solução de litígios "garantir uma solução positiva para as controvérsias", ${ }^{216}$ o Entendimento elege como "preferível" a solução mutuamente acordada para as querelas. Apenas na impossibilidade de se encontrar uma solução mutuamente acordada, e que simultaneamente não desrespeite o conjunto dos acordos abrangidos, é que a atuação do sistema deve se dar, buscando inicialmente a supressão das medidas incompatíveis. Na impossibilidade desta supressão, pode ter lugar a compensação, e apenas como ultima ratio, a suspensão discriminatória de obrigações em face do membro faltoso (retaliação). ${ }^{217} 218$

212 Artigo 4.3. Entendimento Relativo às Normas e Procedimentos sobre Solução de Controvérsias. Versão oficial em português segundo o decreto n. 1.355, de 30 dez. 1994, que promulga a Ata Final que Incorpora os Resultados da Rodada Uruguai de Negociações Comerciais Multilaterais do GATT.

213 PETERSMANN, Ernst-Ulrich. The GATT/WTO Dispute Settlement System: International Law, International Organizations and Dispute Settlement. London: Kluwer Law International, 1997. p. 179.

214 Artigo 4.5. Entendimento Relativo às Normas e Procedimentos sobre Solução de Controvérsias. Versão oficial em português segundo o decreto n. 1.355, de 30 dez. 1994, que promulga a Ata Final que Incorpora os Resultados da Rodada Uruguai de Negociações Comerciais Multilaterais do GATT.

215 Artigo 4.4. Entendimento Relativo às Normas e Procedimentos sobre Solução de Controvérsias. Versão oficial em português segundo o decreto n. 1.355, de 30 dez. 1994, que promulga a Ata Final que Incorpora os Resultados da Rodada Uruguai de Negociações Comerciais Multilaterais do GATT.

216 Artigo 4.7. Entendimento Relativo às Normas e Procedimentos sobre Solução de Controvérsias. Versão oficial em português segundo o decreto n. 1.355, de 30 dez. 1994, que promulga a Ata Final que Incorpora os Resultados da Rodada Uruguai de Negociações Comerciais Multilaterais do GATT.

217 O termo usado formalmente pelo ESC é "a suspensão de concessões ou de outras obrigações", que "são medidas temporárias disponíveis no caso de as recomendações e decisões não serem implementadas dentro de prazo razoável." Como a doutrina tem praticamente de modo unânime adotado o vocábulo retaliação para se referir a esta medida de suspensão discriminatória (apenas em relação ao membro cujo cumprimento não ocorreu) autorizada pelo OSC, nos utilizaremos da expressão para designar referida medida. Para uma visão geral do conceito, de sua função e de sua interpretação pelo Sistema de Solução de Controvérsias, Cf: PEREIRA, Celso de Tarso. Retaliação na OMC: Procedimento, Prática e Objetivos. In: BENJAMIN, Daniela Arruda. (Org). O Sistema de Solução de Controvérsias da OMC: uma perspectiva 
Desenha-se, desse modo, uma ordem de preferência para o instrumento de solução dos litígios, dentre: (1) solução mutuamente acordada; (2) supressão da medida; (3) compensação; (4) retaliação autorizada pelo OSC.

Adiciona-se a estas modificações trazidas pela construção normativa-institucional de um "novo" sistema se solução de controvérsias, elementos inovadores oriundos da própria evolução deste sistema por meio de sua atuação e da interpretação das normas do ESC. São exemplos desta atuação renovadora a possibilidade de participação de Organizações não-governamentais nos procedimentos, através de amicus curiae, em interpretação dos artigos 13.1 e 13.2, e a aplicação da Convenção de Viena sobre o Direito dos Tratados como parâmetro de interpretação ${ }^{219}$ e como abertura do sistema às normas do Direito Internacional Público. ${ }^{220}$

Embora resultado de considerável evolução, como evidenciado supra, o Sistema de Solução de Controvérsias da OMC, assim como todas as instituições jurídicas concretizadas na dimensão fática da realidade, está sujeito a diversas críticas e à diferentes proposições para sua reforma. ${ }^{221} 222$ As propostas de reforma, de modo geral, abarcam elementos como: (i) o incremento da transparência; (ii) a modificação da retaliação de modo a incluir um caráter reparatório, e não apenas prospectivo; e (iii) a inclusão de mecanismos de incentivo a participação de países menos desenvolvidos.

brasileira. Brasília : FUNAG, 2013, p. 595-628.

218 Artigo 4.7. Entendimento Relativo às Normas e Procedimentos sobre Solução de Controvérsias. Versão oficial em português segundo o decreto n. 1.355, de 30 dez. 1994, que promulga a Ata Final que Incorpora os Resultados da Rodada Uruguai de Negociações Comerciais Multilaterais do GATT.

219 Segundo o autor, a aplicação das regras da CVDT na interpretação das controvérsias da OMC é um dos elementos que diferencia o Sistema de Solução de Controvérsias da OMC em relação ao GATT, cujos painéis mantinham uma "[...] preferência pouco salutar pelas circunstâncias históricas do momento da confecção dos artigos do GATT como meio preferencial de interpretação. Isto é obviamente contrário aos Artigos 31 e 32 da Convenção de Viena sobre o Direito dos Tratados [...]” KUYPER, Peter J. O Direito do GATT com um Campo Especial do Direito Internacional: Ignorância, Refinamentos Posteriores ou um Sistema Autocontinente de Direito Internacional? In: CASELLA, Paulo Borba; MERCADANTE, Araminta de (coord.). Guerra comercial ou integração mundial pelo comércio?: a OMC e o Brasil. São Paulo: LTr, 1998, p. 15-49. p. 16.

220 Assim destaca Donald McRae: "The WTO dispute settlement process has also been linked more directly to the general field of international law. The dispute settle- ment system is expressly designed to "preserve the rights and obligations of Members" and to clarify the provisions of the WTO agreements "in accordance with customary rules of interpretation of public international law." McRAE, Donald M. The contribution of international trade law to the development of international law. Recueil des cours, vol. 260, p. 99-238, 1996. p. 184.

221 VAN DER BORGHT, Kim. The Review of the WTO Understanding on Dispute Settlement: Some Reflections on the Current Debate. American University International Law Review, vol. 14, p. 1223-1243, 1998.

222 BARRAL, Welber; PRAZERES, Tatiana. Solução de Controvérsias. In: BARRAL, Welber (Org). O Brasil e a OMC. $2^{\text {a }}$ ed, $5^{\text {a }}$ tir. Curitiba: Juruá, 2006, p. 27-46. 


\subsubsection{Componentes do Sistema}

O Sistema de Solução de Controvérsias da OMC é composto por instâncias adjudicatórias - os painéis e o Órgão de Apelação - e por uma instância política, o Órgão de Solução de Controvérsias (OSC). O estudo destas instâncias, sob a perspectiva de suas competências e limites na engrenagem da solução de litígios é essencial para a compreensão da natureza jurídica desse sistema e das decisões dele resultantes.

Embora não sejam componentes próprios do Sistema de Solução de Controvérsias, cumpre observar que outros órgãos e sujeitos exercem funções relevantes neste sistema. É o caso do Secretariado na OMC, que segundo o ESC, deve (a) fornecer assistência aos painéis, com destaque para as facetas jurídicas, históricas e procedimentais dos temas analisados; (b) conceder apoio jurídico adicional aos países em desenvolvimento; e (c) realizar cursos específicos com a finalidade de treinamento para os membros interessados, sobre os procedimentos de solução de controvérsia da organização. ${ }^{223}$ Outro exemplo é a utilização de peritos individuais ou um grupo deles, que auxiliam o painel na busca por informação em questões de complexidade técnica e científica. ${ }^{224}$

\subsubsection{Instância Política}

223 Artigo 27. Entendimento Relativo às Normas e Procedimentos sobre Solução de Controvérsias. Versão oficial em português segundo o decreto n. 1.355, de 30 dez. 1994, que promulga a Ata Final que Incorpora os Resultados da Rodada Uruguai de Negociações Comerciais Multilaterais do GATT.

224 Artigo 13.2. Entendimento Relativo às Normas e Procedimentos sobre Solução de Controvérsias. Versão oficial em português segundo o decreto n. 1.355, de 30 dez. 1994, que promulga a Ata Final que Incorpora os Resultados da Rodada Uruguai de Negociações Comerciais Multilaterais do GATT. 
O Órgão de Solução de Controvérsias é considerado a instância política da engrenagem da solução de litígios na OMC, ${ }^{225}$ dada sua natureza diplomática. ${ }^{226}$ Assim é que a juridicidade do procedimento de solução de controvérsias na OMC "se insere em um contexto mais amplo, de natureza diplomática”. 227228

No que tange a seus componentes, o OSC é uma emanação, um "alter ego" do Conselho Geral da OMC, ${ }^{229}$ uma vez que sua composição é idêntica à do Conselho Geral, que se reúne como OSC para administrar os dispositivos do ESC. ${ }^{230}$

O marco normativo inicial do Órgão de Solução de Controvérsias é, pois, o ESC, que estabelece tal órgão como responsável pela aplicação e administração das normas de solução de controvérsias presentes no Entendimento. Criado para ser o "guardião" das normas procedimentais de solução de litígios na OMC, foi concedida ao OSC a competência para gerir e operacionalizar este sistema.

Para tal, o OSC possui competência para diversas ações, dentre as quais destacamos: (a) o estabelecimento dos painéis; (b) a adoção de relatórios dos painéis e do Órgão de Apelação; (c) a supervisão da aplicação das decisões e recomendações; (d) a

225 Neste sentido explana Petros Mavroidis: "The Dispute Settlement Body (DSB) is not an adjudicating body since it can only adopt or reject (as presented) the findings of panels or the Appellate Body (AB). [...]" MAVROIDIS, Petros. Outsourcing of Law? WTO Law as Practiced By WTO Courts. American Journal of International Law, vol. 2, p. 421-474, 2008. p. 421

226 Assim explicita Celso Lafer: "O adensamento de juridicidade, que estou realçando, não exclui, muito pelo contrário, o papel do OSC como instância política diplomática de solução de controvérsias na OMC. [...]" LAFER, Celso. O Sistema de Solução de Controvérsias da Organização Mundial do Comércio. In: CASELLA, Paulo Borba; MERCADANTE, Araminta de (coord.). Guerra comercial ou integração mundial pelo comércio?: a OMC e o Brasil. São Paulo: LTr, 1998, p. 729-755. p. 751

227 LAFER, Celso. O Sistema de Solução de Controvérsias da Organização Mundial do Comércio. In: CASELlA, Paulo Borba; MERCADANTE, Araminta de (coord.). Guerra comercial ou integração mundial pelo comércio?: a OMC e o Brasil. São Paulo: LTr, 1998, p. 729-755. p. 749.

228 Embora parte da doutrina the atribua natureza jurisdicional, ou quase-jurisdicional, aproximando-o de um tribunal administrativo, diversos são os obstáculos para tal reconhecimento. Com base nos elementos de sua composição, poderes e atuação, como explicita-se em seguida, esta pesquisa confere ao OSC a natureza de órgão político (ou diplomático). Não se pode, pois, confundir a natureza do OSC, com a sua relação com os painéis e o Órgão de Apelação, ou com a sua função de vocalizador das decisões do Sistema de Solução de Controvérsias- este de natureza adjudicatória. Como exemplos de autores que conferem a natureza jurisdicional: "The DSB, especially the Appellate Body, has many characteristics of an administrative tribunal and other more established international tribunals, and some of a domestic court. [...]" CAMERON, James; GRAY, Kevin R. Principles of International Law in the WTO Dispute Settlement Body. International and Comparative Law Quarterly, vol. 50, p. 249-298, 2001. (Nota-se que pode ter havido um erro formal, de troca do DSB [Dispute Settlement Body] por DSS [Dispute Settlement System], pois os autores incluem o Órgão de Apelação como parte do Órgão de Solução de Controvérsias, o que não corresponde à arquitetura desenhada pelo Entendimento).

229 VAN DEN BOSSCHE, Peter; ZDOUC, Werner. The Law and Policy of the World Trade Organization. $3^{\mathrm{a}}$ ed. Cambridge: Cambridge University Press, 2013. p. 206.

230 Artigo 2.2. Acordo constitutivo da Organização Mundial do Comércio. Versão oficial em português segundo o decreto n. 1.355, de 30 dez. 1994, que promulga a Ata Final que Incorpora os Resultados da Rodada Uruguai de Negociações Comerciais Multilaterais do GATT. 
autorização da suspensão de concessões e de outras obrigações previstas pelos acordos abrangidos, ${ }^{231}$ e (e) a informação aos pertinentes Conselhos e Comitês da OMC sobre o andamento de controvérsias. ${ }^{232}$

O artigo 2.4 explicita que o procedimento de tomada de decisão pelo OSC se dá por consenso. A nota de rodapé constante deste artigo enuncia a regra para configuração deste consenso, ao determinar que "Considerar-se-á que o OSC decidiu por consenso matéria submetida a sua consideração quando nenhum Membro presente à reunião do OSC na qual a decisão foi adotada a ela se opuser formalmente." 233

De maior relevância, contudo, é o fato de que para a maioria das decisões essenciais ao funcionamento prático do mecanismo, prevalece o que se denomina de consenso reverso, ou consenso negativo. O consenso reverso se consubstancia na inversão da regra do consenso enunciada no artigo 2.4, isto é, se considera que o OSC tomou uma decisão, salvo quando houver consenso no sentido de não tomar a referida decisão. ${ }^{234}$

Por sua relevância fulcral, vejamos como essa regra se desenha no estabelecimento dos painéis, na adoção dos relatórios dos painéis, na adoção dos relatórios do Órgão de Apelação e na autorização para retaliação.

Em relação ao estabelecimento dos painéis, o artigo 6.1 assim enuncia:

Se a parte reclamante assim o solicitar, um grupo especial será estabelecido no mais tardar na reunião do OSC seguinte àquela em que a solicitação aparece pela primeira vez como item da agenda do OSC, a menos que nessa reunião o OSC

231 Artigo 2.1. Entendimento Relativo às Normas e Procedimentos sobre Solução de Controvérsias. Versão oficial em português segundo o decreto n. 1.355, de 30 dez. 1994, que promulga a Ata Final que Incorpora os Resultados da Rodada Uruguai de Negociações Comerciais Multilaterais do GATT.

232 Artigo 2.2. Entendimento Relativo às Normas e Procedimentos sobre Solução de Controvérsias. Versão oficial em português segundo o decreto n. 1.355, de 30 dez. 1994, que promulga a Ata Final que Incorpora os Resultados da Rodada Uruguai de Negociações Comerciais Multilaterais do GATT.

233 Artigo 2.4 e nota de rodapé n. 1. Entendimento Relativo às Normas e Procedimentos sobre Solução de Controvérsias. Versão oficial em português segundo o decreto n. 1.355, de 30 dez. 1994, que promulga a Ata Final que Incorpora os Resultados da Rodada Uruguai de Negociações Comerciais Multilaterais do GATT.

234 Sobre este assunto, John Croome comenta: "In effect, they [negotiators] retained the consensus rule, but turned it on its head. Whereas consensus had been required in order to move the dispute settlement process forward at each stage, they provided that, in future, consensus agreement would be required not to move. The effect would be to end the possibility of a country unilaterally blocking the dispute mechanism, and to build automaticity into the progress of a dispute through the system, unless all countries agreed that the process should be halted." CROOME, John. Reshaping the World Trading System: A history of the Uruguay Round. $2 \mathrm{a} \quad$ ed. [S.1.]: [S.n.], $1998 . \quad$ Disponível em: $<$ http://www.hse.ru/data/2011/12/05/1271919456/Reshaping\%202_e.pdf > Acesso em: 12 fev. 2014. p. 283. 
decida por consenso não estabelecer o grupo especial. (grifo nosso). ${ }^{235}$

O artigo 16.4 do ESC, relativo à adoção dos relatórios dos painéis, explicita lógica correlata, adicionando o elemento temporal como gatilho para a adoção automática:

Dentro dos 60 dias seguintes à data de distribuição de um relatório de um grupo especial a seus Membros, o relatório será adotado em uma reunião do OSC a menos que uma das partes na controvérsia notifique formalmente ao OSC de sua decisão de apelar ou que o OSC decida por consenso não adotar o relatório. Se uma parte notificar sua decisão de apelar, o relatório do grupo especial não deverá ser considerado para efeito de adoção pelo OSC até que seja concluído o processo de apelação. O referido procedimento de adoção não prejudicará o direito dos Membros de expressar suas opiniões sobre o relatório do grupo especial. (grifo nosso) ${ }^{236}$

De modo análogo, a adoção dos relatórios do Órgão de Apelação segue a regra do consenso reverso, reforçada pelo prazo previsto:

Os relatórios do órgão de Apelação serão adotados pelo OSC e aceitos sem restrições pelas partes em controvérsia a menos que o OSC decida por consenso não adotar o relatório do órgão de Apelação dentro do prazo de 30 dias contados a partir da sua distribuição aos Membros. Este procedimento de adoção não prejudicará o direito dos Membros de expor suas opiniões sobre o relatório do órgão de Apelação. (grifo nosso) ${ }^{237}$

Cumpre ainda explicitar a regra do artigo 22.6, relativa à autorização para suspender concessões ou outras obrigações, como consequência do descumprimento das decisões:

Quando ocorrer a situação descrita no parágrafo 2 [Se o Membro afetado não adaptar a um acordo abrangido a medida considerada incompatível ou não cumprir de outro modo as recomendações e decisões adotadas dentro do prazo razoável] o OSC, a pedido, poderá conceder autorização para suspender concessões ou outras obrigações dentro de 30 dias seguintes à expiração do prazo razoável, salvo se o OSC decidir por consenso rejeitar o pedido. [...] (grifo nosso) $^{238}$

235 Artigo 6.1. Entendimento Relativo às Normas e Procedimentos sobre Solução de Controvérsias. Versão oficial em português segundo o decreto n. 1.355, de 30 dez. 1994, que promulga a Ata Final que Incorpora os Resultados da Rodada Uruguai de Negociações Comerciais Multilaterais do GATT.

236 Artigo 16.4. Entendimento Relativo às Normas e Procedimentos sobre Solução de Controvérsias. Versão oficial em português segundo o decreto n. 1.355, de 30 dez. 1994, que promulga a Ata Final que Incorpora os Resultados da Rodada Uruguai de Negociações Comerciais Multilaterais do GATT.

237 Artigo 17.4. Entendimento Relativo às Normas e Procedimentos sobre Solução de Controvérsias. Versão oficial em português segundo o decreto n. 1.355, de 30 dez. 1994, que promulga a Ata Final que Incorpora os Resultados da Rodada Uruguai de Negociações Comerciais Multilaterais do GATT.

238 Artigo 22.6. Entendimento Relativo às Normas e Procedimentos sobre Solução de 
A doutrina reconhece, assim, que a regra do consenso reverso, na prática, torna a adoção dos relatórios dos órgãos jurisdicionais - bem como o estabelecimento do painel e a autorização para retaliação - "quase automática", 239 ou automática. 240241242243

Isso se dá na medida em que, em situações normais, ao menos um membro do OSC - aquele cuja pretensão se beneficia com a posição explicitada no relatório - possuirá interesse substancial a ser resguardado, sendo improvável que se construa nesse órgão o consenso necessário para que não seja adotada a decisão. ${ }^{244}$

Como consequência, o papel do OSC e seu impacto na sistemática da solução de controvérsias da OMC é de fato limitado. Neste sentido é a reflexão de PETER VAN DEN BOSSCHE e WERNER ZDOUC:

\begin{abstract}
Como resultado do fato de que o OSC toma as decisões centrais sobre a solução de controvérsias por consenso reverso, o impacto e a influência do OSC sobre consultas e adjudicação pelos painéis e pelo Órgão de Apelação em disputas específicas são muito limitados. O envolvimento do OSC é, em grande medida, um legado do passado, no qual a solução de disputas comerciais era mais diplomática e política que judicial em sua natureza. No entanto, o envolvimento do OSC em cada grande passo de uma disputa cumpre três funções úteis: (1) mantém todos os membros da OMC diretamente informados da solução de controvérsias da OMC; (2) assegura a vigilância multilateral das recomendações e decisões do OSC, exercendo assim a pressão sobre o ofensor a cumprir; e (3) garante aos membros da OMC um fórum político designado em que as questões
\end{abstract}

Controvérsias. Versão oficial em português segundo o decreto n. 1.355, de 30 dez. 1994, que promulga a Ata Final que Incorpora os Resultados da Rodada Uruguai de Negociações Comerciais Multilaterais do GATT.

239 PETERSMANN, Ernst-Ulrich. The GATT/WTO Dispute Settlement System: International Law, International Organizations and Dispute Settlement. London: Kluwer Law International, 1997. p. 179.

240 VAN DEN BOSSCHE, Peter.; ZDOUC, Werner. The Law and Policy of the World Trade Organization. $3^{\text {a }}$ ed. Cambridge: Cambridge University Press, 2013. p. 207.

241 O autor menciona a "automaticidade" como característica do Sistema de Solução de Controvérsias, em especial na adoção dos relatórios. LAFER, Celso. O Sistema de Solução de Controvérsias da Organização Mundial do Comércio. In: CASELLA, Paulo Borba; MERCADANTE, Araminta de (coord.). Guerra comercial ou integração mundial pelo comércio?: a OMC e o Brasil. São Paulo: LTr, 1998, p. 729-755. p. 745-747.

242 Neste sentido explana o autor: "[...] automaticity into the progress of a dispute through the system, unless all countries agreed that the process should be halted." CROOME, John. Reshaping the World Trading System: A history of the Uruguay Round. 2a ed. [S.1.]: [S.n.], 1998. Disponível em: $<$ http://www.hse.ru/data/2011/12/05/1271919456/Reshaping\%202_e.pdf $>$ Acesso em: 12 fev. 2014. p. 283.

243 Também compartilhado deste entendimento: "[...]This change is attributable to the negative consensus rule under the DSU where Panel and Appellate Body reports are automatically binding, subject to a negative vote by the parties in the Dispute Settlement Body. [...]'.'CAMERON, James; GRAY, Kevin R. Principles of International Law in the WTO Dispute Settlement Body. International and Comparative Law Quarterly, vol. 50, p. 249-298, 2001. p. 249-250.

244 VAN DEN BOSSCHE, Peter.; ZDOUC, Werner. The Law and Policy of the World Trade Organization. $3^{\text {a }}$ ed. Cambridge: Cambridge University Press, 2013. p. 207. 
decorrentes da utilização do sistema de solução de controvérsias podem ser debatidas. ${ }^{245}$

O OSC funciona, assim, como a instância vocalizadora da decisão, que, contudo, emana como resultado do procedimento tido no Sistema de Solução de Controvérsias da OMC, e por isso sua atuação não impede ou anula a juridicidade dos relatórios dos órgãos adjudicantes do sistema. Por outro lado, é a sua aprovação ao(s) relatório(s), ainda que sob a regra do consenso negativo, que confere formalmente a esses documentos efeitos jurídicos de uma decisão adjudicatória internacional. ${ }^{246}$

\subsubsection{Instâncias Adjudicatórias}

O Entendimento explicita que os painéis são grupos de especialistas formados com as funções principais de (a) avaliar objetivamente o litígio que lhe seja submetido, sob os aspectos dos fatos e de sua conformidade em relação aos dispositivos dos respectivos acordos; e (b) elaborar conclusões que auxiliem o OSC na formulação de recomendações e

245 Tradução livre do original em língua inglesa: "As a result of the fact that the DSB takes the core dispute settlement decisions referred to above by reverse consensus, the DSB's impact and influence over consultations and adjudication by panels and the Appellate Body in specific disputes is very limited. The involvment of the DSB is, to a large extent, a legacy of the past in which trade dispute settlemet was more diplomatic and political that judicial in nature. Nevertheless, the involvement of the DSB in each major step of a dispute fulfils three useful purposes: (1) it keeps all WTO Members directly informed of the WTO dispute settlement; (2) it ensures multilateral surveillance of DSB recommendations and rulings, thereby exerting pressure on the offending party to comply; and (3) it gives WTO members a designated political fórum in which issues arising from the use of the dispute settlement system can be debated". VAN DEN BOSSCHE, Peter.; ZDOUC, Werner. The Law and Policy of the World Trade Organization. $3^{\mathrm{a}}$ ed. Cambridge: Cambridge University Press, 2013. p. 208.

246 Assim sintetiza o autor: "Estilo e automaticidades, acima examinados e comentados, não convertem os reports dos panels e do Appellate Body em sentenças judiciais. Com efeito, os reports só adquirem plenitude de efeitos jurídicos quando aprovados pelos Estados-membros, através de um órgão criado pela constituição da OMC - o "Dispute Settlement Body", o Órgão de Solução de Controvérsias - [...] Essa aprovação, ainda que tenha o potencial de automaticidade, é o que configura o exequatur, através de uma homologação política, por via de regra, do consenso negativo." LAFER, Celso. O Sistema de Solução de Controvérsias da Organização Mundial do Comércio. In: CASELLA, Paulo Borba; MERCADANTE, Araminta de (coord.). Guerra comercial ou integração mundial pelo comércio?: a OMC e o Brasil. São Paulo: LTr, 1998, p. 729-755. p. 747. 
decisões. ${ }^{247}$

Embora a regra do consenso reverso esvazie a função do OSC na solução de controvérsias, empoderando as instâncias jurisdicionais, o texto do Entendimento busca conferir preponderância desse órgão sob o painel, ao enunciar que a função do painel é auxiliar o "OSC a desempenhar as obrigações que lhe são atribuidas". ${ }^{248}$

O painel é estabelecido pelo OSC, no mais tardar em sua reunião seguinte àquela na qual a solicitação de estabelecimento do painel consta como item da agenda, a menos que, segundo a lógica do consenso reverso, haja unanimidade pelo não estabelecimento. ${ }^{249}$ Esta requisição para estabelecimento de um painel se dá por meio de instrumento escrito, no qual a parte requerente deve necessariamente descrever a medida em discussão e explicitar a base jurídica do pedido. ${ }^{250}$

O painel é composto por indivíduos bem qualificados, especialistas em direito do comércio internacional ou política comercial internacional, escolhidos em sua capacidade individual, ainda que sejam funcionários governamentais. ${ }^{251}$ Embora os indivíduos possam ser selecionados dentre os nomes de uma lista indicada pelos membros, periodicamente atualizada, e na qual constam suas respectivas áreas ou setores de experiência ou competência técnica, a sua atuação deve se pautar pela independência na análise dos

247 Artigo 11. Entendimento Relativo às Normas e Procedimentos sobre Solução de Controvérsias. Versão oficial em português segundo o decreto n. 1.355, de 30 dez. 1994, que promulga a Ata Final que Incorpora os Resultados da Rodada Uruguai de Negociações Comerciais Multilaterais do GATT.

248 Artigo 11. Entendimento Relativo às Normas e Procedimentos sobre Solução de Controvérsias. Versão oficial em português segundo o decreto n. 1.355, de 30 dez. 1994, que promulga a Ata Final que Incorpora os Resultados da Rodada Uruguai de Negociações Comerciais Multilaterais do GATT.

249 Artigo 6.1. Entendimento Relativo às Normas e Procedimentos sobre Solução de Controvérsias. Versão oficial em português segundo o decreto n. 1.355, de 30 dez. 1994, que promulga a Ata Final que Incorpora os Resultados da Rodada Uruguai de Negociações Comerciais Multilaterais do GATT.

250 Artigo 6.2. Entendimento Relativo às Normas e Procedimentos sobre Solução de Controvérsias. Versão oficial em português segundo o decreto n. 1.355, de 30 dez. 1994, que promulga a Ata Final que Incorpora os Resultados da Rodada Uruguai de Negociações Comerciais Multilaterais do GATT.

251 O Artigo 8:1 explicita de modo amplo o espectro funcional dos membros do painel, permitindo não só a participação de agentes governamentais como de indivíduos que tenham representando alguma parte em um outro procedimento do mecanismo de solução de controvérsias: "1. Os grupos especiais serão compostos por pessoas qualificadas, funcionários governamentais ou não, incluindo aquelas que tenham integrado um grupo especial ou a ele apresentado uma argumentação, que tenham atuado como representantes de um Membro ou de uma parte contratante do GATT 1947 ou como representante no Conselho ou Comitê de qualquer acordo abrangido ou do respectivo acordo precedente, ou que tenha atuado no Secretariado, exercido atividade docente ou publicado trabalhos sobre direito ou política comercial internacional, ou que tenha sido alto funcionário na área de política comercial de um dos Membros." Entendimento Relativo às Normas e Procedimentos sobre Solução de Controvérsias. Versão oficial em português segundo o decreto n. 1.355, de 30 dez. 1994, que promulga a Ata Final que Incorpora os Resultados da Rodada Uruguai de Negociações Comerciais Multilaterais do GATT. 
litígios. ${ }^{252}$

Assim é que o Entendimento expressamente enuncia:

8.9. Os integrantes dos grupos especiais deverão atuar a título pessoal e não como representantes de governos ou de uma organização. Assim sendo, os Membros não lhes fornecerão instruções nem procurarão influenciá-los com relação aos assuntos submetidos ao grupo especial. 253

Contudo, de modo a reforçar o impedimento de influências externas às qualidades técnicas individuais, inicialmente não se permite que nacionais de membros que constem como parte - ou terceiras partes - na controvérsia sejam convocados para o desempenho desta função, embora a restrição possa ser superada se as partes estiverem de comum acordo. $^{254}$

Em relação ao número de painelistas, a regra geral prevê que os painéis serão integrados por três indivíduos, mas as partes podem acordar no sentido de formá-los com cinco integrantes. ${ }^{255}$ Os nomes devem ser escolhidos pelas partes de comum acordo, a partir de proposição feita às partes pelo Secretariado. ${ }^{256}$ Diante da ausência de acordo, no prazo de 20 dias do estabelecimento do painel, caberá ao Diretor-Geral da OMC determinar sua composição. ${ }^{257}$

No que tange ao mandato específico de cada painel, sentiu-se a necessidade de delimitá-lo expressamente em cada controvérsia, explicitado por meio do instrumento denominado Termos de Referência. ${ }^{258}$ Além de sua relevância para o exercício do

252 Artigo 8.3 e 8.4. Entendimento Relativo às Normas e Procedimentos sobre Solução de Controvérsias. Versão oficial em português segundo o decreto n. 1.355, de 30 dez. 1994, que promulga a Ata Final que Incorpora os Resultados da Rodada Uruguai de Negociações Comerciais Multilaterais do GATT.

253 Artigo 8.9. Entendimento Relativo às Normas e Procedimentos sobre Solução de Controvérsias. Versão oficial em português segundo o decreto n. 1.355, de 30 dez. 1994, que promulga a Ata Final que Incorpora os Resultados da Rodada Uruguai de Negociações Comerciais Multilaterais do GATT.

254 Artigo 8.3. Entendimento Relativo às Normas e Procedimentos sobre Solução de Controvérsias. Versão oficial em português segundo o decreto n. 1.355, de 30 dez. 1994, que promulga a Ata Final que Incorpora os Resultados da Rodada Uruguai de Negociações Comerciais Multilaterais do GATT.

255 Artigo 8.5. Entendimento Relativo às Normas e Procedimentos sobre Solução de Controvérsias. Versão oficial em português segundo o decreto n. 1.355, de 30 dez. 1994, que promulga a Ata Final que Incorpora os Resultados da Rodada Uruguai de Negociações Comerciais Multilaterais do GATT.

256 Artigo 8.6. Entendimento Relativo às Normas e Procedimentos sobre Solução de Controvérsias. Versão oficial em português segundo o decreto n. 1.355, de 30 dez. 1994, que promulga a Ata Final que Incorpora os Resultados da Rodada Uruguai de Negociações Comerciais Multilaterais do GATT.

257 Artigo 8.7. Entendimento Relativo às Normas e Procedimentos sobre Solução de Controvérsias. Versão oficial em português segundo o decreto n. 1.355, de 30 dez. 1994, que promulga a Ata Final que Incorpora os Resultados da Rodada Uruguai de Negociações Comerciais Multilaterais do GATT.

258 Artigo 7.1. "Os termos de referência dos grupos especiais serão os seguintes, a menos que as partes 
contraditório, os Termos de Referência tem a função clara de estabelecer a competência do painel, ao definir as alegações que deverão ser avaliadas no litígio, submetendo a atividade do painel a estes termos. ${ }^{259}$

A segunda instância adjudicatória do Sistema de Solução de Controvérsias da OMC é o Órgão de Apelação, que foi instituído pelo OSC com a função de examinar apelações das decisões dos painéis, e é considerado pela doutrina como uma espécie de tribunal internacional permanente. ${ }^{260261262263}$

O Órgão de Apelação é composto por sete membros, que atuam alternadamente em turmas de três integrantes ${ }^{264}$ e são nomeados por períodos de quatro anos. ${ }^{265}$ Os

envolvidas na controvérsia acordem diferentemente dentro do prazo de 20 dias a partir da data de estabelecimento do grupo especial: 'Examinar, à luz das disposições pertinentes no (indicar o(s) acordo(s) abrangido(s) citado(s) pelas partes em controvérsia), a questão submetida ao OSC por (nome da parte) no documento ... estabelecer conclusões que auxiliem o OSC a fazer recomendações ou emitir decisões previstas naquele(s) acordo(s)'." Entendimento Relativo às Normas e Procedimentos sobre Solução de Controvérsias. Versão oficial em português segundo o decreto n. 1.355, de 30 dez. 1994, que promulga a Ata Final que Incorpora os Resultados da Rodada Uruguai de Negociações Comerciais Multilaterais do GATT.

259 Neste sentido, um dos primeiros painéis explicitou: "A panel's terms of reference are important for two reasons. First, terms of reference fulfil an important due process objective -- they give the parties and third parties sufficient information concerning the claims at issue in the dispute in order to allow them an opportunity to respond to the complainant's case. Second, they establish the jurisdiction of the panel by defining the precise claims at issue in the dispute." WTO. Panel Report, Brazil - Measures Affecting Desiccated Coconut. WT/DS22/R, 21 fev. 1997. p. 22.

260 Este é o entendimento de Cesare Romano: “[...] disputes between WTO members are to be submitted to an ad hoc panel, composed of three experts chosen by the parties. These elements closely recall arbitral tribunals. The Appellate Body, conversely, has more pronounced judicial features. It is a standing organ that decides appeals against findings of ad hoc panels and is composed of seven persons, three of whom sit on any one case in rotation and can hear only appeals relating to points of law covered in the report and legal interpretations developed by the panel." ROMANO, Cesare. A Taxonomy of International Rule of Law Institutions. Journal of International Dispute Settlement, vol. 2, n. 1, p. 241-277, 2011. p. 262.

261 Assim explicitam os autores: "The DSU furthers the role of legal adjudication in international trade law by creating a permanent appellate tribunal. [...]." CAMERON, James; GRAY, Kevin R. Principles of International Law in the WTO Dispute Settlement Body. International and Comparative Law Quarterly, vol. 50, p. 249-298, 2001. p. 249.

262 O autor prefere caracterizá-lo como um órgão "jurídico": "Certain words are never used formally for the DSS [Dispute Settlement System], for instance, “court," "tribunal," or "judicial." These words seem too threatening to some notions of sovereignty. Yet some informal or academic comments have explicitly used these or similar terms to describe the system. For some of these reasons, this book uses the slightly more ambiguous term of "juridical," to describe the WTO DSS." JACKSON, John. Sovereignty, the WTO and Changing Fundamentals of International Law. New York: Cambridge University Press, 2006. p. 136.

263 O autor destaca que o Órgão de Apelação não é chamado formalmente de tribunal internacional por seus instrumentos institutivos, o que se justifica por razões históricas que remontam ao GATT e à transição do GATT para a OMC: "[...] the Appellate Body is not formally called a tribunal. There are well known historical reasons for that, going back to the fact that the GATT (the predecessor of the WTO) was a transitional arrangement, pending the institution of the ITO. [...]" ABI-SAAB, GEORGES. The Normalization of International Adjudication: Convergence and Divergencies. New York University Journal of International Law \& Policy, vol. 43, p.1-43, 2010-2011. p. 12.

264 Artigo 17.1. Entendimento Relativo às Normas e Procedimentos sobre Solução de Controvérsias. Versão oficial em português segundo o decreto n. 1.355, de 30 dez. 1994, que promulga a Ata Final que Incorpora os Resultados da Rodada Uruguai de Negociações Comerciais Multilaterais do GATT.

265 Artigo 17.2. Entendimento Relativo às Normas e Procedimentos sobre Solução de 
indivíduos escolhidos para sua composição devem ser de notória competência e possuidores de comprovada experiência em direito e em comércio internacional, bem como nas temáticas abarcadas pelos acordos. Diferentemente dos membros do painel, os membros apontados para o Órgão de Apelação não podem estar vinculados a nenhum governo. $^{266}$

No que tange à competência deste órgão, cabe a ele (i) confirmar; (ii) modificar ou (iii) revogar as conclusões e decisões jurídicas do painel. ${ }^{267}$ A sua análise, contudo, deve se enquadrar nos limites da apelação pelos membros, que apenas podem contestar as questões de direito mencionadas no relatório do painel e as interpretações jurídicas adotadas. $^{268}$

Por meio de suas competências formalmente instituídas - ou na visão de alguns, para além destas - 269270271 o Órgão de Apelação exerce função sistêmica essencial, ao

Controvérsias. Versão oficial em português segundo o decreto n. 1.355, de 30 dez. 1994, que promulga a Ata Final que Incorpora os Resultados da Rodada Uruguai de Negociações Comerciais Multilaterais do GATT.

266 Artigo 17.3. Entendimento Relativo às Normas e Procedimentos sobre Solução de Controvérsias. Versão oficial em português segundo o decreto n. 1.355, de $30 \mathrm{dez}$. 1994, que promulga a Ata Final que Incorpora os Resultados da Rodada Uruguai de Negociações Comerciais Multilaterais do GATT.

267 Artigo 17.13. Entendimento Relativo às Normas e Procedimentos sobre Solução de Controvérsias. Versão oficial em português segundo o decreto n. 1.355, de 30 dez. 1994, que promulga a Ata Final que Incorpora os Resultados da Rodada Uruguai de Negociações Comerciais Multilaterais do GATT.

268 Artigo 17.6. Entendimento Relativo às Normas e Procedimentos sobre Solução de Controvérsias. Versão oficial em português segundo o decreto n. 1.355, de 30 dez. 1994, que promulga a Ata Final que Incorpora os Resultados da Rodada Uruguai de Negociações Comerciais Multilaterais do GATT.

269 A esse título, observe-se o seguinte argumento: "The vigor of the WTO dispute settlement depends on voluntary compliance - and a strong case can be made against voluntary compliance with dispute resolution decisions that are the product of the policy preferences of WTO panels and the Appellate Body rather than a neutral reading of the language of WTO agreements. At issue is not whether an open international trading system based on agreed rules is the right policy goal, but wether the system can withstand activist panels and an activist Appellate Body that are seen as imposing their views of the 'correct' meaning of WTO rules, even where a member's interpretation would seem to be a reasonable, a permissible, or, in some cases, the better, alternative." GREENWALD, John. WTO Dispute Settlement: an exercise in trade law legislation? Journal of International Economic Law, v. 6, n. 1, p.113-124, 2003. p. 115. Sobre os eventuais "custos políticos" deste ativismo ("[....] It now seems clear that there will be potentially significant costs arising from the dynamic effects of AB activism. [...]), Cf: TARULLO, Daniel. K. The Hidden Costs of International Dispute Settlement: WTO Review of Domestic Anti-Dumping Decisions. Law \& Policy in International Business, vol. 34, p. 109-181, 2002-2003. p. 178.

270 Para uma visão contrária, de que não há que se falar em ativismo judicial, sendo apenas o exercício legítimo de suas funções: "[...] in all of the prominent instances where the AB has been accused of excceeding its authority, it has based itself upon a defensible interpretation of WTO law, consistent with the interpretative rules and principles in the Vienna Convention on the Law of Treaties. [...]" HOWSE, Robert. The Most Dangerous Branch? WTO Appellate Body Jurisprudence on the Nature and Limits of the Judicial Power. Chapter 1. In: COTTIER, Thomas; MAVROIDIS, Petros C. (Eds) The Role of the Judge in International Trade Regulation: Experience and Lessons for the WTO. Michigan: University of Michigan Press, 2003, p. 11-41.p. 13.

271 A esse respeito, relevante a reflexão de Piet Eeckout sobre a a "responsabilidade" dos membros do Sistema de Solução de Controvérsias: "[...] the adjudicators need not limit themselve - to paraphrase Dworkin - to the best constructive interpretation of the political structure and legal doctrine of the WTO community, within the bounds of the covered agreements. WTO Members are not just that, they form the 
promover a homogeneidade da interpretação e aplicação das regras multilaterais, em celebração da previsibilidade que é elemento tão caro ao comércio internacional.

Embora o sistema não esteja pautado no stare decisis, e suas decisões sejam a princípio válidas apenas para as partes em litígio, é inegável a legítima expectativa de continuidade e respeito aos pronunciamentos anteriores sobre um mesmo tema, o que permite o desenvolvimento jurisprudencial do sistema multilateral. A atividade do Órgão de Apelação promove, portanto, adensamento do componente jurisprudencial deste sistema, destacado pela hierarquia de suas manifestações em face das interpretações dos painéis. $^{272}$

\subsubsection{Especificidades do Sistema de Solução de Controvérsias da OMC}

Destacam-se como especificidades do Sistema de Solução de Controvérsias da OMC, em relação aos demais procedimentos adjudicatórios de solução de controvérsias no Direito Internacional: (i) a relação entre os órgãos adjudicatórios e o OSC na solução de litígios; (ii) a presença marcante do aspecto negocial em seu procedimento, seja na fase de consultas ou durante as demais etapas do procedimento; e (iii) o caráter "aberto" das decisões resultantes deste mecanismo, deixando um "espaço de manobra" para a colmatação pelo membro condenado.

Em relação à primeira especificidade, retoma-se brevemente o que se explicitou no

international community, with the exception of a very limited set of States which have not joined yet. Guidance as to the importance of a value or interest protected by the General Exceptions can be sought in multilateral treaties and conventions and in the work of international organizations. It is the case of course that most multilateral instruments have not been signed up to by all WTO Members. Some type of majoritarian approach is therefore called for. It is submitted that, when employed carefully, that approach is legitimate, even in an organization with a membership as diverse as that of the WTO." EECKOUT, Piet. The Scales of Trade - Reflections on the Growth and Functions of the WTO Adjudicative Branch. Journal of International Economic Law, vol. 13, p. 3-26, 2010. p. 26.

272 COZENDEY, Carlos Márcio Bicalho. O Sistema de Solução de Controvérsias da OMC: para além dos contenciosos, a política externa. Disponível em: <http:/www.itamaraty.gov.br/temas/temasmultilaterais/copy_of_desenvolvimento-comercio-e-financas/organizacao-mundial-do-comercio/solucao-decontroversias/cgc/artigo-cozendey> Acesso em: 15 dez. 2013. p. 6. 
tópico 2.1.2 e seus subtópicos. A apurada relação entre os órgãos adjudicatórios - os painéis e o Órgão de Apelação - e o órgão político, é explicada por motivações históricas da negociação da passagem do GATT para a OMC. A regra do consenso reverso, contudo, trazendo automaticidade na adoção dos relatórios dos órgão adjudicantes, esvazia das funções concretas do OSC o controle prático de análises jurídicas. A existência deste controle - muito mais teórica que prática - não tem, portanto, o condão de impossibilitar o reconhecimento da natureza adjudicatória deste Sistema de Solução de Controvérsias, como se avalia em seguida.

GeOrges ABI-SAAB explica esta especificidade do Sistema de Solução de Controvérsias da OMC, com base na busca pela conciliação e satisfação de expectativas políticas naquele sistema, individualizadas por meio de ambientes e mandatos particulares, requisitos tanto para o exercício de sua função judicial quanto de sua legitimação:

\begin{abstract}
O Órgão de Apelação veio, assim, a existir como parte de uma organização cuja sutil atmosfera, prologando-se da era GATT, é encapsulada no mantra de que "esta é uma organização dirigida pelos membros", e o sentimento geral de que são os próprios membros que tomam todas as decisões finais. Tinha por mandato interpretar e aplicar as disposições muito detalhadas dos acordos, de elaboração pouco cuidadosa, com a prescrição de que suas decisões "não podem aumentar ou diminuir os direitos e obrigações previstos" nesses tratados; e com os órgãos políticos e os Estados membros acompanhando de perto (para não dizer que olhavam sobre seus ombros) como ele interpreta e aplica tais disposições. Mas, ao mesmo tempo, o Órgão de Apelação teve que agir com o grau de independência como requisito necessário para o exercício da função judiciária internacional. 273
\end{abstract}

É, pois, no passado de cinquenta anos de GATT que essas peculiaridades do sistema de solução de controvérsia da OMC se justificam. Isto é, se por um lado as evoluções alcançadas no desenho do "novo" sistema de solução de litígios foram de pertinência substancial, por outro lado a manutenção de certos traços - potencializada por uma linguagem árida e tecnicista, que expressa de modo austero suas regras institucionais -

273 Tradução livre do original em língua inglesa: “The Appellate body thus came into being as part of an Organization whose pervasive atmosphere, lingering from the GATT era, is encapsulated in the mantra that "this is a member-driven organization", and the general feeling that it is the members themselves that take all the final decisions. It had for mandate to interpret and apply very detailed treaty provisions, shoddily drafted, with the injunction that its rulings "cannot add to or diminish the rights and obligations provided in" these treaties; and with the political organs and the member states closely watching (not to say looking over its shoulder) how it interprets and applies them. But at the same time, the Appellate Body had to act with the necessary degree of independence requisite for the exercise of the international judicial function." ABISAAB, GEORGES. The Normalization of International Adjudication: Convergence and Divergencies. New York University Journal of International Law \& Policy, vol. 43, p.1-43, 2010-2011. p. 13-14. 
foi elemento que garantiu o sucesso da negociação do então "novo" sistema.

Neste sentido, a manutenção de um controle político da função adjudicante dos painéis e do Órgão de Apelação, embora na prática inoperante, foi um dos elementos que entraram na equação das negociações para a criação da OMC. ${ }^{274}$ Foram criadas, ademais, limitações à atuação das instâncias adjudicantes - como o cuidado com o equilíbrio entre os direitos e deveres expressamente previstos nos acordos às partes e os limites à revisão na apelação.

A segunda característica marcante do Sistema de Solução de Controvérsias da OMC é a inclusão da negociabilidade em diversas etapas e dimensões do procedimento. Isto pois o Sistema de Solução de Controvérsias da OMC apresenta uma combinação única de métodos de solução de conflitos, com especial espaço para a negociação em todas as fases do procedimento. ${ }^{275}$

Em um sentido mais amplo, Carlos Marcos Bicalho Cozendey cita que o Sistema de Solução de Controvérsias da OMC se relaciona intimamente com a negociação de regras no âmbito da OMC em sentido mais amplo: o Sistema de Solução de Controvérsias exerce influência sobre as negociações, por exemplo, nos casos em que nele se forma consenso em relação a uma interpretação consagrada, que tende a se cristalizar em novas regras, ou de maneira oposta, nos casos em que uma interpretação recorrente do Órgão de Apelação continua a ser desrespeitada, havendo, pois, um estímulo à modificação normativa. ${ }^{276}$ Desse modo, haveria uma forte interação entre a solução de controvérsias e a produção normativa, sendo esse um elemento a ser crescentemente ponderado nos cálculos dos negociadores. ${ }^{277}$

Embora haja quem critique o caráter negocial do procedimento, JOOST PAUWELYN clama por maior papel da negociação no procedimento, que em sua opinião poderia ser

274 Neste sentido é análise de Georges Abi-Saab: "Indeed, one of the conditions by several states, and not the least, for accepting the vast extension of substantive regulation operated by the Marrakesh Agreements was the establishment of a mechanism of judicial control." ABI-SAAB, GEORGES. The Normalization of International Adjudication: Convergence and Divergencies. New York University Journal of International Law \& Policy, vol. 43, p.1-43, 2010-2011. p. 13.

275 SPAIN, Anna. Integration Matters: Rethinking The Architecture Of International Dispute Resolution. University of Pennsylvania Journal of International Law, vol. 32, p. 1-56, 2010-2011.

276 É o exemplo das propostas norte-americanas sobre o instituto do zeroing, e a temática do antidumping.

277 COZENDEY, Carlos Márcio Bicalho. O Sistema de Solução de Controvérsias da OMC: para além dos contenciosos, a política externa. Disponível em: <http:/www.itamaraty.gov.br/temas/temasmultilaterais/copy_of_desenvolvimento-comercio-e-financas/organizacao-mundial-do-comercio/solucao-decontroversias/cgc/artigo-cozendey> Acesso em: 15 dez. 2013. p. 7-8. 
incrementado nas fases pré-litígio, durante o litígio e pós-litígio. Adicionalmente, defende a negociação ou a arbitragem como uma alternativa ao litígio. ${ }^{278}$

Neste mesmo estudo, o autor rotula como "americanização" do Sistema de Solução de Controvérsias da OMC o foco crescente na litigância, a prescindir da negociação. Esse fenômeno de "americanização" - que não seria inesperado haja vista a grande influência que os EUA exerceram na negociação da Rodada do Uruguai - se manifestaria em três características do Sistema de Solução de Controvérsias: (i) o direito ao estabelecimento de um painel automaticamente; ${ }^{279}$ (ii) a juridificação trazida pela criação do Órgão de Apelação e sua linguagem legalista; ${ }^{280}$ e (iii) a natureza adversarial do mecanismo, derivada da natureza bilateral das obrigações da OMC.

Roberto CARvalHo DE AZEVÊDo salienta a necessidade de explorar as muitas complexidades deste sistema, antes de impingir qualquer análise. O seu processo é singular, e como já explicitado, embora seja eminente técnico - e portanto jurídico - traz uma dimensão política que deve ser interpretada caso a caso:

\footnotetext{
Embora o processo seja técnico, costuma trazer em seu bojo uma dimensão "política - variável conforme o caso - que precisa ser levada em conta nos diversos estágios de um caso: a decisão de iniciá-lo, os argumentos a serem apresentados, os passos que devem ou não ser adotados com vistas à implementação das decisões. ${ }^{281}$
}

A terceira especificidade do Sistema de Solução de Controvérsias da OMC, que será desenvolvida no tópico 2.5 , diz respeito a aspectos formais e materiais da decisão adjudicatória resultante deste sistema. Cumpre destacar, desde logo, que a decisão é emanada pelo OSC, como vocalizador do resultado do procedimento, protagonizado pelos órgãos adjudicatórios. A aprovação pelo OSC, seja expressa ou pelo decorrer do prazo

278 PAUWELYN, Joost. The Limits of Litigation: "Americanization” and Negotiation in the Settlement of WTO Disputes. Ohio State Journal On Dispute Resolution, vol. 19: issue 1, p. 121-140, 2003. p. 137. 279 PAUWELYN, Joost. The Limits of Litigation: "Americanization" and Negotiation in the Settlement of WTO Disputes. Ohio State Journal On Dispute Resolution, vol. 19: issue 1, p. 121-140, 2003. p. 122. 280 PAUWELYN, Joost. The Limits of Litigation: "Americanization" and Negotiation in the Settlement of WTO Disputes. Ohio State Journal On Dispute Resolution, vol. 19: issue 1, p. 121-140, 2003. p. 124. 281 AZEVEDO, Roberto Carvalho de. Prefácio. In: BENJAMIN, Daniela Arruda. (Org). O Sistema de Solução de Controvérsias da OMC : uma perspectiva brasileira. Brasília : FUNAG, 2013, p. 23-30. p. 24. 
estabelecido no ESC, é condição formal para conferir aos relatórios o status de decisão do Sistema de Solução de Controvérsias. ${ }^{282}$

No que se refere ao aspecto material destas decisões, o Sistema de Solução de Controvérsias da OMC se destaca pelo caráter aberto de sua formulação. Diferentemente da maioria das decisões adjudicatórias - ou sentenças internacionais - , neste sistema, em regra, apenas reconhece-se a desconformidade da conduta analisada, não havendo ad initio a cominação de consequências ou a determinação de condutas específicas. Deste modo, cabendo ao membro cuja conduta foi considerada desconforme adaptá-la às regras do sistema multilateral de comércio, lhe é concedido um espaço de discricionariedade na escolha dos meios pelos quais a conduta será trazida à conformidade.

Essas especificidades, que fazem do Sistema de Solução de Controvérsias da OMC um mecanismo único de solução de litígios, levaram à uma interpretação isolada ${ }^{283} \mathrm{e}$ equivocada de seus dispositivos, e do significado de suas decisões no contexto do sistema jurídico internacional como um todo. Contudo, certas facetas de seu procedimento, tal como a combinação não tradicional entre os meios para solução de litígios, podem inclusive ser vistas como bem sucedidas - o caminho para o qual a solução de controvérsias no Direito Internacional poderia evoluir. ${ }^{284} 285$

282 Na direção dos ensinamentos de Celso Lafer: “[...] entendo que os reports continuam tendo, no sistema da OMC, formalmente, a natureza jurídica de um parecer, de um tertius, acima das partes, dotado de vis directiva. A mudança - o desenvolvimento progressivo-reside no adensamento da juridicidade tanto do due process quanto da conversão do seu produto, os pareceres, em findings, dotados de eficácia jurídica." LAFER, Celso. O Sistema de Solução de Controvérsias da Organização Mundial do Comércio. In: CASELLA, Paulo Borba; MERCADANTE, Araminta de (coord.). Guerra comercial ou integração mundial pelo comércio?: a OMC e o Brasil. São Paulo: LTr, 1998, p. 729-755. p. 748.

283 O autor avalia que esta interpretação isolada e tecnicista vem perdendo espaço para uma visão mais aberta, em face de críticas sobre o papel deste sistema: "These opposing considerations led the Appellate Body to stick closely to the specificities of the matter put before it, and to follow a judicial policy of "strict constructionism" in interpretation, with marked reluctance to indulge in interpretation on the basis of general principles or even the object and purpose of the agreements. But I have to say that this initial judicial policy has been slowly evolving towards more openness in the face of scathing criticisms of the WTO in general, and its Dispute Settlement System in particular, as a ruthless vehicle of economic globalization, oblivious (and to the detriment) of other major values or concerns of the international community." ABISAAB, GEORGES. The Normalization of International Adjudication: Convergence and Divergencies. New York University Journal of International Law \& Policy, vol. 43, p.1-43, 2010-2011. p. 13.

284 SPAIN, Anna. Integration Matters: Rethinking The Architecture of International Dispute Resolution. University of Pennsylvania Journal of International Law, vol. 32, p. 1-56, 2010-2011.

285 Destaca-se o ponto apresentado por Carlos Cozendey: “[...] Numerosos casos foram resolvidos sem a necessidade de alcançar a fase de painel, demonstrando que, apesar da maior jurisdicionalidade, o sistema não perdeu a capacidade de criar espaços de negociação. É claro que o êxito de tais negociações se deve em boa parte à percepção de que o sistema funciona e de que, portanto, diante de posição frágil à luz das disciplinas multilaterais, melhor corrigir a situação de forma controlada por meio da negociação do que sujeitar-se a recomendações cujo escopo e conteúdo podem ir além do esperado. [...] "COZENDEY, Carlos Márcio Bicalho. O Sistema de Solução de Controvérsias da OMC: para além dos contenciosos, a política 
Se por um lado estas especificidades - sejam reais ou aparentes - levam alguns autores a captarem de modo enganoso a solução de controvérsias na OMC e o seu status em face do Direito Internacional, são também elas que conferem ao Sistema de Solução de Controvérsias da OMC singularidade e destaque em face dos demais mecanismos de solução de litígios existentes na atualidade. ${ }^{286}$

\subsubsection{Natureza Jurídica}

Exatamente em função das especificidades deste sistema único, e do caráter híbrido de seu procedimento, para alguns autores predominaria a natureza política do sistema, o que os leva a interpretá-lo como um sistema “quase judicial”. ${ }^{287} 288$

A melhor análise, contudo, é aquela que reconhece ao Sistema de Solução de Controvérsias da OMC uma natureza jurisdicional, como um sistema de função adjudicatória no Direito Internacional. Isto pois, embora a linguagem "árida" do Entendimento abstenha-se do uso de termos como "Tribunal", "Corte" ou "judicial" para

externa. Disponível em: <http://www.itamaraty.gov.br/temas/temas-multilaterais/copy_of_desenvolvimentocomercio-e-financas/organizacao-mundial-do-comercio/solucao-de-controversias/cgc/artigo-cozendey> Acesso em: 15 dez. 2013. p. 16.

286 Remete-se ao ensinamento de John Jackson: "This DSS is unique in international law and institutions, both at present and historically. It embraces mandatory exclusive jurisdiction and virtually automatic adoption of dispute settlement reports, extraordinary for an institution with such broad-ranging competence and responsibilities as the WTO - virtually every aspect of economic regulation and policy is touched upon at least potentially, if not actually, and it is already imposing obligations on 148 nations (out of 192 recognized), comprising 93 percent of world trade, and 87 percent of world population. The DSS has been described as the most important and most powerful of any international law tribunals, although some observers reserve that primary place to the World Court (International Court of Justice). Even some experienced World Court advocates, however, have been willing to concede that primacy under some criteria to the WTO DSS." JACKSON, John. Sovereignty, the WTO and Changing Fundamentals of International Law. New York: Cambridge University Press, 2006. p. 139.

287 Assim se posiciona Naigen Zhang: "The WTO dispute settlement has the character of a quasijudicial procedure, i.e. a mixture of judiciary-oriented procedural rules and diplomatic negotiation to settle disputes, [...]'ZZHANG, Naigen. Implementation of WTO Dispute Settlement. Manchester Journal of International Economic Law, vol. 5, issue 2, p.111-125, 2008. p. 112

288 Para uma distinta visão, na qual o Sistema de Solução de Controvérsias da OMC se aproximaria de um sistema jurisdicional nacional de tradição civil, que permite o recurso à arbitragem, Cf: TANIGUCHI, Yasuhei. WTO Dispute Settlement as Seen by a Proceduralist. Cornell International Law Journal, vol. 42, p. 1-21, 2009. 
se referir ao Sistema de Solução de Controvérsias, importa à sua caracterização a verificação dos requisitos da solução jurisdicional, como passamos a destacar. ${ }^{289}$

Isto pois as suas complexidades e especificidades não afastam sua classificação como solução jurisdicional de litígios, sob a perspectiva de que há uma terceira parte, que soluciona de modo obrigatório e definitivo a controvérsia, com base no Direito Internacional. $^{290}$

Embora seja um meio mais intrusivo, pelo qual a solução é imposta às partes, ao escolherem a via jurisdicional, os Estados optam entre soluções de natureza arbitral (tribunal ad hoc) e de natureza judicial, pela submissão do litígio a um tribunal préconstituído e permanente. ${ }^{291}$

Conforme destaca LuCIUS CAFLISH, a arbitragem e a solução judiciária formam a categoria dos meios adjudicatórios, e se distinguem do meios diplomáticos pelos seguintes elementos: (i) são compostos por procedimentos em contraditório, que correntemente se consubstanciam em uma fase escrita e uma fase oral, gerido por sujeitos independentes; (ii) os procedimentos objetivam alcançar uma solução de mérito definitiva para a controvérsia; (iii) a solução deve ser buscada no Direito Internacional, salvo acordo diverso entre as partes; (iv) a decisão é soberana e irrecorrível, e portanto vinculante às partes em litígio. ${ }^{292}$

Assim, se por um lado as decisões diplomáticas ou políticas são flexíveis e de adoção opcional, por outro as decisões jurisdicionais se caracterizam pela rigidez e vinculação ao resultado. Contudo, reside exatamente nestas características a sua vantagem, pois promotoras da substituição do poder pelo direito como meio de resolver os litígios:

289 O autor prefere utilizar o termo jurídico: "Certain words are never used formally for the DSS, for instance, "court," "tribunal," or "judicial." These words seem too threatening to some notions of sovereignty. Yet some informal or academic comments have explicitly used these or similar terms to describe the system. For some of these reasons, this book uses the slightly more ambiguous term of "juridical," to describe the WTO DSS." JACKSON, John. Sovereignty, the WTO and Changing Fundamentals of International Law. New York: Cambridge University Press, 2006. p. 136.

290 Este é o conceito apresentado por Lucius Caflisch: "Les modes juridictionnels de règlement consistent à charger une tierce partie de régler un litige de manière obligatoire et définitive sur la base du droit international." CAFLISCH, Lucius. Cent ans de règlement pacifique des différends interétatiques. Recueil des cours, vol. 288, p. 245-467, 2001. p. 285.

291 CAFLISCH, Lucius. Cent ans de règlement pacifique des différends interétatiques. Recueil des cours, vol. 288, p. 245-467, 2001. p. 285.

292 CAFLISCH, Lucius. Cent ans de règlement pacifique des différends interétatiques. Recueil des cours, vol. 288, p. 245-467, 2001. p. 286. 
Em outras palavras, enquanto os meios diplomáticos são caracterizados pela sua flexibilidade e resultado opcional, a solução jurisdicional se distingue pela sua rigidez e da natureza definitiva e obrigatória de seu resultado e, portanto, por sua natureza altamente intrusiva. Por esta razão, os governos são muitas vezes relutantes em aceitá-la. No entanto, estas alegadas desvantagens são, ao mesmo tempo, os principais pontos fortes do recurso aos meios jurisdicionais; eles colocam um fim à disputa com base no direito internacional, e, assim, contribuem para a promoção do papel do direito na condução das relações internacionais. (grifo nosso) ${ }^{293}$

Adentrando na análise estrutural das decisões jurisdicionais, referido autor explicita que essas decisões compreendem três partes: "[a] decisão, que inclui a qualificação (composição do órgão judicial, histórico do procedimento, fatos), os considerandos ou os motivos e o dispositivo (pontos decididos), é adotada pela maioria dos árbitros ou juízes." 294

Dessas análises podemos destacar que o que marca uma decisão como jurisdicional, portanto, é o caráter de obrigatoriedade ${ }^{295}$ e de definitividade, ${ }^{296}$ e não a sua maior ou menor definição no tocante aos meios para implementar aquele comando.

Cesare Romano, em seu minucioso estudo, se inspira na técnica da taxonomia, inicialmente criada para a biologia, objetivando classificar escalonadamente as instituições relacionadas ao International Rule of Law, e salienta que as especificidades são um desafio a toda forma de classificação. ${ }^{297}$

293 Tradução livre do original em língua francesa: “Autrement dit, alors que les moyens diplomatiques se caractérisent par leur souplesse et leur issue facultative, le règlement juridictionnel se dis- tingue par sa rigidité et par le caractère contraignant et final de son résultat, donc par sa nature hautement intrusive. Pour cette raison, les Etats, souvent, hésitent à l'accepter. Toutefois, ces prétendus inconvénients sont, en même temps, les principaux atouts des moyens juridictionnels; ceux-ci mettent un point final au litige, sur la base du droit des gens, et contribuent ainsi à promouvoir le rôle du droit dans la conduite des relations internationales." CAFLISCH, Lucius. Cent ans de règlement pacifique des différends interétatiques. Recueil des cours, vol. 288, p. 245-467, 2001. p. 286.

294 Tradução livre do original em límgua francesa: "La décision, qui comprend les qualités (composition de l'organe juridictionnel, historique de la procédure, faits), les considérants ou motifs et le dispositif (points décidés), est adopté à la majorité des arbitres ou juges" CAFLISCH, Lucius. Cent ans de règlement pacifique des différends interétatiques. Recueil des cours, vol. 288, p. 245-467, 2001. p. 411.

295 Relevante destacar que a obrigatoriedade da decisão se restringe às partes em conflito: “ $L$ 'article 59 du Statut de la CIJ dispose en effet que "[l] a décision ... n'est obligatoire que pour les parties en litige et dans le cas qui a été décidé», cette dernière précision impliquant que la force obligatoire de la décision est limitée au dispositif de celle-ci." CAFLISCH, Lucius. Cent ans de règlement pacifique des différends interétatiques. Recueil des cours, vol. 288, p. 245-467, 2001. p. 413.

296 A definividade de uma decisão implica que esta se constitui como coisa julgada (res judicata): "Cela signifie en premier lieu que le contentieux est réglé et ne peut, en tant que tel, faire l'objet d'une nouvelle procédure arbitrale ou d'un recours, à moins que le contraire ne soit ou n'ait été convenu entre les Etats concernés". CAFLISCH, Lucius. Cent ans de règlement pacifique des différends interétatiques. Recueil des cours, vol. 288, p. 245-467, 2001. p. 413.

297 ROMANO, Cesare. A Taxonomy of International Rule of Law Institutions. Journal of 
Contudo, apesar das especificidades, o autor classifica o Sistema de Solução de Controvérsias da OMC como instituição inserida (i) no “domínio" das Organizações Internacionais Governamentais; ${ }^{298}$ (ii) no "reino" dos órgãos e procedimentos do International Rule of Law; ${ }^{299}$ (iii) na "classe" dos meios adjudicatórios. ${ }^{300}$

Continuando a classificação, agora tomando em conta as características do Órgão de Apelação da OMC, este se insere (iv) na "ordem" das Cortes e Tribunais Internacionais 301 - embora os painéis se insiram na "ordem" dos Tribunais Arbitrais -, ${ }^{302}$ e (v) na “família” dos Tribunais Internacionais responsáveis por litígios interestatais. ${ }^{303}$

Assim, ao reconhecê-lo como sistema adjudicatório, não se adentrando nas classificações posteriores, está-se a reafirmar que o Sistema de Solução de Controvérsias da OMC foi constituído com a finalidade de resolver litígios com base nas normas, respeitando o procedimento fixado pelo ESC, por parte de membros independentes, e tendo

International Dispute Settlement, vol. 2, n. 1, p. 241-277, 2011.

298 Sobre o "domínio" das Organizações Internacionais governamentais: "All international governmental organizations share three fundamental char-acteristics. They are: (i) Associations of states and/or other international governmental organizations; (ii) established by a treaty or other instruments governed by international law; and (iii) capable of generating through their organs an autonomous will distinct from the will of its members." ROMANO, Cesare. A Taxonomy of International Rule of Law Institutions. Journal of International Dispute Settlement, vol. 2, n. 1, p. 241-277, 2011. p. 249.

299 Sobre este "reino": "[...] what characterizes bodies within this Kingdom and separates them from other kingdoms are three further criteria: (iv) They apply international legal standards; ( $v$ ) act on the basis of pre-determined rules of procedure; (vi) at least one of the parties to the cases they decide, or situation they consider, is a State or an international organization.” ROMANO, Cesare. A Taxonomy of International Rule of Law Institutions. Journal of International Dispute Settlement, vol. 2, n. 1, p. 241-277, 2011. p. 251.

300 Sobre esta "classe": "[...] but what sets the Class of Adjudicative Means apart from the class of Non-Adjudicative Means are two features. (vii) They produce binding outcomes; (viii) They are composed of independent members." ROMANO, Cesare. A Taxonomy of International Rule of Law Institutions. Journal of International Dispute Settlement, vol. 2, n. 1, p. 241-277, 2011. p. 253.

301 Sobre esta "ordem”: “(...)International Courts and Tribunals: all bodies within the Order of International Courts and Tribunals share seven fundamental traits. They: (i) have been established by an international legal instrument; (ii) rely on international law as applicable law; (iii) decide cases on the basis of pre-determined rules of procedure; (iv) are composed of independent members/judges; (v) only hear cases in which at least one party is a State or an international organization; (vi) issue legally binding judgments; and (vii) are permanent." ROMANO, Cesare. A Taxonomy of International Rule of Law Institutions. Journal of International Dispute Settlement, vol. 2, n. 1, p. 241-277, 2011. p. 261-262.

302 Sobre esta peculiaridade: "Bodies can straddle different orders. For example, the World Trade Organization (WTO) and Mercosur (Mercado Comun del Sur) dispute settlement machineries have a twolevel structure: an arbitral panel, as first instance of jurisdiction, and an appellate body. The first level of jurisdiction fits the order of Arbitral Tribunals, but the appellate level falls in the order of International Courts and Tribunals, and specifically the family of State-only Courts and the Genus of Courts with Specialized Jurisdiction." ROMANO, Cesare. A Taxonomy of International Rule of Law Institutions. Journal of International Dispute Settlement, vol. 2, n. 1, p. 241-277, 2011. p. 248.

303 Sobre esta "família”: "(a) State-only Courts: International Courts and Tribunals of this family have jurisdiction mostly if not exclusively over cases between sovereign states." ROMANO, Cesare. A Taxonomy of International Rule of Law Institutions. Journal of International Dispute Settlement, vol. 2, n. 1, p. 241277, 2011. p. 264. 
como resultado uma decisão obrigatória aos membros em litígio. ${ }^{304}$

RICHARD BILDER, em análise sobre as vantagens e desvantagens às partes na escolha de dirimir seus litígios por meio de adjudicação internacional, aponta as seguintes vantagens que podem ser alcançadas pela adjudicação: (1) o caráter dispositivo da adjudicação, que com uma decisão jurídica põe fim à controvérsia; (2) a imparcialidade da adjudicação, pela qual uma terceira parte neutra e não envolvida pode decidir a disputa de modo mais justo; (3) o caráter principiológico da adjudicação, que consiste na aplicação do império do direito e dos princípios que o norteiam; (4) a autoridade da adjudicação, que pelo consentimento das partes presume legitimidade e respeito pela comunidade; (5) a impessoalidade da adjudicação, pela qual não há imputabilidade dos governos nacionais pelas decisões; (6) a seriedade da adjudicação, que por sua complexidade, custos e riscos para as partes, envolve um cálculo de confiança na legitimidade de seu pleito; (7) o caráter ordenado da adjudicação, a qual envolve um procedimento de fases e de cooperação em contraditório entre as partes; (8) o caráter de autoexecutoriedade da adjudicação, ligado à expectativa de cumprimento da decisão e ao fortalecimento do sistema internacional como um todo; (9) o caráter pacificador da adjudicação, que pode se traduzir em redução das tensões e negociação entre as partes; e (10) a criação de precedentes pela adjudicação, e seu auxílio no desenvolvimento do Direito Internacional, ao criar guias de conduta futura e esclarecer o conteúdo do Direito Internacional. ${ }^{305}$

Essas vantagens podem ser retomadas também em relação ao Sistema de Solução de Controvérsias da OMC, na medida em que lhe conferimos natureza jurídica adjudicatória. Cumpre destacar, por fim, que a natureza adjudicatória deste sistema é correntemente reconhecida por diplomatas e advogados que atuam no dia-a-dia de seu procedimento. ${ }^{306}$

304 Independentemente do nome dado à decisão: "First, the decisions of the organizations and bodies belonging to the Adjudicative Means class are binding, legally binding. It means that the outcome of the process, be it called decision, award, report or otherwise creates a new legal obligation on the parties, namely compliance with the outcome." ROMANO, Cesare. A Taxonomy of International Rule of Law Institutions. Journal of International Dispute Settlement, vol. 2, n. 1, p. 241-277, 2011. p. 263.

305 BILDER, Richard B. Some Limitations of Adjudication as an International Dispute Settlement Technique. Virginia Journal of International Law, vol. 231, p. 146-151, 1982.

306 Os autores, diplomatas brasileiros, destacam esta visão: "While the discussion still rages about the correct nature of the dispute settlement mechanism of the WTO, the answer is quite clear to those that have found themselves in the middle of a panel or Appellate Body proceeding, especially in the hearings themselves: it looks like a court, it works much like a court, and one litigates as in a court. Although still evolving and still with some features atypical for judicial bodies ("recommendations"and not judgements"are passed, formal adoption of reports is required and performed by the DSB, a political body, and the panel 


\subsection{O Procedimento do Sistema de Solução de Controvérsias}

O objetivo desta seção do trabalho é apresentar, de modo sucinto, as principais fases do procedimento perante o sistema de solução de controvérsias da OMC, tão somente no intuito de evidenciar o percurso deste procedimento, de modo a possibilitar o esclarecimento de noções que serão essenciais ao objeto das reflexões que serão desenvolvidas. Não se trata, portanto, de esgotar a complexidade das regras procedimentais, ou de explorá-las em sua construção jurisprudencial. ${ }^{307}$

\subsubsection{Consultas}

"eport"can be seen and commented on at its interim"stage), the direction of this evolution is clear: a thickening" of legality and of procedural standards/rules. Of course, considerable room remains for diplomatic flexibility," particularly at the consultation phases (both formal and informal), in parallel to the quasi- judicial proceedings, and in the aftermath of the reports. During the panel and appeal stages, however, the nature of the game is quite clear." EVANS, David. PEREIRA, Celso de Tarso. DSU Review: A View From the Inside. In: YEARS, Rufus. WILSON, Bruce. (Ed.). Key Issues in WTO Dispute Settlement: The First Ten Years. Nova Iorque: Cambridge Univesity Press, 2005, p. 251-264. p. 262.

307 Como revisão bibliográfica geral de temas desse procedimento, Cf: AMARAL JUNIOR, Alberto do. A Solução de Controvérsias na OMC. São Paulo: Atlas, 2008. JACKSON, John H. The Jurisprudence of GATT and the WTO. Cambridge: Cambridge University Press, 2000. JACKSON, John H. The World Trade Organization: Constitution and Jurisprudence. London: The Royal institute of International Affairs, 1998. JACKSON, John H.; DAVEY, William J.; SYKES, Alan O. Legal Problems of International Economic Relations. Cases, Materials and Text on the National and International Regulation of Transnational Economic Relations. St. Paul: West. Publishing Co, 2002. MATSUSHITA, Mitsuo; MAVROIDIS, Petros C.; SCHOENBAUM, Thomas J. The World Trade Organization: Law, Practice, and Policy. 2a Ed. Oxford: Oxford University Press, 2006. PETERSMANN, Ernst-Ulrich. The GATT/WTO Dispute Settlement System: International Law, International Organizations and Dispute Settlement. London: Kluwer, 1997. THORSTENSEN, Vera. OMC- Organização Mundial do Comércio: As Regras do Comercio Internacional e a Nova Rodada de Negociacoes Multilaterais. 2a ed. Sao Paulo: Aduaneiras, 2001. VAN DEN BOSSCHE, Peter.; ZDOUC, Werner. The Law and Policy of the World Trade Organization. 3a ed. Cambridge: Cambridge University Press, 2013. BARRAL, Welber. Solução de Controvérsias na Organização Mundial do Comércio. Brasília: Fundação Alexandre de Gusmão, 2007. 
A fase de consultas, que consiste em uma variedade da negociação como meio para resolução de litígios internacionais, ${ }^{308}$ é de inclusão usual como uma etapa preliminar à solução de controvérsias em diversos tratados internacionais. ${ }^{309}$ A sua característica positiva fundamental é o fato de permitir o controle pelas partes em litígio de todo o processo do início à conclusão das consultas. ${ }^{310}$

Assim, no Sistema de Solução de Controvérsias da OMC o procedimento se inicia com esta fase de consultas, na qual a parte cuja medida adotada possa afetar o cumprimento dos acordos abrangidos se compromete a analisar as alegações do membro demandante, buscando, de boa-fé, atingir solução negociada e pré-litigiosa para a medida desafiada. ${ }^{311}$

A fase de consultas busca, portanto, atingir solução mutuamente satisfatória para a questão, sendo neste procedimento um passo compulsório anterior ao estabelecimento de um painel. Iniciada com a solicitação de consultas por escrito - acompanhada de descrição da medida e embasamento jurídico da reclamação -, é fixado o prazo inicial de 10 (dez) dias para resposta deste requerimento pelo membro questionado, e as consultas deverão se dar em prazo não superior a 30 (trinta) dias a partir do recebimento da solicitação. Contudo, se o membro não respeitar os prazos previstos, ou houver eventual dilação acordada pelas partes para a fase de consultas, o membro requerente poderá encaminhar diretamente o pedido para estabelecimento de um painel relativo à medida em questão. ${ }^{312}$

Iniciadas as consultas, que se dão de maneira confidencial, ${ }^{313}$ e em regra apenas

308 Segundo o Manual da ONU sobre a Solução Pacífica de Controvérsias, produzido pela Divisão de Codificação: "Consultations may be considered as a variety of negotiations." United Nations. Handbook on the Peaceful Settlement of Disputes between States. New York: United Nations, 1992. Office of Legal Affairs, Codification Division. OLA/COD/2394. p. 9.

309 United Nations. Handbook on the Peaceful Settlement of Disputes between States. New York: United Nations, 1992. Office of Legal Affairs, Codification Division. OLA/COD/2394. p. 11.

310 Assim explicita o referido manual: "Because, unlike the other means listed in Article 33 of the Charter, it involves only the States parties to the dispute, those States can monitor all the phases of the process from its initiation to its conclusion and conduct it in the way they deem most appropriate." United Nations. Handbook on the Peaceful Settlement of Disputes between States. New York: United Nations, 1992. Office of Legal Affairs, Codification Division. OLA/COD/2394. p. 9.

311 Artigo 4.1, 4.2 e 4.3. Entendimento Relativo às Normas e Procedimentos sobre Solução de Controvérsias. Versão oficial em português segundo o decreto n. 1.355, de 30 dez. 1994, que promulga a Ata Final que Incorpora os Resultados da Rodada Uruguai de Negociações Comerciais Multilaterais do GATT.

312 Artigo 4.3, 4.4 e 4.5. Entendimento Relativo às Normas e Procedimentos sobre Solução de Controvérsias. Versão oficial em português segundo o decreto n. 1.355, de 30 dez. 1994, que promulga a Ata Final que Incorpora os Resultados da Rodada Uruguai de Negociações Comerciais Multilaterais do GATT.

313 Artigo 4.6. Entendimento Relativo às Normas e Procedimentos sobre Solução de Controvérsias. Versão oficial em português segundo o decreto n. 1.355, de 30 dez. 1994, que promulga a Ata Final que Incorpora os Resultados da Rodada Uruguai de Negociações Comerciais Multilaterais do GATT. 
entre o reclamante e o membro reclamado, ${ }^{314}$ caso as negociações não alcancem resultado no prazo de 60 (sessenta) dias a partir do recebimento do requerimento de consultas, o membro reclamante poderá solicitar o estabelecimento de um painel. Este prazo poderá ser reduzido caso as partes conjuntamente concluam que as consultas não são capazes de alcançar solução para a desavença. ${ }^{315}$

Cumpre destacar, contudo, que não há prazo máximo para o término das consultas, sendo praxe usual do mecanismo de solução de controvérsias da OMC a existência de consultas formalmente em aberto por anos. Isto é, embora haja o prazo mínimo - a princípio de 60 dias - a partir do qual o membro reclamante possa solicitar o estabelecimento do painel, não há prazo máximo para que o faça. ${ }^{316}$

Embora não haja o instituto das medidas provisionais - ou medidas de urgência nesse mecanismo, o ESC prevê que, em casos de urgência, inclusos casos relacionados a bens perecíveis, os prazos para início das consultas e para estabelecimento do painel por frustração das consultas seja reduzido de 30 (trinta) para 10 (dez) dias e de 60 (sessenta) para 20 (vinte) dias, respectivamente. ${ }^{317}$

Embora a passagem do GATT para a OMC tenha trazido o adensamento de juridicidade em seu procedimento de solução de controvérsias, a fase de consultas continua

314 O Artigo 4.11. prevê hipóteses excepcionais nas quais outro membro, entendendo possuir interesse substancial nas consultas poderá integrá-las, neste caso com a anuência do membro que instaurou o procedimento. "11. Quando um Membro não participante das consultas considerar que tem interesse comercial substancial nas consultas baseadas no parágrafo 1 do Artigo 22 do GATT 1994, parágrafo 1 do Artigo 22 do GATS, ou nas disposições pertinentes de outros acordos abrangidos 4 tal Membro poderá notificar os Membros participantes da consulta e o OSC, dentro de um prazo de 10 dias contados da data da distribuição da solicitação de consultas baseadas em tal artigo, de seu desejo de integrar-se às mesmas. Tal Membro deverá associar-se às consultas desde que o Membro ao qual a solicitação de consultas foi encaminhada entenda que a pretensão de interesse substancial tenha fundamento. Nesse caso, o OSC deverá ser devidamente informado. Se a requisição para a participação das consultas não for aceita, o Membro requerente poderá solicitar consultas com base no parágrafo 1 do Artigo 22 ou parágrafo 1 do Artigo 23 do GATT 1994, parágrafo 1 do art. 22." Entendimento Relativo às Normas e Procedimentos sobre Solução de Controvérsias. Versão oficial em português segundo o decreto n. 1.355, de 30 dez. 1994, que promulga a Ata Final que Incorpora os Resultados da Rodada Uruguai de Negociações Comerciais Multilaterais do GATT.

315 Artigo 4.7. Entendimento Relativo às Normas e Procedimentos sobre Solução de Controvérsias. Versão oficial em português segundo o decreto n. 1.355, de 30 dez. 1994, que promulga a Ata Final que Incorpora os Resultados da Rodada Uruguai de Negociações Comerciais Multilaterais do GATT.

316 Para um comentário sobre os casos "abandonados" no Sistema de Solução de Controvérsias, que permanecem formalmente na fase de consultas por anos, investigação dos motivos e situação destes casos, Cf: REYNOLDS, Kara M. Why Are So Many WTO Disputes Abandoned? American University. Department of Economics Working Paper Series, n. 2007-05, jun. 2007. Disponível em: <http://aladinrc.wrlc.org/bitstream/handle/1961/4988/2007-05.pdf?sequence=1> Acesso em: 12 mai. 2014.

317 Artigos 4.8 e 4.9. Entendimento Relativo às Normas e Procedimentos sobre Solução de Controvérsias. Versão oficial em português segundo o decreto n. 1.355, de 30 dez. 1994, que promulga a Ata Final que Incorpora os Resultados da Rodada Uruguai de Negociações Comerciais Multilaterais do GATT. 
um elemento crucial deste procedimento, ${ }^{318}$ tendo em vista que parte substancial das disputas se resolve por meio deste mecanismo.

\subsubsection{Painel}

Os painéis deverão seguir os procedimentos de trabalho previstos do Apêndice 3 do ESC, sendo possível a definição de modo diverso, após consulta às partes. ${ }^{319}$ Contudo, esta flexibilidade no procedimento, que busca garantir a qualidade de seus relatórios, não deve violar as disposições expressas do Entendimento. ${ }^{320} 321$

Uma vez formado o painel, sua tarefa inicial é elaborar um calendário específico para seus trabalhos, o quanto antes possível. ${ }^{322}$ Os prazos fixados deverão ser suficientes para que os membros envolvidos apresentem suas argumentações escritas e as partes deverão respeitar tais prazos. ${ }^{323} 324$

318 Este é o entendimento de Robert Alilovic: "Despite the incorporation of a binding legal process, the WTO is a creation of international relations, where dialogue and conciliation have always played a key, if not vital, role in the resolution of disputes. Prior to reaching the panel stage, the DSU has set up rules and procedures, order to attempt to resolve their differences amicably. [...] consultations will continue to remain an active and vital element within the WTO dispute settlement system." ALILOVIC, Robert. Consultations Under The WTO's Dispute Settlement System. Dalhousie Journal of Legal Studies, vol. 9, p. 279-301, 2000. p. 279-280.

319 Artigo 12.1. Entendimento Relativo às Normas e Procedimentos sobre Solução de Controvérsias. Versão oficial em português segundo o decreto n. 1.355, de 30 dez. 1994, que promulga a Ata Final que Incorpora os Resultados da Rodada Uruguai de Negociações Comerciais Multilaterais do GATT.

320 Artigo 12.1, Artigo 1 do Apêndice 3: Procedimentos de Trabalho Entendimento Relativo às Normas e Procedimentos sobre Solução de Controvérsias. Versão oficial em português segundo o decreto n. 1.355, de 30 dez. 1994, que promulga a Ata Final que Incorpora os Resultados da Rodada Uruguai de Negociações Comerciais Multilaterais do GATT.

321 "Although panels enjoy some discretion in establishing their own working procedures, this discretion does not extend to modifying the substantive provisions of the DSU. To be sure, Article 12.1 of the DSU says: Panels shall follow the Working Procedures in Appendix 3 unless the panel decides otherwise after consulting the parties to the dispute." Yet that is all that it says. Nothing in the DSU gives a panel the authority either to disregard or to modify other explicit provisions of the DSU." WTO. Appellate Body Report, India - Patent Protection for Pharmaceutical and Agricultural Chemical Products. WT/DS50/AB/R 19 dez. 1997. para. 92.

322 Artigo 12.3. Entendimento Relativo às Normas e Procedimentos sobre Solução de Controvérsias. Versão oficial em português segundo o decreto n. 1.355, de 30 dez. 1994, que promulga a Ata Final que Incorpora os Resultados da Rodada Uruguai de Negociações Comerciais Multilaterais do GATT.

323 Artigo 12.4 e 12.5. Entendimento Relativo às Normas e Procedimentos sobre Solução de 
Não deverá ser superior a 6 (seis) meses, em regra, o período entre data de estabelecimento do painel e a divulgação do relatório final. Em caso de urgência, incluídas demandas relativas a bens perecíveis, este prazo é reduzido para 3 (três) meses. ${ }^{325}$ Caso o painel entenda não ser possível a divulgação do relatório no prazo citado, deverá informar ao OSC por escrito um novo prazo estimado para sua divulgação, não podendo exceder em nenhuma hipótese o prazo de 9 (nove) meses. ${ }^{326} 327$

Na hipótese de suspensão dos trabalhos do painel, possível a qualquer tempo mediante requerimento da parte reclamante, os prazos para a conclusão do relatório ficam consequentemente suspensos. A suspensão dos trabalhos do painel, contudo, deve durar no máximo 12 meses, após este período considera-se que o painel não mais possui autoridade sob a controvérsia, tendo a mesma caducado. ${ }^{328}$

Controvérsias. Versão oficial em português segundo o decreto n. 1.355, de 30 dez. 1994, que promulga a Ata Final que Incorpora os Resultados da Rodada Uruguai de Negociações Comerciais Multilaterais do GATT. 324 O Artigo 12 dos Procedimentos de Trabalho, Apêndice 3, prevê o seguinte parâmetro para o cronograma de trabalho do painel: "12. Proposta de calendário para os trabalhos do grupo especial: (a) Recebimento das primeiras argumentações escritas das partes: (1) da parte reclamante: 3 a 6 semanas, (2) da parte demandada: 2 a 3 semanas (b) Data, hora e local da primeira reunião substantiva com as partes; sessão destinada a terceiras partes:1 a 2 semanas, (c) Recebimento das réplicas escritas: 2 a 3 semanas, (d) Data, hora e local da segunda reunião substantiva com as partes: 1 a 2 semanas, (e) Distribuição da parte expositiva do relatório às partes: 2 a 4 semanas, (f) Recebimento de comentários das partes sobre a parte expositiva do relatório: 2 semanas, (g) Distribuição às partes de relatório provisório, inclusive verificações e decisões: 2 a 4 semanas, (h) Prazo final para a parte solicitar exame de parte(s) do relatório: 1 semana, (i) Período de revisão pelo grupo especial, inclusive possivel nova reunião com as partes: 2 semanas, (j) Distribuição do relatório definitivo às partes em controvérsia: 2 semanas, (k) Distribuição do relatório definitivo aos Membros: 3 semanas. O calendário acima poderá ser alterado à luz de acontecimentos imprevistos." Entendimento Relativo às Normas e Procedimentos sobre Solução de Controvérsias. Versão oficial em português segundo o decreto n. 1.355, de 30 dez. 1994, que promulga a Ata Final que Incorpora os Resultados da Rodada Uruguai de Negociações Comerciais Multilaterais do GATT.

325 Artigo 12.8. Entendimento Relativo às Normas e Procedimentos sobre Solução de Controvérsias. Versão oficial em português segundo o decreto n. 1.355, de 30 dez. 1994, que promulga a Ata Final que Incorpora os Resultados da Rodada Uruguai de Negociações Comerciais Multilaterais do GATT.

326 Artigo 12.9. Entendimento Relativo às Normas e Procedimentos sobre Solução de Controvérsias. Versão oficial em português segundo o decreto n. 1.355, de 30 dez. 1994, que promulga a Ata Final que Incorpora os Resultados da Rodada Uruguai de Negociações Comerciais Multilaterais do GATT.

327 Estes prazos podem ser estendidos se a controvérsia envolver algum país em desenvolvimento. Artigo 12.10. "10. No âmbito de consultas envolvendo medidas tomadas por um país em desenvolvimento Membro, as partes poderão acordar a extensão dos prazos definidos nos parágrafos 7 e 8 do Artigo 4. Se, após expiração do prazo concernente, as partes em consulta não acordarem com a sua conclusão, o Presidente do OSC deverá decidir, após consultar as partes, se o prazo concernente será prorrogado e, em caso positivo, por quanto tempo. Ademais, ao examinar uma reclamação contra um país em desenvolvimento Membro, o grupo especial deverá proporcionar tempo bastante para que o país em desenvolvimento Membro prepare e apresente sua argumentação. As disposições do parágrafo 1 do Artigo 20 e parágrafo 4 do Artigo 21 não serão afetadas por nenhuma ação decorrente deste parágrafo." Entendimento Relativo às Normas e Procedimentos sobre Solução de Controvérsias. Versão oficial em português segundo o decreto n. 1.355, de 30 dez. 1994, que promulga a Ata Final que Incorpora os Resultados da Rodada Uruguai de Negociações Comerciais Multilaterais do GATT.

328 Artigo 12.12. Entendimento Relativo às Normas e Procedimentos sobre Solução de Controvérsias. Versão oficial em português segundo o decreto n. 1.355, de 30 dez. 1994, que promulga a Ata Final que Incorpora os Resultados da Rodada Uruguai de Negociações Comerciais Multilaterais do GATT. 
Um aspecto muito controvertido do procedimento dos painéis se trata da confidencialidade, que se manifesta nas reuniões a portas fechadas nas quais o painel realiza suas deliberações, ${ }^{329}$ bem como no tratamento de confidencialidade conferido aos documentos submetidos à sua consideração. ${ }^{330}$

O procedimento regular de trabalho dos painéis se materializa na realização da (a) primeira reunião substancial com as partes, e da (b) segunda reunião substancial com as partes, seguidas da (c) distribuição da parte expositiva do relatório às partes, da (d) distribuição do relatório provisório às partes, e finalmente há (e) a distribuição do relatório definitivo às partes em controvérsia. Além das duas reuniões regularmente previstas, outras reuniões poderão ser marcadas caso haja necessidade, e entre as três últimas etapas há a oportunidade para a manifestação das partes sobre a parte expositiva e o relatório provisório do painel.

A apresentação por escrito da argumentação pelas partes deve ter lugar, pois, antes da primeira reunião substantiva dos membros do painel com as partes. ${ }^{331}$ Nesta reunião haverá oportunidade para a apresentação oral das respectivas alegações das partes sobre o objeto da controvérsia, bem como das manifestações das terceiras partes que expressaram seu interesse na demanda. ${ }^{332}$ Como concretização do contraditório, na reunião subsequente há oportunidade para a apresentação da réplica pelas partes em litígio. ${ }^{333}$

Uma vez realizadas as reuniões substanciais com as partes, analisadas as apresentações orais e suas respectivas manifestações escritas, o painel elabora um esboço

329 Artigo 2 do Apêndice 3: Procedimentos de Trabalho Entendimento Relativo às Normas e Procedimentos sobre Solução de Controvérsias. Versão oficial em português segundo o decreto n. 1.355, de 30 dez. 1994, que promulga a Ata Final que Incorpora os Resultados da Rodada Uruguai de Negociações Comerciais Multilaterais do GATT.

$330 \quad$ Artigo 3 do Apêndice 3: Procedimentos de Trabalho Entendimento Relativo às Normas e Procedimentos sobre Solução de Controvérsias. Versão oficial em português segundo o decreto n. 1.355, de 30 dez. 1994, que promulga a Ata Final que Incorpora os Resultados da Rodada Uruguai de Negociações Comerciais Multilaterais do GATT.

331 Artigo 4 do Apêndice 3: Procedimentos de Trabalho Entendimento Relativo às Normas e Procedimentos sobre Solução de Controvérsias. Versão oficial em português segundo o decreto n. 1.355, de 30 dez. 1994, que promulga a Ata Final que Incorpora os Resultados da Rodada Uruguai de Negociações Comerciais Multilaterais do GATT.

332 Artigo 5 e 6 do Apêndice 3: Procedimentos de Trabalho Entendimento Relativo às Normas e Procedimentos sobre Solução de Controvérsias. Versão oficial em português segundo o decreto n. 1.355, de 30 dez. 1994, que promulga a Ata Final que Incorpora os Resultados da Rodada Uruguai de Negociações Comerciais Multilaterais do GATT.

333 Artigo 7 do Apêndice 3: Procedimentos de Trabalho Entendimento Relativo às Normas e Procedimentos sobre Solução de Controvérsias. Versão oficial em português segundo o decreto n. 1.355, de 30 dez. 1994, que promulga a Ata Final que Incorpora os Resultados da Rodada Uruguai de Negociações Comerciais Multilaterais do GATT. 
da parte expositiva do relatório, contendo os fatos e as argumentações, e distribui às partes da controvérsia, que poderão manifestar-se formalmente dentro do prazo designado. ${ }^{334}$

Em seguida, o painel distribui às partes o relatório provisório, fase intermediária de exame da controvérsia, na qual as partes poderão apresentar requerimento para que o painel reexamine pontos específicos constantes desse relatório. ${ }^{335}$ Caso não haja tal solicitação, considerar-se-á o relatório provisório como relatório final do painel para a referida controvérsia. ${ }^{336}$

Como se manifesta em todo o ESC, há notória preferência pela autocomposição do conflito, com uma solução mutuamente satisfatória. Assim, o painel possui o dever de apresentar suas conclusões, na forma de relatório escrito ao OSC, "nos casos em que as partes envolvidas na controvérsia não consigam encontrar uma solução mutuamente satisfatória”. 337

O relatório deverá explicitar os fatos verificados, a aplicação dos dispositivos dos acordos relativos à matéria, e a argumentação pela qual se construíram as decisões e recomendações. Assim, sob o aspecto formal, a estrutura dos relatórios dos painéis é composta por duas partes: (i) a parte expositiva, constituída pelo apanhado dos fatos e resumo das argumentações das partes; e (ii) a parte analítica, que se desdobra nas conclusões do painel.

Após a distribuição do relatório final às partes em litígio, o mesmo é disponibilizado aos demais membros da OMC, representados no OSC. Confere-se então prazo, não inferior a 20 (vinte) dias de sua divulgação, para que os membros analisem o relatório, ao término do qual poderão apresentar eventuais objeções ao relatório, bem como

334 Artigo 15.1. Entendimento Relativo às Normas e Procedimentos sobre Solução de Controvérsias. Versão oficial em português segundo o decreto n. 1.355, de 30 dez. 1994, que promulga a Ata Final que Incorpora os Resultados da Rodada Uruguai de Negociações Comerciais Multilaterais do GATT.

335 O sentido desta etapa é explicado por Ernst-Ulrich Petersmann: "[...] the drafters hoped that the 'interim review' would ensure the consideration of all relevant arguments in the final report, enhance the legal quality of the panel reaoning and, similar to the 'appellate review', reduce the risks of unprecictable panel findings and their quasi-automatic adoption." PETERSMANN, Ernst-Ulrich. The GATT/WTO Dispute Settlement System: International Law, International Organizations and Dispute Settlement. London: Kluwer Law International, 1997. p. 185.

336 Artigo 15.2. Entendimento Relativo às Normas e Procedimentos sobre Solução de Controvérsias. Versão oficial em português segundo o decreto n. 1.355, de 30 dez. 1994, que promulga a Ata Final que Incorpora os Resultados da Rodada Uruguai de Negociações Comerciais Multilaterais do GATT.

337 Artigo 12.7. Entendimento Relativo às Normas e Procedimentos sobre Solução de Controvérsias. Versão oficial em português segundo o decreto n. 1.355, de 30 dez. 1994, que promulga a Ata Final que Incorpora os Resultados da Rodada Uruguai de Negociações Comerciais Multilaterais do GATT. 
as suas respectivas razões. ${ }^{338}$

No prazo de 60 dias a partir da divulgação do relatório do painel aos membros, esse relatório será adotado na reunião do OSC, a menos que uma das partes intencione apelar e notifique formalmente, ou que o OSC decida por consenso de todos os membros pela não adoção, sendo que as partes envolvidas no litígio participam plenamente da consideração do relatório pelo OSC. ${ }^{339}$

\subsubsection{Apelação}

Não deverá ser superior a 60 (sessenta) dias, em regra, o período entre a data de notificação formal da apelação por uma das partes e a divulgação do relatório do Órgão de Apelação. Caso o painel entenda não ser possível a circulação do relatório no prazo citado, deverá informar ao OSC por escrito um novo prazo estimado para sua divulgação, não podendo exceder em nenhuma hipótese o prazo de 90 (noventa) dias. ${ }^{340}$

No que tange aos sujeitos envolvidos, apenas as partes em litígio podem apelar do relatório do painel, embora as terceiras partes possam apresentar formalmente suas manifestações, caso haja recurso ao Órgão de Apelação. ${ }^{341}$

No âmbito substancial da apelação, há relevante aspecto limitador das matérias que podem ser objeto de revisão, enunciado no artigo 17.6 do ESC: “A apelação deverá limitar-se às questões de direito tratadas pelo relatório do grupo especial e às

338 Artigo 16.1 e 16.2. Entendimento Relativo às Normas e Procedimentos sobre Solução de Controvérsias. Versão oficial em português segundo o decreto n. 1.355, de 30 dez. 1994, que promulga a Ata Final que Incorpora os Resultados da Rodada Uruguai de Negociações Comerciais Multilaterais do GATT.

339 Artigo 16.4. Entendimento Relativo às Normas e Procedimentos sobre Solução de Controvérsias. Versão oficial em português segundo o decreto n. 1.355, de 30 dez. 1994, que promulga a Ata Final que Incorpora os Resultados da Rodada Uruguai de Negociações Comerciais Multilaterais do GATT.

340 Artigo 17.5. Entendimento Relativo às Normas e Procedimentos sobre Solução de Controvérsias. Versão oficial em português segundo o decreto n. 1.355, de 30 dez. 1994, que promulga a Ata Final que Incorpora os Resultados da Rodada Uruguai de Negociações Comerciais Multilaterais do GATT.

341 Artigo 17.4. Entendimento Relativo às Normas e Procedimentos sobre Solução de Controvérsias. Versão oficial em português segundo o decreto n. 1.355, de 30 dez. 1994, que promulga a Ata Final que Incorpora os Resultados da Rodada Uruguai de Negociações Comerciais Multilaterais do GATT. 
interpretações jurídicas por ele formuladas. "342

Os procedimentos do Órgão de Apelação são regidos pelo estatuto intitulado Procedimentos de Trabalho para o Exame de Apelação (Working Procedures for Appelate Review). A versão inicial do documento foi elaborada em fevereiro de 1996 pelo Órgão de Apelação, em consulta com o Diretor-Geral da OMC e com o Presidente do OSC ${ }^{343}$, e foi emendada em seis oportunidades, tendo a última ocorrido em julho de $2010{ }^{344}$

Assim como foi mencionado em relação aos painéis, o Órgão de Apelação preza, em seus trabalhos, pela confidencialidade, que se manifesta principalmente na elaboração de seu relatório sem a presença das partes, ${ }^{345}$ e no fato de as posições exteriorizadas no relatório manifestarem a opinião do Órgão de Apelação como um todo, em anonimato das contribuições individuais. ${ }^{346}$

O mandato do Órgão de Apelação se consubstancia nos atos de "confirmar, modificar ou revogar as conclusões e decisões jurídicas" ${ }^{347}$ do painel. A confirmação se dá quando há concordância sobre a fundamentação e sobre a conclusão do painel em face da alegação de violação. A modificação ocorre quando o Órgão de Apelação se filia à conclusão expressa pelo painel, mas altera a fundamentação que sustenta a conclusão. Por fim, o Órgão de Apelação reverte as conclusões do painel quando discorda da avaliação feita sobre a existência ou não das alegações. Assim, nem todos os pontos do relatório do painel podem ser desafiados por meio do recurso.

No prazo de 30 (trinta) dias a partir da distribuição do relatório do Órgão de Apelação aos membros, este será regularmente adotado pelo OSC, "e aceito sem restrições pelas partes", a menos o OSC decida por consenso de todos os membros pela não adoção

342 Artigo 17.6. Entendimento Relativo às Normas e Procedimentos sobre Solução de Controvérsias. Versão oficial em português segundo o decreto n. 1.355, de 30 dez. 1994, que promulga a Ata Final que Incorpora os Resultados da Rodada Uruguai de Negociações Comerciais Multilaterais do GATT.

343 Artigo 17.9. Entendimento Relativo às Normas e Procedimentos sobre Solução de Controvérsias. Versão oficial em português segundo o decreto n. 1.355, de 30 dez. 1994, que promulga a Ata Final que Incorpora os Resultados da Rodada Uruguai de Negociações Comerciais Multilaterais do GATT.

344 A última revisão foi comunicada em documento WT/AB/WP/W/11, de 27 de julho de 2010. Disponível em: < http://www.wto.org/english/tratop_e/dispu_e/ab_e.htm>. Acesso em: 28 de janeiro de 2014.

345 Artigo 17.10. Entendimento Relativo às Normas e Procedimentos sobre Solução de Controvérsias. Versão oficial em português segundo o decreto n. 1.355, de 30 dez. 1994, que promulga a Ata Final que Incorpora os Resultados da Rodada Uruguai de Negociações Comerciais Multilaterais do GATT.

346 Artigo 17.11 Entendimento Relativo às Normas e Procedimentos sobre Solução de Controvérsias. Versão oficial em português segundo o decreto n. 1.355, de 30 dez. 1994, que promulga a Ata Final que Incorpora os Resultados da Rodada Uruguai de Negociações Comerciais Multilaterais do GATT.

347 Artigo 17.13 Entendimento Relativo às Normas e Procedimentos sobre Solução de Controvérsias. Versão oficial em português segundo o decreto n. 1.355, de 30 dez. 1994, que promulga a Ata Final que Incorpora os Resultados da Rodada Uruguai de Negociações Comerciais Multilaterais do GATT. 
do relatório. ${ }^{348}$

\subsubsection{Implementação e Execução}

No intuito de garantir o pronto cumprimento das decisões e recomendações endossadas pelo OSC, o membro cuja medida se julgou desconforme deverá expressar formalmente as suas intenções em relação à implementação dos comandos proferidos pelo OSC. Em não sendo possível o seu cumprimento imediato, o membro deverá implementálos em "prazo razoável". 349

A definição deste prazo razoável dependerá das circunstâncias específicas do caso, mas poderá derivar-se, em ordem de preferência: (a) de proposta do membro que carrega o dever de implementação, com a aprovação do OSC; (b) de comum acordo entre as partes, a ser alcançado no prazo de 45 dias da adoção do relatório pelo OSC; (c) de determinação de arbitragem compulsória - específica para este fim - na qual o árbitro tentará definir um lapso de tempo que não ultrapasse 15 meses da data de adoção do relatório. ${ }^{350}$

Cumpre ao OSC o acompanhamento da aplicação das recomendações e decisões, e a sua arguição pode ser feita por qualquer membro do OSC, a qualquer tempo a partir da adoção do relatório. Ao membro cuja medida foi reconhecida desconforme compete apresentar relatórios escritos periódicos sobre esta implementação. ${ }^{351}$

348 Artigo 17.14. Entendimento Relativo às Normas e Procedimentos sobre Solução de Controvérsias. Versão oficial em português segundo o decreto n. 1.355, de 30 dez. 1994, que promulga a Ata Final que Incorpora os Resultados da Rodada Uruguai de Negociações Comerciais Multilaterais do GATT.

349 Artigo 21.1 e 21.3. Entendimento Relativo às Normas e Procedimentos sobre Solução de Controvérsias. Versão oficial em português segundo o decreto n. 1.355, de 30 dez. 1994, que promulga a Ata Final que Incorpora os Resultados da Rodada Uruguai de Negociações Comerciais Multilaterais do GATT.

350 Artigo 21.3. Entendimento Relativo às Normas e Procedimentos sobre Solução de Controvérsias. Versão oficial em português segundo o decreto n. 1.355, de 30 dez. 1994, que promulga a Ata Final que Incorpora os Resultados da Rodada Uruguai de Negociações Comerciais Multilaterais do GATT.

351 Artigo 21.6. Entendimento Relativo às Normas e Procedimentos sobre Solução de Controvérsias. Versão oficial em português segundo o decreto n. 1.355, de 30 dez. 1994, que promulga a Ata Final que Incorpora os Resultados da Rodada Uruguai de Negociações Comerciais Multilaterais do GATT. 
$\mathrm{Na}$ hipótese de desacordo entre as partes quanto ao cumprimento das recomendações e decisões, bem como quanto à compatibilidade das medidas de implementação com os acordos abrangidos, a desavença deverá ser dirimida pelo Sistema de Solução de Controvérsias, com atuação preferencial do painel que examinou o referido litígio. ${ }^{352}$

\subsubsection{Compensação e Retaliação}

Caso as recomendações do relatório adotado não sejam implementadas dentro do prazo razoável, é possível a adoção de duas medidas temporárias: ${ }^{353}$ (a) a compensação e (b) a retaliação (“suspensão de concessões ou de outras obrigações”). ${ }^{354}$

Há, contudo, um expresso comando de preferência entre as opções, ${ }^{355}$ devendo privilegiar-se a efetiva implementação. Apenas caso a implementação não seja possível, deve-se preferir a adoção do primeiro remédio citado e, apenas em última hipótese, deve-se proceder à segunda medida citada. ${ }^{356}$

352 Artigo 21.5. Entendimento Relativo às Normas e Procedimentos sobre Solução de Controvérsias. Versão oficial em português segundo o decreto n. 1.355, de 30 dez. 1994, que promulga a Ata Final que Incorpora os Resultados da Rodada Uruguai de Negociações Comerciais Multilaterais do GATT.

353 Artigo 22.8. Entendimento Relativo às Normas e Procedimentos sobre Solução de Controvérsias. Versão oficial em português segundo o decreto n. 1.355, de 30 dez. 1994, que promulga a Ata Final que Incorpora os Resultados da Rodada Uruguai de Negociações Comerciais Multilaterais do GATT.

354 Artigo 22.1. Entendimento Relativo às Normas e Procedimentos sobre Solução de Controvérsias. Versão oficial em português segundo o decreto n. 1.355, de 30 dez. 1994, que promulga a Ata Final que Incorpora os Resultados da Rodada Uruguai de Negociações Comerciais Multilaterais do GATT.

$355 \mathrm{O}$ autor chama atenção para o fato de alguns membros da OMC tentarem distorcer o exposto no Entendimento, interpretando que a compensação e a retaliação são opções, à escolha da parte vencida: "The DSU quite clearly (as discussed later in this chapter) requires full performance, explicitly stating that the various compensatory or "retaliation" measures are only temporary, pending full compliance. However, some governments have argued the contrary, that they are permitted to use compensatory measures or to tolerate retaliatory measures as a choice rather than comply. This latter position has major policy detriments as well as contravening the obligations as set forth in the DSU.” JACKSON, John. Sovereignty, the WTO and Changing Fundamentals of International Law. New York: Cambridge University Press, 2006. p. 159. 356 Artigo 22.1 e 22.2. Entendimento Relativo às Normas e Procedimentos sobre Solução de Controvérsias. Versão oficial em português segundo o decreto n. 1.355, de 30 dez. 1994, que promulga a Ata Final que Incorpora os Resultados da Rodada Uruguai de Negociações Comerciais Multilaterais do GATT. 
A compensação é medida voluntária, ${ }^{357}$ ou seja, oferecida pelo membro em desacordo, e deverá estar em consonância com os demais acordos da OMC. O estabelecimento dessa compensação se dá em negociações entre as partes envolvidas no procedimento. Caso as negociações não tenham obtido êxito no limite de 20 dias contados do término do prazo razoável, a parte que logrou êxito na análise do painel poderá acionar o OSC, solicitando-lhe a autorização para aplicar retaliação. ${ }^{358}$

A retaliação segue a disciplina do artigo 22.3 do ESC, que delineia os princípios e procedimentos pertinentes. ${ }^{359} \mathrm{Em}$ todo caso, referida suspensão das concessões ou outras obrigações em relação ao membro faltoso deve ser autorizada apenas quando houver permissão no acordo pertinente, e com o grau equivalente ao nível de prejuízo ou anulação de benefícios causados. ${ }^{360}$

A autorização para suspensão das concessões ou outras vantagens deve ser dada, portanto, pelo OSC, seguindo a lógica do consenso reverso, pelo qual considera-se aprovado o remédio, a menos que haja consenso em sua reprovação. Contudo, se houver impugnação quanto ao grau de suspensão, ou quanto ao descumprimento dos princípios e procedimentos, a desavença será submetida a arbitragem, preferencialmente a ser realizada pelo painel que examinou o caso, ou por um árbitro ${ }^{361}$ escolhido pelo Diretor Geral da OMC, a se realizar no lapso de 60 dias contados do término do prazo razoável. ${ }^{362}$

357 Artigo 22.1. Entendimento Relativo às Normas e Procedimentos sobre Solução de Controvérsias. Versão oficial em português segundo o decreto n. 1.355, de 30 dez. 1994, que promulga a Ata Final que Incorpora os Resultados da Rodada Uruguai de Negociações Comerciais Multilaterais do GATT.

358 Artigo 22.2. Entendimento Relativo às Normas e Procedimentos sobre Solução de Controvérsias. Versão oficial em português segundo o decreto n. 1.355, de 30 dez. 1994, que promulga a Ata Final que Incorpora os Resultados da Rodada Uruguai de Negociações Comerciais Multilaterais do GATT.

359 Artigo 22.3. Entendimento Relativo às Normas e Procedimentos sobre Solução de Controvérsias. Versão oficial em português segundo o decreto n. 1.355, de 30 dez. 1994, que promulga a Ata Final que Incorpora os Resultados da Rodada Uruguai de Negociações Comerciais Multilaterais do GATT.

360 Artigo 22.4 e 22.5. Entendimento Relativo às Normas e Procedimentos sobre Solução de Controvérsias. Versão oficial em português segundo o decreto n. 1.355, de 30 dez. 1994, que promulga a Ata Final que Incorpora os Resultados da Rodada Uruguai de Negociações Comerciais Multilaterais do GATT. 361 Artigo 22.6. Entendimento Relativo às Normas e Procedimentos sobre Solução de Controvérsias. Versão oficial em português segundo o decreto n. 1.355, de 30 dez. 1994, que promulga a Ata Final que Incorpora os Resultados da Rodada Uruguai de Negociações Comerciais Multilaterais do GATT.

362 O exame do árbitro/ do painel não deve exceder as impugnações que lhe dão origem. É o que explicita o Artigo 22.7: “7.O árbitro 16 que atuar conforme o parágrafo 6 não deverá examinar a natureza das concessões ou das outras obrigações a serem suspensas, mas deverá determinar se o grau de tal suspensão é equivalente ao grau de anulação ou prejuízo. O árbitro poderá ainda determinar se a proposta de suspensão de concessões ou outras obrigações é autorizada pelo acordo abrangido. No entanto, se a questão submetida à arbitragem inclui a reclamação de que não foram observados os princípios e procedimentos definidos pelo parágrafo 3, o árbitro deverá examinar a reclamação. No caso de o árbitro determinar que aqueles princípios e procedimentos não foram observados, a parte reclamante os aplicará conforme o disposto no parágrafo 3. As partes deverão aceitar a decisão do árbitro como definitiva e as 
O artigo 23 do Entendimento, sob o título do Fortalecimento do Sistema Multilateral, tem crucial relevância, ao estabelecer a natureza compulsória e mandatória dos procedimentos erigidos naquele documento como instrumento para desestimular o não cumprimento de obrigações ou anulação de benefícios resultantes dos acordos abrangidos, 363 em exclusão do direito unilateral de represálias. ${ }^{364}$

Os meios de implementação de decisões jurisdicionais internacionais se concretizam (i) nas medidas unilaterais e (ii) no recurso a organizações internacionais. $\mathrm{O}$ primeiro caminho confere à vítima que logrou êxito no procedimento a busca pelos meios de concretizá-lo, e o segundo traz a um mecanismo coletivo a responsabilidade de promovê-lo. 365

Embora possamos repetir diversas críticas justamente direcionadas à engenharia da retaliação no Sistema de Solução de Controvérsias da OMC, ${ }^{366}$ alcançou-se relevante evolução com a exclusividade de um sofisticado sistema para aplicação desse tipo de sanções. Embora consistam, em última análise, em sanções unilaterais autorizadas por uma

partes envolvidas não deverão procurar uma segunda arbitragem. O OSC deverá ser prontamente informado da decisão do árbitro e deverá, se solicitado, outorgar autorização para a suspensão de concessões ou outras obrigações quando a solicitação estiver conforme à decisão do árbitro, salvo se o OSC decidir por consenso rejeitar a solicitação." Entendimento Relativo às Normas e Procedimentos sobre Solução de Controvérsias. Versão oficial em português segundo o decreto n. 1.355, de 30 dez. 1994, que promulga a Ata Final que Incorpora os Resultados da Rodada Uruguai de Negociações Comerciais Multilaterais do GATT.

363 Artigo 23. "1. Ao procurar reparar o não-cumprimento de obrigações ou outro tipo de anulação ou prejuízo de benefícios resultantes de acordos abrangidos ou um impedimento à obtenção de quaisquer dos objetivos de um acordo abrangido, os Membros deverão recorrer e acatar as normas e procedimentos do presente Entendimento. 2. Em tais casos, os Membros deverão: (a) não fazer determinação de que tenha ocorrido infração, de que benefícios tenham sido anulados ou prejudicados ou de que o cumprimento de quaisquer dos objetivos de um acordo abrangido tenha sido dificultado, salvo através do exercício da solução de controvérsias segundo as normas e procedimentos do presente Entendimento, e deverão fazer tal determinação consoante as conclusões contidas no relatório do grupo especial ou do órgão de Apelação adotado pelo OSC ou em um laudo arbitral elaborado segundo este Entendimento; (b) seguir os procedimentos definidos no Artigo 21 para determinar o prazo razoável para que o Membro interessado implemente as recomendações e decisões; e (c) observar os procedimentos definidos no Artigo 22 para determinar o grau de suspensão de concessões ou outras obrigações e obter autorização do OSC, conforme aqueles procedimentos, antes de suspender concessões ou outras obrigações resultantes dos acordos abrangidos como resposta à não implementação, por parte do Membro interessado, das recomendações e decisões dentro daquele prazo razoável." Entendimento Relativo às Normas e Procedimentos sobre Solução de Controvérsias. Versão oficial em português segundo o decreto n. 1.355, de 30 dez. 1994, que promulga a Ata Final que Incorpora os Resultados da Rodada Uruguai de Negociações Comerciais Multilaterais do GATT.

364 PETERSMANN, Ernst-Ulrich. The GATT/WTO Dispute Settlement System: International Law, International Organizations and Dispute Settlement. London: Kluwer Law International, 1997. p. 182.

365 CAFLISCH, Lucius. Cent ans de règlement pacifique des différends interétatiques. Recueil des cours, vol. 288, p. 245-467, 2001.p. 431

366 Sobre o leque de diferentes visões acerca da natureza jurídica da retaliação na OMC, bem como de sua função e efeitos concretos, Cf: PEREIRA, Celso de Tarso. Retaliação na OMC: Procedimento, Prática e Objetivos. In: BENJAMIN, Daniela Arruda. (Org). O Sistema de Solução de Controvérsias da OMC: uma perspectiva brasileira. Brasília : FUNAG, 2013, p. 595-628. 
decisão coletiva, ${ }^{367}$ são exercidos sobre elas controle de dimensões como legalidade, proporcionalidade, e adequabilidade.

\subsection{Outros Meios de Solução de Controvérsias}

\subsubsection{Bons Ofícios, Conciliação e Mediação}

Bons ofícios é a denominação conferida ao meio de solução de litígios pelo qual, não havendo sucesso das partes em resolver a controvérsia diretamente, a atuação de um terceiro é oferecida voluntariamente ou a requerimento de um dos sujeitos em litígio. O terceiro se presta a facilitador dos esforços das partes em solucionar o litígio, de modo a impedir o deterioramento do embate, incentivando a retomada das negociações e intermediando a comunicação entre eles. ${ }^{368}$

Aproximando-se dos bons ofícios, na mediação o terceiro se presta ao papel de facilitador da composição do litígio, podendo adicionalmente sugerir propostas para a solução da contenda. ${ }^{369}$ Por meio da mediação, portanto, uma terceira parte busca moderar, podendo ainda intervir de modo mais ativo, objetivando reconciliar as demandas

367 CAFLISCH, Lucius. Cent ans de règlement pacifique des différends interétatiques. Recueil des cours, vol. 288, p. 245-467, 2001. p. 436.

368 United Nations. Handbook on the Peaceful Settlement of Disputes between States. New York: United Nations, 1992. Office of Legal Affairs, Codification Division. OLA/COD/2394. p. 33.

369 Assim explicita o Manual da ONU sobre a Solução Pacífica de Controvérsias, produzido pela Divisão de Codificação: "However, there are cases in which the third party exercising good offices is authorized to do more than merely act as a go-between and is allowed to take active part in the dispute settlement process, by making proposals for its solution and holding meetings with the parties to the dispute to discuss such proposals. In such situations, the third party in question may be considered as not only contributing his good offices but also as undertaking mediation. Accordingly, good offices may be said to share a common characterization with mediation as a method of facilitating a dialogue between parties to an international dispute, aimed, as the case may be, at scaling down hostilities and tensions and designed to bring about an ami-cable solution of the dispute." United Nations. Handbook on the Peaceful Settlement of Disputes between States. New York: United Nations, 1992. Office of Legal Affairs, Codification Division. OLA/COD/2394. p. 33. 
das partes envolvidas, em uma solução mutuamente acordada. ${ }^{370}$

A conciliação, de maneira correlata, consiste no meio pacífico de solução de disputas pelo qual uma terceira parte procura oferecer às partes um melhor entendimento do ponto de vista alheio, facilitando a negociação entre elas. É, portanto, um método de solução de controvérsias que combina elementos da mediação e do inquérito. ${ }^{371}$

Embora não sejam obrigatórios no procedimento da OMC, o ESC prevê o recurso voluntário a três meios alternativos de solução de controvérsias: (a) bons ofícios, (b) conciliação e (c) mediação. A voluntariedade do acesso a estes meios de resolução dos litígios é a regra geral, embora na hipótese da controvérsia envolver países menos desenvolvidos o artigo 24.2 do ESC estabeleça para tais países um direito de recorrer a esses meios. ${ }^{372} 373$

De comum acordo, as partes podem adotar os referidos procedimentos, cujas diligências serão confidenciais, e não afetam o direito das partes em acionar os outros recursos de solução de litígios previstos no ESC. ${ }^{374}$ Os bons ofícios, a mediação e a conciliação podem também ser ofertados voluntariamente pelo Diretor-Geral da OMC, hipótese na qual atua ex offici mas não prescinde do consentimento das partes. ${ }^{375}$

370 Sobre o conceito, funções e aplicação: United Nations. Handbook on the Peaceful Settlement of Disputes between States. New York: United Nations, 1992. Office of Legal Affairs, Codification Division. OLA/COD/2394. p. 40-45.

371 Neste sentido, destaca o Manual da ONU sobre a Solução Pacífica de Controvérsias, produzido pela Divisão de Codificação: "Parties to an international dispute may agree to submit it to a peaceful settlement procedure which would, on the one hand, provide them with a better understanding of each other's case by undertaking objective investigation and evaluation of all aspects of the dispute and, on the other hand, provide them with an informal third-party machinery for the negotia-tion and non-judicial appraisal of each other's legal and other claims, includ-ing the opportunity for defining the terms for a solution susceptible of being accepted by them. They would thus submit the dispute to conciliation, the peaceful settlement procedure which combines the elements of both inquiry and mediation." United Nations. Handbook on the Peaceful Settlement of Disputes between States. New York: United Nations, 1992. Office of Legal Affairs, Codification Division. OLA/COD/2394. p. 45.

372 Segundo o autor, o recurso a este artigo é raro. Embora o estudo seja de 2003, o autor indica que o dispositivo havia sido invocado uma vez, no caso DS165 (WTO. Appellate Body Report, United StatesImport Measures on Certain Products from the European Communities. WT/DS165/AB/R, 11 dec. 2000. para. 54.) PAUWELYN, Joost. The Limits of Litigation: "Americanization" and Negotiation in the Settlement of WTO Disputes. Ohio State Journal On Dispute Resolution, vol. 19, issue 1, p. 121-140, 2003. p. 138.

373 Para uma perspectiva dos benefícios potenciais decorrentes de um maior uso da mediação, como meio de lidar com as críticas dos membros em desenvolvimento ao Sistema de Solução de Controvérsias: PHAM, Hansel T. Developing Countries and the WTO: The Need for More Mediation in the DSU. Harvard Negotiation Law Review, vol. 9, p. 331-390, 2004.

374 Artigo 5.1 e 5.2. Entendimento Relativo às Normas e Procedimentos sobre Solução de Controvérsias. Versão oficial em português segundo o decreto n. 1.355, de 30 dez. 1994, que promulga a Ata Final que Incorpora os Resultados da Rodada Uruguai de Negociações Comerciais Multilaterais do GATT.

375 Artigo 5.6. Entendimento Relativo às Normas e Procedimentos sobre Solução de Controvérsias. 
Não há limitação temporal para a utilização dos bons ofícios, conciliação e mediação, instrumentos que podem ter início e término a qualquer tempo. ${ }^{376}$ Há inclusive expressa previsão de que, de comum acordo entre as partes, estes meios alternativos se desenrolem paralelamente aos procedimentos do painel. ${ }^{377}$

\subsubsection{Arbitragem}

Como é cediço no Direito Internacional, a arbitragem é um procedimento estabelecido pelo consentimento mútuo, no qual as partes possuem controle considerável sob o processo, manifesto na indicação do árbitro, na escolha do direito aplicável que resulta em decisões vinculantes às partes. ${ }^{378}$ Embora seja possível visualizar alguns destes elementos no procedimento de constituição e estabelecimento do painel, não se trata de arbitragem strictu sensu.

Reconhecendo expressamente que a celeridade do procedimento arbitral poderia facilitar a solução de controvérsias cujas questões sejam mutuamente e claramente delimitadas pelas partes, o artigo 25 do ESC faculta a escolha de "arbitragem na OMC" para solucionar tais litígios. ${ }^{379}$

A arbitragem prevista neste artigo é verdadeiro meio alternativo ao procedimento regular estabelecido pelo ESC, diferenciando-se portanto daquela prevista nos artigos 21 e

\footnotetext{
Versão oficial em português segundo o decreto n. 1.355, de 30 dez. 1994, que promulga a Ata Final que Incorpora os Resultados da Rodada Uruguai de Negociações Comerciais Multilaterais do GATT.

376 Artigo 5.3. Entendimento Relativo às Normas e Procedimentos sobre Solução de Controvérsias. Versão oficial em português segundo o decreto n. 1.355, de 30 dez. 1994, que promulga a Ata Final que Incorpora os Resultados da Rodada Uruguai de Negociações Comerciais Multilaterais do GATT.

377 Artigo 5.5. Entendimento Relativo às Normas e Procedimentos sobre Solução de Controvérsias. Versão oficial em português segundo o decreto n. 1.355, de 30 dez. 1994, que promulga a Ata Final que Incorpora os Resultados da Rodada Uruguai de Negociações Comerciais Multilaterais do GATT.

378 Sobre o conceito, funções e aplicação: United Nations. Handbook on the Peaceful Settlement of Disputes between States. New York: United Nations, 1992. Office of Legal Affairs, Codification Division. OLA/COD/2394. p. 40-45.

379 Artigo 25.1. Entendimento Relativo às Normas e Procedimentos sobre Solução de Controvérsias. Versão oficial em português segundo o decreto n. 1.355, de 30 dez. 1994, que promulga a Ata Final que Incorpora os Resultados da Rodada Uruguai de Negociações Comerciais Multilaterais do GATT.
} 
22, embora aplique-se aos laudos arbitrais oriundos desta arbitragem as disposições pertinentes desses artigos. ${ }^{380}$

Assim, a arbitragem permitida no artigo 25 é alternativa ao procedimento do painel, podendo ser utilizada para adjudicação das controvérsias sujeitas ao regular procedimento desenhado no ESC. Contudo, até o presente momento, o recurso foi utilizado apenas em um caso, para solucionar o desacordo no estágio de implementação, e portanto não como uma genuína alternativa aos procedimentos regulares do ESC. ${ }^{381} 382$

JoOST PAUWELYN destaca que a arbitragem deste artigo poderia ser uma alternativa verdadeiramente atrativa: (i) em casos envolvendo disputas científicas, nas quais interessaria às partes que a contenda fosse decidida por experts; e (ii) em casos nos quais houvesse extrema urgência. Contudo, em sua avaliação o mecanismo não tem futuro no Sistema de Solução de Controvérsias da $\mathrm{OMC}$, tendo em vista a inexistência de apelação prevista, e a natureza privada do procedimento arbitral, que não atenderia o caráter crescentemente multilateral da OMC. ${ }^{383}$

\subsection{Detalhamento Conceitual}

Em face das dificuldades de aplicação dos moldes tradicionais à singularidade do Sistema de Solução de Controvérsias da OMC, faz-se necessário um detalhamento conceitual, que nos permita tratar dos elementos resultantes da análise jurídica deste

380 Artigo 25.4. Entendimento Relativo às Normas e Procedimentos sobre Solução de Controvérsias. Versão oficial em português segundo o decreto n. 1.355, de 30 dez. 1994, que promulga a Ata Final que Incorpora os Resultados da Rodada Uruguai de Negociações Comerciais Multilaterais do GATT. 381 WTO. Award of the Arbitrators, United States- Section 110(5) of the U.S. Copyright Act (Recourse to Arbitration Under Article 25 of the DSU). WT/DS160/ARB25/1, 9 nov. 2001.

382 Assim explicitaram os autores, que anualmente apresentam uma compilação de estatísticas sobre o Sistema de Solução de Controvérsias da OMC: "DSU Article 25 sets forth a general provision for arbitration. Only one arbitration has been conducted under this provision. This arbitration occurred in the U.S.-Copyright dispute, and it related to the level of nullification or impairment resulting from the findings of violation by the panel in that case." LEITNER, Kara; LESTER, Simon. WTO Dispute Settlement 19952013: A Statistical Analysis. Journal of International Economic Law, vol. 17, p. 191-201, 2014. p. 199. 383 PAUWELYN, Joost. The Limits of Litigation: "Americanization" and Negotiation in the Settlement of WTO Disputes. Ohio State Journal On Dispute Resolution, vol. 19, issue 1, p. 121-140, 2003. p. 138. 
sistema, e que serão de relevância às reflexões dos próximos capítulos.

A tarefa não é simples, pois os conceitos foram apresentados no ESC de forma embaralhada e pouco clara, ${ }^{384}$ adicionando-se a isso confusões provocadas pela tradução “oficial” para o português. ${ }^{385}$ De todo modo, buscamos nos embasar inicialmente na literalidade dos artigos do ESC, não nos furtando da análise comparativa entre as versões em inglês e português, embora reconhecendo as limitações desta análise. ${ }^{386}$ Assim, trataremos dos conceitos de (i) relatório, (ii) recomendações, e (iii) decisões, como abstraídos do ESC e do modo como são utilizados neste trabalho.

A palavra "report", como substantivo, no singular ou plural, encontra-se expressa 73 vezes na versão original em inglês do ESC e seus apêndices. ${ }^{387} \mathrm{O}$ relatório é o instrumento formal que apresenta o resultado dos trabalhos desenvolvidos pelo painel e pelo Órgão de Apelação. É, portanto, o documento pelo qual estas instâncias expressam a sua análise jurídica do objeto em exame.

Assim é que o artigo 12.7 do ESC explicita: "Nos casos em que as partes envolvidas na controvérsia não consigam encontrar uma solução mutuamente satisfatória, o grupo especial deverá apresentar suas conclusões em forma de relatório escrito ao OSC. [...]."

384 Esta obscuridade é proposital, como uma técnica de negociação de acordos internacionais: "[...] muitas vezes, para negociar um acordo, os Membros concordam em colocar um texto que evita comprometimento definitivo em relação ao problema então abordado. Esta estratégia negociadora já foi denominada de "ambigüidade construtiva" no jargão da OMC. [...]" BARRAL, Welber. Solução de Controvérsias na Organização Mundial do Comércio. Brasília: FUNAG, 2007. p. 68.

385 Ao longo do trabalho nos referimos à versão oficial em português dos Acordos, inclusivo do ESC, tal qual consta do decreto n. 1.355, de 30 dez. 1994, que "promulga a Ata Final que Incorpora os Resultados da Rodada Uruguai de Negociações Comerciais Multilaterais do GATT.” Este é o nosso parâmetro inicial para citações ao longo do trabalho, com exceção de vocábulos cujo uso diverso foi adotado pela prática dos doutrinadores e atores do Sistema de Solução de Controvérsias da OMC.

386 Destaca-se que, sob a perspectiva institucional da OMC e inclusive para fins de aplicação da CVDT (art. 33), apenas os Acordos em inglês, francês e espanhol são autênticos, sendo as versões nas demais línguas - e inclusive a versão em português - não autênticas. Contudo, os tratados "plurilíngues" apresentam rotineiramente desafios em sua interpretação uma vez que as versões autênticas são igualmente válidas sob o aspecto jurídico, mas podem apresentar disparidades próprias da dificuldade de tradução exata de institutos em línguas cuja tradição jurídica é diversa. Para uma análise atenta desta problemática na OMC, bem como da prática do Sistema de Solução de Controvérsias a este respeito, Cf: CONDON, Bradly J. Lost in Translation: Plurilingual Interpretation of WTO Law. Journal of International Dispute Settlement, vol. 1, n. 1, p. 191-216, 2010.

387 Na versão oficial em português do Entendimento Relativo às Normas e Procedimentos sobre Solução de Controvérsias, dada pelo Decreto Legislativo n. 1.355, de 30 de Dezembro de 1994, o vocábulo "relatório" encontra-se expresso 70 vezes. A pequena disparidade se deve à questões linguísticas, e não afeta materialmente o sentido. As menções adicionais do original em inglês, se comparado com a versão em português se referem a um subtítulo entre o artigo 17.13 e 17.14, que foi suprimido, e também à repetições do vocábulo nos artigos 20 e 26.2 . 
Como um instrumento e um documento escrito, o relatório possui duas diferentes dimensões: a dimensão material, e a dimensão formal. Sob o aspecto material, ainda segundo o mesmo artigo, o relatório do painel deve conter (a) a verificação dos fatos; (b) a aplicabilidade dos dispositivos pertinentes e (c) a fundamentação por detrás de “ [...] qualquer determinações e "recomendações" que ele fizer." ${ }^{388}$ Sob o aspecto formal, o documento se compõe, portanto, de uma parte expositiva - apresentação dos fatos e argumentação - ${ }^{389}$ e de uma parte de exame técnico-jurídico da controvérsia, seguida de conclusão. ${ }^{390}$

Assim, o resultado final do relatório se manifesta por meio de conclusões (“findings"). Tais conclusões podem se materializar por meio de determinações (“rulings") e recomendações ("recomendations"). 391

Como já explicitado, o conteúdo do relatório está limitado pelos Termos de Referência do painel. Os termos de referência adotados regularmente, caso as partes não acordem de modo diverso, estão expressos no artigo 7.1 do ESC:

\footnotetext{
Examinar, à luz das disposições pertinentes no (indicar o(s) acordo(s) abrangido(s) citado(s) pelas partes em controvérsia), a questão submetida ao OSC por (nome da parte) no documento ... estabelecer conclusões que auxiliem o OSC a fazer recomendações ou emitir decisões previstas naquele(s) $\operatorname{acordo}(\mathrm{s}){ }^{392}$
}

388 Do original em inglês: “ [...] the report of a panel shall set out the findings of fact, the applicability of relevant provisions and the basic rationale behind any findings and recommendations that it makes. [...]". Embora a versão oficial em português conste como " [...] o relatório do grupo especial deverá expor as verificações de fatos, a aplicabilidade de disposições pertinentes e o arrazoado em que se baseiam suas decisões e recomendações [...]", acredita-se que a melhor tradução do termo "rulings", tendo em vista este refinamento conceitual, seja "determinações".

389 Artigo 15.1: “Após consideração das réplicas e apresentações orais, o grupo especial distribuirá os capítulos expositivos (fatos e argumentações) de esboço de seu relatório para as partes em controvérsia $[\ldots]$ ”

390 Artigo 15.2: “[...] o grupo especial distribuirá às partes um relatório provisório, nele incluindo tanto os capítulos descritivos quanto as determinações e conclusões do grupo especial. [...]"

391 É relevante destacar que a versão original em inglês se refere a "rullings" e "findings", juntamente com "recommendation". Na maior parte dos casos as duas primeiras expressões são traduzidas como “decisões". Apenas no artigo 15.2 se traduz findings como "determinações", e nos artigos 9.2, 11, 12.7, 15.3, 19.2 e 23.2 se traduz "findings" como "conclusões". No artigo 7.1 o que se traduz como "conclusões" está expresso como "rullings". O artigo 12.7. é um exemplo da não preocupação com o uso específico das palavras na tradução em português, uma vez que a mesma expressão "findings" é traduzida ora como "conclusões" e ora como "decisões".

392 Artigo 23.2.a. Entendimento Relativo às Normas e Procedimentos sobre Solução de Controvérsias. Versão oficial em português segundo o decreto n. 1.355, de 30 dez. 1994, que promulga a Ata Final que Incorpora os Resultados da Rodada Uruguai de Negociações Comerciais Multilaterais do GATT. 
Este documento, que na prática delimita a competência e a função do painel, destaca que o papel do painel - a ser concretizado pelo relatório - subjaz-se (a) no exame da controvérsia, e (b) na enunciação de conclusões, que deverão auxiliar o OSC a "fazer recomendações elou emitir decisões [...]".

Embora a linguagem adotada não seja cristalina, em especial no que tange à versão oficial em português traduzida do inglês, é possível perceber que o foco de "decisão" é conferido ao OSC, com base nas determinações e recomendações elaboradas da análise do painel e/ou do Órgão de Apelação, e contidas nos respectivos relatórios.

O artigo 11 do ESC reforça esse quadro, ao expressar a função dos painéis:

[...] um grupo especial deverá fazer uma avaliação objetiva do assunto que lhe seja submetido, incluindo uma avaliação objetiva dos fatos, da aplicabilidade e concordância com os acordos abrangidos pertinentes, e formular conclusões que auxiliem o OSC a fazer recomendações ou emitir decisões previstas nos acordos abrangidos. 393

Embora possamos, em sentido latu, mencionar as "decisões" do painel ou do Órgão de Apelação, no intuito de fazer referência ao substrato material de sua análise fáticojurídica, e que em última instância "delibera" sobre o assunto, em um sentido técnico preferimos nos referir apenas a decisões uma vez que o respectivo relatório foi adotado, e portanto ganha validade formal como decisão adjudicatória, ao colocar fim de modo definitivo e obrigatório a uma controvérsia, com base no Direito Internacional. ${ }^{394} 395$

É relevante destacar que, em sendo o OSC o "alter ego" da OMC, as decisões do

393 Artigo 11. Entendimento Relativo às Normas e Procedimentos sobre Solução de Controvérsias. Versão oficial em português segundo o decreto n. 1.355, de 30 dez. 1994, que promulga a Ata Final que Incorpora os Resultados da Rodada Uruguai de Negociações Comerciais Multilaterais do GATT.

394 Segundo Celso Lafer, os pareceres dos painéis e do Órgão de Apelação transformam-se em findings, dotados de eficácia jurídica. LAFER, Celso. O Sistema de Solução de Controvérsias da Organização Mundial do Comércio. In: CASELLA, Paulo Borba; MERCADANTE, Araminta de (coord.). Guerra comercial ou integração mundial pelo comércio?: a OMC e o Brasil. São Paulo: LTr, 1998, p. 729-755. p. 748.

395 Destaca-se o seguinte trecho do relatório do painel: "[...] Recommendations by a panel and/or Appellate Body under Article 19 of the DSU (or Article 4.7 of the SCM Agreement) become effective only upon their adoption by the DSB. Once the DSB adopts a dispute settlement report, the findings and recommendations in that report become collective, operative DSB rulings and recommendations. The very notion of "measures taken to comply with the recommendations and rulings" in the text of Article 21.5 of the DSU is predicated upon DSB adoption of a panel/ Appellate Body report. No compliance obligation would arise unless and until panel and Appellate Body recommendations and rulings are adopted by the DSB to become DSB recommendations and rulings. "WTO. Panel Report, United States - Tax Treatment for Foreign Sales Corporations." WT/DS108/R, 8 out. 1999. para. 7.34-7.35. 
OSC passam a ser decisões do Sistema de Solução de Controvérsias da OMC como um todo, e é assim que preferimos tratá-las. Isto pois a natureza política do OSC, em uma análise apressada, pode obstaculizar a sua percepção como uma decisão adjudicatória. Mas ela o será, em face do papel formalmente existente, mas na prática virtualmente "automático" de adoção dos relatórios.

Assim, reforçamos o delicado desenho da deliberação: é a chancela (praticamente) automática de um órgão de natureza política que confere validade formal à análise jurídica realizada por órgãos de natureza adjudicatória, e que emana como uma decisão do Sistema de Solução de Controvérsias da OMC em sua visão totalizante.

Oportuno relembrar que, de certo modo, o documento que resulta do trabalho de revisão do Órgão de Apelação é mais significativamente limitado em seu aspecto material, uma vez que este documento analisará "apenas" as questões pleiteadas no pedido de apelação. 396 Assim, no mesmo espírito já evidenciado por GEORGES AB-SAAB, não incumbe ao Órgão de Apelação "analisar e decidir a controvérsia", mas the são conferidas três possibilidades: (a) confirmar, (b) modificar ou (c) revogar as determinações e conclusões jurídicas do painel.

Lembrando que o texto de um tratado internacional é um resultado delicado de embates de interesses e visões no momento de sua negociação, o artigo 19 do ESC enuncia o verdadeiro conteúdo material do relatório dos painéis e do Órgão de Apelação, o que nos leva a detalhar o conceito das "recomendações" contidas nestes relatórios.

A palavra "recommendations", é expressa 37 vezes na versão original em inglês do ESC e seus apêndices, assim como o vocábulo recomendações na versão em português, e se refere tanto ao conteúdo material das deliberações das instâncias adjudicatórias, quanto à manifestações surgidas do OSC.

No tocante às recomendações contidas nos relatórios dos painéis e do Órgão de Apelação, o artigo 19, cujo título é Recomendações dos Grupos Especiais e do Órgão de Apelação, expressa:

396 Artigo 17.12. Entendimento Relativo às Normas e Procedimentos sobre Solução de Controvérsias. Versão oficial em português segundo o decreto n. 1.355, de 30 dez. 1994, que promulga a Ata Final que Incorpora os Resultados da Rodada Uruguai de Negociações Comerciais Multilaterais do GATT. 
Quando um grupo especial ou o Órgão de Apelação concluir que uma medida é incompatível com um acordo abrangido, deverá recomendar que o Membro interessado torne a medida compatível com o acordo. Além de suas recomendações, o grupo especial ou o órgão de Apelação poderá sugerir a maneira pela qual o Membro interessado poderá implementar as recomendações. 397

Na primeira parte do artigo consta o resultado da análise que deve ser apresentado pelo painel e pelo Órgão de Apelação. Na segunda parte deste artigo, contudo consta uma observação de um elemento material opcional, sugestões sobre o meio pelo qual o membro que deve trazer a medida à conformidade, que podem ser expressas no relatório.

Enquanto o relatório deve recomendar que o membro desconforme torne a medida compatível, em caso de conclusão da análise pelo descumprimento ${ }^{398}$ o relatório pode conter sugestões de meios pelos quais concretizar sua recomendação. Há, pois, uma clara distinção entre (a) recomendações e (b) sugestões. ${ }^{399}$

Relevante pontuar que quanto às recomendações, o ESC não confere discricionariedade em relação a seu conteúdo substantivo, pois seu conteúdo material deve ser o de indicar que o autor da conduta ilegal deve torná-la conforme ("bring into compliance"). O resultado é que cabe ao membro destinatário da recomendação uma substancial margem de discricionariedade, quanto ao caminho a ser trilhado para dar concretude a esta recomendação. ${ }^{400}$

397 Artigo 19.1. Entendimento Relativo às Normas e Procedimentos sobre Solução de Controvérsias. Versão oficial em português segundo o decreto n. 1.355, de 30 dez. 1994, que promulga a Ata Final que Incorpora os Resultados da Rodada Uruguai de Negociações Comerciais Multilaterais do GATT.

398 Esta recomendação, contudo, não será necessária em casos nos quais a medida em discussão não esteja em vigor. "[...] The rationale for this approach has to do with the (consistente by now) understanding of WTO adjudicating bodies that the purpode of dispute settlement is to help resolve ongoing disputes. A recomendation to withdraw a measure is of no assistance to the resolution of the disputes. [...]" MATSUSHITA, Mitsuo; MAVROIDIS, Petros C.; SCHOENBAUM, Thomas J. The World Trade Organization: Law, Practice, and Policy. 2a Ed. Oxford: Oxford University Press, 2006. p. 146.

399 MATSUSHITA, Mitsuo; MAVROIDIS, Petros C.; SCHOENBAUM, Thomas J. The World Trade Organization: Law, Practice, and Policy. 2a Ed. Oxford: Oxford University Press, 2006. p. 146.

400 Como o painel explicitou no Relatório US- Section 301 Trade Act: "The obligation on Members to bring their laws into conformity with WTO obligations is a fundamental feature of the system and, despite the fact that it affects the internal legal system of a State, has to be applied rigorously. At the same time, enforcement of this obligation must be done in at the least intrusive way possible. The Member concerned must be allowed the maximum autonomy in ensuring such conformity and, if there is ore than one lawful way to achieve this, should have the freedom to choose that way which suits it best." WTO. Panel Report, United States - Sections 301-310 of the Trade Act of 1974. WT/DS152/R, $22 \mathrm{dez} 1999$. para 7.102. 
Em relação à força jurídica dessas recomendações, tendo em vista o consenso reverso, adotamos a perspectiva explicitada por Mitsui MATSUSHITA, PETROS MAVROIDIS e THOMAS SCHOENBAUM:

\footnotetext{
Em virtude do fato de que uma recomendação será parte de uma decisão do OSC direcionada ao membro da OMC em causa (forma), e devido à redação ambígua do art. 19 ESC (substância), esta recomendação é obrigatória para o seu destinatário. 401
}

As sugestões, por outro lado, se prestam a facilitar a implementação da recomendação, servindo como guias para se alcançar o seu cumprimento. Ainda que sejam requeridas, tais sugestões não são vinculantes às partes, quando outro caminho é possível. Contudo, a prática do Sistema de Solução de Controvérsias tem demonstrado que a explicitação de sugestões é mais comum em casos nos quais há apenas o meio sugerido como possibilidade de implementação. ${ }^{402}$

\subsection{Características das Decisões do Sistema de Solução de Controvérsias da OMC}

Com base na arquitetura normativa-institucional explicitada neste capítulo, compreende-se que as decisões do Sistema de Solução de Controvérsias da OMC são decisões adjudicatórias internacionais. Ressalte-se, o OSC atua como vocalizador de tais decisões, que emanam como resultado de uma complexa inter-relação entre os órgãos do sistema. É a juridicidade do sistema que se manifesta em um contexto de diplomacia, reduzido ou quase anulado em sua dimensão prática.

401 Tradução livre do original em língua inglesa: "By virtue of the fact that a recommendation will be part of a DSB decision addressed to the WTO Member concerned (form), and because of the unambiguous wording of Art. 19 DSU (substance), it is binding upon its adressee." MATSUSHITA, Mitsuo; MAVROIDIS, Petros C.; SCHOENBAUM, Thomas J. The World Trade Organization: Law, Practice, and Policy. 2a Ed. Oxford: Oxford University Press, 2006. p. 147.

402 MATSUSHITA, Mitsuo; MAVROIDIS, Petros C.; SCHOENBAUM, Thomas J. The World Trade Organization: Law, Practice, and Policy. 2a Ed. Oxford: Oxford University Press, 2006. p. 151. 
Assim, faz-se necessário brevemente explicitar as características dessas decisões, resultado do procedimento de solução de litígios submetidos ao Sistema de Solução de Controvérsias da OMC. Tais características consistem em uma síntese de discussões tidas ao longo deste capítulo, pois são consequências diretas das análises desenvolvidas.

\subsubsection{Juridicidade}

O Sistema de Solução de Controvérsias da OMC, conquanto resultado de um delicado balanceamento histórico de interesses políticos e ainda com peculiaridades remanescentes desta origem, representa uma vitória do direito na resolução de litígios no Direito Internacional Econômico.

Em sua operacionalização, o Sistema de Solução de Controvérsias da OMC demonstra, ainda, um abandono do voluntarismo estatal na solução de litígios, sendo um avanço significativo nesta área. A obrigação de observância de regras pré-fixadas, bem como o caráter obrigatório de suas decisões, tornam o Sistema de Solução de Controvérsias da OMC um instrumento de aplicação do Direito Internacional:

As decisões são vinculantes, e trazem consequências jurídicas; o mecanismo, em suma, é uma parte integrante do Direito Internacional Público, e orienta-se pelo devido processo legal, que é dotado de significado e relevância 403

Enquanto resultado de uma apreciação em procedimento adjudicatório, as decisões emanadas deste sistema são definitivas e obrigatórias, e embasadas no Direito Internacional, motivos pelos quais se caracterizam como jurídicas, em contraposição às

403 Tradução livre do original em língua inglesa: "The decisions are binding, and bring about legal consequences; the mechanism, in sum, is an integral part of Public International Law, and orients itself by the due process of law, what is endowed with significance and relevance”. TRINDADE, Antônio Augusto Cançado. International law for humankind: towards a new jus gentium (II). General course on public international law. Recueil des cours, vol. 317, p. 9-312, 2005. p. 205. 
decisões oriundas dos meios diplomáticos de solução de controvérsias.

\subsubsection{Obrigatoriedade}

Há certa discussão acerca da existência de uma obrigação de cumprir as decisões emanadas do Sistema de Solução de Controvérsias da OMC, já que o ESC não expressa esta obrigatoriedade em todas as letras, como o faz por exemplo a Carta da ONU a respeito da CIJ. ${ }^{404}$

As características peculiares do Sistema de Solução de Controvérsias da OMC, e a linguagem do ESC, levaram a uma interpretação restritiva por parte de alguns autores, no sentido de que não haveria uma obrigatoriedade no cumprimento de suas decisões, ${ }^{405}$ supostamente havendo uma legítima e livre "opção" entre o realizar o cumprimento ou enfrentar as consequências do descumprimento. ${ }^{406}$

Corroboramos, contudo, do entendimento de que, em uma leitura sistemática e teleológica, há diversos dispositivos que indicam esta obrigação de cumprir. ${ }^{407}$

Destacando-se apenas alguns desses dispositivos, o artigo 3.7 do ESC indica que " $O$ primeiro objetivo do mecanismo de solução de controvérsias será geralmente o de

404 Carta da ONU. Versão oficial em português conforme o Decreto n. 18.841, de 22 de outubro de 1945. "Artigo 94. 1. Cada Membro das Nações Unidas se compromete a conformarse com a decisão da Corte Internacional de Justiça em qualquer caso em que for parte." Estatuto da Corte Internacional de Justiça. Versão oficial em português conforme o Decreto n. 18.841, de 22 de outubro de 1945. "Artigo 59. A decisão da Côrte só será obrigatória para as partes litigantes e a respeito do caso em questão."

405 Nas palavras da autora: "[T]he WTO rules are simply not binding"in the traditional sense. When a panel established under the WTO Dispute Settlement Understanding issues a ruling adverse to a member, there is no prospect of incarceration, injunctive relief, damages for harm inflicted or police enforcement. The WTO has no jailhouse, no bail bondsmen, no blue helmets, no truncheons or tear gas. Rather, the WTOessentially a confederation of sovereign national governments- relies upon voluntary compliance." BELLO, Judith Hippler. The WTO Dispute Settlement Understanding: Less Is More. Editorial Comment. American Journal of International Law, vol. 90, p. 416-418, 1996. p. 416.

406 Deste modo, conclui a sua interpretação: "[...] Compliance with the WTO, as interpreted through dispute settlement panels, remains elective. If its law or measure is successfully challenged, a members enjoys three choices. [...]" BELLO, Judith Hippler. The WTO Dispute Settlement Understanding: Less Is More. Editorial Comment. American Journal of International Law, vol. 90, p. 416-418, 1996. p. 417.

407 JACKSON, John. Sovereignty, the WTO and Changing Fundamentals of International Law. New York: Cambridge University Press, 2006. p. 168. 
conseguir a supressão das medidas de que se trata [...]”. ${ }^{408} \mathrm{O}$ artigo 21.1 expressa que "[o] pronto cumprimento das recomendações e decisões do OSC é fundamental para assegurar a efetiva solução das controvérsias, em benefício de todos os membros." 409

$\mathrm{O}$ artigo 21.6 do ESC estabelece o dever de vigilância do OSC na "aplicação das recomendações e decisões", sendo previsto que "a questão da implementação das recomendações e decisões [...] deverá permanecer na agenda do OSC até que seja resolvida". ${ }^{410}$

O artigo 22.8 também é claro ao explicitar que “[a] suspensão de concessões ou outras obrigações deverá ser temporária [...]", ${ }^{411}$ evidenciando, portanto, que o membro continua em falta com suas obrigações até promover a implementação, ou haver uma solução mutuamente acordada.

Há, por fim, a obrigação postulada no artigo XVI parágrafo 4 do Acordo que estabelece a OMC, segundo o qual “[t]odo membro deverá assegurar a conformidade de suas leis, regulamentos e procedimentos administrativos com as obrigações constantes dos Acordos anexos." 412

A análise de JOHN JACKSON, citada por muitos outros autores, é coerente com o texto dos Acordos, ao reconhecer no sistema multilateral de comércio a obrigação do membro em violação da disciplina normativa de tornar suas medidas conformes ao corpus juris da OMC. Além da análise textual dos Acordos, o autor aplicou a metodologia de

408 Artigo 3.7. Entendimento Relativo às Normas e Procedimentos sobre Solução de Controvérsias. Versão oficial em português segundo o decreto n. 1.355, de 30 dez. 1994, que promulga a Ata Final que Incorpora os Resultados da Rodada Uruguai de Negociações Comerciais Multilaterais do GATT.

409 Artigo 21.1. Entendimento Relativo às Normas e Procedimentos sobre Solução de Controvérsias. Versão oficial em português segundo o decreto n. 1.355, de 30 dez. 1994, que promulga a Ata Final que Incorpora os Resultados da Rodada Uruguai de Negociações Comerciais Multilaterais do GATT.

410 Artigo 21.6. Entendimento Relativo às Normas e Procedimentos sobre Solução de Controvérsias. Versão oficial em português segundo o decreto n. 1.355, de 30 dez. 1994, que promulga a Ata Final que Incorpora os Resultados da Rodada Uruguai de Negociações Comerciais Multilaterais do GATT.

411 Artigo 22.8. Entendimento Relativo às Normas e Procedimentos sobre Solução de Controvérsias. Versão oficial em português segundo o decreto n. 1.355, de 30 dez. 1994, que promulga a Ata Final que Incorpora os Resultados da Rodada Uruguai de Negociações Comerciais Multilaterais do GATT.

412 É aguçada a análise de Jackson a respeito deste parágrafo: "That sentence in particular can serve as an important basis for the notion that the result of the DS procedure is to establish an international law obligation to comply with the results of the interpretations and applications made in the DS process." JACKSON, John. International Law Status of WTO Dispute Settlement Reports: Obligation to Comply or Option to Buy Out? American Journal of International Law, vol. 98, p. 109-125, 2004. p. 112. 
interpretação da CVDT ${ }^{413}$ para confirmar sua constatação de que o resultado último do Sistema de Solução de Controvérsias é, pois, a obrigação de implementar a determinação das instâncias adjudicatórias. ${ }^{414}$

Ademais destes dispositivos legais, contidos em um tratado internacional, o autor aponta fortes razões políticas para o reconhecimento da existência de uma obrigação internacional de cumprimento das "recomendações" do Sistema de Solução de Controvérsias, uma vez que o ESC explicita a relevância desse sistema a fim de garantir "segurança e previsibilidade para o sistema multilateral". Assim, ao reconhecermos que esse sistema permitiria uma escolha do membro em desconformidade, sobre cumprir ou "pagar", isentando-se do descumprimento, haveria um grave dano à sua credibilidade. ${ }^{415}$

Embora parte da doutrina discorde, ${ }^{416} 417$ prevalece a análise entabulada por Jackson de que, em uma perspectiva jurídica, as regras da OMC, como interpretadas pelo Sistema de Solução de Controvérsias, constituem obrigações jurídicas constituídas perante o Direito Internacional, cuja obrigatoriedade, ademais, resulta da Convenção de Viena do Direito dos Tratados, conforme se explicitou no subtópico 1.6.3. ${ }^{418} 419$

413 Pela relevância de suas palavras, remete-se ao trecho de Jackson: "After carefully and thoroughly examining the WTO text as found in Article XVI of the WTO Charter and in twelve or more clauses of the DSU, I would argue that there is over-whelning support for the view that the result of a WTO dispute in a panel or (sometimes) appellate report that rules that the laws or other measures of a respondent nation are inconsistent with its WTO obligations is to create an international law obligation to comply with that report (when it is adopted, as they almost always are). Furthermore, in using other standard treaty interpretation techniques, this conclusion is reinforced by the text, object and purpose, context, and practice of the GATT and WTO over more than five decades." JACKSON, John. International Law Status of WTO Dispute Settlement Reports: Obligation to Comply or Option to Buy Out? American Journal of International Law, vol. 98, p. 109-125, 2004. p. 123.

414 Se coaduna, pois, com a visão do autor: "In my view, these clauses over whelmingly imply, in the light of the practices of GATT, that the legal effect of an adopted panel report is the international law obligation to perform the recommendation or to comply with the "ulings"of the panel or appellate report." JACKSON, John. International Law Status of WTO Dispute Settlement Reports: Obligation to Comply or Option to Buy Out? American Journal of International Law, vol. 98, p. 109-125, 2004. p. 115.

415 JACKSON, John. Sovereignty, the WTO and Changing Fundamentals of International Law. New York: Cambridge University Press, 2006. p. 168.

416 Como exemplo desta posição, cita-se a posição dos autores: “[...] we simply note that the provisions of the DSU, taken as a whole, allow a violator to continue a violation in perpetuity, as long as it compensates or is willing to bear the costs of the retaliatory suspension of concessions. If WTO members really wanted to make compliance with dispute resolution findings mandatory, they would have imposed some greater penalty for noncompliance to induce it." SCHWARTZ, Warren.; SYKES, Alan 0. The Economic Structure of Renegotiation and Dispute Resolution in the World Trade Organization. Journal of Legal Studies, vol. 31, 179-204, 2002. p. 181.

417 Também sobre a possibilidade de "pagar" pelo descumprimento, segundo Joel Trachman a OMC "[...] does not normatively demand compliance at all costs. [...] the WTO's dispute settlement mechanism functions de facto, though not in a strictly legal sense, as a system of 'breach and pay'”. TRACHTMAN, Joel P. The WTO Cathedral. Standford Journal of International Law, vol. 43, p. 127-167, 2007. p. 130.

418 Este é o entendimento de Petros Mavroidis: "[...] the WTO member author of the illegal act continues the illegality and has not fulfilled its international obligations” MAVROIDIS, Petros. Remedies in 
Os órgãos adjudicatórios do Sistema de Solução de Controvérsias da OMC já destacaram em diversas oportunidades a obrigatoriedade das decisões. A exemplo, cita-se o seguinte entendimento:

\begin{abstract}
É axiomático que as alegadas violações dos acordos abrangidos devem ser analisadas exclusivamente por meio dos procedimentos estabelecidos no ESC, que prevê o exame de tais alegações por um painel e, possivelmente, pelo Órgão de Apelação, e que, se as violações forem reconhecidas e os respectivos relatórios forem aprovados pelo OSC, o membro demandado é obrigado a implementar imediatamente as recomendações e decisões do OSC. Estas recomendações e decisões são obrigatórias para os membros que devem implementá-las, e dão origem a uma obrigação de tornar as suas medidas reconhecidas como inconsistentes com a OMC em medidas conforme as suas obrigações previstas nos acordos abrangidos. ${ }^{420}$
\end{abstract}

A obrigatoriedade apreendida de uma interpretação sistemática e teleológica dos dispositivos do OSC se confirma como uma das características das decisões emanadas de órgãos de natureza adjudicatória, uma vez que "[o]s resultados de processos contenciosos que envolvem disputas internacionais são decisões que são finais e vinculantes para as partes". ${ }^{421}$

Por fim, é necessário relembrar que o descumprimento de um comando jurídico não o torna inoperante, ou retira sua obrigatoriedade. $\mathrm{O}$ caráter vinculante de uma decisão adjudicatória e os eventuais níveis concretos de descumprimento desvelam dimensões

the WTO Legal System: Between a Rock and a Hard Place. European Journal of International Law, vol. 11, 763-813, 2000. p. 800.

419 Como exemplo deste entendimento: "With respect to the 'bindingness' of the DSB recommendations, it is widely acknowledged that the Member concerned whose measures have been found to be in violation of the WTO Agreements is 'bound' or bears a 'legal obligation' to implement the DSB recommendations. Nevertheless, persistent scepticism exists with regard to the 'bindingness' of the DSB recommendations." FUKUNAGA, Yuka. Securing Compliance Through the WTO Dispute Settlement System: Implementation of DSB Recommendations. Journal of International Economic Law, vol. 9, issue 2, p. 383-426, mai 2006. p. 396.

420 Tradução livre do original em língua inglesa: "It is axiomatic that alleged violations of the covered agreements must be redressed exclusively through the procedures set out in the DSU, providing for examination of such allegations by a panel and possibly the Appellate Body, and that, if violations are found and the relevant reports are adopted by the DSB, the respondent Member is obliged to implement promptly the recommendations and rulings of the DSB. These recommendations and rulings are binding on implementing Members, and give rise to an obligation to bring their WTO-inconsistent measures into conformity with their obligations under the covered agreements" WTO. European Communities - Customs Classification of Frozen Boneless Chicken Cuts (Arbitration under Article 21.3(c) of the DSU). WT/DS269/13, 24 nov. 2005. para 55.

421 Tradução livre do original em língua inglesa: “[...][t]he outcomes of contentious proceedings involving international disputes are decisions which are final and binding on the parties." United Nations.

Handbook on the Peaceful Settlement of Disputes between States. New York: United Nations, 1992. Office of Legal Affairs, Codification Division. OLA/COD/2394. p. 80. 
distintas do fenômeno jurídico. ${ }^{422}$ Basta lembrar que o descumprimento não é exclusividade do Direito Internacional, sendo aspecto rotineiro da ordem jurídica interna dos Estados, decorrente da diferença entre o mundo do ser (sein) e o mundo do dever-ser (sollen). ${ }^{423}$

O fato de um membro não cumprir as obrigações presentes em uma decisão do Sistema de Solução de Controvérsias da OMC, buscando promover a compensação ou submetendo-se à retaliação, não tem o condão de extinguir sua obrigação de cumprir referida decisão. Este membro continua em violação de suas obrigações contraídas por meio dos Acordos da OMC enquanto persistir o descumprimento. ${ }^{424} 425$

\subsection{3 (In)determinabilidade}

Uma característica marcante das decisões do Sistema de Solução de Controvérsias da OMC é o caráter aberto dos comandos dessa decisão. Isto é, trata-se de um sistema substancialmente diferente da prática mais comum dos Tribunais Internacionais, que, em geral, ao julgarem uma violação a uma norma jurídica internacional determinam medidas

422 É certo que afirmar o caráter vinculante de uma obrigação no Direito Internacional não significa necessariamente garantir-lhe efeitos concretos em sua aplicabilidade: "Of course, once the binding" international law obligation to follow a panel or appellate report has been established, international law is not always efficient or effective in inducing compliance. [...]" United Nations. Handbook on the Peaceful Settlement of Disputes between States. New York: United Nations, 1992. Office of Legal Affairs, Codification Division. OLA/COD/2394. p. 117.

423 KELSEN, Hans. Teoria pura do direito. $7^{\text {a }}$ ed. São Paulo: Editora WMF Martins Fontes, 2006. CÂMARA FILHO, José Sette. Hans Kelsen e a teoria pura do Direito Internacional. Boletim da Sociedade Brasileira de Direito Internacional, n. 8, p. 70-91, jul./dez. 1948. p. 71-72.

424 Neste sentido é a posição do autor: "[...] However, in line with as long as a WTO Member is willing and able, either to compensate other Members affected by its treaty violation, or to endure trade retaliationwhose amount is determined by binding arbitration-the existing mechanism does indeed enable WTO Members to temporarily deviate from some of their obligations under WTO law. However, as noted above, this does not lead to the disappearance of the formal obligation to fully comply at some point in the future". ZIMMERMANN, Claus D. Toleration of Temporary Non-Compliance: The Systematic Safety Valve of WTO Dispute Settlement Revisited. Trade, Law \& Developmentm, vol. 3, p. 382-406, 2011. p. 386.

425 Em modo correlato expressa Jackson: "[...] The D.S.U. makes compensation only a fall-back when performance does not occur, and keeps a matter under surveillance as long as performance has not occurred. [...]" JACKSON, John. The Great 1994 Sovereignty Debate: United States Acceptance and Implementation of the Uruguay Round Results. Columbia Journal of Transnational Law, vol. 36, p. 157-188, 1998. p. 180. 
precisas para a reparação desta ilegalidade.

Este caráter indeterminado, mas determinável, das obrigações meio para se alcançar a obrigação de resultado - o fim da desconformidade com a normativa multilateral - é decorrente da literalidade da primeira parte do artigo 19.1 do ESC, que assim estabelece:

\begin{abstract}
Quando um grupo especial ou o órgão de Apelação concluir que uma medida é incompatível com um acordo abrangido, deverá recomendar que o Membro interessado torne a medida compatível com o acordo. Além de suas recomendações, o grupo especial ou o órgão de Apelação poderá sugerir a maneira pela qual o Membro interessado poderá implementar as recomendações (grifo nosso).
\end{abstract}

Em caso de violação das obrigações contidas nos Acordos da OMC, haverá, portanto, a recomendação de que o membro torne a medida compatível com referido Acordo violado. A princípio, o meio pelo qual o membro tornará a medida compatível insere-se em seu espaço de discricionariedade, podendo o painel sugerir meios pelos quais a implementação pode se concretizar.

No caso United States - Final Dumping Determination on Softwood Lumber from Canada (Softwood Lumber V), o painel destacou que não há uma obrigatoriedade em sugerir estes meios de implementação, mesmo quando uma das partes lhe solicita: " $[p]$ or força do artigo 19.1, os painéis têm discrição ("pode") para sugerir maneiras pelas quais um membro poderia implementar a recomendação relevante. No entanto, um painel não é obrigado a fazer uma sugestão quando não considera adequado fazer isso. ", 426

No caso Korea - Anti Dumping Duties on Imports of Certain Paper from Indonesia, o painel explicita que esta faculdade teria caráter excepcional, sendo, pois, discricionariedade do painel a explicitação destas sugestões:

Notamos que a regra geral nos termos do artigo 19.1 do ESC, no que diz respeito às recomendações dos painéis da $\mathrm{OMC}$, é recomendar que o membro em causa

426 Tradução livre do original em língua inglesa: “ [...] [b]y virtue of Article 19.1, panels have discretion ("may") to suggest ways in which a Member could implement the relevant recommendation. However, a panel is not required to make a suggestion should it not deem it appropriate to do so." WTO. Panel Report, United States - Final Dumping Determination on Softwood Lumber from Canada (Softwood Lumber V). WT/DS264/R, 13 abr. 2004. para. 8.6. 
torne sua medida conforme com as disposições pertinentes dos acordos abrangidos em questão. Excepcionalmente, o artigo 19.1 também autoriza os painéis a sugerir maneiras pelas quais essas recomendações podem ser implementadas $[\ldots]$. $^{427}$

Em diversas oportunidades o painel preferiu não formular a sugestão, mesmo quando requerida. ${ }^{428}$ Ainda quando o painel exerça este direito, e formule sugestão do meio de implementação, a decisão do modo pelo qual cumprir a decisão do OSC fica a critério da parte: "[...] enquanto um painel pode sugerir formas de implementar a sua recomendação, a escolha dos meios de implementação é decidida, em primeira instância, pelo membro responsável pela implementação". 429

A título de exemplificação, vejamos como o painel já preencheu esse espaço de discricionariedade na sugestão dos meios, tornando sua decisão mais evidentemente determinada. A extinção da medida foi a sugestão do painel em diversas situações, tais como nos casos United States - Restrictions on Imports of Cotton and Man made Fibre Underwear, ${ }^{430}$ Guatemala - Anti Dumping Investigation Regarding Portland Cement from

427 Tradução livre do original em língua inglesa: "We note that the general rule under Article 19.1 of the $D S U$ with respect to the recommendations of WTO panels is to recommend that the Member concerned bring its measure into conformity with the relevant provisions of the covered agreements at issue. Exceptionally, Article 19.1 also authorizes the panels to suggest ways in which such recommendations could be implemented." WTO. Panel Report, Korea - Anti Dumping Duties on Imports of Certain Paper from Indonesia. WT/DS312/R, 28 out. 2005. para. 9.3-9.4.

428 WTO. Panel Report, United States - Anti Dumping Measures on Certain Hot Rolled Steel Products from Japan, WT/DS184/R, 28 fev. 2001. para. 8.11.; WTO. Panel Report, United States - Anti Dumping Measures on Stainless Steel Plate in Coils and Stainless Steel Sheet and Strip from Korea. WT/DS179/R, 22 dez. 2000. para. 7.10.; WTO. Panel Report, United States - Definitive Safeguard Measures on Imports of Circular Welded Carbon Quality Line Pipe from Korea. WT/DS202/R, 29 out. 2001. para. 8.6.; WTO. Panel Report, Chile - Price Band System and Safeguard Measures Relating to Certain Agricultural Products. WT/DS207/R, 3 mai. 2002. para. 8.3. WTO. Panel Report, European Communities - Trade Description of Sardines. WT/DS231/R, 29 mai. 2002. para. 8.3.; WTO. Panel Report, United States - Countervailing Measures Concerning Certain Products from the European Communities. WT/DS212/R, 31 jul. 2002. para. 6.43.; WTO. Panel Report, European Communities - Conditions for the Granting of Tariff Preferences to Developing Countries, WT/DS246/R, 1 dez. 2003. para. 8.3.; WTO. Panel Report, United States - Sunset Reviews of Anti Dumping Measures on Oil Country Tubular Goods from Argentina. WT/DS268/R, 16 jul. 2004. para. 8.3-8.5.; WTO. Panel Report, European Communities - Anti Dumping Duties on Malleable Cast Iron Tube or Pipe Fittings from Brazil. WT/DS219/R, 7 mar. 2003. para. 8.9 and 8.11; WTO. Panel Report, United States - Countervailing Duty Investigation on Dynamic Random Access Memory Semiconductors (DRAMS) from Korea. WT/DS296/R, 21 fev. 2005. para. 8.4.

429 Tradução livre do original em língua inglesa: “[...] while a panel may suggest ways of implementing its recommendation, the choice of means of implementation is decided, in the first instance, by the Member concerned" WTO. WTO. Panel Report, United States - Anti Dumping Measures on Stainless Steel Plate in Coils and Stainless Steel Sheet and Strip from Korea. WT/DS179/R, 22 dez. 2000. para. 8.8.

$430 \quad$ Neste caso o painel formulou a seguinte sugestão: "We find that such compliance can best be achieved and further nullification and impairment of benefits accruing to Costa Rica under the ATC best be avoided by prompt removal of the measure inconsistent with the obligations of the United States. We further suggest that the United States bring the measure challenged by Costa Rica into compliance with US obligations under the ATC by immediately withdrawing the restriction imposed by the measure." WTO. 
Mexico, ${ }^{431}$ United States - Transitional Safeguard Measure on Combed Cotton Yarn from

Pakistan, ${ }^{432}$ United States - Continued Dumping and Subsidy Offset Act of 2000, ${ }^{433}$

Argentina - Definitive Anti Dumping Duties on Poultry from Brazil, ${ }^{434}$ Mexico - Anti

Dumping Duties on Steel Pipes and Tubes from Guatemala. ${ }^{435}$

No caso European Communities - Regime for the Importation, Sale and Distribution of Bananas (Bananas III), tendo em vista que tentativas anteriores de implementar não haviam tido como efeito o cumprimento da decisão, o painel sugeriu alguns meios concretos:

\begin{abstract}
Em primeiro lugar, as Comunidades Europeias podem optar por implementar um sistema unicamente tarifário sobre bananas, sem uma quota tarifária. Isto pode incluir uma preferência tarifária (zero ou outro valor preferencial) para bananas oriundas dos ACP. Se assim for, uma renúncia à preferência tarifária talvez seja necessária a menos que a necessidade de uma renúncia seja evitado, por exemplo, pela criação de uma zona de livre comércio compatível com o artigo XXIV do GATT. Esta opção evitaria a necessidade de buscar um acordo sobre quotas tarifárias.
\end{abstract}

Em segundo lugar, as Comunidades Europeias podem optar por implementar um sistema unicamente tarifário de bananas, com uma cota tarifária para as bananas oriundas dos ACP cobertos por uma renúncia adequada.

Panel Report, United States - Restrictions on Imports of Cotton and Man made Fibre Underwear. WT/DS24/R, 8 nov. 1996. para. 8.3.

431 Neste caso o painel formulou a seguinte sugestão: "[...] [T] he entire investigation rested on an insufficient basis, and therefore should never have been conducted. This is, in our view, a violation which cannot be corrected effectively by any actions during the course of the ensuing investigation. Therefore, we suggest that Guatemala revoke the existing anti-dumping measure on imports of Mexican cement, because, in our view, this is the only appropriate means of implementing our recommendation." WTO. Panel Report, Guatemala - Anti Dumping Investigation Regarding Portland Cement from Mexico. WT/DS60/R, 19 jun. 1998. para. 8.6.

432 Neste caso o painel formulou a seguinte sugestão: "In this case, we recommend that the Dispute Settlement Body request that the United States bring the measure at issue into conformity with its obligations under the ATC. We suggest that this can best be achieved by prompt removal of the import restriction." WTO. Panel Report, United States - Transitional Safeguard Measure on Combed Cotton Yarn from Pakistan. WT/DS192/R, 31 mai. 2001. para. 8.5.

433 Neste caso o painel formulou a seguinte sugestão: "[...] although there could potentially be a number of ways in which the United States could bring the [concerned measure] into conformity [...] difficult to conceive of any method which would be more appropriate and/or effective than the repeal of the [...] measure". WTO. Panel Report, United States - Continued Dumping and Subsidy Offset Act of 2000. WT/DS217/R, WT/DS234/R, 16 set. 2002. para. 8.6.

434 Neste caso o painel formulou a seguinte sugestão: “[...]not perceive how Argentina could properly implement [the] recommendation without revoking the anti-dumping measure at issue in this dispute. Accordingly, [the Panel suggested] that Argentina repeals Resolution No. 574/2000 imposing definitive antidumping measures on eviscerated poultry from Brazil." WTO. Panel Report, Argentina - Definitive Anti Dumping Duties on Poultry from Brazil. WT/DS241/R, 22 abr. 2003. para. 8.7.

435 Neste caso o painel formulou a seguinte sugestão: "[...] revoke the anti-dumping measures applied to steel pipes and tubes from Guatemala in order to implement properly the conclusions and recommendations identified in this case". WTO. Panel Report, Mexico - Anti Dumping Duties on Steel Pipes and Tubes from Guatemala. WT/DS331/R, 8 jun. 2007. para. 8.12. 
Em terceiro lugar, as Comunidades Europeias poderiam manter suas atuais quotas tarifárias com base na nação mais favorecida (NMF), ou sem alocar quaisquer quotas específicas de cada país ou alocando tais quotas por acordo com todos os fornecedores substanciais de forma consistente com os requisitos do caput do artigo XIII: 2. A quota tarifária da NMF poderia ser combinada com a extensão da isenção de impostos (ou direitos preferenciais) para as importações ACP ${ }^{436}$

O painel também sugeriu um dos caminhos pelos quais a UE/CE poderia tornar a medida conforme no caso European Communities - Protection of Trademarks and Geographical Indications for Agricultural Products and Foodstuffs, Complaint by the United States:

\begin{abstract}
[U]ma maneira pela qual as Comunidades Europeias poderia implementar a recomendação acima com relação às condições de equivalência e de reciprocidade seria por meio da alteração do regulamento de modo que essas condições não se aplicariam aos procedimentos para o registro de Indicações Geográficas localizadas em outros membros da OMC, nos quais, como foi apresentado ao Painel, isto já ocorre. ${ }^{437}$
\end{abstract}

No caso India - Patent Protection for Pharmaceutical and Agricultural Chemical Products, embora o painel não tenha sugerido uma maneira pela qual a demandada deveria implementar a decisão, o painel sugeriu que a Índia levasse em conta certos elementos, no estabelecimento do mecanismo de implementação:

436 Tradução livre do original em língua inglesa: "First, the European Communities could choose to implement a tariff-only system for bananas, without a tariff quota. This could include a tariff preference (at zero or another preferential rate) for ACP bananas. If so, a waiver for the tariff preference maybe necessary unless the need for a waiver is obviated, for example, by the creation of a free-trade area consistent with Article XXIV of GATT. This option would avoid the need to seek agreement on tariff quota shares. Second, the European Communities could choose to implement a tariff-only system for bananas, with a tariff quota for ACP bananas covered by a suitable waiver. Third, the European Communities could maintain its current bound and autonomous MFN tariff quotas, either without allocating any country-specific shares or allocating such shares by agreement with all substantial suppliers consistently with the requirements of the chapeau to Article XIII:2. The MFN tariff quota could be combined with the extension of duty-free treatment (or preferential duties) to ACP imports" WTO. Panel Report, European Communities - Regime for the Importation, Sale and Distribution of Bananas (Recourse to Article 21.5 of the DSU by Ecuador). WT/DS27/RW/ECU, 12 abr. 1999. para. 6.155-6.158.

437 Tradução livre do original em língua inglesa: “[...] [0] ne way in which the European Communities could implement the above recommendation with respect to the equivalence and reciprocity conditions, would be to amend the Regulation so as for those conditions not to apply to the procedures for registration of [Geographical Indications] located in other WTO Members which, it submitted to the Panel, is already the case." WTO. Panel Reports, European Communities - Protection of Trademarks and Geographical Indications for Agricultural Products and Foodstuffs, Complaint by the United States. WT/DS174/R, 15 mar. 2005. para. 8.5. 
$[\mathrm{N}] \mathrm{a}$ criação de um mecanismo que preserve a novidade e a prioridade em relação aos pedidos de patentes de produtos em matéria de invenções químicas farmacêuticas e agrícolas durante o período de transição, a Índia deve levar em conta os interesses das pessoas que teriam apresentado pedidos de patentes caso houvesse um mecanismo adequado desde a expiração da Portaria sobre Patentes, de 1994, bem como daqueles que já entraram com tais pedidos sob a guarida desta Portaria ou das práticas administrativas atualmente em vigor 438

A escolha do meio pelo qual implementar a decisão, contudo, permanece a critério do membro cuja conduta deve ser reformulada, ${ }^{439}$ embora as sugestões explicitadas possam ser de auxílio para guiar a implementação por parte do membro demandado, especialmente em casos de maior complexidade.

Referida discricionariedade na escolha do meio de implementação, contudo, não é um direito absoluto ou ilimitado, como expressou o árbitro no caso European Communities - Export Subsidies on Sugar:

A escolha do método de implementação recai sobre os membros que devem promovê-la. No entanto, os membros não tem um direito irrestrito de escolher qualquer método de implementação. Além de ser compatível com as obrigações do membro na OMC, o método escolhido deve ser tal que possa ser implementado dentro de um período razoável de tempo, de acordo com as diretrizes contidas no artigo 21.3 (c). Objetivos que sejam alheios ou irrelevantes para as recomendações e decisões do OSC na disputa em questão podem não ser incluídos no método de implementação se essa inclusão for para prolongar o período de execução. Acima de tudo, presume-se que os membros em fase de implementação devem agir de "boa fé" na seleção do método que considerem mais adequado para a implementação das recomendações e decisões do OSC. ${ }^{440}$

438 Tradução livre do original em língua inglesa: “[...] [I]n establishing a mechanism that preserves novelty and priority in respect of applications for product patents in respect of pharmaceutical and agricultural chemical inventions during the transitional period, India should take into account the interests of those persons who would have filed patent applications had an appropriate mechanism been maintained since the expiry of the Patents Ordinance 1994, as well as those who have already filed such applications under that Ordinance or the administrative practices currently in place." WTO. Panel Report, India - Patent Protection for Pharmaceutical and Agricultural Chemical Products, Complaint by the United States. WT/DS50/R, 5 set. 1997. para. 6.2.

$439 \quad$ Neste sentido explicitou o árbitro deste caso: “[...] Moreover, although the suggestion by the Panel, as part of a panel report adopted by the DSB, could serve as a useful contribution to the decision-making process in the implementing Member, I do not believe that the existence of such a suggestion ultimately affects the well-established principle that "choosing the means of implementation is, and should be, the prerogative of the implementing Member". WTO. Award of the Arbitrator, United States - Continued Dumping and Subsidy Offset Act of 2000 (Arbitration under Article 21.3(c) of the DSU). WT/DS217/14, WT/DS234/22, 13 jun. 2003. para. 52.

440 Tradução livre do original em língua inglesa: "[T] he choice of the method of implementation rests with the implementing Member. However, the implementing Member does not have an unfettered right to 
Entendimento semelhante foi expressado no laudo do árbitro do caso European Communities - Customs Classification of Frozen Boneless Chicken Cuts, no qual ficou estabelecido:

\begin{abstract}
Embora os membros geralmente tenham discricionariedade para determinar os seus meios de implementação, esta discricionariedade não é sem limites. Ao dizer que a seleção dos meios de implementação das recomendações e decisões do OSC é prerrogativa do membro responsável pela implementação não é de modo algum correspondente a dizer que "vale tudo". Afirmar o contrário seria permitir aos membros cuja implementação se exige a discricionariedade também de adotar medidas de implementação que desnecessariamente e indevidamente prorroguem o prazo razoável de tempo necessário para a implementação. E isso seria contrário ao objetivo do artigo 21.3 do ESC. [... $]^{441}$
\end{abstract}

Como restou demonstrado, as decisões do Sistema de Solução de Controvérsias da OMC, cujo conteúdo material expressa as recomendações de seus órgãos adjudicatórios, se apresentam como comandos de resultado, ao exigirem que a medida reconhecidamente desconforme seja tornada adequada às obrigações multilaterais. A escolha do meio pelo qual será atingido o resultado é de determinação do Estado, em seu espaço de discricionariedade.

Reitera-se que esta peculiaridade do resultado do procedimento perante o Sistema de Solução de Controvérsias da OMC não o descaracteriza como um sistema de natureza adjudicatória, não sendo a precisão do comando explicitado o requisito que diferencie as

choose any method of implementation. Besides being consistent with the Member's WTO obligations, the chosen method must be such that it could be implemented within a reasonable period of time in accordance with guidelines contained in Article 21.3(c). Objectives that are extraneous to the recommendations and rulings of the DSB in the dispute concerned may not be included in the method if such inclusion were to prolong the implementation period. Above all, it is assumed that the implementing Member will act in "good faith" in the selection of the method that it deems most appropriate for implementation of the recommendations and rulings of the DSB." WTO. Award of the Arbitrator, European Communities - Export Subsidies on Sugar (Arbitration under Article 21.3(c) of the DSU). WT/DS265/33, WT/DS266/33, WT/DS283/14, 28 out. 2005. para. 69.

441 Tradução livre do original em língua inglesa: "Although Members generally have discretion to determine their means of implementation, this discretion is not without bounds. Saying that selecting the means of implementing the recommendations and rulings of the DSB is the prerogative of the implementing member is not at all the same as saying that "anything goes". To declare otherwise would be to allow implementing Members the discretion also to pursue implementation measures that needlessly and unduly extend the reasonable period of time needed for implementation. And this would be contrary to the objective of Article 21.3 of the DSU." Award of the Arbitrator, European Communities - Customs Classification of Frozen Boneless Chicken Cuts (Arbitration under Article 21.3(c) of the DSU). WT/DS269/13, WT/DS286/15, 20 fev. 2006. para. 56 
decisões adjudicatórias de decisões de outra natureza. ${ }^{442}$ Há quem compreenda, contudo, que tal especificidade se conecta à natureza prospectiva e não reparatória do Sistema de Solução de Controvérsias. ${ }^{443}$

442 Até mesmo as decisões da CIJ não expressam sempre uma obrigação de fazer especificada: "In the majority of cases, the judgements are those requiring performance, but as has been done in some of the judgments of the International Court of Justice, a court may be requested to render declaratory judgements in which the court determines the guiding legal principles to be followed in dealing with a particular dispute, without giving a definitive decision on the dispute, or establishes that the violation of the principle of international law in question has no practical remedy." United Nations. Handbook on the Peaceful Settlement of Disputes between States. New York: United Nations, 1992. Office of Legal Affairs, Codification Division. OLA/COD/2394. p. 81.

443 A maior parte da doutrina explicita que o Sistema de Solução de Controvérsias busca apenas impedir a continuidade da violação, não buscando reparar os danos causados. Parte crescente da doutrina se posiciona no sentido de sugerir a inclusão do elemento reparatório como meio de tornar o Sistema de Solução de Controvérsias mais eficiente, em especial aos países em desenvolvimento, Cf: OLIVEIRA, Luciana Maria de. A Eficácia da "Suspensão de Concessões ou de Outras Obrigações" para a Implementação das Recomendações do Órgão de Solução de Controvérsias (OSC) da OMC e os Membros em Desenvolvimento. In: VEÇOSO, Fabia Fernandes Carvalho (Coord.). Direito Internacional em Contexto. Direito, Gestão e Prática. Série GVlaw. Direito, Gestão e Prática. São Paulo: Ed. Saraiva, 2012, p. 285-322. Para uma visão inovadora, buscando reforçar o papel de remédios retrospectivos como indutor do cumprimento, e sua aplicação ao Sistema de Solução de Controvérsias da OMC, Cf: VIDIGAL, Geraldo. Re-assessing WTO Remedies: The Prospective and the Retrospective. Journal of International Economic Law, vol. 16, p. 505534, 2013. 


\section{A IMPLEMENTAÇÃO DAS DECISÕES DO SISTEMA DE SOLUÇÃO DE CONTROVÉRSIAS DA OMC: ANÁLISE DE CASOS}

\subsection{Comentários Iniciais Sobre a Implementação das Decisões}

Como delimitado no capítulo anterior, a fase de implementação das decisões se inaugura com a adoção do relatório pelo OSC. Esse relatório, que então assume o status de decisão do Sistema de Solução de Controvérsias da OMC, pode conter recomendações, e eventualmente sugestões de maneiras pelas quais o membro deve adequar a sua conduta.

Uma vez adotado o relatório, e emitida a decisão pelo OSC, deve-se promover " $o$ pronto cumprimento das recomendações e decisões do OSC". ${ }^{444} \mathrm{O}$ conceito de pronto cumprimento se concretiza por meio da (i) retirada/ revogação da medida; ou (ii) modificação da medida, na parte que contenha a violação reconhecida pelo relatório como se evidenciará melhor nas análises deste capítulo.

À guisa de introdução à análise de implementação das decisões, é relevante destacar que embora haja uma distância entre a dimensão normativa explicitada pelas decisões do Sistema de Solução de Controvérsias e a dimensão fática, manifestada na realidade dos ordenamentos jurídicos internos e nas dificuldades concretas de sua implementação, há um significativo reconhecimento de legitimidade deste sistema.

Isto pois, tendo em vista que os argumentos "tradicionais" de recusa de implementação de uma decisão jurisdicional internacional evocados pelos Estados são (i) a dificuldade e/ou impossibilidade de sua execução, e (ii) a invalidade da decisão adjudicante, ${ }^{445}$ esses não se apresentam de modo regular em relação ao Sistema de

444 Artigo 21.1 Entendimento Relativo às Normas e Procedimentos sobre Solução de Controvérsias. Versão oficial em português segundo o decreto n. 1.355, de 30 dez. 1994, que promulga a Ata Final que Incorpora os Resultados da Rodada Uruguai de Negociações Comerciais Multilaterais do GATT.

445 Assim explicita Lucius Caflish: “Ainsi une première catégorie des motifs pour refuser l'exécution est celle de la difficulté voire impossibilité d'exécution. Un deuxième type d'arguments invoqués par les Etats défaillants sont ceux alléguant l'invalidité de la decision" CAFLISCH, Lucius. Cent ans de règlement 
Solução de Controvérsias da OMC. Embora as dificuldades internas de implementação sirvam como argumento para que o membro requeira mais tempo para a sua concretização - ou como incentivo para a busca por soluções negociadas -, este estudo desconhece caso no qual o membro demandado tenha se colocado formalmente contra a validade e legitimidade de uma decisão desse sistema.

Por outro lado, sob a perspectiva do membro vencedor, é sobretudo na fase de implementação que se manifesta com destaque o cálculo político e diplomático. Isso pois, tendo em vista que as decisões do Sistema de Solução de Controvérsias da OMC não são "autoexecutórias", a implementação depende certamente de ato de vontade do membro “perdedor", estimulado pela utilização de diversos mecanismos possíveis por parte do membro ganhador. ${ }^{446}$ A decisão de requerer e exercer o seu direito de retaliação e/ou de empreender negociações na fase de implementação exige cálculo complexo, a depender de elementos do caso concreto, e principalmente do perfil de relação comercial pré-existente entre as partes.

\title{
Assim conclui RoBerto CARVALHO DE AZEVÊDO:
}

\begin{abstract}
Como a prática tem demonstrado, não é trivial a decisão de retaliar um país estrangeiro por descumprimento de recomendações do OSC. Muitas vezes a retaliação é virtualmente impossível, seja em vista da inexistência de volume de comércio expressivo (caso das disputas aeronáuticas entre Brasil e Canadá), seja em razão de marcada assimetria nas relações comerciais. Há casos, por exemplo, em que o país vencedor importa do vencido bens essenciais, como alimentos e insumos produtivos, o que tornaria a retaliação um esforço penoso, além de possivelmente ineficaz. Ainda que o Mecanismo de Solução de Controvérsias seja a "Corte" mais eficaz entre seus pares no plano internacional, é na implementação que o sistema encontra e testa os seus limites de efetividade. (grifo nosso) $^{447}$
\end{abstract}

No que tange ao elemento das dificuldades internas de implementação, trata-se de uma problemática real dos Estados, e abarca diversas e complexas dimensões, que serão exemplificadas no capítulo 4. Tais complexidades decorrem do desenho de competências estabelecido pela Constituição às instituições nacionais, bem como da possibilidade de

pacifique des différends interétatiques. Recueil des cours, vol. 288, p. 245-467, 2001. p. 426.

446 AZEVEDO, Roberto Carvalho de. Prefácio. In: BENJAMIN, Daniela Arruda. (Org). O Sistema de

Solução de Controvérsias da OMC : uma perspectiva brasileira. Brasília : FUNAG, 2013, p. 23-30. p. 28.

447 AZEVEDO, Roberto Carvalho de. Prefácio. In: BENJAMIN, Daniela Arruda. (Org). O Sistema de Solução de Controvérsias da OMC : uma perspectiva brasileira. Brasília : FUNAG, 2013, p. 23-30. p. 28. 
invocar e exigir as obrigações decorrentes dos Acordos da OMC e das decisões do Sistema de Solução de Controvérsias da OMC nos ordenamentos internos. Essas complexidades se ampliam ainda mais na União Europeia, tendo em conta os desafios adicionais trazidos pela ordem comunitária.

\subsection{Comentários Iniciais sobre a Participação do Brasil no Sistema de Solução de} Controvérsias da OMC

Desde a criação da OMC, em 1995, o Brasil atuou - como demandante, demandado ou terceira parte - em 126 dos 482 contenciosos iniciados na OMC. ${ }^{448} \mathrm{O}$ país ficou atrás apenas dos Estados Unidos, ${ }^{449}$ União Europeia (UE), ${ }^{450}$ Japão, ${ }^{451}$ China, ${ }^{452}$ Canadá ${ }^{453}$ e Índia, ${ }^{454}$ que ocupam, respectivamente, do $1^{\circ}$ ao $6^{\circ}$ lugar na ordem de membros mais atuantes deste sistema de solução de litígios.

448 Durante a realização da pesquisa, os dados se modificaram diversas vezes. Os dados citados estão atualizados até 10 de julho de 2014, e foram retirados da base de dados de solução de controvérsias da OMC: $<$ http://www.wto.org/english/tratop_e/dispu_e/dispu_by_country_e.htm>

449 Os EUA participaram de 342 casos, dentre os quais atuaram em 107 como demandante, em 121 como demandado, e em 114 como terceira parte. Dados atualizados até 10 de julho de 2014, retirados da base de dados de solução de controvérsias da OMC: $<$ http://www.wto.org/english/tratop_e/dispu_e/dispu_by_country_e.htm>

450 A União Europeia (anteriormente denominada na $\mathrm{OMC}$ de Comunidades Europeias) participou de 316 casos, dentre os quais atuou em 93 como demandante, em 79 como demandada, e em 144 como terceira parte. Dados atualizados até 10 de julho de 2014, retirados da base de dados de solução de controvérsias da OMC: $<$ http://www.wto.org/english/tratop_e/dispu_e/dispu_by_country_e.htm>

451 O Japão participou de 178 casos, dentre os quais atuou em 19 como demandante, em 15 como demandado, e em 144 como terceira parte. Dados atualizados até 10 de julho de 2014, retirados da base de dados de solução de controvérsias da $<$ http://www.wto.org/english/tratop_e/dispu_e/dispu_by_country_e.htm>

452 A China participou de $15 \overline{3}$ casos, dentre os quais atuou em 12 como demandante, em 31 como demandada, e em 110 como terceira parte. Dados atualizados até 10 de julho de 2014, retirados da base de dados de solução de controvérsias da OMC: $<$ http://www.wto.org/english/tratop_e/dispu_e/dispu_by_country_e.htm>

453 O Canadá participou de $1 \overline{4} 7$ casos, dentre os quais atuou em 33 como demandante, em 18 como demandado, e em 96 como terceira parte. Dados atualizados até 10 de julho de 2014, retirados da base de dados de solução de controvérsias da OMC: $<$ http://www.wto.org/english/tratop_e/dispu_e/dispu_by_country_e.htm>

454 A Índia participou de $14 \overline{2}$ casos, dentre os quais atuou em 21 como demandante, em 22 como demandada, e em 99 como terceira parte. Dados atualizados até 10 de julho de 2014, retirados da base de dados de solução de controvérsias da OMC: 
Conforme será desvelado nos subtópicos que se seguem, dos 126 casos citados, o Brasil participou em 26 casos como demandante, ${ }^{455}$ em 15 casos como demandado, ${ }^{456} \mathrm{e}$ em 85 casos como terceira parte. ${ }^{457}$

Observa-se, pois, uma participação intensa - mas simultaneamente responsável - do Brasil neste sistema de solução de litígios. ${ }^{458}$ Isto pois, como parte reclamante, sua atuação tem se dado embasada na existência de um entrave comercial real, e como vocalização de reclamações de setores internos nacionais.

A prática indica, assim, que o Brasil tem usado primordialmente o Sistema de Solução de Controvérsias quando seus interesses comerciais são afetados. Contudo, a decisão de acionar o mecanismo se revela como uma escolha institucional complexa, que envolve diversas variáveis que não apenas a viabilidade jurídica da tese a ser levantada, mas questões pragmáticas e que importam num complexo equilíbrio entre diversos interesses. $^{459} 460$

Embora envolto nessa dimensão política, o Sistema de Solução de Controvérsias

$<$ http://www.wto.org/english/tratop_e/dispu_e/dispu_by_country_e.htm $>$

455 DS4, DS69, DS70, DS71, DS112, DS154, DS190, DS208, DS209, DS216, DS217, DS218, DS219, DS222, DS224, DS239, DS241, DS250, DS259, DS266, DS267, DS269, DS365, DS382, DS409, DS439 Dados atualizados até 10 de julho de 2014, retirados da base de dados de solução de controvérsias da OMC: $<$ http://www.wto.org/english/tratop_e/dispu_e/dispu_by_country_e.htm>

456 DS22, DS30, DS46, DS51, DS52, DS65, DS81, DS116, DS183, DS197, DS199, DS229, DS332, DS355, DS472 Dados atualizados até 10 de julho de 2014, retirados da base de dados de solução de controvérsias da OMC: $<$ http://www.wto.org/english/tratop_e/dispu_e/dispu_by_country_e.htm>

457 DS27, DS76, DS108, DS114, DS121, DS135, DS138, DS152, DS160, DS174, DS184, DS204, DS207, DS212, DS234, DS244, DS245, DS246, DS248, DS249, DS251, DS252, DS253, DS254, DS258, DS265, DS283, DS286, DS290, DS291, DS292, DS293, DS294, DS315, DS316, DS317, DS320, DS321, DS335, DS339, DS340, DS342, DS343, DS344, DS345, DS347, DS350, DS353, DS362, DS375, DS376, DS377, DS379, DS381, DS384, DS386, DS391, DS392, DS394, DS395, DS397, DS398, DS405, DS406, DS412, DS420, DS426, DS430, DS431, DS432, DS433, DS434, DS435, DS437, DS441, DS447, DS453, DS456, DS457, DS458, DS462, DS464, DS467, DS469, DS471. Dados atualizados até 10 de julho de 2014, retirados da base de dados de solução de controvérsias da OMC:

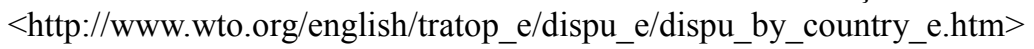

458 COZENDEY, Carlos Márcio Bicalho. O Sistema de Solução de Controvérsias da OMC: para além dos contenciosos, a política externa. Disponível em: <http://www.itamaraty.gov.br/temas/temasmultilaterais/copy_of_desenvolvimento-comercio-e-financas/organizacao-mundial-do-comercio/solucao-decontroversias/cgc/artigo-cozendey> Acesso em: 15 dez. 2013. p. 11.

459 Assim explicita Roberto Carvalho de Azevêdo: "Um país responsável deve sempre ponderar se a tese que defende em determinado caso não lhe será nociva em outro. Precisa, ainda, avaliar se a vitória será útil, não só do ponto de vista comercial, mas também político e diplomático. Há, portanto, um importante trabalho de avaliação, que ultrapassa considerações de viabilidade jurídica, na condução de uma controvérsia." AZEVEDO, Roberto Carvalho de. Prefácio. In: BENJAMIN, Daniela Arruda. (Org). o Sistema de Solução de Controvérsias da OMC: uma perspectiva brasileira. Brasília : FUNAG, 2013, p. 2330. p. 24.

460 Para uma análise da tomada de decisão no Brasil sobre iniciar um contencioso na OMC, Cf: ARBIX, Daniel A. Contenciosos brasileiros na OMC: pauta comercial, política e instituições. Contexto Internacional, vol. 30, n. 3, p. 655-699, 2008. 
desencadeia atos de natureza jurídica, podendo culminar em última análise na necessidade de implementação de uma decisão adjudicatória. Assim, a escolha de recorrer ao Sistema de Solução de Controvérsias - ainda que possa por um lado ser interpretada como um ato de diplomacia - ${ }^{461}$ inaugura um procedimento governado pelo direito, e cuja decisão possui conteúdo jurídico determinável e deve ser cumprida.

Observa-se, nesse sentido, que a política externa brasileira erigiu como relevante pilar na área comercial a utilização do Sistema de Solução de Controvérsias da OMC, ${ }^{462}$ em respeito à sua tradição diplomática de privilégio do multilateralismo e de resolução pacífica de seus litígios, e em adequado cumprimento do comando principiológico insculpido na Constituição. ${ }^{463}$

Ademais, nessa linha de observação, a atuação como demandante no Sistema de Solução de Controvérsias não tem sido guiada, sob a perspectiva brasileira, pela utilização da instauração de procedimentos como arma política ou instrumento de retaliação, ${ }^{464} \mathrm{e}$ nem tem sido contida pelo temor em ser também demandado por motivo de sua intensa participação. ${ }^{465}$

461 Este é o entendimento de Carlos Cozendey: "O recurso ao sistema não deixa, porém, jamais de ser um ato político e de ser entendido como tal. É, portanto, decisão que precisa ser tomada tendo em mente o contexto global do relacionamento bilateral, o tema de que se trate, e a conjuntura multilateral. $\dot{E}$, mais do que um ato jurídico, um pleno ato de diplomacia." COZENDEY, Carlos Márcio Bicalho. O Sistema de Solução de Controvérsias da OMC: para além dos contenciosos, a política externa. Disponível em: $<\mathrm{http}$ //www.itamaraty.gov.br/temas/temas-multilaterais/copy_of_desenvolvimento-comercio-e-

financas/organizacao-mundial-do-comercio/solucao-de-controversias/cgc/artigo-cozendey> Acesso em: 15 dez. 2013. p. 2.

462 COZENDEY, Carlos Márcio Bicalho. O Sistema de Solução de Controvérsias da OMC: para além dos contenciosos, a política externa. Disponível em: <http://www.itamaraty.gov.br/temas/temasmultilaterais/copy_of_desenvolvimento-comercio-e-financas/organizacao-mundial-do-comercio/solucao-decontroversias/cgc/artigo-cozendey> Acesso em: 15 dez. 2013.

463 LAFER, Celso. A Constituição de 1998 e as Relações Internacionais. In: TORRES, Heleno Taveira (Org). Direito e Poder nas Instituições e nos Valores do Público e do Privado Contemporâneos. Estudos em Homenagem a Nelson Saldanha. Barueri: Manole, 2005, p. 215-232.

464 Não é exatamente esta a análise do caso das aeronaves entre Brasil e Canadá. Houve, naquele contexto, um complexo substrato fático-normativo que demandava uma apreciação em conjunto dos casos imbrincados. Isto é, a intenção do Brasil ao iniciar o procedimento se ligava ao intuito de demonstrar que as práticas por ele adotadas eram correlatas às do governo canadense, e não como um instrumento de "retaliação". Para mais detalhes, Cf: SERRADOR NETO, José. O contencioso comercial EmbraerBombardier. In: BENJAMIN, Daniela Arruda. (Org). O Sistema de Solução de Controvérsias da OMC: uma perspectiva brasileira. Brasília : FUNAG, 2013, p. 281-312.

465 Segundo explana Carlos Cozendei: "Não há preocupação de que uma atuação muito ativa no marco do sistema pudesse atrair processos contra o país com o objetivo de baixar-lhe o perfil, o que, de resto, não se coaduna com as características normais do sistema, fortemente pragmático e centrado em casos em que o interesse comercial concreto é a motivação principal." COZENDEY, Carlos Márcio Bicalho. O Sistema de Solução de Controvérsias da OMC: para além dos contenciosos, a política externa. Disponível em: $<\mathrm{http}: / /$ www.itamaraty.gov.br/temas/temas-multilaterais/copy_of_desenvolvimento-comercio-e-

financas/organizacao-mundial-do-comercio/solucao-de-controversias/cgc/artigo-cozendey> Acesso em: 15 
Como demandado, diante da experiência dos primeiros casos, o Brasil implementou um processo de desenvolvimento técnico especializado do corpo de agentes envolvidos da preparação e vocalização de suas defesas no Sistema de Solução de Controvérsias. Ademais, a intensificação da cooperação interinstitucional e interministerial, bem como da articulação com os setores nacionais envolvidos nos respectivos litígios, tem sido elemento relevante para a atuação do Brasil nos casos em que é demandado.

Promoveu-se, portanto, uma sofisticação dos recursos disponíveis para a atuação brasileira no Sistema de Solução de Controvérsias, em resposta à notória complexidade dos temas objeto das controvérsias. A estrutura de participação do Brasil no Sistema de Solução de Controvérsias da OMC envolve três pilares: (i) a Coordenação Geral de Contenciosos do MRE; ${ }^{466}$ (ii) a Delegação do Brasil em Genebra; e (iii) escritório de advocacia privado - contratado quando há necessidade. ${ }^{467}$ Soma-se a este tripé a participação do setor privado organizado, que recentemente tem incrementado a sua contribuição para auxiliar as posições brasileiras nesse sistema. ${ }^{468} 469$

Como terceira parte, a atuação brasileira se dá em face do aspecto sistêmico, isto é, tendo em vista potenciais efeitos de uma decisão e da construção de precedentes ${ }^{470} \mathrm{em}$ áreas que lhe são estratégicas, o Brasil tem buscado integrar as discussões e acompanhar de perto as interpretações desenvolvidas pelo Sistema de Solução de Controvérsias.

dez. 2013. p. 12 .

466 Criado apenas em 10 out. 2001, como se comentará adiante.

467 Na maior parte dos casos, esta contratação é financiada pela associação do setor interessado na instauração da medida. Para uma lista completa dos respectivos escritórios contratados para os casos nos quais o Brasil atuou, e das instituições que financiaram tal contratação, Cf: Para uma lista detalhada SHAFFER, Gregory; RATTON SANCHEZ, Michelle; ROSENBERG, Barbara. The Trials of Winning at the WTO: What Lies Behind Brazil's Success. Cornell International Law Journal, vol. 41, issue 2, p. 383-501, 2008. p. 490-500.

468 Para uma análise da participação do setor privado no Sistema de Solução de Controvérsias, sua evolução e atual configuração, Cf: MESQUITA, Paulo Estivallet de. O papel central do setor privado na atuação do Brasil no Sistema de Solução de Controvérsias da OMC. In: BENJAMIN, Daniela Arruda. (Org). O Sistema de Solução de Controvérsias da OMC: uma perspectiva brasileira. Brasília : FUNAG, 2013, p. 251-264.

469 PEREIRA, Celso de Tarso, COSTA, Valéria Mendes; ARAÚJO, Leandro Rocha de. 100 Casos na OMC: a experiência brasileira em solução de controvérsias. Política Externa, vol. 20, n. 4, p. 121-134, mar/abr/maio 2012. p. 129.

470 Há certa discussão doutrinaria acerca da noção de precedente no Sistema de Solução de Controvérsias da OMC. Embora a literalidade dos dispositivos do Entendimento afaste a aplicação do princípio do stare decisis neste sistema, é geral a percepção de que na prática os relatórios tendem a seguir as interpretações anteriormente formuladas. Acerca deste debate, das vantagens de um reconhecimento formal do precedente vinculante, e das formas pelas quais este reconhecimento pode se dar, Cf: BAHALA, Raj. The Power Of The Past: Towards de Jure Stare Decisis In WTO Adjudication (Part Three of a Trilogy). George Washington International Law Review, vol. 33, p. 873-978, 2000-2001. 
Em relação à perspectiva sistêmica, a atuação brasileira tem se dado no sentido da defesa do respeito às regras multilaterais, e de incremento da legitimidade do sistema multilateral de comércio como um instrumento jurídico de operacionalização do império do direito nas relações comerciais internacionais.

Assim, para além dos interesses comerciais concretos e seus potenciais impactos econômicos - que de fato são relevantes e tem sido essenciais na escolha de rumos para a atuação brasileira no Sistema de Solução de Controvérsias da OMC -, o cumprimento das decisões desse sistema, e portanto a análise de sua implementação, é aspecto crucial para o Brasil sob diferentes enfoques que serão adiante melhor explicitados.

A promoção do cumprimento das decisões adjudicatórias deste sistema e o fortalecimento do Direito Internacional nesta seara, historicamente marcada pelo protagonismo da política e pelas assimetrias de poder, se inserem na tradição da diplomacia brasileira, ${ }^{471}$ se adequam aos comandos constitucionais, e contribuem para a previsibilidade, segurança jurídica e justiça no comércio internacional.

\subsection{Comentários sobre o Recorte Adotado na Análise}

Com o intuito de aplicar a estratégia metodológica de estudo de caso para analisar os mecanismos nacionais de implementação das decisões do Sistema de Solução de Controvérsias da OMC, faz-se necessário primeiramente explicitar claramente os parâmetros e justificar os motivos determinantes para a escolha dos casos a serem examinados nesta abordagem.

Assim, uma vez que o estudo de caso ${ }^{472} 473$ se apresenta como estratégia mais adequada ${ }^{474}$ para a análise do universo das disputas em que houve a necessidade de

471 CORDEIRO, Enio. Considerações finais. In: BENJAMIN, Daniela Arruda. (Org). O Sistema de Solução de Controvérsias da OMC: uma perspectiva brasileira. Brasília: FUNAG, 2013, p.731-734. p. 733. 472 Embora haja diversidade de sentidos para o "estudo de caso", relevante destacar a concepção de Robert Yin: "Um estudo de caso é uma investigação empírica que investiga um fenômeno contemporâneo dentro de seu contexto da vida real, especialmente quando os limites entre o fenômeno e o contexto não estão 
implementação da decisão, é necessário um recorte intencional na totalidade destes casos, e a definição de critérios de filtragem dos aspectos evidenciados pela investigação aproximada dos casos. Tratando-se, pois, de estudo de caso de caráter exploratório, a análise empírica empreendida objetiva evidenciar a diversidade dos mecanismos e variáveis nacionais de implementação, com enfoque na realidade brasileira de atuação nesse sistema.

A participação do Brasil nos procedimentos é, pois, o primeiro grande recorte, que resulta na delimitação do universo de casos que serão objeto de análises preliminares, com objetivo de uma posterior seleção para a aplicação da estratégia metodológica de escolha de casos. Assim, a escolha dos casos a serem, em um segundo momento, examinados em profundidade, não se dá de modo aleatório, mas sim pela metodologia de escolha de casos diversos. $^{475}$

Acerca deste primeiro recorte, destacamos que a delimitação leva em conta não apenas os casos em que o Brasil foi a parte demandada, a quem incumbia a implementação, mas inclusive os casos em que o Brasil foi demandante e, ainda, aqueles em que o Brasil atuou como terceira parte.

Embora o enfoque primário seja de fato a análise da implementação pelo Brasil, o exame de casos em que o Brasil atuou como demandante e como terceira parte, nos quais houve necessidade de implementação pelo membro demandado, pode explicitar variáveis e mecanismos que também são pertinentes ao Brasil, enquanto detentor de interesses diretos ou sistêmicos nas respectivas áreas e medidas.

claramente definidos." YIN, Robert. Estudo de Caso. Planejamento e métodos. Porto Alegre: Bookman, 2001. p. 32.

473 Em abordagem um pouco mais restrita: “ [...] the intensive (qualitative or quantitative) analysis of a single unit or a small number of units (the cases), where the researcher's goal is to understand a larger class of similar units (a population of cases)." SEAWRIGHT, Jason.; GERRING, John. Case Selection Techniques in Case Study Research: A Menu of Qualitative and Quantitative. Political Research Quarterly, vol. 61, n. 2, p. 294-308, jun. 2008. p. 296.

474 A adequabilidade se abstrai da subsunção das características da implementação das decisões do Sistema de Solução de Controvérsias da OMC à posição de Robert Yin: "A investigação de estudo de caso enfrenta uma situação tecnicamente única em que haverá muito mais variáveis de interesse do que pontos de dados, e, como resultado, baseia-se em várias fontes de evidências, com os dados precisando convergir em um formato de triângulo, e, como outro resultado, beneficia-se do desenvolvimento prévio de proposições teóricas para conduzir a coleta e a análise de dados." YIN, Robert. Estudo de Caso. Planejamento e métodos. Porto Alegre: Bookman, 2001. p. 32- 33.

475 Os autores classificam entre sete metodologias de escolhas de casos para o estudo de casos: (i) típica, (ii) diversa, (iii) extrema, (iv) desviante, (v) influencial, (vi) mais similar, (vii) mais diferente. SEAWRIGHT, Jason.; GERRING, John. Case Selection Techniques in Case Study Research: A Menu of Qualitative and Quantitative. Political Research Quarterly, vol. 61, n. 2, p. 294-308, jun. 2008. 
Assim, a inclusão dos casos em que o Brasil atuou como demandado no universo da pesquisa é de motivação cristalina, uma vez que é a partir de sua verificação empírica que se busca evidenciar mecanismos nacionais utilizados em sua efetivação, a partir dos quais delinearemos análises que auxiliaram na proposta de um modelo, como expresso no capítulo 5 .

Com o intuito de respeito e preservação do sistema, é necessário que se traga à discussão não apenas os mecanismos para implementação nos casos em que o Brasil se logrou vitorioso, mas também dos casos em que o Brasil precise implementar as respectivas decisões. Isso pois é interesse último do Brasil o respeito jurídico às disciplinas da OMC, e a consolidação das regras do sistema multilateral de comércio. ${ }^{476}$

Por sua vez, a inclusão dos casos em que o Brasil atuou como demandante no universo da pesquisa se justifica pelo interesse na análise de implementação quando o cumprimento deve se dar por outro membro demandante, por violações reconhecidas em face do Brasil. Nestes casos o interesse brasileiro é direto e, uma vez reconhecido por uma decisão do Sistema de Solução de Controvérsias da OMC, inicia-se o desafio de garantir que a respectiva vitória se reverta em benefícios concretos.

Por fim, a inclusão dos casos em que o Brasil atuou como terceira parte se justifica pela relevância dos respectivos temas e medidas sob a perspectiva sistêmica, e suas possíveis implicações normativas e jurisprudenciais, que podem afetar diretamente os interesses brasileiros. Assim é que, em médio e em longo prazo, a função interpretativa dos painéis e a implementação das decisões como indicador do incremento de legitimidade do Sistema de Solução de Controvérsias da OMC importam diretamente ao Brasil e repercutem em seus interesses comerciais. ${ }^{477} 478$

476 MACHADO, Luiz Alberto Figueiredo. Apresentação. In: BENJAMIN, Daniela Arruda. (Org). O Sistema de Solução de Controvérsias da OMC : uma perspectiva brasileira. Brasília: FUNAG, 2013.

477 Sobre a relevância da análise também da participação brasileira como terceira parte nos procedimentos: "A relevância do Mecanismo de Solução de Controvérsias não se limita aos casos em que o Brasil atua como parte, seja reclamante ou reclamada. A função desempenhada pelos painéis e pelo Órgão de Apelação na interpretação dos Acordos representa, possivelmente, a atividade com maior repercussão sobre os interesses comerciais brasileiros no médio e longo prazo. Como determinado pelo Entendimento sobre Solução de Controvérsias, uma das funções do Sistema é esclarecer o conteúdo e oferecer previsibilidade à aplicação das disciplinas multilaterais de comércio. Muito embora as decisões do Órgão de Apelação não sejam marcadas pelo stare decisis, a jurisprudência dele emanada desempenha, na prática, papel determinante nas decisões futuras dos painéis e do próprio Órgão de Apelação." AZEVEDO, Roberto Carvalho de. Prefácio. In: BENJAMIN, Daniela Arruda. (Org). O Sistema de Solução de Controvérsias da OMC : uma perspectiva brasileira. Brasília : FUNAG, 2013, p. 23-30. p. 26.

478 Em um sentido correlato expressam os diplomatas: “[...] a participação expressiva como terceira 
Uma vez explicitadas as razões pelas quais, da totalidade dos casos do sistema, optou-se pela redução do universo da pesquisa aos casos que tiveram participação do Brasil, como demandado, demandante e como terceira parte, nos compete explicitar as classificações e os "filtros" metodológicos utilizados neste universo de casos, com fins de realizar uma escolha intencional daqueles a serem examinados pelo estudo de casos.

Na análise de Celso de Tarso Pereira, Valéria Mendes Costa e Leandro Rocha DE ARAúJo, diplomatas da Coordenação Geral de Contenciosos do MRE, a participação do Brasil pode ser classificada como buscando questionar medidas relativas às seguintes disciplinas:

\begin{abstract}
A maioria dos casos em que o Brasil participou, como parte ou terceira parte, envolveu questionamentos sobre a legalidade da aplicação por parceiros comerciais do Brasil de: (i) subsídios (agrícolas e não agrícolas); (ii) medidas antidumping; (iii)medidas sanitárias e fitossanitárias; (iv) barreiras técnicas; e (v) medidas relacionadas a propriedade intelectual. ${ }^{479}$
\end{abstract}

Abstraímos dessa análise os principais interesses de cumprimento e efetivação das decisões do Sistema de Solução de Controvérsias da OMC pelo Brasil. Assim, tomamos referida classificação como uma lente do espectro de interesses principais do Brasil nesse sistema, núcleos normativos centrais dentre as regras multilaterais.

Assim, opta-se pela escolha de casos intencionalmente diferentes, em relação ao Acordo, às medidas e ao membro responsável pela implementação, no intuito de que tais casos evidenciem diversos aspectos e experiências de implementação.

Em especial, buscou-se privilegiar a escolha dos casos nos quais houve recurso à arbitragem do artigo 21.3. (c) do ESC para determinação do "período de tempo razoável" para a implementação. Isso pois referida fase do procedimento denota oportunidade de apresentação e detalhamento pelas partes que devem implementar sobre as medidas de

parte reflete a intenção brasileira de estar a par dos grandes temas em disputa entre os Membros da OMC e de influenciar, na medida do possível, a formação de jurisprudência consistente com as regras multilaterais.” PEREIRA, Celso de Tarso, COSTA, Valéria Mendes; ARAÚJO, Leandro Rocha de. 100 Casos na OMC: a experiência brasileira em solução de controvérsias. Política Externa, vol. 20, n. 4, p. 121134, mar/abr/maio 2012. p. 122.

479 PEREIRA, Celso de Tarso, COSTA, Valéria Mendes; ARAÚJO, Leandro Rocha de. 100 Casos na OMC: a experiência brasileira em solução de controvérsias. Política Externa, vol. 20, n. 4, p. 121-134, mar/abr/maio 2012. p. 122. 
implementação, no intuito de convencimento do árbitro, constituindo material para investigação dos diferentes mecanismos de implementação, bem como comparação entre os mecanismos planejados e aqueles efetivamente utilizados.

\subsection{A Implementação das Decisões do Sistema de Solução de Controvérsias pelo Brasil}

A temática da implementação das decisões do Sistema de Solução de Controvérsias da OMC, e dos mecanismos a serem orquestrados pelos agentes de diferentes esferas de poder, assume relevância central, tendo em vista o respeito do Brasil ao Direito Internacional em sentido amplo, e sua tradição diplomática de busca pelo império do direito nas relações internacionais. ${ }^{480}$

Ademais, o apreço pela solução pacífica dos litígios entre os Estados, traço marcante do posicionamento brasileiro ao longo dos séculos, traz o "encargo" do cumprimento, quando é ao Brasil que se coloca a decisão de uma instância adjudicatória, cabendo-lhe implementar a solução determinada. Se sob a perspectiva dos interesses diretos dos setores envolvidos a implementação pode criar algum "desconforto", em uma análise holística é de interesse último do Brasil que a efetivação da decisão tenha lugar, como um instrumento de fortalecimento da solução pacífica dos litígios que tanto tem buscado.

Adiciona-se o fato de o Brasil ser, desde 2009, signatário da Convenção de Viena sobre o Direito dos Tratados, que como já delineamos em tópico anterior, enrobustece a

480 A este respeito, breve comentário de Paulo Roberto de Almeida: "Não parece haver duvidas que a diplomacia brasileira dispõe, historicamente, de ideias, ou de um pensamento, a sustentar-lhe as ações. Uma adesão inquestionável ao direito internacional, o não recurso à força para a resolução de disputas entre Estados, o respeito à não ingerência e à não intervenção nos assuntos internos de outros países, a observância dos direitos humanos e de um conjunto de valores próprios ao nosso patrimônio civilizatório, são todos elementos constitutivos da ação diplomática brasileira, ainda que não se possa dizer que eles sejam exclusivamente ou essencialmente brasileiros, na forma e mesmo no conteúdo." ALMEIDA, Paulo Roberto de. Pensamento diplomático brasileiro: Introdução metodológica às ideias e ações de alguns dos seus representantes. In: PIMENTEL, José Vicente de Sá (org). Pensamento diplomático brasileiro: formuladores e agentes da política externa (1750-1950). Brasília: FUNAG, 2013. Vol. I, p. 15-40. p. 15. 
obrigação jurídica internacional de cumprimento. Isto pois o Sistema de Solução de Controvérsias da OMC foi criado por meio de tratado internacional, e como tal um eventual desrespeito a este sistema implica em uma violação a obrigação convencional erigida pelo ESC, anexo do Acordo Constitutivo da OMC.

Cumpre ainda destacar que a relevância da análise da implementação das decisões do Sistema de Solução de Controvérsias da OMC se apresenta cristalina, em face de elementos constitucionais basilares como a caracterização de nosso ordenamento jurídico enquanto "Estado democrático de direito", e em vista da elaboração de políticas públicas. 481

Inegavelmente, a concretização das decisões internacionais envolve diversas complexidades em nosso ordenamento, de esferas múltiplas como a normativa, a prática e a institucional. Adicione-se a estas já existentes complexidades, as singularidades da decisão do Sistema de Solução de Controvérsias da OMC, e observamos se tratar de um objeto delicado de investigação, conforme será melhor detalhado no capítulo 5.

\subsubsection{Análise Preliminar e Definição dos Casos a Serem Examinados}

A tabela constante do Apêndice A faz o cruzamento entre a classificação dos casos segundo critérios do objeto temático da controvérsias e a fase até a qual o procedimento avançou ou a fase em que o caso se encontra dentre os possíveis passos de um procedimento na solução de litígios do Sistema de Solução de Controvérsias da OMC.

Desse cruzamento, abstraímos que apenas dois casos se inserem na área destacada, que evidencia o foco desta pesquisa, pois seleciona os casos que efetivamente chegaram até a fase de implementação da decisão do Sistema de Solução de Controvérsias da OMC. 482 Para uma descrição preliminar desses casos analisados, com a explicitação das

481 AZEVEDO, Roberto Carvalho de. Prefácio. In: BENJAMIN, Daniela Arruda. (Org). O Sistema de Solução de Controvérsias da OMC : uma perspectiva brasileira. Brasília : FUNAG, 2013, p. 23-30.

482 Exclui-se do escopo desta análise os casos nos quais não houve implementação, e que se encontram 
informações essenciais do respectivo caso, bem como dos dispositivos multilaterais alegados pelas partes, remete-se ao Apêndice B.

Dentre os 15 procedimentos nos quais o Brasil foi demandado, 10 deles se estagnaram na fase se consultas. ${ }^{483}$ São eles os procedimentos DS30, DS51, DS52, DS65, DS81, DS116, DS183, DS197, DS229 e DS472. O procedimento DS199, por sua vez, findou-se por desistência/ solução mutuamente acordada durante o procedimento, e no caso DS355 a autoridade do painel caducou. ${ }^{484}$

Assim, dos 15 procedimentos, apenas 3 chegaram ao exame do painel e à emissão de relatório com suas conclusões. Dentre tais casos, pode-se interpretar que houve ganho de causa pelo Brasil no procedimento DS22, com o relatório adotado sem necessidade de conduta corretiva pelo Brasil, e nos procedimentos DS46 e DS332 ${ }^{485}$ houve a necessidade de adequação da medida brasileira questionada à disciplina multilateral. $\mathrm{O}$ foco de nossa análise se concentra, pois, nestes dois casos, que são analisados em seguida.

\subsubsection{Caso DS46: Brazil - Export Financing Programme for Aircraft}

na fase de retaliação autorizada.

483 Dentre esses constam os casos DS51, DS52 e DS65, o caso DS81, que segundo o autor: "[...] 4 casos relativos a uma mesma medida no setor automotivo foram resolvidos por negociação de quotas de importação isentas da medida." COZENDEY, Carlos Márcio Bicalho. O Sistema de Solução de Controvérsias da OMC: para além dos contenciosos, a política externa. Disponível em: $<$ http://www.itamaraty.gov.br/temas/temas-multilaterais/copy_of_desenvolvimento-comercio-e-

financas/organizacao-mundial-do-comercio/solucao-de-controversias/cgc/artigo-cozendey> Acesso em: 15 dez. 2013. p. 13.

484 Situação na qual a autoridade do painel caduca está prevista no Artigo 12. 12 do ESC: "O grupo especial poderá suspender seu trabalho a qualquer tempo a pedido da parte reclamante por periodo não superior a doze meses. Ocorrendo tal suspensão, os prazos fixados nos parágrafos 8 e deste Artigo, parágrafo 1 do Artigo 20, e parágrafo 4 do Artigo 21 deverão ser prorrogados pela mesma extensão de tempo em que forem suspensos os trabalhos. Se o trabalho do grupo especial tiver sido suspenso por mais de 12 meses, a autoridade para estabelecer o grupo especial caducará." Entendimento Relativo às Normas e Procedimentos sobre Solução de Controvérsias. Versão oficial em português segundo o decreto n. 1.355, de 30 dez. 1994, que promulga a Ata Final que Incorpora os Resultados da Rodada Uruguai de Negociações Comerciais Multilaterais do GATT.

485 É corrente a interpretação de que o caso DS332 foi um ganho parcial do Brasil, uma vez que o relatório não atacou a medida em sua necessidade e legitimidade, mas no modo como estava sendo aplicada. De toda forma, entendemos que ao demandar uma mudança na aplicação da medida, trata-se de uma exigência de implementação. p. 13. COZENDEY, Carlos Márcio Bicalho. O Sistema de Solução de Controvérsias da OMC: para além dos contenciosos, a política externa. Disponível em: $<$ http://www.itamaraty.gov.br/temas/temas-multilaterais/copy_of_desenvolvimento-comercio-efinancas/organizacao-mundial-do-comercio/solucao-de-controversias/cgc/artigo-cozendey> Acesso em: 15 dez. 2013. 
O caso DS46, formalmente denominado Brazil - Export Financing Programme for Aircraft, e conhecido informalmente como um dos casos da contenda EmbraerBombardier, teve como demandante o Canadá, e como terceiras partes a Austrália, a UE/CE, a República da Coreia e os EUA.

As consultas desta controvérsia se iniciaram em 19 de junho de 1996 e, em 16 de setembro de 1996, houve um pedido inicial do Canadá para o estabelecimento do painel, que foi posteriormente retirado antes da reunião do OSC. Em 10 de julho de 1998, o Canadá formulou novo pedido para estabelecimento do painel, que foi então estabelecido e iniciou os seus trabalhos. O relatório do painel foi divulgado em 14 de abril de 1999 e o relatório do Órgão de Apelação foi divulgado em 2 de agosto de 1999.

É pertinente destacar que em 10 de março de 1997 o Brasil havia iniciado os procedimentos DS70 e DS 71 contra o Canadá, ${ }^{486}$ que tinham como objeto a política de subsídios aplicada ao setor aeronáutico canadense, e em 10 de julho de 1998 requisitou a constituição de painel. Assim, o pedido de estabelecimento do painel pelo Canadá no procedimento DS46, que estava há dois anos na fase de consultas, foi uma resposta direta à divergência recíproca entre ambos os governos e à impossibilidade de acordo na fase de consultas. $^{487}$

A demanda questionava o Programa de Financiamento às Exportações, no subsídio por via do prévio pagamento da exportação de aviões regionais mediante a equalização da taxa de juros ("PROEX - Equalização"). Segundo o demandante, o programa violava os artigos 3.1(a), 27.4 e 27.5 do Acordo sobre Subsídios e Medidas Compensatórias (ASMC).

486 Para uma visão mais específica e sistemática da controvérsia em si, faz-se necessário analisar em conjunto a demanda DS70, no qual o Brasil obteve sucesso em demonstrar que o Canadá desenvolvia diversos programas de subsídios naquele setor em desconformidade com as regras multilaterais (Export Development Canada, Technology Partnerships Canada). Entendemos, contudo, que para os fins da pesquisa proposta é mais pertinente a análise do caso em separado, focada nas medidas de implementação da decisão. 487 Relevante o relato dos autores, diplomatas, acerca deste período de consultas: "Na verdade, foram os dois anos que passaram entre o primeiro pedido canadense até o estabelecimento do painel, em 1998 utilizados em consultas informais e tentativas de mediação, que permitiram ao Brasil organizar-se e obter os dados necessários para questionar esquemas de subsídios canadenses semelhantes aos que lhe eram imputados." PEREIRA, Celso de Tarso, COSTA, Valéria Mendes; ARAÚJO, Leandro Rocha de. 100 Casos na OMC: a experiência brasileira em solução de controvérsias. Política Externa, vol. 20, n. 4, p. 121-134, mar/abr/maio 2012. p. 124. 
Em sua defesa, o Brasil reconheceu que o mecanismo de equalização da taxa de juros PROEX era um subsídio, mas o classificava como um subsídio permitido sob a chancela do item (k) do Anexo 1 daquele Acordo. O painel, contudo, concluiu que a medida brasileira era inconsistente com os artigos 3.1(a) e 27.4 do ASMC. ${ }^{488}$

Seguindo o procedimento específico do ASMC, explicitado no artigo 4.7, ${ }^{489}$ que prevê que o painel recomende ao membro que retire o subsídio "sem demora", o relatório do painel conclui com esta recomendação:

[...] Assim, tendo em conta a natureza das medidas e dos procedimentos que possam ser necessários para implementar a nossa recomendação, por um lado, e a exigência de que o Brasil retire seus subsídios "sem demora ", por outro, concluímos que o Brasil deve retirar os subsídios no prazo de 90 dias. ${ }^{490}$

Relevante destacar, contudo, que observando a prática do Sistema de Solução de Controvérsias da OMC, o painel absteve-se de adentrar nos passos que deveriam ser tomados pelo Brasil para a retirada da medida desconforme, deixando essa decisão a cargo do membro:

[...] Presumivelmente, espera-se que levemos em conta a natureza das medidas e as dificuldades que possam ser enfrentadas na implementação da recomendação ao especificar qual período representaria a retirada "sem demora" da medida em desconformidade. Notamos, no entanto, que não há experiência com relação a quais medidas poderiam constituir "retirada" dos subsídios em várias circunstâncias factuais, e não consideramos que se insira dentro do nosso mandato dizer ao Brasil que medidas são necessárias para implementar nossa recomendação. [...] 491

488 WTO. Panel Report, Brazil - Export Financing Programme For Aircraft. WT/DS46/R, 14 abr. 1999. para. 8.1 e 8.2 .

489 Acordo sobre Subsídios e Medidas Compensatórias. Versão oficial em português segundo o decreto n. 1.355, de 30 dez. 1994, que promulga a Ata Final que Incorpora os Resultados da Rodada Uruguai de Negociações Comerciais Multilaterais do GATT. "4.7. Se a medida em análise for considerada subsídio proibido, o grupo especial deverá recomendar ao Membro outorgante que a retire sem demora. A esse respeito, o grupo especial deverá especificar em sua recomendação o prazo em que a medida devera ser retirada."

490 Tradução livre do original em língua inglesa: “[...] Accordingly, taking into account the nature of the measures and the procedures which may be required to implement our recommendation, on the one hand, and the requirement that Brazil withdraw its subsidies "without delay" on the other, we conclude that Brazil shall withdraw the subsidies within 90 days." WTO. Panel Report, Brazil - Export Financing Programme For Aircraft. WT/DS46/R, 14 abr. 1999

491 Tradução livre do original em língua inglesa: “[...] Presumably, we are expected to take into account the nature of the measures and the difficulties likely to be faced in implementing the recommendation when 
Provocado pelo Brasil, o Órgão de Apelação apreciou o relatório do painel, confirmando suas conclusões, apenas modificando a interpretação do conceito de "vantagem material" do item (k) do Anexo 1. Assim, o Órgão de Apelação confirmou a recomendação do painel de que o Brasil revogasse o subsídio do PROEX no prazo de 90 dias. ${ }^{492}$ O relatório do Órgão de Apelação foi adotado pelo OSC em 20 de agosto de 1999, juntamente com o relatório do painel devidamente modificado pelo Órgão de Apelação.

Em 13 de setembro de 1999, a Missão Permanente do Brasil informou ao OSC, em cumprimento ao artigo 4.9 do Acordo de Subsídios, sobre sua intenção de cumprir a recomendação daquele órgão. ${ }^{493}$ Em 19 de novembro de 1999, a Missão Permanente do Brasil anunciou formalmente que seu governo havia "implementado efetivamente" a recomendação do OSC, retirando a medida desconforme dentro do prazo de 90 dias. ${ }^{494}$

Neste comunicado o Brasil cita como medidas de implementação, tendo em vista a medida provisória 1892-32, datada de 22 de outubro de 1999, que à época mantinha o PROEX:

(ii) a Resolução do Conselho Monetário Nacional 2667, de 19 de novembro de 1999, alterando a Resolução anterior de n. 2576, datada de 17 de dezembro de 1998, que estabelece os critérios aplicáveis à equalização de taxas de juros do PROEX;

(iii) uma Carta Circular do Banco Central, que estabelece um novo percentual máximo de equalização e revoga a Carta Circular n. 2843, datada de 25 de março de 1999.

Com tais medidas, o Brasil teria realizado modificações na configuração original do Programa, que por isso passou a ser denominado de PROEX II.

O Canadá, contudo, entendendo que o Brasil não havia cumprido integralmente a decisão do OSC - no que dizia respeito aos subsídios relativos a aeronaves a serem

specifying what period would represent withdrawal "without delay". We note, however, that there is no experience with respect to what steps could constitute "withdrawal" of the subsidies in various factual circumstances, and we do not consider that it is within our mandate to tell Brazil what steps are required in order to implement our recommendation. [...]" WTO. Panel Report, Brazil - Export Financing Programme For Aircraft. WT/DS46/R, 14 abr. 1999. para. 8.5.

492 WTO. Appellate Body Report, Brazil - Export Financing Programme For Aircraft. WT/DS46/AB/R, 02 ago. 1999.

493 WTO. Communication from Brazil, Brazil - Export Financing Programme For Aircraft. WT/DS46/11, 16 set. 1999.

494 WTO. Communication from Brazil, Brazil - Export Financing Programme For Aircraft. WT/DS46/12, 24 nov. 1999. 
entregues após 18 de novembro de 1999, resultantes de contratos de datas anteriores a 18 de novembro de 1999 - requisitou em 23 de novembro de 1999 o estabelecimento de procedimento para a verificação de cumprimento, sob a égide do artigo 21.5 do ESC. ${ }^{495}$

Em sua reunião de 9 de dezembro de 1999, o OSC decidiu remeter a questão ao painel original, ${ }^{496}$ que exarou seu relatório em 9 de maio de 2000 . O painel concluiu que o Brasil não havia cumprido com as obrigações oriundas da decisão do OSC, uma vez que suas medidas para a implementação das recomendações e decisões do OSC eram inexistentes ou inconsistentes com o ASMC. ${ }^{497}$

O Brasil apelou desta interpretação e, ${ }^{498}$ em seu relatório de 21 de julho de 2000, o Órgão de Apelação confirmou as conclusões do painel de verificação de cumprimento, segundo as quais o Brasil havia falhado na implementação das recomendações, em função de subsídio concedido a aeronaves após 18 de novembro de 1999, relativas a cartas de compromisso emitidas antes de 18 de novembro de $1999 .{ }^{499}$

O relatório do Órgão de Apelação foi adotado pelo OSC em 4 de agosto de 2000, juntamente com o relatório do painel de verificação de cumprimento, devidamente modificado pelo Órgão de Apelação. 500

Paralelamente à apelação pelo Brasil do relatório do painel de verificação, com base neste relatório o demandante requereu, em 10 de maio de 2000, autorização para aplicar medidas compensatórias no valor de 700 milhões de dólares canadenses por ano, com fulcro no artigo 4.10 do ASMC e no artigo 22.2 do ESC. ${ }^{501} \mathrm{O}$ Brasil rejeitou a suspensão de direitos proposta pelo Canadá, e requisitou o estabelecimento de arbitragem

495 WTO. Recourse by Canada to Article 21.5 of the DSU, Brazil - Export Financing Programme For Aircraft. WT/DS46/13, 26 nov. 1999.

496 WTO. Note by the Secretariat, Brazil - Export Financing Programme For Aircraft. WT/DS46/14, 17 dez. 1999.

497 WTO. Panel Report, Brazil - Export Financing Programme For Aircraft (Recourse By Canada to Article 21.5 of The DSU). WT/DS46/RW, 09 mai. 2000. para. 7.1.

498 WTO. Notification of an Appeal by Brazil under paragraph 8 of Article 4 of the Agreement on Subsidies and Countervailing Measures and paragraph 4 of Article 16 of the Understanding on Rules and Procedures Governing the Settlement of Disputes, Brazil - Export Financing Programme For Aircraft (Recourse By Canada to Article 21.5 of The DSU). WT/DS46/17, 22 mai. 2000.

499 WTO. Relatório do Órgão de Apelação, Brazil - Export Financing Programme For Aircraft (Recourse By Canada to Article 21.5 of The DSU). WT/DS46/AB/RW, 21 de junho de 2000. para. 82.

500 WTO. Action by the Dispute Settlement Body, Brazil - Export Financing Programme For Aircraft (Appellate Body Report and Panel Report pursuant to Article 21.5 of the DSU). WT/DS46/24, 14 ago. 2000. 501 WTO. Brazil - Export Financing Programme for Aircraft. (Recourse by Canada to Article 4.10 of the SCM Agreement and 22.2 of the DSU). WT/DS46/16, 11 mai. 2000. 
com fulcro no artigo 22.6 do ESC e no artigo 4.11 do Acordo de Subsídios, para definição da aplicação da medida. ${ }^{502}$

Como o pedido foi realizado na pendência do relatório do Órgão de Apelação, ficou determinado que nenhuma medida seria aplicada antes da deliberação do Órgão de Apelação e da arbitragem convocada a este propósito, realizada pelo painel original. ${ }^{503}$

A decisão da arbitragem, divulgada em 28 de agosto de 2000, fixava as contramedidas apropriadas em 344.2 milhões de dólares canadenses por ano. ${ }^{504}$ Assim, na reunião de 12 de dezembro de 2000, o Canadá obteve autorização para suspender concessões tarifárias ou outras obrigações originárias do GATT, do Acordo de Têxteis e do Acordo sobre Procedimentos para o Licenciamento de Importações, no limite máximo fixado pela arbitragem. ${ }^{505}$

Naquela mesma reunião, o Brasil informou que havia lançado o novo PROEX III, modificando o mecanismo de equalização de taxas de juros do Programa de Financiamento às Exportações, e que, portanto, estaria em conformidade com o ASMC e com as decisões do OSC naquela controvérsia. A nova revisão do elemento de equalização do programa, configurando-o como PROEX III, foi realizada por meio de nova resolução do Banco Central, a saber a Resolução 2799, de 6 de dezembro de 2000. ${ }^{506}$

Houve, contudo, novo desacordo sobre o cumprimento da decisão do OSC por meio da alteração da medida, uma vez que o demandante entendia que o programa continuava em desacordo com a normativa da OMC na temática de subsídios. O Canadá requereu, em 19 de janeiro de 2001, um segundo procedimento de verificação de cumprimento, ${ }^{507}$ e a questão foi submetida ao painel original. ${ }^{508}$

502 WTO. Request by Brazil for Arbitration under Article 22.6 of the DSU and Article 4.11 of the SCM Agreement, Brazil - Export Financing Programme for Aircraft. WT/DS46/18, 9 jun. 2000.

503 A doutrina denomina esta situação de "sequencing issue". Embora o ESC estabeleça uma "ordem de preferência", na prática em diversos casos o pedido de autorização para suspender concessões é realizado simultaneamente com o pedido de estabelecimento de um painel para averiguar a implementação. Cf: MATSUSHITA, Mitsuo; MAVROIDIS, Petros C.; SCHOENBAUM, Thomas J. The World Trade Organization: Law, Practice, and Policy. 2a Ed. Oxford: Oxford University Press, 2006. p. 161-163. 504 WTO. Decision By The Arbitrators, Brazil - Export Financing Programme For Aircraft (Recourse To Arbitration By Brazil Under Article 22.6 Of The DSU and Article 4.11 Of The SCM Agreement). WT/DS46/ARB, 28 ago. 2000.

505 WTO. Brazil - Export Financing Programme For Aircraft (Second Recourse by Canada to Article 21.5 of the DSU). WT/DS46/26, 22 jan. 2001.

506 WTO. Brazil - Export Financing Programme For Aircraft (Second Recourse by Canada to Article 21.5 of the DSU). WT/DS46/26, 22 jan. 2001. para. 2.3-2.10.

507 WTO. Brazil - Export Financing Programme For Aircraft (Second Recourse by Canada to Article 
Em 26 de julho de 2001, o painel emitiu relatório sobre o segundo recurso do Canadá para verificação de cumprimento, afirmando que o PROEX III estava em conformidade com a normativa multilateral, e concluindo, portanto, pelo cumprimento por parte do demandado. ${ }^{509}$ O Relatório foi aprovado na reunião de 23 de agosto de 2001 do OSC. ${ }^{510}$

\subsubsection{Caso DS332: Brazil - Measures Affecting Imports of Retreaded Tyres}

O substrato fático-jurídico da controvérsia DS332, Brazil - Measures Affecting Imports of Retreaded Tyres, tem como ponto central o Laudo VI do Tribunal Arbitral Ad Hoc do MERCOSUL, que criava para o Brasil a obrigação de aceitar a importação de pneus reformados oriundos dos Estados membros do MERCOSUL, em exceção à regra geral de proibição de importação. ${ }^{511}$

Em resumo, naquele caso o Uruguai questionava a Portaria SECEX 08/2000, ${ }^{512}$ que proibia a concessão de licenças de importações de pneus recauchutados e usados, ${ }^{513}$

21.5 of the DSU). WT/DS46/26, 22 jan. 2001.

508 WTO. Constitution of the Panel, Note by the Secretariat, Brazil-Export Financing Programme For Aircraft (Second Recourse by Canada to Article 21.5 of the DSU). WT/DS46/27, 22 fev. 2001.

509 WTO. Report of the Panel, Brazil - Export Financing Programme For Aircraft (Second Recourse by Canada to Article 21.5 of the DSU). WT/DS46/RW2, 26 jul. 2001.

510 WTO. Panel Report Pursuant to Article 21.5 of the DSU - Action by the Dispute Settlement Body, Brazil - Export Financing Programme For Aircraft. WT/DS46/29, 28 ago. 2001.

511 Para maiores informações sobre o substrato fático do caso, e as argumentação do Brasil nas diversas fases, Cf: MAREGA, Flávio. O contencioso sobre pneus reformados na OMC: uma importante vitória multilateral do Brasil. In: BENJAMIN, Daniela Arruda. (Org). O Sistema de Solução de Controvérsias da OMC: uma perspectiva brasileira. Brasília : FUNAG, 2013, pp. 155-184.

512 Secretaria de Comércio Exterior do Ministério do Desenvolvimento, Indústria e Comércio. Portaria n. 8/2000, de 8 fev. 2000. Altera os limites quantitativos estabelecidos pela Portaria SECEX n 9/98 (importações brasileiras de confecções e respectivas categorias constantes do Anexo A da Portaria Interministerial MICT/MF $\mathrm{n}^{\circ}$ 7/97).

513 Embora as portarias precedentes limitassem a importação de pneus usados, afetavam somente os produtos classificados na sub-posição 4012.20 ("pneumáticos usados") da Nomenclatura Comum do MERCOSUL (NCM). Assim, a Portaria SECEX 08/2000 se refere aos produtos Classificados na posição 4012 ("pneumáticos recauchutados ou usados, de borracha; protetores, bandas de rodagem para pneumáticos e "flaps", de borracha"), abarcando também a sub-posição 4012.10 ("pneumáticos recauchutados") na Nomenclatura Comum do MERCOSUL (NCM). De acordo com o laudo do Tribunal Arbitral, a sub-posição 4012.10 refere-se tecnicamente aos pneus "reformados", que incluem os pneus "remoldados", objeto da controvérsia em questão, os pneus "recauchutados" e os pneus "recapados". 
entendendo que havia sido introduzida proibição nova, em descumprimento a dispositivos do Tratado de Assunção e da Decisão 22/2000 do Conselho do Mercado Comum que previam a não adoção de medidas restritivas ao comércio recíproco.

O Tribunal Arbitral Ad Hoc rejeitou as alegações brasileiras, reconhecendo a incompatibilidade da proibição com as normativas do Mercosul, e impelindo o país a promover a adaptação de sua legislação interna. ${ }^{514}$ Contudo, ao resultar numa obrigatoriedade ao Brasil de excepcionar os países membros do Mercosul da regra geral de proibição de importação, referido Laudo arbitral causou questionamentos na esfera multilateral acerca do tratamento discriminatório de tal medida.

Em face desta situação, o caso DS332 Brazil - Measures Affecting Imports of Retreaded Tyres, foi iniciado pela UE/CE do Sistema de Solução de Controvérsias da OMC, tendo como terceiras partes Argentina, Austrália, China, Cuba, Guatemala, Japão, República da Coreia, México, Paraguai, Taiwan (Taipei Chinês), Tailândia e Estados Unidos.

O procedimento foi instaurado em 20 de junho de 2005, quando foram requeridas pela UE/CE consultas em relação ao Brasil, ${ }^{515}$ embasadas no entendimento de que tais medidas afetavam desfavoravelmente as exportações comunitárias de pneus reformados. Após a fase de consultas, sem que se alcançasse uma solução mutuamente satisfatória, em 17 de novembro de 2005 foi requisitado o estabelecimento de um painel, ${ }^{516}$ que foi estabelecido em reunião do OSC de 20 de janeiro de 2006, ${ }^{517}$ e então iniciou os seus trabalhos.

Em termos gerais, a demanda se embasava na alegação de que o demandado agiu de maneira discriminatória, ao eliminar a proibição aos membros MERCOSUL, mas deixando de estender a vantagem garantida a produtos originários de outros países, em violação aos artigos I:1, III:4, XI:1, e XIII:1 do GATT 1994.

O Brasil se defendeu argumentando que a discriminação seria consistente com a disciplina multilateral, uma vez que se encaixava nas exceções às regras do GATT 1994

514 MERCOSUL. Tribunal Arbitral Ad Hoc. Laudo VI, 01/2002. 09 jan. 2002.

515 WTO. Request for Consultations by the European Communities, Brazil - Measures Affecting Imports Of Retreaded Tyres. WT/DS332/1, 23 jun. 2005.

516 WTO. Request for the Establishment of a Panel by the European Communities, Brazil - Measures Affecting Imports of Retreaded Tyres. WT/DS332/4, 18 nov. 2006.

517 WTO. Constitution of the Panel Established at the Request of the European Communities - Note by the Secretariat, Brazil - Measures Affecting Imports Of Retreaded Tyres. WT/DS332/5, 17 mar. 2006. 
previstas nos artigos XXIV e XX(b) do mesmo Acordo. O primeiro dispositivo era citado em menção à permissão de constituição de Acordos Regionais de Comércio, de natureza necessariamente discriminatória, uma vez que o MERCOSUL se caracterizaria como uma União Aduaneira formalmente instituída. O segundo artigo citado trata da permissão de imposição de medidas restritivas ao comércio, quando necessárias à proteção de valores outros, como a vida humana, animal, vegetal e o meio ambiente.

Em seu relatório, ${ }^{518}$ divulgado em 12 de junho de 2007, o painel interpretou que as medidas questionadas consubstanciavam proibição à importação de mercadorias, sendo $a$ priori incompatíveis com as normas do GATT 1994. O Brasil, contudo, no entendimento explicitado pelo painel, havia sido capaz de demonstrar a real existência de riscos à vida $\mathrm{e}$ à saúde humana e, desse modo, tal proibição de caracterizava como medida eficaz e necessária à redução de tais riscos, em respeito ao artigo XX caput e (b).

Entretanto, o painel adiciona um outro elemento à sua ponderação, antes de concluir a análise. Segundo seu raciocínio, embora as medidas tenham sido legítimas em sua finalidade, a concessão de decisões judiciais liminares por juízes nacionais, que permitiam a entrada de pneus oriundos de terceiros países, prejudicava o alcance do objetivo protetivo, tornando a aplicação das medidas discriminatória e injustificável, em violação do artigo XX caput.

Com a provocação da UE/CE, ${ }^{519}$ o Órgão de Apelação apreciou o relatório do painel, revertendo o entendimento sobre a conformidade das medidas adotadas em função do laudo arbitral do MERCOSUL com as regras do GATT 1994. Conforme explicitado no relatório do Órgão de Apelação, ${ }^{520}$ divulgado em 3 de dezembro de 2007, a aplicação discriminatória das medidas restritivas se dava não somente em razão da concessão das liminares por juízes nacionais, mas também por motivo da autorização da importação de pneus oriundos dos membros do bloco. ${ }^{521}$

\footnotetext{
518 WTO. Panel Report, Brazil - Measures Affecting Imports of Retreated Tyres. WT/DS332/R, 12 jul. 2007.

519 WTO. Notification of an Appeal by the European Communities, Brazil - Measures Affecting Imports of Retreated Tyres. WT/DS332/R, 4 jul. 2007.

520 WTO. Apellate Body Report, Brazil - Measures Affecting Imports of Retreated Tyres. $\mathrm{WT} / \mathrm{DS} 332 / \mathrm{AB} / \mathrm{R}, 3$ dez. 2007.

521 "In our view, the ruling issued by the MERCOSUR arbitral tribunal is not an acceptable rationale for the discrimination, because it bears no relationship to the legitimate objective pursued by the Import Ban that falls within the purview of Article $X X(b)$, and even goes against this objective, to however small a degree. Accordingly, we are of the view that the MERCOSUR exemption has resulted in the Import Ban being applied in a manner that constitutes arbitrary or unjustifiable discrimination. (...) Like the Panel, we
} 
O relatório do Órgão de Apelação foi adotado pelo OSC em reunião de 17 de dezembro de 2007, juntamente com o relatório do painel devidamente modificado pelo Órgão de Apelação. ${ }^{522} \mathrm{Na}$ reunião seguinte, de 15 de janeiro de 2008, o Brasil notificou aos membros de sua intenção de implementar as recomendações aprovadas pelo OSC naquela controvérsia, afirmando, contudo, que precisaria de um "período de tempo razoável" para proceder à implementação. ${ }^{523}$

Como não houve um acordo entre as partes sobre qual seria o período de tempo razoável para a implementação, conforme o artigo 21.3(c) do ESC, foi requisitada a realização de arbitragem para a determinação do período razoável de tempo. ${ }^{524} \mathrm{O}$ árbitro, Sr. Yasuhei Taniguchi, foi designado pelo Diretor Geral da OMC em 26 de junho de 2008. 525

O laudo da arbitragem, exarado em 29 de Agosto de 2008, é de relevante análise, vez que traz informações pertinentes sobre a implementação da medida naquele caso. Antes de adentrar em sua interpretação, o árbitro compila os principais argumentos explicitados pelas partes, no tocante à implementação, com vistas à determinação do prazo razoável de tempo.

O Brasil destacava que o artigo 21.3(c) deixava, ao próprio sistema jurídico do membro cuja implementação é necessária, a decisão do meio pelo qual tornar a medida compatível com a disciplina multilateral e que o período razoável de tempo poderia variar, tendo em vista o meio de implementação escolhido pelo membro. Embora reconheça que o período razoável de tempo deve ser "o menor período de tempo possível no sistema

believe that Brazil's decision to act in order to comply with the MERCOSUR ruling cannot be viewed as 'capricious'or 'random'. Acts implementing a decision of a judicial or quasi-judicial body-such as the MERCOSUR arbitral tribunal_can hardly be characterized as a decision that is "apricious"or "andom." However, discrimination can result from a rational decision or behaviour, and still be ärbitrary or unjustifiable," because it is explained by a rationale that bears no relationship to the objective of a measure provisionally justified under one of the paragraphs of Article XX, or goes against that objective." WTO. Apellate Body Report, Brazil - Measures Affecting Imports of Retreated Tyres. WT/DS332/AB/R, 3 dez. 2007.

522 WTO. Appellate Body Report and Panel Report, Action by the Dispute Settlement Body, Brazil Measures Affecting Imports of Retreated Tyres. WT/DS332/12, 19 dez. 2007.

523 WTO. Extension of Time Period under Article 21.3(c) of the DSU, Brazil - Measures Affecting Imports of Retreated Tyres. WT/DS332/13, 13 fev. 2008.

524 WTO. Extension of Time Period under Article 21.3(c) of the DSU, Brazil - Measures Affecting Imports of Retreated Tyres. WT/DS332/13, 13 fev. 2008.

525 WTO. Appointment of Arbitrator by the Director-General under Article 21.3(c) of the Understanding on Rules and Procedures Governing the Settlement of Disputes, Note by the Secretariat, Brazil - Measures Affecting Imports of Retreated Tyres. WT/DS332/15, 2 jul. 2008. 
jurídico do membro", ${ }^{526}$ o Brasil requisitava que o período razoável de tempo fosse determinado em 21 meses, afirmando que condições específicas e particulares deste caso justificavam a exceção ao prazo máximo de 15 meses previsto no artigo 21.3 (c) do ESC. 527

Naquela oportunidade, o Brasil afirmava que sua intenção de implementar a decisão do OSC naquela controvérsia seguiria os seguintes passos, que demandariam os respectivos lapsos temporais: ${ }^{528}$

(i) a instauração de medida especial (Arguição de Descumprimento de Preceito Fundamental - ADPF) como meio de bloquear a importação de pneus usados autorizada por liminares, e o período razoável para sua conclusão seria de 21 meses; ${ }^{529}$

(ii) o estabelecimento de "novas disciplinas regulatórias para pneus usados e remoldados no âmbito do MERCOSUL”, e 19 meses seria período de tempo razoável para a negociação de novo regime com os parceiros do bloco; ${ }^{530} \mathrm{e}$

(iii) a declaração de inconstitucionalidade das medidas estaduais (do Rio Grande do Sul) que permitiam a importação dos pneus remoldados, o que requereria 21 meses como

526 Tradução livre do original em língua inglesa: "[...] shortest period possible within the legal system of the Member." WTO. Award of the Arbitrator, European Communities - Measures Concerning Meat and Meat Products (Hormones) (Arbitration under Article 21.3(c) of the DSU). WT/DS26/15, WT/DS48/13, 29 maio 1998. para. 26.

527 WTO. Brazil - Measures Affecting Imports of Retreated Tyres (Arbitration under Article 21.3(c) of the Understanding on Rules and Procedures Governing the Settlement of Disputes). WT/DS332/16, 29 ago. 2008. para 9.

528 O prazo de 21 meses foi estabelecido tendo como referência o fato de que a única ADPF então julgada pelo STF havia durado 41 meses, e que a duração média das ADIs seria de 34 meses. Somando-se ao prazo médio de 34 meses o prazo de 2 meses para a notificação dos tribunais sobre a decisão do STF, chegase ao prazo estimado de 36 meses. Como a ADPF 101 foi iniciada em setembro de 2006, subtraindo-se 15 meses (período desde o início da ação até a adoção do Relatório do Órgão de Apelação) restaria ao Brasil o prazo de 21 meses como o período razoável para a implementação. WTO. Brazil - Measures Affecting Imports of Retreated Tyres (Arbitration under Article 21.3(c) of the Understanding on Rules and Procedures Governing the Settlement of Disputes). WT/DS332/16, 29 ago. 2008. para 10-15.

529 Segundo a posição brasileira, estender a aplicação da restrição de importação erga omnes, isto é, também aos países do MERCOSUL, não seria viável, pois violaria a decisão do Sistema de Solução de Controvérsias do MERCOSUL. Chegou-se ao prazo de 19 dias pois para a negociação de um novo regime de pneus no âmbito do bloco seria necessária a aprovação do Grupo do Mercado Comum ("GMC") e pelo Conselho do Mercado Comum ("CMC"). WTO. Brazil - Measures Affecting Imports of Retreated Tyres (Arbitration under Article 21.3(c) of the Understanding on Rules and Procedures Governing the Settlement of Disputes). WT/DS332/16, 29 ago. 2008. para 16-19.

530 O prazo corresponde ao período estimado para a decisão de ADI que objetivava reconhecer a inconstitucionalidade de medidas adotadas pelo Estado do Rio Grande do Sul. A ADI foi iniciada em setembro de 2006, sendo feita a mesma lógica de subtração esboçada para a ADPF, chegando-se ao prazo de 21 meses. WTO. Brazil - Measures Affecting Imports of Retreated Tyres (Arbitration under Article 21.3(c) of the Understanding on Rules and Procedures Governing the Settlement of Disputes). WT/DS332/16, 29 ago. 2008. para 20-21. 
período de tempo razoável. ${ }^{531}$

A demandante do caso, contudo, buscando defender seus interesses no modo de implementação da decisão, alegava que o único meio viável do Brasil adequar sua conduta com a decisão do OSC neste caso seria a revogação da portaria e do decreto presidencial que previam a proibição de importação. Para tal revogação, segundo suas alegações, bastariam alguns meses ou mesmo semanas, uma vez que o recurso compatível seria a utilização de medidas provisórias. Em sua argumentação, a expectativa do governo brasileiro de que o STF declararia a inconstitucionalidade das liminares seria de ordem especulativa, tendo em vista a independência funcional deste órgão, e caso o demandado intencionasse manter a medida deveria modificá-la por meio de atos legislativos ou administrativos - que por encarnarem maior controle do Poder Executivo importariam em um controle de resultado pelo governo brasileiro. ${ }^{532}$

Na ponderação do árbitro, são reforçadas noções relevantes de laudos passados, sobre a função e os limites da arbitragem prevista no artigo 21.3 (c) do ESC, como meio de explicitar o que entende como seu papel. Por sua relevância, transcrevemos trecho do seu laudo arbitral:

\begin{abstract}
Eu também me guio pelos princípios articulados em decisões arbitrais anteriores. Assim, o meu mandato relaciona-se com o tempo ao fim do qual os membros responsáveis pela implementação devem ter alcançado o cumprimento, e não à maneira pela qual que os membros atingem tal cumprimento. No entanto, considero que o quando um membro deve ter implementado não pode ser determinado de forma isolada dos meios escolhidos para implementação. Na realidade, está intimamente relacionado com a questão de como um membro intencione cumprir as recomendações e decisões do OSC. Nesse sentido, o árbitro no caso US - 1916 Act afirmou que "[r]espondendo à pergunta sobre o que constituiria o 'prazo razoável' para a implementação, neste caso, eu preciso olhar primeiro para o tipo de medida proposta a ser utilizada para a implementação." Da mesma forma, o árbitro no caso Japan - DRAMs (Korea) constatou que, a fim de "determinar quando um membro deve implementar, pode ser necessário considerar como um membro se propõe a fazê-lo.
\end{abstract}

\title{
$[\ldots]$
}

Não é minha tarefa como árbitro identificar um meio particular de implementação; sou chamado apenas para determinar se os passos propostos pelo Brasil se inserem no conjunto de ações admissíveis que podem ser tomadas

531 WTO. Brazil - Measures Affecting Imports of Retreated Tyres (Arbitration under Article 21.3(c) of the Understanding on Rules and Procedures Governing the Settlement of Disputes). WT/DS332/16, 29 ago. 2008. para 8.

532 WTO. Brazil - Measures Affecting Imports of Retreated Tyres (Arbitration under Article 21.3(c) of the Understanding on Rules and Procedures Governing the Settlement of Disputes). WT/DS332/16, 29 ago. 2008. para 25-42, 63. 
para implementar as recomendações e decisões do DSB. ${ }^{533}$

O árbitro resgata a relevante noção de que, embora como um pressuposto inicial, o membro responsável pela implementação tenha uma certa discricionariedade na escolha dos meios para a implementação, ele não possui um direito irrestrito na escolha dos meios de implementação. Ademais, se por um lado há a expectativa de que o membro responsável pela implementação use de flexibilidade disponível em seu ordenamento jurídico, por outro lado não se pode exigir que este recorra a procedimentos extraordinários". 534

O árbitro esclarece, ainda, que inserida no espaço de discricionariedade de escolha da maneira pela qual o membro implementará a decisão, está a opção entre revogar a medida declarada desconforme ou modificá-la de modo a trazê-la à conformidade. ${ }^{535}$ Ao mencionar que a retirada da medida inconsistente é o primeiro objetivo do Sistema de Solução de Controvérsias, o artigo 3.7 do ESC deixa implícito que esta não seria a única opção. ${ }^{536}$ Assim, a adequação da medida de proibição de importação ao caput do artigo $\mathrm{XX}$ se inseria no rol de condutas permissivas ao Brasil com vistas ao cumprimento com as determinações do OSC, assim como a retirada da proibição.

É de certa inovação a implementação por meio de conduta do Poder Judiciário. A

533 Tradução livre do original em língua inglesa: "I also draw guidance from principles articulated in previous arbitration awards. Accordingly, my mandate relates to the time by when the implementing Member must have achieved compliance, not to the manner in which that Member achieves compliance. Yet, I consider that when a Member must comply cannot be determined in isolation from the chosen means of implementation. It closely relates to the question of how a Member intends to comply with the recommendations and rulings of the DSB. In that vein, the arbitrator in US - 1916 Act stated that, [t] urning to the question of what would constitute the 'reasonable period of time' for implementation in this case, I need to look first at the type of measure proposed to be used for implementation. "Similarly, the arbitrator in Japan-DRAMs (Korea) found that, in order to determine when a Member must comply, it may be necessary to consider how a Member proposes to do so. [...] It is not my task as Arbitrator to identify a particular means of implementation; I am called only to determine whether the steps proposed by Brazil fall within the range of permissible actions that can be taken to implement the recommendations and rulings of the DSB." WTO. Brazil - Measures Affecting Imports of Retreated Tyres (Arbitration under Article 21.3(c) of the Understanding on Rules and Procedures Governing the Settlement of Disputes). WT/DS332/16, 29 ago. 2008. para 47.

534 WTO. Brazil - Measures Affecting Imports of Retreated Tyres (Arbitration under Article 21.3(c) of the Understanding on Rules and Procedures Governing the Settlement of Disputes). WT/DS332/16, 29 ago. 2008. para 48/ 67.

535 WTO. Brazil - Measures Affecting Imports of Retreated Tyres (Arbitration under Article 21.3(c) of the Understanding on Rules and Procedures Governing the Settlement of Disputes). WT/DS332/16, 29 ago. 2008. para 57.

536 WTO. Brazil - Measures Affecting Imports of Retreated Tyres (Arbitration under Article 21.3(c) of the Understanding on Rules and Procedures Governing the Settlement of Disputes). WT/DS332/16, 29 ago. 2008. para 57. 
este respeito, o Brasil defende a posição de que os atos do poder judiciário são atribuíveis ao Estado de igual maneira, e que este ramo do Estado seria, portanto, capaz de contribuir - tal qual o Poder Executivo e o Poder Legislativo - para a implementação de suas obrigações internacionais. ${ }^{537}$

O árbitro chega, pois, ao prazo de 12 meses como a determinação do tempo razoável para a implementação, ${ }^{538}$ ao interpretar que, segundo o regimento interno do STF, o relator do caso poderia requerer prioridade ao caso, e entendendo que a implementação poderia se dar exclusivamente por instrumentos de direito interno, a prescindir da negociação de novo marco regulatório no âmbito do MERCOSUL. ${ }^{539}$

Na data de 17 de dezembro de 2008, prazo designado pelo árbitro, a implementação ainda estava em curso, uma vez que a ADPF 101 não havia sido julgada no mérito. As partes da controvérsia negociaram, assim, uma dilação no prazo, sem que isso implicasse na renúncia ao direito de buscar compensações pela UE/CE. ${ }^{540}$

Em consonância com o artigo 21.6 do ESC, o Brasil informou periodicamente ao OSC sobre a evolução nas medidas para implementação ${ }^{541}$ e, em comunicado de 14 de

537 "At the oral hearing, Brazil indicated that acts of the judiciary had to be attributed to the state just as acts of the legislature or of the executive. Therefore, the judiciary, like other branches of power, could contribute to achieving compliance with international obligations. Brazil considered t'otally misplaced"the European Communities' focus on the government's ability to control the achievement of the intended objective of proposed implementation acts. Brazil argued that the Federal Government could not ënsure"that its intended results would be achieved, irrespective of whether it undertook action through the legislature or judiciary in order to implement the recommendations and rulings of the DSB, because both the legislature and the judiciary are separate from the executive. Brazil stated that, even though these two powers operate with a different degree of autonomy, there is no difference in the sense that Brazil's Federal Government cannot guarantee a certain outcome either in the National Congress or before the Federal Supreme Court." WTO. Brazil - Measures Affecting Imports of Retreated Tyres (Arbitration under Article 21.3(c) of the Understanding on Rules and Procedures Governing the Settlement of Disputes). WT/DS332/16, 29 ago. 2008. para 57.

538 WTO. Brazil - Measures Affecting Imports of Retreated Tyres (Arbitration under Article 21.3(c) of the Understanding on Rules and Procedures Governing the Settlement of Disputes). WT/DS332/16, 29 ago. 2008. para 91.

539 Destaque para a ressalva feita pelo árbitro: "Having said that, I wish to clarify that I am not suggesting that Brazil could not seek to negotiate a MERCOSUR-wide tyre regime with its MERCOSUR partners. My decision in no way is intended to curtail Brazil's discretion as to which means Brazil may choose to modify its import regime concerning retreaded tyres. Rather, my decision is limited to the question whether or not I should factor into my determination the 19 months requested by Brazil for negotiations with MERCOSUR countries and incorporation of the results into its legal system". WTO. Brazil - Measures Affecting Imports of Retreated Tyres (Arbitration under Article 21.3(c) of the Understanding on Rules and Procedures Governing the Settlement of Disputes). WT/DS332/16, 29 ago. 2008. para 86.

540 WTO. Understanding between Brazil and the European Communities Regarding Procedures under Article 22 of the DSU, Brazil - Measures Affecting Imports of Retreated Tyres. WT/DS332/18, 9 jan. 2009.

541 WTO. Status Report by Brazil, Brazil - Measures Affecting Imports of Retreated Tyres. WT/DS332/19, 10 mar. 2009. WTO. Status Report by Brazil (Addendum), Brazil - Measures Affecting Imports of Retreated Tyres. WT/DS332/19/Add.1, 9 abr. 2009. WTO. Status Report by Brazil (Addendum), Brazil - Measures Affecting Imports of Retreated Tyres. WT/DS332/19/Add.2, 8 maio 2009. WTO. Status 
setembro de 2009, notificou a completa implementação: ${ }^{542}$

\begin{abstract}
Na sequência desta decisão [do STF na ADPF 101], e de acordo com um parecer da Procuradoria Geral da União, a Secretária de Comércio Exterior do Brasil emitiu uma nova regulamentação, a Portaria SECEX 24/2009, que foi publicada no Diário Oficial em 28 de agosto de 2009. Este regulamento proíbe novas licenças para a importação de pneus usados e reformados a serem emitidas, independentemente da sua origem. Regulamentos anteriores permitiam a importação de uma quantidade limitada de uma categoria específica de pneus reformados de outros países do Mercosul. Tomados em conjunto, a decisão da Suprema Corte e a Portaria SECEX 24/2009 eliminaram os aspectos da aplicação pelo Brasil de sua proibição de importação de pneus reformados que tinham sido consideradas incompatíveis com as disciplinas comerciais pelo Órgão de Apelação. O Brasil está, portanto, em plena conformidade com as recomendações e decisões do OSC nesta disputa. ${ }^{543}$
\end{abstract}

O Brasil destacou, ainda, a coerência do resultado da ADPF 101 com a interpretação dos princípios e valores constitucionais, de modo a reconhecer a relevância da política pública da proibição da importação dos pneus reformados, e a tornar a medida conforme à disciplina multilateral. ${ }^{544}$

Report by Brazil (Addendum), Brazil - Measures Affecting Imports of Retreated Tyres. WT/DS332/19/Add.3, 9 jun. 2009. WTO. Status Report by Brazil (Addendum), Brazil - Measures Affecting Imports of Retreated Tyres. WT/DS332/19/Add.4, 10 jul. 2009. WTO. Status Report by Brazil (Addendum), Brazil - Measures Affecting Imports of Retreated Tyres. WT/DS332/19/Add.5, 21 ago. 2009. WTO. Status Report by Brazil (Addendum), Brazil - Measures Affecting Imports of Retreated Tyres. WT/DS332/19/Add.6, 15 set. 2009.

542 WTO. Status Report by Brazil, Brazil - Measures Affecting Imports of Retreated Tyres. WT/DS332/19, 10 mar. 2009.

543 Tradução livre do original em língua inglesa: "Following this decision and in line with an Opinion by the Union's Attorney General Office, Brazil's Secretary of Foreign Trade issued a new regulation, Portaria SECEX 24/2009, which was published in the Official Gazette on 28 August 2009. This regulation prohibits new licenses for the importation of used and retreaded tyres to be issued, irrespective of their origin. Previous regulations allowed the importation of a limited amount of a specific category of retreaded tyres from other Mercosul countries. Taken together, the Supreme Court ruling and Portaria SECEX 24/2009 eliminated the aspects of the application by Brazil of its import ban on retreaded tyres that had been considered inconsistent with trade disciplines by the Appellate Body. Brazil is therefore in full compliance with the DSB recommendations and rulings in this dispute". WTO. Status Report by Brazil (Addendum), Brazil - Measures Affecting Imports of Retreated Tyres. WT/DS332/19/Add.6, 15 set. 2009. para. 6.

544 "The outcome of ADPF 101 is in line with core values and principles that guide Brazil's constitutional order. The Supreme Court decision supports a critical public policy pursued by the Brazilian Government to protect the Brazilian population from the risks associated with the generation, transportation and accumulation of used tyres. Within the legal framework provided by Article XX(b) of the GATT 1994, the Panel and the Appellate Body recognized the key role played by the prohibition on the importation of retreaded tyres for the success of such policy. Brazil's Supreme Court reached a similar conclusion with regard to the importation of used tyres authorized by some lower courts and, in so doing, took an extremely important step to bring Brazil into full compliance with the recommendations and rulings adopted by the DSB in this dispute." WTO. Status Report by Brazil (Addendum), Brazil - Measures Affecting Imports of Retreated Tyres. WT/DS332/19/Add.5, 21 ago. 2009. para. 6. 


\subsubsection{Observações}

O caso DS46, formalmente denominado Brazil - Export Financing Programme for Aircraft, é parte de uma contenda maior - que envolvia a prática de subsídios pelos governos brasileiro e canadense, cujas beneficiárias eram, respectivamente, as empresas Embraer e Bombardier. ${ }^{545} \mathrm{O}$ contexto da contenda, sob a perspectiva brasileira, dizia respeito à empresa brasileira entrante no mercado internacional de jatos regionais, buscando se estabelecer em um setor estratégico, no qual a empresa canadense era monopolista.

Focando na perspectiva da implementação, abstrairemos de comentar os detalhes fáticos e os aspectos técnicos dos relatórios do painel e do Órgão de Apelação. ${ }^{546}$ Cumpre lembrar que o Órgão de Apelação havia reconhecido que o PROEX - a medida brasileira questionada -, não era estruturalmente ilegal, mas o componente da taxa de juros deveria adequar-se ao padrão de referência de mercado.

Como verificou-se, a implementação da decisão foi possível por meio de alterações normativas deste Programa, no âmbito legislativo e no âmbito administrativo. Assim, as medidas tomadas para a adequação do PROEX envolveram: (i) alteração da lei 8.187/91, por meio da edição de consecutivas medidas provisórias e, ao fim do procedimento, a edição da lei 10.184/01 e (ii) alteração de Resoluções do Banco Central.

Este caso foi de relevância fulcral para o Brasil, ensejando mudanças em sua estrutura relativa à capacidade de participação no Sistema de Solução de Controvérsias da OMC, bem como na percepção da relevância deste sistema para a defesa de interesses brasileiros pelos setores industriais e pela sociedade no geral. ${ }^{547} 548$

545 Brazil - Export Financing Programme for Aircraft (DS46), Canada-Measures Affecting the Export of Civilian Aircraft (DS70), e Canada - Export Credits and Loan Guarantees for Regional Aircraft (DS222).

546 Para uma visão maior da negociação entre os países, e dos resultados mais amplos do contencioso para o Brasil, Cf: SERRADOR NETO, José. O contencioso comercial Embraer-Bombardier. In: BENJAMIN, Daniela Arruda. (Org). O Sistema de Solução de Controvérsias da OMC: uma perspectiva brasileira. Brasília : FUNAG, 2013, p. 281-312.

547 Embora o Brasil já tivesse participado de casos do início do Sistema de Solução de Controvérsias da OMC, vide casos DS4 (US - Gasoline) e DS22 (Brazil - Desiccated Coconut), tais casos não ganharam 
Este caso teve, pois, relevância para a construção de um modelo de interação concreta entre a diplomacia, a sociedade brasileira, e o Sistema de Solução de Controvérsias da OMC. A caracterização do contencioso da Embraer como um "divisor de águas" da atuação do Brasil na solução de litígios na OMC, no desenvolvimento de sua capacidade interna para lidar com este sistema, é uma constatação geral entre os diplomatas e os analistas externos. 549550551

A atuação do Brasil envolveu, pois: (i) a habilidade de negociação com o Canadá, paralela ao respeito pelas decisões do Sistema de Solução de Controvérsias da OMC; ${ }^{552}$ (ii) a coordenação com o setor privado; e (iii) a coordenação intergovernamental. ${ }^{553}$

destaque na mídia, ou mobilizaram o setor industrial. Essa mudança ocorreu a partir do contencioso da Embraer.

$548 \quad$ Assim se posicionam os autores: "Until these cases, the Brazilian government had been developing ad hoc, case-by-case strategies to handle WTO cases, and Brazilian industry, academia, and civil society had generally devoted less attention to the WTO system." SHAFFER, Gregory; RATTON SANCHEZ, Michelle; ROSENBERG, Barbara. The Trials of Winning at the WTO: What Lies Behind Brazil's Success. Cornell International Law Journal, vol. 41, issue 2, p. 383-501, 2008. p. 417.

549 A este respeito, relevante a observação de Daniel Roberto Pinto: “[...] Houve outros importantes impactos, porém, inclusive no âmbito do sistema multilateral de comércio, dentro e fora da OMC. Internamente, o Brasil soube extrair numerosas lições do processo, o que contribuiu para desenvolver estrutura negociadora criativa, abrangente e eficaz." PINTO, Daniel Roberto. Muito mais que a Embraer: os contenciosos Brasil-Canadá e o país que queremos ser. In: BENJAMIN, Daniela Arruda. (Org). O Sistema de Solução de Controvérsias da OMC : uma perspectiva brasileira. Brasília : FUNAG, 2013, p. 45-84. p. 48

550 Também em sentido correlato: "The Canada-Aircraft and Brazil-Export Financing Programme for Aircraft cases, involving Embraer and Bombardier, were landmark cases in terms of the intensity with which Brazilian officials worked with law firms that Embraer hired in a public-private partnership for WTO litigation." SHAFFER, Gregory; RATTON SANCHEZ, Michelle; ROSENBERG, Barbara. The Trials of Winning at the WTO: What Lies Behind Brazil's Success. Cornell International Law Journal, vol. 41, issue 2, p. 383-501, 2008. p. 458.

551 Em entendimento similar: "[...] o Brasil soube tirar sua lição do contencioso, ao perceber que a defesa de importantes interesses nacionais poderia passar pela análise de complexos temas do comércio internacional no sistema de solução de controvérsias da OMC. Nesse sistema, como se viu, não há espaço algum para a improvisação e, por isso, foi necessária a busca de uma estratégia de atuação condizente com a sofisticação existente" PEREIRA, Celso de Tarso, COSTA, Valéria Mendes; ARAÚJO, Leandro Rocha de. 100 Casos na OMC: a experiência brasileira em solução de controvérsias. Política Externa, vol. 20, n. 4, p. 121-134, mar/abr/maio 2012. p. 124.

552 O diplomata aponta como o desrespeito à decisão não era uma opção viável tendo em vista a tradição da diplomacia brasileira: “[...]Além disso, ignorar as decisões da OMC significaria deixar de lado toda a nossa história e tradição diplomáticas, voltadas para a solução pacífica de controvérsias e a defesa de uma ordem internacional com regras válidas para todos.” PINTO, Daniel Roberto. Muito mais que a Embraer: os contenciosos Brasil-Canadá e o país que queremos ser. In: BENJAMIN, Daniela Arruda. (Org). O Sistema de Solução de Controvérsias da OMC : uma perspectiva brasileira. Brasília : FUNAG, 2013, p. 45-84. p. 80.

553 Por sua relevância, retomamos ao testemunho deum dos diplomatas envolvidos no caso: "Para enfrentar essa batalha, o Brasil precisou reavaliar os mecanismos de sua participação nas negociações comerciais internacionais. O Itamaraty de imediato se coordenou com outros ministérios, com o BNDES, cujo programa PROEX era objeto do questionamento canadense, com a Seguradora Brasileira de Crédito à Exportação (SBCE), que proporcionava as garantias, com a própria Embraer e com a equipe de advogados dos EUA contratados por esta (Sidley Austin LLP, de Washington, D.C.)” PINTO, Daniel Roberto. Muito mais que a Embraer: os contenciosos Brasil-Canadá e o país que queremos ser. In: BENJAMIN, Daniela 
Ainda que tenha sido interpretado como um relativo sucesso, ${ }^{554} \mathrm{o}$ contencioso evidenciou fragilidades do Brasil na operacionalização desse Sistema de Solução de Controvérsias, em especial no tocante à ausência de recursos humanos disponíveis, em comparação a outros membros desenvolvidos.

Essa percepção foi crucial, portanto, na tomada de medidas, que foram projetadas à construção desta capacidade no longo prazo. Pode-se citar como medidas de longo alcance: (a) a busca pela capacitação diplomática nesta área, em especial com a criação da Coordenação-Geral de Contenciosos (CGC), em 2001; (b) a busca pela capacitação de advogados da iniciativa privada nesta área, o Programa de Formação para Jovens Advogados de escritórios brasileiros. ${ }^{555}$

Em relação ao segundo contencioso que viria a demandar implementação de uma decisão do OSC pelo Brasil, o caso dos pneus reformados apresenta características distintas, que exigiram uma sofisticação dos mecanismos utilizados para implementação. Se no contencioso envolvendo os subsídios ao setor aeronáutico a medida partia dos órgãos administrativos do Poder Executivo, e havia uma evidenciação clara do interesse nacional, no caso dos pneus reformados a medida questionada extrapolava o âmbito dos órgãos do Poder Executivo, tendo havido o envolvimento do Poder Judiciário, em um contexto de interesses contrapostos.

Como foi destacado na análise supra, a medida protetiva da saúde pública e do meio ambiente não foi considerada estruturalmente inconsistente com a disciplina multilateral, mas apenas na medida em que se apresentava aplicada de modo discriminatório. Em tese, a implementação da decisão do OSC poderia, portanto, se dar: (a)

Arruda. (Org). O Sistema de Solução de Controvérsias da OMC : uma perspectiva brasileira. Brasília : FUNAG, 2013, p. 45-84. p. 81.

554 Observe-se pronunciamento do então Ministro das Relações Exteriores, Celso Amorim: “[...] [o Brasil] quando não foi vitorioso, teve bons resultados, como é o caso entre a Embraer e a Bombardier. Eu diria que a Embraer-Bombardier foi um pouco um empate, porque começou com a Bombardier nos ganhando de 4 a 1, depois empatou em 4 a 4, mais ou menos, no número de casos, não no valor das retaliações. E aí alguém uma vez completou: “foi empate no campo do adversário". Então, com valor especial, pois foi esse empate entre a Embraer e a Bombardier que permitiu que se chegasse depois a um acordo que é vantajoso, pelo menos positivo, do ponto de vista da nossa indústria. É natural que seja assim porque éramos "newcomers" nesse processo". Palestra Proferida na abertura do seminário Comemorativo dos 10 anos do Centro Brasileiro de Relações Internacionais (Cebri). Rio de Janeiro, 2 set. 2008. AMORIM, Celso. Discursos, palestras e artigos do Chanceler Celso Amorim: 2003-2010. Brasília: Ministério das Relações Exteriores, Departamento de Comunicações e Documentação: Coordenação-Geral de Documentação Diplomática, 2011. p. 127.

555 PINTO, Daniel Roberto. Muito mais que a Embraer: os contenciosos Brasil-Canadá e o país que queremos ser. In: BENJAMIN, Daniela Arruda. (Org). O Sistema de Solução de Controvérsias da OMC : uma perspectiva brasileira. Brasília : FUNAG, 2013, p. 45-84. p. 81. 
por meio da revogação da proibição sob a importação dos pneus reformados; (b) por meio da retirada dos entraves à aplicação da medida de modo não-discriminatório.

O Brasil, tendo escolhido a opção que melhor refletia os interesse nacionais, como pautados inclusive na Constituição, optou pela manutenção da medida, buscando modificar os aspectos que tornavam a medida discriminatória em sua aplicação, a saber: (i) a abertura à importação de pneus reformados oriundos dos países do MERCOSUL, e (ii) a abertura à importação/exportação por empresas que conseguiram autorização judicial.

As medidas de implementação escolhidas pelo Brasil foram, respectivamente: (i) a negociação com os parceiros do MERCOSUL, e (ii) o ajuizamento de uma ação de descumprimento de preceito fundamental, com o intuito de uniformização de jurisprudência.

Em relação à primeira medida, sua justificativa encontra razão no fato de a abertura aos países do MERCOSUL resultar não de voluntariedade brasileira, mas de decisão de seu mecanismo de solução de controvérsias. Contudo, esta foi uma medida externa, um processo que independia dos órgãos internos do Brasil.

O árbitro ponderou que esta não seria uma medida necessária, e portanto não foi levada em conta para determinação do período de tempo razoável, ${ }^{556}$ o que não significa que o país tenha sido desestimulado a concretizar tal negociação. ${ }^{557}$ É de se refletir, contudo, qual resultado poderia advir de uma eventual negativa de renegociação por parte dos países do MERCOSUL, sendo razoável supor que restaria ao Brasil descumprir uma das decisões dos órgãos adjudicatórios aos quais se encontra juridicamente submetido.

556 "However, I note that these negotiations on a new MERCOSUR-wide tyre regime are an external process that is outside the law-making and regulatory system of Brazil. Yet, the recommendations and rulings of the DSB are addressed specifically to Brazil and not to its MERCOSUR partners. Article 3.3 of the DSU confirms that WTO dispute settlement is concerned with measures taken by a particular Member. The measure at issue, Portaria SECEX 14/2004, is a domestic regulatory act adopted by the SECEX, a subdivision of the Brazilian Federal Ministry of Development, Industry and Foreign Trade. The legal basis for Portaria SECEX 14/2004, as identified in its preamble, is Article 15 of Annex I to Decree No. 4.632 dated 21 March 2003, which, in turn, is a domestic legal instrument. [...]" WTO. Brazil - Measures Affecting Imports of Retreated Tyres (Arbitration under Article 21.3(c) of the Understanding on Rules and Procedures Governing the Settlement of Disputes). WT/DS332/16, 29 ago. 2008. para 79.

557 "Having said that, I wish to clarify that I am not suggesting that Brazil could not seek to negotiate a MERCOSUR-wide tyre regime with its MERCOSUR partners. My decision in no way is intended to curtail Brazil's discretion as to which means Brazil may choose to modify its import regime concerning retreaded tyres. Rather, my decision is limited to the question whether or not I should factor into my determination the 19 months requested by Brazil for negotiations with MERCOSUR countries and incorporation of the results into its legal system.” WTO. Brazil - Measures Affecting Imports of Retreated Tyres (Arbitration under Article 21.3(c) of the Understanding on Rules and Procedures Governing the Settlement of Disputes). WT/DS332/16, 29 ago. 2008. para 86. 
Em relação à segunda medida, foi de arquitetura engenhosa a solução encontrada pelo governo brasileiro, utilizando-se de uma espécie de ação de controle de constitucionalidade, apoiada na proteção ao meio ambiente e à saúde pública que está refletida na Constituição. A inovação da medida de implementação encontra-se no recurso ao Poder Judiciário, que sob a perspectiva brasileira pode contribuir, tal qual os poderes executivo e legislativo, na implementação de suas obrigações internacionais. ${ }^{558}$

Se o contencioso da Embraer deixou algumas lições, foi na implementação do caso dos pneus reformados que a articulação interinstitucional se manifestou de modo intenso. 559 Sob a coordenação conduzida por uma já estabelecida Coordenação Geral de Contenciosos, o Itamaraty orquestrou tal articulação, que manifestou-se, contudo, ainda mais forte na fase da construção da defesa brasileira no contencioso do que na fase de implementação da decisão. ${ }^{560}$

A implementação da decisão do OSC neste segundo caso foi um desafio maior ao Brasil, tendo em conta a existência de interesses internos divergentes, e a necessidade de atuação de diversos órgãos, de diferentes poderes, na concretização das mudanças

558 "In previous arbitrations, implementing Members have usually proposed either legislative or regulatory means to implement DSB recommendations and rulings. However, I do not consider that implementation through the judiciary can be a priori excluded from the range of permissible action that can be taken to implement DSB recommendations and rulings and bring about compliance with a Member's obligations under the covered agreements. The degree of government control may well be different with respect to the executive, the legislative, and the judiciary branches of power. Implementation action, whether it is taken by the legislature, or the judiciary, may not be executed in the way envisaged by the government. Yet the possibility of failure to achieve the intended compliance has not been regarded by previous arbitrators as a reason to question the permissibility of implementation by means of legislation, nor, in my view, does it exclude judicial action from the range of a permissible means of implementation. [...] "WTO. Brazil Measures Affecting Imports of Retreated Tyres (Arbitration under Article 21.3(c) of the Understanding on Rules and Procedures Governing the Settlement of Disputes). WT/DS332/16, 29 ago. 2008. para 68.

559 Assim explicitam os diplomatas envolvidos naquele caso: "Embora todos os contenciosos envolvam, em maior ou menor grau, importante esforço de "diplomacia interna", o contencioso dos pneus reformados foi emblemático nesse sentido, o que se explica pela multiplicidade de atores com interesse sobre o objeto da controvérsia." RIBEIRO, Haroldo de Macedo; LEÃO, Bruno Guerra Carneiro. O contencioso dos pneus reformados: articulação interinstitucional e diplomacia interna. In: BENJAMIN, Daniela Arruda. (Org). O Sistema de Solução de Controvérsias da OMC: uma perspectiva brasileira. Brasília : FUNAG, 2013, p. 265-280. p. 267-8.

560 Neste sentido, assim se deu a articulação: “Dentro do próprio MRE, esse fator implicou permanente coordenação com a Divisão de Política Ambiental e Desenvolvimento Sustentável (DPAD), atualmente subdividida em Coordenação-Geral de Desenvolvimento Sustentável e Divisão de Clima, Ozônio e Segurança Química, além de grande mobilização da rede de Postos no exterior, que contribuiu, em sucessivas oportunidades, com informações sobre práticas regulatórias locais e sobre gestão do passivo ambiental relacionado aos pneus. Na Esplanada, os parceiros prioritários da CGC nesse tema foram o Ministério do Meio Ambiente (MMA), o IBAMA, o Ministério da Saúde (MS), o Ministério do Desenvolvimento Indústria e Comércio Exterior (MDIC), o INMETRO e o DENATRAN." RIBEIRO, Haroldo de Macedo; LEÃO, Bruno Guerra Carneiro. O contencioso dos pneus reformados: articulação interinstitucional e diplomacia interna. In: BENJAMIN, Daniela Arruda. (Org). O Sistema de Solução de Controvérsias da OMC: uma perspectiva brasileira. Brasília : FUNAG, 2013, p. 265-280. p. 271-2. 
necessárias.

Conforme narra a rica experiência de dois diplomatas envolvidos na concretização desta medida, se por um lado o governo e a sociedade civil organizada se mostravam envolvidos com a realização do legítimo fim último da medida, esta posição encontrava obstáculos em grupos empresariais que teriam um benefício econômico com a importação dos pneus reformados, a prescindir do custo ambiental/sanitário que não suportavam diretamente:

Essa atuação manifestou-se em três vertentes paralelas: mobilização de parlamentares em favor de projeto de lei para liberalizar a importação de pneus usados; ações judiciais para obtenção de autorizações individuais com base no princípio constitucional da livre iniciativa; e deslocamento de unidades reformadoras para países vizinhos do Mercosul, que permitiam a importação de carcaças para, com base na exceção aberta ao bloco, exportar pneus reformados desses países para o Brasil. ${ }^{561}$

Portanto, com o intuito de refrear os significativos esforços destes grupos, a Coordenação Geral de Contenciosos se empenhou na cooperação com órgãos internos do MRE (a Assessoria para Assuntos Federativos e Parlamentares e a Divisão de Mercosul), e com órgãos da estrutura governamental (a Casa Civil da Presidência da República ${ }^{562}$ e a Advocacia-Geral da União). ${ }^{563}$

561 RIBEIRO, Haroldo de Macedo; LEÃO, Bruno Guerra Carneiro. O contencioso dos pneus reformados: articulação interinstitucional e diplomacia interna. In: BENJAMIN, Daniela Arruda. (Org). O Sistema de Solução de Controvérsias da OMC: uma perspectiva brasileira. Brasília : FUNAG, 2013, p. 265-280. p. 276-7.

562 Por sua relevância, retomamos o testemunho dos diplomatas: "A Subchefia de Acompanhamento de Políticas Governamentais da Casa Civil foi a entidade crucial para que se pudesse fazer chegar aos parlamentares a clara noção de que a liberalização das importações de pneus usados implicaria derrota do Brasil no contencioso contra a UE (já que toda a lógica da proibição de importações de pneus reformados seria solapada) e, mais gravemente, um retrocesso em matéria de políticas públicas na área de saúde pública e meio ambiente." RIBEIRO, Haroldo de Macedo; LEÃO, Bruno Guerra Carneiro. O contencioso dos pneus reformados: articulação interinstitucional e diplomacia interna. In: BENJAMIN, Daniela Arruda. (Org). O Sistema de Solução de Controvérsias da OMC: uma perspectiva brasileira. Brasília : FUNAG, 2013, p. 265-280. p. 277.

563 Em relação à AGU: “A articulação com a AGU e com a Subchefia de Assuntos Jurídicos da Casa Civil foi, por sua vez, instrumental para que a questão das autorizações judiciais fosse superada, por meio da Arguição de Descumprimento de Preceito Fundamental no 101, em que o Supremo Tribunal Federal (STF) declarou a inconstitucionalidade das medidas judiciais que autorizavam as importações de pneus usados e reformados." RIBEIRO, Haroldo de Macedo; LEÃO, Bruno Guerra Carneiro. O contencioso dos pneus reformados: articulação interinstitucional e diplomacia interna. In: BENJAMIN, Daniela Arruda. (Org). O Sistema de Solução de Controvérsias da OMC: uma perspectiva brasileira. Brasília : FUNAG, 2013, p. 265-280. p. 276-7. 
A implementação neste caso evidenciou a relevância do diálogo entre os órgãos governamentais, a sociedade civil e o setor privado, e principalmente a necessidade do desenvolvimento de canais para facilitar tal diálogo e institucionalizá-lo, de modo que as disputas no Sistema de Solução de Controvérsias da OMC sejam um exercício coletivo. ${ }^{564}$

\subsection{A Implementação das Decisões do Sistema de Solução de Controvérsias nos Casos em que o Brasil Foi Demandante}

A atuação de um membro como demandante no Sistema de Solução de Controvérsias pode ser determinada pela conjunção de diversos fatores, tais como a sua agenda comercial, os obstáculos ao comércio erigidos pelos demais membros e seu impacto sob a economia deste determinado membro, a correlação entre o setor privado e o governo, os recursos humanos, técnicos e financeiros disponíveis.

A decisão de instaurar um caso no Sistema de Solução de Controvérsias da OMC, portanto, envolve um delicado cálculo político por parte dos membros, que precisarão alocar esforços consideráveis para atingir uma vitória.

Há, ademais, a preocupação de que as vitórias neste sistema não sejam "vitórias de Pirro", 565 sendo da maior relevância a boa-fé das partes no momento da implementação, bem como a articulação da negociação entre as partes inclusive no pós-litígio, de modo a

564 Assim concluem os diplomatas: "O caso assinala a importância do diálogo permanente entre as diferentes áreas do Governo e entre estas e os atores não governamentais, de forma que o enorme desafio que é vencer disputas jurídicas internacionais, muito frequentemente em enfrentamentos assimétricos contra potências como os EUA e a UE, não seja um desafio solitário da CGC ou mesmo do MRE. Os contenciosos na OMC envolvem interesses empresariais de centenas de milhões de dólares ou interesses não comerciais de valor inestimável, como no caso dos pneus reformados. A vitória ou a derrota nessas controvérsias nunca são apenas da diplomacia brasileira; nada mais natural, portanto, que a condução desses processos seja sempre um exercício coletivo, em que o MRE possa beneficiar-se da colaboração das outras áreas do Governo, do setor privado e da sociedade civil organizada." RIBEIRO, Haroldo de Macedo; LEÃO, Bruno Guerra Carneiro. O contencioso dos pneus reformados: articulação interinstitucional e diplomacia interna. In: BENJAMIN, Daniela Arruda. (Org). O Sistema de Solução de Controvérsias da OMC: uma perspectiva brasileira. Brasília : FUNAG, 2013, p. 265-280. p. 279.

565 AZEVEDO, Roberto Carvalho de. Prefácio. In: BENJAMIN, Daniela Arruda. (Org). O Sistema de Solução de Controvérsias da OMC : uma perspectiva brasileira. Brasília : FUNAG, 2013, p. 23-30. p. 29. 
possibilitar que a decisão do Sistema de Solução de Controvérsias da OMC se reverta em aspectos concretos. 566567

No tocante ao Brasil, a decisão final de ingressar com um contencioso no Sistema de Solução de Controvérsias da OMC compete formalmente à Câmara de Comércio Exterior (CAMEX), embora estudos apontem que a posição desta no tocante aos contenciosos endossa na maior parte das vezes a visão do MRE apresentada nessa Câmara. A Coordenação-Geral de Contenciosos (CGC) do MRE, acaba por desempenhar papel destacado não só na condução destes contenciosos, mas também em sua seleção estratégica. $^{568}$

$\mathrm{Na}$ escolha de instaurar um procedimento, influenciam interconectados aspectos políticos, econômicos e jurídicos, relacionados à viabilidade jurídica do pleito, à conveniência política de sua instauração, 569570 e à disponibilidade do setor privado interessado de dispor dos recursos financeiros para custear o pleito, ${ }^{571}$ bem como à previsão de reversão destes custos em benefícios econômicos concretos. ${ }^{572}$

566 Sobre a preferência de negociar nos contenciosos da Embraer- Bombardier, ao invés de aplicar a retaliação, Cf: PEREIRA, Celso de Tarso; COSTA, Valéria Mendes; ARAÚJO, Leandro Rocha de. 100 Casos na OMC: a experiência brasileira em solução de controvérsias. Política Externa, vol. 20, n. 4, p. 121-134, mar/abr/maio 2012. p. 124.

567 Esta preocupação se manifestou em especial no caso do algodão, a partir do qual o diplomada destaca a necessidade de se "[...] discutir, entre outras questões, o que implica uma vitória no Mecanismo de Solução de Controvérsias (MSC) da OMC. Vencer pode significar "ganhar e não levar". Pode ter um significado do ponto de vista político-diplomático, outro do ponto de vista jurídico e ainda um terceiro da perspectiva dos interesses econômicos envolvidos." ANDRADE, Luciano Mazza de. O contencioso do algodão: o desafio da implementação. In: BENJAMIN, Daniela Arruda. (Org). O Sistema de Solução de Controvérsias da OMC: uma perspectiva brasileira. Brasília : FUNAG, 2013, p. 85-112. p. 87.

568 ARBIX, Daniel A. Contenciosos brasileiros na OMC: pauta comercial, política e instituições. Contexto Internacional, vol. 30, n. 3, p. 655-699, 2008. p. 669.

569 Embora o Brasil não tenha se abstido de demandar em face de parceiros econômicos de peso, como os EUA e a UE/CE, há inegavelmente uma decisão política sobre a conveniência do pleito. Assim, não há uma relação de "temor" ao ingressar com uma demanda contra os maiores players do comércio internacional, mas há uma escolha estratégica.

570 Destaque-se o testemunho de Celso Amorim: “Os advogados nunca podem ser dispensados. Mas é preciso dar orientação, pois o advogado pode se decidir por um caminho prejudicial a outros interesses. Também pode ser interessante seguir em frente e também aí é preciso alertá-lo. No caso da EmbraerBombardier, aconteceu isso e eu disse para irem em frente, para tentarmos empatar o jogo. Este é o tipo de decisão que o advogado não pode tomar, pois é política, mas tem de ser técnica também. Nós temos desenvolvido capacidades nos contenciosos e estamos tentando desenvolver cada vez mais." AMORIM, Celso. Depoimento. In: COSTA, Sérgio Rodrigues; BUENO, Miguel Garcia. A saga do algodão: das primeiras lavouras à ação na OMC. Rio de Janeiro: Insight Engenharia, 2004, p. 128-133. p. 132. Disponível em:

$<$ http://www.abrapa.com.br/biblioteca/Documents/institucional/publicacoes/A\%20Saga\%20do\%20Algodao.p df>. Acesso em: 20 mar. 2014.

571 Segundo a investigação dos autores, a maioria dos casos em que o Brasil atuou como demandantes foi custeado pelo setor interessado, o que seria um dos motivos do sucesso da participação brasileira: SHAFFER, Gregory; RATTON SANCHEZ, Michelle; ROSENBERG, Barbara. The Trials of Winning at the 


\subsubsection{Análise Preliminar e Escolha dos Casos a Serem Examinados}

Assim como já explicitado, a tabela constante do Apêndice C contém os procedimentos nos quais o Brasil foi demandante, tendo sido feito o cruzamento entre a classificação dos casos segundo critérios do objeto temático da controvérsias e a fase até a qual o procedimento avançou ou a fase em que o caso se encontra dentre os possíveis passos de um procedimento na solução de litígios do Sistema de Solução de Controvérsias da OMC.

De tal cruzamento, abstraímos que 8 casos se inserem na área destacada, que evidencia o foco desta pesquisa, pois seleciona os casos que efetivamente chegaram até a fase de implementação da decisão do Sistema de Solução de Controvérsias da OMC. ${ }^{573}$ Para uma descrição preliminar desses casos analisados, com a explicitação das informações essenciais do respectivo caso, bem como dos dispositivos multilaterais alegados pelas partes, remete-se ao Apêndice D.

WTO: What Lies Behind Brazil's Success. Cornell International Law Journal, vol. 41, issue 2, p. 383-501, 2008.

572 Um relato de Roberto de Azevêdo, então à frente da CGC, possibilita visualizar como estes diversos aspectos foram sopesados na decisão de ingressar com o pleito do algodão: "Com esse pano de fundo, na última reunião da Camex no governo FHC, decidiu-se que o Brasil solicitaria consultas no âmbito do MSC da OMC. A decisão foi, porém, precedida de estudo aprofundado dos vários aspectos envolvidos na matéria e de debates, na própria Camex, sobre a conveniência e a oportunidade de formalizarmos a queixa contra os subsídios norte-americanos ao algodão. A essa altura, já se havia identificado quem poderia ser o economista responsável pelo modelo econométrico, quais os principais parâmetros desse estudo; já se havia identificado também os principais argumentos de que nos valeríamos. A conclusão técnica que precedeu a decisão política, colegiada, foi de que se estava diante de um caso juridicamente sólido, que apresentava boas perspectivas de vitória para o Brasil na OMC. Com base nesse insumo técnico, os ministros decidiram, na Camex, levar adiante o contencioso, com o pedido de consultas, formalizado em setembro de 2002." AZEVÊDO, Roberto. Depoimento. In: COSTA, Sérgio Rodrigues; BUENO, Miguel Garcia. A saga do algodão: das primeiras lavouras à ação na OMC. Rio de Janeiro: Insight Engenharia, 2004, p. 89-97. p. 92. Disponível

$<$ http://www.abrapa.com.br/biblioteca/Documents/institucional/publicacoes/A\%20Saga\%20do\%20Algodao.p df >. Acesso em: 20 mar. 2014.

573 Exclui-se do escopo desta análise os casos nos quais a não implementação pelo membro demandado deu lugar à autorização para retaliação: DS217, DS222, e DS267. O caso DS267 será objeto de análise, sob perspectiva diversa, no capítulo 5 , item no qual serão avaliados mecanismos de efetivação do direito de retaliação pelo governo brasileiro. 
Dentre os 26 procedimentos nos quais o Brasil foi demandante, 11 deles se estagnaram na fase se consultas. ${ }^{574}$ São eles os procedimentos DS71, DS112, DS154, DS208, DS209, DS216, DS218, DS224, DS239, DS409, DS439. O procedimento DS365, por sua vez, continua na fase do painel. Os procedimentos DS190 e DS250 findaram-se por desistência/ solução mutuamente acordada durante o procedimento.

Assim, dos 26 procedimentos, 12 chegaram ao exame do painel e à emissão de relatório com suas conclusões. O Brasil obteve ganho de causa em todos eles, sendo que apenas no caso DS259 o relatório foi adotado sem necessidade de conduta pelo Estado demandado, uma vez que antes de sua adoção o demandante já havia retirado a vigência da medida desconforme.

Nos demais 11 procedimentos - DS4, DS69, DS70, DS217, DS219, DS222, DS241, DS266, DS267, DS269 e DS382 - houve o reconhecimento da violação por parte do Estado demandado, e a necessidade de adequação da medida questionada à disciplina multilateral.

Tendo em vista o recorte metodológico explicitado, o foco de nossa análise se concentrará, pois, nos casos DS219 e DS269, que serão analisados em seguida.

\subsubsection{Caso DS219: European Communities - Anti-Dumping Duties on Malleable} Cast Iron Tube or Pipe Fittings from Brazil

O caso DS219, European Communities - Anti-Dumping Duties on Malleable Cast Iron Tube or Pipe Fittings from Brazil, foi iniciado pelo Brasil, em face da UE/EC, e contou com Chile, Japão, México e Estados Unidos como terceiras partes. ${ }^{575}$

574 Em diversos destes procedimentos, o problema foi resolvido favoravelmente ao Brasil, sem que o processo alcançasse a fase de relatório do painel. COZENDEY, Carlos Márcio Bicalho. O Sistema de Solução de Controvérsias da OMC: para além dos contenciosos, a política externa. p. 13. Disponível em: $<$ http://www.itamaraty.gov.br/temas/temas-multilaterais/copy_of_desenvolvimento-comercio-e-

financas/organizacao-mundial-do-comercio/solucao-de-controversias/cgc/artigo-cozendey> Acesso em: 15 dez. 2013.

575 Para uma visão dos aspectos técnicos e específicos da análise deste caso, Cf: HORN, Henrik.; 
O pedido de consultas foi formulado em 21 de dezembro de 2000, em razão de direitos antidumping impostos pelo Regulamento do Conselho n. 1784/2000, sob a importação de acessórios para tubos de ferro fundido maleável, originados do Brasil, dentre outros. No entendimento do Brasil, referida imposição violava diversas obrigações multilaterais, em especial os artigos I e VI do GATT 1994, e os artigos 1, 2, 2.1, 2.2, 2.4, 2.6, 3, 3.1, 3.2, 3.3, 3.4, 3.5, 4, 4.1, 5, 5.2, 5.3, 5.4, 5.5, 5.7, 5.8, 6, 6.1, 6.2, 6.12, 7, 9, 11 , 12 e 15 do Acordo Antidumping (AAD). Isto pois, em sua interpretação, a avaliação dos fatos pela UE/CE no procedimento provisório e no definitivo não teria sido objetiva e imparcial. ${ }^{576}$

O painel foi estabelecido em 24 de julho de 2001, e composto em 5 de setembro de 2001. ${ }^{577}$ Tendo iniciado os seus trabalhos, em 15 de janeiro de 2002 as partes requisitaram a sua suspensão, com vistas à negociação de uma solução mutuamente acordada. ${ }^{578}$ Novamente, em 28 de fevereiro, as partes requisitaram uma prorrogação da suspensão de seus trabalhos. ${ }^{579}$ Em 22 de abril de 2002, com pedido do Brasil, o painel retomou os trabalhos, e em 07 de março de 2003 divulgou seu relatório. ${ }^{580}$

$\mathrm{Na}$ interpretação do painel, explicitada no relatório, a medida questionada estava em desconformidade apenas em relação aos artigos 2.4.2, 12.2 e 12.2.2 do AAD, não havendo violação dos demais dispositivos suscitados pelo Brasil. ${ }^{581} \mathrm{O}$ painel, portanto,

MAVROIDIS, Petros C. EC - Antidumping Duties on Malleable Cast Iron Tube or Pipe Fittings from Brazil (WT/DS219/AB/R:DSR 2003: VI, 2613). American Law Institute, 2003. Disponível em $<$ http://www.ali.org/doc/wto/wto2003/Chapter_5.pdf>. Acesso em: 15 dez. 2013.

576 WTO. Request for Consultations by Brazil, European Communities - Anti-Dumping Duties on Malleable Cast Iron Tube or Pipe Fittings from Brazil. WT/DS219/1, G/L/432, G/ADP/D32/1, 9 jan. 2001.

577 WTO. Constitution of the Panel Established at the Request of Brazil, Note by the Secretariat, European Communities - Anti-Dumping Duties on Malleable Cast Iron Tube or Pipe Fittings from Brazil. WT/DS219/3, 11 set. 2001.

578 WTO. Communication from the Chairman of the Panel, European Communities - Anti-Dumping Duties on Malleable Cast Iron Tube or Pipe Fittings from Brazil. WT/DS219/4, 18 jan. 2002.

579 WTO. Communication from the Chairman of the Panel, European Communities - Anti-Dumping Duties on Malleable Cast Iron Tube or Pipe Fittings from Brazil. WT/DS219/5, 5 mar. 2002.

580 WTO. Communication from the Chairman of the Panel, European Communities - Anti-Dumping Duties on Malleable Cast Iron Tube or Pipe Fittings from Brazil. WT/DS219/6, 6 mai. 2002.

581 "VIII.1 In light of our findings above, we conclude that: (a) The European Communities has acted inconsistently with its obligations under: (i) Article 2.4 .2 of the Anti-Dumping Agreement in "zeroing" negative dumping margins in its dumping determination; and (ii) Article 12.2 and 12.2 .2 in that it is not directly discernible from the published Provisional or Definitive Determination that the European Communities addressed or explained the lack of significance of certain injury factors listed in Article 3.4. [...]" WTO. Panel Report, European Communities - Anti-Dumping Duties on Malleable Cast Iron Tube or Pipe Fittings from Brazil. WT/DS219/R, 7 mar. 2003. 
recomendou que o OSC requisitasse à UE/CE a adequação da medida em desconformidade. ${ }^{582}$

O desrespeito ao artigo 2.4 .2 se dava pelo uso da metodologia do "zeroing" às margens de dumping negativas na determinação do dumping, e o desrespeito aos artigos 12.2 e 12.2.2 teria ocorrido pelo fato da demandada não ter tornado diretamente discernível das determinações provisórias ou definitivas a insignificância de certos fatores de prejuízo, enumerados no artigo 3.4 do AAD.

Embora o Brasil tivesse requisitado que o painel sugerisse o modo de implementação da medida, o painel decidiu não exercer sua discricionariedade nesta oportunidade, não formulando sugestão de implementação. ${ }^{583}$

O Brasil informou o OSC sobre sua decisão de apelar do relatório do painel. ${ }^{584} \mathrm{O}$ relatório do Órgão de Apelação, divulgado em 22 de julho de 2003, confirmou a maior parte das interpretações e conclusões do painel, apenas revertendo a interpretação do painel para reconhecer a desconformidade da medida em questão também aos artigos 6.2 e 6.4 do AAD. ${ }^{585}$

582 "VIII.2 In light of our finding that the European Communities acted inconsistently with its obligations under Article 2.4.2 by applying zeroing" in its dumping determination, we have carefully considered these arguments of the European Communities. The EC measure referred to in our terms of reference and that that we have found to be inconsistent with the EC obligations under the Agreement remains in force. VIII. 3 We therefore recommend that the Dispute Settlement Body request the European Communities to bring its measure into conformity with its obligations under the Anti-Dumping Agreement" WTO. Panel Report, European Communities - Anti-Dumping Duties on Malleable Cast Iron Tube or Pipe Fittings from Brazil. WT/DS219/R, 7 mar. 2003.

583 "VIII.4 Brazil requests that we exercise our discretion under Article 19.1 of the DSU to suggest ways in which the European Communities could implement our recommendation. Specifically, Brazil requests us to suggest that, the European Communities repeal its anti-dumping duty order and reimburse all antidumping duties collected thereunder. (...) VIII.6 By virtue of Article 19.1 of the DSU, a panel has discretion to ('hay)' suggest ways in which a Member could implement the recommendation that the Member concerned bring the measure into conformity with the covered agreement in question. Clearly, however, a panel is by no means required to make a suggestion should it not deem it appropriate to do so. Thus, while we are free to suggest ways in which we believe the European Communities could appropriately implement our recommendation, we decide not to do so in this case." WTO. Panel Report, European Communities - AntiDumping Duties on Malleable Cast Iron Tube or Pipe Fittings from Brazil. WT/DS219/R, 7 mar. 2003.

584 WTO. Notification of an Appeal by Brazil under paragraph 4 of Article 16 of the Understanding on Rules and Procedures Governing the Settlement of Disputes (DSU), European Communities - Anti-Dumping Duties on Malleable Cast Iron Tube or Pipe Fittings from Brazil. WT/DS219/7, 27 abr. 2003.

585 "For the reasons set out in this Report, the Appellate Body: (e) reverses the Panel's finding, in paragraphs 7.348 and 7.349 of the Panel Report, and finds, instead, that the European Communities acted inconsistently with Articles 6.2 and 6.4 of the Anti-Dumping Agreement, by failing to disclose to the interested parties during the anti-dumping investigation the information on the injury factors listed in Article 3.4 that is contained in Exhibit EC-12". WTO. Appellate Body Report, European Communities - AntiDumping Duties on Malleable Cast Iron Tube or Pipe Fittings from Brazil. WT/DS219/AB/R, 22 jul. 2003. para. 196. 
O Órgão de Apelação acatou, pois, argumentação brasileira de que a demandada desrespeitou os artigos 6.2 e 6.4 do AAD por abster-se de divulgar às partes interessadas, durante o procedimento, certas informações referentes à avaliação da indústria doméstica. Tal violação à relevantes obrigações de natureza procedimental, referentes ao devido processo legal, teria prejudicado a possibilidade de defesa pela exportadora brasileira. ${ }^{586}$ Assim, o Órgão de Apelação recomendava ao OSC que requeira à UE/CE a adequação da medida considerada desconforme. ${ }^{587}$

O Relatório do Órgão de Apelação e o relatório do painel, com as devidas modificações, foram adotados em reunião de 18 de agosto de 2003. ${ }^{588}$ Em comunicado de 15 de setembro, a demandada confirmou sua intenção de implementar a decisão, ${ }^{589}$ e as partes chegaram ao acordo de que o período de 7 meses seria o prazo razoável para esta implementação, findando em 19 de março de $2004 .{ }^{590}$

Em comunicado de 17 de março de 2004, a demandada informou que havia modificado a medida contestada, por meio do Regulamento do Conselho n. 436/2004, de 8 de março de 2004, que emendava o Regulamento do Conselho n. 1784/2000, que havia imposto os direitos antidumping. ${ }^{591}$

Em referido Regulamento, explicita-se ter sido concedido acesso aos fatores mencionados no AAD, ${ }^{592}$ bem como ter sido realizado o recálculo da margem de

586 WTO. Appellate Body Report, European Communities - Anti-Dumping Duties on Malleable Cast Iron Tube or Pipe Fittings from Brazil. WT/DS219/AB/R, 22 jul. 2003. para 135-150.

587 "The Appellate Body therefore recommends that the Dispute Settlement Body request the European Communities to bring its measure, which has been found in this Report, and in the Panel Report as modified by this Report, to be inconsistent with its obligations under the Anti-Dumping Agreement, into conformity with that Agreement." WTO. Appellate Body Report, European Communities - Anti-Dumping Duties on Malleable Cast Iron Tube or Pipe Fittings from Brazil. WT/DS219/AB/R, 22 jul. 2003. para. 197.

588 WTO. Appellate Body Report and Panel Report, Action by the Dispute Settlement Body, European Communities - Anti-Dumping Duties on Malleable Cast Iron Tube or Pipe Fittings from Brazil. WT/DS219/10, 27 ago. 2003.

589 WTO. Communication from the European Communities, European Communities - Anti-Dumping Duties on Malleable Cast Iron Tube or Pipe Fittings from Brazil. WT/DS219/11, 17 set. 2003.

590 WTO. Agreement under Article 21.3(b) of the DSU, European Communities - Anti-Dumping Duties on Malleable Cast Iron Tube or Pipe Fittings from Brazil. WT/DS219/12, 3 out. 2003.

591 WTO. Appellate Body Report, European Communities - Anti-Dumping Duties on Malleable Cast Iron Tube or Pipe Fittings from Brazil. WT/DS219/13, 23 mar. 2004.

592 “(5) Following the adoption of the ABR by the DSB the interested parties in this proceeding, i.e. the Brazilian exporting producer and the Community industry ('CI'), received disclosure of the facts and considerations on the dumping calculation and the injury factors mentioned under recital 3(ii). All parties were informed of the essential facts and considerations on the basis of which it was intended to amend and confirm the Definitive Regulation. They were also granted a period within which to make representations subsequent to this disclosure. All interested parties were granted an opportunity to be heard by the Commission. However, no such hearing was requested by any interested party". COUNCIL REGULATION (EC) No 436/2004, de 8 de março de 2004. 
dumping, sem a metodologia do "zeroing", passando-se da aplicação original de 34,8\%, para a aplicação de $32 \% .{ }^{593}$

Na reunião de 20 de abril de 2004, o Brasil contestou que a demandada tivesse implementado integralmente as determinações do OSC, vez que abandonara a metodologia do "zeroing" mas não havia modificado seu procedimento de investigação de direitos antidumping, de modo a garantir requisitos do devido processo legal. Não houve, contudo, ato formal no procedimento, após a comunicação da UE/CE. ${ }^{594}$

\subsubsection{Caso DS269: European Communities - Customs Classification of Frozen Boneless Chicken Cuts}

O caso DS269, European Communities - Customs Classification of Frozen Boneless Chicken Cuts, foi iniciado pelo Brasil, em face da UE/CE, e contou com a China, Tailândia e os EUA como terceiras partes. ${ }^{595} 596$

As consultas dessa controvérsia se iniciaram em 11 de outubro de 2002, surgidas em razão do Regulamento da Comissão n. 1223/2002 e da Decisão 2003/97/EC, que fixavam uma nova descrição dos cortes de frango congelado sem osso dentro da nomenclatura da UE/CE. Tais atos reclassificavam o produto da nomenclatura 02.10 ("meat and edible meat offal, salted, in brine, dried or smoked") para a rubrica 02.07

593 "(14) The revised dumping margin expressed as a percentage of the cif import price at the Community frontier is: Indústria de Fundição Tupy Ltda: $32 \%$ (...)(51) As shown above, a full examination of the facts established and the conclusions reached in the original investigation, taking account of the recommendations and rulings set out in the Reports, demonstrates that imports from Brazil were still injuriously dumped, although at a slightly lower level” . COUNCIL REGULATION (EC) No 436/2004, de 8 de março de 2004.

594 Conforme informação disponível na base dados sobre a solução de controvérsias da OMC: $<$ http://www.wto.org/english/tratop_e/dispu_e/cases_e/ds219_e.htm>

595 Para maiores detalhes sobre a controvérsia, Cf: ZAV̄ALLA, José Akcell. "European communities customs classification of frozen boneless chicken cuts" In: BENJAMIN, Daniela Arruda. (Org). O Sistema de Solução de Controvérsias da OMC: uma perspectiva brasileira. Brasília: FUNAG, 2013, p. 185-198.

596 Sobre a relevância "comercial, econômica e social" deste setor para o país, e sua inserção em um universo maior de contenciosos de carne de frango instaurados pelo Brasil, "que leva o frango muito a sério”, Cf: CAETANO, Ana T. Os contenciosos sobre carne de frango In: BENJAMIN, Daniela Arruda. (Org). O Sistema de Solução de Controvérsias da OMC: uma perspectiva brasileira. Brasília : FUNAG, 2013, p. 351-368. 
("meat and edible offal, of the poultry of heading No. 0105, fresh, chilled or frozen"), com a incidência de tarifa diferente.

No entendimento do demandante, a nova nomenclatura incluía o sal como ingrediente do produto que não existia antes, e submetia este produto a uma tarifa maior que aquela aplicável à carne salgada, em violação das obrigações multilaterais constantes dos artigos II, II:1, XXIII, XXIII:1 e XXVIII do GATT 1994.

Em 19 de setembro de 2003, o Brasil requisitou o estabelecimento do painel, que foi deferido em 2 de outubro de 2003. Contudo, com pedido da Tailândia para o estabelecimento de painel sobre a mesma medida, o OSC deferiu, em 21 de novembro de 2003, o estabelecimento de um painel único para ambas as controvérsias, tendo em consideração o artigo 9.1 do ESC e o acordo entre as partes. O painel foi composto em 28 de junho de 2004. O relatório do painel único, para as controvérsia DS269 e DS286, foi divulgado em 30 de maio de 2005, e o relatório do Órgão de Apelação foi divulgado em 12 de setembro de 2005.

Durante a sua análise da controvérsia, o painel requisitou consultas à OMA, ${ }^{597} \mathrm{com}$ base no artigo 13.1 do ESC, que lhe permite buscar informações que considere relevantes para a resolução da questão. ${ }^{598} \mathrm{O}$ relatório do painel, divulgado em 30 de maio de 2005 , interpretava que a medida era inconsistente com as obrigações da demandante constante dos artigos II:1(a) e II:1(b) do GATT 1994, uma vez que os produtos afetados pela medida estavam inseridos em uma concessão feita pela demandante. ${ }^{599}$

597 Assim, José Akcell Zavalla resume o resultado consulta à OMA: “Uma vez que o contencioso versava sobre questões relativas à classificação aduaneira de mercadorias, a OMA foi consultada, mas limitou-se inicialmente a descrever os procedimentos constantes do Artigo 10 da Convenção do Sistema Harmonizado, relativos a solução de controvérsias. Posteriormente, a OMA opinou que a posição 0207 ofereceria uma descrição mais especifica por se referir à carne de aves. Por outro lado, também admitiu a possibilidade de que a posição 0210 fosse considerada mais especifica se considerado o processo ao qual a carne é submetida (salga)." ZAVALLA, José Akcell. "European communities - customs classification of frozen boneless chicken cuts" In: BENJAMIN, Daniela Arruda. (Org). O Sistema de Solução de Controvérsias da OMC: uma perspectiva brasileira. Brasília: FUNAG, 2013, p. 185-198. p. 195.

598 Artigo 13.1: “Todo grupo especial terá direito de recorrer à informação e ao assessoramento técnico de qualquer pessoa ou entidade que considere conveniente. Contudo, antes de procurar informação ou assessoramento técnico de pessoa ou entidade submetida à jurisdição de um Membro o grupo especial deverá informar as autoridades de tal Membro. O Membro deverá dar resposta rápida e completa a toda solicitação de informação que um grupo especial considere necessária e pertinente. A informação confidencial fornecida não será divulgada sem autorização formal da pessoa, entidade ou autoridade que a proporcionou.” Entendimento Relativo às Normas e Procedimentos sobre Solução de Controvérsias. Versão oficial em português segundo o decreto n. 1.355, de 30 dez. 1994, que promulga a Ata Final que Incorpora os Resultados da Rodada Uruguai de Negociações Comerciais Multilaterais do GATT.

599 "VIII.1 The Panel concludes that: (a) Frozen boneless chicken cuts that have been impregnated with salt, with a salt content of $1.2 \%$ - 3\% (the products at issue) are covered by the concession contained in 
Houve recurso de ambas as partes e, em seu relatório divulgado em 12 de setembro de 2005, o Órgão de Apelação confirmou as conclusões do painel sobre a desconformidade da medida com a disciplina multilateral, embora tenha se apoiado em diferente argumentação. Nesta oportunidade, o Órgão de Apelação reverteu o entendimento do painel de que a prática da demandante de classificar o produto em questão como carne salgada, entre 1996 e 2002, consistiria em prática subsequente a um tratado internacional, nos termos do artigo 31(3)(b) da CVDT. ${ }^{600}$

O relatório do Órgão de Apelação e o relatório do painel, com as devidas modificações, foram adotados em reunião de 27 de setembro de 2005. Em reunião do OSC de 18 de outubro de 2005, a UE/CE confirmou sua intenção de implementar adequadamente a decisão, afirmando que - em razão de “diversas questões altamente técnicas" - precisaria de um período de tempo razoável para tal.

$\mathrm{Na}$ ausência de acordo entre as partes sobre qual seria o prazo, o Brasil requereu a arbitragem do artigo 21.3(b) do ESC para determinação do período razoável para implementação. ${ }^{601} \mathrm{O}$ árbitro, Sr. James Bacchus, foi indicado de comum acordo pelas partes. ${ }^{602}$

heading 02.10 of the EC Schedule; (b) EC Regulation No. 1223/2002 and EC Decision 2003/97/EC result in the imposition of customs duties on the products at issue that are in excess of the duties provided for in respect of the concession contained in heading 02.10 of the EC Schedule; and (c) Accordingly, the European Communities has acted inconsistently with the requirements of Articles II:1(a) and II:1(b) of the GATT 1994 and, thus, nullified or impaired benefits accruing to Brazil. VIII.2 Therefore, the Panel recommends that the Dispute Settlement Body request the European Communities to bring EC Regulation No. 1223/2002 and EC Decision 2003/97/EC into conformity with its obligations under the GATT 1994." WTO. Panel Report, European Communities - Customs Classification of Frozen Boneless Chicken Cuts. WT/DS269/R, 30 maio 2005.

600 "For the reasons set forth in this Report, the Appellate Body: [...] (c) upholds the Panel's findings, in paragraphs 7.424 and 8.1 of the Panel Reports, that: (i) frozen boneless chicken cuts that have been impregnated with salt, with a salt content of 1.2 to 3 per cent (the products at issue) are covered by the tariff commitment under heading 02.10 of the EC Schedule; (ii) EC Regulation 1223/2002 and EC Decision 2003/97/EC result in the imposition of customs duties on the products at issue that are in excess of the duties provided for in respect of the tariff commitment under heading 02.10 of the EC Schedule; and (iii) accordingly, that the European Communities has acted inconsistently with the requirements of Articles II: 1(a) and II:1(b) of the GATT 1994 and, thus, nullified or impaired benefits accruing to Brazil and Thailand [...]. 348. The Appellate Body recommends that the Dispute Settlement Body request the European Communities to bring its measures, found in this Report and in the Panel Report as modified by this Report to be inconsistent with the General Agreement on Tariff and Trade1994, into conformity with its obligations under that Agreement." WTO. Appellate Body Report, European Communities - Customs Classification of Frozen Boneless Chicken Cuts. WT/DS269/AB/R, 12 set. 2005. para. 347.

601 WTO. Request from Brazil for Arbitration under Article 21.3(c) of the DSU, European Communities - Customs Classification of Frozen Boneless Chicken Cuts. WT/DS269/11, 24 nov. 2005.

602 WTO. Appointment of Arbitrator under Article 21.3(c) of the Understanding on Rules and Procedures Governing the Settlement of Disputes, European Communities - Customs Classification of Frozen Boneless Chicken Cuts. WT/DS269/12, 16 dez. 2005. 
O laudo foi exarado em 20 de fevereiro de 2006, no qual ficava estabelecido o período de 9 meses para a implementação, que findaria em 27 de junho de $2006 .{ }^{603} \mathrm{~A}$ análise dos argumentos e das considerações explicitadas no laudo é capaz de evidenciar aspectos relevantes da implementação da decisão.

A UE/CE, que durante o procedimento do painel e do Órgão de Apelação havia buscado, sem sucesso, legitimar a reclassificação com base na Organização Mundial de Aduanas OMA, afirmou que intencionava cumprir a recomendação por meio das seguintes medidas, que requeriam 26 meses:

(a) busca de decisão da OMA sobre a interpretação das respectivas nomenclaturas;

(b) com base na decisão da OMA, adoção de Regulamento da Comissão com as modificações;

(c) se necessário, adoção de Regulamento classificatório em relação ao produto em questão. ${ }^{604}$

O Brasil argumentou que o período deveria ser de cinco meses e dez dias e que o fato de a UE/EC não ter tomado nenhuma ação no intuito de implementação demonstraria uma negligência a ser levada em consideração para o cálculo do tempo. Ademais, o Brasil afirmou que a suposta primeira fase de implementação, a busca pela decisão da OMA, seria medida que não guardaria pertinência ou relevância com o cumprimento e que, por outro lado, sugeriria que as conclusões do Órgão de Apelação estariam sujeitas à aprovação daquela organização. ${ }^{605}$

Em relação à medida pertinente no ordenamento comunitário, o Brasil contesta o prazo requerido pela $\mathrm{UE} / \mathrm{CE}$, pois a implementação poderia se dar por meio de uma simples emenda à nomenclatura comum. Tendo em vista que a Comissão tem a competência para adotar medidas emendando e clarificando a nomenclatura sem acionar o Conselho, segundo o seu entendimento, a implementação requerida teria natureza

603 WTO. European Communities - Customs Classification of Frozen Boneless Chicken Cuts (Arbitration under Article 21.3(c) of the DSU). WT/DS269/13, 24 nov. 2005.

604 WTO. European Communities - Customs Classification of Frozen Boneless Chicken Cuts (Arbitration under Article 21.3(c) of the DSU). WT/DS269/13, 24 nov. 2005. para 5-18.

605 WTO. European Communities - Customs Classification of Frozen Boneless Chicken Cuts (Arbitration under Article 21.3(c) of the DSU). WT/DS269/13, 24 nov. 2005. para 19-25. 
executiva ou administrativa, a prescindir de natureza legislativa, como afirmava a demandada. ${ }^{606}$

Por fim, o Brasil destacava que na determinação do período razoável de tempo, o árbitro deve levar em conta o artigo 21.2 do ESC, uma vez que este artigo se aplicaria para a atuação de países em desenvolvimento como demandantes e como demandados, sem distinção. Salienta, ainda, a relevância deste setor para a economia e desenvolvimento social brasileiros, prejudicados pela medida comunitária inconsistente com a disciplina multilateral. ${ }^{607}$

A Tailândia, parte demandante na disputa DS285, julgada em conjunto com a disputa DS269, pedia ao árbitro que determinasse o período de 6 meses, fundada em argumentação similar à brasileira. ${ }^{608}$

O árbitro inicia sua análise reforçando os limites de seu mandato, e a discricionariedade do membro para escolher o caminho para implementação:

[...] Assim, no cumprimento desse mandato limitado, reconheço que os membros responsáveis pela implementação tem uma discricionariedade na escolha dos meios de implementação que considerem mais adequados em outras palavras, no que diz respeito à medida de implementação, a minha tarefa centra-se no quando, e não no como. Minha preocupação é com o tempo, não com a técnica. Além disso, concordo com árbitros anteriores que realizaram mandatos semelhantes nos termos do artigo 21.3 que eu devo basear a minha determinação no menor período de tempo possível dentro do sistema jurídico dos membros, e que ao fazê-lo eu devo ter em mente que o espera-se do membro responsável pela implementação o uso de qualquer flexibilidade disponível dentro de seu sistema jurídico em seus esforços para cumprir suas obrigações na OMC. Essa flexibilidade, no entanto, não precisa necessariamente incluir o recurso a procedimentos "excepcionais".

$[\ldots]$

Embora os membros geralmente tenham discricionariedade para determinar os seus meios de implementação, esta discricionariedade não é sem limites. Ao dizer que a seleção dos meios de implementação das recomendações e decisões do OSC é prerrogativa do membro responsável pela implementação não é de modo algum correspondente a dizer que "vale tudo". 609

606 WTO. European Communities - Customs Classification of Frozen Boneless Chicken Cuts (Arbitration under Article 21.3(c) of the DSU). WT/DS269/13, 24 nov. 2005. para 26-29.

607 WTO. European Communities - Customs Classification of Frozen Boneless Chicken Cuts (Arbitration under Article 21.3(c) of the DSU). WT/DS269/13, 24 nov. 2005. para 30-32.

608 Para maiores detalhes sobre os argumentos da Tailândia, Cf: WTO. European Communities Customs Classification of Frozen Boneless Chicken Cuts (Arbitration under Article 21.3(c) of the DSU). WT/DS269/13, 24 nov. 2005. para 33-43.

609 Tradução livre do original em inglês: "Thus, in fulfilling this limited mandate, I acknowledge that 
O árbitro decide não levar em conta a busca por uma decisão na OMA como motivo para o cálculo do tempo razoável, uma vez que tratava-se de recurso à processos externos, fora do ordenamento jurídico "interno" do membro, que não se incluem comumente nas formas de implementação das recomendações e decisões do OSC, havendo ainda o potencial de criar obstáculos à implementação. ${ }^{610}$

Em relação ao processo de emenda ao Regulamento desconforme, tendo em vista que ele pode se dar com atuação exclusiva da Comissão, sem o envolvimento do Conselho ou do Parlamento, trata-se de processo de implementação de natureza administrativa, e não "legislativa". ${ }^{611}$ Essa caracterização tem relevância para a determinação do prazo razoável, como indica o árbitro:

[...] Arbitragens anteriores destacaram que a implementação atingida por meio de processos administrativos geralmente exigem menos tempo do que a aplicação por meio de legislação. Esta distinção baseia-se no fato de que a ação administrativa em geral pode ser realizada por apenas uma instituição (muitas vezes o Poder Executivo) do membro, enquanto que a ação legislativa geralmente exige a participação de instituições adicionais (tipicamente, pelo menos, o Poder Legislativo - susceptível de ter processos mais lentos, e mais deliberativos - e possivelmente também em conjunto com o Poder Executivo)" 612

the implementing Member has a measure of discretion in selecting the means of implementation that it deems most appropriate; in other words, with respect to the implementing measure, my task focuses on the when, not the what. My concern is with time, not technique. Furthermore, I agree with previous arbitrators who have carried out like mandates under Article 21.3 that I should base my determination on the shortest period of time possible within the legal system of the implementing Member, and that in doing so I should bear in mind that the implementing Member is expected to use whatever flexibility is available within its legal system in its efforts to fulfil its WTO obligations. Such flexibility, however, need not necessarily include recourse to ëxtraordinary"procedures. [...] Although Members generally have discretion to determine their means of implementation, this discretion is not without bounds. Saying that selecting the means of implementing the recommendations and rulings of the DSB is the prerogative of the implementing Member is not at all the same as saying that änything goes". WTO. European Communities - Customs Classification of Frozen Boneless Chicken Cuts (Arbitration under Article 21.3(c) of the DSU). WT/DS269/13, 24 nov. 2005. para $46 / 52$.

610 WTO. European Communities - Customs Classification of Frozen Boneless Chicken Cuts (Arbitration under Article 21.3(c) of the DSU). WT/DS269/13, 24 nov. 2005. para 52-54. WTO.

611 WTO. European Communities - Customs Classification of Frozen Boneless Chicken Cuts (Arbitration under Article 21.3(c) of the DSU). WT/DS269/13, 24 nov. 2005. para 67.

612 Tradução livre do original em língua inglesa: "Previous arbitrations have highlighted that implementation achieved through administrative processes generally requires less time than implementing legislation. 86 This distinction is premised on the fact that administrative action generally may be accomplished solely by one institution (often the Executive Branch) of the implementing Member, whereas legislative action generally requires the participation of additional institutions (typically at least the Legislative Branch-likely to have slower, more deliberative processes-possibly in conjunction with the Executive Branch as well)" WTO. European Communities - Customs Classification of Frozen Boneless 
Em seu cálculo, o árbitro leva também em conta o fato de que a demandada não iniciou esforços para a implementação, ${ }^{613}$ e concorda com o argumento brasileiro da aplicabilidade do artigo 21.2 a situações nas quais o membro em desenvolvimento é a parte reclamante, embora isto não tenha afetado o cálculo do tempo pois esse se deu segundo o menor período de tempo possível. ${ }^{614}$

Em comunicado inicial sobre o status da implementação, de 8 de junho de 2006, a UE/CE informou que estava em processo de adoção um Regulamento da Comissão em emenda ao Regulamento do Conselho n. 2658/87, que promoveria a implementação da decisão do OSC. ${ }^{615}$ Em comunicado posterior, de 30 de junho de 2005, a demandada informou adoção do Regulamento da Comissão n. 949/2006, de 27 de junho de 2006, emendando o Anexo 1 do Regulamento do Conselho n. 2658/87. ${ }^{616}$

A demandante informou, portanto, na reunião do OSC de 19 de julho 2006, que havia implementado em sua totalidade as recomendações do OSC com a adoção do Regulamento da Comissão n. 949/2006. Tendo em vista que o demandante ainda estava averiguando o escopo e efeitos da medida de implementação, em 26 de julho de 2006, Brasil e UE/CE informaram ao OSC que haviam chegado a um entendimento, nos termos dos artigos 21 e 22 do ESC. A Tailândia, demandante em procedimento correlato, também informou a conclusão de entendimento. ${ }^{617}$

Contudo, logo em seguida à implementação da decisão, por meio do Regulamento da Comissão supracitado, a UE/CE notificou sua intenção de modificar concessões tarifarias da Lista LXXX, relativas ao produto objeto da controvérsia. Assim, se por um

Chicken Cuts (Arbitration under Article 21.3(c) of the DSU). WT/DS269/13, 24 nov. 2005. para 67.

613 "Based on the European Communities' submission, all that seems to have occurred thus far is internal discussions within the European Communities. Mere discussion is not implementation. There must be something more to evidence that a Member is moving toward implementation. I therefore agree with Brazil and Thailand that this failure to commence implementation of the DSB's recommendations and rulings is a factor that I should take into account in determining the reasonable period of time for implementation." WTO. European Communities - Customs Classification of Frozen Boneless Chicken Cuts (Arbitration under Article 21.3(c) of the DSU). WT/DS269/13, 24 nov. 2005. para 66.

614 WTO. European Communities - Customs Classification of Frozen Boneless Chicken Cuts (Arbitration under Article 21.3(c) of the DSU). WT/DS269/13, 24 nov. 2005. para 82.

615 WTO. Status Report by the European Communities, European Communities - Customs Classification of Frozen Boneless Chicken Cuts. WT/DS269/15, 9 jun. 2006.

616 WTO. Status Report by the European Communities, European Communities - Customs Classification of Frozen Boneless Chicken Cuts. WT/DS269/16, 4 jul. 2006.

617 WTO. Understanding between Brazil and the European Communities Regarding Procedures under Articles 21 and 22 of the DSU, European Communities - Customs Classification of Frozen Boneless Chicken Cuts. WT/DS269/16, 31 jul. 2006. 
lado é possível a interpretação de que houve, na realidade, "evasão" da real concretização da medida, ${ }^{618}$ destaca-se que não há óbice para que uma decisão do Sistema de Solução de Controvérsias seja substrato para a renegociação dos direitos e obrigações compactuados. Ao contrário, o respeito pela decisão do OSC evidenciou a legitimidade desse sistema em reconhecer violações aos compromissos acordados, o que não impede a renegociação com novo equilíbrio de direitos e deveres - de normas que obstem a adoção de uma medida com ampla legitimidade interna. ${ }^{619}$

\subsubsection{Observações}

O primeiro caso explicitado trata de reconhecimento de aplicação da metodologia "zeroing" da margem de dumping, bem como de negativa de direitos processuais aos investigados. Observa-se, de início, que as controvérsias sobre medidas antidumping trazem frequentemente a discussão metodologias e questões procedimentais, estabelecendo parâmetros que extrapolam o caso concreto de investigação sob exame. ${ }^{620}$

Tendo em conta que a controvérsia envolvia procedimento de investigação de produto exportado por apenas uma empresa brasileira, é razoável supor que a decisão de

618 "Com esse movimento, a União Europeia evadiu o cumprimento da recomendação do OSC com relação ao contencioso do "frango salgado". Embora o desdobramento do caso não tenha sido o esperado pelo setor, vale registrar o engajamento do Brasil nas negociações sob o artigo XXVIII e o sucesso, dentro daquele contexto e realidade, do volume negociado da quota tarifária para as importações originarias do Brasil." CAETANO, Ana T. Os contenciosos sobre carne de frango In: BENJAMIN, Daniela Arruda. (Org). O Sistema de Solução de Controvérsias da OMC: uma perspectiva brasileira. Brasília : FUNAG, 2013, p. 351-368. p. 363.

619 "Em termos práticos, se bem a UE cumpriu formalmente com a implementação das recomendações do painel e do Órgão de Apelação, reconhecendo que a decisão de mudar a classificação aduaneira teve o efeito de conferir tratamento menos favorável ao produto em questão do que aquele estabelecido em seus compromissos tarifários ao final da Rodada Uruguai, a renegociação da tarifa para a posição 0210, mesmo em troca de compensações, evidenciou o interesse de manter a elevação da proteção tarifaria introduzida pelas medidas objeto do contencioso, frustrando, assim, as expectativas dos exportadores de frango do Brasil e da Tailândia, bem como dos próprios consumidores europeus, quanto à resolução da disputa." ZAVALLA, José Akcell. "European communities - customs classification of frozen boneless chicken cuts" In: BENJAMIN, Daniela Arruda. (Org). O Sistema de Solução de Controvérsias da OMC: uma perspectiva brasileira. Brasília: FUNAG, 2013, p. 185-198. p. 197.

620 A metodologia do zeroing foi objeto de uma série de contenciosos em face da UE/CE e em face dos EUA. 
instaurar esta demanda teve em conta interesses extrapolavam a dimensão econômica daquela investigação específica, alcançando o combate à metodologia e à violação de direitos do devido processo durante os procedimentos de investigação. ${ }^{621}$

Na implementação, contudo, a UE/CE cuidou de recalcular o nível dos direitos estabelecidos, reestabelecendo os direitos processuais naquele procedimento específico. A implementação da decisão, pois, não envolveu uma reformulação das regras gerais de metodologia/procedimento de investigações de antidumping, embora o caso tenha contribuído para o efeito sistêmico de consolidação de uma jurisprudência contrária ao zeroing.

Em relação ao segundo caso analisado, a medida ilegal tratava de reclassificação do produto na nomenclatura comum do bloco. Embora a medida pudesse claramente ser modificada por ato de natureza executiva, a demandada argumentou ao árbitro que buscaria renegociar a nomenclatura na OMA e, após uma definição no âmbito internacional iniciaria, as implementações no âmbito comunitário.

Esse caso foi pertinente ao evidenciar que há um esforço de cumprimento das decisões do Sistema de Solução de Controvérsias por parte de membros da OMC, mesmo que se busque uma renegociação dos compromissos acordados. Isto é, a prescindir de um descumprimento da decisão do OSC, a UE/CE procurou implementar, e em seguida combinar a modificação de compromissos, que pudesse conferir legitimidade à medida declarada inconsistente.

Embora os casos escolhidos dentre as controvérsias ajuizadas pelo Brasil não tenham sido os de maior destaque na imprensa e na sociedade brasileira, são relevantes ao demonstrarem a variedade das medidas questionadas, bem como das respectivas medidas de implementação, e das variáveis que lhe circundam.

De fato, a controvérsia recente de maior destaque no Brasil - o caso do algodão não pode ser objeto desta análise mais detalhada pois não envolveu medida de implementação strictu sensu. Ao contrário, diante da não implementação pelos EUA,

621 Embora a própria empresa envolvida (Tupy) tenha financiado o escritório privado que atuou neste caso (Theodor Goddard), ainda assim a instauração de um caso envolve um cálculo político, como explicitado supra. SHAFFER, Gregory; RATTON SANCHEZ, Michelle; ROSENBERG, Barbara. The Trials of Winning at the WTO: What Lies Behind Brazil's Success. Cornell International Law Journal, vol. 41, issue 2, p. 383-501, 2008. p. 463/490. 
houve autorização para retaliação cruzada por parte do Brasil. Embora não possa ser, pois, analisado como exemplo de implementação, abordaremos a controvérsia mais adiante sob a perspectiva aos mecanismos utilizados pelo Brasil na busca da concretização de seu direito de retaliação.

\subsection{A Implementação das Decisões do Sistema de Solução de Controvérsias nos Casos em que o Brasil Atuou como Terceira Parte}

O procedimento do Sistema de Solução de Controvérsias da OMC prevê a participação de terceiras partes, como disciplinado pelo artigo 10 do ESC. Referido artigo estabelece que, além dos interesses das partes em disputa, os interesses dos demais membros deverão ser levados em conta durante o procedimento do painel. ${ }^{622}$

A princípio, os direitos de terceira parte estão apresentados na literalidade dos parágrafos 2 e 3 do artigo 10 do ESC, e do parágrafo 6 do anexo 3. Envolvem, portanto: (i) o recebimento das comunicações das partes, na primeira reunião do painel, (ii) a oportunidade de ser ouvido pelo painel e de submeter manifestações por escrito, (iii) a oportunidade de estar presente durante a primeira reunião substantiva do painel. ${ }^{623}$

622 Artigo 10.1: "Os interesses das partes em controvérsia e os dos demais Membros decorrentes do acordo abrangido ao qual se refira a controvérsia deverão ser integralmente levados em consideração no correr dos trabalhos dos grupos especiais." Entendimento Relativo às Normas e Procedimentos sobre Solução de Controvérsias. Versão oficial em português segundo o decreto n. 1.355, de 30 dez. 1994, que promulga a Ata Final que Incorpora os Resultados da Rodada Uruguai de Negociações Comerciais Multilaterais do GATT.

623 Artigo 10.2: "Todo Membro que tenha interesse concreto em um assunto submetido a um grupo especial e que tenha notificado esse interesse ao OSC (denominado no presente Entendimento t'erceiro)' terá oportunidade de ser ouvido pelo grupo especial e de apresentar-lhe comunicações escritas. Estas comunicações serão também fornecidas às partes em controvérsia e constarão do relatório do grupo especial." Artigo 10.2: "Os terceiros receberão as comunicações das partes em controvérsia apresentadas ao grupo especial em sua primeira reunião.” Apêndice 3 Procedimentos de Trabalho, parágrafo 6: "Todas as terceiras partes interessadas que tenham notificado ao OSC seu interesse na controvérsia deverão ser convidadas por escrito a apresentar suas opiniões durante a primeira reunião substantiva em sessão especial destinada a essa finalidade. Todas as terceiras partes poderão estar presentes à totalidade desta sessão." Entendimento Relativo às Normas e Procedimentos sobre Solução de Controvérsias. Versão oficial em português segundo o decreto n. 1.355, de 30 dez. 1994, que promulga a Ata Final que Incorpora os Resultados da Rodada Uruguai de Negociações Comerciais Multilaterais do GATT. 
Contudo, a jurisprudência do Órgão de Apelação reconhece a possibilidade de conferir diferentes graus de "direitos adicionais" às terceiras partes, concessão sujeita à discricionariedade do painel. Esses direitos adicionais podem incluir um acesso maior às audiências e aos documentos submetidos pelas partes, e a possibilidade de participar da fase da apelação, mas dependem de circunstâncias individuais do caso. ${ }^{624}$

Embora pareça haver um apoio geral à extensão dos diretos de terceira parte - sendo esta até mesmo uma demanda de parte dos defensores da conveniência de uma revisão no Sistema de Solução de Controvérsias da OMC -, não se deve descuidar do desafio de estabelecer um equilíbrio, conservando a distinção entre os direitos procedimentais de terceiras partes e os direitos das partes da demanda. ${ }^{625}$

Essa possibilidade de buscar contribuir na construção do entendimento dos painéis, do Órgão de Apelação e, portanto, do Sistema de Solução de Controvérsias como um todo, tem sido largamente utilizada pelo Brasil. A participação brasileira neste papel tem sido desempenhada em função do objeto da demanda envolver interesses comerciais "sensíveis" ao país, ou de interesse "sistêmico", relacionados à construção da interpretação de tópicos relevantes ao corpus juris da OMC. ${ }^{626}$

Contudo, tal participação deve ser estrategicamente pensada pelo país, uma vez que envolve um posicionamento político, que na prática resulta em apoio a uma das partes em disputa, bem como pode "comprometer" a legitimidade de defesa de argumento oposto em futura atuação como parte em litígio. ${ }^{627}$

624 Para uma lista dos casos em que houve o pedido, a concessão e a denegação de "enhanced third parties rights", bem como os fatores levados em conta na decisão de conceder ou denegar, Cf: Dispute Settlement Understanding, Article 7, para. 494. WTO, Legal Affairs Division. WTO analytical index: Guide to WTO Law and Practice. Cambridge University Press: 2012. Disponível em: $<$ http://www.wto.org/english/res_e/booksp_e/analytic_index_e/analytic_index_e.htm>. Acesso em: 10 jul. 2014.

625 EVANS, David. PEREIRA, Celso de Tarso. DSU Review: A View From the Inside. In: YEARS, Rufus. WILSON, Bruce. (Ed.). Key Issues in WTO Dispute Settlement: The First Ten Years. Nova Iorque: Cambridge Univesity Press, 2005, p. 251-264. p. 258-9.

626 Sobre a relevância real da construção da jurisprudência como fonte do Direito: "Embora cada decisão aplique-se apenas ao caso em tela, na prática a análise dos painéis e do Órgão de Apelação acaba gerando expectativas e influenciando o julgamento de casos comparáveis. A participação do Secretariado na assessoria aos painéis também contribui para a padronização de decisões em casos semelhantes. Como o processo de negociação e aprovação dos textos dos acordos baseia-se no consenso, é inevitável que haja ambiguidades e lacunas. Por mais que os painéis e o Órgão de Apelação busquem ser conservadores na interpretação, suas decisões tendem a suprir algumas daquelas lacunas. Com isso, o sistema ganha em coerência, mas se afasta do principio do consentimento. A jurisprudência acaba, dessa forma, constituindo uma fonte de direito não explicitada na OMC." MESQUITA, Paulo Estivallet de. A Organização Mundial do Comércio. Brasília: FUNAG, 2013. p. 83.

627 COZENDEY, Carlos Márcio Bicalho. O Sistema de Solução de Controvérsias da OMC: para 
Além da natureza sistêmica do interesse em relação à controvérsia, pode também afetar na decisão de atuar como terceira-parte em uma controvérsia - ao invés de participar como demandante - a relação entre os custos de participação e a disposição do setor privado em arcar com esse dispêndio. Em sua atuação como terceira parte, o Brasil pode conduzir a participação por meio de seu escritório em Genebra, sem a necessidade de contratar um escritório privado especializado, o que não ocorre no tocante aos casos em que atua como demandante, tendo em conta a alta complexidade das casos em disputa. ${ }^{628}$

\subsubsection{Análise Preliminar e Escolha dos Casos a Serem Examinados}

De maneira correlata, a tabela constante do Apêndice E - elaborada com os procedimentos que tiveram o Brasil como terceira-parte - faz o cruzamento entre a classificação dos casos segundo critérios do objeto temático da controvérsias e a fase até a qual o procedimento avançou ou a fase em que o caso se encontra dentre os possíveis passos de um procedimento na solução de litígios do Sistema de Solução de Controvérsias da OMC.

Desse cruzamento, abstraímos que 43 casos se inserem na área destacada, que evidencia o foco desta pesquisa, pois seleciona os casos que efetivamente chegaram até a fase de implementação da decisão do Sistema de Solução de Controvérsias da OMC. ${ }^{629}$ Para uma descrição preliminar desses casos analisados, com a explicitação das informações essenciais do respectivo caso, bem como dos dispositivos multilaterais alegados pelas partes, remete-se ao Apêndice F.

além dos contenciosos, a política externa. Disponível em: <http://www.itamaraty.gov.br/temas/temasmultilaterais/copy_of_desenvolvimento-comercio-e-financas/organizacao-mundial-do-comercio/solucao-decontroversias/cgc/artigo-cozendey> Acesso em: $15 \mathrm{dez} .2013$.

628 SHAFFER, Gregory; RATTON SANCHEZ, Michelle; ROSENBERG, Barbara. The Trials of Winning at the WTO: What Lies Behind Brazil's Success. Cornell International Law Journal, vol. 41, issue 2, p. 383-501, 2008. p. 469.

629 Exclui-se do escopo desta análise os casos nos quais a não implementação pelo membro demandado deu lugar à autorização para retaliação: DS160, DS234, DS291 e DS406. 
Dentre os 85 procedimentos que o Brasil integra como terceira parte, 16 procedimentos seguem na fase do painel: DS420, DS430, DS434, DS435, DS437, DS441, DS447, DS453, DS456, DS457, DS458, DS462, DS464, DS467, DS469 e DS471.

Os procedimentos DS431, DS432 e DS433 estão atualmente na fase de apelação. Os procedimentos DS27, DS292, DS293, DS344 e DS391 findaram-se por desistência/solução mutuamente acordada durante o procedimento. No procedimento DS347 a autoridade do painel caducou.

Assim, até a conclusão deste trabalho, dos 85 procedimentos, 61 tiveram a adoção de relatório do painel/Órgão de apelação com o exame fático do caso e emissão de suas conclusões. Destes procedimentos, em 13 casos o relatório foi adotado sem necessidade de conduta corretiva, nos casos: DS135, DS152, DS244, DS248, DS249, DS251, DS252, DS253, DS254, DS258, DS320, DS321 e DS392.

Dentre os procedimentos com adoção de relatório recomendando a modificação da medida, abstraímos os seguintes casos cuja implementação foi notificada ou está pendente de concretização: DS114, DS121, DS138, DS174, DS184, DS204, DS212, DS246, DS265, DS283, DS286, DS290, DS315, DS335, DS339, DS340, DS342, DS343, DS345, DS350, DS362, DS375, DS376, DS377, DS379, DS394, DS395, DS398, DS405, DS412 e DS426.

Inseridos neste universo dos casos em que houve o reconhecimento da violação por parte do Estado demandado, e a necessidade de adequação da medida questionada à disciplina multilateral, encontramos ainda os casos DS76, DS108 e DS245 - nos quais houve solução mutuamente acordada para implementação -, os casos DS207 e DS294 cujos painéis de verificação concluíram pela existência de descumprimento -, e os casos DS316, DS317, DS353, DS381, DS384, DS386 e DS397 - que se encontram atualmente na fase do painel de verificação de cumprimento.

Buscando abarcar a diversidade de casos e medidas que requerem a implementação por parte dos membros da OMC, tendo em vista o recorte metodológico explicitado, o foco de nossa análise se concentrará, pois, nos casos DS362 e DS381, que serão examinados em seguida. 


\subsubsection{Caso DS362: China - Measures Affecting the Protection and Enforcement of Intellectual Property Rights}

O caso DS362: China - Measures Affecting the Protection and Enforcement of Intellectual Property Rights, foi iniciado pelos EUA, em face da China, e contou com Argentina, Austrália, Brasil, Canadá, UE/CE, Índia, Japão, República da Coréia, México, Taiwan (Taipei Chinês), Tailândia e Turquia como terceiras partes. ${ }^{630}$

As consultas desta controvérsia se iniciaram em 10 de abril de 2007, surgidas em razão de certos aspectos relativos à proteção dos direitos de propriedade intelectual na China. Em especial, o demandante indicou quatro aspectos objeto da consulta: (i) a falta de procedimentos e penalidades para que certos atos de falsificação de marcas e pirataria na China pudessem ser objeto de processos penais e de penalidades; (ii) a destinação dos bens apreendidos em violação aos direitos de propriedade intelectual; (iii) o âmbito de aplicação dos processos penais e penalidades para a reprodução/distribuição não autorizada de obras protegidas por direitos autorais; e (iv) a negação de proteção a direitos de autor e direitos conexos a trabalhos criativos de autoria, gravações sonoras e performances que não tivessem sido autorizados para publicação ou distribuição no interior na China. Segundo os EUA, tais aspectos da proteção de direitos de propriedade intelectual na China seriam violação aos artigos 3.1, 9.1, 14, 41.1, 46, 59 e 61 do TRIPS. ${ }^{631}$

O painel foi estabelecido em reunião do OSC de 25 de setembro de 2007, e composto pelo Diretor-Geral da OMC em 13 de dezembro de $2007 .{ }^{632}$ O relatório do painel foi divulgado aos membros em 26 de janeiro de $2009 .{ }^{633}$

630 Para maiores detalhes sobre os detalhes do caso, Cf: POLIDO, Fabrício Bertini Pasquot. Contribuições ao Estudo do Direito Internacional da Propriedade Intelectual na Era Pós-Organização Mundial do Comércio: Fronteiras da Proteção, Composição do Equilíbrio e Expansão do Domínio Publico. 2010. 535 p. Tese (Doutorado em Direito) - Faculdade de Direito, Universidade de São Paulo, São Paulo. p. 304-314.

631 WTO. Request for Consultations by the United States, China - Measures Affecting the Protection and Enforcement of Intellectual Property Rights. WT/DS362/1, G/L/819, IP/D/26, 16 abr. 2007.

632 WTO. Constitution of the Panel Established at the Request of the United States, Note by the Secretariat, China - Measures Affecting the Protection and Enforcement of Intellectual Property Rights. WT/DS362/8, 13 dez. 2007.

633 WTO. Panel Report, China - Measures Affecting the Protection and Enforcement of Intellectual Property Rights. WT/DS362/R, 26 jan. 2009. 
Em sua interpretação, a Lei de direitos autorais chinesa, especialmente em seu artigo $4^{\circ}$, seria inconsistente com as obrigações assumidas pela China em face do artigo 5(1) da Convenção de Berna de 1971, como incorporada pelo artigo 9.1 do TRIPS, e do artigo 9.1 do TRIPS. Isso pois, embora a China tenha o direito de proibir a circulação de certas obras, tendo em conta o artigo 17 da Convenção de Berna, tal direito não justifica a denegação completa de proteção de direitos autorais desses trabalhos proibidos. ${ }^{634}$

Em relação às acusações referentes às medidas aduaneiras, o painel interpretou que o demandante não conseguiu estabelecer provas de que haveria inconsistência com o artigo 61 do TRIPS, como alegado. No que tange aos remédios relativos aos bens que violem direitos de propriedade intelectual, como previsto no artigo 59 do TRIPS, o painel afirmou que as medidas de fronteira não estão sujeitas à aplicação deste artigo, uma vez que não são aplicáveis à exportação. Em relação às importações, o painel concluiu que a maneira pela qual ocorriam os leilões aduaneiros dos bens apreendidos na China seria incompatível com o art. 59, já que aconteceria em mais oportunidades do que apenas casos excepcionais. $^{635}$

O painel exerceu "economia judicial” em relação aos demais artigos alegados, entendendo que não havia necessidade de analisá-los, em face das constatações delineadas. ${ }^{636}$ Tendo em conta as conclusões explicitadas em seu relatório, o painel recomendava ao OSC que a China adequasse as medidas consideradas desconformes. ${ }^{637}$

634 "For the reasons set out in this Report, the Panel concludes as follows: (a) the Copyright Law, specifically the first sentence of Article 4, is inconsistent with China's obligations under: (i) Article 5(1) of the Berne Convention (1971), as incorporated by Article 9.1 of the TRIPS Agreement; and (ii) Article 41.1 of the TRIPS Agreement [...]" WTO. Panel Report, China - Measures Affecting the Protection and Enforcement of Intellectual Property Rights. WT/DS362/R, 26 jan. 2009. para. VII.1- VII.16.

635 "For the reasons set out in this Report, the Panel concludes as follows: [...] (b) with respect to the Customs measures: (i) Article 59 of the TRIPS Agreement is not applicable to the Customs measures insofar as those measures apply to goods destined for exportation; (ii) the United States has not established that the Customs measures are inconsistent with Article 59 of the TRIPS Agreement, as it incorporates the principles set out in the first sentence of Article 46 of the TRIPS Agreement; and (iii) the Customs measures are inconsistent with Article 59 of the TRIPS Agreement, as it incorporates the principle set out in the fourth sentence of Article 46 of the TRIPS Agreement; and (c) the United States has not established that the criminal thresholds are inconsistent with China's obligations under the first sentence of Article 61 of the TRIPS Agreement." WTO. Panel Report, China - Measures Affecting the Protection and Enforcement of Intellectual Property Rights. WT/DS362/R, 26 jan. 2009. para. VII.1- VII.16.

636 "The Panel exercises judicial economy with respect to: (a) the claim under Article 5(2) of the Berne Convention (1971), as incorporated by Article 9.1 of the TRIPS Agreement; and the claims under Article 61 of the TRIPS Agreement (with respect to the Copyright Law); and (b) the claims under Article 41.1 of the TRIPS Agreement and under the second sentence of Article 61 of the TRIPS Agreement (with respect to the criminal thresholds)." WTO. Panel Report, China - Measures Affecting the Protection and Enforcement of Intellectual Property Rights. WT/DS362/R, 26 jan. 2009. para. VIII.2.

637 "In light of these conclusions, the Panel recommends pursuant to Article 19.1 of the DSU that China 
Não tendo havido apelação, o OSC adotou o relatório do painel em 20 de março de 2009. ${ }^{638}$ Em comunicado de 15 de abril de 2009, a China informou sobre sua intenção de implementar a decisão do OSC e, avaliando suas opções para tal, precisaria de um prazo razoável de tempo. ${ }^{639}$

Em 29 de junho de 2009, as partes informaram ao OSC que haviam chegado a um acordo, nos termos do artigo 21.3(b), estabelecendo que o período de tempo razoável para a implementação deveria ser de 12 meses, expirando em 20 de março de $2010{ }^{640}$

Em 7 de janeiro de 2010, a China enviou relatório de acompanhamento da implementação, nos termos do artigo 21.6 do ESC, no qual informava que as propostas legislativas de emenda da Lei de Direitos Autorais e dos Regulamentos de Proteção Aduaneira de Direitos de Propriedade Intelectual haviam sido submetidas ao exame do Conselho de Estado. ${ }^{641}$

Em 8 de março de 2010, a China submeteu novo relatório de acompanhamento, informando que havia implementado a decisão do OSC ao modificar a sua lei de direitos autorais, e estava buscando a implementação no tocante à proteção aduaneira. ${ }^{642}$

Em 19 de março de 2010, a China informou que, além da aprovação da emenda à Lei de Direitos Autorais, pelo Congresso em 26 de fevereiro de 2010, o Conselho de Estado havia adotado em 17 de março de 2010 a decisão de revisar os Regulamentos

bring the Copyright Law and the Customs measures into conformity with its obligations under the TRIPS Agreement." WTO. Panel Report, China - Measures Affecting the Protection and Enforcement of Intellectual Property Rights. WT/DS362/R, 26 jan. 2009. para. VIII.4.

638 WTO. Panel Report, Action by the Dispute Settlement Body, China - Measures Affecting the Protection and Enforcement of Intellectual Property Rights. WT/DS362/10, IP/D/26/Add.1, 27 mar. 2009.

639 WTO. Communication from China, China - Measures Affecting the Protection and Enforcement of Intellectual Property Rights. WT/DS362/11, 15 abr. 2009.

640 WTO. Communication from China and the United States Concerning Article 21.3(b) of the DSU, China - Measures Affecting the Protection and Enforcement of Intellectual Property Rights. WT/DS362/13, 3 jul. 2009.

641 WTO. Status Report by China, China - Measures Affecting the Protection and Enforcement of Intellectual Property Rights. WT/DS362/14, 8 jan. 2010.

642 "The Decision of the Standing Committee of the Eleventh National People's Congress on Amending the Copyright Law of the People's Republic of China was adopted at the 13th Meeting of the Standing Committee of the Eleventh National People's Congress of the People's Republic of China on 26 February 2010. China has implemented the recommendations and rulings of the DSB with respect to the Copyright Law. The legislative proposals relating to the amendment of the Regulations for Customs Protection of Intellectual Property Rights have been submitted to the State Council for examination. China will continue working on the amendment of the regulation, according to its domestic legislative procedures, that would resolve this matter" WTO. Status Report by China, Addendum, China - Measures Affecting the Protection and Enforcement of Intellectual Property Rights. WT/DS362/14/Add.2, 9 mar. 2010. 
relativos à proteção aduaneira. Assim, a demandada teria completado os procedimentos legislativos internos relevantes à implementação. ${ }^{643}$

Tendo em vista incertezas da parte dos EUA em relação à completa implementação do relatório do painel, como adotado pelo OSC, em 8 de abril de 2010 as partes notificaram o OSC sobre a celebração de um acordo relativo aos artigos 21 e 22 do ESC. ${ }^{644}$

\subsubsection{Caso DS381: United States — Measures Concerning the Importation, Marketing and Sale of Tuna and Tuna Products}

O caso DS381: United States - Measures Concerning the Importation, Marketing and Sale of Tuna and Tuna Products, foi iniciado pelo México, em face dos EUA, e contou com Argentina, Austrália, Brasil, Canadá, China, Equador, UE/CE, Guatemala, Japão, Coreia do Sul, Nova Zelândia, Taipé chinês (Taiwan), Tailândia, Turquia, Venezuela e Noruega como terceiras partes. ${ }^{645}$

O pedido de consultas foi formulado em 24 de outubro de 2008 , em relação às seguintes medidas: (i) o Código dos Estados Unidos, Título 16, Seção 1385 ("Dolphin Protection Consumer Information Act"), (ii) o Código de Regulamentos Federais, Título 50, Seção 216,91 ("Dolphin-safe labeling standards") e Seção 216.92 ("Dolphin-safe requirements for tuna harvested in the ETP [Eastern Tropical Pacific Ocean] by large purse seine vessels") e (iii) a decisão proferida no caso Earth Island Institute v. Hogarth (494 F.3d 757, 9th Cir. 2007).

643 WTO. Status Report by China, Addendum, China - Measures Affecting the Protection and Enforcement of Intellectual Property Rights. WT/DS362/14/Add.2, 9 mar. 2010.

644 WTO. Understanding between China and the United States. Regarding Procedures under Articles 21 and 22 of the DSU, China - Measures Affecting the Protection and Enforcement of Intellectual Property Rights. WT/DS362/15, 13 abr. 2010.

645 Para maiores detalhes sobre o caso, Cf: WOLANSKI, Pedro Henrique Fleider. A jurisprudência recente do Órgão de Apelação sobre o Acordo TBT: os casos "EUA - Atum II" e "EUA - Cigarros de Cravo" In: BENJAMIN, Daniela Arruda. (Org). O Sistema de Solução de Controvérsias da OMC: uma perspectiva brasileira. Brasília : FUNAG, 2013, p 417-436. 
Segundo o México, referidas medidas que estabelecem as condições para a utilização do rótulo de "dolphin safe" para produtos de atum, seriam inconsistentes com os artigos I: 1 e III: 4 do GATT 1994 e com os artigos 2.1, 2.2 e 2.4 do TBT, ao exigirem provas documentais sobre a área onde o atum é pescado e o método de pesca, de modo desnecessário e discriminatório. ${ }^{646}$

Em 9 de março de 2009, o México requisitou o estabelecimento do painel, que foi autorizado em reunião do OSC de 20 de março de 2009. O painel foi estabelecido em 20 de abril de 2009, e composto pelo Diretor-Geral em 14 de dezembro de 2009. ${ }^{647}$ Em 12 de agosto de 2010, com a morte de um dos membros do painel, as partes acordaram a nova composição do painel. ${ }^{648} \mathrm{O}$ painel divulgou seu relatório aos membros em 15 de setembro de 2011. ${ }^{649}$

Inicialmente, o painel reconheceu que as disposições relativas às condições para a rotulação de "dolphin-safe" constituiam um regulamento técnico obrigatório para fins de aplicação do TBT e do anexo 1.1. ${ }^{650} \mathrm{O}$ painel então interpretou que as medidas não eram discriminatórias em relação aos produtos mexicanos, pois não resultavam em situação menos favorável do que a concedida aos produtos nacionais e originários de outros membros. ${ }^{651}$

646 WTO. Request for Consultations by Mexico, United States - Measures Concerning the Importation, Marketing and Sale of Tuna and Tuna Products. WT/DS381/1, G/L/858, G/TBT/D/32, 28 out. 2008.

647 WTO. Constitution of the Panel Established at the Request of Mexico, United States - Measures Concerning the Importation, Marketing and Sale of Tuna and Tuna Products. Note by the Secretariat. WT/DS381/5, 15 dez. 2009.

648 WTO. Replacement of a Member of the Panel, Note by the Secretariat, United States - Measures Concerning the Importation, Marketing and Sale of Tuna and Tuna Products. WT/DS381/7, 24 ago. 2010.

649 WTO. Panel Report, United States - Measures Concerning the Importation, Marketing and Sale of Tuna and Tuna Products. WT/DS381/R, 15 set. 2011.

650 "In light of all the above, we find that the measures at issue establish labelling requirements, compliance with which is mandatory [...]" Observa-se que houve uma opinião em separado nesta questão, como explicitado no relatório. "[...]Notwithstanding this conclusion, I consider it appropriate to pursue the analysis of the measures at issue as a technical regulation, on the basis of the opinion of the majority of the Panel. Without prejudice to my views with respect to this initial determination, I therefore associate myself with the remainder of these findings." WTO. Panel Report, United States - Measures Concerning the Importation, Marketing and Sale of Tuna and Tuna Products. WT/DS381/R, 15 set. 2011. para. VII.46/ VII.89.

651 "In conclusion, based on the evidence presented to us, we are not persuaded that Mexico has demonstrated that the US dolphin-safe provisions afford less favourable treatment to Mexican tuna products within the meaning of Article 2.1 of the TBT Agreement. That these measures may, through the operation of origin-neutral regulatory categories, have a detrimental impact on certain imports does not, in our view, necessarily imply that the measures afford less favourable treatment to such imported products within the meaning of Article 2.1. [...]" WTO. Panel Report, United States - Measures Concerning the Importation, Marketing and Sale of Tuna and Tuna Products. WT/DS381/R, 15 set. 2011. para. VII.108- VII.109. 
No tocante à alegada violação ao artigo 2.2, o painel interpretou que o México havia demonstrado que as medidas eram mais restritivas ao comércio do que o necessário para atingir os objetivos legítimos, constituindo um obstáculo desnecessário ao comércio. 652

Em relação às alegações de violação do artigo 2.4 do TBT, o painel interpretou que não houve referida violação, uma vez que o standard apresentado pelo México não seria apropriado ou efetivo para atingir os objetivos norte-americanos. ${ }^{653}$ No tocante às alegações de violação aos dispositivos do GATT 1994, o painel usou sua discricionariedade para abster-se de analisá-las, em exercício de economia judicial. ${ }^{654}$

Desse modo, o painel conclui reconhecendo a desconformidade da conduta norteamericana com o artigo 2.2 do TBT, e recomendou que o OSC requeira aos EUA que adeque a sua medida em desconformidade. ${ }^{655}$

Em 31 de outubro de 2011, as partes solicitaram ao OSC que prorrogasse o prazo de 60 dias inicialmente estipulado no artigo 16.4 do ESC. Em reunião de 11 de novembro de 2011, o OSC concordou com o pedido, determinando que caso não houvesse

652 "In light of our determinations above in relation to both objectives of the US dolphin-safe provisions, we find that these measures are more trade-restrictive than necessary to fulfil their legitimate objectives, taking account of the risks non-fulfilment would create. Consequently, the Panel finds that the US dolphin-safe provisions are inconsistent with Article 2.2 of the TBT Agreement. VII.2 As described above, we make this determination taking into account our finding that the US dolphin-safe measures, as applied, only partly address the adverse effects on dolphins of tuna fishing that the United States has identified as relevant it the context of its objectives of informing consumers and contributing to the protection of dolphins in relation to the impact of such fishing techniques. Specifically, the US dolphin-safe provisions do not address observed mortality, and any resulting adverse effects on dolphin populations, for tuna not caught by setting on dolphins or high seas driftnet fishing outside the ETP. Similarly, the proposed AIDCP dolphin-safe standard which Mexico identified as part of its proposed alternative measure would also not address the entirety of the adverse effects identified by the United States, insofar as it would not address unobserved mortalities from setting on dolphins, and any resulting adverse effects on dolphin populations" WTO. Panel Report, United States - Measures Concerning the Importation, Marketing and Sale of Tuna and Tuna Products. WT/DS381/R, 15 set. 2011. para. VII.1.

653 "We also note that, to the extent that the AIDCP standard addresses setting on dolphins and not other fishing techniques that may also result in adverse effects on dolphins, it would also not provide an effective or appropriate means of fulfilling the US objectives in this respect. VII.20 For all these reasons, we find that Mexico has failed to demonstrate that the AIDCP dolphin-safe standard is an effective and appropriate means to fulfil the US objectives at the United States' chosen level of protection" WTO. Panel Report, United States - Measures Concerning the Importation, Marketing and Sale of Tuna and Tuna Products. WT/DS381/R, 15 set. 2011. para. VII.19.

654 "For the reasons explained in Section VII of this Report, the Panel exercises judicial economy with respect to Mexico's claims under Articles I:1 and III:4 of the GATT 1994." WTO. Panel Report, United States - Measures Concerning the Importation, Marketing and Sale of Tuna and Tuna Products. WT/DS381/R, 15 set. 2011. para. VIII.2.

655 "[...] We therefore recommend that the DSB request the United States to bring its measures into conformity with its obligations under the TBT Agreement." WTO. Panel Report, United States - Measures Concerning the Importation, Marketing and Sale of Tuna and Tuna Products. WT/DS381/R, 15 set. 2011. para. VIII.3. 
comunicação das partes sobre apelação, o OSC aprovaria o relatório do painel em 20 de janeiro de 2012. ${ }^{656}$

Em 20 de janeiro de 2012, os EUA notificaram o OSC sobre sua decisão de apelar, ${ }^{657}$ o que também foi realizado pelo México em 25 de janeiro de $2012 .{ }^{658}$ Devido à complexidade das questões e ao acúmulo de casos sob revisão, o Órgão de Apelação informou, em 20 de março de 2012, que não conseguiria divulgar seu relatório no prazo de 90 dias. $^{659}$

O relatório do Órgão de Apelação foi divulgado em 16 de maio de 2012, modificando diversas interpretações desenvolvidas pelo painel. ${ }^{660}$ Embora tenha confirmado a interpretação de que as medidas questionadas consistiam em "regulamento técnico" para fins do Anexo 1.1 do TBT, o Órgão de Apelação reverteu o entendimento do painel no tocante à violação do artigo 2.1 do TBT, entendendo que as medidas em exame resultavam em tratamento menos favorável aos produtos de atum originários do México. ${ }^{661}$

O Órgão de Apelação reverteu, por outro lado, o reconhecimento de violação ao artigo 2.2 que havia sido formulado pelo painel, interpretando que a análise e comparação realizada pelo painel não teriam sido adequados, vez que as medidas alternativas

656 WTO. Joint request by Mexico and the United States for a decision by the DSB, United States Measures Concerning the Importation, Marketing and Sale of Tuna and Tuna Products. WT/DS381/9, 1 nov. 2011.

657 WTO. Notification of an Appeal by the United States under Article 16.4 and Article 17 of the Understanding on Rules and Procedures Governing the Settlement of Disputes (DSU), and under Rule 20(1) of the Working Procedures for Appellate Review, United States - Measures Concerning the Importation, Marketing and Sale of Tuna and Tuna Products. WT/DS381/10, 24 jan. 2012.

658 WTO. Notification of an Other Appeal by Mexico under Article 16.4 and Article 17 of the Understanding on Rules and Procedures Governing the Settlement of Disputes (DSU), and under Rule 23(1) of the Working Procedures for Appellate Review, United States - Measures Concerning the Importation, Marketing and Sale of Tuna and Tuna Products. WT/DS381/11, 27 jan. 2012.

659 WTO. Communication from the Appellate Body, United States - Measures Concerning the Importation, Marketing and Sale of Tuna and Tuna Products. WT/DS381/12, 22 mar. 2012.

660 WTO. Appellate Body Report, United States - Measures Concerning the Importation, Marketing and Sale of Tuna and Tuna Products. Report from the Appellate Body. WT/DS381/AB/R, 16 maio 2012.

661 "For the reasons set out in this Report, the Appellate Body: [...] (b) finds that the Panel erred in its interpretation and application of the phrase "treatment no less favourable" in Article 2.1 of the TBT Agreement; reverses the Panel's finding, in paragraphs 7.374 and 8.1(a) of the Panel Report, that the US "dolphin-safe" labelling provisions are not inconsistent with Article 2.1 of the TBT Agreement; and finds instead that the US "dolphin-safe" labelling provisions are inconsistent with Article 2.1 of the TBT Agreement [...]" WTO. Appellate Body Report, United States - Measures Concerning the Importation, Marketing and Sale of Tuna and Tuna Products. Report from the Appellate Body. WT/DS381/AB/R, 16 maio 2012. para. 407. 
argumentadas pelo demandante não trariam contribuição equivalente aos objetivos legítimos do demandado. ${ }^{662}$

No tocante à análise da violação do artigo 2.4, embora o Órgão de Apelação concorde com a conclusão do painel de que as medidas não seriam inconsistentes com referido dispositivo, reverteu a interpretação de que o standard mencionado seria um "relevante standard internacional" para o sentido daquele artigo. ${ }^{663}$

Por fim, o Órgão de Apelação entendeu que o painel agiu de maneira inconsistente com o artigo 11 do ESC na decisão de exercício de economia judicial. ${ }^{664}$ Desse modo, o Órgão de Apelação conclui seu relatório recomendando que o OSC requeresse aos EUA a adequação das medidas reconhecidas inconsistentes com o Acordo TBT. ${ }^{665}$

O relatório do Órgão da Apelação e o relatório do painel, com as devidas modificações, foram adotados em 13 de junho de $2012 .{ }^{666} \mathrm{Na}$ reunião do OSC de 25 de

662 "For the reasons set out in this Report, the Appellate Body: [...] (c) finds that the Panel erred in concluding, in paragraphs 7.620 and 8.1(b) of the Panel Report, that it has been demonstrated that the measure at issue is more trade restrictive than necessary to fulfil the United States' legitimate objectives, taking account of the risks non-fulfilment would create; and therefore reverses the Panel's finding that the measure at issue is inconsistent with Article 2.2 of the TBT Agreement; (d) rejects Mexico's claim that the Panel erred in finding that the United States' objective of "contributing to the protection of dolphins, by ensuring that the US market is not used to encourage fishing fleets to catch tuna in a manner that adversely affects dolphins" is a legitimate objective within the meaning of Article 2.2 of the TBT Agreement; (e) rejects Mexico's request to find the measure at issue inconsistent with Article 2.2 of the TBT Agreement based on the Panel's finding that the measure did not entirely fulfil its objectives [...]" WTO. Appellate Body Report, United States - Measures Concerning the Importation, Marketing and Sale of Tuna and Tuna Products. Report from the Appellate Body. WT/DS381/AB/R, 16 maio 2012. para. 407.

663 "For the reasons set out in this Report, the Appellate Body: [...] (f) reverses the Panel's finding, in paragraph 7.707 of the Panel Report, that the "AIDCP dolphin-safe definition and certification" constitute a "relevant international standard" within the meaning of Article 2.4 of the TBT Agreement. In the light of this, the Panel's finding, in paragraph 8.1(c) of the Panel Report, that the measure at issue is not inconsistent with Article 2.4 of the TBT Agreement stands [...] " WTO. Appellate Body Report, United States - Measures Concerning the Importation, Marketing and Sale of Tuna and Tuna Products. Report from the Appellate Body. WT/DS381/AB/R, 16 maio 2012. para. 407.

664 "For the reasons set out in this Report, the Appellate Body: (...) (g) finds that the Panel acted inconsistently with Article 11 of the DSU in deciding to exercise judicial economy with respect to Mexico's claims under Articles I:1 and III:4 of the GATT 1994.” WTO. Appellate Body Report, United States Measures Concerning the Importation, Marketing and Sale of Tuna and Tuna Products. Report from the Appellate Body. WT/DS381/AB/R, 16 maio 2012. para. 407.

665 "The Appellate Body recommends that the DSB request the United States to bring its measure, found in the Panel Report, as modified by this Report, to be inconsistent with the TBT Agreement, into conformity with its obligations under that Agreement." WTO. Appellate Body Report, United States Measures Concerning the Importation, Marketing and Sale of Tuna and Tuna Products. Report from the Appellate Body. WT/DS381/AB/R, 16 maio 2012. para. 408.

666 WTO. Appellate Body report and Panel report - Action by the Dispute Settlement Body, United States - Measures Concerning the Importation, Marketing and Sale of Tuna and Tuna Products. WT/DS381/15, 15 jun. 2012. 
junho de 2012, os EUA informaram sobre sua intenção de implementar a decisão do OSC e que, para tal, precisaria de um prazo razoável de tempo. ${ }^{667}$

Em 17 de setembro de 2012, as partes informaram ao OSC que haviam chegado a um acordo, nos termos do artigo 21.3(b) do ESC, estabelecendo que o período de tempo razoável para a implementação deveria ser de 13 meses, expirando em 13 de julho de 2013. 668

Em 11 de abril de 2013, aos EUA submeteram um relatório de acompanhamento, informando que em 5 de abril de 2013 haviam publicado a proposta de nova regra relacionada aos requerimentos para a etiqueta "dolphin-safe", com objetivo de implementação da decisão do OSC. ${ }^{669}$ Nos relatórios seguintes, foi apenas reiterada a mesma informação, não havendo menção a alteração no status de implementação. ${ }^{670} 671$

Em comunicado de 11 de julho de 2013, os EUA informaram que, em 9 de julho de 2013, havia sido publicada decisão final acerca do rótulo "dolphin-safe". Este novo regulamento requer que capitães, ou observadores qualificados, certifiquem que nenhum golfinho foi morto ou seriamente machucado durante operações de pesca fora do Oceano Pacífico tropical oriental. Deste modo, teria concluído a implementação da decisão do OSC no período de tempo razoável. ${ }^{672}$

Tendo em vista incertezas da parte dos EUA em relação à completa implementação do relatório do painel, como adotado pelo OSC, em 2 de agosto de 2013 as partes notificaram ao OSC sobre a celebração de um acordo relativo aos artigos 21 e 22 do ESC. 673

667 WTO. Communication from Mexico and the United States concerning Article 21.3(c) of the DSU, United States - Measures Concerning the Importation, Marketing and Sale of Tuna and Tuna Products. WT/DS381/16, 6 ago. 2012.

668 WTO. Agreement under article 21.3(b) of the DSU, United States - Measures Concerning the Importation, Marketing and Sale of Tuna and Tuna Products. WT/DS381/17, 19 set. 2012.

669 WTO. Status report by the United States, United States - Measures Concerning the Importation, Marketing and Sale of Tuna and Tuna Products. WT/DS381/18, 12 abr. 2013.

670 WTO. Status report by the United States (Addendum), United States - Measures Concerning the Importation, Marketing and Sale of Tuna and Tuna Products. WT/DS381/18/Add.1, 14 maio 2013.

671 WTO. Status report by the United States (Addendum), United States - Measures Concerning the Importation, Marketing and Sale of Tuna and Tuna Products. WT/DS381/18/Add.2, 14 jun. 2013.

672 WTO. Status report by the United States (Addendum), United States - Measures Concerning the Importation, Marketing and Sale of Tuna and Tuna Products. WT/DS381/18/Add.3, 12 jul. 2013.

673 WTO. Understanding Between The United States And Mexico Regarding Procedures Under Articles 21 and 22 of the DSU, United States - Measures Concerning the Importation, Marketing and Sale of Tuna and Tuna Products. WT/DS381/19, 7 ago. 2013. 
Em 14 de novembro de 2013, o México requisitou a formação de um painel de verificação de cumprimento. ${ }^{674}$ Em 22 de janeiro de 2014, o OSC decidiu submeter o exame ao painel original e, em 27 de janeiro de 2014 , o painel foi composto. ${ }^{675}$

Austrália, Canadá, China, União Europeia, Guatemala, Japão, República da Coreia, Noruega, Nova Zelândia e Tailândia reservaram seus direitos como terceira parte no painel. Até a conclusão deste trabalho, o painel continua a realizar seus trabalhos, e espera emitir relatório final às partes em dezembro de 2014 . $^{676}$

\subsubsection{Observações}

O primeiro caso dessa seção tratou de medida relacionada ao TRIPS. Pela natureza das obrigações entabuladas neste acordo, é de se esperar que os casos comumente questionem aspectos da legislação interna responsável por sua implementação. Isso pois o TRIPS prevê standards mínimos, limites básicos de proteção que devem ser observadas na normativa interna.

No caso em tela, a China estava em desconformidade ao não garantir direitos autorais mínimos a obras de circulação não autorizada, bem como pela destinação dada a produtos contrafeitos. As medidas de implementação foram concretizadas pela China, por meio de emendas à legislação concretizadas pelo Congresso, e por meio de medidas administrativas realizadas pelo Conselho de Estado.

674 WTO. Recourse to article 21.5 of the DSU by Mexico - Request for the establishment of a panel, United States - Measures Concerning the Importation, Marketing and Sale of Tuna and Tuna Products. Documento WT/DS381/20, 15 nov. 2013.

675 WTO. Recourse to article 21.5 of the DSU by Mexico - Constitution of the Panel - Note by the Secretariat, United States - Measures Concerning the Importation, Marketing and Sale of Tuna and Tuna Products. WT/DS381/21, 6 fev. 2014.

676 WTO. Recourse to article 21.5 of the DSU by Mexico - Communication from the Panel, United States - Measures Concerning the Importation, Marketing and Sale of Tuna and Tuna Products. WT/DS381/22, 17 abr. 2014. 
Embora o ingresso da China na OMC tenha suscitado diversas dúvidas sobre a sua capacidade de implementar os Acordos e as decisões do OSC, nesta oportunidade a implementação ocorreu de modo diligente, e dentro do prazo estabelecido.

No tocante ao segundo caso analisado nessa seção, a violação encontrada refere-se ao Acordo TBT, que prevê normas em relação ao estabelecimento de barreiras técnicas ao comércio pelos Estados. Não é possível confirmar se a medida executada pelos EUA trouxe efetivamente a implementação, uma vez que o painel de acompanhamento continua os seus trabalhos, pendente de decisão. A medida de suposta implementação, concretizada pelos EUA, tratou-se de ato administrativo em modificação ao regulamento. 


\title{
4 IMPLEMENTAÇÃO DAS DECISÕES DO SISTEMA DE SOLUÇÃO DE CONTROVÉRSIAS DA OMC: EXPERIÊNCIAS, MECANISMOS E VARIÁVEIS
}

\subsection{Aspectos Relevantes da Implementação}

Uma vez adotado o relatório, e explanada a decisão pelo OSC, deve-se promover " $O$ pronto cumprimento das recomendações e decisões do OSC". ${ }^{677} \mathrm{O}$ conceito de "pronto cumprimento" se concretiza por meio da (i) retirada/ revogação da medida; ou (ii) modificação da medida, na parte que contenha a violação reconhecida pelo(s) relatório(s) adotado(s).

Este foi o entendimento explicitado no laudo do árbitro no caso Argentina Measures Affecting the Export of Bovine Hides and Import of Finished Leather:

\begin{abstract}
[A] medida desconforme deve ser levada ao estado de conformidade com as disposições dos tratados específicos, ou revogando tal medida completamente, ou modificando-a de maneira a corrigir a parte ofensiva da medida em questão. Se a medida desconforme é um estatuto, um estatuto revogador ou modificador é normalmente necessário. Se a medida em causa é um regulamento administrativo, um novo estatuto pode ou não ser necessário, mas um regulamento revogador ou modificador é normalmente necessário.

Parece, assim, que o conceito de cumprimento ou implementação prescrita no ESC é um conceito técnico com um conteúdo específico: a retirada ou alteração de uma medida, ou parte de uma medida, cujo estabelecimento ou aplicação por um membro da OMC constituiu a violação de uma disposição de um acordo abrangido 678679
\end{abstract}

677 Artigo 21.1: "O pronto cumprimento das recomendações e decisões do OSC é fundamental para assegurar a efetiva solução das controvérsias, em beneficio de todos os Membros.” Entendimento Relativo às Normas e Procedimentos sobre Solução de Controvérsias. Versão oficial em português segundo o decreto n. 1.355, de 30 dez. 1994, que promulga a Ata Final que Incorpora os Resultados da Rodada Uruguai de Negociações Comerciais Multilaterais do GATT.

678 Tradução livre do original em língua inglesa: "[T]he non-conforming measure is to be brought into a state of conformity with specified treaty provisions either by withdrawing such measure completely, or by modifying it by excising or correcting the offending portion of the measure involved. Where the non- 
De modo similar, o árbitro do caso Japan - Countervailing Duties on Dynamic Random Access Memories from Korea, assim consignou:

[U]m Membro cuja medida tenha sido considerada incompatível com os acordos abrangidos em geral pode escolher entre dois cursos de ação: a retirada da medida; ou a modificação da medida por medidas corretivas. Enquanto a retirada possa ser a opção preferida para assegurar "o cumprimento imediato", um Membro pode, se a retirada for considerada impraticável, optar por modificar a medida, desde que isso seja feito no menor tempo possível, e que tal modificação seja permitida pelas recomendações e decisões do OSC. ${ }^{680}$

No caso Colombia - Indicative Prices and Restrictions on Ports of Entry, o árbitro ponderou que o artigo 3.7 do ESC prevê uma preferência na retirada da medida como meio de implementação, conduto existiriam outras condutas possíveis por parte do membro demandado:

No entanto, não excluo que a Colômbia poderia tornar-se em conformidade com as recomendações e decisões do OSC por meio da modificação do mecanismo de preços indicativos e dos portos de entrada relativos à medida de uma forma que retifica as inconsistências específicas com a OMC identificadas pelo Painel. A meu ver, a modificação tanto do mecanismo de preços indicativos quanto dos portos de entrada relativos à medida está inserida no "leque de ações permitidas"

conforming measure is a statute, a repealing or amendatory statute is commonly needed. Where the measure involved is an administrative regulation, a new statute may or may not be necessary, but a repealing or amendatory regulation is commonly required. It thus appears that the concept of compliance or implementation prescribed in the DSU is a technical concept with a specific content: The withdrawal or modification of a measure, or part of a measure, the establishment or application of which by a Member of the WTO constituted the violation of a provision of a covered agreement [...]" WTO. Award of the Arbitrator, Argentina - Measures Affecting the Export of Bovine Hides and Import of Finished Leather (Arbitration under Article 21.3(c) of the DSU), WT/DS155/10, 31 ago. 2001. paras. 40-41.

$679 \quad$ Nota de rodapé originariamente contida no texto: "The non-conforming measure might also assume other forms: e.g., an executive or administrative practice actually carried out but not specifically mandated or authorized by statute or administrative regulation; or a "quasi-judicial" determination by an administrative body. Since the Argentine measures involved in this arbitration are not of these kinds, it is not necessary to examine the requirements of compliance where those other kinds of measures are concerned." 680 Tradução livre do original em língua inglesa: "[A] Member whose measure has been found to be inconsistent with the covered agreements may generally choose between two courses of action: withdrawal of the measure; or modification of the measure by remedial action. While withdrawal may be the preferred option to secure "prompt compliance", a Member may, where withdrawal is deemed impracticable, choose to modify the measure, provided that this is done in the shortest time possible, and that such modification is permissible under the DSB's recommendations and rulings." WTO. Award of the Arbitrator, Japan Countervailing Duties on Dynamic Random Access Memories from Korea (Arbitration under Article 21.3(c) of the DSU). WT/DS336/16, 5 maio 2008. para. 37. 
disponíveis para a Colômbia no intuito de implementar as recomendações e decisões do OSC nesta disputa. 681

Este dever de "pronto cumprimento", contudo, aceita certa flexibilidade na concretização da decisão do Sistema de Solução de Controvérsias, expressa inclusive por meio do período razoável de tempo para o cumprimento, como explicitado pelo árbitro no caso Chile - Taxes on Alcoholic Beverages:

\begin{abstract}
O ESC salientou claramente o interesse sistêmico de todos os membros da OMC no cumprimento "imediato" das recomendações e decisões do OSC pelo membro responsável pela implementação. Lendo os artigos 21.1 e 21.3 em conjunto, "pronto" cumprimento é, em princípio, o cumprimento "imediato". Ao mesmo tempo, no entanto, caso o cumprimento "imediato" seja "impraticável" - pode-se notar que o ESC não usa o termo "impossível", muito mais rigoroso - o membro em questão torna-se habilitado a um "período de tempo razoável" para tornar-se em conformidade com suas obrigações na OMC. Claramente, um certo elemento de flexibilidade em relação ao tempo é construído na noção de cumprimento das recomendações e decisões do OSC. Esse elemento parece ser essencial para que o "pronto" cumprimento", num mundo de Estados soberanos, seja uma concepção equilibrada e objetiva. ${ }^{682}$
\end{abstract}

Assim, embora a concretização da decisão do OSC, como vocalizador das decisões do Sistema de Solução de Controvérsias da OMC, exija o esforço de implementação por parte do membro faltoso, cabe-lhe um espaço de discricionariedade na escolha do meio pelo qual procederá à implementação. Este espaço conferido ao membro, contudo, não é

681 Tradução livre do original em língua inglesa: "However, I do not exclude that Colombia could bring itself into conformity with the recommendations and rulings of the DSB by modifying both the indicative prices mechanism and the ports of entry measure in a manner that rectifies the particular WTOinconsistencies identified by the Panel. In my view, modification of both the indicative prices mechanism and the ports of entry measure is within the "range of permissible actions" available for Colombia to implement the recommendations and rulings of the DSB in this dispute." WTO. Award of the Arbitrator, Colombia Indicative Prices and Restrictions on Ports of Entry (Arbitration under Article 21.3(c) of the DSU) WT/DS366/13, 2 out. 2009. para. 77.

682 Tradução livre do original em língua inglesa: "The DSU clearly stressed the systemic interest of all WTO Members in the Member concerned complying 'immediately' with the recommendations and rulings of the DSB. Reading Articles 21.1 and 21.3 together, 'prompt' compliance is, in principle, 'immediate' compliance. At the same time, however, should 'immediate' compliance be 'impracticable' — it may be noted that the DSU does not use the far more rigorous term 'impossible' - the Member concerned becomes entitled to a 'reasonable period of time' to bring itself into a state of conformity with its WTO obligations. Clearly, a certain element of flexibility in respect of time is built into the notion of compliance with the recommendations and rulings of the DSB. That element would appear to be essential if 'prompt' compliance, in a world of sovereign states, is to be a balanced conception and objective." WTO. Award of the Arbitrator, Chile - Taxes on Alcoholic Beverages (Arbitration under Article 21.3(c) of the DSU). WT/DS87/15, WT/DS110/14, 23 maio 2000. para. 38. 
ilimitado, estando os desvios possivelmente sujeitos à apreciação posterior pelo Sistema de Solução de Controvérsias.

\subsection{Breve Exame da Implementação por Outros Membros}

A implementação das decisões do Sistema de Solução de Controvérsias da OMC envolve diversas variáveis, não somente ligadas à natureza da medida questionada em face da disciplina multilateral, mas principalmente relacionadas à especificidades dos sistemas jurídicos internos dos respectivos membros. A complexidade da implementação, portanto, aumenta na medida em que cada ordenamento jurídico interno possui um arranjo próprio entre os poderes e os respectivos órgãos envolvidos nas diversas temáticas que - embora tenham sido elevadas à normatização internacional - pertencem classicamente ao âmbito de atuação das instituições nacionais.

A título de evidenciação de tais complexidades, e das diversas abordagens incidentes sobre o tratamento das decisões do sistema multilateral de comércio, propõe-se uma breve introdução às perspectivas dos principais participantes do Sistema de Solução de Controvérsias da OMC, respectivamente: Estados Unidos, União Europeia, Japão e China.

\subsubsection{Estados Unidos da América}

No que tange aos Estados Unidos da América (EUA), desde o GATT há um posicionamento claro e explícito no sentido de afastar dos Acordos comerciais o efeito de 
autoexecutoriedade. ${ }^{683}$ Em uma perspectiva dualista, portanto, a obrigação existente no Direito Internacional não se comunica com o direito (interno) aplicável pelos tribunais norte-americanos. ${ }^{684}$

É nítida a percepção de que os EUA, um dos principais atores do sistema, acumulam diversos casos de não implementação das decisões. ${ }^{685}$ Há, contudo, reconhecimento de modificações legislativas relevantes que foram resultado de decisões do Sistema de Solução de Controvérsias, tendo os EUA frequentemente prometido a implementação de decisões que lhe tenham sido desfavoráveis.

Para uma análise consciente das bases internas, bem como dos procedimentos previstos para a implementação, faz-se necessário brevemente explicitar a construção do parâmetro Charming Betsy, e de seu confronto com a doutrina Chevron, e com o Ato que adota os Acordos da Rodada do Uruguai (Uruguai Round Agreements Act- URAA).

O princípio Charming Betsy, construído há mais de duzentos anos, enuncia que "um ato do Congresso nunca deverá ser interpretado de forma a violar a lei das nações, se resta qualquer outra construção possível." 686 Segundo este cânone, tribunais norteamericanos devem interpretar as leis de modo consistente com o Direito Internacional, a menos que haja uma expressão clara de intenção em contrário oriunda do Poder Legislativo.

Contudo, em diversos casos os tribunais norte-americanos tem se isentado de

683 Assim consta de relatório de consultora do Congresso Norte-Americano sobre o assunto: "As is the case with previous trade agreements, including the North American Free Trade Agreement (NAFTA) and the GATT Tokyo Round agreements, Congress considers the Uruguay Round agreements to be non-selfexecuting; that is, their legal effect in the United States is based on their implementing legislation (i.e., the Uruguay Round Agreements Act (URAA)). To this end, the URAA approves the agreements and contains provisions "necessary or appropriate" to implement them." GRIMMETT, Jeanne J. World Trade Organization (WTO) decisions and their effect in U.S. law. Washington, DC: Congressional Research Service, 2011. Disponível em: <http://digitalcommons.ilr.cornell.edu/key_workplace/807>. Acesso em: 10 mar. 2014. p. 1.

684 JACKSON, John. Sovereignty, the WTO and Changing Fundamentals of International Law. New York: Cambridge Univeristy Press, 2006. p. 126.

685 Segundo a análise de Carlos Cozendey: "Cerca de metade desses casos [11 casos, ao final do primeiro semestre de 2007] envolvem temas de implementação administrativa, boa parte relacionada a temas de defesa comercial, enquanto a outra metade envolve temas que requerem ação legislativa, algumas de interesse direto para o Brasil, como o caso dos subsídios ao algodão." COZENDEY, Carlos Márcio Bicalho. O Sistema de Solução de Controvérsias da OMC: para além dos contenciosos, a política externa. Disponível em: $\quad<\mathrm{http} / /$ www.itamaraty.gov.br/temas/temas-multilaterais/copy_of_desenvolvimentocomercio-e-financas/organizacao-mundial-do-comercio/solucao-de-controversias/cgc/artigo-cozendey> Acesso em: 15 dez. 2013. p. 16.

686 Tradução livre do original em língua inglesa: "an act of Congress ought never be construed to violate the law of nations, if any other possible construction remains." Murray v. The Schooner Charming Betsy, 6. U.S. (2 Cranch) 64, 118 (1804). 
aplicar esse cânone interpretativo em relação aos Acordos da OMC e às decisões do OSC. Em casos nos quais a decisão de uma agência federal é inconsistente com as obrigações multilaterais - notadamente em demandas relacionadas ao zeroing como metodologia para cálculo de dumping - ${ }^{687}$ os tribunais afastaram a aplicação do princípio Charming Betsy em prol da doutrina Chevron, ${ }^{688}$ pela qual deve ser conferida deferência à interpretação do órgão executivo. ${ }^{689} 690$

O princípio Charming Betsy é um sólido pilar interpretativo consolidado na Suprema Corte norte-americana, que pugna pela interpretação da legislação interna conforme o Direito Internacional - costumeiro ou oriundo de acordos dos quais os EUA sejam parte. Assim, se as decisões do OSC são vistas como integrantes do direito internacional, vinculantes às partes em disputa, devem ser parâmetros para a interpretação conforme da legislação interna. ${ }^{691}$

Contudo, como se abordará, o sistema jurídico norte-americano preferiu evidenciar em leis os procedimentos pelos quais o relatório dos órgãos adjudicatórios do Sistema de Solução de Controvérsias da OMC poderia ser implementado, em expressão da vontade do legislador em limitar a relação do Sistema de Solução de Controvérsias com o direito interno norte-americano. ${ }^{692}$

687 CANIZARES, Alex O. Is Charming Betsy Loosing Her Charm? Interpreting U.S. Statutes Consistently with International Trade Agreements and the Chevron Doctrine. Emory International Law Review, vol. 20, p. 592-650, 2006.

688 Chevron, U.S.A., Inc. v. Natural Res. Def. Council, Inc., 467 U.S. 837 (1984).

689 Conforme relata o autor: "In the 2005 Corus Staal v. Department of Commerce (Corus Staal II) case,' the Federal Circuit deferred to the Department of Commerce's (Commerce)' reading of an antidumping provision, refusing to overturn the Department's "zeroing" practice "based on any ruling of the WTO or other international body unless and until such ruling has been adopted" by the political branches. The court held that DSB reports "have no binding effect" in U.S. courts, rejecting the argument that they should have an effect, and therefore are governed by Charming Betsy." CANIZARES, Alex O. Is Charming Betsy Loosing Her Charm? Interpreting U.S. Statutes Consistently with International Trade Agreements and the Chevron Doctrine. Emory International Law Review, vol. 20, p. 592-650, 2006. p. 593.

$690 \mathrm{Na}$ análise de Carla Amaral de Andrade Junqueira: "A jurisprudência americana sugere certa deferência por parte do judiciário as medidas tomadas por autoridades administrativas domesticas, sendo o principal exemplo a denominada Doutrina Chevron, que ficou amplamente conhecida nos EUA, no final da década de 80, e pela qual se outorgava às agencias reguladoras estadunidenses a prerrogativa de definir, em caso de ambiguidade da norma, a melhor interpretação para ela. Nem mesmo o Poder Judiciário poderia substituir a interpretação realizada pelas agências, nessas hipóteses, por outra própria." JUNQUEIRA, Carla Amaral de Andrade. A Técnica Interpretativa do Órgão de Apelação da Organização Mundial do Comércio. 2010. 268 f. Tese (Doutorado em Direito) - Faculdade de Direito, Universidade de São Paulo, São Paulo. p. 69-70.

691 CANIZARES, Alex O. Is Charming Betsy Loosing Her Charm? Interpreting U.S. Statutes Consistently with International Trade Agreements and the Chevron Doctrine. Emory International Law Review, vol. 20, p. 592-650, 2006. p. 600.

692 RYAN, John M. Interplay of of WTO and U.S. Domestic Judicial Review: When the Same U.S. Administrative Determinations Are Appealed Under the WTO Agreements and Under U.S. Law, Do the 
A aplicação do princípio Charming Betsy em relação às decisões do Sistema de Solução de Controvérsias da OMC se difere, a depender do tema em questão, expressando distintos graus de propensão dos órgãos domésticos norte-americanos à convergência com os julgados multilaterais. Na avaliação de subsídios, relativas ao caso DS212, ${ }^{693}$ por exemplo, a Corte acabou seguindo a mesma interpretação do Órgão de Apelação, mas explicitando que não estava obrigada pelo relatório daquele órgão da OMC. ${ }^{694} 695$ Já nos múltiplos casos ligados à metodologia do zeroing - como por exemplo o caso DS322 - os tribunais de modo majoritário negaram a aplicação do princípio Charming Betsy, preferindo acolher o parâmetro Chevron. ${ }^{696} 697$

Por outro lado, sob uma perspectiva evolutiva, autores afirmam que o princípio do Charming Betsy teria passado por uma modificação temporal em sua aplicabilidade em

Respective Decisions and Available Remedies Coexist or Collide? Tulane Journal of International \& Comparative Law, vol. 17, p. 353-387, 2008-2009. p. 426.

693 WTO. Appellate Body Report, United States - Countervailing Measures Concerning Certain Products from the European Communities. WT/DS212/AB/R, 9 dez. 2002.

694 Confira, a exemplo, o precedente: "[...] this court recognizes that the Charming Betsy doctrine is only a guide; the WTO's appellate report does not bind this court in construing domestic countervailing duty law. Nonetheless, this guideline supports the trial court's judgment." Allegheny Ludlum Corp. vs. United States, 367 E3d 1348 (Fed. Cir. 2004). RYAN, John M. Interplay of of WTO and U.S. Domestic Judicial Review: When the Same U.S. Administrative Determinations Are Appealed Under the WTO Agreements and Under U.S. Law, Do the Respective Decisions and Available Remedies Coexist or Collide? Tulane Journal of International \& Comparative Law, vol. 17, p. 353-387, 2008-2009. p. 353-387.

695 Em síntese: “[...] courts have not viewed $\$ 102$ (c) of the URAA as preventing them from hearing a WTO-based argument in these challenges. 31 When faced with such arguments, some federal courts have deemed WTO. decisions to be "persuasive" or a source of useful reasoning, "if sound," to inform a court's decision, but have stated that WTO decisions are not binding on the United States, U.S. agencies, or the judiciary. More commonly, however, federal courts have made clear that, given the statutory scheme established in the URAA for implementing adverse WTO decisions, questions as to whether the United States should comply with an adverse WTO decision and what the extent of U.S. compliance should be are matters falling within the province of the executive branch." GRIMMETT, Jeanne J. World Trade Organization (WTO) decisions and their effect in U.S. law. Washington, DC: Congressional Research Service, 2011. Disponível em: <http://digitalcommons.ilr.cornell.edu/key_workplace/807>. Acesso em: 10 mar. 2014. p. 89.

696 Um dos precedentes mais citados é o caso Cours Staal: "[w]e will not attempt to perform duties that fall within the exclusive province of the political branches, and we therefore refuse to overturn Commerce's zeroing practice based on any ruling by the WTO or other international body unless and until such ruling has been adopted pursuant to the specified statutory scheme." Corus Staal, BV v. Department of Commerce, 395 E3d 1343, 1349 (Fed. Cir. 2005). RYAN, John M. Interplay of of WTO and U.S. Domestic Judicial Review: When the Same U.S. Administrative Determinations Are Appealed Under the WTO Agreements and Under U.S. Law, Do the Respective Decisions and Available Remedies Coexist or Collide? Tulane Journal of International \& Comparative Law, vol. 17, p. 353-387, 2008-2009.

697 Assim explica a autora: "The issue of the interaction of Chevron and Charming Betsy appears to have arisen most frequently in court cases challenging Commerce Department antidumping determinations in which dumping margins were calculated with the use of "zeroing," [...] U.S. courts, using the Chevron standard of review, have regularly held that, although the U.S. antidumping statute does not unambiguously require zeroing, the Commerce Department's interpretation of the statute as allowing the practice is a permissible one [...]" GRIMMETT, Jeanne J. World Trade Organization (WTO) decisions and their effect in U.S. law. Washington, DC: Congressional Research Service, 2011. Disponível em: $<$ http://digitalcommons.ilr.cornell.edu/key_workplace/807>. Acesso em: 10 mar. 2014. 
relação às decisões do OSC da OMC. De 2002 a 2004, teria havido certa compatibilidade e aplicação do raciocínio do Charming Betsy pelas Cortes norte-americanas e pela Corte de Comércio Internacional (United States Court of International Trade- USCIT). Após 2005, com um precedente que reafirmava a decisão no caso Corus Staal I, passou-se a conceder primazia aos dispositivos do URAA sob uma análise com base no parâmetro Charming Betsy. 698699700

O URAA, legislação que orienta a aplicação dos Acordos da OMC e das decisões do Sistema de Solução de Controvérsias no ordenamento norte-americano, é claro em diversos sentidos, ao buscar afastar qualquer direito das partes privadas:

\footnotetext{
(C) EFEITO DE ACORDO COM RESPEITO AOS RECURSOS PRIVADOS

(1) LIMITATIONS.-Nenhuma pessoa que não os Estados Unidos,

(A) deve ter qualquer causa de ação ou de defesa ao abrigo dos acordos da Rodada Uruguai, ou em virtude de aprovação no Congresso de um acordo desse tipo, ou

(B) pode impugnar, em qualquer ação ajuizada ao abrigo de qualquer disposição de direito, qualquer ação ou omissão por parte de qualquer departamento, agência ou outra instrumentalidade dos Estados Unidos, qualquer estadomembro, ou qualquer subdivisão política de um estado-membro, alegando que tal ação ou omissão é incompatível com tal acordo. ${ }^{701}$
}

O mesmo documento afirma a impossibilidade de uma parte privada requerer a implementação direta de um relatório dos painéis e/ou Órgão de Apelação, vez que

698 Para uma análise extensiva dos casos antes e após a mudança de precedentes, Cf: DAVENPORT, Filicia. The Uruguay Round Agreements Act Supremacy Clause: Congressional Preclusion of the Charming Betsy Standard with Respect to WTO Agreements. The Federal Circuit Bar Journal, vol. 15, n. 2, p. 279314, 2005-2006.

699 Para uma análise do caso, e reflexão sobre a mudança de posicionamento, Cf: GREENWALD, John D. After Corus Staal-Is There Any Role, And Should There Be-For Wto Jurisprudence In The Review Of U.S. Trade Measures By U.S. Courts? Georgetown Journal of International Law, vol. 39, p. 199-216, 2007-2008.

700 Para uma visão crítica, sugerindo que o parâmetro Charming Betsy deve se manter em primazia, prestando-se ao papel de expressar desaprovação pelo judiciário norte-americano em relação à falha das agências executivas em adotar interpretações consistentes com a OMC, Cf: DAVIES, Arwel. Connecting or Compartmentalizing the WTO and United States Legal Systems? The Role Of The Charming Betsy Canon. Journal of International Economic Law, vol. 10, issue 1, p. 117-149, jan. 2007.

701 Tradução livre do original em língua inglesa: “(c) EFFECT OF AGREEMENT WITH RESPECT TO PRIVATE REMEDIES (1) LIMITATIONS.-No person other than the United States - (A) shall have any cause of action or defense under any of the Uruguay Round Agreements or by virtue of congressional approval of such an agreement, or (B) may challenge, in any action brought under any provision of law, any action or inaction by any department, agency, or other instrumentality of the United States, any State, or any political subdivision of a State on the ground that such action or inaction is inconsistent with such agreement." Uruguay Round Agreements Act (URAA), section 102. Disponível em: <http://www.gpo.gov/fdsys/pkg/BILLS-103hr5110enr/pdf/BILLS-103hr5110enr.pdf> Acesso em: 10 jul. 2014. 
somente o Congresso e órgãos da Administração poderiam decidir se implementarão uma recomendação do painel e, caso decidam por implementá-la, como o farão. ${ }^{702}$

Assim, logo em seguida à divulgação de um relatório, o United States Trade Representative (USTR- Representante dos EUA para o Comércio) ${ }^{703}$ deve: (i) notificar as respectivas Comissões Parlamentares; (ii) consultar as Comissões Parlamentares sobre uma apelação a ser feita; (iii) sendo o relatório desfavorável aos EUA, deve ainda consultar as respectivas Comissões Parlamentares sobre se o relatório será implementado, qual será a maneira de implementação e o período necessário para tal. ${ }^{704}$

É ainda no URAA que encontramos a previsão de dois procedimentos pelos quais "um relatório da OMC" pode ser implementado no direito norte-americano. Em ambos os procedimentos, contudo, a implementação só é possível caso não haja conflito com leis norte-americanas, situação na qual se exige conduta por parte do Congresso dos EUA. ${ }^{705}$

O primeiro procedimento, constante da seção 123 do URAA, prevê os passos para a modificação de um regulamento ou prática de uma agência (Poder Executivo), que esteja em desconformidade com a OMC. O USTR e o Departamento de Comércio (Department of Commerce - DOC) devem realizar consultas a Comissões do Congresso e a Comitês do setor privado, bem como à esfera pública em geral, antes de definirem como e quando

702 BARNETT, Mark A. The United States Court of International Trade in the Middle-International Tribunals: An Overview. Tulane Journal of International \& Comparative Law, vol. 19, p. 421-432, 20102011. p. 423.

703 Para uma perspectiva geral da história e competências do USTR, e em especial comparação com a estrutura institucional da CAMEX, Cf: RAMOS, Guilherme Cantarino da Costa. IBI - the institute of brazilian business \& public management issues. Minerva program - spring 2010. CAMEX and USTR: an institutional analysis of the conduct of trade policy in brazil and the U.S. Elliot School of International Affairs. George Washington University. Washington DC, abr. 2010. Disponível em: $<$ http://www.gwu.edu/ ibi/minerva/Spring2010/Ramos.pdf $>$. Acesso em: 10 jul. 2014.

704 É o que se verifica no seguinte trecho do URAA: “(f) Actions upon circulation of reports: Promptly after the circulation of a report of a panel or of the Appellate Body to WTO members in a proceeding described in subsection (d) of this section, the Trade Representative shall- (1) notify the appropriate congressional committees of the report; (2) in the case of a report of a panel, consult with the appropriate congressional committees concerning the nature of any appeal that may be taken of the report; and (3) if the report is adverse to the United States, consult with the appropriate congressional committees concerning whether to implement the report's recommendation and, if so, the manner of such implementation and the period of time needed for such implementation." Uruguay Round Agreements Act (URAA), section 123 Disponível em: <http://www.gpo.gov/fdsys/pkg/BILLS-103hr5110enr/pdf/BILLS-103hr5110enr.pdf>. Acesso em: 10 jul. 2014.

705 A este respeito: “[...] section 102 of the URAA and its legislative history establish that domestic law supersedes any inconsistent provisions of WTO agreements approved and implemented in the URAA and that WTO decisions involving U.S. laws or regulatory actions that are successfully challenged in the WTO do not have direct or automatic legal effect in the United States." GRIMMETT, Jeanne J. World Trade Organization (WTO) decisions and their effect in U.S. law. Washington, DC: Congressional Research Service, 2011. Disponível em: <http://digitalcommons.ilr.cornell.edu/key_workplace/807>. Acesso em: 10 mar. 2014. p. 1. 
implementar um relatório da OMC. ${ }^{706}$

Assim, segundo este procedimento, para que seja promovida a mudança da prática ou regulamento de uma agência norte-americana, com o intuito de adequação à disciplina multilateral, é necessário assegurar:

(i) consulta às respectivas Comissões do Congresso, com apresentação de Relatório por parte do USTR, explanando as razões da modificação proposta;

(ii) consulta ao setor privado, por meio de Comitês estabelecidos para esta finalidade;

(iii) oportunidade pública de comentários à modificação proposta, mediante sua publicação com a respectiva explanação justificadora;

(iv) publicação da modificação final. ${ }^{707}$

Há também uma regra temporal que prevê que a modificação final entrará em vigor apenas 60 dias depois da consulta formulada às Comissões do Congresso relativa à versão final da modificação, a menos que o Presidente, fundado em interesse nacional, determine de modo diverso. ${ }^{708}$ Durante este período de 60 dias, a Comissão de Meios e Andamentos da Câmara dos Deputados e a Comissão de Finanças do Senado podem se manifestar por

706 BARNETT, Mark A. The United States Court of International Trade in the Middle-International Tribunals: An Overview. Tulane Journal of International \& Comparative Law, vol. 19, p. 421-432, 20102011. p. 424.

707 "Section 123(g): Requirements for agency action (1) Changes in agency regulations or practice- In any case in which a dispute settlement panel or the Appellate Body finds in its report that a regulation or practice of a department or agency of the United States is inconsistent with any of the Uruguay Round Agreements, that regulation or practice may not be amended, rescinded, or otherwise modified in the implementation of such report unless and until-(A) the appropriate congressional committees have been consulted under subsection (f) of this section; (B) the Trade Representative has sought advice regarding the modification from relevant private sector advisory committees established under section 2155 of this title; (C) the head of the relevant department or agency has provided an opportunity for public comment by publishing in the Federal Register the proposed modification and the explanation for the modification; (D) the Trade Representative has submitted to the appropriate congressional committees a report describing the proposed modification, the reasons for the modification, and a summary of the advice obtained under subparagraph (B) with respect to the modification; (E) the Trade Representative and the head of the relevant department or agency have consulted with the appropriate congressional committees on the proposed contents of the final rule or other modification; and $(F)$ the final rule or other modification has been published in the Federal Register." Uruguay Round Agreements Act (URAA), section 123 Disponível em: $<$ http://www.gpo.gov/fdsys/pkg/BILLS-103hr5110enr/pdf/BILLS-103hr5110enr.pdf>. Acesso em: 10 jul. 2014.

708 "Section 123(g): Requirements for agency action (2) Effective date of modification-A final rule or other modification to which paragraph (1) applies may not go into effect before the end of the 60-day period beginning on the date on which consultations under paragraph (1)(E) begin, unless the President determines that an earlier effective date is in the national interest." Uruguay Round Agreements Act (URAA), section 123 Disponível em: <http://www.gpo.gov/fdsys/pkg/BILLS-103hr5110enr/pdf/BILLS-103hr5110enr.pdf>. Acesso em: 10 jul. 2014. 
meio de votação, mas o posicionamento expresso na votação não será vinculante sob a agência ou departamento que procede à implementação. ${ }^{709}$

O Segundo procedimento, constante da seção 129 do URAA, tem o escopo mais restrito que o primeiro, ${ }^{710}$ aplicando-se especificamente à ação da International Trade Comission (ITC, Comissão para o Comércio Internacional dos EUA) em casos relativos ao Acordo Antidumping e ao Acordo sobre Salvaguardas, bem como ao Acordo sobre Subsídios e Medidas Compensatórias. No caso da implementação necessária se relacionar a um destes acordos, o USTR pode requerer à ITC um parecer (advisory report) sobre a compatibilidade da modificação a ser implementada com certos dispositivos de direito interno ${ }^{711} \mathrm{e}$, a depender do resultado deste parecer, deve ser também realizada consulta às respectivas Comissões do Congresso. ${ }^{712}$

Se a maioria dos membros da ITC se posicionar a favor da modificação, a Comissão deve emanar uma determinação de modo a tornar compatível a medida com a

709 "Section 123(g): Requirements for agency action (3) Vote by congressional committees- During the 60-day period described in paragraph (2), the Committee on Ways and Means of the House of Representatives and the Committee on Finance of the Senate may vote to indicate the agreement or disagreement of the committee with the proposed contents of the final rule or other modification. Any such vote shall not be binding on the department or agency which is implementing the rule or other modification." Uruguay Round Agreements Act (URAA), section 123 Disponível em: $<$ http://www.gpo.gov/fdsys/pkg/BILLS-103hr5110enr/pdf/BILLS-103hr5110enr.pdf $>$. Acesso em: 10 jul. 2014.

710 Uruguay Round Agreements Act (URAA), section 129. Disponível em: $<$ http://www.gpo.gov/fdsys/pkg/BILLS-103hr5110enr/pdf/BILLS-103hr5110enr.pdf>. Acesso em: 10 jul. 2014.

711 “(a) Action by United States International Trade Commission - (1) Advisory report- If a dispute settlement panel finds in an interim report under Article 15 of the Dispute Settlement Understanding, or the Appellate Body finds in a report under Article 17 of that Understanding, that an action by the International Trade Commission in connection with a particular proceeding is not in conformity with the obligations of the United States under the Antidumping Agreement, the Safeguards Agreement, or the Agreement on Subsidies and Countervailing Measures, the Trade Representative may request the Commission to issue an advisory report on whether title VII of the Tariff Act of 1930 [19 U.S.C. 1671 et seq.] or title II of the Trade Act of 1974 [19 U.S.C. 2251 et seq.], as the case may be, permits the Commission to take steps in connection with the particular proceeding that would render its action not inconsistent with the findings of the panel or the Appellate Body concerning those obligations. The Trade Representative shall notify the congressional committees of such request. (2) Time limits for report - The Commission shall transmit its report under paragraph (1) to the Trade Representative- (A) in the case of an interim report described in paragraph (1), within 30 calendar days after the Trade Representative requests the report; and $(B)$ in the case of a report of the Appellate Body, within 21 calendar days after the Trade Representative requests the report." Uruguay Round Agreements Act (URAA), section 129. Disponível em: <http:/www.gpo.gov/fdsys/pkg/BILLS103hr5110enr/pdf/BILLS-103hr5110enr.pdf>. Acesso em: 10 jul. 2014.

712 “(3) Consultations on request for Commission determination - If a majority of the Commissioners issues an affirmative report under paragraph (1), the Trade Representative shall consult with the congressional committees concerning the matter.” Uruguay Round Agreements Act (URAA), section 129. Disponível em: <http://www.gpo.gov/fdsys/pkg/BILLS-103hr5110enr/pdf/BILLS-103hr5110enr.pdf>. Acesso em: 10 jul. 2014. 
recomendação do painel ou do Órgão de Apelação. ${ }^{713}$ O USTR deve consultar as Comissões do Congresso antes de implementar a determinação da ITC, ${ }^{714}$ ou de determinar a revogação de uma decisão de aplicação de antidumping ou de medidas compensatórias. ${ }^{715}$

É prevista nessa seção procedimento correlato quando a ação deve se dar não pela ITC, mas pela autoridade administrativa (“administering authority"), devendo então o USTR consultar esta autoridade e os respectivos Comitês do Congresso para a tomada de decisão. ${ }^{716}$

Assim como no primeiro procedimento - insculpido na seção 123(g) do URAA-,

713 “(4) Commission determination - Notwithstanding any provision of the Tariff Act of 1930 [19 U.S.C. 1202 et seq.] or title II of the Trade Act of 1974 [19 U.S.C. 2251 et seq.], if a majority of the Commissioners issues an affirmative report under paragraph (1), the Commission, upon the written request of the Trade Representative, shall issue a determination in connection with the particular proceeding that would render the Commission's action described in paragraph (1) not inconsistent with the findings of the panel or Appellate Body. The Commission shall issue its determination not later than 120 days after the request from the Trade Representative is made." Uruguay Round Agreements Act (URAA), section 129. Disponível em: $<$ http://www.gpo.gov/fdsys/pkg/BILLS-103hr5110enr/pdf/BILLS-103hr5110enr.pdf>. Acesso em: 10 jul. 2014.

714 “(5) Consultations on implementation of Commission determination- The Trade Representative shall consult with the congressional committees before the Commission's determination under paragraph (4) is implemented." Uruguay Round Agreements Act (URAA), section 123 Disponível em: <http://www.gpo.gov/fdsys/pkg/BILLS-103hr5110enr/pdf/BILLS-103hr5110enr.pdf>. Acesso em: 10 jul. 2014.

715 “(6) Revocation of order - If, by virtue of the Commission's determination under paragraph (4), an antidumping or countervailing duty order with respect to some or all of the imports that are subject to the action of the Commission described in paragraph (1) is no longer supported by an affirmative Commission determination under title VII of the Tariff Act of 1930 [19 U.S.C. 1671 et seq.] or this subsection, the Trade Representative may, after consulting with the congressional committees under paragraph (5), direct the administering authority to revoke the antidumping or countervailing duty order in whole or in part." Uruguay Round Agreements Act (URAA), section 129. Disponível em: $<$ http://www.gpo.gov/fdsys/pkg/BILLS-103hr5110enr/pdf/BILLS-103hr5110enr.pdf $>$. Acesso em: 10 jul. 2014.

716 “(b) Action by administering authority (1) Consultations with administering authority and congressional committees- Promptly after a report by a dispute settlement panel or the Appellate Body is issued that contains findings that an action by the administering authority in a proceeding under title VII of the Tariff Act of 1930 [19 U.S.C. 1671 et seq.] is not in conformity with the obligations of the United States under the Antidumping Agreement or the Agreement on Subsidies and Countervailing Measures, the Trade Representative shall consult with the administering authority and the congressional committees on the matter. (2) Determination by administering authority - Notwithstanding any provision of the Tariff Act of 1930 [19 U.S.C. 1202 et seq.], the administering authority shall, within 180 days after receipt of a written request from the Trade Representative, issue a determination in connection with the particular proceeding that would render the administering authority's action described in paragraph (1) not inconsistent with the findings of the panel or the Appellate Body. (3) Consultations before implementation-Before the administering authority implements any determination under paragraph (2), the Trade Representative shall consult with the administering authority and the congressional committees with respect to such determination. (4) Implementation of determination- The Trade Representative may, after consulting with the administering authority and the congressional committees under paragraph (3), direct the administering authority to implement, in whole or in part, the determination made under paragraph (2)." Uruguay Round Agreements Act (URAA), section 123 Disponível em: <http://www.gpo.gov/fdsys/pkg/BILLS103hr5110enr/pdf/BILLS-103hr5110enr.pdf>. Acesso em: 10 jul. 2014. 
neste segundo procedimento - previsto pela seção 129 - há a possibilidade de apresentação de comentários por partes interessadas, de modo escrito ou durante uma sessão pública, a respeito da medida de implementação. ${ }^{717}$

É relevante destacar, portanto, que no caso da metodologia do zeroing, os tribunais norte-americanos adotaram de maneira consistente uma postura de interpretação segundo a qual apenas por meio dos procedimentos de implementação previstos no URAA é que a conduta poderia ser modificada, não cabendo ao judiciário se imiscuir nesta seara. ${ }^{718}$ Assim, sob tal perspectiva, por meio desses procedimentos previstos no URAA, o legislativo norte-americano teria buscado construir uma barreira entre o judiciário norteamericano e o Direito da OMC, explicitamente afastando sua aplicabilidade direta e invocabilidade pelas partes. ${ }^{719}$

Por outro lado, contudo, o procedimento da tomada de decisões relativas à implementação das decisões do Sistema de Solução de Controvérsias da OMC pelos EUA, como previsto no URAA, se configura de modo transparente, e permite a participação de diversos sujeitos, ao conferir publicidade aos principais passos e oportunidade de manifestação pelos setores interessados. Se destaca, por fim, o papel de relevo exercido pelo Congresso Norte-Americano na tomada de decisão, coerente com a estrutura

717 “(d) Opportunity for comment by interested parties- Prior to issuing a determination under this section, the administering authority or the Commission, as the case may be, shall provide interested parties with an opportunity to submit written comments and, in appropriate cases, may hold a hearing, with respect to the determination." Uruguay Round Agreements Act (URAA), section 123 Disponível em: <http://www.gpo.gov/fdsys/pkg/BILLS-103hr5110enr/pdf/BILLS-103hr5110enr.pdf>. Acesso em: 10 jul. 2014.

718 "We will not attempt to perform duties that fall within the exclusive province of the political branches, and we therefore refuse to overturn [DOC]'s zeroing practice based on any ruling by the WTO or other international body unless and until such ruling has been adopted pursuant to the specified statutory scheme." (Corus Staal BV v. Dep't of Commerce, 395 E3d, para. 1343, Fed. Cir. 2004); BARNETT, Mark A. The United States Court of International Trade in the Middle-International Tribunals: An Overview. Tulane Journal of International \& Comparative Law, vol. 19, p. 421-432, 2010-2011. O autor identificou, neste sentido, diversas decisões que se recusaram a modificar a decisão do departamento de comércio, como explicita em nota de rodapé n. 43, p. 428: "Koyo Seiko Co. v. United States, 551 E3d 1286, 1291 (Fed. Cir. 2008); SKF USA v. United States, 537 E3d 1373, 1381 (Fed. Cir. 2008) (We have addressed the practice of 'zeroing' numerous times, however, and have unequivocally upheld this practice.)'; NSK Ltd. v. United States, 510 E3d 1375, 1380 (Fed. Cir. 2007); Corus Staal BV v. United States, 502 E3d 1370, 1375 (Fed. Cir. 2007); Dongbu Steel Co. v. United States, 677 F Supp. 2d 1353, 1366 (Ct. Int'l Trade 2010); Andaman Seafood Co. v. United States, 675 F. Supp. $2 d$ 1363, 1370-71 (Ct. Int'l Trade 2010); SKF USA Inc. v. United States, 675 F. Supp. $2 d$ 1264, 1286 (Ct. Int'l Trade 2009); JTEKT Corp. v. United States, 675 F. Supp. 2d 1206, 1216 (Ct. Int'l Trade 2009)."

719 "Neither the GATT nor any enabling international agreement outlining compliance therewith... trumps domestic legislation; if U.S. statutory provisions are inconsistent with the GATT or an enabling agreement, it is strictly a matter for Congress" (Corus Staal II, 395 F.3d para. 1348 - Fed. Cir. 2005)". DAVENPORT, Filicia. The Uruguay Round Agreements Act Supremacy Clause: Congressional Preclusion of the CharmingBetsy Standard with Respect to WTO Agreements. The Federal Circuit Bar Journal, vol. 15, n. 2, p. 279-314, 2005-2006. p. 311. 
institucional de definição de políticas de comércio exterior pelos EUA, no qual o USTR se insere como uma agência do Poder Executivo, mas com ligação próxima ao Poder Legislativo. $^{720}$

\subsubsection{União Europeia (UE/CE)}

A participação da União Europeia na OMC, e consequentemente no Sistema de Solução de Controvérsias, abarca uma série de peculiaridades decorrentes de sua natureza jurídica não-estatal. Inicialmente, cumpre brevemente destacar que a estrutura jurídica que permite a participação da UE na OMC é ainda hoje um emaranhado de ambiguidades jurídicas, ${ }^{721}$ no que tange ao compartilhamento das competências entre a União e os seus Estados membros e aos efeitos do Direito da OMC na ordem jurídica comunitária.

A conclusão da Ata de Marrakesh se deu na forma de um acordo misto, ${ }^{722}{ }^{723}$ no qual os Estados membros aderiram juntamente com a União - então denominada Comunidades Europeias -, em função da opinião consultiva 1/94 do Tribunal de Justiça da

720 "The USTR's relationship with Congress is fundamental to the effective exercise of U.S. trade policy. Though Congress has a constitutional mandate to regulate U.S. trade with other countries, the executive branch has to implement, enforce and monitor the policy adopted by the country." RAMOS, Guilherme Cantarino da Costa. IBI - the institute of brazilian business \& public management issues. Minerva program spring 2010. CAMEX and USTR: an institutional analysis of the conduct of trade policy in brazil and the U.S. Elliot School of International Affairs. George Washington University. Washington DC, abr. 2010. Disponível em: <http://www.gwu.edu/ ibi/minerva/Spring2010/Ramos.pdf $>$ Acesso em: 10 jul. 2014.

721 Para uma visão geral desse "emaranhado", Cf: KUIJPER, Pieter J. The Conclusion and Implementation of the Uruguay Round Results by the European Community. European Journal of International Law, vol. 6, p. 222-244, 1995.; LEAL-ARCAS, Rafael. Polycephalous Anatomy of The EC in the WTO: An Analysis of Law and Practice. Flórida Journal of International Law, vol. 19, p. 569-670, 2007.; BRAND, Ronald A. Direct Effect of International Economic Law in the United States and the European Union. Northwestern Journal of International Law \& Business, vol. 17, issue 1, p. 556-608, 1996-1997.

722 HELISKOSKI, Joni. Mixed Agreements as a Technique for Organizing the International Relations of the European Community and its Member States. Boston: Kluer Law International, 2001. BASTOS, Fernando Loureiro. Os Acordos Mistos em Direito Comunitário: Contributo para a compreensão do seu fundamento jurídico. Lisboa: SPB II Editores, 1999.

723 Para uma reflexão sobre as consequências jurídicas da celebração dos Acordos da OMC como acordos mistos na divisão de responsabilidade, com base na Convenção de Viena sobre o Direito dos Tratados de 1986, Cf: STEINBERGER, Eva. The WTO Treaty as a Mixed Agreement: Problems with the EC's and the EC Member States' Membership of the WTO. European Journal of International Law, vol. 17 n.4, p. 837-862, 2006. 
União Europeia (TJUE/TJCE). ${ }^{724}$ Naquela oportunidade, o TJUE/TJCE considerou que a regra do single undertaking exigia a participação dos Estados membros em sua capacidade individual na OMC, uma vez que não havia competência comunitária exclusiva para abarcar todos os Acordos.

Tal competência exclusiva existia apenas para o Acordo GATT 1994, relativo ao comércio de bens, o Acordo sobre Agricultura, o Acordo de Medidas Sanitárias e Fitossanitárias, e o Acordo sobre Barreiras Técnicas ao Comércio, por força do então artigo 133 do Tratado da CE. ${ }^{725}$ No que se referia ao GATS, o Tribunal concluiu que alguns modos de fornecimento ("consumption abroad", "commercial presence" e "presence of natural persons") não estariam abarcados pela política comercial comunitária, envolvendo competência compartilhada com os Estados membros. De modo similar, em relação ao TRIPS, o Tribunal concluiu que havia competência compartilhada, pois a regulamentação trazida pelo Regulamento do Conselho n. 3842/86 não configurava uma completa harmonização em nível comunitário.

Embora tenha declarado, portanto, a necessidade de comprometimento em conjunto pelos Estados membros e pela então Comunidade para participação na arquitetura normativa da OMC, o Tribunal perdeu a oportunidade de esclarecer com precisão a relação entre a então Comunidade e os Estados membros nesta matéria, o que futuramente originou uma série de controvérsias sobre a divisão de responsabilidades entre os Estados e a União em relação a violações de regras multilaterais. ${ }^{726}$

Outra complexidade diz respeito à definição dos efeitos do Direito da OMC no ordenamento jurídico da União. Em face de preceito contido originariamente no Tratado de Roma, pelo qual tratados celebrados entre a Comunidade e um ou mais de seus Estados membros, ou entre a Comunidade e uma Organização Internacional seriam vinculantes para as instituições comunitárias, surgiram discussões acerca da aplicabilidade direta dos acordos internacionais concluídos pela Comunidade.

O TJUE/TJCE desenvolveu, contudo, uma cautelosa interpretação em sua jurisprudência acerca dos requisitos para a aplicabilidade direta dos acordos internacionais,

724 Opinion 1/94 (Rec.1994, p.I-5267), 15 nov. 1994.

725 Artigo 133 do Tratado que institui a CE, que por força do artigo 188-C do Tratado de Lisboa, passou a ser renumerado como o Artigo 207 do TFUE.

726 TRACHTMAN, Joel P. Bananas, Direct Effect and Compliance. European Journal of International Law, vol 10. N. 4. p. 655-678, 1999. 
como nos casos Haegemann, ${ }^{727}$ Bresciani, ${ }^{728}$ e Demirel. ${ }^{729}$

Contudo, em todas as oportunidades em que foi convocado para decidir sobre a aplicabilidade do GATT 1947, o Tribunal ponderou elementos de peculiaridade do Acordo para negar sua aplicabilidade direta e, portanto, sua exigibilidade nas Cortes. Nos casos International Fruit Company, ${ }^{730}$ Schlüter-Lörrach, ${ }^{731}$ SIOT, ${ }^{732}$ Michelin Italiana (SAMI), 733 e Bananas, ${ }^{734}$ o Tribunal negou aplicabilidade direta ao GATT 1947, afirmando a impossibilidade de invocar suas provisões para questionar a legalidade de atos comunitários, em razão do caráter "condicionado" e "flexível" dos compromissos que este Acordo estabelece.

Ao reconhecimento geral da não aplicabilidade do direito decorrente do GATT 1947, o Tribunal reconheceu duas exceções restritas, nos casos Fediol ${ }^{735}$ e Nakajima. ${ }^{736}$ No primeiro caso, embora reafirmando que as regras do GATT não tinham efeito direto, o Tribunal aceitou uma ação judicial com base na violação de um Regulamento da Comissão que fazia referência expressa ao GATT 1947. No Segundo caso, um Regulamento antidumping foi questionado com base nas regras do GATT 1947, e o Tribunal aceitou examinar sua legalidade pois era uma medida tomada pela CE que intencionava implementar uma obrigação em particular.

727 No caso Haegeman, o Tribunal explicitou que: “[...] an agreement concluded by the council under articles 228 and 238 of the eec treaty is, as far as concerns the community, an act of one of the institutions of the community the meaning of subparagraph $(b)$ of the first paragraph of article 177 . From the date it comes into force, its provisions form an integral part of community law." Haegemann v. Belgian State (Rec.1974, p.449), Case 181/73, 30 abr. 1974.

728 No caso Bresciani, o Tribunal concluiu que sendo uma obrigação decorrente do Tratado Internacional "[...] specific and not subject to any implied or express reservation on the part of the community, it is capable of conferring on those subject to community law the right to rely on it before the courts. " Bresciani v. Amministrazione delle finanze dello Stato (Rec.1976, p.129), Case 87/75, 5 fev. 1976.

729 De modo similar, no caso Demirel foi explicitado que "[...] a provision in an agreement concluded by the community with non-member countries must be regarded as being directly applicable when, regard being had to its wording and the purpose and nature of the agreement itself, the provision contains a clear and precise obligation which is not subject, in its implementation or effects, to the adoption of any subsequent measure." Demirel v. Stadt Schwäbisch Gmünd (Rec.1987, p.3719), Case 12/86, 30 out. 1987.

730 International Fruit Company and others v. Produktschap voor Groenten en Fruit (Rec.1972, p.1219), Case 21/72, 12 dez. 1972.

731 Schlüter v. Hauptzollamt Lörrach (Rec.1973, p.1135), Case 9/73, 24 out. 1973.

732 SIOT v. Ministero delle finanze (Rec.1983, p.731), Case 266/81, 16 mar. 1983.

733 Amministrazione delle finanze dello Stato v. SPI and SAMI (Rec.1983, p.801), Case 267/81, 16 mar. 1983.

734 Germany v. Council (Rec.1994, p.I-4973), Case 280/93, 5 out. 1994.

735 Fédération de l'industrie de l'huilerie de la CEE (Fediol) v. Commission (Rec.1989, p. 1-1781), Case C-70/87, 22 jun. 1989.

$736 \quad$ Nakajima All Precision Co. Ltd v. Council (Rec.1991, p. 1-2069), Case C-69/89, 7 maio 1991. 
Com a passagem do GATT 1947 para a OMC, teve lugar uma profunda institucionalização e adensamento de sua juridicidade, por meio de sua arquitetura normativa e pelo seu Sistema de Solução de Controvérsias. Embora com a diminuição da condicionalidade e da flexibilidade das regras multilaterais houvesse expectativa de que a interpretação do Tribunal pudesse se modificar, quando chamado a se pronunciar no caso Portugal v. Council (149/96), o Tribunal declarou a negação da aplicabilidade direta também às regras da OMC. Embora a controvérsia tenha sido solucionada no âmbito da interpretação jurisdicional do Tribunal, a este respeito, a resolução da Comissão da UE aprovando a Ata de Marrakesh, ao Conselho de Ministros, já mencionava que, na visão da Comissão, os Acordos por si só não eram diretamente aplicáveis. ${ }^{737}$

No caso 149/96, o Tribunal não aceitou a invocação de regras da OMC por Portugal como base para questionar uma decisão do Conselho. ${ }^{738}$ Naquela oportunidade, o Tribunal destacou o caráter negocial das obrigações e dos procedimentos do Sistema de Solução de Controvérsias da OMC, ${ }^{739}$ e o fato de que outros membros da OMC não consideravam as regras multilaterais vinculantes e diretamente aplicáveis às suas Cortes, ${ }^{740}$ para manter sua interpretação restritiva.

E assim, segundo a interpretação deste Tribunal, "segue-se que os acordos da OMC, interpretados à luz do seu objeto e finalidade, não fixam os meios jurídicos adequados para assegurar que estes sejam aplicados de boa-fé na ordem jurídica das partes contratantes." 741

737 94/800/EC: Council Decision (of 22 December 1994) concerning the conclusion on behalf of the European Community, as regards matters within its competence, of the agreements reached in the Uruguay Round multilateral negotiations (1986-1994), OJ L 336, 23.12.1994, p. 1-2. Commission of the European Communities, Proposal for a Council Decision Concerning the Conclusion of the Uruguay Round of Multilateral Trade Negotiations (1986-94) Com(94), 143 apr. 15, 1994.

$738 \quad$ Portugal v. Council (Rec.1999, p.I-8395), Case C-149/96, 23 nov. 1999. para. 41.

739 Portugal v. Council (Rec.1999, p.I-8395), Case C-149/96, 23 nov. 1999. para. 42. "As regards, more particularly, the application of the WTO agreements in the Community legal order, it must be noted that, according to its preamble, the agreement establishing the WTO, including the annexes, is still founded, like GATT 1947, on the principle of negotiations with a view to 'entering into reciprocal and mutually advantageous arrangements' and is thus distinguished, from the viewpoint of the Community, from the agreements concluded between the Community and non-member countries which introduce a certain asymmetry of obligations, or create special relations of integration with the Community, such as the agreement which the Court was required to interpret in Kupferberg".

$740 \quad$ Portugal v. Council (Rec.1999, p.I-8395), Case C-149/96, 23 nov. 1999. para. 44. "Admittedly, the fact that the courts of one of the parties consider that some of the provisions of the agreement concluded by the Community are of direct application whereas the courts of the other party do not recognise such direct application is not in itself such as to constitute a lack of reciprocity in the implementation of the agreement (Kupferberg, paragraph 18)."

741 Tradução livre do original em língua inglesa: “[...] follows that the WTO agreements, interpreted in the light of their subject-matter and purpose, do not determine the appropriate legal means of ensuring that 
A posição do TJUE/TJCE enfrentou críticas na doutrina, ${ }^{742} 743744$ que de maneira geral o acusou de sobrepesar elementos políticos no julgamento, ao invés de realizar uma análise jurídica. 745746747

Embora constitua um precedente relevante, que até atualmente embasa decisões do TJUE/TJCE nesta temática, a doutrina enfatiza que no caso Portugal os Acordos da OMC foram alegados pelo demandante como um parâmetro para questionar a legalidade de medidas comunitárias. Situação consideravelmente distinta seria aquela na qual o Tribunal tem à sua frente uma decisão do Sistema de Solução de Controvérsias da OMC, que deve ser considerada - apesar de certamente conter suas peculiaridades - como uma decisão jurídica vinculante de um órgão adjudicatório internacional. ${ }^{748}$

Desde a opinião no caso Atlanta, ${ }^{749}$ o TJUE/TJCE teria perdido preciosas oportunidades de realizar essa inevitável diferenciação, tornando sua jurisprudência "confusa e desencorajadora" nessa seara. ${ }^{750}$ No caso Biret, ${ }^{751}$ embora tenha destacado que

they are applied in good faith in the legal order of the contracting parties." Portugal v. Council (Rec.1999, p.I-8395), Case C-149/96, 23 nov. 1999.

742 ANTONIADIS, Antonis. The European Union and WTO law: a nexus of reactive, coactive and proactive approaches. World trade review, vol. 6, n. 1, p. 45-87, 2007.

743 ZONNEKEYN, Geert A. The Latest on Indirect Efect of WTO Law in the legal order: The Nakajima Case Law Misjudged? Journal of International Economic Law, p. 597-608, 2001.

744 EECKHOUT, Piet. Judicial Enforcement of WTO Law in the European Union - Some Further Reflections. Journal of International Economic Law, vol. 5, p. 91-110, 2005. p. 107.

745 MENGOZZI, Paolo. Istituzione di Diritto Comunitario e Dell Unione Europea. Padova: CEDAM, 2003. p. 367-369.

746 Como sustenta Rafael Leal-Arcas: "If the ECJ wants to maintain its doctrine that the GATT does not meet the direct effect test and extends it to other WTO Agreements, it will need to devise standards, other than those it has used until now, to deny direct effect to the GATT and WTO Agreements." LEAL-ARCAS, Rafael. Polycephalous Anatomy of The EC in the WTO: An Analysis of Law and Practice. Flórida Journal of International Law, vol. 19, p. 569-670, 2007. p. 209.

747 Em posição contrária, Cf: "[...] it should be noted that the main conclusion reached by the Court of Justice makes perfect sense. The WTO is a global intergovernmental endeavor, with an emphasis on a balance of concessions or, to quote the Preamble of the Marrakesh Agreement, 'reciprocal and mutually advantageous arrangements'. Individual companies are not granted any direct right to a particular reduction of tariffs or other barriers to trade. [...] None of the major trading powers accord direct effect to the WTO Agreements in their internal legal orders." ROSAS, Allan. Implementation and Enforcement of WTO Dispute Settlement Findings: An EU Perspective. Journal of International Economic Law, vol. 4, p. 131144, 2001. p. 140.

748 MENGOZZI, Paolo. Istituzione di Diritto Comunitario e Dell'Unione Europea. Padova: CEDAM, 2003. p. 367-369.

749 Opinion of Mr Advocate General Mischo delivered on 6 May 1999. Atlanta AG and others $v$ Commission of the European Communities and Council of the European Union (Rec.1999, p.I-06983), Case C-104/97, 14 out. 1999. Foi a primeira situação na qual o tribunal foi chamado para expressar sua posição sobre o status de um Relatório adotado pelo Órgão de Solução de Controvérsias no ordenamento jurídico comunitário. Cf: ZONNEKEYN, Geert A. The legal status of WTO panel reports in the EC legal order: Some reflections on the opinion of advocate general Mischo in the Atlanta case. Journal of International Economic Law, vol 2, p. 713-722, 1999.

750 ERRICO, John. The WTO in the EU: Unwinding the Knot. Cornell International Law Journal, vol. 44, p. 179-208, 2011. 
o Tribunal de primeira instância deveria ter diferenciado em sua análise o precedente contido no caso Portugal da situação na qual um relatório adotado pelo OSC não foi implementado pela UE, o Tribunal evitou adentrar na análise da controvérsia, reconhecendo que o demandante não poderia ter sofrido danos em função de elementos factuais do caso, ${ }^{752}$ esquivando-se de avaliar as consequências jurídicas da diferenciação do precedente.

No referido caso, o Advogado Geral reconheceu que a finalidade última do direito da OMC é a proteção dos indivíduos e que, portanto, as decisões do Sistema de Solução de Controvérsias deveriam poder ser invocadas pelas partes nos órgãos jurisdicionais comunitários. ${ }^{753}$

Com base nesse caso, parte da doutrina interpreta que o TJUE/TJCE teria deixado a porta aberta para o reconhecimento de uma obrigação da UE consubstanciada nos relatórios adotados pelo OSC, e uma consequente responsabilidade no caso de não implementação das decisões do Sistema de Solução de Controvérsias da OMC. 754755756 Contudo, nos anos seguintes a este caso, observou-se uma recrudescência da perspectiva expressa no precedente Portugal, ${ }^{757}$ com a rejeição das demandas nos casos IKEA, ${ }^{758}$

751 ltablissements Biret et Cie SA v. Council (Rec.2003, p. I-10565), Case C-94/02, 30 set. 2003.

752 O fato de que o prazo para a implementação da decisão do OSC se esgoatava em 1999, e a empresa Biret foi objeto de liquidação judicial em 1995.

753 "It seems unfair to deny a citizen a right to claim damages where the Community legislature, by failing to act, maintains a state of affairs that is contrary to WTO law more than four years after the expiry of the period allowed to comply [...] and continues unlawfully to reduce the citizen's fundamental rights." Opinion of Advocate General Alber, ltablissements Biret et Cie SA v. Council (Rec.2003, p. I-10565), Case C-94/02, 15 maio 2003. para. 92.

754 ALEMANNO, Alberto. Judicial Enforcement of the WTO Hormones Ruling within the European Community: Toward EC Liability for the Non-Implementation of WTO Dispute Settlement Decisions. Harvard International Law Journal, vol. 45, p. 547-562, 2004.

755 ZONNEKEY, Geert A. EC Liability for the Non-Implementation of WTO Dispute Settlement Decisions - Advocate General Alber Proposes a 'Copernican Innovation' in the Case Law of the ECJ. Journal of International Economic Law, vol. 6, p. 761-769, 2003.

756 O pricípio enunciado no caso Nakajima, como uma das exceções à não aplicabilidade, e retomado no caso Portugal poderia ser um pilar para este reconhecimento: "The principle of implementation clearly offers nice opportunities for communication between the vessels of EU and WTO law, and between judicial operators of both systems. It would be particularly useful if it were applied, not only in straightforward cases of EC acts expressing to implement parts or provisions of WTO law, but also in the more politically charged context of implementation of WTO dispute rulings [...]" EECKHOUT, Piet. Judicial Enforcement of WTO Law in the European Union - Some Further Reflections. Journal of International Economic Law, vol. 5, p. 91-110, 2005. p. 109.

757 DE MEY, Delphine. The Effect of WTO Dispute Settlement Rulings in the EC Legal Order: Reviewing Van Parys v Belgische Interventie-en Restitutiebureau (C-377/02). German Law Journal, vol. 6, p. 1025-1032, 2005. EGLI, Patricia. European Community-EC compliance with rulings of WTO Dispute Settlement Body in Bananas dispute- effect of WTO agreements and dispute settlement rulings in EC lawstanding to challenge EC legislation as inconsistent with WTO agreements and rulings. American Journal of International Law, vol. 100, p. 449-454, 2006. ERRICO, John. The WTO in the EU: Unwinding the Knot. Cornell International Law Journal, vol. 44, p. 179-208, 2011. 
Leon Van Parys, ${ }^{759}$ e Chiquita. ${ }^{760}$ Por fim, nos casos FIAMM, ${ }^{761}$ o TJUE/TJCE rejeitou repetidamente a possibilidade de demandas com base em violação do Direito da OMC ou decisões do OSC sustentadas no artigo 340(2) do Tratado sobre o Funcionamento da União Europeia (TFUE). ${ }^{762} 763$

A posição de não aplicabilidade direta das regras multilaterais e das decisões do Sistema de Solução de Controvérsias da OMC parece consagrar uma posição pragmática do Tribunal, tendo em vista uma indesejabilidade do reconhecimento destas decisões como vinculantes às instituições comunitárias. Isto pois a sua jurisprudência é farta em conceitos e perspectivas que poderiam embasar a posição inversa. ${ }^{764}$ A este propósito vale destacar que na Opinião 1/91, o Tribunal reconheceu que, sob certas circunstâncias, a Comunidade poderia se submeter a um órgão adjudicatório internacional, e que suas decisões seriam vinculantes e cogentes às instituições comunitárias:

\footnotetext{
Quando, todavia, um acordo internacional estabelece o seu próprio sistema de tribunais, incluindo um tribunal competente para dirimir litígios entre as partes contratantes do acordo e, como resultado, para interpretar as suas disposições, as decisões do tribunal serão vinculativas às instituições comunitárias, incluindo o Tribunal de Justiça. Essas decisões também serão obrigatórias no caso de o Tribunal de Justiça ser chamado a pronunciar-se, por meio de decisão preliminar ou em uma ação direta, sobre a interpretação do acordo internacional, na medida em que o acordo é parte integrante de da ordem jurídica comunitária.
}

758 Ikea Wholesale Ltd v. Comm'rs of Customs \& Excise (Rec.2007, p. 1-7723), Case C-351/04, 27 set. 2007.

759 Lon Van Parys NV v. Belgisch Interventie-en Restitutiebureau (BIRB) (Rec. 2005, p. 1-1465), Case C-377/02, 1 mar. 2005.

760 Chiquita Brands International, Inc. and Others v. Commission (Rec.2005, p. 11-315), Case T-19/01, 3 fev. 2005.

761 Fabbrica Italiana Accumulatori Motocarri Montecchio SpA v. Council (Rec.2008, p. 1-6513, 2324, 30), Joined Cases C-120/06P \& C-121/06P, 9 set. 2008.

762 Anteriormente artigo 288 do Tratado CE, Artigo 340 para 2 na atual versão do Tratado sobre o Funcionamento da União europeia, como modificado pelo Tratdo de Lisboa: "Em matéria de responsabilidade extracontratual, a União deve indemnizar, de acordo com os princípios gerais comuns aos direitos dos Estados-Membros, os danos causados pelas suas instituições ou pelos seus agentes no exercício das suas funções."

763 Assim explicita Antonello Tancredi: "The main critique moved towards the Court's reasoning is that by misinterpreting the DSU provisions the ECJ has reached the incorrect conclusion that compensation and toleration of retaliation are suitable, albeit temporary, alternatives to full and immediate compliance. In other words, the ECJ seems to imply that compliance is negotiable, if provisionally, in the WTO." TANCREDI, Antonello. EC Practice in the WTO: How Wide is the 'Scope for Manoeuvre'? European Journal of International Law, vol. 15, n. 5, p. 933-961, 2004. p. 944.

764 Em sentido correlato: "[...] The ECJ is the direct effect court par excellence, and by refusing to extend the direct effect doctrine to WTO law, it is refusing to impose duties upon itself analogous to those which it has imposed on courts and tribunals in the EC Member States. By developing the notion of direct effect, the ECJ has urged domestic courts to give effect to EC law, but it is itself refusing to give effect to WTO law [...]" EECKHOUT, Piet. Judicial Enforcement of WTO Law in the European Union - Some Further Reflections. Journal of International Economic Law, vol. 5, p. 91-110, 2005. p. 98. 
Um acordo internacional que preveja tal sistema jurisdicional é, em princípio, compatível com o direito comunitário. A competência da Comunidade no domínio das relações internacionais e sua capacidade para celebrar acordos internacionais necessariamente implica no poder de submeter-se às decisões de um tribunal que seja criado ou designado por um acordo desse tipo no que diz respeito à interpretação e aplicação das suas disposições. 765

A UE/CE mantém seu multilateralismo como elemento central da projeção internacional de sua política comercial, buscando promover uma implementação "mais expedita" das decisões do Sistema de Solução de Controvérsias da OMC. Isto pois o multilateralismo econômico traduzido pela dimensão jurídica da OMC seria base de legitimidade e fortalecimento de sua própria colocação no comércio internacional. ${ }^{766}$

Por outro lado, esse emaranhado de imprecisões jurídicas, como brevemente destacamos, por vezes causa dificuldades à implementação das decisões, e quanto à distribuição de competências e responsabilidades entre os Estados membros e a União. Pode-se mencionar, por exemplo, a controvérsia European Communities - Customs Classification of Certain Computer Equipment, ${ }^{767}$ na qual os EUA entenderam que a UE e os seus Estados membros Irlanda e Reino Unido seriam responsáveis pela violação de disposições do GATT 1994, requisitando a formação de três painéis diversos para analisar a questão. Na oportunidade, a UE tratou de firmar um acordo com os EUA, garantindo que somente contra ela seria a demanda. Referido caso explicitou o interesse da UE em não

765 Tradução livre do original em língua inglesa: “Where, however, an international agreement provides for its own system of courts, including a court with jurisdiction to settle disputes between the Contracting Parties to the agreement, and, as a result, to interpret its provisions, the decisions of that court will be binding on the Community institutions, including the Court of Justice. Those decisions will also be binding in the event that the Court of Justice is called upon to rule, by way of preliminary ruling or in a direct action, on the interpretation of the international agreement, in so far as that agreement is an integral part of the Community legal order. An international agreement providing for such a system of courts is in principle compatible with Community law. The Community's competence in the field of international relations and its capacity to conclude international agreements necessarily entails the power to submit to the decisions of a court which is created or designated by such an agreement as regards the interpretation and application of its provisions." Opinion 1/91, Draft agreement relating to the creation of the European Economic Area (Rec. 1991, p. 1-6079), 14 dez. 1991. para. 39-40.

$766 \quad$ Neste sentido se posiciona Carlos Cozendey: “Ao mesmo tempo, por não dispor de coesão interna similar a um Estado, a Comunidade Europeia (e também a União Europeia no seu alcance mais amplo) utiliza melhor seus fatores de poder num ambiente regulado por regras explicitas do que num cenário onde prevaleçam os elementos anárquicos do sistema internacional. Na União Europeia, o sistema internacional e o papel que nele possam representar os países que a constituem são uma justificativa de sua própria existência." COZENDEY, Carlos Márcio Bicalho. O Sistema de Solução de Controvérsias da OMC: para além dos contenciosos, a política externa. Disponível em: <http://www.itamaraty.gov.br/temas/temasmultilaterais/copy_of_desenvolvimento-comercio-e-financas/organizacao-mundial-do-comercio/solucao-decontroversias/cgc/artigo-cozendey> Acesso em: 15 dez. 2013. p. 16.

767 WTO. Apellate Body Report, European Communities - Customs Classification of Certain Computer Equipment. WT/DS62/AB/R, WT/DS67/AB/R, WT/DS68/AB/R, 05 jun. 1998. 
permitir interferências externas, do OSC ou dos demais membros da OMC, na delimitação de competências e responsabilidades entre a UE e seus Estados membros, questões que o próprio Painel evitou adentrar. ${ }^{768}$

É relevante também mencionar que a própria operacionalização da participação da UE na OMC é temática complexa, e pouco transparente na relação entre as instituições comunitárias. Se formalmente a UE e todos os seus Estados são membros da OMC em seu status individual, na prática o bloco personifica um ator único nas negociações multilaterais, e no Sistema de Solução de Controvérsias, ${ }^{769}$ como se evidencia no caso supracitado.

O desenvolvimento da política comercial comum fica a cargo da Comissão, que pela complexidade de sua tarefa necessitou desenvolver instrumentos e procedimentos para a sua realização, como brevemente abordaremos. A tomada de decisão pela Comissão na esfera da OMC é criticada por seus reduzidos níveis de transparência, legitimidade e accountability, princípios basilares do direito comunitário. ${ }^{770}$ Houve, contudo, um avanço significativo na inclusão do parlamento europeu nas competências da definição da política comercial comum, que na redação original do então artigo 133 do Tratado que institui a CE ${ }^{771}$ ficava de fora da tomada de decisão nesta matéria, alterada pelo Tratado de Lisboa. ${ }^{772}$

768 CAPUCIO, Camilla. O Regionalismo e o Comércio Internacional. Belo Horizonte: Editora Arraes, 2012. CAPUCIO, Camilla. O Status Jurídico da União Européia como Membro da OMC: Estudo sobre os Acordos Mistos no Direito Comunitário. In: MENEZES, Wagner. Estudos de Direito Internacional: Anais do $7^{\circ}$ Congresso Brasileiro de Direito Internacional. Vol. XVII. Curitiba: Juruá, 2009, p. 135-146.

769 SERDAREVIC, Asja. European Union and Its Member States as a Collective Actor in WTO Decision-Making Process. American Consortium on European Union Studies (ACES). EU Center of Excellence Washington. ACES Cases, n. 2010.3. Disponível em: <http://transatlantic.saisjhu.edu/ACES/ACES_Cases/2010.3_ACES_Cases_Serdarevic.pdf >. Acesso em: 05 mar. 2014.

770 SERDAREVIC, Asja. European Union and Its Member States as a Collective Actor in WTO Decision-Making Process. American Consortium on European Union Studies (ACES). EU Center of Excellence Washington. ACES Cases, n. 2010.3. Disponível em: <http://transatlantic.saisjhu.edu/ACES/ACES_Cases/2010.3_ACES_Cases_Serdarevic.pdf $>$.Acesso em: 05 mar. 2014.p. 1.

771 Artigo 133 constante na Redação do Tratado que institui a CE: "1. A política comercial comum assenta em princípios uniformes, designadamente no que diz respeito às modificações pautais, à celebração de acordos pautais e comerciais, à uniformização das medidas de liberalização, à política de exportação, bem como às medidas de defesa comercial, tais como as medidas a tomar em caso de dumping e de subsídios. 2. Tendo em vista a execução desta política comercial comum, a Comissão submete propostas ao Conselho. 3. Quando devam ser negociados acordos com um ou mais Estados ou organizações internacionais, a Comissão apresenta, para o efeito, recomendações ao Conselho, que a autoriza a encetar as negociações necessárias. Cabe ao Conselho e à Comissão assegurar que os acordos negociados sejam compatíveis com as politicas e normas internas da Comunidade. As negociações são conduzidas pela Comissão, em consulta com um comité especial designado pelo Conselho para a assistir nessas funções e no âmbito das directrizes que o Conselho lhe possa endereçar. A Comissão apresenta regularmente ao comité especial um relatório sobre a situação das negociações. [...]"

772 Nova redação deste artigo, que por força do artigo 188-C do Tratado de Lisboa, passou a ser 
No que tange especificamente ao gerenciamento da participação da UE no Sistema de Solução de Controvérsias da OMC, a Comissão desempenha um papel central. Dois órgãos da estrutura interna da Comissão são relevantes para o desempenho deste papel: o Directorate-General for Trade (DG Trade, Diretório Geral de Comércio) e o Legal Service. ${ }^{773}$

Existem dois procedimentos para o estabelecimento de uma disputa no Sistema de Solução de Controvérsias da OMC pela União Europeia. ${ }^{774} \mathrm{O}$ primeiro procedimento, embasado no artigo 207 do TFEU, ${ }^{775}$ mas de caráter informal e não escrito, permite que partes interessadas - do setor privado ou os Estados membros - apresentem um requerimento à Comissão para o estabelecimento de uma disputa no Sistema de Solução de Controvérsias da OMC. ${ }^{776}$

renumerado como o Artigo 207 do TFUE: "1. A politica comercial comum assenta em princípios uniformes, designadamente no que diz respeito às modificações pautais, à celebração de acordos pautais e comerciais sobre comércio de mercadorias e serviços, e aos aspectos comerciais da propriedade intelectual, ao investimento estrangeiro directo, à uniformização das medidas de liberalização, à política de exportação, bem como às medidas de defesa comercial, tais como as medidas a tomar em caso de dumping e de subsídios. A política comercial comum é conduzida de acordo com os princípios e objectivos da aç̧ão externa da União. 2. O Parlamento Europeu e o Conselho, por meio de regulamentos adoptados de acordo com o processo legislativo ordinário, estabelecem as medidas que definem o quadro em que é executada a politica comercial comum. 3. Quando devam ser negociados e celebrados acordos com um ou mais países terceiros ou organizações internacionais, é aplicável o artigo 218.o, sob reserva das disposições específicas do presente artigo. Para o efeito, a Comissão apresenta recomendações ao Conselho, que a autoriza a encetar as negociações necessárias. Cabe ao Conselho e à Comissão assegurar que os acordos negociados sejam compativeis com as políticas e normas internas da União. As negociações são conduzidas pela Comissão, em consulta com um comité especial designado pelo Conselho para a assistir nessas funções e no âmbito das directrizes que o Conselho lhe possa endereçar. A Comissão apresenta regularmente ao comité especial e ao Parlamento Europeu um relatório sobre a situação das negociações [...]"

773 Segundo a autora: "DG Trade is responsible for the political aspects of WTO dispute settlements, while the Legal Service deals with the legal aspects. DG Trade decides over the initiation of disputes and requesting consultations with third parties, while the Legal Service is responsible for arguing the EU "s case before the Panel and the Appellate Body of the WTO. The two DGs are mutually dependent on each other, since the Legal Service relies on the investigations and reports of $D G$ Trade for obtaining facts important for a case, and DG Trade depends on the Legal Service for a successful outcome." SERDAREVIC, Asja. European Union and Its Member States as a Collective Actor in WTO Decision-Making Process. American Consortium on European Union Studies (ACES). EU Center of Excellence Washington. ACES Cases, $\mathrm{n}$. 2010.3. Disponível em: <http://transatlantic.saisjhu.edu/ACES/ACES_Cases/2010.3_ACES_Cases_Serdarevic.pdf $>$. Acesso em: 05 mar. 2014.p. 8.

774 Para uma comparação entre ambos os caminhos, sob a perspectiva de seu uso prático, e das vantagens e desvantagens, Cf: SHAFFER, Gregory C. Is the EC moving towards a U.S. Partnership Model? Capitulo 4. In: SHAFFER, Gregory C. Defending Interests: Public-private Partnerships in WTO Litigation. Washington: Brooking Institutions Press, 2003, p. 65-101.

775 Artigo 133 do Tratado que institui a CE, que por força do artigo 188-C do Tratado de Lisboa, passou a ser renumerado como o Artigo 207 do TFUE.

776 Especoficamente sobre o iter deste pedido, a autora descreve: "The usual procedure is that officials in DG Trade first examine and scrutinize the complaint in close cooperation with lawyers of the WTO and International Trade Team in the Commission "s Legal Service. The issue is then discussed in the Trade Policy Committee before the Commission takes a final decision whether to launch a WTO dispute, as sometimes a final opinion of the Committee is requested.55 Furthermore, the Member States are informed about the 
O segundo caminho é embasado no Regulamento de Barreiras ao Comércio (Trade Barriers Regulation - TBR, Regulamento da Comissão n. 3286/94), ${ }^{777}$ que também permite a partes interessadas e a Estados membros ingressar com requerimento à Comissão para investigação de barreiras ao comércio que lhe sejam prejudiciais. Nesse procedimento, o Conselho da UE e os Estados membros podem atuar, por meio de um Comitê (advisory comitte), havendo inclusive a possibilidade de adoção de medidas retaliatórias pelo Conselho. ${ }^{778}$

$\mathrm{Na}$ realidade, os processos de decisão relativos aos acordos comerciais internacionais se embasam no então artigo 133 do Tratado da CE, ${ }^{779}$ e por isso o grupo de agentes nacionais com experiência e conhecimento em comércio internacional, que representa o Conselho na temática da OMC é conhecido como o "Comitê 133". Sua composição, ${ }^{780}$ operacionalização, ${ }^{781} 782$ mandato ${ }^{783}$ e controle ${ }^{784} 785$ são de delimitação imprecisa, uma vez que poucas informações oficiais estão disponíveis sobre esse tema.

developments in the dispute settlement proceedings during the Trade Policy Committee "s meetings and the INTA committee is also briefed on the progress." SERDAREVIC, Asja. European Union and Its Member States as a Collective Actor in WTO Decision-Making Process. American Consortium on European Union Studies (ACES). EU Center of Excellence Washington. ACES Cases, n. 2010.3. Disponível em: $<$ http://transatlantic.sais-jhu.edu/ACES/ACES_Cases/2010.3_ACES_Cases_Serdarevic.pdf $>$. Acesso em: 05 mar. 2014. p. 11.

777 Council Regulation EC N. 3286/94 of 22 December 1994 laying down Community procedures in the field of the common commercial policy in order to ensure the exercise of the Community's rights under international trade rules, in particular those established under the auspices of the World Trade Organization. Official Journal L 349, 31 dez. 1994. p. 0071 - 0078.

778 Segundo o autor, foram também editados mecanismos semelhantes específicos para antidumping e subsídios: “[...] allows trade operators' complaints to be channelled through an administrative mechanism that, at any rate, ascribes mainly to the EC Commission the choice to either bring a complaint before the WTO supervisory organs or to terminate/suspend the investigation, or alternatively to seek an agreed solution. Therefore, the TBR - at least partly - seems to share the function and the nature of the traditional diplomatic protection remedy provided for by general international law. TBR-like twin mechanisms have also been set up in the field of anti-dumping and for subsidized imports.". TANCREDI, Antonello. EC Practice in the WTO: How Wide is the 'Scope for Manoeuvre'? European Journal of International Law, vol. 15, n. 5, p. 933-961, 2004. p. 240.

779 Artigo 133 do Tratado que institui a CE, que por força do artigo 188-C do Tratado de Lisboa, passou a ser renumerado como o Artigo 207 do TFUE.

780 Assim destaca um relatório do World Wide Fund For Nature: "The Committee has no set numbers of participants and there can be around 50 people at its meetings. It operates at two main levels: - Deputy level: 3-4 national trade officials from each member state: Commerce or Trade Counsellors from the Permanent Representations in Brussels, plus 2-3 trade experts from the national capitals who meet on a Friday $\bullet$ Full member level or "top configuration": a monthly Friday meeting of national Trade Directors-General from member states, plus supporting officials. In addition, other meetings of national experts examine specific issues on behalf of the 133 Committee where specialist discussion is needed." WWF, World Wide Fund For Nature. A League of Gentlemen: Who really runs EU Trade Decision-Making? nov. 2003. Disponível em: $<\mathrm{http}: / /$ www.google.com.br/url? sa $=\mathrm{t} \& \mathrm{rct}=\mathrm{j} \& \mathrm{q}=\& \mathrm{esrc}=\mathrm{s} \&$ source $=$ web\&cd $=1 \& \mathrm{ved}=0 \mathrm{CC} 8 \mathrm{QFjAA}>$. Acesso em: 6 mar. 2014. p. 8.

781 Sobre sua operacionalização, o relatório destaca: "The 133 Committee thus has the main responsibility for ensuring necessary amendments to the Commission's proposals for EU positions in trade agreements. Like other Council Advisory Committees, the 133 Committee has no formal operational 
Embora a transparência seja um dos princípios norteadores da atuação interna das instituições comunitárias, haveria uma mitigação desse princípio no que tange ao processo decisório relacionado ao Sistema de Solução de Controvérsias da OMC, uma vez que as reuniões e documentos dos órgãos internos da Comissão que compõem a tomada de decisão nesta matéria não estão disponíveis ao acesso do público. ${ }^{786}$

Contudo, alega-se que dado o caráter técnico e estratégico da matéria, o incremento de transparência, accountability e legitimidade seria contraproducente, e poderia afetar a agilidade com que as posições devem ser tomadas, podendo inclusive "ameaçar" a posição

guidelines. The Committee works by consensus and 'gentleman's agreement'; there are almost no formal votes - as one 133 Committee member stated: "we hardly ever vote". WWF, World Wide Fund For Nature. A League of Gentlemen: Who really runs EU Trade Decision-Making? nov. 2003. Disponível em: $<$ http:/www.google.com.br/url? sa=t\&rct=j\&q=\&esrc=s\&source=web\&cd=1\&ved=0CC8QFjAA $>$. Acesso em: 6 mar. 2014. p. 9.

782 Também a este respeito, Anna Murphy observa: “As a result, the 113 Committee's formal role remains advisory. On the other hand, as policy has been channelled through representatives of the Member States in the Committee, opinions of the 113 Committee are rarely overturned by the Council and are sometimes treated as if they were official decisions of the Council. Although it does not formally vote and Council decisions are taken on the basis of qualified majority, the Committee seeks consensus amongst the members. At a minimum, it tried to ensure that there is no blocking minority before passing matters upwards to the next level of decision-making. Conscious efforts are made not to ignore or isolate individual Member States". MURPHY, Anna. In the maelstrom of change: The Article 113 Committee in the governance of external economic policy. In: CHRISTIANSEN, Thomas. KIRCHNER, Emil. (eds.) Committee Governance in the European Union. Manchester: Manchester University Press, 2000, p. 98-104. p. 99.

783 Assim explicita Rafael Leal-Arcas: "The three main tasks of the Article 133 Committee are: 1) to advise the Commission in the negotiations on trade and tariff matters, which the Commission conducts on behalf of the Community; 2) to act as a typical Council preparatory body when preparing certain legislation for adoption by the EU Council; and 3) to advise the Commission on routine matters on which the Commission makes decisions vis-à-vis third countries in the management of the EC's common commercial policy." LEAL-ARCAS, Rafael. The EU Institutions and Their Modus Operandi in the World Trading System. Columbia Journal Of European Law, vol. 12, p. 147-238, 2005. p. 161.

784 Por sua relevância no descortinamento deste assunto, nos referimos novamente ao relatório da World Wide Fund For Nature: "Like other Council Advisory Committee meetings, this Committee operates in camera normally without public agendas. However, the role of other Committees is balanced by a wider consultation process, which includes the European Parliament from the start. There are some significant differences in the discussions of the 133 Committee on international trade agreements which increase the impact of its secretive operations, compared with discussions of Council Committees in other policy areas: • It is the sole body consulted on proposed EU positions for trade agreements; Parliament is excluded from the consultation process. - It debates an unpublished Commission proposal. • It is strongly influenced by expert and highly experienced Commission officials - in the words of one national expert: "it's the one committee where a very vocal and active Commission has the lead role, not governments". - It holds substantial decision-making powers in itself, particularly on the EU negotiating mandate, as national Trade Ministers do not often get involved in the technical details." WWF, World Wide Fund For Nature. A League of Gentlemen: Who really runs EU Trade Decision-Making? nov. 2003. Disponível em: $<$ http://www.google.com.br/url? sa=t\&rct=j\&q=\&esrc=s\&source=web\&cd=1\&ved=0CC8QFjAA $>$. Acesso em: 6 mar. 2014. p. 8-9.

785 "The 113 Committee lacks openness and transparency concerning its work." MURPHY, Anna. In the maelstrom of change: The Article 113 Committee in the governance of external economic policy. In: CHRISTIANSEN, Thomas. KIRCHNER, Emil. (eds.) Committee Governance in the European Union. Manchester: Manchester University Press, 2000, p. 98-104. p. 99.

786 SERDAREVIC, Asja. European Union and Its Member States as a Collective Actor in WTO Decision-Making Process. American Consortium on European Union Studies (ACES). EU Center of Excellence Washington. ACES Cases, n. 2010.3. Disponível em: <http://transatlantic.saisjhu.edu/ACES/ACES_Cases/2010.3_ACES_Cases_Serdarevic.pdf>. Acesso em: 05 mar. 2014. p. 17. 
da UE no Sistema de Solução de Controvérsias da OMC. De todo modo, o procedimento previsto pelo regulamento das barreiras ao comércio oferece um relevante canal para participação dos setores interessados. ${ }^{787}$

Como se mencionou, recentes modificações nas competências das instituições comunitárias trazidas pelo Tratado de Lisboa permitem a participação do Parlamento Europeu na tomada de decisão em assuntos relativos à OMC, o que certamente pode ser interpretado como uma tentativa de incremento na transparência, accountability e legitimidade nas negociações comerciais, mas com o custo de delongá-las e com o risco de afetar sua eficiência e sua flexibilidade. ${ }^{788}$

Cabe lembrar que já houve proposta do parlamento da UE para a constituição de um órgão de caráter parlamentar na OMC, ${ }^{789}$ objetivando um controle mais efetivo das atividades normativas da $\mathrm{OMC}$, tendo em vista a percepção de que, nesta temática, há “[...] 'assimetrias de informação' e desconfiança democrática em face da construção intergovernamental de regras em instituições em todo o mundo, longe de cidadãos nacionais e grupos parlamentares." 790

Por fim, retomando a temática da implementação das decisões do Sistema de Solução de Controvérsias da OMC pela União Europeia, explicite-se o pertinente diagnóstico de ANTONELLO TANCREDI:

787 SERDAREVIC, Asja. European Union and Its Member States as a Collective Actor in WTO Decision-Making Process. American Consortium on European Union Studies (ACES). EU Center of Excellence Washington. ACES Cases, n. 2010.3. Disponível em: <http://transatlantic.saisjhu.edu/ACES/ACES_Cases/2010.3_ACES_Cases_Serdarevic.pdf>.Acesso em: 05 mar. 2014.p. 27.

788 "The implementation of trade policy stays with the Commission, but the Council and the EP will have some say in these matters. It is yet to be seen how the EP will use its legislative powers in trade policy to influence implementation." SERDAREVIC, Asja. European Union and Its Member States as a Collective Actor in WTO Decision-Making Process. American Consortium on European Union Studies (ACES). EU Center of Excellence Washington. ACES Cases, n. 2010.3. Disponível em: <http://transatlantic.saisjhu.edu/ACES/ACES_Cases/2010.3_ACES_Cases_Serdarevic.pdf>. Acesso em: 05 mar. 2014. p. 28.

789 Assim narra a autora: “[.... In November 1999, it [European Parliament] had adopted a resoltution calling on 'the Council and the Commission to examine the possibility of setting up a WTO Parliamentary Assembly to achieve greater democratic accountability'. The proposal was then taken up and unanimously approved by the parliamentarians from WTO Member states at the Seattle Ministerial, calling the 'establishment of a Standing Body of Parliamentarians whereby members of parliament can Exchange views, be informed and monitor WTO negotiations and activities." MANN, Erika. A Parliamentary Dimension to the WTO: More than Just a Vision. Reforming the World Trading System. In: PETERSMANN, Ernst-Ulrich. Reforming the World Trading System. Legitimacy, Efficiency and Democratic Governance. Oxford: Oxford University Press, 2005, p. 421-428. p. 424.

790 Tradução livre do original em língua inglesa: "[...] "information asymmetries" and "democratic distrust" vis-à-vis intergovernmental rule-making in worldwide institutions far away from domestic citizens and parliamentary constituencies." PETERSMANN, Ernst-Ulrich. Multi-Level Judicial Trade Governance without Justice? On the Role of Domestic Courts in the WTO Legal and Dispute Settlement System. European University Institute, Department of Law, EUI Working Paper LAW, n. 2006/44. p. 19. 


\begin{abstract}
Esta visão sumária mostra que o registro de implementação da CE, embora não seja exemplar, não se vincula a uma abordagem de não- cumprimento em geral. $\mathrm{Na}$ maioria dos casos, de fato, a Comunidade manifestou a sua vontade de cumprir as decisões do OSC, tendo adotado as medidas de aplicação, embora com atrasos muito longos (medidas adotadas após o termo do período de tempo razoável), e não sem contestação quanto à sua coerência com a decisão desfavorável. Por outro lado, os registros parecem refletir uma atitude que, de acordo com a visão tradicionalmente mantida pelo Tribunal de Justiça Europeu (TJE) desde o caso International Fruit até o caso Portugal, encontra o seu fundamento no princípio das negociações com vistas a alcançar soluções mutuamente satisfatórias, mesmo para além dos limites estabelecidos pelo ESC. O número de litígios resolvidos pela Comunidade, por si só ou em conjunto com os seus Estados-Membros, por meio de uma solução mutuamente acordada, apoia este ponto de vista. . $^{7}$
\end{abstract}

No que se refere à aplicação de direitos oriundos de decisões do OSC, tais como a retaliação cruzada, é certo que a existência de competências compartilhadas entre a União e seus Estados membros torna ainda mais complexa a sua concretização, embora o TJUE/TJCE tenha estabelecido um dever de cooperação entre os membros e a Comissão nesta matéria. ${ }^{792}$

Com a intenção de facilitar a aplicação de medidas retaliatórias devidamente autorizadas pelo OSC, foi aprovado este ano um regulamento que sistematiza a matéria, prevendo um procedimento único. Até então as medidas eram desenhadas caso a caso, por meio de propostas formuladas pela Comissão ao Conselho, que adotava as medidas apropriadas, como por exemplo o Regulamento do Conselho n. 673/2005, relativo à controvérsia United States - Continued Dumping and Subsidy Offset Act of 2000 e o

791 Tradução livre do original em língua inglesa: "This cursory overview shows that the EC's implementation record, though not exemplary, does not add up to a generally non-complying approach. In the majority of cases, in fact, the Community has declared its willingness to comply with the DSB's rulings, and has adopted implementation measures, albeit with exceedingly lengthy delays (measures adopted after the expiry of the reasonable period of time), and not without contestation as to their consistency with the adverse decision. On the other hand, the record seems to reflect an attitude that, in accordance with the view traditionally maintained by the European Court of Justice (ECJ) from International Fruit to Portugal, finds its cornerstone in the principle of negotiations with a view to achieving mutually satisfactory solutions, even beyond the limits set by the DSU. The number of disputes settled by the Community, alone or jointly with its Member States, by means of a mutually agreed solution, supports this view”. TANCREDI, Antonello. EC Practice in the WTO: How Wide is the 'Scope for Manoeuvre'? European Journal of International Law, vol. 15, n. 5, p. 933-961, 2004. p. 936-937.

792 MURPHY, Anna. In the maelstrom of change: The Article 113 Committee in the governance of external economic policy. In: CHRISTIANSEN, Thomas. KIRCHNER, Emil. (eds.) Committee Governance in the European Union. Manchester: Manchester University Press, 2000, p. 98-104. p. 105. 
Regulamento do Conselho n. 728/2006, relativo ao caso United States - Tax Treatment for "Foreign Sales Corporations". 793

O novo Regulamento, aprovado pelo parlamento europeu em 2 de abril de $2014{ }^{794}$ e adotado pelo Conselho em 7 de maio de 2014, ${ }^{795}$ é aplicável não somente às situações nas quais o OSC autorizou a suspensão de concessões ou outras obrigações, como modo de induzir o cumprimento, mas também com o intuito da imposição de contramedidas, com base no artigo 8 do Acordo de Salvaguardas, e em casos de reequilíbrio de concessões, com base no artigo XXVIII do GATT 1994. ${ }^{796}$ O documento estabelece alguns critérios nos quais a aplicação das medidas deve se embasar, ${ }^{797}$ reforçando a previsibilidade e a segurança jurídica em sua aplicação.

793 Nos dados oficiais divulgados na página da UE, consta a explicação do motivo pelo qual até 2012, quando o Regulamento do procedimento foi enviado, não havia este procedimento unificado. "However, prior to the Treaty of Lisbon, the distinction between legislative and executive functions was not clearly defined and, therefore, the allocation of responsibilities to the EU institutions was not as balanced as today. Moreover, there was no single framework to refer to when the EU was called to take action to defend its trade rights and interests." Press Release. Proposal for new enforcement framework for international trade rules European Commission - MEMO/12/1006, 18 dez. 2012. Disponível em: < http://europa.eu/rapid/pressrelease_MEMO-12-1006_en.htm>. Acesso em: 20 mar. 2014.

794 European Parliament legislative resolution of 2 April 2014 on the proposal for a regulation of the European Parliament and of the Council concerning the exercise of the Union's rights for the application and enforcement of international trade rules (COM(2012)0773 - C7-0415/2012 - 2012/0359(COD)). Disponível em: <http://www.europarl.europa.eu/sides/getDoc.do?pubRef=-//EP//TEXT+TA+P7-TA-20140264+0+DOC+XML+V0//EN\&language=EN\#top >. Acesso em: 20 mar. 2014.

795 Disponível em: < http://register.consilium.europa.eu/doc/srv?l=EN\&f=ST\%209433\%202014\%20INIT >. Acesso em: 20 mar. 2014.

796 "Article 3 Scope-This Regulation applies: (a) following the adjudication of trade disputes under the WTO Understanding on Rules and Procedures Governing the Settlement of Disputes (WTO Dispute Settlement Understanding), when the Union has been authorised to suspend concessions or other obligations under the multilateral and plurilateral agreements covered by the WTO Dispute Settlement Understanding; (b) following the adjudication of trade disputes under other international trade agreements, including regional or bilateral agreements, when the Union has the right to suspend concessions or other obligations under such agreements; (c) for the rebalancing of concessions or other obligations, to which the application of a safeguard measure by a third country may give right pursuant to Article 8 of the WTO Agreement on Safeguards, or to the provisions on safeguards included in other international trade agreements, including regional or bilateral agreements; (d) in cases of modification of concessions by a WTO member under Article XXVIII of the GATT 1994, where no compensatory adjustments have been agreed." Disponível em: < http://register.consilium.europa.eu/doc/srv?l=EN\&f=ST\%209433\%202014\%20INIT >. Acesso em: 20 mar. 2014.

797 "Article 4 Exercise of the Union's rights: [...] 3. Commercial policy measures referred to in paragraph 1 shall be determined on the basis of the following criteria, in light of available information and of the Union's general interest: (a) effectiveness of the measures in inducing compliance of third countries with international trade rules; (b) potential of the measures to provide relief to economic operators within the Union affected by third country measures; (c) availability of alternative sources of supply for the goods or services concerned, in order to avoid or minimise any negative impact on downstream industries, contracting authorities or entities, or final consumers within the Union; (d) avoidance of disproportionate administrative complexity and costs in the application of the measures; (e) any specific criteria that may be established in international trade agreements in connection with the cases referred to in Article 3." Disponível em: <http://register.consilium.europa.eu/doc/srv?l=EN\&f=ST\%209433\%202014\%20INIT>. 


\subsubsection{Japão}

Embora no Japão haja uma previsão constitucional que parece conceder implicitamente aplicabilidade direta aos tratados internacionais, ${ }^{798} \mathrm{em}$ casos concretos se evitaria na prática conceder aos Acordos multilaterais de comércio essa aplicação. ${ }^{799}$

No sistema jurídico japonês, de modo geral, os tratados internacionais gozam de força de lei, e prevalecem sobre o direito interno, embora estejam submetidos à Constituição. Não há necessidade de um ato de transformação, motivo pelo qual se poderia interpretar que foi adotada a perspectiva monista. Deste modo, resta clara a aplicabilidade direta do Direito da OMC no Japão, ${ }^{800}$ mas não a invocabilidade direta.

As cortes japonesas, contudo, negaram invocabilidade direta ao GATT 1947, ${ }^{801} \mathrm{em}$ função da imprecisão e incondicionalidade de seus dispositivos, e não houve mudança substancial no tratamento do tema, embora haja a aplicabilidade indireta como parâmetro de interpretação. Assim, em relação à $\mathrm{OMC}$, embora não tenha havido pronunciamento oficial sobre o tema, permanece a posição de que não haveria uma tradução de seu sentido em "direitos" no ordenamento jurídico interno. ${ }^{802}$

Deste modo, apesar da previsão existente na Constituição, segundo a doutrina consultada o sistema jurídico japonês não confere caráter autoexecutório às decisões do OSC, que dependeriam de medida específica do governo, em geral, um ato administrativo

Acesso em: 20 mar. 2014.

798 Artigo 98(2) da Constituição Japonesa prevê que os Tratados Internacionais "devem ser fielmente observados”. Cf: MATSUSHITA, Mitsuo; MAVROIDS, Petros C.; SCHOENBAUM, Thomas J. The World Trade Organization: Law, Practice, and Policy. 2a Ed. Oxford: Oxford University Press, 2006, p. 99.

799 JACKSON, John. Sovereignty, the WTO and Changing Fundamentals of International Law. New York: Cambridge Univeristy Press, 2006. p. 127.

800 ZHANG, Xin. Domestic Effect of the WTO Agreement in China: Trends and Implications. The Journal of World Investment, vol. 3, p. 912-937, 2002. p. 923.

801 Kyoto Necktie Case. Para maiores detalhes e análise do caso, Cf: YUJI, Iasawa. Effectuation of International Law in the Municipal Legal Order of Japan. SIK, Ko Swan; SYATAUW J. J. G., PINTO M. C. W. (Eds.) Asian Yearbook of International Law, vol. 4, p. 143-169, 1995. p. 157.

802 YAMANE, Hiroko. The WTO Dispute Settlement Mechanism and Japanese Traders. Journal of International Economic Law, vol. 1, p. 683-689, 1998. 
adotado pelo Executivo. ${ }^{803}$

Contudo, é relevante destacar que esta pesquisa se deparou com especiais dificuldades para encontrar descrições específicas do tratamento conferido pelo ordenamento jurídico japonês às decisões do Sistema de Solução de Controvérsias da OMC, bem como de seu tratamento no intuito de implementação.

\subsubsection{China}

Diante do silêncio da constituição chinesa no tocante à relação entre os tratados e o direito interno, apenas estabelecendo a competência geral de órgãos estatais para participarem do procedimento de conclusão de tratados (tiaoyue) e acordos (xieding) internacionais, a análise do status destes instrumentos internacionais no direito interno chinês demanda uma análise caso a caso. ${ }^{804}$

Em relação ao status dos tratados internacionais no sistema jurídico chinês, cumpre destacar que a China adota a abordagem monista, pela qual os tratados internacionais se tornam parte do ordenamento jurídico interno após a ratificação (bingru), a prescindir de um ato específico de transformação (zhuanhua). ${ }^{805}$

No que se refere ao status dos tratados internacionais em face das normais internas, o posicionamento tradicional da Corte Suprema Chinesa é de que os tribunais chineses devem aplicar um tratado internacional quando houver um conflito com o direito interno, com exceção dos casos nos quais a China formulou reservas na sua conclusão ou adesão.

Assim, segundo explicita XIN ZHANG, por meio da acessão da China à OMC, os Acordos da OMC se tornaram automaticamente parte do direito chinês, tendo em vista a prática geral derivada da perspectiva monista. Contudo, o fato das autoridades dos

803 BENJAMIN, Daniela Arruda. Introdução. In: BENJAMIN, Daniela Arruda. (Org). O Sistema de Solução de Controvérsias da OMC: uma perspectiva brasileira. Brasília : FUNAG, 2013, p. 31-41. p. 585. 804 Para a diferenciação entre os institutos, Cf: ZHANG, Xin. Domestic Effect of the WTO Agreement in China: Trends and Implications. The Journal of World Investment, vol. 3, p. 912-937, 2002. p. 923.

805 WANG, Tieya. International Law in China: Historical and Contemporary Perspectives, Recueil des Cours, vol. 221, p. 195-369, 1990. p. 326-327. 
diferentes poderes não necessitarem de um ato de incorporação dos Acordos da OMC ao direito chinês não implica necessariamente em sua invocabilidade direta. ${ }^{806}$

A invocabilidade direta, capacidade dos entes privados invocarem os dispositivos dos Acordos nas cortes chinesas, não poderia ser deduzida de nenhum dispositivo normativo ou constitucional existente. A esse respeito, existem três escolas de pensamento na doutrina chinesa: (a) a escola minoritária, que defende a invocabilidade direta dos Acordos da OMC; (b) a escola majoritária, que defende que a China deveria rejeitar totalmente a invocabilidade direta dos Acordos da OMC - com base na natureza política destes acordos, na não concessão da invocabilidade direta pelos demais membros da OMC e na complexidade da aplicação e interpretação destes acordos pelo judiciário chinês -; e (c) a escola mista, que defende uma distinção entre as obrigações multilaterais passíveis e as não passíveis de invocabilidade direta, segundo certo critério.

Contudo, em 27 de agosto de 2002, a Suprema Corte da China exarou uma interpretação judicial denominada "Measures on Several Issues Relating to the Adjudication of International Trade Administrative Litigations", documento no qual previa normas para que partes privadas pudessem suscitar a revisão judicial de um procedimento administrativo (xingzlheng susong), para apreciação de casos nos quais o comportamento dos órgãos administrativos se relacione ao comércio internacional. ${ }^{807}$

Embora o documento não mencione expressamente uma recusa à aplicabilidade direta dos Acordos da OMC, os seus principais dispositivos possuiriam tal efeito, ao determinarem que os tribunais chineses deverão aplicar os instrumentos normativos chineses nesses litígios, impedindo na prática a invocabilidade direta das normas multilaterais. ${ }^{808}$ Haveria espaço, contudo, para a discussão da possibilidade de

806 ZHANG, Xin. Domestic Effect of the WTO Agreement in China: Trends and Implications. The Journal of World Investment, vol. 3, p. 912-937, 2002. p. 923.

807 De modo geral, o escopo desta revisão se apresenta da seguinte forma: "The court will consider the following aspects in the judicial review of such administrative behaviour addressed to the claimant: whether the evidence is adequate and sufficient; whether the application of laws and regulations is correct; whether the organ violates due procedure; whether the organ acts ultra vires; whether the organ abuses the administrative powers; whether the administrative penalties are ostensibly unfair; and whether the organ refuses or delays to perform its administrative duties." ZHANG, Xin. Domestic Effect of the WTO Agreement in China: Trends and Implications. The Journal of World Investment, vol. 3, p. 912-937, 2002. p. 932 .

808 "The most notable parts of the Measures are Articles 7 and 8. Article 7 provides that, when the courts adjudicate international trade administrative litigations, they shall apply PRC laws, administrative regulations, and local regulations issued by the local legislatures within the relevant legislative competence that relate to or affect international trade," while Article 8 allows the courts to thake reference to "the ministerial rules issued by the Ministries, Departments or Commissions of the State Council and the local 
invocabilidade direta dos efeitos do TRIPS em casos comerciais e cíveis, uma vez que esse acordo preveria direitos claros e identificáveis a sujeitos privados.

Relevante destacar que o documento contém também um dispositivo que exige a reciprocidade para que partes privadas estrangeiras acessem o judiciário para tal revisão relativa a atos administrativos ligados ao comércio internacional. ${ }^{809}$ Por fim, o artigo 9 estabelece o princípio da interpretação consistente, pelo qual deve-se priorizar a interpretação de um dispositivo de lei relativa ao comércio internacional que esteja em conformidade com o tratado internacional, ${ }^{810}$ estabelecendo, de modo indireto, a obrigação de respeito às obrigações multilaterais. ${ }^{811}$

Em relação à participação da China nos contenciosos da OMC, observa-se que diversos casos foram concluídos por meio de solução mutuamente acordada, na qual as partes chegaram a um acordo sobre a modificação da medida questionada. É relevante destacar que esta pré-disposição a resolver os conflitos por meio de acordos é apontada como reflexo da cultura chinesa, sob sua perspectiva confuciana, de desestímulo ao confronto judicial. ${ }^{812} 813$ Sob a perspectiva de implementação, embora nesses casos não

rules issued by the local governments within their legislative competence." ZHANG, Xin. Domestic Effect of the WTO Agreement in China: Trends and Implications. The Journal of World Investment, vol. 3, p. 912937, 2002. p. 932.

809 Artigo 10: "Foreign nationals, stateless persons and foreign organizations that are engaged in administrative litigations in the People's Republic of China shall have the same litigation rights and obligations as citizens and organizations of the People's Republic of China. Should the courts of a foreign country impose restrictions on the administrative litigation rights of the citizens and organizations of the People's Republic of China, the Chinese People's Courts shall follow the principle of reciprocity regarding the administrative litigation rights of the citizens and organizations ofthat foreign country." ZHANG, Xin. Domestic Effect of the WTO Agreement in China: Trends and Implications. The Journal of World Investment, vol. 3, p. 912-937, 2002. p. 933.

$810 \quad$ Artigo 9: "When there exist two or more than two reasonable interpretations of the provisions of applicable law or regulation in adjudicating international trade administrative litigations, and one interpretation is consistent with the relevant provision of international treaties concluded or acceded to by [China], the courts shall choose the interpretation consistent with the relevant international treaty, unless relating to clauses to which China has declared reservation." ZHANG, Xin. Domestic Effect of the WTO Agreement in China: Trends and Implications. The Journal of World Investment, vol. 3, p. 912-937, 2002. p. 934.

811 "This will not only avoid conflict between Chinese law and the WTO Agreement, but it also implies the judicial attitude is to interpret the domestic law as far as possible to be consistent with international obligations. Consequently, the WTo Agreement may have an indirect effect in China through the back door, thanks to the application of such a principle." ZHANG, Xin. Domestic Effect of the WTO Agreement in China: Trends and Implications. The Journal of World Investment, vol. 3, p. 912-937, 2002. p. 934.

812 Sobre a perspectiva confuciana e seus possíveis reflexos na participação da China da OMC, Cf: PENG, Shin-yi. WTO Legalistic Approach and East Asia: From the Legal Culture Perspective. Asian-Pacific Law \& Policy Journal, vol. 1, p. 1-35, 2000.

813 Ao contrário, para uma tentativa de "desmistificação" desta afirmativa, concluindo que diversos outros aspectos -que não a suposta cultura asiática contra o litígio - influenciam a participação dos países asiáticos no Sistema de Solução de Controvérsias: "Finally, there is no evidence of an immutable Asian culture of non- litigiousness within the international law sphere. As illustrated by the various examples cited 
tenha havido uma decisão adjudicatória internacional, a concretização do acordo celebrado entre as partes tende a se dar de modo mais satisfatório, pois envolve o elemento da voluntariedade. ${ }^{814}$

Embora tenha havido certo temor inicial das dificuldades de implementação que adviriam do ordenamento jurídico chinês, ${ }^{815}$ em análise dos casos nos dez primeiros anos de participação da China no Sistema de Solução de Controvérsias da OMC, XIULI HAN avalia que, assim como a maioria dos perdedores no procedimento do Sistema de Solução de Controvérsias da OMC, a China tem implementado as decisões desse mecanismo nos casos que lhe são desfavoráveis. ${ }^{816}$

São identificáveis diversos caminhos pelos quais a China estaria buscando um incremento de sua capacidade geral de enfrentamento dos procedimentos, tais como: (a) o reestabelecimento de uma agência estatal específica para lidar com desavenças comerciais; (b) o fortalecimento da conexão entre o governo e a academia no ramo do Direito da OMC; (c) a indicação de nacionais chineses para o posto de painelistas e membros do Órgão de Apelação; e (d) a participação da China como terceira parte nos procedimentos. ${ }^{817}$

A China mudou sua postura em face do Sistema de Solução de Controvérsias, partindo inicialmente de uma postura cautelosa, na qual buscava solucionar rapidamente com o demandante as controvérsias de modo negocial, para uma participação mais ativa no sistema, inclusive como terceira parte em praticamente todos os litígios, tornando-se, por fim, um litigante agressivo no sistema. ${ }^{818}$ Assim, de uma postura relutante, na qual

in this article, Asian developing countries are willing to adopt over time more active dispute settlement strategies as China and Korea did. Thus any apparent reticence in initiating and converting disputes is symptomatic of other factors rather than reflecting any Asian culture of non-litigiousness." EWING-CHOW, Michael.; GOH, Alex W. S. Goh.; PATIL, Akshay Kolse. Are Asian Wto Members Using The WTO DSU 'Effectively'? Journal of International Economic Law, vol. 16, p. 669-705, set. 2013. p. 704.

814 HAN, Xiuli. China's First Ten Years in WTO Dispute Settlement. Journal of World Investment \& Trade, vol. 12, p. 49-64, 2011. p. 55.

815 Na oportunidade da acessão da China à $\mathrm{OMC}$, é presente na doutrina certo ceticismo em relação à capacidade da China em cumprir amplamente os compromissos acordados, em especial no tocante ao Sistema de Solução de Controvérsias. Cf: DUNCAN, Christopher. Out of Conformity: China's Capacity to Implement World Trade Organization Dispute Settlement Body Decisions After Accession. American University International Law Review, vol. 18, n. 2, p. 399-506, 2002.

816 Citando os casos DS339, DS340, DS342, DS362, DS363. HAN, Xiuli. China's First Ten Years in WTO Dispute Settlement. Journal of World Investment \& Trade, vol. 12, p. 49-64, 2011. p. 55-57.

817 HAN, Xiuli. China's First Ten Years in WTO Dispute Settlement. Journal of World Investment \& Trade, vol. 12, p. 49-64, 2011. p. 55. p. 57-63.

818 Segundo o autor, existiram três fases da China no Sistema de Solução de Controvérsias da OMC: (1) "rule-taker", (2) "rule-shaker", (3) "rule-maker". "In summary, the past nine years have witnessed China adopting shifting strategies in WTO dispute settlement system: starting as a newcomer that largely passively 'took' obligations and commitments imposed upon it, China has transformed into a seasoned Member that 
inicialmente desempenhava o papel de demandante tímido e de demandado sempre à busca de um acordo, a China teria passado a exercer um papel de demandante proativo e de demandado mais árduo. ${ }^{819}$

De acordo com uma segunda análise, a China teria um comportamento "exemplar" no quesito da implementação dos relatórios adotados, demonstrando respeito ao Sistema de Solução de Controvérsias em suas determinações. Por outro lado, os principais oponentes da China - EUA e UE - não teriam um histórico tão imaculado de implementação. Nas três situações de implementação citadas ${ }^{820}$ a implementação envolveu ação legislativa com difíceis entraves internos, e não apenas um ato administrativo de mais simples execução, evidenciando o compromisso da China com a efetivação das decisões. ${ }^{821}$

De modo correlato, em uma terceira interpretação, os autores reconhecem que embora a China tenha demonstrado o devido respeito às decisões do Sistema de Solução de Controvérsias da OMC, expressando seu intuito de implementar, e os casos demonstrem uma efetiva implementação das decisões, a falha na implementação de membros como os EUA e a UE/CE poderia abrir espaço para uma postura reticente em casos econômica e politicamente sensíveis ao país. ${ }^{822}$

\subsection{Considerações sobre os Efeitos da Decisão do Sistema de Solução de Controvérsias da OMC e os Mecanismos Nacionais de Implementação}

skillfully 'shook' the existing rules to tilt in its favor, and now even a shrewd player that attempts to 'make' new rules reflecting its own interests by advancing strategic claims in dispute settlement. If the current trend continues, China will not only continue to be a heavy 'user'of the system, but also eventually become an 'owner'of the system." GAO, Henry. Elephant in the Room: Challenges of Integrating China into the WTO System. Asian Journal of WTO \& International Health Law \& Policy, vol. 6, p. 137-168, 2011. p. 158. 819 QI, Tong. China's First Decade Experience in the WTO Dispute Settlement System: Practice and Prospect. Asian Journal of WTO \& International Health Law \& Policy, vol. 7, p. 143-180, 2012.

820 WTO. Appellate Body Reports, China - Measures Affecting Imports of Automobile Parts. WT/DS339/AB/R, WT/DS340/AB/R, WT/DS342/AB/R, 15 dez. 2008.; WTO. Appellate Body Report, Brazil - Measures Affecting Imports of Retreaded Tyres. WT/DS332/AB/R, 3 dez. 2007.; WTO. Appellate Body Report, China - Measures Affecting Trading Rights and Distribution Services for Certain Publications and Audiovisual Entertainment Products. WT/DS363/AB/R, 21 dez. 2009.

821 QI, Tong. China's First Decade Experience in the WTO Dispute Settlement System: Practice and Prospect. Asian Journal of WTO \& International Health Law \& Policy, vol. 7, p. 143-180, 2012. p. 164166.

822 JI, Wenhua; HUANG, Cui. China's Experience in Dealing with WTO Dispute Settlement: A Chinese Perspective. Journal of World Trade, vol. 45, n. 1, p. 1-37, 2011. p. 30-31. 
A temática dos efeitos no ordenamento jurídico interno não é uniforme, e permite uma pluralidade de significados e dimensões, o que claramente demonstra a complexidade do tema. A análise de seu sentido, contudo, parte da disciplina constitucional do determinado Estado, bem como de sua perspectiva adotada em face do Direito Internacional. Antes de adentrarmos, pois, no status jurídico do decisão do Sistema de Solução de Controvérsias da OMC em um determinado sistema jurídico, é necessário revisitar a condição do Direito da OMC neste ordenamento interno.

Não há uma categorização uniforme dos efeitos jurídicos internos de um tratado internacional ou uma decisão internacional no ordenamento jurídico nacional, sendo recorrente a utilização de diversos termos para se referir a fenômenos correlatos. ${ }^{823} \mathrm{Na}$ busca por um refinamento conceitual, contudo, é relevante destacar três aspectos - distintos mas inter-relacionados - do estudo dos efeitos jurídicos nos ordenamentos nacionais: (a) autoexecutoriedade; (b) aplicabilidade direta e (c) invocablilidade direta.

Para diferenciar os dois primeiros conceitos, adota-se a distinção traçada por THOMAS BuERGENTAL, para quem autoexecutoriedade diz respeito à aplicação interna dos tratados internacionais, relacionada ao fato de um ordenamento jurídico nacional optar pela desnecessidade de um ato adicional para sua incorporação ao direito nacional, enquanto a aplicabilidade direta corresponde à obrigação internacional de concretizar as obrigações do tratado no plano interno. ${ }^{824}$

Assim, tendo em conta essa distinção, o caráter autoexecutório de um tratado internacional em um determinado país depende do comando constitucional que define a colocação do Direito Internacional na ordem jurídica do Estado específico, e da desnecessidade de um ato adicional para internalizá-lo, tendo essa noção especial utilidade em Estados denominados "monistas". Nesses Estados pode ganhar espaço a distinção entre os acordos autoexecutórios e os acordos não-autoexecutórios, como uma técnica que

823 ZHANG, Xin. Domestic Effect of the WTO Agreement in China: Trends and Implications. The Journal of World Investment, vol. 3, p. 912-937, 2002. p. 923.

824 Assim o autor explicita a tentativda de diferenciar os conceitos: "Therefore, to avoid confusion, we will try in these lectures to use the terms 'self-executing' and 'non-self-executing' when dealing with the domestic application of treaties, reserving the concept of 'directly applicable' to the international law obligation to make the provisions of the treaty self-executing on the domestic plane". BUERGENTHAL, Thomas. Self-executing and non-self-executing treaties in national and international law. Recueil des cours, vol. 235, p. 303-400, 1992. p. 321. 
permite aos Estados determinar quais tratados adquirem eficácia jurídica plena sem a necessidade de medidas (legislativas, executivas ou judiciais) de implementação. ${ }^{825}$

A aplicabilidade direta, por outro lado, seria característica dos tratados que foram concluídos com o objetivo de criar direitos diretamente invocáveis no âmbito jurídico interno, contribuindo para a sua configuração a análise de sua linguagem e do propósito das partes. ${ }^{826}$ Embora o autor confira destaque à origem internacional dessa categoria, não deixa de explicitar que é na interpretação conferida pelas respectivas Cortes nacionais que um determinado tratado se torna diretamente aplicável "naquele” ordenamento jurídico. ${ }^{827}$

A invocabilidade direta, como decorrência, é uma consequência da aplicabilidade direta dos tratados internacionais, significando a capacidade que as partes privadas possuem de invocar referido tratado internacional em litígio nos tribunais nacionais. A invocabilidade direta trata, portanto, da possibilidade dos sujeitos se apoiarem nesses tratados como fonte de direitos e deveres concretos, e pode estar limitada pelo status que suas respectivas normas adquirem no ordenamento jurídico interno, em relação aos demais atos legislativos nacionais. ${ }^{828}$

825 Desse modo, a distinção trata de separar a pespectiva interna da internacional: “The distinction was intended to emphasize the point that the question whether a treaty is or is not self-executing is a domestic law question; whereas the question whether the States parties to it intended its provisions to be directly enforceable as such on the domestic plane is a question of international law." BUERGENTHAL, Thomas. Self-executing and non-self-executing treaties in national and international law. Recueil des cours, vol. 235 , p. 303-400, 1992. p. 322.

826 Em resumo: "In that sense, the concepts of self-executing treaties and that of directly applicable treaties are founded on very different assumptions. A treaty may be self-executing in a country because its courts conclude that individuals are its intended beneficiaries and because it is drafted in a form that enables these national courts to apply it without additional legislation. For a treaty to be self-executing, however, it is not necessary that the States parties to it should have intended to make its provisions directly applicable as a matter of international law. The intention of the States parties in the latter case must have been to establish some special régime designed to ensure that individuals, as the beneficiaries of certain rights, can invoke the specific provisions of the treaty in national courts; in the case of self-executing treaties, all that will often be needed is an intention to create rights in which individuals may have a legal interest to enforce and the capacity of national courts to give effect to those rights without further legislative measures. In this latter case, the contracting States are interested, as a matter of international law, only in compliance with the substantive obligation established by the treaty, leaving it to the States parties to decide how that will be done. In the case of directly applicable treaties, the contracting States are deemed to have assumed two international legal obliga-tions : one relating to the substance of the right and the other relating to the manner of its domestic enforcement." BUERGENTHAL, Thomas. Self-executing and non-self-executing treaties in national and international law. Recueil des cours, vol. 235, p. 303-400, 1992. p. 329.

827 Contudo, o teste aplicado pelas Cortes tem se embasado majoritariamente na linguagem e no objetivo dos negociadores com o tratado, e portanto em aspectos "internacionais".

828 ZHANG, Xin. Domestic Effect of the WTO Agreement in China: Trends and Implications. The Journal of World Investment, vol. 3, p. 912-937, 2002. p. 923. 
Ao conjunto de tais conceitos, podemos nos referir como os efeitos ou os impactos de um tratado internacional - e, em decorrência, de uma decisão adjudicatória internacional - no ordenamento de um determinado Estado.

Antes de avançarmos é preciso destacar que uma outra perspectiva destes conceitos os diferencia pelo respectivo locus de surgimento. Se em um sentido amplo ambos se referem à produção concreta de efeitos de um tratado entre sujeitos do direito interno de membros desta fonte convencional, o conceito dos tratados autoexecutórios seria instituto oriundo do direito norte-americano, ${ }^{829}$ e a doutrina da aplicabilidade direta seria surgida da interpretação dos efeitos dos tratados constitutivos da ordem comunitária pelo TJUE/TJCE. ${ }^{830}$

Os Acordos da OMC não possuem menção expressa à sua aplicabilidade ou invocabilidade nos ordenamentos jurídicos de seus membros, ficando a cargo de cada sistema jurídico nacional a definição desta problemática. ${ }^{831}{ }^{832}$ Como evidenciou-se do exame nos subtópicos supra, por diversos motivos e embasamentos, os membros tem comumente negado aplicabilidade e invocabilidade direta aos acordos da OMC. ${ }^{833}$ XIN ZHANG faz uma análise comparativa, de modo a evidenciar que três dos membros mais

829 VAZQUEZ, Carlos Manuel. The Four Doctrines of Self-Executing Treaties. American Journal of International Law. Vol. 89, 1995. p. 695- 723.

830 MARTINES, Francesca. Direct Effect of International Agreements of the European Union. European journal of International Law, vol. 25 n. 1, p. 129-147, 2014.

831 Assim explicita Welber Barral: “[...] Como regra geral, o próprio efeito direto das normas da OMC dependerá da estrutura constitucional e do status concedidos aos tratados pela ordem jurídica de cada Membro. [...] Na OMC, entretanto, não há regras que gerem efeitos diretos, para a esfera normativa nacional dos Membros, das decisões do OSC ou das interpretações eventualmente adotadas pelos painéis e pelo OAp." BARRAL, Welber. Solução de Controvérsias na Organização Mundial do Comércio. Brasília: Fundação Alexandre de Gusmão, 2007. p. 70.

832 Para uma visão distinta, acerca da obrigação de garantir acesso à jusrisdição nacional por violações da normativa multilateral, remete-se à perspectiva de Petersmann: "Even though WTO law provides for a multilevel legal and dispute settlement system protecting also individual 'access to justice' in domestic courts (cf. GATT Article X and numerous other WTO provisions), many governments limit their domestic legal and judicial accountability for harmful violations of their WTO obligations by insisting that domestic courts should not protect domestic citizens against violations of WTO obligations and WTO dispute settlement rulings to the detriment of adversely affected citizens seeking judicial remedies in domestic courts." PETERSMANN, Ernst-Ulrich. Multilevel Governance Problems of the World Trading System beyond the WTO Conference at Bali 2013. Journal of International Economic Law, vol. 17, p. 233-270, 2014. p. 248. 833 A autora explicita esta constatação: "Indeed, it appears that among the countries that, as a matter of principle, deny direct effect to WTO Agreements are all the major trading members of the WTO, namely the US, the EU, Canada, Japan, China, and so on. And yet they represent roughly 70 to 75 per cent of world trade. Through this lens, the denial of direct effect to the WTO agreements becomes more massive. At the same time, this approach evidences that the reasons cannot be exclusively legal. It is all the more true that some of these WTO members, such as the EU, could, according to the structure of their legal systems, eas-ily accommodate direct effect, at least for some provisions of WTO law, meeting the usual substantive requirements for granting direct effect." FABRI, Hélène Ruiz. Is There a Case - Legally and Politically - for Direct Effect of WTO Obligations? European Journal of International Law, vol. 25, n. 1, p. 151-173, 2014. p. 155. 
influentes do comércio internacional, os EUA, a UE/CE e o Japão buscaram esvair-se de sua prática em relação à aplicabilidade de tratados internacionais, para negar ao Direito da OMC efeitos diretos e invocabilidade em seus tribunais. ${ }^{834}$

Interessante destacar, pois, que o fato de outros ordenamentos jurídicos não conferirem aplicabilidade e invocabilidade direta foi um dos argumentos nos quais se embasou o TJUE/TJCE para negar esses efeitos, e esta argumentação tende a ser utilizada por outros membros. ${ }^{835}$ Deste modo, constrói-se uma lógica de certo modo tautológica e que leva à tendência de ampliação da limitação da possibilidade de exercício de direitos legítimos pelos indivíduos em diversos ordenamentos.

Em termos conceituais, é preciso atentar para a distinção entre aplicabilidade e/ou invocabilidade conferidas a certo tratado internacional em um dado ordenamento, e a aplicabilidade e/ou invocabilidade conferidas às decisões de um órgão/sistema adjudicatório criado pelo tratado. Embora os tribunais nacionais, como demonstram as análises realizadas, tenham demonstrado certa tendência a tratar essas noções de modo similar, as obrigações decorrentes do Acordos da OMC, e aquelas decorrentes de decisões do Sistema de Solução de Controvérsias da OMC são oriundas de categorias notadamente distintas.

Um dos pressupostos lógicos da aplicabilidade e invocabilidade nas cortes nacionais das recomendações contidas nos relatórios, adotados pelo OSC, é a sua obrigatoriedade. A respeito desse pressuposto, como o capítulo 2 buscou explicitar, entende-se como decorrente da caracterização das decisões do OSC como decisões

834 Em resumo, estes são os principais argumentos para negar aplicabilidade direta: "However, it is necessary to explore the underlying rationale for the EC, the United states and Japan to reject the direct invocability of the WTO Agreement regardless of their traditions and the obvious advantages. There are three argument against direct effect. First, the recognition of direct effect will undermine the sovereignty enjoyed by the Member and, in particular, by the legislature. The United States is the typical example. Second, such recognition will deprive legislative and administrative bodies of political flexibility and make their actions more susceptible to challenges by private parties. The ECJ holds this position. Third, the nature and structure of the WTO Agreement are flexible and not mandatory or precise enough to confer rights on private parties. The EC and Japan take such a view. [...] In conclusion, the group of leading world trading entities deviate from their normal position and specifically deny the direct invocability of the WTO Agreements or adopt a more restrictive attitude toward their domestic application." ZHANG, Xin. Domestic Effect of the WTO Agreement in China: Trends and Implications. The Journal of World Investment, vol. 3, p. 912-937, 2002. p. 923.

835 Portugal v. Council (Rec.1999, p.I-8395), Case C-149/96, 23 nov. 1999. para. 44. "Admittedly, the fact that the courts of one of the parties consider that some of the provisions of the agreement concluded by the Community are of direct application whereas the courts of the other party do not recognise such direct application is not in itself such as to constitute a lack of reciprocity in the implementation of the agreement (Kupferberg, paragraph 18)." 
adjudicatórias do Sistema de Solução de Controvérsias da OMC. Essa posição se reforça na análise sistêmica dos dispositivos do ESC, bem como da cogência codificada na CVDT.

No tocante aos mecanismos nacionais de implementação, esses podem envolver a ação de um ou de mais poderes do Estado, sendo que o modo de cumprimento mais "simples" costuma se dar nas implementações que demandam uma ação do Poder Executivo, no exercício de sua função de gerenciamento e definição de políticas baseadas em seu ponderamento sobre a situação e os interesses do Estado.

As medidas de implementação que envolvem o Poder Legislativo são, via de regra, mais demoradas e complexas. São ações nas quais se exige a modificação de uma legislação strictu sensu, e essa dificuldade pode resultar de diversos fatores. Além dos procedimentos e prazos regularmente exigidos para o processo legiferante, pode haver composição política dos órgãos legislativos não necessariamente em consonância com o partido que exerce o Poder Executivo, ou uma percepção pelos parlamentares de que a modificação exigida pela decisão do OSC não é pertinente ou oportuna. A implementação por meio de conduta do Congresso tem se mostrado especialmente problemática nos EUA. 836

Medidas de implementação com a participação do Poder Judiciário não são comuns, mas não podem ser descartadas da sistemática da implementação pelos membros da OMC. No caso dos pneus reformados, por exemplo, o recurso à ADPF, uma espécie de ação de controle de constitucionalidade, foi essencial para tornar possível o cumprimento sem revogar a medida, que em sua substância era legítima.

Os mecanismos de implementação podem ser ad hoc ou podem ter parâmetros previstos em um marco normativo geral. Um exemplo de marco normativo geral é o procedimento expresso na legislação norte-americana (URRA), que estabelece consultas a Comitês do Congresso, Comitês do setor privado, e à esfera pública em geral, antes da definição do modo pelo qual será implementada a decisão do Sistema de Solução de Controvérsias da OMC.

836 DAVEY, William J. Implementation in WTO Dispute Settlement: An Introduction to the Problems and Possible Solutions. The Research Institute of Economy, Trade and Industry. RIETI Discussion Paper Series, n. 05-E-013, mar. 2005. p. 9. 


\subsection{Considerações sobre as Variáveis Envolvidas na Implementação}

A partir da filtragem dos casos analisados no capítulo anterior, podemos vislumbrar o amplo universo de medidas que - podendo constituir violação às normas multilaterais e/ou causando anulação ou redução de benefícios - estão sujeitas à apreciação do Sistema de Solução de Controvérsias da OMC.

Os diferentes mecanismos nacionais de implementação dependem, contudo, do caráter próprio da medida cuja desconformidade com a disciplina multilateral foi reconhecida. Assim, para os fins de sistematização dos mecanismos de implementação, faz-se necessária uma classificação das medidas sob as quais os respectivos mecanismos incidirão, embora se tratem de medidas notadamente distintas. ${ }^{837}$

Elegendo-se o critério da competência subjetiva da medida, podemos vislumbrar:

(i) medidas emanadas de órgãos executivos;

(ii) medidas emanadas de órgãos legislativos;

(iii) medidas emanadas de órgãos judiciários.

Atos dos três poderes são atribuíveis aos Estados, e portanto ensejam responsabilidade internacional. ${ }^{838}$ Não é diferente com o Sistema de Solução de Controvérsias da OMC, como foi reconhecido já em um de seus primeiros casos, o United

837 "[...]In principle, a measure which has been 'taken to comply with the recommendations and rulings' of the DSB will not be the same measure as the measure which was the subject of the original dispute, so that, in principle, there would be two separate and distinct measures: the original measure which gave rise to the recommendations and rulings of the DSB, and the 'measures taken to comply' which are or should be - adopted to implement those recommendations and rulings. In these Article 21.5 proceedings, the measure at issue is a new measure, the revised TPC programme, which became effective on 18 November 1999 and which Canada presents as a 'measure taken to comply with the recommendations and rulings' of the DSB." WTO. Appellate Body Report, Canada - Measures Affecting the Export of Civilian Aircraft (Recourse by Brazil to Article 21.5 of the DSU). WT/DS70/AB/RW, 21 jul. 2000. para 36.

838 Assim explicita Welber Barral: "[...] o objeto da reclamação ao OSC é uma medida nacional, cuja vigência viola, de acordo com o Membro reclamante, uma determinada obrigação constante nos acordos da OMC. Se esta medida provém do legislativo, do executivo, ou do judiciário do Membro reclamado, este é um problema de direito constitucional, alheio às possibilidades de regulamentação do Direito Internacional Econômico." BARRAL, Welber. Solução de Controvérsias na Organização Mundial do Comércio. Brasília: Fundação Alexandre de Gusmão, 2007. p. 70. 
States-Standards for Reformulated and Conventional Gasoline: “[...] os Estados Unidos, é claro, carregam a responsabilidade pelas ações de ambos os departamentos de governo: legislativo e executivo." 839

Esta noção foi reforçada no caso United States - Import Prohibition of Certain Shrimp and Shrimp Products: "Os Estados Unidos, como todos os outros membros da OMC e da comunidade dos Estados em geral, são responsáveis por atos de todos os seus departamentos de governo, incluindo seu judiciário." 840

Assim, se as medidas que constituem violação à normativa multilateral podem emanar de órgãos dos três poderes, é razoável supor que a implementação possa requerer medidas de todos esses poderes. Assim é que o Órgão de Apelação explicitou, no caso United States - Measures Relating to Zeroing and Sunset Reviews:

\begin{abstract}
Notamos que um membro da OMC "é responsável por atos de todos os seus departamentos de governo, incluindo seu judiciário." Isto é corroborado pelo artigo 18.4 do Acordo Antidumping, pelo Artigo XVI: 4 do Acordo da OMC, e pelo artigo 27 da Convenção de Viena, o Poder Judiciário é um órgão do Estado e mesmo se um ato ou omissão deriva do judiciário de um membro da OMC, é, no entanto, ainda imputável a esse membro da OMC. Assim, os Estados Unidos não podem procurar evitar a obrigação de cumprir as recomendações e decisões do OSC dentro do período razoável de tempo, se apoiando no argumento de que o momento da liquidação é "controlado pelo Poder Judiciário independente". ${ }^{841}$
\end{abstract}

Foi essa a posição do Brasil ao propor a ADPF como medida de implementação da decisão do caso Brazil - Measures Affecting Imports of Retreated Tyres. ${ }^{842}$ Embora o

839 Tradução livre do original em língua inglesa: “[...] the United States, of course, carries responsibility for actions of both the executive and legislative departments of government." WTO. Appellate Body Report, United States - Standards for Reformulated and Conventional Gasoline. WT/DS2/AB/R, 29 abr. 1996. p. 28.

840 Tradução livre do original em língua inglesa: "The United States, like all other Members of the WTO and of the general community of states, bears responsibility for acts of all its departments of government, including its judiciary." WTO. Appellate Body Report, United States - Import Prohibition of Certain Shrimp and Shrimp Products. WT/DS58/AB/R, 22 out. 2001. para. 173.

841 Tradução livre do original em língua inglesa: "We note that a WTO Member "bears responsibility for acts of all its departments of government, including its judiciary." This is supported by Article 18.4 of the Anti-Dumping Agreement, Article XVI:4 of the WTO Agreement, and Article 27 of the Vienna Convention, The judiciary is a state organ and even if an act or omission derives from a WTO Member's judiciary, it is nevertheless still attributable to that WTO Member. Thus, the United States cannot seek to avoid the obligation to comply with the DSB's recommendations and rulings within the reasonable period of time, by relying on the timing of liquidation being "controlled by the independent judiciary" WTO. Appellate Body Report, United States - Measures Relating to Zeroing and Sunset Reviews (Recourse to Article 21.5 of the DSU by Japan). WT/DS322/AB/RW, 29 ago. 2008. para. 182.

842 "At the oral hearing, Brazil indicated that acts of the judiciary had to be attributed to the state 
Judiciário constitua ramo independente, e portanto fora do controle do Poder Executivo, isso não impede a sua atuação na implementação da decisão. A este respeito, pode-se argumentar que o Poder Legislativo é também ramo independente do Poder Executivo, e nem por isso fica excluído de participação na implementação das decisões.

Deste modo o árbitro do caso analisa:

\begin{abstract}
Nas arbitragens anteriores, os membros responsáveis pela implementação têm geralmente proposto meios legislativos ou regulamentares para implementar as recomendações e decisões do OSC. No entanto, não considero que a implementação através do judiciário possa ser a priori excluída do raio de ações permissíveis que podem ser tomadas para implementar as recomendações e decisões do OSC e trazer a conformidade das obrigações de um membro ao abrigo dos acordos abrangidos. O grau de controle do governo pode muito bem ser diferente em relação ao executivo, ao legislativo, e aos ramos judiciários do poder. A ação de implementação, seja ela feita pelo poder legislativo, ou pelo poder judiciário, pode não ser executada na forma prevista pelo governo. No entanto, a possibilidade de fracasso em alcançar a conformidade pretendida não tem sido considerada por árbitros anteriores como uma razão para questionar a legitimidade da implementação por meio de legislação, nem, na minha opinião, excluiria a ação judicial do conjunto de meios admissíveis de implementação. $[\ldots]^{843}$
\end{abstract}

\footnotetext{
just as acts of the legislature or of the executive. Therefore, the judiciary, like other branches of power, could contribute to achieving compliance with international obligations. Brazil considered t'otally misplaced"the European Communities' focus on the government's ability to control the achievement of the intended objective of proposed implementation acts. Brazil argued that the Federal Government could not ënsure"that its intended results would be achieved, irrespective of whether it undertook action through the legislature or judiciary in order to implement the recommendations and rulings of the DSB, because both the legislature and the judiciary are separate from the executive. Brazil stated that, even though these two powers operate with a different degree of autonomy, there is no difference in the sense that Brazil's Federal Government cannot guarantee a certain outcome either in the National Congress or before the Federal Supreme Court". WTO. Brazil - Measures Affecting Imports of Retreated Tyres (Arbitration under Article 21.3(c) of the Understanding on Rules and Procedures Governing the Settlement of Disputes). WT/DS332/16, 29 ago. 2008. para 65.

843 Tradução livre do original em língua inglesa: "In previous arbitrations, implementing Members have usually proposed either legislative or regulatory means to implement DSB recommendations and rulings. However, I do not consider that implementation through the judiciary can be a priori excluded from the range of permissible action that can be taken to implement DSB recommendations and rulings and bring about compliance with a Member's obligations under the covered agreements. The degree of government control may well be different with respect to the executive, the legislative, and the judiciary branches of power. Implementation action, whether it is taken by the legislature, or the judiciary, may not be executed in the way envisaged by the government. Yet the possibility of failure to achieve the intended compliance has not been regarded by previous arbitrators as a reason to question the permissibility of implementation by means of legislation, nor, in my view, does it exclude judicial action from the range of a permissible means of implementation. [...]'WTO. Brazil - Measures Affecting Imports of Retreated Tyres (Arbitration under Article 21.3(c) of the Understanding on Rules and Procedures Governing the Settlement of Disputes). WT/DS332/16, 29 ago. 2008. para 68.
} 
A maior parte dos casos, contudo, envolve a implementação por meio de medidas do Poder Executivo e/ou do Poder Legislativo, em suas atividades de natureza administrativa e legislativa. A este respeito, desenvolveu-se uma diferenciação entre as medidas administrativas e legislativas de cumprimento, para fins do cálculo do tempo razoável para implementação:

Por exemplo, se a implementação é por via administrativa, como através de um regulamento, então o "período de tempo razoável" será normalmente mais curto do que para a implementação pela via legislativa. Parece razoável supor, a menos que se prove o contrário - devido a circunstâncias incomuns em um caso concreto, que os regulamentos podem ser alterados mais rapidamente do que estatutos. Certamente, o processo administrativo pode ser por vezes longo, mas o processo legislativo pode muitas vezes ser mais longo. ${ }^{844}$

Segundo tem desenvolvido a jurisprudência do Sistema de Solução de Controvérsias da OMC, o foco deve se dar na natureza da medida, e não necessariamente na natureza do órgão envolvido:

[...] Esta distinção baseia-se no fato de que a ação administrativa em geral pode ser realizada apenas por uma instituição (muitas vezes o Poder Executivo) dos membros responsáveis pela implementação, enquanto que a ação legislativa em geral exige a participação de instituições adicionais (tipicamente ao menos o poder Legislativo, propenso a ter processos deliberativos mais lentos possivelmente em conjunto com o Poder Executivo também). As etapas de implementação propostos pelas Comunidades Europeias no âmbito do direito comunitário deverão ser realizadas exclusivamente pela Comissão, sem o envolvimento do Conselho ou do Parlamento Europeu. Portanto, não considero que estes passos sejam "legislativos", no sentido em que acredito que o termo passou a ser entendido no contexto de arbitragens do artigo 21.3 (c). Assim, devo ter em conta na minha determinação a natureza administrativa do processo de implementação proposto. 845

844 Tradução livre do original em língua inglesa: "For example, if implementation is by administrative means, such as through a regulation, then the Heasonable period of time"will normally be shorter than for implementation through legislative means. It seems reasonable to assume, unless proven otherwise due to unusual circumstances in a given case, that regulations can be changed more quickly than statutes. To be sure, the administrative process can sometimes be long; but the legislative process can oftentimes be longer." WTO. Award of the Arbitrator, Canada - Patent Protection of Pharmaceutical Products (Arbitration under Article 21.3(c) of the DSU). WT/DS114/13, 18 ago. 2000. para. 49.

845 Tradução livre do original em língua inglesa: "[...] This distinction is premised on the fact that administrative action generally may be accomplished solely by one institution (often the Executive Branch) of the implementing Member, whereas legislative action generally requires the participation of additional institutions (typically at last the Legislative Branch-likely to have slower, more deliberative processes possibly in conjunction with the Executive Branch as well).The implementation steps proposed by the European Communities under Community law are expected to be accomplished exclusively by the Commission, without involvement by the Council or the European Parliament. I therefore do not consider 
Assim, a primeira variável da implementação recai sob a natureza do mecanismo de implementação, sendo diretamente relacionada à natureza da medida em desconformidade, e às competências estabelecidas pelo direito interno. A implementação poderá, pois, envolver medidas em conjunto e em separado, oriundas do (a) Poder Executivo; (b) Poder Legislativo; e (c) Poder Judiciário. Tais medidas podem ter natureza (a) administrativa; (b) legislativa; ou (c) jurisdicional.

Tendo em vista o critério da amplitude da medida desconforme, podemos classificar entre:

(i) medidas singulares, especificas ou ad hoc (tratam apenas de um ato ou produtos identificáveis e distinguíveis);

(ii) medidas de aplicabilidade geral (tratam de procedimentos, metodologias).

Esta classificação foi apresentada no caso United States - Sections 301310 of the Trade Act of 1974, em relação às medidas que poderiam violar o artigo 23 do ESC, mas pode ser expandida para as medidas em desconformidade com a normativa multilateral como um todo:

\begin{abstract}
Artigo 23 proíbe, portanto, mais do que a ação em disputas específicas, também proporciona disciplina para o processo geral que os membros da OMC devem seguir quando buscam a reparação de inconsistências com a OMC. A violação das disposições expressas do artigo 23 pode, portanto, ser de dois tipos diferentes. Ela pode ser causada

(a) por um ato ad hoc, específico em um determinado litígio, ou

(b) por medidas de aplicabilidade geral, por exemplo legislação ou regulamentos, que preveem um determinado processo a ser seguido e que, digamos, não incluía o recurso ao sistema de solução de controvérsias ou respeite as regras e os procedimentos do ESC. ${ }^{846}$
\end{abstract}

these steps to be "legislative" in the sense in which I believe that term has come to be understood in the context of arbitrations under Article 21.3(c). Accordingly, I must take into account in my determination the administrative nature of the proposed implementation process." WTO. Award of the Arbitrator, European Communities - Customs Classification of Frozen Boneless Chicken Cuts (Arbitration under Article 21.3(c) of the DSU). WT/DS269/13, WT/DS286/15, 20 fev. 2006. para. 67.

846 Tradução livre do original em língua inglesa: "Article 23 interdicts, thus, more than action in specific disputes, it also provides discipline for the general process WTO Members must follow when seeking redress of WTO inconsistencies. A violation of the explicit provisions of Article 23 can, therefore, be of two different kinds. It can be caused by (a) by an ad hoc, specific action in a given dispute, or (b) by measures of general applicability, e.g. legislation or regulations, providing for a certain process to be followed which does not, say, include recourse to the DSU dispute settlement system or abide by the rules and procedures of 
De maneira correlata, as medidas de implementação correspondentes tendem a acompanhar o escopo de amplitude da medida desconforme. Por exemplo, o questionamento de uma investigação antidumping específica, ou da aplicação de uma salvaguarda temporária, tende a ser implementada por meio de revisão específica daquele ato em isolado. Por outro lado, a correção de aspectos discriminatórios de uma legislação que gera seus efeitos continuamente, ou o questionamento da desconformidade da lei de propriedade intelectual em relação às obrigações do TRIPS, deve ter a sua implementação por meio de uma medida de aplicabilidade igualmente geral.

Assim, a segunda variável da implementação recai sob a amplitude do mecanismo de implementação, sendo diretamente relacionada ao escopo da medida em desconformidade, e às competências estabelecidas pelo direito interno. A implementação poderá, pois, envolver medidas em conjunto e em separado, de caráter: (a) específico; ou (b) geral.

Esta variável se relaciona diretamente com o Acordo cuja norma ensejou a desconformidade da conduta do membro, destacando que pela regra do single undertaking a OMC agrupou temáticas muito diferentes em seu conjunto de obrigações. Assim, resta claro que a interação entre a natureza das obrigações entabuladas nos acordos, os interesses envolvidos nas respectivas áreas, e os mecanismos previstos em cada Acordo pode resultar em graus diversos de complexidade da implementação exigida.

Essa questão foi tratada por pesquisa empírica de WILLIAN DAVIS, na qual o autor conclui pela notável diferença dos registros de implementação entre os respectivos Acordos da OMC base das controvérsias. ${ }^{847}$ Embora a investigação tenha sido realizada em 2005, e portanto com um universo de casos ainda restrito, pode-se dizer que suas conclusões qualitativas permanecem relevantes.

Assim, uma das suas primeiras conclusões é que as controvérsias relativas às salvaguardas não apresentam problemas na implementação, tendo havido nesses casos diligente remoção das salvaguardas ilegais. Contudo, isso resultaria do fato de que o tempo

the DSU." WTO. Panel Report, United States - Sections 301310 of the Trade Act of 1974. WT/DS152/R, 22 dez. 1999. para 7.46.

847 DAVEY, William J. Implementation in WTO Dispute Settlement: An Introduction to the Problems and Possible Solutions. The Research Institute of Economy, Trade and Industry. RIETI Discussion Paper Series, n. 05-E-013, mar. 2005. p. 9. 
do procedimento da OMC para se reconhecer a desconformidade da salvaguarda, já garantiria ao membro a concretização do seu propósito com a medida, uma vez que somente com a decisão do OSC o membro se vê compelido a removê-la. ${ }^{848}$

Ainda segundo o autor, as controvérsias referentes ao GATT 1994, embora com um histórico de implementação menos exemplar, não apresentam problemas gerais de implementação. A exceção ocorreria em relação a casos de extrema complexidade, como o caso European Communities - Regime for the Importation, Sale and Distribution of Bananas.

Em relação às demandas do TRIPS, a implementação tem sido de modo geral satisfatória, com exceção dos casos em que a parte demandada é os EUA, pois a implementação exigiria medida do Congresso, o que seria um fator de complicação dado a delicada distribuição de competências no âmbito interno. ${ }^{849}$

Segundo sua análise, existiriam três áreas especialmente problemáticas no tocante à implementação: (i) subsídios, (ii) medidas sanitárias e fitossanitárias e (iii) remédios comerciais.

No tocante aos subsídios, a implementação tem de fato se mostrado mais difícil, tendo havido atraso em alguns casos de implementação, e permanência da violação em outros. O autor explica tal dificuldade ponderando que o setor que consegue receber subsídios do governo tende a ser significativo o suficiente para influenciar no atraso da implementação. ${ }^{850}$

No tocante aos casos relativos a medidas sanitárias e fitossanitárias, as dificuldades na implementação podem ser explicadas por preocupações genuínas com a segurança alimentar, bem como com os impactos políticos dessas mudanças. Deve ser ainda destacado que grande parte desses casos envolve produtos agrícolas, o que pode ser um

848 DAVEY, William J. Implementation in WTO Dispute Settlement: An Introduction to the Problems and Possible Solutions. The Research Institute of Economy, Trade and Industry. RIETI Discussion Paper Series, n. 05-E-013, mar. 2005. p. 9.

849 DAVEY, William J. Implementation in WTO Dispute Settlement: An Introduction to the Problems and Possible Solutions. The Research Institute of Economy, Trade and Industry. RIETI Discussion Paper Series, n. 05-E-013, mar. 2005. p. 11.

850 DAVEY, William J. Implementation in WTO Dispute Settlement: An Introduction to the Problems and Possible Solutions. The Research Institute of Economy, Trade and Industry. RIETI Discussion Paper Series, n. 05-E-013, mar. 2005. p. 11. 
complicador no intuito de implementação. ${ }^{851}$

As dificuldades na implementação dos remédios comercias, por sua vez, estariam ligadas à conduta norte-americana, que foi considerada ilegal em reiterados casos em função da metodologia do zeroing, e que em alguns casos exigia medida do Congresso. De modo geral, contudo, o autor faz observação semelhante ao comentário sobre as salvaguardas, que o tempo de aplicação dessas medidas até o reconhecimento de sua desconformidade - aliada ao fato de que comumente estes procedimentos são revistos - e não eliminados - faz questionar a real efetividade e o impacto da implementação. ${ }^{852}$

Adicionalmente, outras variáveis podem contribuir para o desenho da medida de implementação, e notadamente: (a) aspectos jurídicos e políticos da estrutura de poder no interior do Estado; (b) polarização dos interesses envolvidos nas controvérsias e capacidade de influenciar a implementação.

851 DAVEY, William J. Implementation in WTO Dispute Settlement: An Introduction to the Problems and Possible Solutions. The Research Institute of Economy, Trade and Industry. RIETI Discussion Paper Series, n. 05-E-013, mar. 2005. p. 10.

852 "In addition, it is worth mentioning that the overall time taken for safeguards and trade remedy cases may mean that even prompt implementation, typically by removal or revision of the contested measure, will not control improper use of safeguard and trade remedy measures. Thus, other remedies may need to be considered." DAVEY, William J. Implementation in WTO Dispute Settlement: An Introduction to the Problems and Possible Solutions. The Research Institute of Economy, Trade and Industry. RIETI Discussion Paper Series, n. 05-E-013, mar. 2005. p. 11. 


\title{
5 PROPOSIÇÃO PARA UM MODELO BRASILEIRO
}

\author{
5.1 O Contexto da Implementação das Decisões de Tribunais Internacionais no \\ Brasil
}

A implementação das decisões do Sistema de Solução de Controvérsias da OMC se insere na temática mais ampla da implementação das decisões dos Tribunais Internacionais no Brasil. Este tema é de alta complexidade, em face do silêncio da Constituição a este respeito, e da prática ambígua existente no Brasil.

As decisões de Tribunais Internacionais - também denominadas sentenças internacionais - são notadamente diversas das sentenças estrangeiras e, portanto, dispensam homologação pelo STJ, procedimento exigido para que as sentenças estrangeiras adquiram exigibilidade em território nacional. Tal distinção, que já se encontrava esclarecida na doutrina, ${ }^{853}$ foi também explicitada em julgado do STJ. ${ }^{854}$

853 É clara essa distinção, explicitada por André de Carvalho Ramos: “[...] Só que esta não é a natureza jurídica da sentença judicial internacional, em especial a da sentença da Corte Interamericana de Direitos Humanos. Pelo contrário, sendo a Corte Interamericana de Direitos Humanos um órgão internacional, sua sentença tem a natureza jurídica de decisão de uma organização internacional. A decisão de uma organização internacional não encontra identidade em uma sentença judicial oriunda de um Estado estrangeiro. Logo, não é necessário nem autorizado, pelo nosso ordenamento, a homologação da citada sentença internacional pelo Superior Tribunal de Justiça, sob pena de violarmos a própria Constituição brasileira que estabelece os limites da competência do STJ." RAMOS, André de Carvalho. Processo Internacional dos Direitos Humanos. São Paulo: Saraiva, 2012. p. 353-354.

854 "SENTENÇA ESTRANGEIRA. DECISÃO PROFERIDA PELA CORTE PERMANENTE DE JUSTICA INTERNACIONAL DE HAIA, EM 1929, TENDO COMO PARTES O GOVERNO BRASILEIRO E O GOVERNO FRANCÊS. ILEGITIMIDADE DE EMPRESA ESTRANHA À DECISÃO PARA POSTULAR A SUA HOMOLOGAÇÃO. ADEMAIS, DECISÃO QUE NÃO SE SUBSUME AO CONCEITO DE SENTENÇA ESTRANGEIRA E CUJA HOMOLOGAÇÃO AFRONTARIA A SOBERANIA NACIONAL. I - Inexiste sentença estrangeira a ser homologada, em nome da parte requerente. A decisão submetida à validação do Judiciário brasileiro advém da Corte Permanente de Justiça Internacional de Haia, que, à época, proferiu decisão arbitral em contenda instalada entre os Governos Brasileiro e Francês, quanto a empréstimo por aquele efetuado nos idos de 1909 e os juros aplicáveis. [...] IV - De se considerar, ademais, que a Corte Internacional não profere decisão que se subsuma ao conceito de "sentença estrangeira", visto que é órgão supranacional. A propósito, relevo o documento expedido pela Corte Internacional de Justiça, em 24 de outubro de 2007, juntado pelo requerente, às fls. 323, em que se esclarece: "a CPIJ, assim como a Corte Internacional de Justiça, não são cortes ou tribunais estrangeiros, cujos julgamentos não são decisões judiciais ou sentenças estrangeiras que requeiram qualquer tipo de exequator ou homologação". $V$ - Em 
Seu fundamento de obrigatoriedade e exigibilidade se funda, pois, nos elementos internacionais constitutivos - os respectivos tratados internacionais constitutivos das Organizações Internacionais aos quais estejam ligados e/ou estatutos das Cortes e Tribunais Internacionais - aos quais o Brasil decidiu se vincular. ${ }^{855}$

É de amplo conhecimento a regra geral de obrigatoriedade de cumprimento das obrigações internacionais entabuladas em tratados internacionais devidamente ratificados pelos Estados, ${ }^{856}$ bem como aquela que proíbe que um Estado se exima do cumprimento de uma obrigação internacional alegando dispositivo de seu direito interno, ambas codificadas pela Convenção de Viena sobre o Direito dos Tratados. ${ }^{857}$

O procedimento para a implementação dessas decisões adjudicatórias internacionais, contudo, não é disciplinado pelo Direito Internacional, ficando a cargo dos respectivos ordenamentos jurídicos internos. No Brasil, inexiste a previsão de um procedimento e, na prática, a implementação tem se dado de modo casuístico - a depender das peculiaridades e singularidades do caso concreto. ${ }^{858}$

conclusão, não há sentença estrangeira stricto sensu a ser homologada e, tampouco, é legítima a empresa Gespart Comércio Participações Ltda. para solicitar tal homologação a qual, enfim, afrontaria a soberania nacional. [...]” BRASIL. Superior Tribunal de Justiça. Sentença Estrangeira Contestada, SEC 2707 / NL (SEC 2007/02568161). Relator: Min. Francisco Falcão. Órgão julgador Corte Especial. Brasília, 3 dez. 2008. DJE 19 fev. 2009.

855 Não há que se falar em restrição à soberania, tendo em vista que esta decisão de se vincular à Organização Internacional e/ou ao Tribunal Internacional foi uma escolha soberana: "Por consequência, a decisão de um Estado de aderir a uma organização internacional é um atributo de soberania, ainda que a organização possua o poder (poder este que lhe foi conferido pelos próprios Estados) de adotar regras que lhes são vinculativas. Ao ratificar instrumentos internacionais, o Estado exerce a sua soberania e assume obrigações das quais não se deve poder eximir, sob pena de responsabilização internacional." LOBO, Maria Teresa de Carcomo Lobo. Execução de Decisões Judiciais de Cortes Internacionais Contra Estados Soberanos. Boletim Científico do ESMPU, a. II , n. 8, p. 121-132, jul./set. 2003. p. 125.

856 Convenção de Viena do Direito dos Tratados. Versão oficial em português segundo o decreto n. 7.030, 14 dez. 2009, que promulga a Convenção de Viena sobre o Direito dos Tratados, concluída em 23 de maio de 1969, com reserva aos Artigos 25 e 66. "Artigo 26 Pacta sunt servanda - Todo tratado em vigor obriga as partes e deve ser cumprido por elas de boa fé."

857 Convenção de Viena do Direito dos Tratados. Versão oficial em português segundo o decreto n. 7.030, 14 dez. 2009, que promulga a Convenção de Viena sobre o Direito dos Tratados, concluída em 23 de maio de 1969, com reserva aos Artigos 25 e 66. "Artigo 27 Direito Interno e Observância de Tratados - Uma parte não pode invocar as disposições de seu direito interno para justificar o inadimplemento de um tratado. Esta regra não prejudica o artigo 46."

858 Situando-as na categoria mais ampla da decisões de Organizações Internacionais, é relevante destacar que na oportunidade da revisão do texto constitucional, em 1994, o Congresso Nacional recusou proposta de emenda destinada a acrescentar novo parágrafo ao artigo 4o da CF, que estabeleceria: “As normas emanadas dos órgãos competentes das organizações internacionais de que a República Federativa do Brasil seja parte vigoram na ordem interna, desde que expressamente estabelecido nos respectivos tratados constitutivos". Cf: DALLARI, Pedro Bohomoletz de Abreu. Constituição e Tratados Internacionais. São Paulo: Saraiva, 2003. p. 120. 
A discussão da implementação das decisões internacionais tem ganhado espaço no Brasil principalmente no tocante às decisões da Corte Interamericana de Direitos Humanos $(\mathrm{CIDH}) .{ }^{859} \mathrm{~A}$ condenação do Brasil nessa jurisdição resulta na necessidade de cumprir simultaneamente obrigações de diversas naturezas, tais como o pagamento de multas - de natureza pecuniária-, a adoção de medidas protetivas de alcance coletivo - obrigações de fazer e obrigações de não fazer.

A respeito das decisões da CIDH, destaca-se que no caso Damião Ximenez Lopes, ${ }^{860}$ a indenização pecuniária foi paga por meio de decreto específico. ${ }^{861}$ Por outro lado, no caso Gomez Lund e Outros ${ }^{862}$ pode-se dizer que sentença não foi implementada em sua totalidade, sendo tema de discussão na doutrina as possibilidades de implementação integral da sentença, uma vez que o STF julgou na ADPF 153 a constitucionalidade da lei de Anistia, em resultado distinto daquele exigido pela sentença da Corte Interamericana. ${ }^{863}$

Visando a colmatar as lacunas normativas e procedimentais relativas à implementação dessas decisões pelo governo brasileiro no seu aspecto pecuniário, ${ }^{864}$ foi

859 DUARTE, Mônica. Execução de Decisões de Organismos Internacionais de Proteção de Direitos Humanos no Ordenamento Jurídico Brasileiro. 2010. 133 p. Dissertação (Mestrado em Ciência Jurídica), Centro de Educação de Ciências Sociais e Jurídicas, Universidade do Vale do Itajaí, Itajaí.

860 CIDH. Caso Ximenes Lopes vs Brasil. 4 jul. 2006.

861 Decreto $\mathbf{n}^{\mathbf{0}} \mathbf{6 . 1 8 5}$, de 13 ago. 2007. Autoriza a Secretaria Especial dos Direitos Humanos da Presidência da República a dar cumprimento à sentença exarada pela Corte Interamericana de Direitos Humanos. "O PRESIDENTE DA REPÚBLICA, no uso da atribuição que lhe confere o art. 84, inciso IV, da Constituição, e considerando a sentença da Corte Interamericana de Direitos Humanos no caso Damião Ximenes Lopes; considerando a existência de previsão orçamentária para pagamento de indenização a vítimas de violação das obrigações contraídas pela União por meio da adesão a tratados internacionais de proteção dos direitos humanos; DECRETA: Art. lo Fica autorizada a Secretaria Especial dos Direitos Humanos da Presidência da República a promover as gestões necessárias ao cumprimento da sentença da Corte Interamericana de Direitos Humanos, expedida em 4 de julho de 2006, referente ao caso Damião Ximenes Lopes, em especial a indenização pelas violações dos direitos humanos aos familiares ou a quem de direito couber, na forma do Anexo a este Decreto. Art. 20 Este Decreto entra em vigor na data de sua publicação." Disponível em <http://www.planalto.gov.br/ccivil_03/_Ato20072010/2007/Decreto/D6185.htm>

862 CIDH. Caso Gomes Lund e Outros (“Guerrilha Do Araguaia”) vs. Brasil. 24 nov. 2010.

863 Para o autor, pode haver uma compatibilização entre ambas as decisões, pela teoria do duplo controle, Segundo a qual o STF exerce controle de constitucionalidade e a CIDH exerce controle de convencionalidade. RAMOS, André de Carvalho. Processo Internacional de Direitos Humanos. 2a ed. São Paulo: Saraiva, 2012. p. 361-376.

864 Assim consta da justificação do referido projeto de lei, em sua parte mais relevante: "[...] O que nos resta claro é que, apesar da ratificação, as decisões dessas instâncias não estão sendo respeitadas pelo Brasil. O Poder Executivo manifesta interesse no cumprimento das decisões dos organismos de proteção, seja no âmbito regional ou global, porém alega a inexistência de legislação ordinária nacional destinada a disciplinar a matéria. O intuito deste projeto de lei é sanar as lacunas jurídicas entre a jurisdição dos organismos estabelecidos no âmbito da ONU e da Convenção Americana sobre Direitos Humanos e a jurisdição nacional. Não é possível admitir-se que, mesmo depois da ratificação, o Brasil ainda não implemente as decisões e recomendações dessas instâncias. Hoje existem dezenas de casos brasileiros que estão sendo apreciados pela CIDH e, em breve, certamente, existirão outros que serão decididos no âmbito da Corte Interamericana. Ressalta-se que somente são apreciados no âmbito dessas instâncias 
apresentado em 2004 o projeto de lei da Câmara dos Deputados n. 4667/2004. ${ }^{865} 866$ O projeto foi aprovado em 2010 pela Câmara e, tendo sido enviado para apreciação do Senado Federal, atualmente está sob análise da Comissão de Constituição, Cidadania e Justiça. ${ }^{867} 868$

Referido projeto de lei objetiva, pois, facilitar a implementação das sentenças da CIDH, reconhecendo-lhes expressamente a produção de efeitos jurídicos imediatos no âmbito do ordenamento interno, e tratando da implementação de obrigações indenizatórias. De aplicação mais complexa, contudo, tem sido a concretização de obrigações de outra natureza resultantes das sentenças dessa Corte. ${ }^{869}$

internacionais, os casos extremamente graves de violações dos direitos humanos que tenham ficado impunes embora já tramitado nas vias internas. Através deste projeto de lei, queremos também permitir que a União assuma a responsabilidade pelo pagamento das indenizações quando assim for decidido pelos organismos podendo, no entanto, intentar ação regressiva contra o Estado da Federação, pessoa jurídica ou fisica que tenha sido responsável pelos danos causados à vítima. Desta forma, é um projeto que aperfeiçoa a vigência e eficácia jurídica dos sistemas global e regional de proteção aos direitos humanos na jurisdição brasileira. [...]" Projeto de lei 4667/2004. Justificação. Disponível em <http://www.camara.gov.br/proposicoesWeb/prop_mostrarintegra?codteor=259112\&filename=PL+4667/200 4>

865 O projeto de lei n. 4667/2004 é de relatoria do então Deputado Federal do PT/Sp José Eduardo Cardozo. Na justificação consta que projeto foi apresentado originariamente pelo deputado Marcos Rolim, mas tendo sido arquivado antes de constar em pauta para votação, o Deputado José Eduardo Cardoso decidiu resgatá-lo, com algumas modificações. <http://www.camara.gov.br/proposicoesWeb/prop_mostrarintegra?codteor=259112\&filename=PL+4667/200 4>

866 Projeto de lei 4667/2004. "Dispõe sobre os efeitos jurídicos das decisões dos Organismos Internacionais de Proteção aos Direitos Humanos e dá outras providências. O Congresso Nacional decreta: Art. 1o. As decisões dos Organismos Internacionais de Proteção aos Direitos Humanos cuja competência foi reconhecida pelo Estado Brasileiro, produzem efeitos jurídicos imediatos no âmbito do ordenamento interno brasileiro. Art. 2o. Quando as decisões forem de caráter indenizatório, constituir-se-ão em títulos executivos judiciais e estarão sujeitas à execução direta contra a Fazenda Pública Federal. § 1o. O valor a ser fixado na indenização respeitará os parâmetros estabelecidos pelos organismos internacionais. $\S 20$. O crédito terá, para todos os efeitos legais, natureza alimentícia. Art. 3o. Será cabível ação regressiva da União contra as pessoas fisicas ou jurídicas, privadas ou públicas, responsáveis direta ou indiretamente pelos atos ilícitos que ensejaram a decisão de caráter indenizatório. Art. 4o. Esta lei entrará em vigor na data de sua publicação."

867 Em 18 nov. 2010 foi remetido ao Senado pela Mesa Diretora da Câmara dos Deputados, por meio do Ofício $\quad \mathrm{n}^{\circ} \quad$ 805/10/PS-GSE. <http://www.camara.gov.br/proposicoesWeb/fichadetramitacao?idProposicao=273650>.

868 No Senado tramita como PLC n.170/2010. Último registro explicita que em 04/06/2014, o projeto estava pronto para a pauta da CCJ - Comissão de Constituição, Justiça e Cidadania, com relatório do Senador Ricardo Ferraço, com voto favorável ao Projeto, com uma emenda. A emenda apresentada pelo relator modifica o artigo 1o do projeto, buscando restringí-lo. A redação sugerida é: "Art. 1o As decisões condenatórias a reparação econômica ou prestação pecuniária emanadas de Organismos Internacionais de Proteção aos Direitos Humanos cuja jurisdição for reconhecida pelo Estado brasileiro terão força de título executivo. " Disponível em: <http://www.senado.gov.br/atividade/materia/detalhes.asp?p_cod_mate=98360> 869 Para comentários mais específicos sobre o conteúdo e as modificações das versões dos projetos de lei destinados a implementar deliberações internacionais de direitos humanos, Cf: RAMOS, André de Carvalho. Processo Internacional de Direitos Humanos. 2a ed. São Paulo: Saraiva, 2012. p. 359-361. 
Em estudo sobre a implementação das decisões da CIDH pelos Estados sujeitos a sua jurisdição, ViVIANA KRSTICEVIC destaca que, embora não seja imprescindível, a criação de uma lei desenhando a estrutura geral de implementação é instrumento valioso para facilitar o processo de execução interna destas sentenças, conferindo-lhe coerência, agilidade e efetividade. ${ }^{870}$

Em resposta à percepção da necessidade de estabelecimento de normas específicas que facilitem a implementação das decisões desse sistema de proteção dos direitos humanos, ${ }^{871} 872$ bem como da necessidade de definição de mecanismos ou organismos incumbidos da implementação, diversos Estados têm desenvolvido iniciativas legislativas nesta matéria. 873874

O estabelecimento de um marco normativo para a implementação de decisões de tribunais internacionais é especialmente enriquecedor aos Estados cuja Constituição não fixa competências e responsabilidades na implementação, oferecendo respostas a estes e a outros desafios institucionais resultantes da jurisdicionalização do sistema jurídico internacional.

870 KRSTICEVIC, Viviana. Implementación de las decisiones del Sistema Interamericano de Derechos Humanos: Aportes para los procesos legislativos. Buenos Aires: Center for Justice and International Law - CEJIL, 2009.

871 "[...] es absolutamente necesaria la recepción a través de las normas internas de cumplimiento (que se podría denominar legal instrumental), que constituyen el puente para que las resoluciones internacionales transiten con naturalidad y sin tardanza ni tropiezo hacia la aplicación interna, que implica medidas ejecutivas inmediatas y adecuadamente facilitadas. No digo que esa normativa sea condición para la validez de las disposiciones internacionales; sólo recuerdo que es medio natural para su eficacia." Corte IDH. Caso García Prieto. Voto concurrente del Juez García Ramírez. para. 11.

872 KRSTICEVIC, Viviana. Implementación de las decisiones del Sistema Interamericano de Derechos Humanos: Aportes para los procesos legislativos. Buenos Aires: Center for Justice and International Law - CEJIL, 2009. p. 17.

873 Como exemplos de países que adotaram legislação com esta finalidade, tem-se Colômbia e Peru. Cf: Colombia. Lei n. 288, de 5 jul. 1996. Ementa: "Por medio de la cual se establecen instrumentos para la indemnización de perjuicio a las víctimas de violaciones de derechos humanos en virtud de lo dispuesto por determinados órganos internacionales de Derechos Humanos." Disponível em: $<$ http://www.alcaldiabogota.gov.co/sisjur/normas/Norma1.jsp?i=28597>; Perú. Lei n. 27.775, de 27 jun. 2002. "Ementa: Ley que regula el procedimiento de ejecución de sentencias emitidas por tribunales supranacionales." Disponível em: <http://www.congreso.gob.pe/ntley/Imagenes/Leyes/27775.pdf $>$.

874 Além do Brasil, a Argentina possui projeto de Lei em tramitação (Argentina Proyecto de Ley Expediente 3528 - S - 2000. Alberto J. Rodríguez Saa). Outros países, como México, Guatemala, Equador e Paraguai criaram mecanismos e procedimentos de implementação por meio de decretos. 


\subsection{O Status Jurídico dos Acordos da OMC e das Decisões do Sistema de Solução de Controvérsias no Ordenamento Brasileiro}

Antes de adentrarmos nos mecanismos possíveis para implementação das decisões do Sistema de Solução de Controvérsias da OMC, é necessário explicitar que, sob o aspecto formal, duas dimensões correlatas mas distintas se apresentam. Tais dimensões se relacionam: (i) ao meio pelo qual o Direito da $\mathrm{OMC}$, em seu aspecto normativo, é "incorporado" ao ordenamento jurídico nacional; e (ii) ao meio pelo qual uma decisão do Sistema de Solução de Controvérsias da OMC é "internalizada" no direito brasileiro.

Sob o aspecto material, de modo similar, é preciso enfrentar duas dimensões distintas e interligadas que se apresentam: (i) a aplicabilidade e invocabilidade dos Acordos da OMC no ordenamento jurídico brasileiro; e (ii) o potencial de aplicabilidade e invocabilidade das decisões do Sistema de Solução de Controvérsias da OMC no ordenamento pátrio.

A Constituição Federal Brasileira de 1988 (CF/88) é silente no tocante a diversas temáticas do Direito Internacional, inclusive em relação à internalização de tratados internacionais, de atos de Organizações Internacionais e de decisões adjudicatórias internacionais. ${ }^{875} 876877$ Em matéria de Direito Internacional, a CF/88 se concentra na enunciação dos princípios que devem reger o Brasil em suas relações internacionais, e na fixação de competências para alguns atos, como a negociação e a ratificação de tratados

875 Apesar das especificidades das decisões dos Tribunais Internacionais, confere-se a elas natureza de decisões de Organizações Internacionais, sob a perspectiva do ordenamento jurídico interno. Contudo, é oportuno fazer uma classificação, dentro do gênero mais amplo de "decisões de Organizações Internacionais" vislumbrar a diferenciação entre "decisões adjudicatórias" e "decisões não adjudicatórias".

876 Assim explicita o autor, que os tribunais internacionais "[...] se estruturam ou na forma de organização internacional - é o caso da Corte Internacional de Justiça - ou então, de instância de organização internacional - como a Corte Interamericana de Direitos Humanos, que integra a Organização dos Estados Americanos (OEA). Portanto, os julgados têm justamente a natureza jurídica de decisão de organização de Direito Internacional Público.” DALLARI, Pedro Bohomoletz de Abreu. Constituição e os Tratados Internacionais. São Paulo: Saraiva, 2003. p. 121.

877 Embora não haja menção expressa, André de Carvalho Ramos observa que “[...] a Lei Suprema brasileira, a Constituição Federal, não é hostil a tribunais internacionais e em consequência disto não repele a responsabilização internacional do Estado brasileiro por violação de seus compromissos internacionais." RAMOS, André de Carvalho. Processo Internacional de Direitos Humanos. 2a ed. São Paulo: Saraiva, 2012. p. 377. 
internacionais, a acreditação de representantes no Exterior, e o julgamento de ações que se fundem em tratados internacionais. ${ }^{878} 879$

Diante desta omissão, tem cabido à jurisprudência pátria a definiçãa dessas questões, embora não se possa considerar que a prática judicial tenha construído uma interpretação coerente ou unívoca.

Não se objetiva retomar a discussão sobre a caracterização do Brasil como "monista" ou "dualista" - e as suas moderações e radicalismos. 880881882 É de amplo conhecimento da comunidade jurídica brasileira que, na atual composição do STF, é vitoriosa a posição de que os tratados internacionais, como regra geral, possuem status de lei ordinária federal, estando suas normas sujeitas à aplicação dos critérios temporal, cronológico e hierárquico para a solução de antinomias em face das demais normas jurídicas do ordenamento pátrio. ${ }^{883} 884$

878 SANCHEZ, Michelle Ratton et al. Política Externa Como Política Pública: Uma Análise pela Regulamentação Constitucional Brasileira. (1967-1988) Revista de Sociologia e Política, vol. 27, p. 125143, nov. 2006.

879 Cf: "[...] A emergência de cortes internacionais especializadas, sendo exemplo o Tribunal Internacional do Direito do Mar, às quais o Brasil está vinculado, acentua a necessidade de que não pairem dúvidas quanto ao acatamento das respectivas deliberações [...]" DALLARI, Pedro Bohomoletz de Abreu. Constituição e os Tratados Internacionais. São Paulo: Saraiva, 2003. p. 121.

880 Para uma explicação sobre as diferentes doutrinas e as posições no Brasil, Cf:. CASELLA, Paulo Borba.; ACCIOLY, Hildebrando.; NASCIMENTO E SILVA, G. E. do. Manual de direito internacional público. São Paulo: Saraiva, 2009. p. 233-249.

881 Para uma reflexão sobre o tema, Cf: LUPI, André Lipp Pinto Basto. O Brasil é dualista? Anotações sobre a vigência de normas internacionais no ordenamento brasileiro. Revista de Informação legislativa, a. 46, n. 184, p. 29-45, out./dez. 2009.

882 Tratando da relação entre o Sistema de Solução de Controvérsias da OMC e os judiciários nacionais, Welber Barral destaca a insuficiência desse debate: “[...] O problema é bastante amplo, pois envolve desde particularidades constitucionais até o efeito direto dos tratados nas ordens jurídicas internas. Por muito tempo, este problema foi abordado a partir do debate simplório entre monistas e dualistas, cujos modelos demonstraram ser insuficientes para explicar todas as variáveis envolvidas neste problema." BARRAL, Welber. Solução de Controvérsias na Organização Mundial do Comércio. Brasília: Fundação Alexandre de Gusmão, 2007. p. 70.

883 Embora não se desconheça deste posicionamento majoritário na Corte Constitucional, compartilhamos do entendimento de Paulo Borba Casella: "Oportuna e necessária, para adequadamente acolher a norma internacional, no plano interno, a reorientação da jurisprudência, em curso. Ante a inocorrência de dispositivo constitucional que nos regule a questão da hierarquia da norma internacional, quando de sua inserção no direito interno- 'a grande ausência', de que nos falava Celso D. de A. Mello (1994)- coube como ainda cabe à jurisprudência suprir a lacuna legal e determinar onde e como se há de fazer tal inserção. Por isso, a reorientação em curso, no sentido de acolher a indispensável percepção e efeitos da norma internacional, que não se pode esgotar como equivalente da norma interna, porque não o é e vincula o país, não somente no plano internacional, e pode chegar a caracterizar a responsabilidade internacional do estado (sic). Erro técnico dizer que a norma interna superveniente altere ou suprima a norma internacional, também vigente no plano interno. Politicamente inaceitável, também, tal descuidada interpretação.[...]" CASELLA, Paulo Borba. Direito Internacional e Direito Interno na CR (1988). In: VIEIRA, José Ribas (Org). 20 Anos da Constituição Cidadã de 1988: Efetivação ou impasse institucional? Rio de Janeiro: Forense, 2008. p. 483-508. p. 507. 
As exceções a esse quadro geral ficam por conta dos tratados internacionais de direitos humanos e dos tratados internacionais de natureza tributária. Os tratados internacionais de direitos humanos assumem status de norma constitucional ou supralegal, a depender do rito de sua aprovação. ${ }^{885}$ Os tratados internacionais de natureza tributária, por sua vez, guardam relação diferenciada com as normas nacionais por força do artigo 98 do Código Tributário Nacional. ${ }^{886}$

Além da definição do status das normas internacionais no Brasil, uma complexidade distante de ser pacificada diz respeito ao modo de incorporação dessas normas no ordenamento jurídico pátrio. ${ }^{887}$

No Brasil, a aprovação do tratado internacional pelo Congresso Nacional se concretiza por meio de decreto legislativo. Este decreto é requisito para que o Presidente da República promova dois atos: a ratificação, ato de caráter internacional, e a promulgação, ato de direito interno. A promulgação, por sua vez, se concretiza por meio de decreto do Presidente da República, que teria dois efeitos principais: (a) conferir publicidade ao texto do tratado internacional, cuja versão em português é anexada ao decreto presidencial, e (b) inserir o tratado no ordenamento jurídico brasileiro. ${ }^{888} 889$

884 Celso de Albuquerque Mello entende não ser de relevância a discussão sobre estas correntes, mas sim a afirmação da primazia do Direito Internacional: "A própria discussão entre monistas e dualistas não apresenta relevância no tocante ao âmago do problema: o primado do DIP. [...] Ser dualista ou monista não tem reflexo na 'aplicação real do direito internacional ou comunitário'." MELLO, Celso Duvivier de Albuquerque. O Direito Internacional Público no Direito Brasileiro. In: CASELLA, Paulo Borba. Dimensão Internacional do Direito. Estudos em Homenagem a G. E. do Nascimento e Silva. São Paulo: LTr, 2000, p. 297-310. p. 299.

885 RAMOS, André de Carvalho. Curso de Direitos Humanos. São Paulo: Saraiva, 2014. p. 392-396. 886 SCHOUERI, Luís Eduardo. Direito tributário. $3^{a}$ ed. São Paulo: Saraiva, 2013. p. 97-114.

887 BENJAMIN, Daniela Arruda. A aplicação interna das decisões do Órgão de Solução de Controvérsias da OMC na prática. In: BENJAMIN, Daniela Arruda. (Org). O Sistema de Solução de Controvérsias da OMC: uma perspectiva brasileira. Brasília: FUNAG, 2013, p. 573-594. p. 579-580.

888 Para o detalhamento deste processo, antecedentes e prática, Cf: GABSCH, Rodrigo D'Araujo. Aprovação de tratados internacionais pelo Brasil: possíveis opções para acelerar o seu processo. Brasília: FUNAG, 2010.

889 A este respeito, merece destaque o seguinte precedente do STF, no qual lê-se em parte da ementa: "[...] PROCEDIMENTO CONSTITUCIONAL DE INCORPORAÇÃO DE CONVENÇÕES INTERNACIONAIS EM GERAL E DE TRATADOS DE INTEGRAÇÃO (MERCOSUL). - A recepção dos tratados internacionais em geral e dos acordos celebrados pelo Brasil no âmbito do MERCOSUL depende, para efeito de sua ulterior execução no plano interno, de uma sucessão causal e ordenada de atos revestidos de caráter político-jurídico, assim definidos: (a) aprovação, pelo Congresso Nacional, mediante decreto legislativo, de tais convenções; (b) ratificação desses atos internacionais, pelo Chefe de Estado, mediante depósito do respectivo instrumento; (c) promulgação de tais acordos ou tratados, pelo Presidente da República, mediante decreto, em ordem a viabilizar a produção dos seguintes efeitos básicos, essenciais à sua vigência doméstica: (1) publicação oficial do texto do tratado e (2) executoriedade do ato de direito internacional público, que passa, então - e somente então - a vincular e a obrigar no plano do direito positivo interno." BRASIL. Supremo Tribunal Federal. Agravo Regimental em Carta Rogatória, CR 8279 AgR / AT - ARGENTINA. Relator: Min. Celso de Mello. Brasília, 17 jun. 1998. 
É de toda a relevância destacar que este ato formal de incorporação ao ordenamento jurídico brasileiro se coaduna com o respeito aos princípios da publicidade e da legalidade, exigidos pela Constituição. ${ }^{890}$ É, portanto, a publicação do decreto no Diário Oficial da União, com o respectivo texto do tratado internacional em português, que conferiria à norma internacional vigência interna, sendo, pois, requisito essencial para sua invocabilidade e exigibilidade interna. ${ }^{891}$

Assim, a Ata Final da Rodada do Uruguai, juntamente com seus anexos - com menção em separado ao Acordo Plurilateral sobre Carne Bovina, e às listas de concessões do Brasil na área tarifária (Lista III) e no setor de serviços - , foi aprovada pelo Congresso Nacional, por meio do decreto legislativo $\mathrm{n}^{\circ} 30$, de 15 de dezembro de 1994, publicado no DOU em 19 de dezembro de 1994, ${ }^{892}$ e os referidos Acordos foram promulgados por meio do decreto presidencial n. 1.355 de 30/12/94, publicado no DOU de 31 de dezembro de 1994. ${ }^{893}$

890 DALLARI, Pedro Bohomoletz de Abreu. Constituição e os Tratados Internacionais. São Paulo: Saraiva, 2003. p. 98.

891 "A ausência de publicação não exime o Brasil de responder internacionalmente pelo tratado que houver ratificado, mas impossibilita a exigibilidade de suas normas no plano interno. Não obstante, há registros de acordos que são ratificados pelo País mas, por lapso, deixam de ser promulgados e publicados, como o Tratado de Comércio e Navegação com o Chile." GABSCH, Rodrigo D'Araujo. Aprovação de tratados internacionais pelo Brasil: possíveis opções para acelerar o seu processo. Brasília : FUNAG, 2010. p. 55.

892 Decreto Legislativo $\mathbf{n}^{\mathbf{0}}$ 30, de 1994. Aprova a Ata Final da Rodada Uruguai de Negociações Comerciais Multilaterais do GATT, as listas de concessões do Brasil na área tarifária (Lista III) e no setor de serviços e o texto do Acordo Plurilateral sobre Carne Bovina. "O CONGRESSO NACIONAL decreta: Art. $1^{\circ}$. São aprovadas a Ata Final da Rodada Uruguai de Negociações Comerciais Multilaterais do Acordo Geral de Tarifas e Comércio - GATT, as listas de concessões do Brasil na área tarifária (Lista III) e no setor de serviços e o texto do Acordo Plurilateral sobre Carne Bovina. Parágrafo único. São sujeitos à apreciação do Congresso Nacional quaisquer atos que resultem em revisão dos acordos mencionados no caput deste artigo, ou que acarretem encargos ou compromissos gravosos ao patrimônio nacional, nos termos do art. 49, I, da Constituição Federal. Art. $2^{\circ}$. Caberá às Comissões Técnicas Permanentes da Câmara dos Deputados e do Senado Federal o acompanhamento e fiscalização da execução dos acordos previstos neste decreto legislativo para, oportunamente, apresentar sugestões e propostas ao Congresso Nacional. Art. $3^{o}$. Este Decreto Legislativo entra em vigor na data de sua publicação." Disponível em: < http://www2.camara.leg.br/legin/fed/decleg/1994/decretolegislativo-30-15-dezembro-1994-358328-

publicacaooriginal-1-pl.html>

893 Decreto n. 1.355, de 30 dez. 1994. "Promulgo a Ata Final que Incorpora os Resultados da Rodada Uruguai de Negociações Comerciais Multilaterais do GATT. O PRESIDENTE DA REPÚBLICA, no uso de suas atribuições, e Considerando que o Congresso Nacional aprovou, pelo Decreto Legislativo $n^{\circ}$ 30, de 15 de dezembro de 1994, a Ata Final que Incorpora aos Resultados da Rodada Uruguai de Negociações Comerciais Multilaterais do GATT, assinada em Maraqueche, em 12 de abril de 1994; Considerando que o Instrumento de Ratificação da referida Ata Final pela República Federativa do Brasil foi depositado em Genebra, junto ao Diretor do GATT, em 21 de dezembro de 1994; Considerando que a referida Ata Final entra em vigor para a República Federativa do Brasil em $1^{\circ}$ de janeiro de 1995, DECRETA: Art. $1^{\circ}$ A Ata Final que Incorpora os Resultados da Rodada Uruguai de Negociações Comerciais Multilaterais do GATT, apensa por cópia ao presente decreto, será executada e cumprida tão inteiramente como nele contém. Art. $2^{\circ}$ Este decreto entra em vigor na data de sua publicação, revogadas as disposições em contrário." Disponível em: < http://www.planalto.gov.br/ccivil_03/decreto/Antigos/D1355.htm> 
Contudo, é difícil avaliar a aplicabilidade e invocabilidade dos Acordos da OMC no ordenamento jurídico nacional como um conjunto unitário. Isto pois suas características próprias, técnicas de redação e matérias objeto de regulamentação são de geometria variável. $^{894}$

O primeiro elemento de complexidade diz respeito ao fato de que diversos dos acordos da OMC podem ser interpretados como possuindo natureza tributária, conforme o STF reconhecidamente já explicitou em relação ao GATT, o que lhes confere um status diferenciado da lei ordinária. ${ }^{895}$

Se sob o aspecto teórico, os Acordos da OMC encontram-se, pois, incorporados ao ordenamento jurídico brasileiro, possuindo "força de lei", ${ }^{896}$ entende-se necessário verificar a prática judicial brasileira a este respeito. Embora a afirmação precisa da maneira como os Acordos da OMC tem sido aplicados pelos tribunais brasileiros exija uma pesquisa mais detalhada, que fugiria ao escopo deste trabalho, uma pesquisa preliminar é capaz de evidenciar que a sua invocabilidade e aplicabilidade não são de tamanha impossibilidade e limitação como se poderia supor.

894 Para uma visão diversa, que trata da normativa multilateral como um todo, sem diferenciar expressamente os Acordos, Cf: “A partir dos casos citados é possível constatar que a normativa da OMC -e também os precedentes do sistema de solução de controvérsias - são objeto de consideração pelo judiciário brasileiro no seu processo decisório e dotadas, portanto, de efeito direto." OLIVEIRA, João Paulo de. Adjudicação e Comércio Internacional - o Caso dos Pneus Reformados. 2012. 152 p. Dissertação (Mestrado ), Programa de Pós-graduação em Integração da América Latina, Universidade de São Paulo, São Paulo. p. 60.

895 A este respeito, o STF já decidiu: “A celebração de um acordo internacional em matéria tributária tem efeitos que transcendem os interesses localizados de entes federados e contribuintes individuais, pois, nessas hipóteses, a União atua em nome de toda a Federação (e.g., o estabelecimento de isenções de tributos de competência de outros entes federados; c.f., por todos, o RE 543.943-AgR, rel. min. Celso de Mello, Segunda Turma, DJe de 15.02.2011). Assim, os acordos internacionais em matéria tributária projetam expectativas legítimas para Estados, instituições e empresas estrangeiras que, se frustradas, podem expor toda a Nação a situações delicadas no plano internacional (cf., e.g., os temores pelo risco de retaliação comercial na OMC, presentes na manifestação da União apresentada no julgamento do RE 564.413, rel. min. Marco Aurélio, Pleno, DJ e de 03.12.2010, agora repetidos em razão do aumento do IPI para veículos importados). Como a Constituição é a base imediata tanto da competência tributária como das regras que regem a conduta nacional perante os demais Estados soberanos, entendo que a discussão sobre a violação do GATT tem alçada constitucional. [...]” BRASIL. Supremo Tribunal Federal. Repercussão Geral no Recurso Extraordinário, RE 627280 RG / RJ. Relator: Min. Joaquim Barbosa. Brasília, 17 nov. 2011. DJE 23 fev. 2012.

896 "[...] a legislação brasileira guarda coerência com as regras multilaterais e o Acordo da OMC tem força de lei no ordenamento jurídico interno, o que reduz as vulnerabilidades no sistema de solução de controvérsias e se reflete no baixo número de controvérsias contra o Brasil que resultaram em necessidade de modificar de alguma forma a legislação (duas medidas, questionadas em cinco controvérsias)" COZENDEY, Carlos Márcio Bicalho. O Sistema de Solução de Controvérsias da OMC: para além dos contenciosos, a política externa. Disponível em: <http:/www.itamaraty.gov.br/temas/temasmultilaterais/copy_of_desenvolvimento-comercio-e-financas/organizacao-mundial-do-comercio/solucao-decontroversias/cgc/artigo-cozendey> Acesso em: 15 dez. 2013. p. 12. 
Uma pesquisa simples na jurisprudência do STF pelo vocábulo OMC resulta em 3 processos. ${ }^{897} 898 \mathrm{Na}$ jurisprudência do STJ, a busca pelo vocábulo OMC gera 17 resultados, relacionados majoritariamente à aplicação do GATT para extensão ao produto importado de benefício fiscal (ICMS) concedido ao similar nacional. ${ }^{899} 900901$

Assim, repita-se que no tocante à aplicabilidade e invocabilidade direta, não se pode dizer de sua impossibilidade no direito brasileiro. Um exemplo pode ser encontrado inclusive no tocante ao TRIPS. Em pesquisa sobre os precedentes no STJ, verifica-se que houve discussão acerca da aplicabilidade do TRIPS no tocante à temática das patentes pipeline. Houve uma mudança na jurisprudência do STJ, que chegou a aceitar sua invocabilidade em alguns acórdãos, ${ }^{902}$ para depois recusá-la, consolidando o novo entendimento.

$897 \quad R E$ 474132/SC, RE 564413/SC e ADPF 101. Em ambos os Recursos Extraordinários, que tratavam da Contribuição Social Sobre o Lucro Líquido (CSLL), a menção à OMC foi feita no voto da Min. Carmén Lúcia, sustentando que extensão da imunidade tributária à referida contribuição poderia acarretar violação do ASMC da OMC. Este pode ser um exemplo de efeito indireto dos acordos da OMC no ordenamento jurídico pátrio, uma vez que foram usados como parâmetros para interpretação de normas posteriores: "Não é razoável, na interpretação da Emenda Constitucional 33/01, entender que tenha pretendido efeito violador de acordos internacionais firmados no âmbito da OMC, mormente quando há exegese adequada no sentido de que a imunidade estabelecida não tem tal alcance." (BRASIL. Supremo Tribunal Federal. Recurso Extraordinário, RE 474132 / SC, Relator: Min. Gilmar Mendes. Brasília, 12 ago. 2010. DJE 01 dez. 2010. BRASIL. Supremo Tribunal Federal. Recurso Extraordinário, RE 564413 / SC, Relator: Min. Marco Aurélio. Brasília, 12 ago. 2010. DJE 06 dez. 2010.)

898 A busca na jurisprudência do STF pelo vocábulo GATT gera 385 acórdãos e 2 acórdãos de repercussão geral, a busca pelo vocábulo dumping resulta em 18 acórdãos, e a busca pelo vocábulo TRIPS não gera resultados. Nos abstemos da análise destes resultados, pois esta tarefa fugiria ao escopo da tese, reconhecendo, contudo, a relevância de uma investigação com este objetivo.

899 Com base nas súmulas 20 e 71, os seguintes resultados se relacionam a esta aplicação: (a) Bacalhau: AgRg no REsp 216185 / PE, REsp 961078 / PE, REsp 696713 / RS, AgRg no REsp 793118 / RJ, AgRg no REsp 437188 / SP; (b) Salmão: AgRg no Ag 444132 / SP, REsp 434703 / SP, REsp 316255 / SP, REsp 285311 / SP, REsp 275898 / SP; (c) Leite: AgRg no AREsp 22336 / PE, EDcl no REsp 642663 / RS, REsp $642663 / R S$.

900 Os demais resultados do vocábulo OMC tratam de (a) patente pipeline: REsp 1165845 / RJ; de (b) medida antidumping aplicada: $M S 14641 / D F, M S 13413 / D F$; (c) Erro material de citação, referência seria à OMS: REsp $971845 / D F$.

901 A busca na jurisprudência do STJ pelo vocábulo GATT gera 734 resultados, a busca pelo vocábulo dumping gera 24 resultados, e a busca pelo vocábulo TRIPS gera 22 resultados (todos relacionados às patentes pipeline). Nos abstemos da análise destes resultados, pois esta tarefa fugiria ao escopo da tese, reconhecendo-se, contudo, a relevância de uma investigação com este objetivo.

902 Exemplos de acórdãos que aceitaram implicitamente a invocabilidade do TRIPS: BRASIL. Superior Tribunal de Justiça. Recurso Especial, REsp 667025 / RJ (2004/0086618-6), Relator: Min. Castro Filho, Órgão Julgador Terceira Turma. Brasília, 14 dez. 2006. DJ 12 fev. 2007. BRASIL. Superior Tribunal de Justiça. Recurso Especial, REsp 661536 / RJ (2004/0068155-5), Relator: Min. Carlos Alberto Menezes Direito, Órgão Julgador Terceira Turma. Brasília, 7 abr. 2005. DJ 30 maio 2005. O acórdão do TRF 3a região questionado pelo REsp 661536 expressamente previa: "MANDADO DE SEGURANÇA PROPRIEDADE INDUSTRIAL - TRIPS - DIREITO INTERTEMPORAL - PATENTE - VIGÊNCIA. 1. Ao aprovar e promulgar o TRIPS, o legislador brasileiro afastou a vacatio legis de quarenta e cinco dias e deu ao TRIPS vigor a partir de sua publicação oficial, transformando-o em Lei interna. Preenchidos os requisitos de ordem jurídica brasileira, para que se tenha força e obrigatoriedade de Lei, passou o TRIPS a incidir nas relações jurídicas constituídas no Brasil. [...]”. 
Assim, o caso que consolidou o entendimento mais recente explicita como teria havido um engano inicial, no reconhecimento implícito da geração de efeitos ao TRIPS, quando o STJ teria tomado por premissa o fundamento segundo o qual o TRIPS passou a produzir efeitos sobre as relações privadas referentes às patentes. Segundo o novo entendimento, o TRIPS não é uma lei uniforme, não tendo sido formulado com o objetivo de garantir sua aplicação às relações jurídicas de direito privado em substituição à atividade legislativa dos países. ${ }^{903}$

Outro exemplo pode ser encontrado na aplicação de longa data do GATT 1947 (e em seguida do GATT 1994) em relação à ampliação de isenção tributária concedida ao produto similar nacional, em respeito à cláusula do tratamento nacional. Em caso relativo à aplicabilidade do artigo 7 do Tratado de Montevideo, o STJ fez menção à autoaplicabilidade da cláusula do tratamento nacional, determinando que o juízo de origem procedesse ao "teste de duas fases", entabulado na jurisprudência da OMC. 904905

903 Por sua relevância, transcrevemos parte substancial do voto: "O primeiro ponto essencial que ficou à margem de análise nos precedentes anteriores diz respeito a se estabelecer os limites de aplicação do Acordo TRIPS na perspectiva da definição dos possíveis destinatários do tratado. Com efeito, até hoje, o STJ vem decidindo sobre prazos de prorrogação de patentes tomando como base, de forma implícita, a tese segundo a qual o TRIPS, depois de recepcionado na ordem interna brasileira, teria inteiras condições de incidir sobre relações jurídicas particulares nas quais um dos polos é ocupado pelos detentores de privilégio de invenção. É fundamental que se atente, portanto, para o fato de que, na verdade, quando o STJ discutiu a prorrogação do prazo de 15 anos previsto na anterior Lei $n^{\circ} 5.771 / 71$ para 20 anos, com base no Acordo TRIPS, tomou por premissa necessária um fundamento que não chegou a ser questionado e que está longe de ser pacífico, segundo o qual tal Acordo, no momento de sua recepção pelo Estado brasileiro, passou a produzir efeitos sobre as relações jurídicas privadas que tinham em um dos polos detentores de patentes ainda em curso de fruição. Diz-se que tal ponto é uma premissa ainda não examinada a contento porque, com efeito, só há sentido em discutir se, na hipótese, a recorrente tem direito a ver prorrogado em cinco anos o gozo de sua patente se, antes, ficar estabelecido definitivamente que o apontado fundamento legal desse suposto direito - justamente o Acordo TRIPS - tem, em si, condições de gerá-lo. Assim colocada essa primeira questão - que, por si, já seria motivo bastante para trazer o Acordo TRIPS a um reexame por esta Turma - verifica-se que os precedentes estão fundados em premissa insustentável. O TRIPS não é uma Lei Uniforme; em outras palavras, não é um tratado que foi editado de forma a propiciar sua literal aplicação nas relações jurídicas de direito privado ocorrentes em cada um dos Estados que a ele aderem, substituindo de forma plena a atividade legislativa desses países, que estaria então limitada à declaração de sua recepção, por instrumento próprio (no nosso caso, por Decreto Legislativo). Há, portanto, tratados que estabelecem arcabouços normativos completos sobre determinada matéria e estão, dessa forma, aptos a fornecerem disciplina jurídica aplicável às relações jurídicas entre particulares, podendo-se atribuir às suas normas a qualidade de 'autoexecutivas'; outros, porém, se limitam a estipular obrigações que só podem ser exigidas dos próprios Estados que a ele aderem, apesar de sua essência se referir a questões de direito privado, porque, na verdade, o âmbito desses tratados é o de fornecer balizas para a adequação legislativa interna de cada país (cf. BARBOSA, Denis Borges. "Propriedade intelectual: a aplicação do Acordo TRIPS. Rio de Janeiro: Lumen Júris Editora, $2^{a}$ Edição, 2005, p. 18 e ss.)” BRASIL. Superior Tribunal de Justiça. Voto da Relatora. Recurso Especial, REsp 960728 / RJ (2007/0134388-8). Relatora: Min. Nancy Andrighi, Órgão Julgador Terceira Turma. Brasília, 17 mar. 2009. DJE 15 abr. 2009.

904 Na ementa, lê-se: "[...] 4. A cláusula de "Obrigação de Tratamento Nacional" é norma autoaplicável pois tem como condicionante apenas o "Teste de duas Fases", ou seja: $1^{\text {o }) ~ A ~ v e r i f i c a c ̧ a ̃ o ~ d a ~}$ similaridade entre os produtos doméstico e importado e, $2^{\circ}$ ) A verificação da ocorrência da tributação superior do produto importado em relação ao doméstico. Nesse sentido, a aplicação da cláusula no âmbito 
Um estudo mais detalhado sobre o tema poderia também explorar se a jurisprudência brasileira reconhece a distinção entre os acordos contrato e acordos lei no tocante aos diferentes acordos da OMC, como pode se apreender do precedente mencionado relativo ao TRIPS, e como tal distinção se desenha na prática dos tribunais.

Retomando o status das decisões do Sistema de Solução de Controvérsias da OMC, a participação do Brasil no Sistema de Solução de Controvérsias até o presente momento não ofereceu oportunidade para se testar a invocabilidade dessas decisões pelas partes em ações judiciais, pela própria natureza das medidas contestadas. Desconhece-se, da pesquisa doutrinária e da investigação jurisprudencial empreendidas, procedimento no qual o relatório aprovado pelo OSC tenha sido alegado como fonte de obrigações pertinentes à partes em um litígio em tribunais brasileiros.

do GATT 1994 já foi reconhecida por diversas vezes pela jurisprudência do STF e deste STJ gerando os seguintes precedentes: Súmula n. 575/STF; Súmula n. 20/STJ; Súmula n. 71/STJ; e recurso representativo da controvérsia RESP. N. 871.760/BA, Primeira Seção, Rel. Min. Luiz. Fux, julgado em 11.03.2009. No âmbito do MERCOSUL já houve aplicação da cláusula nos seguintes precedentes do STJ: REsp. n. 480.563-RS, Primeira Turma, Rel. Min. Luiz Fux, julgado em 6.09.2005; REsp. n. 1.002.069/CE, Segunda Turma, Rel. Min. Castro Meira, julgado em 22.04.2008. 5. Tendo em vista que a Corte de Origem julgou o processo afastando a autoaplicabilidade da referida cláusula, restam sem solução diversas questões fáticas condicionantes de sua aplicação que não podem ser apreciadas em sede de recurso especial, cabendo à Corte de Origem enfrentá-las no "Teste de Duas Fases", consoante a prova dos autos. [...]" BRASIL. Superior Tribunal de Justiça. Recurso Especial, REsp 1205393 / RJ (2010/0138530-1). Relator: Min. Mauro Campbell Marques, Órgão Julgador Segunda Turma. Brasília, 9 abr. 2013. DJE 16 abr. 2013.

905 Por sua relevância, transcrevemos parte do voto do Relator: "A cláusula de "Obrigação de Tratamento Nacional" (artigo III do GATT 1994), ao lado da cláusula de "Tratamento da Nação Mais Favorecida" (artigo I do GATT 1994 e art. 8o, "d" do Tratado de Assunção) é uma das formas de concretização do "Princípio da não-discriminação", tido como pedra angular de todo e qualquer sistema multilateral de comércio exterior, dando-lhe justiça e previsibilidade. Tal princípio consiste em não tratar de maneira menos favorável quaisquer produtos em relação a todos os produtos "similares", independentemente de sua origem ou se eles são importados ou produzidos localmente. Com efeito, a cartilha oficial para solução de controvérsias produzida pela OMC (Organização Mundial do Comércio) no âmbito da Conferência das Nações Unidas sobre Comércio e Desenvolvimento (United Nations Conference on Trade and Development - UNCTAD. Solução de Controvérsias. Disponível em: $<$ http://unctad.org(pt/docsledmmisc232add33_pt.pdf>. Acesso em: 02.04.2013) trouxe como parâmetros para a aplicação da referida cláusula apenas a aplicação do chamado "Teste de Duas Fases". A primeira fase consiste em verificar se há similaridade entre os produtos doméstico e importado. A segunda fase é a verificação da ocorrência da tributação superior do produto importado em relação ao doméstico. Fez também a observação de que por tributos internos devem ser compreendidos o IVA, os impostos sobre vendas e os impostos sobre o consumo (campos onde inegavelmente se encontra o IPI brasileiro), dando evidente autoaplicabilidade ao dispositivo. Nesse ponto, reforçando a autoaplicabilidade dessa cláusula no âmbito do GATT, tanto o STF quanto o STJ já se manifestaram inúmeras vezes, tendo sido produzidos três enunciados sumulares e um recurso representativo da controvérsia, a saber: Súmula n. 575/STF: “ $A$ mercadoria importada de país signatário do GATT, ou membro da ALALC, estende-se a isenção do imposto de circulação de mercadorias concedida a similar nacional". Súmula n. 20/STJ: "A mercadoria importada de país signatário do GATT é isenta do ICM, quando contemplado com esse favor o similar nacional". Súmula n. 71/STJ: "O bacalhau importado de país signatário do GATT é isento do ICM". BRASIL. Superior Tribunal de Justiça. Recurso Especial, REsp 1205393 / RJ (2010/0138530-1). Relator: Min. Mauro Campbell Marques, Órgão Julgador Segunda Turma. Brasília, 9 abr. 2013. DJE 16 abr. 2013. 
A inexistência de julgados neste sentido, contudo, não pode encerrar o debate sobre a eventual aplicabilidade e invocabilidade das decisões do Sistema de Solução de Controvérsias da OMC no Brasil, já que não se pode prever a natureza dos interesses envolvidos nos casos a serem futuramente decididos pelo Sistema de Solução de Controvérsias da OMC.

A priori, pode-se afirmar que o ESC, base legal da obrigatoriedade das decisões do Sistema de Solução de Controvérsias da OMC, foi devidamente incorporado ao direito brasileiro pelo decreto n. 1.355 de 30 de dezembro de 1994, o que poderia constituir o embasamento jurídico para a sua exigibilidade em tribunais brasileiros, em especial quando o prazo razoável para implementar as decisões já se esgotou. ${ }^{906}$

Ademais, no ordenamento jurídico pátrio vigora o princípio da inafastabilidade da jurisdição, constante do rol de direitos e garantias fundamentais da Constituição Brasileira de 1988, na qual expressamente se postula que "a lei não excluirá da apreciação do poder judiciário lesão ou ameaça a direito". 907908 Embora tal princípio deva ser interpretado em face de outros parâmetros, dentre eles o princípio da tripartição dos poderes, não há uma limitação - a priori - para que uma decisão do Sistema de Solução de Controvérsias da OMC seja apreciada pelas instâncias judiciais brasileiras. ${ }^{909}$

906 A este respeito, destaca-se a sugestão de Ernst-Ulrich Petersmann: "Domestic courts could play an important role in the prevention of WTO disputes as well as in the decentralized enforcement of precise and unconditional WTO obligations, including legally binding WTO dispute settlement findings on the protection of private rights once the "reasonable period" for the domestic implementation of WTO rulings has expired." PETERSMANN, Ernst-Ulrich. Multi-Level Judicial Trade Governance without Justice? On the Role of Domestic Courts in the WTO Legal and Dispute Settlement System. European University Institute, Department of Law, EUI Working Paper LAW, n. 2006/44. p. 3.

907 BRASIL. Constituição da República Federativa do Brasil de 1988. Artigo 5º XXXV.

908 Sobre a amplitude da interpretação contemporânea do referido princípio, destaque-se o ensinamento de Cândido Rangel Dinamarco: "O inc. $X X X V$ do art. $5^{\circ}$ da Constituição, antes interpretado como portador somente da garantia da ação, tem o significado político de pôr sob controle dos órgãos da jurisdição todas as crises jurídicas capazes de gerar estados de insatisfação às pessoas e, portanto, o sentimento de infelicidade por pretenderem e não terem outro meio de obter o bem da vida. Esse dispositivo não se traduz em garantia de mero ingresso em juízo ou somente do julgamento de pretensões trazidas, mas da própria a tutela jurisdicional a quem tiver razão... O princípio da inafastabilidade do controle jurisdicional manda que as pretensões sejam deduzidas em juízo, sejam processadas e julgada, que a tutela seja oferecida por ato do juiz àquele que tiver direito a ela - e, sobretudo, que seja efetiva como resultado prático do processo". DINAMARCO, Cândido Rangel. Instituições de Direito Processual Civil. Volume I. $5^{\text {a }}$ ed. São Paulo: Malheiros Editores, 2005. p. 217-218.

909 A respeito do princípio da tripartição dos poderes, Carla Junqueira avalia: "Com base nesses dispositivos, a jurisprudência brasileira tem interpretado os limites da revisão judicial, em especial no caso da revisão judicial de decisões tomadas por autoridades administrativas ou de violações a direitos individuais [...] há também, no sistema brasileiro, decisões relativas à revisão pelo Poder Judiciário de avaliações de conveniência e oportunidade efetuadas por autoridades administrativas no âmbito de sua competência especializada. O principio norteador dessas decisões é a tripartição de poderes, consagrado constitucionalmente." JUNQUEIRA, Carla Amaral de Andrade. A Técnica Interpretativa do Órgão de 
Em tese, contudo, um obstáculo formal poderia ser a ausência de um ato de internalização dessa decisão no Brasil. Destaque-se que, embora o Brasil não conteste a obrigatoriedade das decisões desta instância, as decisões do Sistema de Solução de Controvérsias da OMC não têm sido até o presente momento "internalizadas" formalmente no direito brasileiro. ${ }^{910}$ Tem cabido, pois, ao Poder executivo a "liberdade" de implementá-las, de modo similar à decisão por aplicar uma diretriz negociada internacionalmente, e sem trazê-las formalmente ao universo jurídico nacional. ${ }^{911}$

No Brasil, a prática da internalização das decisões de Organizações Internacionais tem se mostrado confusa e inconsistente. Em geral, essa internalização tem se dado em função da nomenclatura dos atos, por meio de: (i) relação clássica entre o Poder Executivo e o Poder Legislativo, rito estabelecido para os tratados internacionais; (ii) decreto executório da Presidência; ou (iii) publicação do órgão responsável pela negociação. ${ }^{912}$

Assim, embora inexista no Brasil discussões acerca da obrigatoriedade desta decisão adjudicatória internacional, a não internalização das decisões tem o efeito contrário

Apelação da Organização Mundial do Comércio. 2010. 268 f. Tese (Doutorado em Direito) - Faculdade de Direito, Universidade de São Paulo, São Paulo. p. 74-75.

910 É relevante o parecer de Vicente Marotta Rangel, como consultor jurídico do MRE, que explicita a exigência de decreto e publicação para decisões de Organizações Internacionais no Brasil: "12. $A$ Constituição brasileira é omissa no tocante quer às decisões, quer às resoluções de órgãos ou organismos internacionais. Ela reza, todavia, que "ninguém será obrigado a fazer ou deixar de fazer alguma coisa senão em virtude de lei” (art. 5o - II). Consagra-se, destarte, o princípio de legalidade, ilustrado apropriadamente pela ideia de pirâmide, em cujo ápice está a própria Constituição e, abaixo, em escala descendente e hierárquica, todas as demais leis e atos. Legalidade, nesse caso, não significa apenas a lei (ordinária ou constitucional), mas a qualidade daquilo que é conforme à lei (José CRETELLA JUNIOR, Comentários à Constituição Brasileira de 1988, vol. I, Rio de Janeiro/São Paulo: Forense Universitária, p. 198-199). Nesse sentido, decisões e resoluções são inegavelmente leis ou atos conformes às leis, uma vez que promanam de órgãos contemplados em tratado internacional que se incorporou ao ordenamento jurídico brasileiro, nos termos da Constituição e demais leis do País. 13. Ao proceder ao exame específico de resoluções e decisões de órgãos do MERCOSUL, é possível identificar aquelas que possuem aplicabilidade no direito interno brasileiro. Assim se me afiguram, verbi gratia, a decisão 12/91, bem como as resoluções 9/91, 10/91 e 9/92. Ora, para que tais normas sejam eficazes e obriguem a todos no ordenamento jurídico brasileiro, é indeclinável o atendimento de dois procedimentos legais: a) que se lhes expeça decreto ou regulamento com vistas à "sua fiel execução" (Constituição Federal, art. 84 - IV); b) e que tais normas sejam objeto de publicação oficial (Lei de Introdução ao Código Civil, art. 1o).” MAROTTA RANGEL, Vicente. Tratado de Assunção. Órgãos do MERCOSUL. Decisões e resoluções. Fontes do direito internacional. Direito interno das organizações internacionais e dos Estados Membros. Delimitação do âmbito de consulta. (1992). In: CACHAPUZ de MEDEIROS, Antônio Paulo. Pareceres Dos Consultores Jurídicos Do Itamaraty. Volume IX (1990-2000). Brasília: Fundação Alexandre de Gusmão, 2009, p. 125-129. p. 128.

911 Contudo, é pertinente a reflexão de João Paulo de Oliveira: “Consequentemente, a eventual ausência de publicidade da sentença internacional não deve ser um impeditivo de seu cumprimento em território brasileiro. Se a publicidade é imprescindível para que atos processuais e da administração adequem-se à Constituição Federal, a falha do Estado em promovê-la não gera o direito de desatender o comando estampado na sentença." OLIVEIRA, João Paulo de. Adjudicação e Comércio Internacional - o Caso dos Pneus Reformados. 2012. 152 p. Dissertação (Mestrado ), Programa de Pós-graduação em Integração da América Latina, Universidade de São Paulo, São Paulo. p. 111.

912 VENTURA, Deisy. ONUKI, Janina. MEDEIROS, Marcelo et alli. Internalização das normas do MERCOSUL. Série Pensando o Direito, vol. 45. Brasília: Ministério da Justiça, 2012. 
de torná-las formalmente inexistentes ao ordenamento jurídico pátrio. Esta situação abre um indesejável espaço para que o Poder Executivo maneje a implementação dessas decisões de modo correlato ao manejo de negociações internacionais, embora sob o aspecto jurídico interno trate-se de atividade administrativa, e que deve ser pautada pelos princípios que regem tais atos, e inclusive pela potencialidade de seu controle.

Em conclusão, nos filiamos ao entendimento de que a resposta para a potencial aplicabilidade e invocabilidade das decisões do Sistema de Solução de Controvérsias da OMC no judiciário brasileiro ainda está para ser construída ${ }^{913}$ e que portanto, não há uma impossibilidade "lógica" ou normativa de sua ocorrência no ordenamento pátrio. ${ }^{914}$ Isto é, a prática brasileira até o momento parece trazer muito mais perguntas do que respostas acerca do status jurídico das decisões do Sistema de Solução de Controvérsias no Brasil.

\subsection{Mecanismos Nacionais de Efetivação Existentes na Sistemática Brasileira}

913 Citamos, nesta linha, o lúcido posicionamento de Daniela Arruda Benjamin: "Em termos de alcance, ainda não há como afirmar se os Tribunais nacionais aceitariam atribuir efeitos jurídicos concretos às decisões do OSC porventura invocados em ações jurídicas internas na ausência de um ato administrativo de incorporação. [...] Dada a descentralização do sistema Judiciário e a falta de clareza no ordenamento jurídico brasileiro sobre o real alcance dos atos emanados das OI é difícil saber se essa abertura do Judiciário brasileiro à aplicação dos acordos da OMC - que de resto ainda teria que ser confirmada por meio de uma análise mais exaustiva da jurisprudência que excede o escopo do presente trabalho - se estenderia, igualmente, às decisões do OSC. [...] Por outro, no entanto, diante das dúvidas que ainda pairam sobre a natureza das decisões do OSC não seria de estranhar se os Tribunais nacionais optassem por seguir a linha adotada por outros países e afastassem essa aplicação com o argumento de que, por força dos próprios Tratados da OMC, o Executivo teria discricionariedade suficiente para decidir não dar cumprimento à decisão, sujeitando-se às medidas previstas nos Acordos nessa hipótese.” BENJAMIN, Daniela Arruda. A aplicação interna das decisões do Órgão de Solução de Controvérsias da OMC na prática. In: BENJAMIN, Daniela Arruda. (Org.). O Sistema de Solução de Controvérsias da OMC: uma perspectiva brasileira. Brasília: FUNAG, 2013, p. 573-594. p. 585

914 Para uma posição contrária, acerca de uma suposta impossibilidade 'lógica' da aplicação direta, Cf: "A decisão da OMC não é aplicável diretamente no ordenamento jurídico interno. Nem poderia ser. Explicamos o porquê. No direito brasileiro, por exemplo, o tratado tem valor normativo de lei ordinária. Se uma lei nacional posterior ao tratado dispõe de forma contrária a este, é posição pacífica do STF que a nova norma revoga o tratado anterior. Ora, dez anos após a OMC, é mais provável que qualquer norma que seja considerada em desacordo com os tratados comerciais multilaterais seja mais recente do que as normas da OMC e, segundo a lógica tradicional, prevaleceria sobre os estes (sic). Se se tratar de norma constitucional, sequer se poderia pretender que esta seria revogada pela decisão, cujo poder normativo deriva de um tratado. [...]" VARELLA, Marcelo D. Direito Internacional Público. $3^{\text {a }}$ ed. São Paulo: Saraiva, 2011. p. 460. 
Como evidenciado pela análise do capitulo 4, nos casos em que exigiu-se a implementação de decisão do Sistema de Solução de Controvérsias, a implementação ocorreu de modo "difuso". Assim, além de inexistir em ambos os casos ato formal de incorporação da decisão ao ordenamento jurídico interno, a implementação ocorreu "mediante adoção de atos internos de adequação da legislação contestada na OMC, inspirados nas decisões do OSC, mas não necessariamente embasados juridicamente nas mesmas." 915

No caso das Aeronaves, a implementação da decisão foi operacionalizada por meio de mudanças em atos normativos exarados pelo Poder Executivo (portarias do BACEN), bem como na Lei 8.187/91, que instituía o programa considerado desconforme com as obrigações multilaterais, em sua formulação original.

O caso dos Pneus mostrou-se excepcional, na medida em que o poder judiciário, no exercício de suas competências ordinárias internas, praticava conduta que obstruía a realização da finalidade protetiva da medida instituída pelo Poder Executivo. Deste modo, a implementação da decisão do Sistema de Solução de Controvérsias da OMC envolvia uma necessidade de uniformizar a jurisprudência nacional, no intuito de garantir que não seriam concedidas tutelas jurisdicionais que permitissem a importação de pneus reformados, proibida pelo Poder Executivo.

O instrumento escolhido nessa situação, como observamos supra, foi um mecanismo do controle concentrado de constitucionalidade, a Arguição de Descumprimento de Preceito Fundamental, prevista no artigo 102 para $1^{\circ}$ da $\mathrm{CF}$ como um mecanismo de resguardo da eficácia da Constituição. Embora o caso dos pneus tenha sido citado durante o procedimento - na petição inicial, durante audiências, e na decisão final da ADPF -, a decisão baseou-se no direito interno, parecendo considerar a decisão do Sistema de Solução de Controvérsias da OMC como um fato, e não necessariamente como um condicionante jurídico à atuação dos órgãos internos. Caberia, pois, a reflexão sobre qual teria sido o caminho escolhido para a implementação na circunstância de não haver embasamento constitucional coincidente na temática.

915 BENJAMIN, Daniela Arruda. A aplicação interna das decisões do Órgão de Solução de Controvérsias da OMC na prática. In: BENJAMIN, Daniela Arruda. (Org.). O Sistema de Solução de Controvérsias da OMC: uma perspectiva brasileira. Brasília: FUNAG, 2013, p. 573-594. p. 587. 
Assim, sob uma perspectiva holística, é possível afirmar que os mecanismos disponíveis no Brasil para a implementação das decisões do OSC são os remédios regularmente utilizados no âmbito interno para modificação de atos ilegais ou inconvenientes ao interesse público: atos administrativos, leis, e ações jurisdicionais. Não há a previsão de mecanismos ou procedimentos específicos para implementação, que podem oferecer garantias adicionais à legitimidade da tomada de decisão, como abordaremos adiante.

Merece destaque, contudo, neste tópico, o estudo do mecanismo utilizado pelo governo brasileiro para a implementação da retaliação autorizada pelo OSC, por motivo de não cumprimento pelos EUA de decisão no caso do Algodão. ${ }^{916} 917$ Não se trata, pois, de implementação no sentido de cumprimento da decisão adjudicatória internacional, com o qual se preocupa prioritariamente esta pesquisa, mas sim em relação à aplicação do seu direito de suspensão de certas obrigações em face do membro faltoso. ${ }^{918}$

A omissão da análise desta controvérsia no capitulo 3 ocorreu em respeito a uma opção metodológica, de não inclusão de exame de casos em fase de retaliação, pois escapariam à categoria conceitual de implementação da decisão adjudicatória do Sistema de Solução de Controvérsias da OMC, como definido no capítulo 2. Contudo, ao avaliarmos os mecanismos de implementação das decisões do OSC no Brasil, ganha

916 Para análise sobre os dados técnicos do caso, e sobre a evolução da controvérsia, Cf: ANDRADE, Luciano Mazza de. O contencioso do algodão: o desafio da implementação. In: BENJAMIN, Daniela Arruda. (Org). O Sistema de Solução de Controvérsias da OMC: uma perspectiva brasileira. Brasília : FUNAG, 2013, p. 85-112.

917 Para uma visão interna do setor cotonicultor brasileiro em relação à controvérsia, com um especial destaque à cooperação governo-setor privado, e aos depoimentos de autoridades envolvidas no desenvolvimento do caso na OMC, Cf: COSTA, Sérgio Rodrigues; BUENO, Miguel Garcia. A saga do algodão: das primeiras lavouras à ação na OMC. Rio de Janeiro: Insight Engenharia, 2004, p. 128-133. Disponível

em: <http://www.abrapa.com.br/biblioteca/Documents/institucional/publicacoes/A\%20Saga\%20do\%20Algodao. pdf>. Acesso em: 20 mar. 2014.

918 Reitera-se que o foco principal da pesquisa se refere aos mecanismos de implementação strictu sensu, para cumprimento da decisão do Sistema de Solução de Controvérsias da OMC, em um sentido mais restrito do termo implementação. Contudo, a aplicação das consequências do descumprimento das decisões do Sistema de Solução de Controvérsias da OMC também poderia se enquadrar em uma noção de implementação latu sensu. Neste sentido, Cf: "The implementation process can be perceived from different time-frameworks. They can be categorized into four modalities or functions: (1) the facilitation of compliance;(2) the assurance of compliance; (3) the deterrence of non-compliance;(4) and the correction of non-compliance. The core of the four modalities is compliance with the WTO Agreements, the first two concerning the positive aspects of compliance and the latter two concerning the negative aspects. The positive aspects of compliance cover the implementing mechanisms that facilitate or encourage the Members to act in line with the WTO obligations. In contrast, the negative aspects of compliance involve the threat or use of implementing mechanisms that deter the Members from breaching the WTO obligations or enforcing those obligations to correct such breaches. [...]”. ZHANG, Xin. Implementation of the WTO Agreements: Framework and Reform. Northwestern Journal of International Law \& Business, vol. 23, p. 383-432, 2002-2003. p. 386. 
destaque o exame do caminho escolhido pelo governo brasileiro para aplicar a retaliação, por evidenciar alguns aspectos que não podem ser negligenciados no procedimento de implementação das decisões adjudicatórias do Sistema de Solução de Controvérsias da OMC pelo Brasil.

Com a autorização para retaliar os EUA pelo não cumprimento da decisão da controvérsia, o Brasil passou a enfrentar o desafio de sua concretização efetiva. Neste intuito, estabeleceu-se intensa e abrangente cooperação do MRE com outros órgãos da administração pública federal. É de toda a relevância a descrição do diplomata envolvido na tarefa, que explica que "optou-se por dar maior institucionalidade ao processo." ${ }^{919} \mathrm{O}$ autor identifica, pois, esta institucionalização como uma opção do governo, dando a entender que poderia ser feita de modo autônomo pelo Poder Executivo, sem qualquer tipo de consulta.

Ainda segundo a análise do diplomata, "[...] do ponto de vista jurídico, no plano doméstico, o Executivo detém ampla liberdade para implementar a retaliação em bens." ${ }^{920}$ O óbice jurídico, em sua visão, estaria no aspecto regional, uma vez que a integração econômica no âmbito do MERCOSUL estabelece uma Tarifa Externa Comum (TEC) a ser seguida por seus membros. Foi este o contexto de negociações no âmbito do MERCOSUL, que resultaram na aprovação da Decisão n. 18/09 do Conselho do Mercado Comum, em 7 de dezembro de 2009. ${ }^{921}$ A decisão estabelece uma permissão geral no bloco - e portanto, extensível a todos os membros e a casos futuros - de aumento de tarifas extra-zona, em função do regime multilateral. ${ }^{922}$

919 SCHMIDT, Luiz Fellipe Flores. A construção da retaliação brasileira no caso algodão: os desafios do pioneirismo. In: BENJAMIN, Daniela Arruda. (Org.). O Sistema de Solução de Controvérsias da OMC: uma perspectiva brasileira. Brasília : FUNAG, 2013, p. 629-648. p. 633.

920 SCHMIDT, Luiz Fellipe Flores. A construção da retaliação brasileira no caso algodão: os desafios do pioneirismo. In: BENJAMIN, Daniela Arruda. (Org). O Sistema de Solução de Controvérsias da OMC: uma perspectiva brasileira. Brasília : FUNAG, 2013, p. 629-648. p. 634.

921 Decisão MERCOSUL/CMC/DEC No. 18/2009, de 7/12/2009. Disponível em: < http://www.mercosur.int/innovaportal/v/1028/1/secretaria/decisões_2009>

922 É este o texto da decisão: "Art. 1 - Um Estado Parte poderá elevar acima do estabelecido na Tarifa Externa Comum, por um prazo máximo inicial de dois anos, o direito de importação extrazona que aplica a terceiros países, de maneira consistente com suas obrigações na Organização Mundial de Comércio, nas seguintes situações: (a) quando tenha sido autorizado pelo Órgão de Solução de Controvérsias da OMC a suspender concessões ou outras obrigações como consequência de um procedimento de solução de controvérsias; e (b) quando, em consonância com o disposto no Artigo XXVIII do GATT de 1994, exerça a faculdade de retirar concessões substancialmente equivalentes que tenham sido negociadas originalmente com um Membro da OMC que pretenda modificar ou retirar concessões." 
A “institucionalização" descrita se concretizou por meio da Resolução n. 63 da CAMEX, de outubro de 2009, 923924 instituindo o Grupo Técnico (GT), criado com o objetivo de "identificar, avaliar e formular propostas de implementação das contramedidas autorizadas, conforme decisões dos árbitros manifestadas nos documentos WT/DS267/ARB/1 e WT/DS267/ARB2 da OMC", estando tais propostas sujeitas à apreciação do Conselho de Ministros da CAMEX. ${ }^{925}$

O GT criado passou a ser composto por: (i) um representante do Ministério das Relações Exteriores - MRE, responsável por sua coordenação; (ii) um representante da Secretaria Executiva da CAMEX; (iii) um representante do Ministério do Desenvolvimento Indústria e Comércio Exterior (MDIC); (iv) um representante da Casa Civil da Presidência da República; (v) um representante do Ministério da Fazenda (MF); um representante do Ministério da Agricultura, Pecuária e do Abastecimento; um representante do Ministério do Desenvolvimento Agrário; um representante do Ministério do Planejamento, Orçamento e Gestão; um representante do Ministério da Saúde; e um representante do Grupo Interministerial de Propriedade Intelectual (GIPI), indicado pelo Ministro do Desenvolvimento. Ademais, o GT poderia "recomendar a participação de outros órgãos e entidades de direito público e privado nas reuniões a serem realizadas". 926927

923 CAMEX. Resolução no 63, de 28 out. de 2009. Publicação no DOU 29 out. 2009. Institui Grupo Técnico identificar, avaliar, e formular propostas de implementação de contramedidas no âmbito do contencioso "Estados Unidos-Subsídios ao Algodão".

924 Referida criação se embasou formalmente, como descrito no texto da Resolução, em atribuições amplas conferidas ao Presidente da CAMEX e à CAMEX expressas, respectivamente, no artigo $4^{\circ}$, I do Decreto $\mathrm{n}^{\circ}$ 4.732, de 10 de junho de 2003 ("Art. 4o A CAMEX terá como órgão de deliberação superior e final um Conselho de Ministros composto pelos seguintes Ministros de Estado: I - do Desenvolvimento, Indústria e Comércio Exterior, que o presidirá (...)”) e artigo $2^{\mathrm{o}}$, incisos II, IV, VI e XV, e $\S 2^{\circ}$ do mesmo decreto ("Art. 20 Compete à CAMEX, dentre outros atos necessários à consecução dos objetivos da política de comércio exterior: (...) II - coordenar e orientar as ações dos órgãos que possuem competências na área de comércio exterior; (...)IV - estabelecer as diretrizes para as negociações de acordos e convênios relativos ao comércio exterior, de natureza bilateral, regional ou multilateral; (...) VI - formular diretrizes básicas da política tarifária na importação e exportação; (...) $X V$-fixar direitos antidumping e compensatórios, provisórios ou definitivos, e salvaguardas; (...)§ 2o A CAMEX proporá as medidas que considerar pertinentes para proteger os interesses comerciais brasileiros nas relações comerciais com países que descumprirem acordos firmados bilateral, regional ou multilateralmente.").

925 Art. $1^{\circ}$. CAMEX. Resolução no 63, de 28 out. de 2009. Publicação no Diário Oficial da União: 29 out. 2009.

926 Art. $2^{\text {o. }}$ CAMEX. Resolução no 63, de 28 out. de 2009. Publicação no Diário Oficial da União: 29 out. 2009.

927 "A coordenação do "GT Retaliação" coube ao Itamaraty, por meio da Coordenação-Geral de Contenciosos (CGC). [...] Outros órgãos também foram envolvidos, conforme a necessidade, como os ministérios da Educação e da Cultura, além de diversas autarquias - Receita Federal, Banco Central, agências reguladoras e universidades, entre outras.” p. 633. SCHMIDT, Luiz Fellipe Flores. A construção da retaliação brasileira no caso algodão: os desafios do pioneirismo. In: BENJAMIN, Daniela Arruda. 
As competências do GT, como expressas na Resolução que o criou, se consubstanciavam em : (i) identificação, avaliação e proposição de medidas e instrumentos para implementação da decisão, e a elaboração de notas técnicas e avaliações de impacto dessas medidas e/ou instrumentos; (ii) elaboração de listas de bens, serviços e direitos de propriedade intelectual sujeitos à aplicação da retaliação autorizada; (iii) submissão ao exame do Conselho de Ministros da CAMEX de minuta de resolução com os elementos para aplicação da retaliação e (iv) monitoramento do cumprimento de prazos estabelecidos pela CAMEX para a implementação, por órgãos da Administração Pública. ${ }^{928}$

No desenvolvimento de seus trabalhos, o GT buscou inspirar-se na experiência de outros casos no procedimento de aplicação da retaliação, em especial no rito seguido pela União Europeia para retaliar os EUA. ${ }^{929}$ Para tal, a UE convocou, por meio de consulta pública, a participação dos setores interessados e da sociedade civil, antes de selecionar os itens a serem objeto da medida. Selecionados os produtos, em relação aos quais não houvesse dependência significativa das importações dos EUA, tendo em conta as posições expressas por meio da consulta, a Comissão fixou as tarifas adicionais, que aumentariam com o tempo. ${ }^{930}$

Esse procedimento foi, em linhas gerais, um modelo para a retaliação brasileira, uma vez definido pelo GT que a aplicação da retaliação deveria ser amplamente discutida pelos setores da sociedade e da economia brasileira. Seriam adotados os seguintes passos: (i) redação de lista preliminar de produtos, (ii) consulta pública, (iii) consideração dos comentários explicitados na consulta; (iv) elaboração da lista final. ${ }^{931}$

Na elaboração da lista inicial, optou-se pela retaliação por meio de majoração tarifária, e concentrada em bens cujos produtores norte-americanos exercessem um grau significativo de influência política de modo a poderem eficazmente impingir pressão no governo dos EUA. ${ }^{932} \mathrm{Na}$ elaboração da lista levou-se em conta, portanto, aspectos

(Org.). O Sistema de Solução de Controvérsias da OMC: uma perspectiva brasileira. Brasília : FUNAG, 2013. p. 629-648.

928 Art. $3^{\text {o. }}$ CAMEX. Resolução no 63, de 28 out. de 2009. Publicação no Diário Ofícial da União: 29 out. 2009.

929 SCHMIDT, Luiz Fellipe Flores. A construção da retaliação brasileira no caso algodão: os desafios do pioneirismo. In: BENJAMIN, Daniela Arruda. (Org.). O Sistema de Solução de Controvérsias da OMC: uma perspectiva brasileira. Brasília : FUNAG, 2013, p. 629-648. p. 634.

930 Caso United States - Tax Treatment for "Foreign Sales Corporations" (DS 108).

931 SCHMIDT, Luiz Fellipe Flores. A construção da retaliação brasileira no caso algodão: os desafios do pioneirismo. In: BENJAMIN, Daniela Arruda. (Org). O Sistema de Solução de Controvérsias da OMC: uma perspectiva brasileira. Brasília : FUNAG, 2013, p. 629-648. p. 635.

932 Relevante destacar a linha de raciocínio nesta temática: "Poder-se-ia concentrar a retaliação sobre 
quantitativos e qualitativos, na busca de um equilíbrio entre os efeitos internos de tal majoração tarifária e o gatilho do mecanismo de pressão dos grupos afetados no ordenamento norte-americano.

A lista foi publicada como anexo da Resolução 74/2009 da CAMEX, que também estabelecia consulta pública com o intuito de auxiliar eventual revisão da lista, que originariamente continha 222 itens tarifários. Os comentários das partes interessadas deveria ser encaminhado em via escrita e via digital, e embora não se tenha restringido a participação ao preenchimento de algum requisito, a Resolução explicita que as manifestações deveriam ocorrer "preferencialmente por meio de associações ou Entidades de Classe." 933

Houve significativa participação de diferentes setores e grupos da sociedade ${ }^{934}$, o que permitiu ao grupo de trabalho o contato com dimensões menos evidentes dos potenciais reflexos da medida como esboçada. Nos dizeres do diplomata LUIZ FELLIPE FlORES SCHMIDT, "o recurso à consulta pública, além de mecanismo de ampliação da transparência e da participação da sociedade, confirmou-se como ferramenta valiosa para o processo." 935

pequeno número de bens, aplicando-se-lhes elevadas sobretarifas, de forma a reduzir drasticamente a importação daqueles produtos. Nesse caso, gerar-se-ia maior pressão sobre os grupos afetados que, por sua vez, teriam incentivo maior para influenciar o Congresso dos EUA no sentido de revogar os subsídios condenados; por outro lado, altas excessivas possivelmente inviabilizariam os negócios de muitos importadores domiciliados no Brasil. No outro extremo, havia a opção de adotar sobretarifas leves sobre uma vasta quantidade de itens. Se esta opção tinha o condão de "democratizar" o impacto da retaliação, o impacto individual limitado provavelmente não seria suficiente para galvanizar apoio que levasse a mudanças em Washington”. SCHMIDT, Luiz Fellipe Flores. A construção da retaliação brasileira no caso algodão: os desafios do pioneirismo. In: BENJAMIN, Daniela Arruda. (Org.). O Sistema de Solução de Controvérsias da OMC: uma perspectiva brasileira. Brasília : FUNAG, 2013, p. 629-648. p. 636.

933 CAMEX. Resolução no 74, de 6 nov. de 2009. Publicação no Diário Oficial da União: 9 nov. 2009. "Instaura procedimento de consultas públicas relativa à Lista Preliminar ("Lista") de códigos NCM que poderão estar sujeitos à aplicação de contramedidas em decorrência do não cumprimento, por parte dos EUA, das decisões e recomendações adotadas pelo Órgão de Solução de Controvérsias da OMC no contexto do contencioso "Estados Unidos da América - Subsídios ao Algodão" (WT/DS 267)."

934 "Mais de 700 manifestações foram recebidas da sociedade, principalmente oriundas de empresas e associações de produtores, importadores e consumidores dos bens envolvidos. No entanto, outros agentes também deram sua contribuição, incluindo até mesmo pessoas físicas. (...) Entre os resultados das avaliações quantitativas preliminares, o grupo observou forte correlação positiva entre o número de manifestações recebidas (favoráveis ou contrárias) sobre um determinado bem e a intensidade do fluxo de comércio com os EUA daquele bem. Isso trouxe conforto ao grupo, consistindo em sinal importante de que os "stakeholders" estavam atentos e conscientes da importância daquele processo." SCHMIDT, Luiz Fellipe Flores. A construção da retaliação brasileira no caso algodão: os desafios do pioneirismo. In: BENJAMIN, Daniela Arruda. (Org.). O Sistema de Solução de Controvérsias da OMC: uma perspectiva brasileira. Brasília : FUNAG, 2013, p. 629-648. p. 639.

935 SCHMIDT, Luiz Fellipe Flores. A construção da retaliação brasileira no caso algodão: os desafios do pioneirismo. In: BENJAMIN, Daniela Arruda. (Org.). O Sistema de Solução de Controvérsias da OMC: uma perspectiva brasileira. Brasília : FUNAG, 2013, p. 629-648. p. 640. 
Cerca de 4 meses após a abertura para consultas, a Resolução 15/2010 da CAMEX foi publicada, adotando a lista final de mercadorias objeto de suspensão de concessões assumidas pelo Brasil em relação aos EUA, contendo 102 itens tarifários. Segundo estabelecia, o aumento das alíquotas do Imposto de Importação teria vigência de um ano, e entraria em vigor em 30 dias de sua publicação. ${ }^{936} 937$

Entabulada a retaliação como prevista na Resolução 15/2010, atingindo o nível de "gatilho" estipulado pela decisão do OSC, passaria a ser possível a retaliação cruzada, sob direitos de propriedade intelectual relativos ao TRIPS. Contudo, essa questão oferece dificuldades adicionais, uma vez que os direitos de propriedade intelectual estão protegidos por meio de legislação interna, relacionando-se aos standards mínimos exigidos pelo TRIPS, mas possuindo efeitos independentes. ${ }^{938}$

Objetivando legitimar a medida, perante o ordenamento jurídico brasileiro, foi editada a Medida Provisória 482/10, posteriormente convertida na Lei 12270/10. ${ }^{939}$ A redação da medida foi desenhada por subgrupo dentro do Grupo Interministerial de Propriedade Intelectual (GIPI), aprovada em reunião do Conselho de Ministros da CAMEX, e submetida ao Presidente na forma de projeto de medida provisória elaborada

936 CAMEX. Resolução no 15, de 5 mar. de 2010. Publicação no Diário Oficial da União: 8 mar. 2010. "Adota a lista de mercadorias objeto de suspensão de concessões assumidas pelo Brasil em razão do Acordo Geral de Tarifas e Comércio de 1994, em relação aos Estados Unidos da América e fixa as alíquotas do Imposto de Importação, com vigência de 365 dias, para as mercadorias referidas no art. $1^{\circ}$, quando originárias dos Estados Unidos da América, conforme Anexo a esta Resolução."

937 Em função das negociações com os EUA reiniciadas logo em seguida, o prazo para início da vigência da Resolução foi adiado, inicialmente para 22 de abril de 2010 (Redação dada pela Resolução CAMEX 19, de 05/04/2010), e em seguida para 21 de junho de 2010 (Redação dada pela Resolução CAMEX

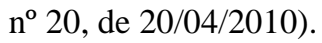

938 A exposição de motivos da Medida Provisória explicita algumas dessas dificuldades de compatibilização normativa, conferindo-lhes o caráter de justificativa para a edição da MP e da lei posteriormente: “[...] Para que seja legalmente possível aplicar retaliação em propriedade intelectual mediante suspensão, de forma discriminatória, de nossas obrigações internacionais na área, julga-se imprescindível a criação de nova norma específica. Isto porque, no ordenamento jurídico brasileiro, a propriedade intelectual encontra-se na esfera dos direitos de caráter privado e está consagrada em leis ordinárias específicas, conforme a área. Desse modo, a despeito de estarem plasmados no ordenamento jurídico internacional, os direitos de propriedade intelectual, enquanto direitos patrimoniais, estão alicerçados em dispositivos legais internos que protegem, em termos gerais, a propriedade e o direito adquirido. [...] 11. A proposta é urgente e relevante, uma vez que estão em pleno andamento as discussões sobre a melhor forma de dar rápida efetividade às medidas de retaliação autorizadas. Recorde-se, a propósito, que eventual retaliação em propriedade intelectual somente pode ser levada a cabo com adequada segurança jurídica se amparada pela correspondente previsão legal." Exposição de Motivos Interministerial- EMI $\mathrm{n}^{\circ}$ 00450, MRE/MF/MDIC. Brasília, 03 de dezembro de 2009. Disponível em <http://www.planalto.gov.br/ccivil_03/_Ato2007-2010/2009/Exm/EMI-450-MRE-MF-MDIC-09-Mpv-48210.htm>.

939 Medida Provisória 482, de 10/2/2010, convertida na Lei no 12270/10, de 24/7/2010. Disponível em < http://www.planalto.gov.br/ccivil_03/_Ato2007-2010/2010/Lei/L12270.htm>. 
pelo MRE, MF e MDIC. ${ }^{940}$

De fato, são inegáveis diversas dificuldades na operacionalização das medidas de retaliação pelo Brasil, pois as medidas de retaliação precisariam ser dotadas de mensurabilidade e reversibilidade. ${ }^{941}$ Ademais, como se mencionou, dificuldades adicionais são causadas exatamente pelas disposições constitucionais e legais existentes acerca dos direitos de propriedade intelectual e sua natureza jurídica. ${ }^{942}$

No intuito similar de ampliar a transparência e participação dos setores interessados, a Resolução 16/2010 da CAMEX foi editada, ${ }^{943}$ visando a realização de consulta pública sobre a aplicação de suspensão de direitos de propriedade intelectual. A Resolução previa a aplicação de 21 medidas distintas, que podem ser agrupadas entre: (a) medidas de subtração do prazo de proteção de diferentes modalidades de direitos de propriedade intelectual (medidas 1 a 5); (b) licenciamento compulsório (medidas 6 a 10); suspensão de direito exclusivo do titular de impedir a importação e comercialização no mercado interno (medidas 11 a 13); (c) majoração sobre os valores devidos para registros (medidas 14 a 16); (d) aplicação de direitos de natureza comercial sob a remuneração oriunda de direitos de propriedade intelectual (medidas 17 a 20); e (e) criação de obrigatoriedade de registro para obtenção e manutenção de direitos patrimoniais de autor e conexos (medida 21).

Segundo narra o diplomata envolvido, a consulta também resultou em participação significativa da sociedade, embora numericamente de modo inferior à consulta anterior, resultado já esperado, uma vez que a lista da retaliação em bens continha diversos itens,

940 Exposição de Motivos Interministerial- EMI no 00450, MRE/MF/MDIC. Brasília, 03 de dezembro de 2009. Disponível em <http://www.planalto.gov.br/ccivil_03/_Ato2007-2010/2009/Exm/EMI-450-MRE-MFMDIC-09-Mpv-482-10.htm>.

941 SCHMIDT, Luiz Fellipe Flores. A construção da retaliação brasileira no caso algodão: os desafios do pioneirismo. In: BENJAMIN, Daniela Arruda. (Org). O Sistema de Solução de Controvérsias da OMC: uma perspectiva brasileira. Brasília : FUNAG, 2013, p. 629-648. p. 641.

942 "[...] Muitas das boas ideias trazidas esbarraram em obstáculos jurídicos intransponíveis, ou seriam de execução muito difícil, especialmente no curto prazo. Nenhuma das iniciativas concernentes ao setor de serviços, por exemplo, logrou maturar a tempo de ser incluída no pacote levado a consulta pública. [...]” . SCHMIDT, Luiz Fellipe Flores. A construção da retaliação brasileira no caso algodão: os desafios do pioneirismo. In: BENJAMIN, Daniela Arruda. (Org.). O Sistema de Solução de Controvérsias da OMC: uma perspectiva brasileira. Brasília : FUNAG, 2013, p. 629-648. p. 641.

943 CAMEX. Resolução no 16, de 12 mar. de 2010. Publicação no Diário Oficial da União: 15 mar. 2010. "Instaura, nos termos da Medida Provisória $n^{\circ} 482$, de 10 de fevereiro de 2010, o procedimento de consulta pública sobre as medidas de suspensão de concessões ou obrigações do País relativas aos direitos de propriedade intelectual e outros, em relação aos Estados Unidos da América, em decorrência do não cumprimento das decisões e recomendações adotadas pelo Órgão de Solução de Controvérsias da OMC, no contexto do contencioso "Estados Unidos da América - Subsídios ao Algodão" (WT/DS 267).” 
dizendo respeito a interesses diretos de múltiplos grupos. ${ }^{944}$

A essa altura, os EUA estavam em negociações com o governo brasileiro, para tentar impedir a concretização da retaliação como já se desenhava. É preciso lembrar que o intuito do mecanismo de retaliação é gerar consequências indesejadas a grupos econômicos do Estado que esteja em descumprimento, o que resultaria em uma pressão política interna, que levaria ao potencial de mudança no posicionamento desse membro.

Assim, o interesse de negociar uma solução para a decisão do OSC não cumprida pelos EUA ia ao encontro do objetivo brasileiro com a medida. Nesse sentido, foram alcançados acordos provisórios bilaterais, que previam a realização de pagamentos do governo norte-americano ao Instituto Brasileiro do Algodão (IBA), até que fosse promulgada nova legislação agrícola. A celebração de tais acordos levou à suspensão dos procedimentos de retaliação, o que ocorreu por meio da Resolução 43/2010. ${ }^{945}$

Desde setembro de 2013, contudo, os EUA suspenderam injustificadamente estes pagamentos, ${ }^{946}$ o que levou a CAMEX a retomar os procedimentos com vistas à retaliação, por meio da Resolução 105/2013, de 18 de dezembro de 2013. ${ }^{947}$

944 "Recebeu-se da sociedade 119 manifestações no âmbito da consulta pública. O número foi bem inferior ao da consulta em bens, crê-se, pelo fato de as medidas atingirem número potencialmente menor de setores, estes também organizados em um menor número de entidades." . SCHMIDT, Luiz Fellipe Flores. A construção da retaliação brasileira no caso algodão: os desafios do pioneirismo. In: BENJAMIN, Daniela Arruda. (Org.). O Sistema de Solução de Controvérsias da OMC: uma perspectiva brasileira. Brasília : FUNAG, 2013, p. 629-648. p. 643.

945 CAMEX. Resolução no 43, de 17 jun. de 2010. Publicação no Diário Oficial da União: 18 jun. 2010. "Suspender a Resolução $n^{\circ} 15$, de 5 de março de 2010, que contempla a lista de mercadorias objeto de suspensão de concessões assumidas pelo Brasil em razão do Acordo Geral de Tarifas e Comércio de 1994 em relação aos EUA, no valor de US\$ 591 milhões autorizado pela Organização Mundial do Comércio $(O M C)$ e Suspende o procedimento iniciado pela Resolução $n^{\circ} 16$, de 12 de março de 2010, para a suspensão de concessões ou outras obrigações do país relativas aos direitos de propriedade intelectual e outros em relação aos Estados Unidos da América, no valor de US\$ 238 milhões autorizado pela Organização Mundial do Comércio".

946 Segundo relatório do Congresso Norte-americano, a suspensão se deu em razão de questionamentos no âmbito interno sobre a conveniência destes pagamentos. "Although the Framework Agreement and its monthly payments succeeded in avoiding, at least temporarily, the imposition of harmful trade countermeasures, the U.S. proposal was met with both praise and criticism. [...] During 2011, several amendments were introduced in the House that would have eliminated or banned the payments to Brazil; however, none of these amendments was enacted. In September 2013, USDA-claiming the effects of the federal budget sequestration process were at play-reduced the payment to Brazil by an amount equal to $5 \%$ of the annual total (\$7.35 million), leaving a payment of just $\$ 4.9$ million. In October, USDA completely stopped the payments." SCHNEPF, Randy. Status of the WTO Brazil-U.S. Cotton Case. Washington, DC: Congressional Research Service, dez. 2013. Disponível em: < http://fas.org/sgp/crs/row/R43336.pdf> Acesso em: 10 mar. 2014. p. 7.

947 CAMEX. Resolução no 105, de 18 dez. de 2013. Publicação no Diário Oficial da União: 19 dez. 2010. "Aprova a retomada dos procedimentos com vistas à suspensão de concessões ou obrigações assumidas pelo País no âmbito do Acordo Geral de Tarifas e Comércio de 1994 e dos direitos de propriedade intelectual e outros, contra os Estados Unidos da América, no contexto do Contencioso "Estados Unidos da América - Subsídios ao Algodão" (WT/DS 267), revoga o art. $2^{\circ}$ da Resolução CAMEX 
Adicionalmente, em reunião de 19 de fevereiro de 2014, a CAMEX autorizou o MRE a instaurar painel de acompanhamento da implementação perante a $\mathrm{OMC}$, vez que na nova legislação agrícola promulgada em 07 de fevereiro persistiriam elementos de distorção relativos ao algodão. ${ }^{948}$

Do procedimento construído para a aplicação da medida retaliatória, abstraímos alguns mecanismos que podem ser utilizados na implementação de decisões do Sistema de Solução de Controvérsias, quais sejam: (i) a "institucionalização" da tomada de decisão; (ii) a transparência em relação aos passos e as escolhas de implementação; (iii) a oportunidade de participação dos diferentes grupos econômicos e da sociedade civil organizada, por meio de consultas públicas; (iv) a elaboração de marcos normativos gerais, ${ }^{949}$ que permitam uma previsibilidade e segurança jurídica, bem como um eventual controle de legalidade e de constitucionalidade.

Esses mesmos mecanismos podem e devem ser expandidos para a implementação das decisão do Sistema de Solução de Controvérsias da OMC pelo Brasil, garantindo que o preenchimento do espaço de discricionariedade na escolha dos meios para o cumprimento ocorra tendo em conta os diferentes interesses presentes na sociedade brasileira. Assim é que propõe-se, no subtópico 5.6, a instituição de um marco normativo geral para guiar o procedimento interno de implementação das decisões desse Sistema de Solução de Controvérsias.

\subsection{A Relação entre as Instituições Nacionais}

$n^{\circ} 43$, de 17 de junho de 2010, e altera o art. $3^{\circ}$ da Resolução CAMEX $n^{\circ} 16$, de 12 de março de 2010." 948 Notícia de 19 fev. 2014. Camex autoriza abertura de painel na OMC sobre legislação agrícola norteamericana. Disponível em: <http://www.camex.gov.br/noticias/ler/item/409>. Acesso em: 30 abr. 2014.

949 Observa-se que a Lei n 12.270, de 2010, originada da MP 482/2009, estabelece um marco normativo geral para a aplicação de retaliação em direitos de propriedade intelectual, sendo aplicável a casos futuros, e não apenas à retaliação no caso do algodão. Cf: "6. A despeito da presente autorização de retaliação relacionar-se com a disputa envolvendo os subsídios norte-americanos ao algodão, o presente Projeto não se restringe a amparar as ações do Governo brasileiro no caso em questão. A proposta foi elaborada para atender, mediante previsões amplas, quaisquer situações futuras de retaliação em propriedade intelectual." Exposição de Motivos Interministerial- EMI nº 00450, MRE/MF/MDIC. Brasília, 03 de dezembro de 2009. Disponível em <http://www.planalto.gov.br/ccivil_03/_Ato2007-2010/2009/Exm/EMI-450-MRE-MFMDIC-09-Mpv-482-10.htm>. 
Da Constituição Federal de 1988, abstraímos o compromisso do Brasil com a solução pacífica de controvérsias, que consta do preâmbulo constitucional, ${ }^{950}$ bem como dos princípios que regem o país em suas relações internacionais. ${ }^{951}$ Contudo, como já reiterado, a CF/88 é silente em relação ao status dos tratados internacionais - dentre eles os Acordos da OMC, bem como em relação ao procedimento para implementar as decisões adjudicatórias internacionais - dentre elas as oriundas do Sistema de Solução de Controvérsias da OMC.

No tocante à distribuição de competências, há menção à competência para celebrar 952 e aprovar ${ }^{953}$ os acordos ou atos internacionais, sem qualquer referência expressa à competência para implementar as decisões oriundas dos órgãos adjudicatórios originados por esses acordos internacionais. A Constituição confere, contudo, ao Poder Executivo, na figura do Presidente, auxiliado pelos Ministros de Estado, ${ }^{954}$ a responsabilidade da manutenção das relações internacionais e diplomáticas, 955 competência "naturalmente" exercida pelo Poder Executivo, face do Estado que se personifica na esfera internacional.

Embora não haja competência definida de forma específica para tal, tendo em vista a natureza notadamente comercial das obrigações internacionais entabuladas na maior parte dos Acordos da OMC, dois ministérios se destacam na condução das relações sob o marco do sistema multilateral de comércio: o Ministério das Relações Exteriores (MRE) e

950 BRASIL. Constituição da República Federativa do Brasil de 1988. Preâmbulo. "Nós, representantes do povo brasileiro, reunidos em Assembleia Nacional Constituinte para instituir um Estado Democrático, destinado a assegurar o exercício dos direitos sociais e individuais, a liberdade, a segurança, o bem-estar, o desenvolvimento, a igualdade e a justiça como valores supremos de uma sociedade fraterna, pluralista e sem preconceitos, fundada na harmonia social e comprometida, na ordem interna e internacional, com a solução pacífica das controvérsias, promulgamos, sob a proteção de Deus, a seguinte Constituição da República Federativa do Brasil."

951 BRASIL. Constituição da República Federativa do Brasil de 1988. "Art. $4^{\circ}$ A República Federativa do Brasil rege-se nas suas relações internacionais pelos seguintes princípios: I - independência nacional; II - prevalência dos direitos humanos; III - autodeterminação dos povos; IV - não-intervenção; $V$ - igualdade entre os Estados; VI - defesa da paz; VII - solução pacífica dos conflitos; VIII - repúdio ao terrorismo e ao racismo; $I X$ - cooperação entre os povos para o progresso da humanidade; $X$ - concessão de asilo político." 952 BRASIL. Constituição da República Federativa do Brasil de 1988. Art. 84. "Compete privativamente ao Presidente da República: [...] VIII - celebrar tratados, convenções e atos internacionais, sujeitos a referendo do Congresso Nacional."

953 BRASIL. Constituição da República Federativa do Brasil de 1988. Art. 49. "É da competência exclusiva do Congresso Nacional: I - resolver definitivamente sobre tratados, acordos ou atos internacionais que acarretem encargos ou compromissos gravosos ao patrimônio nacional [...].”

954 BRASIL. Constituição da República Federativa do Brasil de 1988. Art. 76. “O Poder Executivo é exercido pelo Presidente da República, auxiliado pelos Ministros de Estado.",

955 BRASIL. Constituição da República Federativa do Brasil de 1988. Art. 84. "Compete privativamente ao Presidente da República: [...] VIII - celebrar tratados, convenções e atos internacionais, sujeitos a referendo do Congresso Nacional." 
o Ministério do Desenvolvimento, Indústria e Comércio Exterior (MDIC). No interior destes ministérios, se destacam, respectivamente, duas instituições: a Coordenação Geral de Contenciosos (CGC) e a Câmara de Comércio Exterior (CAMEX).

O MRE, cuja regulamentação mais recente se dá no decreto $\mathrm{n}^{\circ} 7.304$, de 22 de setembro de 2010, é órgão da administração pública direta responsável pela: "I - política internacional; II - relações diplomáticas e serviços consulares; III - participação nas negociações comerciais, econômicas, técnicas e culturais com governos e entidades estrangeiras; IV - programas de cooperação internacional e de promoção comercial; e V apoio a delegações, comitivas e representações brasileiras em agências e organismos internacionais e multilaterais." ${ }^{956}$ Seu regimento interno, criado pela portaria do Ministro das Relações Exteriores No 212, de 30 de Abril de 2008, enumera com mais detalhes os deveres incumbidos ao Ministério. ${ }^{957}$

A Coordenação-Geral de Contenciosos, por sua vez, foi criada pelo decreto $n^{\circ}$ 3.959, de 10 de outubro de 2001, passando a fazer parte da estrutura do MRE. Compete à CGC, como consta do regimento interno do MRE: (i) a coordenação da participação brasileira - como demandante, demandado e terceira-parte - nas múltiplas etapas dos contenciosos no Sistema de Solução de Controvérsias da OMC; (ii) a elaboração ou supervisão da redação dos documentos a serem apresentados; (iii) a definição do conteúdo e de estratégias da argumentação a ser apresentada nas audiências dos contenciosos da OMC, em reuniões prévias; (iv) o recebimento de reclamações do setor privado e a análise de viabilidade de transformá-las em contenciosos; e (v) a coordenação da participação em negociações das normas relacionadas à solução dos litígios econômicos internacionais. ${ }^{958}$

956 Art. $1^{\circ}$, Decreto $\mathrm{n}^{\mathrm{o}} 7.304$, de 22 de setembro de 2010.

957 “Art. $4^{\circ}$ O MRE é o órgão federal encarregado de coordenar, na Administração Pública, os assuntos concernentes às relações externas do País. Parágrafo único. Para assegurar a coerência e a unidade da representação e da defesa dos interesses do Brasil no exterior, deve o MRE: a) participar da formulação de diretrizes e programas setoriais com relevância para a política exterior do pais; b) coordenar os entendimentos de caráter ou nível técnico, entre órgãos e entes públicos brasileiros e agências de Governos estrangeiros, ou de organismos internacionais, especialmente nas áreas comercial, econômica, financeira, científica, técnica e cultural; c) participar da promoção, da execução e do acompanhamento de programas que se realizem no Brasil, com a cooperação de Governos estrangeiros ou de organismos internacionais; d) promover a instituição de comissões e grupos de trabalho interministeriais de natureza executiva ou consultiva; e e) exercitar outros poderes funcionais que lhe sejam, a propósito, deferidos."

958 "Art. 110. Compete à Coordenação-Geral de Contenciosos (CGC): I-coordenar a atuação do Brasil em todas as etapas dos contenciosos comerciais em que o País seja parte ou terceira parte interessada, no âmbito do Mecanismo sobre Solução de Controvérsias (MSC) da Organização Mundial de Comércio (OMC); II - receber reclamações do setor privado sobre barreiras comerciais e coordenar a avaliação da possibilidade de seu questionamento no âmbito do MSC da OMC; III - coordenar, em contato com outros órgãos do Governo brasileiro e setor privado envolvidos, a preparação da participação 
A criação desse órgão na estrutura interna do MRE foi parte de uma estratégia mais ampla de otimizar a participação brasileira no Sistema de Solução de Controvérsias, e tem sido apontada como um dos aspectos institucionais que contribuíram para um diagnóstico de sucesso da atuação nacional neste mecanismo. ${ }^{959}$ Embora se possa apreender que a implementação das decisões do Sistema de Solução de Controvérsias da OMC incumbe a este órgão, sob a perspectiva de que lhe compete "coordenar a atuação do Brasil em todas as etapas dos contenciosos comerciais que o País seja parte ou terceira parte interessada", destaca-se que não há previsão expressa de competências específicas sobre a fase de implementação.

A esse respeito, reflete-se que a fase de implementação, contudo, é etapa do procedimento notadamente distinta das demais fases da solução de controvérsias, uma vez que envolve atos de direito interno, tratando-se, sob esta perspectiva, de atividade da administração pública, o que adiciona complexidade à definição precisa de suas competências, parâmetros e limites, ao retirar-lhe o escopo de negociação internacional.

Outro Ministério que se destaca na implementação das decisões do Sistema de Solução de Controvérsias é o Ministério do Desenvolvimento, Indústria e Comércio Exterior, cuja regulamentação mais recente se dá no decreto n. 7.096, de 4 de fevereiro de 2010, e tem como competência assuntos diversos, afeitos à aplicação dos Acordos da OMC. Compete-lhe, pois: (i) definir e desenvolver a política industrial, comercial e de serviços; (ii) definir políticas de comércio exterior; (iii) coordenar as áreas de propriedade intelectual, metrologia e normalização; (iv) regulamentar e executar os programas e atividades relativas ao comércio exterior; (v) aplicar os mecanismos de defesa comercial; e

\footnotetext{
brasileira no processo de consultas; IV - elaborar ou supervisionar a redação dos documentos a serem apresentados ao longo dos contenciosos comerciais; $V$ - coordenar reuniões preparatórias às reuniões de consultas e às audiências de painéis e do Órgão de Apelação, com o intuito de definir conteúdo e estratégia de apresentação da argumentação brasileira; VI - expor e defender a argumentação brasileira nas reuniões acima mencionadas; VII - quando de interesse para o Brasil, acompanhar a evolução dos contenciosos comerciais de terceiros países e de negociações relativas à solução de controvérsias em foros econômicos internacionais; e VIII - coordenar a participação brasileira nas negociações de normas relativas a solução de controvérsias em foros econômicos internacionais, em especial no âmbito da OMC. Parágrafo único. No exercício de suas atribuições, a Coordenação-Geral de Contenciosos manterá coordenação com as demais áreas pertinentes do MRE, realizando consultas a outras Divisões, sobretudo as Divisões subordinadas ao Departamento Econômico, e delas receberá subsídios. " Portaria do Ministro das Relações Exteriores No 212, de 30 de Abril de 2008.

959 SHAFFER, Gregory; RATTON SANCHEZ, Michelle; ROSENBERG, Barbara. The Trials of Winning at the WTO: What Lies Behind Brazil's Success. Cornell International Law Journal, vol. 41, issue 2, p. 383-501, 2008.
} 
(vii) participar de negociações internacionais relacionadas ao comércio exterior. ${ }^{960}$

Por sua relevância na implementação de obrigações do sistema multilateral de comércio, abordaremos em breve a evolução institucional da CAMEX. Na realidade, é preciso dar um passo anterior, e comentar sucintamente sobre a evolução das estruturas administrativas ligadas à formulação da política comercial brasileira nas últimas décadas. 961

Antes da abertura econômica do país, o órgão responsável pela política comercial era a Carteira de Comércio Exterior do Banco do Brasil (CACEX), incumbida da proteção da indústria nacional, como parte da estratégia de industrialização por substituição de importações. A CACEX foi criada pela lei n. 2.145 de 29 de dezembro de 1953, ${ }^{962}$ tendo sofrido expansão substancial em suas competências, com a criação do Conselho Nacional de Comércio Exterior (CONCEX). ${ }^{963}$ A CACEX passou, então, a atuar como secretaria do

960 Anexo 1: Estrutura Regimental do MDIC. “Art. 10 O Ministério do Desenvolvimento, Indústria e Comércio Exterior, órgão da administração direta, tem como área de competência os seguintes assuntos: I política de desenvolvimento da indústria, do comércio e dos serviços; II - propriedade intelectual e transferência de tecnologia; III - metrologia, normalização e qualidade industrial; IV - políticas de comércio exterior; $V$ - regulamentação e execução dos programas e atividades relativas ao comércio exterior; VI aplicação dos mecanismos de defesa comercial; VII - participação em negociações internacionais relativas ao comércio exterior." Decreto n. 7.096, de 4 de fevereiro de 2010.

961 Assim explicita o autor: "O diagnóstico diante do qual esta pesquisa toma corpo é a constatação de que a política comercial brasileira e o arcabouço institucional em que é coordenada e formulada passaram por importantes transformações a partir da abertura econômica. Suas estruturas administrativas foram completamente remodeladas, sem que se alcançasse um modelo capaz de coordenar de maneira ótima as diversas atividades multidisciplinares que compõe o comércio exterior atual. [...]" FERNANDES, Ivan Filipe de Almeida Lopes. Burocracia e Política: a construção institucional da política comercial brasileira pós - abertura econômica. 2010. 172 p. Dissertação (Mestrado em Ciência Política) - Faculdade de Filosofia, Letras e Ciências Humanas, Universidade de São Paulo, São Paulo. p. 54.

962 Sua competência estava originariamente definida pelo artigo $2^{\circ}$ da Lei: "Art $2^{\circ}$ Compete à Carteira de Comércio Exterior, observadas as decisões e normas que forem estabelecidas pelo Conselho da Superintendência da Moeda e do Crédito: I - emitir licenças de exportação e de importação, aos que o requererem e provarem dispor da cobertura cambial prevista no art. $6^{\circ}$, $\$ \S 1^{\circ}$ e $2^{\circ}$ desta lei ou dela independerem na conformidade de normas previamente estabelecidas; II - exercer a fiscalização de preços, pesos, medidas, classificações e tipos declarados nas operações de exportação e importação, com o fim de evitar fraudes cambiais; III - classificar, ouvida a Comissão Consultiva do Intercâmbio Comercial com o Exterior e dependente de aprovação do Conselho da Superintendência da Moeda e do Crédito, as mercadorias, e produtos de importação, de acordo com a sua natureza e grau de essencialidade, fixando as categorias de sua distribuição para efeito da compra do câmbio; IV - financiar, em casos especiais, e mediante critério que será fixado depois de ouvida a Comissão Consultiva do Intercâmbio Comercial com o Exterior, a exportação e a importação de bens de produção e consumo de alta essencialidade."

963 Lei n. 5.025, de 10 de junho de 1966. Alterou o art. 2o da lei 2145, dando-lhe nova redação: "Art. $2^{\circ}$ Nos termos dos artigos 19 e 59, da Lei $n^{\circ}$ 4.595, de 31 de dezembro de 1964, compete ao Banco da Brasil S.A., através da sua Carteira de Comércio Exterior, observadas as decisões, normas e critérios estabelecidos pelo Conselho Nacional do Comércio Exterior: I - Emitir licenças de exportação e importação, cuja exigência será limitada aos casos impostos pelo interesse nacional. II - Exercer, prévia ou posteriormente a fiscalização de preços, pesos, medidas, classificação, qualidades e tipos, declarados nas operações de exportação, diretamente ou em colaboração com quaisquer outros órgãos governamentais. III - Exercer, prévia ou posteriormente, a fiscalização de preços, pesos, medidas, qualidades e tipos nas operações de importação, respeitadas as atribuições e competência das repartições aduaneiras. IV - Financiar a 
órgão colegiado criado, em função proeminente de executora das políticas comerciais do país, e em exercício de poder normativo e de gestão dos instrumentos de controle e promoção do comércio exterior. ${ }^{964}$ Embora a formulação da política comercial estivesse formalmente a cargo do CONCEX, a prática conferia à CACEX poderes de facto na formulação e execução dessa. ${ }^{965}$

Durante o governo Collor, em um contexto de transição do modelo de participação do país no comércio internacional, a CACEX foi extinta, momento no qual houve um "hiato institucional" até a criação da CAMEX, no governo Fernando Henrique Cardoso. ${ }^{966}$ ${ }^{967}$ No intuito de organizar e centralizar institucionalmente as competências de formulação e controle da política de comércio exterior, a CAMEX foi criada por meio do decreto $\mathrm{n}^{\circ}$ 1.386, de 06 de fevereiro de 1995, com a missão de "formular as políticas e coordenar as atividades relativas ao comércio exterior de bens e serviços". 968

exportação e a produção para exportação de produtos industriais, bem como, quando necessário, adquirir ou financiar, por ordem e conta do Tesouro Nacional, estoques de outros produtos exportáveis. $V$ - Adquirir ou financiar, por ordem e conta do Tesouro Nacional, produtos de importação necessários ao abastecimento do mercado interno, ao equilíbrio dos preços e à formação de estoques reguladores, sempre que o comércio importador não tenha condições de fazê-lo de forma satisfatória. VI - Colaborar, com o órgão competente, na aplicação do regime da similariedade e do mecanismo de draw-back." VII - Elaborar, em cooperação com os órgãos do Ministério da Fazenda, as estatísticas do comércio exterior. VIII - Executar quaisquer outras medidas relacionadas com o comércio exterior que lhe forem atribuidas. [...]"

964 "Por seu turno, sendo o Concex um órgão colegiado, à Cacex foi designada a obrigação de prover os serviços de secretaria-geral deste conselho aos dispor das melhores condições técnicas para o desempenho da função viesse a ser a agência preponderante em matéria de comércio exterior dentro da administração pública federal. A Cacex deixou de ser meramente operacional e passou a ter ingerência em todos os assuntos de comércio exterior.". FERNANDES, Ivan Filipe de Almeida Lopes. Burocracia e Política: a construção institucional da política comercial brasileira pós - abertura económica. 2010.172 p. Dissertação (Mestrado em Ciência Política) - Faculdade de Filosofia, Letras e Ciências Humanas, Universidade de São Paulo, São Paulo. p. 55.

965 "A Carteira devia aquiescência ao Conselho de Comércio Exterior (Concex), instância interministerial responsável por formular a política de comércio exterior, bem como determinar, orientar e coordenar a execução das medidas necessárias à expansão das transações comerciais com o exterior." Na prática, porém, e como se verá no decorrer desta dissertação, prevaleceu a atuação da Cacex, inclusive na elaboração, formulação e execução dessa política, influenciando decisivamente, assim, no mandato legal do Concex." RAMOS, Guilherme Cantarino da Costa Ramos. Comércio Internacional, Política Comercial Brasileira e a Atuação da Câmara da Comércio Exterior (CAMEX) na Condução das Políticas para o Setor. 2008. 312 p. Dissertação (Mestrado em Administração) - Escola Brasileira de Administração Pública e de Empresas, Fundação Getúlio Vargas, Rio de Janeiro. p. 16.

966 RAMOS, Guilherme Cantarino da Costa Ramos. Comércio Internacional, Política Comercial Brasileira e a Atuação da Câmara da Comércio Exterior (CAMEX) na Condução das Políticas para o Setor. 2008. 312 p. Dissertação (Mestrado em Administração) - Escola Brasileira de Administração Pública e de Empresas, Fundação Getúlio Vargas, Rio de Janeiro. p. 17.

967 FERNANDES, Ivan Filipe de Almeida Lopes. Burocracia e Política: a construção institucional da política comercial brasileira pós - abertura económica. 2010. 172 p. Dissertação (Mestrado em Ciência Política) - Faculdade de Filosofia, Letras e Ciências Humanas, Universidade de São Paulo, São Paulo. p. 61. 968 Decreto $\mathrm{n}^{\circ} 1.386$, de 06 de fevereiro de 1995. "Art. $1^{\circ}$ É criada a Câmara de Comércio Exterior, do Conselho de governo, com o objetivo de formular as politicas e coordenar as atividades relativas ao comércio exterior de bens e serviços e, especialmente: I - definir as diretrizes da política de comércio exterior; II - manifestar-se previamente sobre as normas e legislação sobre o comércio exterior e temas 
Configurada inicialmente como órgão do Conselho de Governo ligado à Presidência da República, o desenho original da CAMEX foi alterado ao longo dos anos. 969 Ao longo das quase duas décadas desde a sua criação, diversas reformas em suas competências, formulação, poderes e estrutura tenderam alternadamente a enfraquecer ou a fortalecer a CAMEX como instituição incumbida da formulação e/ou execução de políticas comerciais. Uma das alterações mais significativas - apontada por diversos autores como fonte de fragilidade estrutural - ocorreu quando, meses após a criação do MDIC, a CAMEX foi vinculada institucionalmente a esse Ministério. ${ }^{970}$

O deslocamento deste órgão da Casa Civil para um dos Ministérios envolvidos nos processos decisórios de política comercial teria tornado a CAMEX uma instituição "ambígua", tendo em vista que a sua função formal de articulação supraministerial se enfraqueceria ao estar vinculada organicamente a um dos sujeitos que deveria estar submetidos à sua coordenação. 971972973

correlatos; III - dispor sobre as diretrizes para as alterações das alíquotas dos impostos e de exportação; IV - estabelecer as diretrizes para as investigações relativas a práticas desleais de comércio exterior; $V$ - fixar as diretrizes para a política de financiamento e de seguro de crédito às exportações; VI - estabelecer as diretrizes para a política de desregulamentação do comércio exterior; VII - avaliar o impacto das medidas cambiais, monetárias e fiscais sobre o comércio exterior; VIII - formular a política sobre a concessão de áreas de livre comércio, zonas francas e zonas de processamento de exportações; IX - fixar as diretrizes para a promoção de bens e serviços brasileiros no exterior; $X$ - indicar os parâmetros para as negociações bilaterais e multilaterais relativas ao comércio exterior."

969 Para uma visão detalhada destas reformas, e de suas consequências, Cf: FERNANDES, Ivan Filipe de Almeida Lopes. Burocracia e Política: a construção institucional da política comercial brasileira pós abertura económica. 2010. 172 p. Dissertação (Mestrado em Ciência Política) - Faculdade de Filosofia, Letras e Ciências Humanas, Universidade de São Paulo, São Paulo. p. 77-146.

970 Observe-se que os autores se referem à "subordinação" orgânica ou institucional da CAMEX tendo em vista que (a) a Secretaria da CAMEX está ligada ao MDIC e (b) o Presidente da CAMEX é o Ministro do Desenvolvimento, Indústria e Comércio. Há quem se refira, contudo, à CAMEX como um órgão híbrido, uma vez que o Conselho de Ministros continuaria vinculado à Presidência, e a Secretaria Executiva estaria vinculada ao MDIC. De todo modo, mesmo os autores que reconhecem essa natureza híbrida não se furtam de caracterizá-la como uma fragilidade. A esse respeito, confira-se a reflexão de Regis Bonelli: " [...] $a$ Camex, que é o órgão principal da política de comércio exterior, é simultaneamente um conselho colegiado de ministros de Estado e secretaria do MDIC (ou, ao menos, sua secretaria executiva encontra-se no novo ministério). Essa indefinição institucional - em que um organismo, para ter força decisória, necessita ter ministros de Estado em sua composição mas, para ser operacional, precisa situar-se no âmbito de um determinado ministério (o MDIC) - pode estar inibindo a adoção de medidas mais decididas na esfera das políticas de competitividade.” BONELLI, Regis. Políticas de competitividade industrial no Brasil 1995/2000. Texto para discussão IPEA, n. 810. Rio de Janeiro: IPEA, jul. 2001. Também nesse sentido, Cf: RAMOS, Guilherme Cantarino da Costa Ramos. Comércio Internacional, Política Comercial Brasileira e a Atuação da Câmara da Comércio Exterior (CAMEX) na Condução das Políticas para o Setor. 2008. 312 p. Dissertação (Mestrado em Administração) - Escola Brasileira de Administração Pública e de Empresas, Fundação Getúlio Vargas, Rio de Janeiro.

971 "Em 1998, o ministro do Desenvolvimento passou a ser o presidente da Camex, e o MDIC tornou-se responsável pela secretaria executiva do órgão, gerando uma ambigüidade institucional nítida, ou seja, a Camex é simultaneamente um conselho colegiado da ministros de Estado 'e um órgão cuja secretaria executiva encontra-se no organograma do ministério, subordinando-se, pois, ao MDIC'." VEIGA, Pedro da Motta. IGLESIAS, Roberto Magno. A institucionalidade da política brasileira de comércio exterior. In: 
A CAMEX, em sua atual configuração, aparece regulamentada pelo decreto $\mathrm{n}$. 4.732, de 10 de junho de 2003, ${ }^{974}$ sendo o órgão responsável pela “formulação, adoção, implementação e a coordenação de políticas e atividades relativas ao comércio exterior de bens e serviços", 975 devendo ser consultado previamente em atos que se relacionem ao comercio exterior, ainda que emanados de outros órgãos federais - em especial projetos de lei, decretos e portarias. ${ }^{976} \mathrm{O}$ decreto em questão é um pouco mais específico, ao estabelecer competências expressas ao órgão em dezenove incisos. ${ }^{977}$

CASTELAR, A.; MARKWALD, R. PEREIRA, L. V. (Org.). O desafio das exportações. Rio de Janeiro: BNDES, 2002, $\quad$ p. 51-96. Disponível em: < http://www.bndes.gov.br/SiteBNDES/export/sites/default/bndes_pt/Galerias/Arquivos/conhecimento/livro_de safio/Relatorio-03.pdf $>$. Acesso em: 30 abr. 2014. p. 61.

972 "Decorrente desta transferência, o status institucional da Camex ficou ambíguo, permanecendo nesta situação até hoje. Ao mesmo tempo em que é um órgão colegiado interministerial, sua secretariaexecutiva encontra-se no organograma de um ministério setorial [...] A transferência da Câmara para o MDIC fez com que ela se tornasse um dos instrumentos deste ministério no embate político burocrático, tornando a coordenação do comércio exterior ambígua. O foro de discussão interministerial transformava-se numa agência setorial e à disposição dos interesses perseguidos pelo MDIC." FERNANDES, Ivan Filipe de Almeida Lopes. Burocracia e Política: a construção institucional da política comercial brasileira pós abertura económica. 2010. 172 p. Dissertação (Mestrado em Ciência Política) - Faculdade de Filosofia, Letras e Ciências Humanas, Universidade de São Paulo, São Paulo. p. 86/88.

973 "Apesar de informada por um diagnóstico correto - o de que o gover- no deve explicitamente tratar da coordenação das ações públicas em uma área de politica que envolve diversos ministérios - a CAMEX enfrentou notórias dificuldades para desempenhar sua missão. De um lado, seu status institucional de Câmara da Presidência foi colocado em questão com sua transferência para o MDIC, o que restringe naturalmente seu poder de coordenação interministerial. [...] " VEIGA, Pedro da Motta. Política Comercial no Brasil: características, condicionantes domésticos e policy-making. In: ICONE, FIPE e DFID (Coord.). Instituto de Estudos do Comércio e Negociações Internacionais (ICONE), Fundação Instituto de Pesquisas Econômicas (FIPE) e Kingdon Department for International Development (DFID). Políticas comerciais comparadas: desempenho e modelos organizacionais. São Paulo: Singular, 2007, p. 71-162. Disponível em: $<$ http://www10.iadb.org/intal/intalcdi/PE/2009/03126.pdf >. Acesso em: 30 abr. 2014. p. 152.

974 A criação da CAMEX ocorreu com o Decreto $\mathrm{n}^{\circ} 1.386$, de 06 de fevereiro de 1995. Este foi revogado pelo Decreto $\mathrm{n}^{\mathrm{o}} 3.756$, de 21 de fevereiro de 2001, que por sua vez foi revogado pelo Decreto $\mathrm{n}^{\mathrm{o}}$ 3.981 , de 24 de outubro de 2001. Esse último decreto foi revogado pelo Decreto $\mathrm{n}^{\circ} 4.732$, de 10 de junho 2003, que estabelece a atual configuração da CAMEX, embora tenha sido modificado parcialmente pelos seguintes decretos: Decreto $\mathrm{n}^{\mathrm{o}} 4.857$, de 10 de outubro de 2003; Decreto ${ }^{\mathrm{o}} 4.993$, de 18 de fevereiro de 2004; Decreto $\mathrm{n}^{\circ} 5.398$, de 23 de março 2005; Decreto ${ }^{\circ} 5.453$, de 2 de junho de 2005; Decreto $\mathrm{n}^{\mathrm{o}}$ 6.229, de 9 de outubro de 2007; Decreto $\mathrm{n}^{\circ} 6.547$, de 25 de agosto de 2008 .

975 Art. $1^{\circ}$ Decreto $\mathrm{n}^{\circ} 4.732$, de 10 de junho de 2003.

976 Art. $1^{\circ}$ para. $1^{\circ}$ Decreto ${ }^{\circ} 4.732$, de 10 de junho de 2003.

977 Art. $1^{\circ}$ Decreto $\mathrm{n}^{\mathrm{o}} 4.732$, de 10 de junho de 2003. "Art. 20 Compete à CAMEX, dentre outros atos necessários à consecução dos objetivos da política de comércio exterior: I - definir diretrizes e procedimentos relativos à implementação da política de comércio exterior visando à inserção competitiva do Brasil na economia internacional; II - coordenar e orientar as ações dos órgãos que possuem competências na área de comércio exterior; III - definir, no âmbito das atividades de exportação e importação, diretrizes e orientações sobre normas e procedimentos, para os seguintes temas, observada a reserva legal: a) racionalização e simplificação do sistema administrativo; b) habilitação e credenciamento de empresas para a prática de comércio exterior; c) nomenclatura de mercadoria; d) conceituação de exportação e importação; e) classificação e padronização de produtos; f) marcação e rotulagem de mercadorias; e g) regras de origem e procedencia de mercadorias; IV- estabelecer as diretrizes para as negociações de acordos e convênios relativos ao comércio exterior, de natureza bilateral, regional ou multilateral; $V$ orientar a política aduaneira, observada a competência especifica do Ministério da Fazenda; VI - formular diretrizes básicas da política tarifária na importação e exportação; VII - estabelecer diretrizes e medidas dirigidas à simplificação e racionalização do comércio exterior; VIII - estabelecer diretrizes e procedimentos 
No que tange especificamente à tomada de decisões relacionadas à participação do Brasil no Sistema de Solução de controvérsias da OMC, a CAMEX é formalmente consultada pela CGC do MRE antes de tomar algum passo significativo neste sistema. ${ }^{978}$ No caso do algodão, como se verificou, o procedimento para aplicação do direito de retaliar pelo Brasil tem sido gerido por meio de um grupo técnico no âmbito da CAMEX.

Contudo, além das dificuldades da CAMEX para desempenhar suas funções, ${ }^{979}$ ou até mesmo em função dessas dificuldades, há a percepção - frequente nos estudos e manifestada nas entrevistas realizadas por estes pesquisadores com sujeitos diretamente

para investigações relativas a práticas desleais de comércio exterior; IX - fixar diretrizes para a política de financiamento das exportações de bens e de serviços, bem como para a cobertura dos riscos de operações a prazo, inclusive as relativas ao seguro de crédito às exportações; $X$ - fixar diretrizes e coordenar as politicas de promoção de mercadorias e de serviços no exterior e de informação comercial; XI - opinar sobre política de frete e transportes internacionais, portuários, aeroportuários e de fronteiras, visando à sua adaptação aos objetivos da política de comércio exterior e ao aprimoramento da concorrência; XII - orientar politicas de incentivo à melhoria dos serviços portuários, aeroportuários, de transporte e de turismo, com vistas ao incremento das exportações e da prestação desses serviços a usuários oriundos do exterior; XIII - fixar as alíquotas do imposto de exportação, respeitadas as condições estabelecidas no Decreto-Lei no 1.578, de 11 de outubro de 1977; XIV - fixar as alíquotas do imposto de importação, atendidas as condições e os limites estabelecidos na Lei no 3.244, de 14 de agosto de 1957, no Decreto-Lei no 63, de 21 de novembro de 1966, e no Decreto-Lei no 2.162, de 19 de setembro de 1984; XV - fixar direitos antidumping e compensatórios, provisórios ou definitivos, e salvaguardas; XVI - decidir sobre a suspensão da exigibilidade dos direitos provisórios; XVII - homologar o compromisso previsto no art. 4o da Lei no 9.019, de 30 de março de 1995; XVIII - definir diretrizes para a aplicação das receitas oriundas da cobrança dos direitos de que trata o inciso XV deste artigo; e XIX - alterar, na forma estabelecida nos atos decisórios do Mercado Comum do Sul - MERCOSUL, a Nomenclatura Comum do MERCOSUL de que trata o Decreto no 2.376, de 12 de novembro de 1997."

978 Em consulta às atas das reuniões do Conselho de Ministros da CAMEX é possível verificar que os passos dos contenciosos nos quais o Brasil está envolvido são relatados e há a tomada de decisão relativa ao avanço de etapas no procedimento do ESC. Por exemplo: "100a Reunião do Conselho de Ministros da Câmara de Comércio Exterior - CAMEX 19/02/2014 - 15h30 3. Negociações internacionais 3.1. Brasil EUA. Nova 'Farm Bill' e Contencioso do Algodão na OMC. Decisão: O Conselho de Ministros autorizou o MRE a iniciar um painel de implementação na OMC."; "99a Reunião do Conselho de Ministros da Câmara de Comércio Exterior - CAMEX 18/12/2013 - 15 h30 3.2. Contencioso do algodão na OMC Decisão: $O$ Conselho de Ministros aprovou a Resolução CAMEX que estabelece o reinício do processo de consultas públicas sobre contramedidas em propriedade intelectual e define os prazos para a eventual adoção de contramedidas nas áreas de bens, propriedade intelectual e serviços. Resolução CAMEX $n^{\circ} 105$, de 18/12/2013." Disponível

$<$ http://www.camex.gov.br/conteudo/exibe/area/1/menu/75/Decisões\%20CAMEX $>$. Acesso em: 30 abr. 2014.

979 "De maneira geral, compete à CAMEX definir grandes diretrizes e orientar politicas nas diferentes áreas pertinentes ao comércio exterior e às negociações comerciais. No entanto, desde a sua criação, a CAMEX enfrentou notórias dificuldades para desempenhar sua missão. De um lado, seu status institucional de Câmara da Presidência foi colocado em questão com sua transferência para o MDIC, o que restringiu naturalmente seu poder de coordenação interministerial. De outro, sua capacidade decisória está explicitamente limitada por competências estabelecidas, especialmente na área do Ministério da Fazenda, o que também coloca em xeque sua capacidade de coordenação interministerial. Além disso, dotada de poucos recursos técnicos e humanos, a CAMEX tem dificuldades para acompanhar a implementação de medidas adotadas em seu âmbito e para oferecer ao governo um feedback dos resultados e impactos de suas políticas." VEIGA, Pedro da Motta. IGLESIAS, Roberto Magno. A institucionalidade da política brasileira de comércio exterior. In: CASTELAR, A.; MARKWALD, R. PEREIRA, L. V. (Org.). O desafio das exportações. Rio de Janeiro: BNDES, 2002, p. 51-96. Disponível em: < http://www.bndes.gov.br/SiteBNDES/export/sites/default/bndes_pt/Galerias/Arquivos/conhecimento/livro_de safio/Relatorio-03.pdf>. Acesso em: 30 abr. 2014. p. 83. 
envolvidos nestas instituições - de que nos temas ligados à OMC prevalece o entendimento do MRE. ${ }^{980} 981982$

DANiEla ARRUda Benjamin, chefe da CGC, embora mencione em nota de rodapé que a decisão de instaurar um caso no Sistema de Solução de Controvérsias da OMC recaia "em última instancia, na Câmara de Comércio Exterior (CAMEX), a quem compete avaliar, à luz dos interesses políticos e econômicos em jogo, a viabilidade jurídica do pleito e a conveniência de formalizar pedido de consulta na OMC", 983 explicita que a “CGC é responsável, entre outros, pelo acompanhamento permanente dos casos em andamento, pela condução da função consultiva pré-contenciosa e, não menos importante, pelo monitoramento da implementação dos contenciosos dos quais o Brasil é parte." 984

980 Embora não tratando especificamente das decisões relativas ao Sistema de Solução de Controvérsias da OMC, mas das temáticas da OMC em geral, o autor afirma: "[...] nos conflitos de interesse presentes nas reuniões da CAMEX, o Itamaraty tende a sair vitorioso, boa parte das vezes, por uma sinergia de posições com o Ministério do Desenvolvimento, Indústria e Comércio (MDIC). O ministro do MDIC é o Presidente do Conselho de Ministros da CAMEX, desde 1999, quando a Câmara deixa de ser presidida pelo ministro Chefe da Casa Civil, o que, na visão de alguns analistas, teria contribuído para o enfraquecimento da CAMEX, já que teria passado a ser identificada como ligada a um ministério sectorial" RAMANZINI JÚNIOR, Haroldo. O Brasil e as Negociações no Sistema GATT/OMC: Uma Análise da Rodada Uruguai e da Rodada Doha. 2012. 137 p. Tese (Doutorado em Ciência Política) - Faculdade De Filosofia, Letras E Ciências Humanas, Universidade De São Paulo, São Paulo. p. 186.

981 "Na visão de um funcionário do Ministério da Agricultura 'a CAMEX é para dizer que tem a formalidade da coisa. Os temas de OMC são comandados pelo Itamaraty'. Entrevista com funcionário do Ministério da Agricultura. Brasília, 19/05/2009." RAMANZINI JÚNIOR, Haroldo. O Brasil e as Negociações no Sistema GATT/OMC: Uma Análise da Rodada Uruguai e da Rodada Doha. 2012. 137 p. Tese (Doutorado em Ciência Política) - Faculdade De Filosofia, Letras E Ciências Humanas, Universidade De São Paulo, São Paulo. p. 65 nota 123.

982 Entrevista com funcionário da CAMEX: "Pela minha experiência com o tema, a impressão que tenho é que a CAMEX funciona apenas "a posteriori”". Em várias ocasiões presenciei o MRE apresentando uma proposta (algumas foram previamente concertadas com as partes técnicas dos ministérios que participam da CAMEX, outras não) e, sem muitas explicaçães, pedindo a aprovação da CAMEX. Quando isso acontecia, o MRE costumava pedir a aprovação da proposta naquela mesma reunião, alegando que o "timing" das negociações internacionais assim o exigia, que não se podia esperar uma outra reunião da CAMEX. Em conseqüência, os presentes, com pouco conhecimento técnico da proposta e pouco tempo e capacidade de análise (os técnicos em geral não iam às reuniões), aprovavam o que indicava o MRE. Apenas em ocasiões - limite, quando, por exemplo, um Ministério não reconhecia sua alegada participação na formulação da proposta, os Ministros suspendiam o tema e deixavam para decidir em outro momento. Tenho a impressão também que um fator decisivo para esta primazia do MRE foi o fato do presidente Lula ter abertamente desautorizado o então Ministro do Desenvolvimento (e presidente da CAMEX) Luiz Fernando Furlan em uma rixa que ele teve com o Ministro das Relações Exteriores Celso Amorim. Na época, o Lula disse que o MRE era o responsável pela condução das relações externas”. EPSTEYN, Juan Cláudio. Evolución histórica de modelos institucionales de política comercial. Los casos de Estados Unidos e Brasil. 2009. Tese (Doutorado em Ciência Política e Sociologia) - IUPERJ, Rio de Janeiro. p. 302. Apud RAMANZINI JÚNIOR, Haroldo. O Brasil e as Negociações no Sistema GATT/OMC: Uma Análise da Rodada Uruguai e da Rodada Doha. 2012. 137 p. Tese (Doutorado em Ciência Política) - Faculdade De Filosofia, Letras E Ciências Humanas, Universidade De São Paulo, São Paulo.

983 BENJAMIN, Daniela Arruda. Introdução. In: BENJAMIN, Daniela Arruda. (Org). O Sistema de Solução de Controvérsias da OMC: uma perspectiva brasileira. Brasília : FUNAG, 2013, p. 31-41. p. 40, nota 22.

984 BENJAMIN, Daniela Arruda. Introdução. In: BENJAMIN, Daniela Arruda. (Org). O Sistema de 
Inclusive no tocante à escolha de quais demanda merecerão o abrigo do governo brasileiro para o início de um procedimento no Sistema de Solução de Controvérsias da OMC, DANIEL ARBIX sintetiza esta percepção dos estudiosos, de que "ainda que aparente caber à CAMEX a decisão oficial sobre determinada demanda que o Brasil venha a registrar no MSC, sua gestação e condução é fortemente centralizada na Coordenadoria Geral de Contenciosos (CGC) do Itamaraty". 985

Destaca-se que não se trata de indesejabilidade do manejo destas decisões pela CGC do MRE, que possui notadamente conhecimento técnico imprescindível sobre a atuação do Brasil no Sistema de Solução de Controvérsias da OMC. O que os estudiosos destacam é o reconhecimento de que, nesta temática, a CAMEX é "relegada a segundo plano, submetendo-se a decisões de foros não previstos institucionalmente e não abertos à participação da sociedade civil." 986

Ademais, o primado de longa data do Poder Executivo na temática da construção das políticas de comércio exterior, ${ }^{987}$ e a ausência de participação efetiva do Congresso Nacional, faz com que o aparato burocrático domine a formulação dessas medidas, que são definidas com transparência reduzida. ${ }^{988}$ Neste contexto, se destaca a necessidade do desenvolvimento de mecanismos de transparência e de institucionalização da participação da sociedade civil, que informem a percepção do agente público sobre o interesse público a ser buscado. ${ }^{989}$

Solução de Controvérsias da OMC: uma perspectiva brasileira. Brasília : FUNAG, 2013, p. 31-41. p. 40. 985 ARBIX, Daniel A. Contenciosos brasileiros na OMC: pauta comercial, política e instituições. Contexto Internacional, v. 30, n. 3, p. 655-699, 2008. p. 670.

986 ARBIX, Daniel A. Contenciosos brasileiros na OMC: pauta comercial, política e instituições. Contexto Internacional, v. 30, n. 3, p. 655-699, 2008. p. 666.

987 Rogério de Souza Farias: aponta meados da década de 1950 como momento da confirmação normativa deste desinteresse do poder legislativo: "Com a confecção das Leis de Tarifas e a derrogação dos compromissos brasileiros em meados da década de 1950, o parlamento reduziu sua capacidade de influência na área comercial. Isso foi feito parcialmente de forma voluntária. A criação da CACEX e do CPA ocasionou uma transferência de competência na área comercial para o Executivo. No meio da Rodada Kennedy, deputados e senadores não tinham mais interesse - ou influência - no que ocorria em Genebra. Não se pode esquecer que, além da saída voluntária, militou contra os interesses de longo prazo do Congresso Nacional o golpe de 1964 e, posteriormente, em 1968, o Ato Institucional No 5, que entrou em vigor durante a tramitação do projeto de lei que internalizaria os resultados da Rodada Kennedy." FARIAS, Rogério de Souza. Industriais, Economistas e Diplomatas: O Brasil e as negociações comerciais multilaterais (1946 1967). 2012. 480 p. Tese (Doutorado em Relações Internacionais) - Instituto de Relações Internacionais, Universidade de Brasília. p. 66.

988 ARBIX, Daniel A. Contenciosos brasileiros na OMC: pauta comercial, política e instituições. Contexto Internacional, v. 30, n. 3, p. 655-699, 2008.

989 Assim reflete Pedro da Motta Veiga: "No caso das relações entre o Estado e a sociedade civil, a principal linha de evolução deveria contemplar essencialmente a institucionalização da interlocução entre ambos. É fundamental que o Estado se comprometa com regras de diálogo e consulta, ainda que a ele 
Ademais, é possível aduzir que se a legislação não confere aos órgãos supracitados competência específica e nem exclusiva na operacionalização da tarefa de implementação das decisões do Sistema de Solução de Controvérsias da OMC, não há restrição à frequentemente necessária inter-relação entre os outros órgãos da burocracia pública na implementação destas decisões. ${ }^{990}$

No caso dos pneus, como observou-se, a implementação se deu por meio da interação prática entre diversos entes da estrutura federal, orquestrada pela Coordenação Geral de Contenciosos do MRE. Esta relação, contudo, ocorreu de modo informal e casuístico, conforme os interesses do órgão responsável pela implementação.

Em estudo empírico sobre as competências dos órgãos da administração pública federal, CÁssio França e Michelle RAtTOn SANCHEZ BADIN apontam para uma "horizontalização da política externa brasileira", na medida em que cerca da metade dos órgãos da Presidência e dos Ministérios pode relacionar-se de algum modo com a política externa no exercício de suas competências. ${ }^{991}$

Um dos aspectos mais relevantes do trabalho desses autores foi a evidenciação de um vácuo de previsão normativa de cooperação entre estes órgãos no exercício de competências direta ou indiretamente ligadas à política externa brasileira. Abre-se espaço para a necessidade de investigação sobre os mecanismos de cooperação entre tais órgãos, e para a reflexão sobre a conveniência do desenvolvimento de mecanismos formais de

continue cabendo a arbitragem entre distintas visões e interesses públicos e privados. Nesta mesma linha, é altamente desejável o estabelecimento de regras claras e institucionalizadas para o relacionamento entre o Executivo e o Congresso no que se refere ao processo de negociação comercial, definindo-se direitos e deveres de cada um, procedimentos de consulta e interlocução etc." VEIGA, Pedro da Motta. Política Comercial no Brasil: características, condicionantes domésticos e policy-making. In: ICONE, FIPE e DFID (Coord.). Instituto de Estudos do Comércio e Negociações Internacionais (ICONE), Fundação Instituto de Pesquisas Econômicas (FIPE) e Kingdon Department for International Development (DFID). Políticas comerciais comparadas: desempenho e modelos organizacionais. São Paulo: Singular, 2007. p. 71-162. Disponível em: <http://www10.iadb.org/intal/intalcdi/PE/2009/03126.pdf>. Acesso em: 30 abr. 2014. p. 72.

990 Deste modo também avalia João Paulo de Oliveira: “Em termos práticos, uma decisão com comando dirigido ao Estado brasileiro não surte efeitos exclusivamente sobre determinado órgão receptor no âmbito da administração brasileira. Não é dirigido nem se esgota no Ministério das Relações Exteriores ou qualquer outro. Não há, a princípio, qualquer ditame estabelecendo que a sentença internacional somente penetra na ordem jurídica brasileira até alcançar determinada instância do Itamaraty. Ao contrário, a decisão internacional e seu comando, segundo o conteúdo de seus dispositivos, podem projetarse sobre uma pluralidade de órgãos da administração pública brasileira, aí incluídos órgãos do legislativo o judiciário." OLIVEIRA, João Paulo de. Adjudicação e Comércio Internacional - o Caso dos Pneus Reformados. 2012. 152 p. Dissertação (Mestrado ), Programa de Pós-Graduação em Integração da América Latina, Universidade de São Paulo, São Paulo. p. 104.

991 FRANÇA, Cássio. SANCHEZ BADIN, Michelle Ratton. A inserção internacional do poder Executivo Federal brasileiro. Análises e propostas, n. 40, ago. 2010. Friedrich Ebert no Brasil. Disponível em: <http://library.fes.de/pdf-files/bueros/brasilien/07917.pdf> Acesso em: 16 fev. 2014. 
coordenação. ${ }^{992}$

Tendo em vista a existência dessas competências ligadas à política externa e a participação de diversas instituições da infraestrutura burocrática na concretização da política comercial, não é de se estranhar que a implementação de decisões do Sistema de Solução de Controvérsias da OMC possa frequentemente exigir a cooperação entre tais instituições. A inexistência de um arcabouço normativo para tal reforça a abordagem casuística e informal do procedimento de implementação dessas decisões, com proeminência de facto da Coordenação Geral de Contenciosos do MRE nessa fase.

\subsection{As Especificidades do Objeto em Questão}

Ao inserirmos a temática da implementação das decisões do Sistema de Solução de Controvérsias da OMC em um contexto mais amplo de complexidade da concretização das decisões adjudicatórias internacionais, não se pode descuidar das especificidades que marcam o objeto em questão, exigindo uma reflexão especial por parte dos estudiosos.

As especificidades ligadas à natureza jurídica desta decisão, e às consequentes características de juridicidade, obrigatoriedade e (in)determinabilidade foram abordadas em detalhe no capítulo 2 deste trabalho. Concluiu-se que as decisões do Sistema de Solução de Controvérsias da OMC são decisões adjudicatórias internacionais, sendo comandos jurídicos e obrigatórios de conduta, pondo fim a uma controvérsia internacional, com base no Direito Internacional. Embora não prevejam medidas determinadas para a concretização da obrigação de tornar a medida questionada conforme ao corpus juris da

992 “Com base na regulamentação, as previsões de articulação com o MRE são pontuais e, muitas vezes, não são nem consideradas no caso de órgãos ou unidades administrativas com competência para representar o Brasil internacionalmente. No nível dos ministérios, por exemplo, ainda que vinculadas à figura do ministro e a uma longa manus do presidente da República, não há previsões dos momentos e formas de coordenação com a Presidência. Além desses vácuos, não foi encontrada em nenhuma das regulamentações analisadas a previsão para coordenação entre os ministérios (que não com o MRE). [...]" FRANÇA, Cássio. SANCHEZ BADIN, Michelle Ratton. A inserção internacional do poder Executivo Federal brasileiro. Análises e propostas, n. 40, ago. 2010. Friedrich Ebert no Brasil. Disponível em: $<$ http://library.fes.de/pdf-files/bueros/brasilien/07917.pdf> Acesso em: 16 fev. 2014. 
OMC, essas decisões ensejam uma obrigação jurídica concreta determinável pelo Estado que as deve cumprir, cabendo-lhe escolher o modo pelo qual implementará seu comando.

As especificidades alcançam, também, a multiplicidade das medidas que podem ser utilizadas para proceder ao cumprimento da decisão do Sistema de Solução de Controvérsias da OMC no ordenamento jurídico interno do membro faltoso, conforme vislumbrado pelo capítulo 4. Assim como as medidas consideradas desconformes com a disciplina multilateral podem resultar da ação de sujeitos dos diversos poderes do Estado, as medidas escolhidas ou necessárias para a implementação podem exigir a atuação de diferentes sujeitos.

Por fim, a essa multiplicidade de medidas e de sujeitos envolvidos, adiciona-se a variedade de temáticas submetidas à apreciação do Sistema de Solução de Controvérsias da OMC e que, portanto, podem ser objeto de uma medida de implementação. Assim, diferentemente do GATT, a OMC abarca uma diversidade temática em seus Acordos, o que exige a verificação cuidadosa dos múltiplos interesses em jogo no preenchimento do espaço de discricionariedade conferido ao Estado para a implementação.

Se sob a perspectiva do Sistema de Solução de Controvérsias da OMC o Brasil possui discricionariedade para escolher o modo como implementar as suas decisões embora não seja esse um espaço sem limites -, sob a perspectiva interna, o preenchimento dessa discricionariedade de seleção encontra no interesse público e nos princípios da administração pública os seus limites inafastáveis. ${ }^{993}$

Isso pois, o processo de implementação da decisão do Sistema de Solução de Controvérsias da OMC no Brasil, e os seus respectivos atos, devem ser vislumbrados como um duplo objeto. Trata-se, simultaneamente, de medida ligada à política externa do país e de medida de política pública - atividade administrativa em sentido latu. ${ }^{994}$

993 Considera-se o seguinte conceito de discricionariedade: "O poder discricionário concerne ao da consequência jurídica de uma regulação legal. Ele está então dado, quando a administração na realização de um tipo legal, pode escolher modos de conduta distintos. A lei não liga ao tipo uma consequência jurídica (como na administração legalmente vinculada), mas autoriza a administração para ela própria determinar a consequência jurídica, em que lhe são oferecidas duas ou mais possibilidades ou lhe é destinado um certo âmbito de atuação. O poder discricionário pode-se relacionar a isto, se a administração no fundo, deve intervir e tornar-se ativa (poder discricionário de resolução) ou a isto, qual das medidas possíveis e admissíveis o caso concreto deve ser tomada (poder discricionário de seleção)." MAURER, Hartmut. Direito Administrativo Geral. Barueri, SP: Manole, 2006. p. 143.

994 Sobre o conceito amplo de política pública, que tem desafiado também a doutrina jurídica: "Não existe uma única, nem melhor, definição sobre o que seja política pública. [...] No entanto definições de políticas públicas, mesmo as minimalistas, guiam o nosso olhar para o locus onde os embates em torno de 
Embora seja inegável o conhecimento do MRE na temática, é preciso lembrar que a implementação de uma decisão no âmbito interno - com potencial impacto em políticas públicas de diferentes temáticas - envolve um espectro bem mais amplo de destinatários e, por isso, deve-se atentar para o desenvolvimento de mecanismos de participação dos diferentes setores da sociedade brasileira, no intuito de evidenciação dos diversos interesses contrapostos em uma situação de implementação. ${ }^{995}$

Assim, a discricionariedade do Poder Executivo na definição dos processos e medidas de implementação de uma decisão do Sistema de Solução de Controvérsias da OMC, concretizada por meio da condução pela CGC do MRE, não pode ser confundida com a total liberdade de escolha, desapegada dos princípios da Administração Pública, e do interesse público que deve orientar a tomada de decisão pelo agente público. ${ }^{996}$

A definição do interesse público é tarefa complexa em todas as áreas de atuação do Estado, tendo em vista o caráter pluralista das sociedades contemporâneas. Tal definição exige cuidado reforçado tratando-se do objeto em questão, pois esta é uma seara naturalmente permeável a interesses particulares, que, contudo, gozam de diferentes poderes de influência. Embora o interesse público possa coincidir com interesses particulares, esse cuidado reforçado na identificação do primeiro pode se concretizar por

interesses, preferências e ideias se desenvolvem, isto é, os governos. Apesar de optar por abordagens diferentes, as definições de políticas públicas assumem, em geral, uma visão holística do tema, uma perspectiva de que o todo é mais importante do que a soma das partes e que indivíduos, instituições, interações, ideologia e interesses contam, mesmo que existam diferenças sobre a importância relativa destes fatores." SOUZA, Celina. Políticas Públicas: uma revisão da literatura. Sociologias, ano 8, n. 16, p. 20-45, jul./dez 2006. p. 24-25.

995 Destaque para a reflexão de Priscila Spécie sobre a necessidade de "abertura" do processo decisório no MRE: "É interessante notar que apesar da tradição da burocracia profissional propagar a ideia de centralização e fechamento da condução da política externa brasileira e o discurso de alguns representantes do MRE insistir nessa tradição, não cabe mais falar em insulamento do Itamaraty como em outros tempos. Nesse contexto, por mais que questões de politica externa continuem a tratar de problemas estratégicos, que legitimam a proteção de alguns segredos ou a falta de transparência, tais condutas passam a ser questionadas como regra, sobretudo no processo mais amplo de mudanças da própria natureza da política externa e de amadurecimento das instituições democráticas." SPÉCIE, Priscila. Política Externa e Democracia: Reflexões sobre o acesso à informação na política externa brasileira a partir da inserção da temática ambiental no caso dos pneus entre o Mercosul e a OMC. 2008. 111 p. Dissertação (Mestrado em Ciência Política) - Faculdade de Filosofia, Letras e Ciências Humanas da Universidade de São Paulo, São Paulo. p. 12.

996 Relevante a reflexão de Hartmut Maurer: “O poder discricionário não proporciona liberdade ou até arbitrariedade da administração. Não existe 'poder discricionário livre' (embora essa formulação desorientadora hoje ainda aparece ocasionalmente), mas somente um 'poder discricionário conforme o seu dever', ou melhor: um poder discricionário juridicamente vinculado... Se a autoridade não segue essa vinculação legal, ela atua 'viciosamente no exercício do poder discricionário' e, com isso, antijuridicamente.” MAURER, Hartmut. Direito Administrativo Geral. Barueri, SP: Manole, 2006. p.148. 
meio da institucionalização de mecanismos de consulta aos diferentes grupos econômicos e sociais envolvidos. ${ }^{997} 998$

Seria ilusório e inócuo supor uma separação completa entre o interesse público e os diferentes interesses privados na atuação do Brasil no Sistema de Solução de Controvérsias, uma vez que, pela própria natureza comercial das contendas, é natural que o país busque defender a posição de grupos economicamente relevantes, exercendo uma espécie de "proteção diplomática". Esse entrelaçamento é tamanho que, na maior parte dos casos, o grupo econômico nacional interessado é quem arcou com os custos financeiros do ajuizamento de demandas. ${ }^{999}$

Contudo, no momento da implementação das decisões, o interesse de diversos grupos econômicos nacionais pode estar em conflito, e questões outras que não apenas a comercial podem estar envolvidas, tais como a saúde pública e o meio ambiente. Caso não haja a percepção destas complexidades e a ponderação das múltiplas perspectivas por parte do sujeito responsável pelo preenchimento desta discricionariedade, pode inclusive surgir espaço para a atuação legítima de instituições incumbidas da defesa de interesses da sociedade brasileira - a depender da natureza dos interesses em questão. ${ }^{1000} 10011002$

997 Para Leonor Clodovil, o trata-se de conceito indeterminado mas não indeterminável: "[...] Há, sim, vários interesses em conflito. Há, sim, muito individualismo na sociedade moderna. Contudo, cabe ao Estado, como legítimo representante do interesse, tanto como titular do contrato, quanto como representante democrático, ditá-lo de acordo com as diretrizes que lhe são postas no caso concreto. Como se defendeu anteriormente, ele não é a soma nem o interesse da maioria, é independente. Como postulado ético-político, ele é entregue a este Estado, para que este, com base na experiência e observação, bem como no poder que lhe foi concedido, delimite seu conteúdo." CLODOVIL, Leonor Augusta Giovine. O Interesse Público no Antidumping. 2009. 345 f. Tese (Doutorado em Direito) - Faculdade de Direito, Universidade de São Paulo, São Paulo. p. 111-112.

998 Também a este respeito, sobre a correlação entre "interesses públicos" e "interesses individuais", o autor explicita: “Os 'interesses públicos', todavia, não estão estabelecidos de uma vez, mas são submetidos à mudança do tempo e, também, em seu tempo, frequentemente são controversos. Sobretudo no estado pluralista de nossa atualidade sempre de novo é duvidoso o que pertence aos interesses públicos e qual peso cabe-lhes em conflitos de interesses. Determinantes são, sobretudo, a constituição e, no seu quadro, a dação de leis. Os interesses públicos podem cobrir-se total ou parcialmente com interesses individuais, mas também se opor a eles Com a Lei Fundamental declara a dignidade humana como princípio constitucional supremo e garante os direitos fundamentais energicamente (artigo 1 e seguintes da Lei Fundamental) devem, na perseguição dos interesses públicos, também os interesses do indivíduos ser observados, pode até a salvaguarda de interesses individuais pertencer à tarefa pública (por exemplo, na assistência social)." MAURER, Hartmut. Direito Administrativo Geral. Barueri, SP: Manole, 2006. p. 5.

999 Para uma análise detalhada das entidades do setor privado e/ou empresas que financiaram a contratação de escritórios privados para atuação nos contenciosos, Cf: SHAFFER, Gregory; RATTON SANCHEZ, Michelle; ROSENBERG, Barbara. The Trials of Winning at the WTO: What Lies Behind Brazil's Success. Cornell International Law Journal, vol. 41, issue 2, p. 383-501, 2008. p. 490-500.

1000 Como já explicitado, neste contexto o judiciário pode ser provocado a atuar. "Diante dos mecanismos jurídicos existentes, a área dos Direitos Humanos parece apresentar, até o momento, o maior potencial de judicialização da política externa, o que, no entanto, é um fenômeno que também já estaria ocorrendo na área econômica, por exemplo, através dos panels da Organização Mundial do Comércio - 


\subsection{Direito Internacional, Direito Interno e Política na Implementação das Decisões do Sistema de Solução de Controvérsias da OMC}

Sob a perspectiva da responsabilidade internacional dos Estados, o Direito Internacional considera o Direito Interno dos Estados como um "fato", ignorando as matizes das esferas federativas e das dimensões de poder, para tomar o Estado como um ente uno na sociedade internacional. ${ }^{1003}$ Por meio deste "unilateralismo internacionalista", o Direito Internacional apenas se interessa pela verificação do cumprimento das obrigações internacionais, desconsiderando escusas do Direito Interno dos Estados. ${ }^{1004}$

A relação entre as esferas, contudo, continua objeto de permanente reflexão por parte da doutrina, a partir da verificação concreta da relevância premente desta temática, uma vez que diversos problemas de ordem prática têm se intensificado a partir do

OMC - e de futuros mecanismos que podem vir a ser criados no âmbito do Mercosul e da Alca. É possível visualizar até uma interligação das duas áreas (...)" COUTO, Estevão Ferreira. Judicialização da política externa e direitos humanos. Revista Brasileira de Política Internacional, n. 46, vol. 1, p. 140-161, 2004. p. 148.

1001 Sobre a sindicabilidade das escolhas dos agentes públicos: "Hoje, no Estado Constitucional democrático e "pós-positivista", não há mais - convém grifar - atos exclusivamente políticos (ao menos na seara administrativa), de sorte que o administrador tem o compromisso de agir bem, de forma que a tomada de decisão administrativa deve ser justificável e mensuravelmente avaliada, segundo as políticas de Estado, mais que de governo. Não se trata de cometer o equívoco de afirmar a única solução correta. Quer-se tão-só defender que a liberdade, positiva ou negativamente considerada, precisa ser usufruída de acordo com a finalidade plural do sistema administrativo, cujas abertura e indeterminação fazem múltiplas as possibilidades de aplicação, mas não inviabiliza a refutação de escolhas francamente erradas ou até desonestas." FREITAS, Juarez. O Controle dos Atos Administrativos e os princípios fundamentais. $5^{\mathrm{a}}$ ed. Malheiros Editores: São Paulo, 2013. p. 107.

1002 André de Carvalho Ramos chama a atenção para novos espaços de atuação do Ministério Público Federal que se afirmam em um ambiente internacionalizado no qual o Estado brasileiro atualmente se situa, embora não se referira ao sistema multilateral de comércio. Compreendemos, contudo, que a depender da natureza dos interesses em embate, pode haver espaço para sua atuação na implementação da decisão do OSC. RAMOS, André de Carvalho. Tratados Internacionais: Novos espaços de atuação do Ministério Público. Boletim Científico da ESMPU, n. 7, a. II, p. 81-100, abr.jun. 2003.

1003 RAMOS, André de Carvalho. Teoria geral dos direitos humanos na ordem internacional. São Paulo: Saraiva, 2012. p. 222-224.

1004 RAMOS, André de Carvalho. Teoria geral dos direitos humanos na ordem internacional. São Paulo: Saraiva, 2012. p. 222-224. 
entrelaçamento e estreitamento da relação entre o Direito Internacional e o Direito Interno. 1005

A doutrina clássica inicialmente vislumbrou a relação entre o Direito Internacional e o Direito Interno como uma dicotomia, a partir da qual existiriam dois sistemas distintos, separados e independentes. A escola dualista, instaurada por HEINRICH TRIEPEL, ${ }^{1006}$ foi objeto de críticas que viriam a embasar a concepção monista da relação entre o Direito Interno e o Direito Internacional, que teve em HANS KELSEN seu autor principal. ${ }^{1007} 1008$ Em meio à polarização da discussão, diversas outras teorias surgiram, e passaram a ser denominadas de "teorias conciliatórias", pois buscavam soluções intermediárias para o embate. $^{1009}$

WAGNER MENEZES observa que o cenário contemporâneo, contudo, exige uma reformulação destes entendimentos, pois o mundo não é o mesmo daquele vislumbrado pelos autores, e tampouco o direito que exsurge desta sociedade internacional. É este o contexto da teoria da transnormatividade, como o autor postula:

O conceito de transnormatividade e da construção de um Direito Transnacional,
no entanto, se revitaliza nos dias de hoje à medida que, no cenário
contemporâneo, ampliam-se os mecanismos de interação entre Direito
Internacional e Direito Interno, estabelecendo verdadeiramente uma relação
transnormativa, não só de produção, mas também de efeitos e repercussão de um
Direito - especialmente o internacional - sobre o sistema normativo do outro.
Essa relação transnormativa se caracteriza por vários fatores de alocação de uma
nova realidade internacional que, por meio de seus instrumentos normativos
produzidos no plano internacional, dissolvem as fronteiras e possibilitam uma
interpenetração de normas jurídicas entre o local e o global em um mesmo

1005 MENEZES, Wagner. Ordem Global e Transnormatividade. Ijuí: Editora Unijuí, 2005. p. 175. MENEZES, Wagner. O Direito Internacional Contemporâneo e a Teoria da Transnormatividade. Pensar, vol. 12, p. 134-144, 2007.

1006 TRIEPEL, H. Les rapports entre le droit interne et le droit international. Recueil des cours, vol. 1, p. $77-121,1923$.

1007 Relevante destacar que certos aspectos da posição do autor evoluíram com o passar do tempo. Assim, se na formulação inicial de sua teoria, defendia que do ponto de vista lógico era possível que o direito internacional ou o direito interno estivessem em primazia sob o ponto de vista de um determinado Estado, passou a defender que o Direito Internacional ocuparia lugar de supremacia na pirâmide normativa. Para comentários sobre esta modificação na teoria do autor, Cf: MENEZES, Wagner. O Direito Internacional Contemporâneo e a Teoria da Transnormatividade. Pensar, vol. 12, p. 134-144, 2007. p. 137-138.

1008 Para um tratamento inicial do tema pelo autor, Cf: KELSEN, Hans. Les rapports de système entre le droit interne et le droit international public. Recueil des cours, vol. 14, p. 227-331, 1926. Para uma abordagem da evolução de sua teoria, Cf: KELSEN, Hans. Princípios do Direito Internacional. Ijuí: Unijuí, 2010. (Original publicado em 1952)

1009 Fugiria ao objetivo desta breve menção a análise da diversidade destas teorias. Para revisitar algumas delas, Cf: MENEZES, Wagner. O Direito Internacional Contemporâneo e a Teoria da Transnormatividade. Pensar, vol. 12, p. 134-144, 2007. 
espaço de soberania e competência normativa. Elementos de fundamentação da construção normativa, como as fontes do Direito, incluindo as soft law; o Direito Comunitário e seus mecanismos específicos para regulamentação intrabloco; as regras de direitos humanos que passam de uma simples resolução e adotam cada vez mais o caráter de um jus cogens, um direito imperativo que deve ser respeitado e observado por todos os povos; as organizações internacionais, seus foros e sua atividade pseudolegislativa; a transnacionalização da ordem econômica que envolve um número maior de temas e opera entre fronteiras, não só por intermédio do seu principal objeto, o capital, mas também por sujeitos operacionais, como empresas transnacionais 1010

Desse modo, diante da incapacidade das esferas do Direito Interno e do Direito Internacional, concebidas hermeticamente, de fornecerem explicação à realidade da prática estatal e ao processo de construção normativa internacional que agora envolve lógicas diferenciadas, a transnormatividade evidencia por um lado a porosidade das fronteiras nacionais ao fenômeno jurídico e, por outro, a crescente transposição ao ambiente internacional de anseios primariamente nacionais.

A OMC e seu Sistema de Solução de Controvérsias foram instituídos com o intuito de estabelecerem internacionalmente comandos normativos em áreas "sensíveis" aos Estados, que ficavam tradicionalmente a cargo de decisões nacionais e que impactam enormemente em suas economias e sociedades, em especial tendo em conta a inclusão de novas áreas nessa regulamentação. ${ }^{1011}$ Por outro lado, a aplicação destes comandos e o respeito ou desrespeito a este arcabouço normativo se operacionaliza no ambiente normativo-institucional dos membros da Organização.

Assim, a implementação das decisões do Sistema de Solução de Controvérsias da OMC pelas instituições nacionais, como meio da realização da normatividade adjudicada pelo sistema de controvérsias, se concretiza através de uma dinâmica transnormativa. Contudo, neste momento de adoção de medidas para a produção dos efeitos da decisão de

1010 MENEZES, Wagner. Ordem Global e Transnormatividade. Ijuí: Ed. Unijuí, 2005. Pp. $203-204$. 1011 Relevante destacar o apontamento de Umberto Celli Junior: "[...] Se, de um lado, a inclusão de temas relevantes para o crescimento do comércio internacional, como serviços e investimentos, pode ser vista como um fator positivo, de outro, ela é também reveladora de uma tendência ou potencial, no caso de serviços, e de algo mais efetivo no caso de investimentos, do alto grau, para usar a expressão de Guido Soares, de "invasividade no campo normativo e decisório das autoridades nacionais e dos ordenamentos jurídicos internos, pelas políticas e normas votadas num foro internacional e externo aos Estados". Isso significa que as normas da OMC limitaram, com maior ou menor intensidade, a flexibilidade dos membros quanto à escolha dos instrumentos que podem ser usados na implantação de objetivos de política econômica. Quando não limitam expressamente, deixam em aberto essa possibilidade de restrição do direito dos membros de regular ou legislar, ou, posto de outra forma, de fazer políticas públicas (policy space) como muitos dos membros, sobretudo os desenvolvidos, fizeram no passado." CELLI JUNIOR, Humberto. O Acordo de Serviços (GATS) e de Investimentos (TRIMS) na OMC: Espaço para Políticas de Desenvolvimento. CEBRI Artigos. Vol. 1, a. II, 2007. p. 8. 
solução de controvérsias da OMC, é conferido ao Estado um espaço de escolha sobre os meios para alcançar sua obrigação de resultado: revogar a medida desconforme ou adequála à disciplina multilateral.

Se o Sistema de Solução de Controvérsias da OMC se preocupa com o alcance do resultado pelo membro, no tempo razoável acordado pelas partes ou definido pelo árbitro para cada litígio, sob a perspectiva da ordem jurídica do membro responsável pela implementação, o preenchimento da discricionariedade conferida deve se dar de modo a respeitar seus respectivos parâmetros constitucionais e jurídicos. Isto é, se sob a perspectiva do sistema multilateral de comércio, importa o resultado, mas sob as lentes do ordenamento jurídico interno importa também avaliar e ponderar os meios escolhidos.

O iter de implementação no ordenamento jurídico pátrio é inegavelmente um objeto duplo: se por um lado consiste na escolha de concretização de um posicionamento externo do Brasil, já que faticamente o país poderia não proceder à implementação, por outro lado constitui uma escolha da administração pública brasileira, que deve estar respaldada legalmente e legitimamente, e deve considerar os múltiplos indicadores da escolha guiada pelo interesse público. ${ }^{1012}$

Assim, tanto sob o ponto de vista de constituírem atos relacionados à formulação da política externa brasileira, quanto sob a perspectiva de tratarem de políticas públicas, os mecanismos de implementação não podem ser manejados segundo a livre escolha do Poder Executivo. ${ }^{1013}$ A política comercial e a política externa no Brasil devem ser construídas balizadas nos parâmetros constitucionais e legais vigentes, e possibilitando um controle legislativo, judicial e da opinião pública.

1012 "O princípio do interesse público genuíno prescreve que, em caso de colisão, deve preponderar a vontade geral legítima (o "bem de todos", no dizer do art. 3o da CF) sobre a vontade egoisticamente articulada ou facciosa, sem que aquela volição se confunda com a simples vontade do aparato estatal, tampouco com o desejo da maioria [...] A própria identificação do interesse difuso e do interesse coletivo está prenhe de armadilhas. Por isso, importa assinalar que o interesse público guarda correlação íntima com a tutela da dignidade de todas as pessoas e de cada uma. [...] É a dignidade de todos que justifica a primazia legítima e democrática do interesse público sobre os interesses particularistas." FREITAS, Juarez. O Controle dos Atos Administrativos e os princípios fundamentais. $5^{\text {a }}$ ed. Malheiros Editores: São Paulo, 2013. p. 43-44.

1013 Não há, pois, uma escolha "livre" da Administração: "As escolhas públicas, em maior ou menor escala, devem encontrar fundamentação corretamente lastreada no sistema, para evitar dois fenômenos simétricos nocivos: de uma parte, uma vinculatividade formal dos atos administrativos, materialmente dissociada dos princípios e direitos fundamentais, e, de outro lado, uma noção de discricionariedade tendente a manifesta desvinculação do controle, em termos sistemáticos, da efetivação qualificada das politicas públicas e das prioridades constitucionais". FREITAS, Juarez. O Controle dos Atos Administrativos e os princípios fundamentais. $5^{\text {a }}$ ed. Malheiros Editores: São Paulo, 2013. p. 107. 
No tocante à concepção da política externa, cumpre brevemente destacar certa evolução na compreensão deste conceito. Assim, passou-se de uma abordagem tradicional, centrada na figura dos Estados e no acúmulo do poder, à visão da política externa como mais um vetor de coordenação entre diferentes forças domésticas atuantes em uma dada sociedade. ${ }^{10141015}$

Desse modo, a política externa tende a ser vista na atualidade como um elemento complementar das políticas interna e internacional, imbrincadas na construção de uma política pública integral. ${ }^{1016}$ Isto é, nesta visão, a política externa não é alheia ao equilíbrio entre os diferentes anseios da múltipla sociedade brasileira, mas se projeta como um dos meios de oferecer "respostas do Estado a situações socialmente problematizadas". ${ }^{1017}$

A centralidade do Poder Executivo na condução da política externa é evidente da análise dos dispositivos constitucionais, e representa uma "tradição" de todas as constituições brasileiras. Sob o ponto de vista das competências que o texto constitucional expressamente reserva ao Poder Legislativo e ao Poder Judiciário, cabe-lhes a fiscalização e controle, dentro de determinados parâmetros. ${ }^{1018}$

1014 SILVA, Elaini Cristina Gonzaga da. SPÉCIE, Priscila. VITALE, Denise. Um novo arranjo institucional para a política externa brasileira. Brasília: CEPAL. Escritório do Brasil/IPEA, 2010. Textos para discussão CEPAL/ IPEA. (Texto para Discussão CEPAL-IDEA, 3). p. 10.

1015 Um exemplo concreto dessa mudança na percepção da política externa seria a reformulação do papel do MRE em relação à gestação interna das políticas públicas "Junto com a aproximação interministerial, outro efeito do processo de descentralização horizontal, e da consequente modernização do Itamaraty, é a aproximação do MRE no acompanhamento das várias políticas públicas, que compreendem cada vez mais um momento de política externa. Na realidade, com as transformações ocorridas desde o final da década de 80, todas as políticas públicas passam a ter um momento pelo menos potencial de política externa. Por isso, a tentativa de cumprir uma missão praticamente inalcançável de coordenação geral da política externa que agora incumbe ao MRE, sob risco de perder espaço político. Nesse sentido, por uma interpretação das competências atribuídas ao MRE, conforme seu último RISE (2008), o Itamaraty teria assumido um papel de coordenador geral dos aspectos externos das políticas públicas, incluindo acompanhamento geral ou de definição de agenda, pela participação em suas fases de formulação." SPÉCIE, Priscila. Política Externa e Democracia: Reflexões sobre o acesso à informação na política externa brasileira a partir da inserção da temática ambiental no caso dos pneus entre o Mercosul e a OMC. 2008. 111 p. Dissertação (Mestrado em Ciência Política) - Faculdade de Filosofia, Letras e Ciências Humanas da Universidade de São Paulo, São Paulo. p. 48.

1016 SILVA, Elaini Cristina Gonzaga da. SPÉCIE, Priscila. VITALE, Denise. Um novo arranjo institucional para a política externa brasileira. Brasília: CEPAL. Escritório do Brasil/IPEA, 2010. Textos para discussão CEPAL/ IPEA. (Texto para Discussão CEPAL-IDEA, 3). p. 10.

1017 SILVA, Elaini Cristina Gonzaga da. SPÉCIE, Priscila. VITALE, Denise. Um novo arranjo institucional para a política externa brasileira. Brasília: CEPAL. Escritório do Brasil/IPEA, 2010. Textos para discussão CEPAL/ IPEA. (Texto para Discussão CEPAL-IDEA, 3). p. 125.

1018 "Como observações gerais sobre a distribuição de competências, tanto na Constituição de 1967 como na de 1988, tem-se que: o poder Executivo ainda guarda papel central na formulação e na de-cisão da política externa; o poder Legislativo atua preponderantemente no processo de (co)decisão a posteriori e o poder Judiciário, em eventual participação ad hoc." SANCHEZ, Michelle Ratton et al. Política Externa Como Política Pública: Uma Análise pela Regulamentação Constitucional Brasileira. (1967-1988) Revista de Sociologia e Política, vol. 27, p. 125-143, nov. 2006. p. 131. 
Contudo, retomando a perspectiva da implementação das decisões do Sistema de Solução de Controvérsias da OMC como um objeto duplo, sob a visão da escolha da administração pública brasileira, o Poder Legislativo e o Poder Judiciário podem se utilizar dos meios de controle disponíveis aos atos administrativos no ordenamento jurídico pátrio. Ademais, a aprovação de uma lei com um procedimento geral previamente definido, e com o estabelecimento de parâmetros legais que direcionem a escolha do Poder Executivo, como se propõe no tópico a seguir, insere-se na mais legítima função do Poder Legislativo, e poderia sanar sua reconhecida omissão nessa matéria. ${ }^{1019}$

Quanto às possibilidades de atuação do Poder Judiciário, não se pode ignorar uma notável tendência no Brasil à judicialização da política - aí incluídas as políticas públicas e também a política externa - ${ }^{1020}$ tendo em conta a ineficiência dos demais poderes em fornecer respostas pautadas no interesse público e adequadas aos anseios da sociedade brasileira, e embasada no princípio constitucional da inafastabilidade da jurisdição. ${ }^{1021}$

No que se refere ao controle da administração pública, a política externa não está isenta desse controle a partir dos princípios enumerados no caput do artigo 37 da CF/88, embora sua operacionalização exija reflexões mais profundas. Dentre os princípios explicitados, merece destaque neste estudo o princípio da publicidade, que desemboca em um dever de transparência. ${ }^{1022}$

1019 "Com efeito, na prática, apesar de ter havido esboços (no âmbito interno do Congresso Nacional) de exercer um maior controle, por exemplo, sobre as operações do Brasil com o FMI, o Legislativo tem se mantido omisso nessa questão." COUTO, Estevão Ferreira. Judicialização da política externa e direitos humanos. Revista Brasileira de Política Internacional, vol. 1, n. 46, p. 140-161, 2004. p. 143.

1020 PANNUNZIO, Eduardo. A judicialização das relações internacionais no Brasil em face do princípio constitucional da prevalência dos direitos humanos. 2012. 257 p. Tese (Doutorado em Direito) Faculdade de Direito, Universidade de São Paulo, São Paulo.; COUTO, Estevão Ferreira. Judicialização da política externa e direitos humanos. Revista Brasileira de Política Internacional, vol. 1, n. 46, p. 140-161, 2004.

1021 Assim postula Juarez Freitas, sobre a impossibilidade de restringir a : "O princípio em tela faz com que o Poder Judiciário - sem protagonismo excessivo, mas na linha da melhor compreensão do papel do juiz - examine sem invadir substantivamente o "mérito" (ainda que, por exceção, possa prolatar sentenças aditivas) e sindique todo e qualquer vício de descumprimento dos princípios fundamentais, o que implica o redimensionamento da sindicabilidade das relações administrativas, recordando que inexiste discrição pura ou não controlável pelo Poder Judiciário. Ao fim e ao cabo, todos atos devem estar sujeitos ao controle "negativo", em face da cogência da totalidade dos princípios e objetivos fundamentais. [...] No que diz, portanto, com a extensão o controle judicial dos atos administrativos, urge recordar que não se trata propriamente de sindicabilidade do mérito, mas, sim, a plena assimilação de que o agente publico é livre apenas para alcançar a tutela efetiva do direito fundamental a boa administração pública.[...]” FREITAS, Juarez. O Controle dos Atos Administrativos e os princípios fundamentais. $5^{\text {a }}$ ed. Malheiros Editores: São Paulo, 2013. p. 106.

1022 De modo geral, os autores tratam dos princípios da publicidade e da transparência sem diferenciálos. Sobre a relação entre o princípio da publicidade e o dever de transparência, Cf: “Mas será a transparência um principio autônomo, ou resulta como um efeito jurídico do principio constitucional da 
O princípio da transparência, erguido por KANT à qualificação de princípio transcendental, ${ }^{1023}$ deve permear "todos os setores e todos os âmbitos da atividade administrativa", ${ }^{1024}$ ganhando relevo essencial no Estado Democrático de Direito. Envolto na concepção do Estado Democrático de Direito, o princípio da publicidade se manifesta não apenas em dimensão formal - ligada à divulgação de informações-, mas principalmente se projeta no aspecto material de promoção do acesso dos interessados na formulação, execução e avaliação das atividades administrativas. ${ }^{1025}$

Assim, é o respeito à publicidade e à transparência que garante aos indivíduos a possibilidade de controle e participação nas escolhas do Estado, no intuito de aproximação entre a estrutura de governança estatal e os indivíduos da sociedade - sujeitos últimos da atividade do Estado. Trata-se não apenas de garantia de legalidade da atividade administrativa, mas também de compromisso com sua legitimidade. ${ }^{1026}$

O princípio da publicidade, como insculpido na $\mathrm{CF} / 88$, ganha função renovada e multidimensional na construção do Estado Democrático de Direito já previsto no preâmbulo constitucional. Presta-se, desse modo, não apenas ao intuito de conferir validade e eficácia formal aos atos administrativos, mas cuida de garantir a ação

publicidade da Administração Pública? [...] Doutrinariamente, é variada a compreensão da transparência, que resta indicada como resultado da integração do direito fundamental à informação (dos cidadãos em geral), com o principio da publicidade, ou mesmo como principio autônomo que coexiste com o principio da publicidade, aprofundando e concretizando seu sentido". MIRAGEM, Bruno. Nova Administração Pública e o Direito Administrativo. São Paulo: Revista dos Tribunais, 2011. p. 316.

1023 "Foi Kant quem no Projeto de Paz Perpétua contestou a tradição teórica da razão-de-estado ao afirmar, tanto no plano interno quanto no plano internacional, a publicidade como um princípio transcendental." LAFER, Celso, Diplomacia e Transparência: o Arquivo do Itamaraty. Boletim da Sociedade Brasileira de Direito Internacional. 1987-1989, n. 69-71, p. 108-117. p. 110.

1024 MEDAUAR, Odete. Direito Administrativo Moderno. 15 a ed. São Paulo: Editora RT, 2011. p. 135

1025 "Neste sentido, por Estado de Direito tenha-se o modelo de Estado constitucional em que se assegure a proteção dos direitos e garantias fundamentais da pessoa humana, a efetiva participação da população no processo de formação da vontade política, a alternância no exercício do poder político e o equilíbrio e independência dos Poderes. Nessa realidade, o principio da publicidade surge como elemento de aproximação do Estado e da sociedade, especialmente para efeito de fiscalização e controle da ação administrativa pelos órgãos competentes e pelas vias previstas na legislação” MIRAGEM, Bruno. A nova administração pública e o direito administrativo. São Paulo: Revista dos Tribunais, 2011. p. 308.

1026 "O Estado Democrático de Direito, tal como a Constituição o enuncia, está submetido a duas ordens de valores: à vontade democraticamente definida e à vontade juridicamente positivada. A vontade juridicamente positivada é o campo da legalidade, principio geral já estudado. Já a vontade democraticamente expressa, positivada ou não, situa-se no campo mais vasto da legitimidade, principio substantivo específico do Direito Público, que informa o Direito Constitucional, e o Direito Administrativo, ao regerem manifestações discricionárias. Com efeito a legitimidade se deriva diretamente do principio democrático, por isso entendida como a qualidade do que se harmoniza com o interesse da sociedade, para assim informar a relação entre a vontade geral do povo e as suas expressões politicas, administrativas e judiciárias." MOREIRA NETO, Diogo de Figueiredo. Princípios informativos e interpretativos do direito administrativo. In: Mutações do Direito Público. Rio de Janeiro: Editora Renovar, 2006. p. 276-277. 
transparente do Estado, e a aproximação com a população em seus processos de deliberação. ${ }^{1027}$

Como já ensinava CELSO LAFER à época da elaboração da CF/88, a transparência e a publicidade são vetores que devem permear também a diplomacia contemporânea, como forma de atualizá-la aos conceitos de democracia, participação e interesse público:

\begin{abstract}
A democracia é uma forma de governo que busca integrar as duas acepções [de público], pressupondo que o interesse público deve ser do conhecimento coletivo. Por isso, tem como "regra do jogo" o exercício público do poder comum. Daí a importância do tema da transparência do poder, enquanto instrumento democrático de controle 'ex parte populi' dos governantes.

A transparência do poder está correlacionada com a liberdade de opinião e de expressão, que requer o direito de procurar, receber e difundir informações, consagrado no artigo XIX da Declaração Universal dos Direitos Humanos de 1948. Este direito objetiva a igualitária participação da cidadania na esfera pública. Tem, como fundamento filosófico, o sapere aude kantiano, pois o uso público da própria razão, que enseja a ilustração e a maioridade dos homens, pede uma informação exata e honesta, ao alcance de todos, sem a qual existem súditos mas não cidadãos.

É por esse motivo que, por obra do legado kantiano, no como são tomadas as decisões numa democracia, o princípio da visibilidade do poder é constitutivo. Permite a informação sem a qual todos não podem formar uma opinião apropriada sobre a gestão da coisa comum para, assim, exercer o seu poder de participação e controle. Daí a conclusão: numa democracia a publicidade é a regra e o segredo a exceção. [...] $]^{1028}$
\end{abstract}

A reflexão do autor sobre a necessidade do "exercício público do poder comum" permanece atual e de relevância máxima, conforme o conjunto de princípios arquitetados na $\mathrm{CF} / 88$. Em sentido correlato, PEDRO DALLARI expõe, no tocante à disciplina constitucional do desenvolvimento das relações exteriores, que a perspectiva "administrativista"- pela qual as relações exteriores se desenvolvem como resultado da política externa governamental, se contrapõe à “perspectiva de institucionalização [...] de paradigmas e de regras de procedimento que, vigorando paralelamente ao desenrolar de

1027 MIRAGEM, Bruno. A nova administração pública e o direito administrativo. São Paulo: Revista dos Tribunais, 2011.p. 310.

1028 LAFER, Celso, Diplomacia e Transparência: o Arquivo do Itamaraty. Boletim da Sociedade Brasileira de Direito Internacional. 1987-1989, n. 69-71, p. 108-117. p. 109. 
iniciativas subordinadas à política externa governamental, possibilitem, em relação à esta, o balizamento, o acompanhamento e o controle por parte da sociedade." 1029

Não nos resta dúvidas de que essa última foi a perspectiva vislumbrada pelo constituinte brasileiro, que inovou ao codificar orientações gerais à condução da política externa e ao estabelecer objetivos a serem alcançados. Segundo a interpretação de PAULO Roberto DE AlmeidA, a CF/88 postulou como objetivos: (a) o desenvolvimento e a democracia, na frente interna, e (b) o primado do Direito, a convivência pacífica, a cooperação internacional e a defesa do interesse nacional, na frente externa. ${ }^{1030}$

Assim, se por um lado a $\mathrm{CF} / 88$ é silente no tocante a competências em matéria internacional, por outro lado a Carta traz um programa de atuação aos seus órgãos e agentes, por meio de objetivos orientados teleologicamente e de princípios gerais. Esse é o contexto para a compreensão do verdadeiro alcance dos princípios elencados no artigo $4^{\circ}$ para a condução da política externa brasileira, na busca da concretização destes valores sob as perspectivas interna e internacional.

É neste sentido o ensinamento de CELSO LAFER:

$\mathrm{O}$ art. $4^{\mathrm{o}}$ representa um marco normativo a partir do qual o Executivo, no exercício de suas competências, traduz os interesses nacionais em ação diplomática do país, individualizando sua realização à luz da conjuntura internacional. Assim, o papel desses princípios vai além da função clássica de proibir ou permitir. São diretrizes que claramente almejam promover ações de política externa; vale dizer, são uma expressão do que Bobbio qualifica como uma função promocional do Direito. ${ }^{1031}$

A prescindir dessa orientação teleológica da $\mathrm{CF} / 88$, há - no tocante à definição da participação do Brasil no Sistema de Solução de Controvérsias da OMC, incluindo o momento da implementação dessas decisões - uma percepção frequente da ausência de

1029 DALLARI, Pedro Bohomoletz de Abreu. Constituição e Relações Exteriores. São Paulo: Saraiva, 1994.

1030 ALMEIDA, Paulo Roberto de. Relações Internacionais e Interesse Nacional: As Relações Econômicas do Brasil e a Ordem Constitucional: Boletim da Sociedade Brasileira de Direito Internacional, n. 69-71, p. 164-183, 1987-1989. p. 166.

1031 LAFER, Celso. A Constituição de 1998 e as Relações Internacionais. In: TORRES, Heleno Taveira (Org.). Direito e Poder nas Instituições e nos Valores do Público e do Privado Contemporâneos. Estudos em Homenagem a Nelson Saldanha. Barueri: Manole, 2005, p. 215-232. p. 219-220. 
mecanismos de inclusão da sociedade civil na gestão dessa atuação. ${ }^{1032}$ Cumpre destacar que referida afirmação não expressa um diagnóstico preciso e específico do MRE, mas parte de uma percepção de que a condução da tomada de escolha da política externa brasileira tende a se dar em um diálogo "seletivo", no qual os setores mais organizados são “convidados" a participar da discussão, mas não necessariamente há uma democratização das escolhas. 1033

Não se ignora que a escolha do meio de implementação das decisões do Sistema de Solução de Controvérsias da OMC consubstancia-se em decisões estratégicas e que, portanto, envolvem uma ampla gama de complexidades, que acabam por "convidar" os sujeitos formuladores de tais decisões a buscar conferir-lhes uma gestação mais sigilosa. Contudo, sob a perspectiva de que se trata de um duplo objeto, e tendo em conta a arquitetura principiológica da $\mathrm{CF} / 88$, a implementação dessas decisões exige maior transparência e diálogo com a sociedade, ${ }^{1034}$ como se buscou explicitar.

1032 "No governo brasileiro, e em particular no Ministério das Relações Exteriores, ainda há relutância em adaptar-se à democracia e ao pluralismo. A política externa brasileira deve ser modernizada se for trabalhar em prol do internacionalismo de hoje. Não deve apenas se envolver com outros governos e com o setor privado, como também em deve apoiar e incorporar diálogos com a sociedade civil." p. 3-4 QUEIROZ, Adriana de. Brasil está à beira de uma "revolução do internacionalismo". CEBRI Textos. 2013. Disponível em: <http://www.cebri.org/portal/publicacoes/cebri-textos/revolucao-do-internacionalismo> Acesso em: 10 fev. 2014.

1033 Shiguenoli Miyanamoto chega a apontar como um dos desafios e constrangimentos à política externa brasileira: "[...] a não incorporação dos demais setores da sociedade nacional para auxiliar na definição dos interesses multifacetados que necessariamente devem estar presentes para a elaboração das politicas nacionais e que, aumentando o poder nacional, projetam o país. A sociedade nunca foi chamada para participar de respostas governamentais, nem sequer consultada para ver se concorda com elas. Pelo contrário, instâncias responsáveis pela política externa, como o Itamaraty, mostram-se, na maior parte das vezes, refratárias a influências externas. Ainda que eventos como seminários ou encontros sejam realizados com o meio acadêmico ou setores variados vinculados à presença de brasileiros no exterior, dificilmente sugestões são incorporadas na definição da política externa, tratando-se de mero exercício retórico." MIYAMOTO, Shiguenoli. As grandes linhas da política externa brasileira. Brasília: CEPAL. Escritório do Brasil/IPEA, 2011. Textos para discussão CEPAL/ IPEA. (Texto para Discussão CEPAL-IPEA, 45). p. 199. 1034 "No caso das relações entre o Estado e a sociedade civil, a principal linha de evolução deveria contemplar essencialmente a institucionalização da interlocução entre ambos. É fundamental que o Estado se comprometa com regras de diálogo e consulta, ainda que a ele continue cabendo a arbitragem entre distintas visões e interesses públicos e privados. Nesta mesma linha, é altamente desejável o estabelecimento de regras claras e institucionalizadas para o relacionamento entre o Executivo e o Congresso no que se refere ao processo de negociação comercial, definindo-se direitos e deveres de cada um, procedi-mentos de consulta e interlocução etc." VEIGA, Pedro da Motta. Política Comercial no Brasil: características, condicionantes domésticos e policy-making. In: ICONE, FIPE e DFID (Coord.). Instituto de Estudos do Comércio e Negociações Internacionais (ICONE), Fundação Instituto de Pesquisas Econômicas (FIPE) e Kingdon Department for International Development (DFID). Políticas comerciais comparadas: desempenho e modelos organizacionais. São Paulo: Singular, 2007. p. 71-162. Disponível em: $<$ http://www10.iadb.org/intal/intalcdi/PE/2009/03126.pdf>. Acesso em: 30 abr. 2014. p. 72. 


\subsection{Proposição para o Direito Brasileiro}

\subsubsection{Da Necessidade e das Vantagens do Estabelecimento de um Marco Normativo para Implementação das Decisões do Sistema de Solução de Controvérsias no Brasil}

Como resultado das discussões tidas ao longo do trabalho, entendemos ser premente a necessidade de estabelecimento de um marco normativo que aumente a transparência e previsibilidade na definição do caminho para implementação das decisões do Sistema de Solução de Controvérsias da OMC no Brasil.

Esta premência não é exclusiva das decisões do Sistema de Solução de Controvérsias da OMC, sendo uma necessidade observada no tocante a todos os tribunais internacionais, como exigência de uma nova realidade internacional, no qual os tribunais assumem papel vital de pacificação dos conflitos e afirmação do rule of law, como ensina AntôNio Augusto CANÇADO TRINDADE:

É altamente desejável que, paralelamente aos distintos mecanismos para a supervisão do cumprimento das sentenças dos tribunais internacionais contemporâneos, os Estados adotem procedimentos de direito interno para assegurar, em base permanente, o fiel cumprimento das referidas sentenças dos tribunais internacionais, evitando, assim, soluções casuístas. Enfim, o fiel cumprimento ou execução de suas sentenças é uma preocupação legítima de todos os tribunais internacionais contemporâneos. Tal cumprimento de sentenças deve ser integral, e não parcial ou seletivo. Em meu entendimento, não há aqui lugar para considerações de cunho pragmático; impõe-se uma posição principista, sobre questão de tamanha importância, que concerne à ordre public internacional, e ao rule of law (prééminence du droit) nos planos nacional e internacional.(grifos originais) 1035

No tocante ao Sistema de Solução de Controvérsias da OMC, a proposta não precisaria engessar o necessário espaço de manobra do Poder Executivo na construção da

1035 TRINDADE, Antônio Augusto Cançado. Os tribunais internacionais contemporâneos. Brasília : FUNAG, 2013. P. 64 
continuidade entre políticas, mas permitiria um avanço democrático no preenchimento desse espaço, ao promover maior transparência, legitimidade e controle dos órgãos da administração pública brasileira.

O modelo de participação existente de condução da relação entre os grupos econômicos e os órgãos de facto responsáveis pelas decisões relativas à atuação do país no Sistema de Solução de Controvérsias da OMC, paralelo ao caráter informal da participação concreta destes setores, tende a favorecer aquelas demandas mais institucionalizadas e dominantes, melhor organizadas, mas que não necessariamente expressam todas as matizes de interesses legítimos a serem tutelados pelo Estado brasileiro e não necessariamente estão identificados com o interesse público, que deve ser o norte na tomada de decisão da Administração Pública.

A percepção do interesse público - ou do interesse nacional - a partir da diversidade de interesses que se expressam no interior do Estado brasileiro pode não ser tão cristalina ou polarizada, tendo em vista a complexidade das temáticas influenciadas pelo sistema multilateral de comércio. Embora tal complexidade ainda não tenha se manifestado intensamente nos dois casos que exigiram uma medida de implementação do Brasil, não se pode restringir a possibilidade de futuras demandas contra o país na OMC que gerem interesses divergentes no momento da implementação.

No caso da Embraer, pode-se dizer que o espaço de discricionariedade do modo para implementar a decisão era restrito uma vez que, reconhecida a desconformidade de um aspecto do PROEX, caberia ao governo brasileiro escolher entre as opções de: (a) extinguir a concessão de subsídios ao setor; ou (b) modificar o elemento desconforme com a normativa multilateral, mantendo a concessão de subsídios. O governo brasileiro optou pela manutenção do programa, tendo em conta o caráter estratégico do setor, e até mesmo o simbolismo do sucesso da competitividade da empresa nacional em um setor de alta tecnologia. Não houve, assim, uma necessidade de problematização sobre qual seria o interesse nacional na situação.

No caso dos pneus reformados, por sua vez, a multiplicidade dos interesses se manifestou de modo mais evidente, havendo certa polarização entre os agentes econômicos interessados na importação dos pneus reformados e setores da sociedade civil organizada, legitimamente preocupados com a saúde pública e o meio ambiente. Neste segundo caso, 
embora tenha ocorrido tal polarização, não houve também a problematização sobre a definição do interesse público a ser tutelado na implementação da decisão.

Dada a diferente natureza dos interesses surgidos, pode-se reconhecer uma clara predominância do segundo grupo como coincidente, e de certo modo vocalizador dos interesses primeiros do governo brasileiro com o estabelecimento da medida questionada. Exatamente porque a medida de restrição originariamente se fundava em interesse legítimo de proteção da saúde pública e do meio ambiente, é que não coube fugir da coerência na busca pela manutenção da medida. ${ }^{1036}$

Não se pode afirmar, contudo, que a totalidade das medidas tomadas pelo governo brasileiro - e por qualquer governo do "mundo real" - reflita sempre um consenso construído democraticamente, ou necessariamente promova o interesse público de sua sociedade. É de notório conhecimento que o interesse público não se caracteriza como tal por ser emanado de autoridade administrativa, já que muitas vezes essas atuam à prescindir deste interesse. ${ }^{1037}$ Assim, em sendo tais medidas questionadas no âmbito do Sistema de Solução de Controvérsias, e em se exigindo a implementação de sua decisão, o caminho dessa implementação pode servir como um espaço de discussão da conveniência e oportunidade da medida original. Dizendo de outro modo: mesmo quando as especificidades concretas da decisão do Sistema de Solução de Controvérsias, como vocalizadas pelo OSC, permitirem a manutenção da medida com adequações, não necessariamente seria essa a escolha de melhor interesse para a sociedade brasileira.

Assim, nos parece cristalino que a implementação das decisões do Sistema de Solução de Controvérsias da OMC oferece oportunidade ímpar ao Estado - constituído

1036 A proteção do meio ambiente e da saúde humana pode ser aduzida dos comandos constitucionais, que na situação ofereciam um limite à discricionariedade na definição da aplicação da medida: " $O$ agente econômico, público ou privado, não pode destruir o meio ambiente a pretexto de exercer seu direito constitucionalmente tutelado de livre iniciativa. Um ambiente saudável é o limite ao livre exercício da atividade econômica e, para defendê-lo e garantir a sadia qualidade de vida da população, o Estado tem o poder-dever de intervir na atuação empresarial, mediante a edição de leis e regulamentos que visem a promover o desenvolvimento sustentado”. BARROSO, Luís Roberto. A Ordem Econômica Constitucional e os Limites à Atuação Estatal no Controle de Preços. In: Temas de Direito Constitucional. Tomo II. $2^{\circ}$ edição. Rio de Janeiro: Renovar, 2009. p. 59.

1037 "Uma coisa é a estrutura do interesse público, e outra é a inclusão e o próprio delineamento, no sistema normativo, de tal ou qual interesse que, perante este mesmo sistema, será reconhecido como dispondo desta qualidade. Vale dizer: não é de interesse público a norma, medida ou providência que tal ou qual pessoa ou grupo de pessoas estimem que deva sê-lo - por mais bem-fundadas que estas opiniões o sejam do ponto de vista politico ou sociológico-, mas aquele interesse que como tal haja sido qualificado em dado sistema normativo. (...) Com efeito, dita qualificação quem faz é a Constituição e, a partir dela, o Estado, primeiramente através dos órgãos legislativos, e depois por via dos órgãos administrativos, nos casos e limites da discricionariedade que a lei lhes haja conferido". BANDEIRA DE MELLO, Celso Antônio. Curso de Direito Administrativo. $31^{\text {a }}$ edição. São Paulo: Malheiros Editores, 2014. p. 68. 
como Estado Democrático de Direito- de problematizar, discutir e construir suas medidas à luz da participação do setor privado e da sociedade civil. Ademais, mesmo dentro do setor privado, há um natural embate entre visões, uma vez que os agentes econômicos são afetados de modo muito diferente, podendo uma certa medida de implementação beneficiar alguns e prejudicar outros, e um outro caminho de implementação escolhido inverter esses resultados.

As diferenças são naturais, benéficas e até essenciais a uma democracia. E o Poder Executivo é incumbido da ponderação concreta dessas diferenças na tomada de decisão e na definição de estratégias governamentais, não se pretendendo com este marco normativo substituir o papel dos órgãos decisórios na implementação. O que se defende, contudo, é uma implementação mais transparente, participativa e próxima da sociedade brasileira.

A partir desta reflexão, é possível visualizar múltiplas vantagens do estabelecimento de um marco normativo geral para a implementação das decisões. A primeira vantagem, mencionada ao longo de todo esse capítulo, ocorre no incremento da previsibilidade e da segurança jurídica. Essas são características essenciais à estabilização social, e em última análise, impactam inclusive na captação de investimentos estrangeiros pelo país.

Ademais, a previsão normativa de manifestação e participação institucionalizada pelos interessados confere legitimidade à medida de implementação escolhida pelo Brasil. Não se trata de garantir que todos os grupos terão seus interesses acolhidos pelo procedimento, o que seria impossível, mas de garantir que tais perspectivas serão ponderadas na arbitragem da decisão pautada pelo interesse público.

Também observa-se como uma potencial vantagem do estabelecimento de um marco normativo geral a possibilidade de comprovar - perante os árbitros, em procedimentos do artigo 21. 3 (c) do ESC - uma legítima estimativa do período de tempo razoável, tendo em conta que os mecanismos institucionalizados e com passos compulsórios tendem a ser um parâmetro considerado para a definição de tempo necessário para a implementação.

A criação de um marco normativo pode também evitar obstáculos e complexidades que a omissão normativa poderia permitir como, por exemplo, a previsão de medidas de implementação que envolvam conduta dos demais membros da federação. 
Por fim, conclui-se que a ação responsável do Poder Legislativo nesta seara pode garantir que a discricionariedade do Poder Executivo não seja utilizada de modo a prejudicar os interesses legítimos da sociedade brasileira. Assim, é a fragilidade da prática atual que justifica o oferecimento de proposta de normatização básica do procedimento de implementação das decisões do Sistema de Solução de Controvérsias da OMC no Brasil.

\subsubsection{Proposição de Adoção de Marco Normativo Geral}

A inexistência de procedimentos previstos para a determinação da medida de implementação das decisões do Sistema de Solução de Controvérsias da OMC, em preenchimento ao espaço de discricionariedade pelo Poder Executivo, tem se dado de modo a possibilitar apenas seletivamente a participação de setores interessados, por meio de convite informal.

Nesse contexto, propõe-se a criação de um marco normativo geral para a implementação das decisões do OSC, solucionando obscuridades, e equilibrando a flexibilidade que necessariamente deve existir com a transparência e a possibilidade de participação dos interessados.

Este marco normativo deve, portanto, permitir a flexibilidade necessária para abarcar as situações futuras de implementação, mas deve também enfrentar certos desafios, tais como (a) as obscuridades em relação à aplicabilidade e invocabilidade das decisões do OSC e (b) a ausência de competências expressas para a implementação pelas instituições do ordenamento jurídico.

Tal legislação deve traçar um procedimento para a definição da medida de implementação, que seria seu objetivo final. Por meio da previsão de um conjunto ordenado de etapas, pode-se incrementar a transparência e institucionalizar a participação da sociedade civil e dos grupos econômicos com interesse na implementação, bem como formalizar os meios de cooperação entre os órgãos da Administração Pública. 
De modo geral, vislumbramos que as etapas deste procedimento poderiam ser delineadas da seguinte forma:

(i) Publicação oficial da decisão do Sistema de Solução de Controvérsias da OMC (decisão do OSC e relatório do painel e/ou Órgão de Apelação adotados), por meio de decreto presidencial;

(ii) Criação de um Grupo Técnico no âmbito da CAMEX, com a participação de Ministérios pertinentes à temática da decisão, representantes da sociedade civil organizada e dos principais grupos econômicos envolvidos na temática, e sob a coordenação de um representante da CGC do MRE;

(iii) Consultas à Assessoria Jurídica do MRE, à Advocacia Geral da União e ao Ministério Público Federal (este último órgão, no caso de a implementação envolver temática que lhe possa ser pertinente);

(iv) Divulgação ampla, pelo Grupo Técnico, dos pareceres em questão;

(v) Abertura de consultas para apresentação de contribuições por escrito e realização de audiência(s) pública(s) sobre a decisão e as hipóteses de implementação;

(vi) Apreciação das contribuições recebidas em consulta e nas audiências por parte do Grupo Técnico e discussões sobre as maneiras possíveis de implementar a decisão;

(vii) Elaboração de relatório explanando as maneiras possíveis de implementar a decisão, e as potenciais consequências jurídicas, políticas e econômicas vislumbradas com a sua respectiva adoção; 
(viii) Apresentação desse relatório aos membros do Conselho de Ministros da CAMEX, que deverão votar e escolher o meio de implementar a decisão;

(ix) Publicação da decisão da CAMEX determinando o meio escolhido para a implementação, através de Resolução.

Uma vez escolhido o modo pelo qual a decisão será implementada, e com a divulgação dos principais documentos desse grupo de trabalho, o marco normativo poderia conferir ao MRE, por meio de sua Coordenação Geral de Contenciosos, a competência de operacionalizar a cooperação interinstitucional necessária para concretizar a medida. Embora possa-se alocar essa competência de coordenação em outro órgão - ou inclusive criar um órgão específico para tal - entendemos que a CGC possui a visão globalizante do contencioso, tendo capacidade de atuar no gerenciamento da medida e de sua eventual "defesa" no mecanismo de solução de controvérsias.

É certo que a concretização da medida, a depender de sua natureza e extensão, poderá exigir a participação de outros órgãos, inclusive pertencentes ao Poder Judiciário e ao Poder Legislativo. A partir desse marco normativo sugerido, a Coordenadoria Geral de Contenciosos poderia, embasada no comando da Resolução da CAMEX, buscar acionar os órgãos competentes, segundo a distribuição constitucional e legal de competências ordinárias dos órgãos.

Por meio do procedimento proposto se conferiria a publicidade a e transparência necessárias ao procedimento de escolha da medida de implementação - acompanhadas do incremento de participação da sociedade civil e dos setores privados interessados, possibilitando o controle em diversas esferas, como se pugna necessário.

Assim, não se trata de retirar a competência de jure da CAMEX ou o protagonismo de facto da CGC na implementação das decisões do Sistema de Solução de Controvérsias da OMC, mas de legitimar a tomada de decisão, incrementando as possibilidades de definição do interesse público nacional na concretização da decisão adjudicatória internacional. 
De todo modo, concordamos que o resgate do formato original da CAMEX, e sua vinculação à Casa Civil, seria passo relevante à institucionalidade deste órgão, contribuindo para o seu fortalecimento, que poderia importar também ao modelo que aqui se propõe. ${ }^{1038} 1039$

Além das etapas suscintamente descritas, com as espelhadas competências em matéria de implementação das decisões do Sistema de Solução de Controvérsias da OMC, a lei poderia também elencar parâmetros que direcionem a escolha do Poder Executivo. A definição de linhas mestras para o preenchimento da discricionariedade do Poder Executivo é uma das mais legítimas e rotineiras formas de atuação do poder legislativo, e poderia se materializar por meio da enunciação de princípios e/ou critérios que deverão ser seguidos no momento de escolha pelo meio de implementação da decisão da OMC.

A enunciação destes princípios e/ou critérios deve espelhar os princípios constitucionais já existentes, como os princípios fundantes da ordem econômica, não impedindo, contudo, que o legislador incorpore novos parâmetros a serem seguidos e ponderados na concretização das decisões do Sistema de Solução de Controvérsias da OMC.

1038 Assim sugere por exemplo Pedro da Motta Veiga: "O fato é que, à luz desses objetivos e critérios [eficiência e legitimidade], a concepção original da CAMEX - órgão interministerial vinculado à Presidência da República e dotado de uma instância política (que reúne os Ministros), outra técnica e uma Secretaria Executiva - parece ainda hoje bastante apropriada para desempenhar tal função. Neste sentido, a concentração de poderes em um novo órgão a ser criado ou o deslocamento da CAMEX de volta à Presidência não são incompatíveis com o atual modelo politico de formulação e podem até mesmo fortalecêlo." VEIGA, Pedro da Motta. Política Comercial no Brasil: características, condicionantes domésticos e policy-making. In: ICONE, FIPE e DFID (Coord.). Instituto de Estudos do Comércio e Negociações Internacionais (ICONE), Fundação Instituto de Pesquisas Econômicas (FIPE) e Kingdon Department for International Development (DFID). Políticas comerciais comparadas: desempenho e modelos organizacionais. São Paulo: Singular, 2007, p. 71-162. Disponível em: <http://www10.iadb.org/intal/intalcdi/PE/2009/03126.pdf>. Acesso em: 30 abr. 2014. p. 155.

1039 Em relação ao fortalecimento da CAMEX como meio de incrementar a transparência da participação brasileira no Sistema de Solução de Controvérsias da OMC, confira-ae a reflexão de Daniel Arbix: "Reforçar a Camex ou reconstruir, por outras vias, a coordenação da política de comércio exterior do Brasil parece imperativo para que, além de bem conduzidos, os contenciosos internacionais sejam escolhidos de maneira mais transparente e atenta aos interesses nacionais. Os interessados diretos nesta questão especifica, sejam agentes públicos, sejam privados, já travam diálogos em inúmeros foros, mediados ou não por órgãos governamentais, em busca das bases para o melhor recurso ao OSC (informações, argumentos e meios de combate)." ARBIX, Daniel A. Contenciosos brasileiros na OMC: pauta comercial, política e instituições. Contexto Internacional, v. 30, p. 3, p. 655-699, 2008. p. 681. 


\section{CONCLUSÃO}

Os avanços no caminho da juridificação e jurisdicionalização das relações econômicas internacionais vieram acompanhados de novas responsabilidades, que precisam ser assumidas pelos membros da sociedade internacional. A participação na Organização Mundial do Comércio e a consequente vinculação ao seu Sistema de Solução de Controvérsias trouxeram desafios e complexidades ao Brasil, e aos demais membros do sistema multilateral de comércio.

O Sistema de Solução de Controvérsias da Organização Mundial do Comércio se insere em um contexto contemporâneo de rearquitetura do Direito Internacional, que passa a constituir um corpus juris multifacetado, e que permeia todos os aspectos da vida humana. Dessa forma, o sistema jurídico internacional passa a exigir a participação das instituições internas, imiscuídas com valores internacionais, ao aproximar-se da consciência dos interesses de uma comunidade internacional.

A passagem do GATT para a Organização Mundial do Comércio consubstanciou-se no adensamento de juridicidade do sistema multilateral de comércio, refletido em diversos aspectos normativos e institucionais. A Organização Mundial do Comércio atua, pois, como um veículo para a evolução do Direito Internacional, e constitui um subsistema aberto do Direito Internacional Público - uma vez que dele se origina e com ele mantém constante fluxo.

Uma noção a nosso ver equivocada, frequentemente repetida na doutrina, que se buscou "desnaturalizar" ao longo do trabalho, é a caracterização do Sistema de Solução de Controvérsias da Organização Mundial do Comércio como um mecanismo de resolução de litígios de natureza política, em função da aprovação dos relatórios dos painéis e do Órgão de Apelação pelo Órgão de Solução de Controvérsias, a quem incumbe "decidir". Conforme se explicitou, a necessidade formal de adoção dos relatórios pelo Órgão de Solução de Controvérsias, que se explica por motivações históricas, restou esvaziada de conteúdo com a adoção do consenso reverso.

Constatou-se que o desenho do Sistema de Solução de Controvérsias da 
Organização Mundial do Comércio é ímpar no Direito Internacional, ao incorporar órgãos de natureza adjudicatória, inseridos num contexto diplomático. A existência do Órgão de Solução de Controvérsias, contudo, não esvazia o caráter adjudicatório do mecanismo e de suas decisões. É a juridicidade do sistema que se manifesta em um contexto de diplomacia, reduzido ou quase anulado em sua dimensão prática. Por meio do Órgão de Solução de Controvérsias, são vocalizados comandos jurídicos e obrigatórios de conduta, que assentam fim a um litígio internacional, com base no Direito Internacional.

Em consequência, uma decisão do Sistema de Solução de Controvérsias da Organização Mundial do Comércio - embora não preveja meios determinados para a concretização da obrigação de tornar a medida questionada conforme ao corpus juris da Organização Mundial do Comércio - enseja uma obrigação jurídica concreta determinável pelo Estado que deve cumpri-la, cabendo-lhe escolher o modo pelo qual implementará seu comando. Sua obrigatoriedade se reforça na análise sistêmica dos dispositivos do Entendimento relativo às Normas e Procedimentos sobre Solução de Controvérsias, bem como na cogência codificada pela Convenção de Viena sobre o Direito dos Tratados de 1969.

No tocante aos efeitos das normas e decisões do sistema multilateral de comércio, os Acordos da OMC não possuem menção expressa sobre sua aplicabilidade ou invocabilidade nos ordenamentos jurídicos de seus membros, ficando a cargo de cada sistema jurídico nacional a definição de tal problemática. Do exame realizado, tendo em conta os principais participantes do Sistema de Solução de Controvérsias da Organização Mundial do Comércio - Estados Unidos, União Europeia, Japão e China -, verificou-se uma tendência dos respectivos sistemas jurídicos internos a negar aplicabilidade e invocabilidade direta aos Acordos multilaterais, restringindo ou impossibilitando que as partes se apoiem em suas normas como fonte de direitos e/ou substrato jurídico para ações judiciais.

Em que pese dependerem igualmente do tratamento conferido pela Constituição, leis e jurisprudência de um determinado membro, a temática dos efeitos das decisões do Sistema de Solução de Controvérsias da Organização Mundial do Comércio em um dado ordenamento jurídico diferencia-se conceitualmente da aplicabilidade e invocabilidade conferidas aos Acordos da Organização Mundial do Comércio no mesmo ordenamento. Embora os tribunais nacionais tenham demonstrado certa tendência a tratá-los de modo 
similar, as obrigações decorrentes dos Acordos da Organização Mundial do Comércio, e aquelas decorrentes de decisões do Sistema de Solução de Controvérsias dessa organização são oriundas de fontes notadamente distintas, e portanto a concessão ou denegação de efeitos deveria considerar tal distinção na construção argumentativa acolhida pelos juízes e tribunais nacionais.

A investigação empírica empreendida no universo de casos, com o recorte metodológico devidamente explicitado, tornou evidente a multiplicidade das medidas que podem ser utilizadas para proceder ao cumprimento da decisão do Sistema de Solução de Controvérsias da Organização Mundial do Comércio no ordenamento jurídico interno dos membros. Os diferentes mecanismos nacionais de implementação dependem, contudo, do caráter próprio da medida que se reconheceu desconforme com a disciplina multilateral, e acabam por refletir sua complexidade.

Com o intuito de sistematizar os mecanismos de implementação, verificou-se que a concretização das decisões do Sistema de Solução de Controvérsias da Organização Mundial do Comércio pode requerer medidas em conjunto e/ou em separado, oriundas do Poder Executivo, do Poder Legislativo e/ou do Poder Judiciário, e de natureza administrativa, legislativa ou jurisdicional. Tendo em conta a amplitude da medida, observou-se que a implementação pode envolver medidas especificas ou medidas de aplicabilidade geral.

A essa multiplicidade de medidas e de sujeitos envolvidos, adiciona-se a variedade de temáticas submetidas à apreciação do Sistema de Solução de Controvérsias da Organização Mundial do Comércio e que, portanto, podem ser objeto de uma medida de implementação. Assim, diferentemente do GATT, a Organização Mundial do Comércio abarca uma diversidade temática em seus Acordos, o que exige a verificação cuidadosa dos múltiplos interesses em jogo no preenchimento do espaço de discricionariedade conferido ao Estado para a implementação.

Adentrando no ordenamento jurídico brasileiro, locus final desta investigação, a implementação das decisões do Sistema de Solução de Controvérsias da Organização Mundial do Comércio foi contextualizada na temática mais ampla de implementação das decisões dos Tribunais Internacionais no Brasil, que tem ocorrido de modo casuístico. Embora a Constituição Federal de 1988 não tenha mencionado competências específicas nesse tocante, foi estabelecido um edifício principiológico que deve orientar a busca por 
um procedimento que garanta transparência e possibilite eventual controle por parte da sociedade brasileira.

Conforme observou-se da pesquisa empreendida, as decisões do Sistema de Solução Controvérsias da Organização Mundial do Comércio não são formalmente internalizadas pelo Brasil, e sua implementação tem ocorrido de modo difuso e casuístico, com a predominância de facto da Coordenação Geral de Contenciosos do Ministério das Relações Exteriores nessa atividade. Contudo, a fase de implementação projeta-se como etapa do procedimento da solução de controvérsias notadamente distinta das demais, uma vez que envolve atos de Direito Interno, tratando-se, sob esta perspectiva, de atividade da administração pública brasileira.

Assim, o caminho para implementação dessas decisões no ordenamento jurídico pátrio se configura como um objeto duplo: se por um lado se configura como uma escolha de concretização de um posicionamento externo do Brasil, por outro lado constitui uma escolha da administração pública brasileira, que deve estar respaldada legalmente e legitimamente, e deve considerar os múltiplos indicadores da escolha guiada pelo interesse público. Ademais, essa percepção se insere em uma reflexão mais ampla de que o exercício contemporâneo da política externa dos Estados constitui-se como um aspecto de uma “política pública integral”, indissociável das políticas públicas internas.

A Constituição Brasileira, conquanto não seja explícita no tocante às competências e procedimentos para a implementação de decisões adjudicatórias internacionais, erigiu um plano de ação principiológico, que deve orientar a construção por respostas também nessa temática. A concretização de comandos teleológicos como a democracia e o primado do Direito deve pautar, pois, a escolha do meio pelo qual o Brasil implementará as decisões do Sistema de Solução de Controvérsias da Organização Mundial do Comércio.

Em decorrência das reflexões desenvolvidas, concluiu-se pela necessidade e conveniência do estabelecimento de um marco normativo geral para a implementação das decisões do Sistema de Solução de Controvérsias da Organização Mundial do Comércio no Brasil, que garantiria publicidade e transparência a essa escolha, tornando-a mais legítima e compatível com a disciplina constitucional. Esse procedimento deveria promover, nessa perspectiva, a institucionalização da participação da sociedade civil e dos setores privados interessados, o que poderia aproximá-los da normatividade internacional. 
Assim, se a participação do Brasil no Sistema de Solução de Controvérsias da Organização Mundial do Comércio envolve a assunção de responsabilidades, é preciso se preocupar com a estrutura interna de governança ligada à implementação desses deveres, que se materializam em uma dinâmica transnormativa. É esse o caminho para a construção de capacidade normativa-institucional para a concretização da noção de comunidade internacional, cujas estruturas de efetivação do Direito Internacional estejam próximas dos indivíduos, fim último dos Estados e da ordem jurídica global. 


\section{REFERÊNCIAS BIBLIOGRÁFICAS}

Livros

AMARAL JÚNIOR, Alberto do. A Solução de Controvérsias na OMC. São Paulo: Atlas, 2008.

AMORIM, Celso. Discursos, palestras e artigos do Chanceler Celso Amorim: 20032010. Brasília: Ministério das Relações Exteriores, Departamento de Comunicações e Documentação: Coordenação-Geral de Documentação Diplomática, 2011.

BANDEIRA DE MELlo, Celso Antônio. Curso de Direito Administrativo. $31^{\text {a }}$ edição. São Paulo: Malheiros Editores, 2014.

BARRAL, Welber. Solução de Controvérsias na Organização Mundial do Comércio. Brasília: Fundação Alexandre de Gusmão, 2007.

BASTOS, Fernando Loureiro. Os Acordos Mistos em Direito Comunitário: Contributo para a compreensão do seu fundamento jurídico. Lisboa: SPB II Editores, 1999.

BOBBIO, Norberto. Teoria do Ordenamento Jurídico. $6^{\mathrm{a}}$ ed. Brasília: Editora Universidade de Brasília, 1995.

BULL, Hedley. The Anarchical Society: A Study of Order in World Politics. $3^{\text {rd }}$ ed. Basingstoke; New York: Palgrave, 2002.

CAPUCIO, Camilla. O Regionalismo e o Comércio Internacional. Belo Horizonte: Editora Arraes, 2012.

CASELLA, Paulo Borba.; ACCIOLY, Hildebrando.; NASCIMENTO E SILVA, G. E. do. Manual de direito internacional público. São Paulo: Saraiva, 2009.

CASTRO, Thales. Teoria das relações internacionais. Brasília: FUNAG, 2012. 
CARREAU, Dominique; JUILLARD, Patrick. Droit International Économique. Paris: Editions Dalloz, 2007.

CROOME, John. Reshaping the World Trading System: A history of the Uruguay Round. $\quad 2^{\mathrm{a}} \quad$ ed. $\quad$ [S.1.]: $\quad$ [S.n.], 1998. Disponível em: $<$ http://www.hse.ru/data/2011/12/05/1271919456/Reshaping\%202_e.pdf> Acesso em: 12 fev. 2014.

DALLARI, Pedro Bohomoletz de Abreu. Constituição e Relações Exteriores. São Paulo: Saraiva, 1994.

Constituição e Tratados internacionais. São Paulo: Saraiva, 2003.

DINAMARCO, Cândido Rangel. Instituições de Direito Processual Civil. Volume I. $5^{\text {a }}$ ed. São Paulo: Malheiros Editores, 2005.

FERRAJOLI, Luigi. A soberania no mundo moderno: Nascimento e crise do Estado Nacional. São Paulo: Martins Fontes, 2002.

FERRAZ JUNIOR Tércio Sampaio. Introdução ao Estudo do Direito: técnica, decisão, dominação. $6^{\text {a }}$ ed. São Paulo: Atlas, 2011. p. 145.

FREITAS, Juarez. O Controle dos Atos Administrativos e os princípios fundamentais. $5^{\text {a }}$ ed. Malheiros Editores: São Paulo, 2013.

FRIEDMANN, Wolfgang. The Changing Structure of International Law, New York: Columbia University Press, 1964.

GABSCH, Rodrigo D'Araujo. Aprovação de tratados internacionais pelo Brasil: possíveis opções para acelerar o seu processo. Brasília : FUNAG, 2010.

HART, Herbert Lionel Adolphus. O Conceito de Direito. São Paulo: Editora WMF Martins Fontes, 2009.

HELISKOSKI, Joni. Mixed Agreements as a Technique for Organizing the International Relations of the European Community and its Member States. Boston: Kluer Law International, 2001. 
JACKSON, Jonh H. Sovereignty, the WTO and Changing Fundamentals of International Law. New York: Cambridge University Press, 2006.

. The World Trade Organization: Constitution and Jurisprudence. London: Royal Institute of International Affairs, 1998. Press, 2000.

The Jurisprudence of GATT and the WTO. Cambridge: Cambridge University

JACKSON, John H.; DAVEY, William J.; SYKES JR., Alan O. Legal Problems of International Economic Relations. Cases, Materials and Text. $4^{\mathrm{a}}$ ed. St. Paul: West Group, 2002.

KELSEN, Hans. Princípios do Direito Internacional. Ijuí: Unijuí, 2010.

. Teoria pura do direito. $7^{\mathrm{a}}$ ed. São Paulo: Editora WMF Martins Fontes, 2006.

KRSTICEVIC, Viviana. Implementación de las decisiones del Sistema Interamericano de Derechos Humanos: Aportes para los procesos legislativos. Buenos Aires: Center for Justice and International Law - CEJIL, 2009.

LAFER, Celso. A OMC e a regulamentação do comércio internacional: uma visão brasileira. Porto Alegre: Livraria do Advogado, 1998.

LOSANO, Mario G. Sistema e estrutura no direito. Volume I: das origens à escola histórica. São Paulo: Editora WMF Martins Fontes, 2008.

MATSUSHITA, Mitsuo; MAVROIDS, Petros C.; SCHOENBAUM, Thomas J. The World Trade Organization: Law, Practice, and Policy. 2a Ed. Oxford: Oxford University Press, 2006.

MAURER, Hartmut. Direito Administrativo Geral. Barueri, SP: Manole, 2006.

MEDAUAR, Odete. Direito Administrativo Moderno. $15^{\text {a }}$ ed. São Paulo: Editora RT, 2011.

MENEZES, Wagner. Ordem Global e Transnormatividade. Ijuí: Ed. Unijuí, 2005. 
. Direito Internacional na América Latina. Curitiba: Ed. Juruá, 2007.

. Tribunais Internacionais: Jurisdição e Competência. São Paulo: Saraiva, 2013.

MENGOZZI, Paolo. Istituzione di Diritto Comunitario e Dell'Unione Europea. Padova: CEDAM, 2003.

MESQUiTA, Paulo Estivallet de. A Organização Mundial do Comércio. Brasília : FUNAG, 2013.

MIRAGEM, Bruno. A nova administração pública e o direito administrativo. São Paulo: Revista dos Tribunais, 2011.

MOTA, Pedro Infante. O Sistema GATT/OMC: Introdução Histórica e Princípios Fundamentais. Coimbra: Almedina, 2005.

PAUWELYN, Joost. Conflict of Norms in Public International Law: How WTO Relates to other Rules of International Law. New York: Cambridge University Press. 2003.

PETERSMANN, Ernst-Ulrich. The GATT/WTO Dispute Settlement System: International Law, International Organizations and Dispute Settlement. London: Kluwer Law International, 1997.

RAMOS, André de Carvalho. Curso de Direitos Humanos. São Paulo: Saraiva, 2014.

_. Processo Internacional dos Direitos Humanos. São Paulo: Saraiva, 2012.

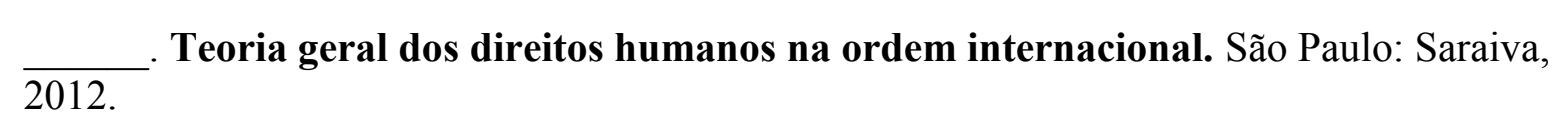

REALE, Miguel. Filosofia do Direito. São Paulo: Saraiva, 2002.

. Fundamentos do direito: contribuição ao estudo da formação da natureza e da

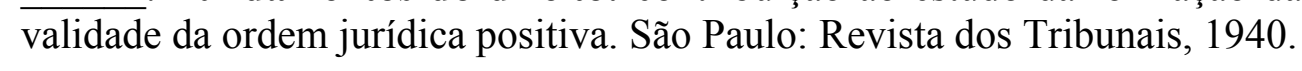


Teoria tridimensional do direito. 5. ed. São Paulo: Saraiva, 1994.

ROMANO, Santi. O ordenamento jurídico. Florianópolis: Boiteux, 2008.

SILVA, Roberto Luiz. Direito econômico internacional e direito comunitário. Belo Horizonte: Del Rey, 1995.

SCHOUERI, Luís Eduardo. Direito tributário. 3a ed. São Paulo: Saraiva, 2013.

ThORSTEnSEN, Vera. OMC- Organização Mundial do Comércio: As Regras do Comércio Internacional e a Nova Rodada de Negociações Multilaterais. $2^{a}$ ed. São Paulo: Aduaneiras, 2001.

TRINDADE, Antônio Augusto Cançado. Os tribunais internacionais contemporâneos. Brasília: FUNAG, 2013.

VAN DEN BOSSCHE, Peter.; ZDOUC, Werner. The Law and Policy of the World Trade Organization. $3^{\mathrm{a}}$ ed. Cambridge: Cambridge University Press, 2013.

VARELLA, Marcelo D. Direito Internacional Público. $3^{\text {a }}$ ed. São Paulo: Saraiva, 2011.

YIN, Robert. Estudo de Caso. Planejamento e métodos. Porto Alegre: Bookman, 2001.

UNITED NATIONS. Handbook on the Peaceful Settlement of Disputes between States. New York: United Nations, 1992. Office of Legal Affairs, Codification Division. OLA/COD/2394.

\section{Capítulos de Livros}

ALMEIDA, Paulo Roberto de. Pensamento diplomático brasileiro: Introdução metodológica às ideias e ações de alguns dos seus representantes. In: PIMENTEL, José Vicente de Sá (org). Pensamento diplomático brasileiro: formuladores e agentes da política externa (1750-1950). Brasília: FUNAG, 2013. Vol. I, p. 15-40. 
AMORIM, Celso. Depoimento. In: COSTA, Sérgio Rodrigues; BUENO, Miguel Garcia. A saga do algodão: das primeiras lavouras à ação na OMC. Rio de Janeiro: Insight Engenharia, 2004, p. 128-133. Disponível em: $<$ http://www.abrapa.com.br/biblioteca/Documents/institucional/publicacoes/A\%20Saga $\% 2$ 0do\%20Algodao.pdf>. Acesso em: 20 mar. 2014.

ANDRADE, Luciano Mazza de. O contencioso do algodão: o desafio da implementação. In: BENJAMIN, Daniela Arruda. (Org.). O Sistema de Solução de Controvérsias da OMC: uma perspectiva brasileira. Brasília: FUNAG, 2013, p. 85-112.

AZEVÊDO, Roberto. Depoimento. In: COSTA, Sérgio Rodrigues; BUENO, Miguel Garcia. A saga do algodão: das primeiras lavouras à ação na OMC. Rio de Janeiro: Insight Engenharia, 2004, p. 89-97. p. 92. Disponível em: $<$ http://www.abrapa.com.br/biblioteca/Documents/institucional/publicacoes/A\%20Saga $\% 2$ 0do\%20Algodao.pdf>. Acesso em: 20 mar. 2014.

, Roberto Carvalho de. Prefácio. In: BENJAMIN, Daniela Arruda. (Org.). O Sistema de Solução de Controvérsias da OMC: uma perspectiva brasileira. Brasília: FUNAG, 2013, p. 23-30.

BARRAL, Welber. A Influência do Comércio Internacional no Processo de Desenvolvimento. In: BARRAL, Welber; PIMENTEL, Luiz Otávio (Org.). Comércio Internacional e Desenvolvimento. Florianópolis: Fundação Boiteaux, 2006, p. 11-35.

. De Bretton Woods a Doha. In: BARRAL, Welber. (Org). O Brasil e a OMC. $2^{\mathrm{a}}$ ed. Curitiba: Juruá, 2006, p. 9-26.

; PRAZERES, Tatiana. Solução de Controvérsias. In: BARRAL, Welber (Org). O Brasil e a OMC. $2^{\text {a }}$ ed., $5^{\text {a }}$ tir. Curitiba: Juruá, 2006, p. 27-46.

BARROSO, Luís Roberto. A Ordem Econômica Constitucional e os Limites à Atuação Estatal no Controle de Preços. In: Temas de Direito Constitucional. Tomo II. $2^{\circ}$ edição. Rio de Janeiro: Renovar, 2009, p. 47-82.

BENJAMIN, Daniela Arruda. A aplicação interna das decisões do Órgão de Solução de Controvérsias da OMC na prática. In: BENJAMIN, Daniela Arruda. (Org). O Sistema de Solução de Controvérsias da OMC: uma perspectiva brasileira. Brasília: FUNAG, 2013, p. 573-594. 
Introdução. In: BENJAMIN, Daniela Arruda. (Org). O Sistema de Solução de

Controvérsias da OMC: uma perspectiva brasileira. Brasília: FUNAG, 2013, p. 31-41.

CAETANO, Ana T. Os contenciosos sobre carne de frango In: BENJAMIN, Daniela Arruda. (Org). O Sistema de Solução de Controvérsias da OMC: uma perspectiva brasileira. Brasília : FUNAG, 2013, p. 351-368.

CASELLA, Paulo Borba. Direito Internacional e Direito Interno na CR (1988). In: VIEIRA, José Ribas (Org). 20 Anos da Constituição Cidadã de 1988: Efetivação ou impasse institucional? Rio de Janeiro: Forense, 2008, p. 483-508.

Direito Internacional Pós-moderno e a revisão dos modelos institucional e normativo. In: BRIC- Brasil, Rússia, Índia, China e África do Sul: uma perspectiva de cooperação internacional. São Paulo: Atlas, 2011, p. 113-137.

CORDEIRO, Ênio. Considerações finais. In: BENJAMIN, Daniela Arruda. (Org). O Sistema de Solução de Controvérsias da OMC: uma perspectiva brasileira. Brasília: FUNAG, 2013, p.731-734.

EVANS, David. PEREIRA, Celso de Tarso. DSU Review: A View From the Inside. In: YEARS, Rufus. WILSON, Bruce. (Ed.). Key Issues in WTO Dispute Settlement: The First Ten Years. Nova Iorque: Cambridge Univesity Press, 2005, p. 251-264.

GINSBURG, Tom; SHAFFER, Gregory C., How Does International Law Work: What Empirical Research Shows. In: The Oxford Handbook to empirical legal research. CANE, Peter; KRITZER, Herbert M (eds.). New York: Oxford University Press, 2010. p. 753-784.

HOWSE, Robert. The Most Dangerous Branch? WTO Appellate Body Jurisprudence on the Nature and Limits of the Judicial Power. Chapter 1. In: COTTIER, Thomas; MAVROIDIS, Petros C. (Eds.) The Role of the Judge in International Trade Regulation: Experience and Lessons for the WTO. Michigan: University of Michigan Press, 2003, p. 11-41.

KUYPER, Peter J. O Direito do GATT com um Campo Especial do Direito Internacional: Ignorância, Refinamentos Posteriores ou um Sistema Autocontinente de Direito Internacional? In: CASELLA, Paulo Borba; MERCADANTE, Araminta de (coord.). Guerra comercial ou integração mundial pelo comércio?: a OMC e o Brasil. São Paulo: LTr, 1998, p. 15-49. 
Taveira (Org). Direito e Poder nas Instituições e nos Valores do Público e do Privado Contemporâneos. Estudos em Homenagem a Nelson Saldanha. Barueri: Manole, 2005, p. 215-232.

. O Sistema de Solução de Controvérsias da Organização Mundial do Comércio. In: CASELLA, Paulo Borba; MERCADANTE, Araminta de (coord.). Guerra comercial ou integração mundial pelo comércio?: a OMC e o Brasil. São Paulo: LTr, 1998, p. 729755.

LUPI, André Lipp Pinto Bastos. Comentários ao Artigo 31. In: SALIBA, Aziz Tuffi (Org.) Direito dos Tratados: Comentários à Convenção de Viena sobre o Direito dos Tratados (1969). Belo Horizonte: Arraes Editores, 2011, p. 223-238.

MACEDO, Paulo Emílio Vauthier Borges de. Comentários ao Artigo 26. In: SALIBA, Aziz Tuffi (Org.) Direito dos Tratados: Comentários à Convenção de Viena sobre o Direito dos Tratados (1969). Belo Horizonte: Arraes Editores, 2011, p. 182-189.

. Comentários ao Artigo 27. In: SALIBA, Aziz Tuffi (Org.) Direito dos Tratados: Comentários à Convenção de Viena sobre o Direito dos Tratados (1969). Belo Horizonte: Arraes Editores, 2011. p. 191-197.

MACHADO, Luiz Alberto Figueiredo. Apresentação. In: BENJAMIN, Daniela Arruda. (Org). O Sistema de Solução de Controvérsias da OMC: uma perspectiva brasileira. Brasília: FUNAG, 2013, p. 7-8.

MANN, Erika. A Parliamentary Dimension to the WTO: More than Just a Vision. Reforming the World Trading System. In: PETERSMANN, Ernst- Ulrich. Reforming the World Trading System. Legitimacy, Efficiency and Democratic Governance. Oxford: Oxford University Press, 2005, p. 421-428.

MAREGA, Flávio. O contencioso sobre pneus reformados na OMC: uma importante vitória multilateral do Brasil. In: BENJAMIN, Daniela Arruda. (Org). O Sistema de Solução de Controvérsias da OMC: uma perspectiva brasileira. Brasília : FUNAG, 2013, p. $155-184$.

MELLO, Celso Duvivier de Albuquerque. O Direito Internacional Público no Direito Brasileiro. In: CASELLA, Paulo Borba. Dimensão Internacional do Direito. Estudos em Homenagem a G. E. do Nascimento e Silva. São Paulo: LTr, 2000, p. 297-310.

. Perspectivas do Direito Internacional Econômico. In: CASELLA, Paulo Borba; MERCADANTE, Araminta de (coord.). Guerra comercial ou integração mundial pelo 
comércio?: a OMC e o Brasil. São Paulo: LTr, 1998, p. 70-93.

MESQUITA, Paulo Estivallet de. O papel central do setor privado na atuação do Brasil no Sistema de Solução de Controvérsias da OMC. In: BENJAMIN, Daniela Arruda. (Org). O Sistema de Solução de Controvérsias da OMC: uma perspectiva brasileira. Brasília : FUNAG, 2013, p. 251-264.

MOREIRA NETO, Diogo de Figueiredo. Princípios informativos e interpretativos do direito administrativo. In: Mutações do Direito Público. Rio de Janeiro: Editora Renovar, 2006, p. 265-314.

MURPHY, Anna. In the maelstrom of change: The Article 113 Committee in the governance of external economic policy. In: CHRISTIANSEN, Thomas. KIRCHNER, Emil. (eds.) Committee Governance in the European Union. Manchester: Manchester University Press, 2000, p. 98-104.

NIELSEN, Laura Beth. The Need for Multi-Method Approaches in Empirical Legal Research. In: The Oxford Handbook to empirical legal research. CANE, Peter; KRITZER, Herbert M (eds.). New York: Oxford University Press, 2010, p. 951-975.

OLIVEIRA, Luciana Maria de. A Eficácia da "Suspensão de Concessões ou de Outras Obrigações" para a Implementação das Recomendações do Órgão de Solução de Controvérsias (OSC) da OMC e os Membros em Desenvolvimento. In: VEÇOSO, Fabia Fernandes Carvalho (Coord.). Direito Internacional em Contexto. Direito, Gestão e Prática. Serie GVlaw. Direito, Gestão e Prática. São Paulo: Ed. Saraiva, 2012, p. 285-322.

PEREIRA, Celso de Tarso. Retaliação na OMC: Procedimento, Prática e Objetivos. In: BENJAMIN, Daniela Arruda. (Org). O Sistema de Solução de Controvérsias da OMC: uma perspectiva brasileira. Brasília : FUNAG, 2013, p. 595-628.

PINTO, Daniel Roberto. Muito mais que a Embraer: os contenciosos Brasil-Canadá e o país que queremos ser. In: BENJAMIN, Daniela Arruda. (Org). O Sistema de Solução de Controvérsias da OMC : uma perspectiva brasileira. Brasília : FUNAG, 2013, p. 45-84.

PRATES, Alcides G. R. Comentários sobre o Acordo Constitutivo da OMC. In: CASELLA, Paulo Borba; MERCADANTE, Araminta de (coord.). Guerra comercial ou integração mundial pelo comércio?: a OMC e o Brasil. São Paulo: LTr, 1998, p. 94-124.

RANGEL, Vicente Marotta. Direito internacional e relações internacionais: a teoria tridimensional no contexto brasileiro. In: Teorias de relaciones internacionales $\mathbf{y}$ de derecho internacional en America Latina. Caracas: 1989, p. 462-483. 
Francisco de Vitoria y el Federalismo Internacional. In: MANGAS MARTÍN, Araceli. La Escuela de Salamanca y el Derecho Internacional en America: del Passado al Futuro. Salamanca: Asociacion Espanola de Professores de Derecho Internacional, 1993, p. 205-214.

. Marraqueche 94 e os Dois GATT: Breve Apresentação. In: CASELLA, Paulo Borba; MERCADANTE, Araminta de (coord.). Guerra comercial ou integração mundial pelo comércio?: a OMC e o Brasil. São Paulo: LTr, 1998, p. 126-136.

. Tratado de Assunção. Órgãos do MERCOSUL. Decisões e resoluções. Fontes do direito internacional. Direito interno das organizações internacionais e dos Estados Membros. Delimitação do âmbito de consulta. (1992). In: CACHAPUZ de MEDEIROS, Antônio Paulo. Pareceres Dos Consultores Jurídicos Do Itamaraty. Volume IX (19902000) . Brasília: Fundação Alexandre de Gusmão, 2009, p. 125-129.

RIBEIRO, Manuel de Almeida. Comentários ao Artigo 5. In: SALIBA, Aziz Tuffi (Org.) Direito dos Tratados: Comentários à Convenção de Viena sobre o Direito dos Tratados (1969). Belo Horizonte: Arraes Editores, 2011, p. 24-26.

RIBEIRO, Haroldo de Macedo; LEÃO, Bruno Guerra Carneiro. O contencioso dos pneus reformados: articulação interinstitucional e diplomacia interna. In: BENJAMIN, Daniela Arruda. (Org). O Sistema de Solução de Controvérsias da OMC: uma perspectiva brasileira. Brasília : FUNAG, 2013, p. 265-280.

SACERDOTI, Giorgio. A Transformação do GATT na Organização Mundial do Comércio. In: CASELLA, Paulo Borba; MERCADANTE, Araminta de (coord.). Guerra comercial ou integração mundial pelo comércio?: a OMC e o Brasil. São Paulo: LTr, 1998, p. 50-69.

SCHMIDT, Luiz Fellipe Flores. A construção da retaliação brasileira no caso algodão: os desafios do pioneirismo. In: BENJAMIN, Daniela Arruda. (Org). O Sistema de Solução de Controvérsias da OMC: uma perspectiva brasileira. Brasília : FUNAG, 2013, p. 629648 .

SERRADOR NETO, José. O contencioso comercial Embraer-Bombardier. In: BENJAMIN, Daniela Arruda. (Org). O Sistema de Solução de Controvérsias da OMC: uma perspectiva brasileira. Brasília : FUNAG, 2013, p. 281-312.

SHAFFER, Gregory C. Is the EC moving towards a U.S. Partnership Model? Capítulo 4. In: SHAFFER, Gregory C. Defending Interests: Public-private Partnerships in WTO 
Litigation. Washington: Brooking Institutions Press, 2003, p. 65-101.

VEIGA, Pedro da Motta. Politica Comercial no Brasil: características, condicionantes domésticos e policy-making. In: ICONE, FIPE e DFID (Coord.). Instituto de Estudos do Comércio e Negociações Internacionais (ICONE), Fundação Instituto de Pesquisas Econômicas (FIPE) e Kingdon Department for International Development (DFID). Políticas comerciais comparadas: desempenho e modelos organizacionais. São Paulo: Singular, 2007, p. 71-162. Disponível em: http://www10.iadb.org/intal/intalcdi/PE/2009/03126.pdf>. Acesso em: 30 abr. 2014.

- IGLESIAS, Roberto Magno. A institucionalidade da política brasileira de comércio exterior. In: CASTELAR, A.; MARKWALD, R. PEREIRA, L. V. (Org.). O desafio das exportações. Rio de Janeiro: BNDES, 2002, p. 51-96. Disponível em: < http://www.bndes.gov.br/SiteBNDES/export/sites/default/bndes_pt/Galerias/Arquivos/con hecimento/livro_desafio/Relatorio-03.pdf $>$.

WATANABE, Érika. "Enforcement" em TRIPS e no Mecanismo de Solução de Controvérsias: uma vitória dos países em desenvolvimento (Org). In: BENJAMIN, Daniela Arruda. (Org). O Sistema de Solução de Controvérsias da OMC: uma perspectiva brasileira. Brasília : FUNAG, 2013, p. 669-688.

WOLANSKI, Pedro Henrique Fleider. A jurisprudência recente do Órgão de Apelação sobre o Acordo TBT: os casos "EUA - Atum II" e "EUA - Cigarros de Cravo" In: BENJAMIN, Daniela Arruda. (Org). O Sistema de Solução de Controvérsias da OMC: uma perspectiva brasileira. Brasília : FUNAG, 2013, p 417-436.

ZACHER, Mark. The Decaying pillars of the Westphalian temple: Implications for International Order and Governance. In: ROSENAU, James; CZEMPIEAL, Ernst-Otto. Governance, Order and Change in World Politics. Cambridge University Press, 1992, p. $58-101$.

ZAVALLA, José Akcell. "European communities - customs classification of frozen boneless chicken cuts" In: BENJAMIN, Daniela Arruda. (Org). O Sistema de Solução de Controvérsias da OMC: uma perspectiva brasileira. Brasília: FUNAG, 2013, p. 185-198. 


\section{Cursos da Academia de Direito Internacional de Haia}

ABI-SAAB, George. Cours Général de Droit International Public. Recueil des Cours, vol. 207, p. 9-463, 1987.

BUERGENTHAL, Thomas. Self-executing and non-self-executing treaties in national and international law. Recueil des cours, vol. 235, p. 303-400, 1992.

CAFLISCH, Lucius. Cent ans de règlement pacifique des différends interétatiques. Recueil des cours, vol. 288, p. 245-467, 2001.

CHARNEY, Jonathan I. Is international law threatened by multiple international tribunals? Recueil des cours, vol. 271, p. 101-382, 1998.

DUPUY, Pierre-Marie. L'unité de l'ordre juridique international: cours général de droit international public (2000). Recueil des cours, vol. 297, pp. 9-489, 2002.

FROWEIN, Jochen A. Reactions by Not Directly Affected States to Breaches of Public International Law. Recueil des cours, vol. 248. p. 349-445, 1994.

KELSEN, Hans. Les rapports de système entre le droit interne et le droit international public. Recueil des cours, vol. 14, p. 227-331, 1926.

LAUTERPACHT, Hersch. Règles générales du droit de la paix. Recueil des cours, vol. 62, pp. 95-422, 1937. 1947. The international protection of human rights. Recueil des cours, vol. 70, p. 1-108,

McRAE, Donald M. The contribution of international trade law to the development of international law. Recueil des cours, vol. 260, p. 99-238, 1996.

PASTOR RIDRUEJO, José Antonio. Le droit international à la veille du vingt et unième siècle: normes, faits et valeurs. Cours général de droit international public. Recueil des cours, vol. 274, p. 9-308, 1998. 
SCELLE, Georges. Règles générales du droit de la paix. Recueil des cours, vol. 46, p. 327-703, 1933.

SCHWARZENBERGER, Georg. The fundamental principles of international law. Recueil des cours, vol. 87, p. 191-385, 1955.

. The principles and standards of international economic law. Recueil des cours, vol. 117, p. 1-98, 1966.

SIMMA, Bruno. From bilateralism to community interest in international law. Recueil des cours, vol. 250, p. 217-384, 1994.

TOMUSCHAT, Christian. International law : ensuring the survival of mankind on the eve of a new century. General course on public international law. Recueil des cours, vol. 281, p. 9-438, 1999.

. Obligations Arising for States without or against Their Will. Recueil des cours, vol. 241, p. 195-374, 1993.

TRIEPEL, Heinrich. Les rapports entre le droit interne et le droit international. Recueil des cours, vol. 1, p. 77-121, 1923.

TRINDADE, Antônio Augusto Cançado. International law for humankind: towards a new jus gentium (II). General course on public international law. Recueil des cours, vol. 317, p. 9-312, 2005.

VERDROSS, Alfred. Le fondement du droit international. Recueil des cours, vol. 16, p. 247-323, 1927.

WALDOCK, Humphrey. General course on public international law. Recueil des cours, vol. 106, p. 1-251, 1962.

WANG, Tieya. International Law in China: Historical and Contemporary Perspectives, Recueil des Cours, vol. 221, p. 195-369, 1990.

YASUAKI, Onuma. A Transcivilizational Perspective on International Law. Questioning Prevalent Cognitive Frameworks in the Emerging Multi-Polar and Multi-Civilizational World of the Twenty-First Century. Recueil des cours, vol. 342, p. 77-418, 2010. 
Artigos, Revistas e Periódicos

ABI-SAAB, Georges. The Normalization of International Adjudication: Convergence and Divergencies. New York University Journal of International Law \& Policy, vol. 43, p. 1-43, 2010-2011.

ALILOVIC, Robert. Consultations Under The WTO's Dispute Settlement System. Dalhousie Journal of Legal Studies, vol. 9, p. 279-301, 2000

ALEMANNO, Alberto. Judicial Enforcement of the WTO Hormones Ruling within the European Community: Toward EC Liability for the Non-Implementation of WTO Dispute Settlement Decisions. Harvard International Law Journal, vol. 45, p. 547-562, 2004.

ALMEIDA, Paulo Roberto de. Relações Internacionais e Interesse Nacional: As Relações Econômicas do Brasil e a Ordem Constitucional. In: Boletim da Sociedade Brasileira de Direito Internacional, n. 69-71, p. 164-183, 1987-1989.

ANTONIADIS, Antonis. The European Union and WTO law: a nexus of reactive, coactive and proactive approaches. World trade review, vol. 6, n. 1, p. 45-87, 2007.

ARBIX, Daniel A. Contenciosos brasileiros na OMC: pauta comercial, política e instituições. Contexto Internacional, vol. 30, n. 3, p. 655-699, 2008.

BAHALA, Raj. The Myth about Stare Decisis and International Trade Law (Part One of a Trilogy). American University International Law Review, vol. 14, p. 845-956, 19981999.

BAHALA, Raj. The Power Of The Past: Towards de Jure Stare Decisis In WTO Adjudication (Part Three of a Trilogy). George Washington International Law Review, vol. 33, p. 873-978, 2000-2001.

BARNETT, Mark A. The United States Court of International Trade in the MiddleInternational Tribunals: An Overview. Tulane Journal of International \& Comparative Law, vol. 19, p. 421-432, 2010-2011. 
BELLO, Judith Hippler. The WTO Dispute Settlement Understanding: Less Is More. Editorial Comment. American Journal of International Law, vol. 90, p. 416-418, 1996.

BILDER, Richard B. Some Limitations of Adjudication as an International Dispute Settlement Technique. Virginia Journal of International Law, vol. 231, pp. 1982.

BONELLI, Regis. Políticas de competitividade industrial no Brasil - 1995/2000. Texto para discussão IPEA, n. 810. Rio de Janeiro: IPEA, jul. 2001.

BRAND, Ronald A. Direct Effect of International Economic Law in the United States and the European Union. Northwestern Journal of International Law \& Business, vol. 17, issue 1, p. 556-608, 1996-1997.

CÂMARA FILHO, José Sette. Hans Kelsen e a teoria pura do Direito Internacional. Boletim da Sociedade Brasileira de Direito Internacional, n. 8, p. 70-91, jul./dez. 1948.

CAMERON, James; GRAY, Kevin R. Principles of International Law in the WTO Dispute Settlement Body. International and Comparative Law Quarterly, vol. 50, p. 249-298, 2001.

CANIZARES, Alex O. Is Charming Betsy Loosing Her Charm? Interpreting U.S. Statutes Consistently with International Trade Agreements and the Chevron Doctrine. Emory International Law Review, vol. 20, p. 592-650, 2006.

CAPUCIO, Camilla. O Status Jurídico da União Europeia como Membro da OMC: Estudo sobre os Acordos Mistos no Direito Comunitário. In: MENEZES, Wagner. Estudos de Direito Internacional: Anais do $7^{\circ}$ Congresso Brasileiro de Direito Internacional. Vol. XVII. Curitiba: Juruá, 2009, p. 135-146.

CASELLA, Paulo Borba. Fundamentos e Perspectivas do Direito Internacional pósModerno. Revista da Faculdade de Direito da Universidade de São Paulo, p. 433-466, $\mathrm{jan} / \mathrm{dez} 2006$.

CASS, Deborah Z. The "Constitutionalization" of International Trade Law: Judicial NormGeneration as the Engine of Constitutional Development in International Trade'. European Journal of International Law, vol. 12, p. 39-75, 2001.

CELLI JUNIOR, Humberto. O Acordo de Serviços (GATS) e de Investimentos (TRIMS) na OMC: Espaço para Políticas de Desenvolvimento. CEBRI Artigos. Vol. 1, a. II, 2007. 
CHO, Sungjoon. Beyond Rationality: A Sociological Construction of the World Trade Organization. Virginia Journal of International Law, vol. 52, p. 321-354, 2011-2012

COHEN, Harlan Grant. From Fragmentation to Constitutionalization. Pacific McGeorge Center for Global Business and Development Law Journal, vol. 25, p. 381-394, 2012.

CONDON, Bradly J. Lost in Translation: Plurilingual Interpretation of WTO Law. Journal of International Dispute Settlement, vol. 1, n. 1, p. 191-216, 2010.

COUTO, Estevão Ferreira. Judicialização da política externa e direitos humanos. Revista Brasileira de Política Internacional, vol. 1, n. 46, p. 140-161, 2004.

COZENDEY, Carlos Márcio Bicalho. O Sistema de Solução de Controvérsias da OMC: para além dos contenciosos, a política externa. Disponível em: $<$ http://www.itamaraty.gov.br/temas/temas-multilaterais/copy_of_desenvolvimentocomercio-e-financas/organizacao-mundial-do-comercio/solucao-decontroversias/cgc/artigo-cozendey> Acesso em: 15 dez. 2013.

DAVENPORT, Filicia. The Uruguay Round Agreements Act Supremacy Clause: Congressional Preclusion of the CharmingBetsy Standard with Respect to WTO Agreements. The Federal Circuit Bar Journal, vol. 15, n. 2, p. 279-314, 2005-2006.

DAVEY, William J. Compliance Problems in WTO Dispute Settlement. Cornell International Law Journal, vol. 42, p. 119-128, 2009.

Implementation in WTO Dispute Settlement: An Introduction to the Problems and Possible Solutions. The Research Institute of Economy, Trade and Industry. RIETI Discussion Paper Series, n. 05-E-013, mar. 2005.

DAVIES, Arwel. Connecting or Compartmentalizing the WTO and United States Legal Systems? The Role Of The Charming Betsy Canon. Journal of International Economic Law, vol. 10, issue 1, 117-149, jan. 2007.

DE MEY, Delphine. The Effect of WTO Dispute Settlement Rulings in the EC Legal Order: Reviewing Van Parys v Belgische Interventie-en Restitutiebureau (C-377/02). German Law Journal, vol. 6, p. 1025-1032, 2005. 
DUPUY, Pierre-Marie. The Constitutional Dimension of the Charter of the United Nations Revisited. In: BOGDANDY, Armin von; WOLFRUM, Rüdiger (eds.). Max Planck Yearbook of United Nations Law, vol. 1, pp. 1-32, 1997.

DUNOFF, Jeffrey L. Constitutional Conceits: The WTO's 'Constitution' and the Discipline of International Law. European Journal of International Law, vol. 17, n. 3, p. 647-675, 2006.

Why Constitutionalism Now? Text, Context and the Historical Contingency of Ideas. Journal of International Law and International Relations, vol. 1, p. 191-211, 2004-2005.

EECKHOUT, Piet. Judicial Enforcement of WTO Law in the European Union - Some Further Reflections. Journal of International Economic Law, vol. 5, p. 91-110, 2005.

. The Scales of Trade-Reflections on the Growth and Functions of the WTO Adjudicative Branch. Journal of International Economic Law, vol. 13, p. 3-26, 2010.

EGLI, Patricia. European Community-EC compliance with rulings of WTO Dispute Settlement Body in Bananas dispute- effect of WTO agreements and dispute settlement rulings in EC law-standing to challenge EC legislation as inconsistent with WTO agreements and rulings. American Journal of International Law, vol. 100, p. 449-454, 2006.

ERRICO, John. The WTO in the EU: Unwinding the Knot. Cornell International Law Journal, vol. 44, p. 179-208, 2011.

EWING-CHOW, Michael.; GOH, Alex W. S. Goh.; PATIL, Akshay Kolse. Are Asian Wto Members Using The WTO DSU 'Effectively'? Journal of International Economic Law, vol. 16(3), p. 669-705, set. 2013. p. 704.

FABRI, Hélène Ruiz. Is There a Case - Legally and Politically - for Direct Effect of WTO Obligations? European Journal of International Law, vol. 25, n. 1, p. 151-173, 2014.

FINGER, Michael J. Implementing the Uruguay Round Agreements: Problems for Developing Countries. Initiative for Policy Dialogue. Network paper. Columbia University, 2001. Disponível em: $<$ http://policydialogue.org/files/publications/Implementing_Uruguay_Round_Finger.pdf $>$ Acesso em: 20 dez. 2013. 
FRANÇA, Cássio. SANCHEZ BADIN, Michelle Ratton. A inserção internacional do poder Executivo Federal brasileiro. Análises e propostas, n. 40, ago. 2010. Friedrich Ebert no Brasil. Disponível em: <http://library.fes.de/pdf-files/bueros/brasilien/07917.pdf> Acesso em: 16 fev. 2014.

FUKUNAGA, Yuka. Securing Compliance Through The Wto Dispute Settlement System: Implementation of DSB Recommendations. Journal of International Economic Law, vol. 9, issue 2, p. 383-426, mai 2006.

GAO, Henry. Elephant in the Room: Challenges of Integrating China into the WTO System. Asian Journal of WTO \& International Health Law \& Policy, vol. 6, p. 137168, 2011.

GREENWALD, John D. After Corus Staal-Is There Any Role, And Should There Be-For Wto Jurisprudence In The Review Of U.S. Trade Measures By U.S. Courts? Georgetown Journal of International Law, vol. 39, p. 199-216, 2007-2008.

GREENWALD, John. WTO Dispute Settlement: an exercise in trade law legislation? Journal of International Economic Law, v. 6, n. 1, p.113-124, 2003.

GRIMMETT, Jeanne J. World Trade Organization (WTO) decisions and their effect in U.S. law. Washington, DC: Congressional Research Service, 2011. Disponível em: $<$ http://digitalcommons.ilr.cornell.edu/key_workplace/807>. Acesso em: 10 mar. 2014.

HORN, Henrik.; MAVROIDIS, Petros C. EC - Antidumping Duties on Malleable Cast Iron Tube or Pipe Fittings from Brazil (WT/DS219/AB/R:DSR 2003: VI, 2613). American Law $\quad$ Institute, 2003. Disponível em <http://www.ali.org/doc/wto/wto2003/Chapter_5.pdf>. Acesso em: 15 dez. 2013.

HSUEH, Ching-wen. Direct Effect, WTO Compliance Mechanism and the Protection for Individuals: Lessons Learned from the EC. Asian Journal of WTO \& International Health Law and Policy, vol. 4, issue 2, p. 521-556, sep. 2009.

HUDEC, Robert E. GATT or GABB? - The Future Design of the General Agreement on Tariffs and Trade. Yale Law Journal, vol. 80, n. 7, p. 1299-1387, jun. 1971.

JACKSON, John. International Law Status of WTO Dispute Settlement Reports: Obligation to Comply or Option to Buy Out? American Journal of International Law, vol. 98, p. 109-125, 2004. 
. The Great 1994 Sovereignty Debate: United States Acceptance and Implementation of the Uruguay Round Results. Columbia Journal of Transnational Law, vol. 36, p. 157-188, 1998.

. The WTO "Constitution" and Proposed Reform: Seven "Mantras" Revisited. Journal of International Economic Law, vol. 4, p. 67-78, 2001.

JI, Wenhua; HUANG, Cui. China's Experience in Dealing with WTO Dispute Settlement: A Chinese Perspective. Journal of World Trade, vol. 45, n. 1, p. 1-37, 2011.

KUIJPER, Pieter J. The Conclusion and Implementation of the Uruguay Round Results by the European Community. European Journal of International Law, vol. 6, p. 222-244, 1995

LAFER, Celso. Dilplomacia e Transparência: o Arquivo do Itamaraty. Boletim da Sociedade Brasileira de Direito Internacional, n. 69-71, p. 108-117, 1987-1989.

jul./ago. 2006.

Miguel Reale (1910-2006) - uma homenagem. Revista USP, n.70, p. 110-119, O Gatt, a Cláusula de Nação mais favorecida e a América Latina. Boletim da

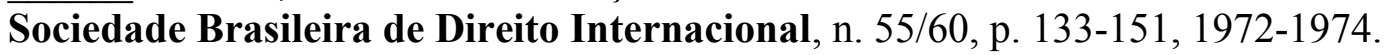

LAMY, Pascal. The Place of the WTO and its Law in the International Legal Order. European Journal of International Law, vol. 17, n. 5, p. 969-984, 2006.

LEAL-ARCAS, Rafael. Polycephalous Anatomy of The EC in the WTO: An Analysis of Law and Practice. Flórida Journal of International Law, vol. 19, p. 569-670, 2007.

LEITNER, Kara; LESTER, Simon. WTO Dispute Settlement 1995-2013: A Statistical Analysis. Journal of International Economic Law, vol. 17, p. 191-201, 2014.

LOBO, Maria Teresa de Carcomo Lobo. Execução de Decisões Judiciais de Cortes Internacionais Contra Estados Soberanos. Boletim Científico da ESMPU, a. II , n. 8, p. 121-132, jul./set. 2003.

LUPI, André Lipp Pinto Basto. O Brasil é dualista? Anotações sobre a vigência de normas internacionais no ordenamento brasileiro. Revista de informação legislativa, a. 46, n. 184, pp. 29-45, out./dez. 2009. 
MARTINES, Francesca. Direct Effect of International Agreements of the European Union. European journal of International Law, vol. 25 n. 1, p. 129-147, 2014.

MARCEAU, Gabrielle. WTO Dispute Settlement and Human Rights. European Journal of International Law, vol. 13, p. 753-814, 2002.

MAVROIDIS, Petros. Outsourcing of Law? WTO Law as Practiced By WTO Courts. American Journal of International Law, vol. 2, p. 421-474, 2008.

. Remedies in the WTO Legal System: Between a Rock and a Hard Place. European Journal of International Law, vol. 11, 763-813, 2000.

McGINNIS, John O. MOVSESIAN, Mark L. The World Trade Constitution. Harvard Law Review, vol. 114, issue 2, p. 511-605, dec. 2000.

MCLACHLAN, Campbell. Principle of Systemic Integration And Article 31(3)(C) of The Vienna Convention. International and Comparative Law Quarterly, vol. 54, p. 279319, 2005.

MENEZES, Wagner. O Direito Internacional Contemporâneo e a Teoria da Transnormatividade. Pensar, vol. 12, p. 134-144, 2007.

MIYAMOTO, Shiguenoli. As grandes linhas da política externa brasileira. Brasília: CEPAL. Escritório do Brasil/IPEA, 2011. Textos para discussão CEPAL/ IPEA. (Texto para Discussão CEPAL-IPEA, 45).

PAUWELYN, Joost. Bridging Fragmentation and Unity: International Law as a universe of Interconnected Islands. Michigan Journal of International Law, vol. 25, p. 903-916, 2003-2004.

. The Role of Public International Law in the WTO: How Far Can We Go? American Journal of International Law, vol. 95, p. 535-578, 2001.

. The Limits of Litigation: "Americanization" and Negotiation in the Settlement of WTO Disputes. Ohio State Journal On Dispute Resolution, vol. 19, issue 1, p. 121-140, 2003. 
$\overline{2005-2006 .}$

The Transformation of World Trade. Michingan Law Review, vol. 104, p. 1-66,

PENG, Shin-yi. WTO Legalistic Approach and East Asia: From the Legal Culture Perspective. Asian-Pacific Law \& Policy Journal, vol. 1, p. 1-35, 2000.

PEREIRA, Celso de Tarso, COSTA, Valéria Mendes; ARAÚJO, Leandro Rocha de. 100 Casos na OMC: a experiência brasileira em solução de controvérsias. Política Externa, vol. 20, n. 4, p. 121-134, mar/abr/maio 2012.

PESCATORE, Pierre. The GATT Dispute Settlement Mechanism: Its Present Situation and its Prospects. Journal of International Arbitration, vol. 10, issue 1, p. 27-42, 1993.

PETERS, Anne. The merits of global Constitutionalism. Indiana Journal of Global Legal Studies, vol. 16, p. 397-411, 2009.

; ARMINGEON, Klaus. Introduction-Global Constitutionalism from an Interdisciplinary Perspective. Indiana Journal of Global Legal Studies, vol. 16, p. 385395, 2009.

PETERSMANN, Ernst-Ulrich. De-Fragmentation of International Economic Law through Constitutional Interpretation and Adjudication with Due Respect for Reasonable Disagreement. Loyola University Chicago International Law Review, vol. 6, issue 1, p. 209-248, 2008-2009.

From the Hobbesian International Law of Coexistence to Modern Integration Law: The WTO Dispute Settlement System, Journal of International Economic Law, vol. 1, issue 2, p. 175-198, 1998.

How to Constitutionalize International Law and Foreign Policy for the Benefit of Civil Society? Michigan Journal of International Law, vol. 20, p. 1-30, 1998.

. Human Rights, International Economic Law and Constitutional Justice: A Rejoinder. European Journal of International Law , vol. 19, issue 5, p. 955-960, 2008.

Legal, Economic and Political Objectives of National and International Competition Policies: Constitutional Functions of WTO "Linking Principles" for Trade and Competition. New England Law Review, vol. 34, p. 145-162, 1999 
. Multilevel Governance Problems of the World Trading System beyond the WTO Conference at Bali 2013. Journal of International Economic Law, vol. 17, p. 233-270, 2014.

- Multilevel Judicial Governance as Guardian of the Constitutional Unity of International Economic Law. Loyola of Los Angeles International and Comparative Law Review, vol. 30, Issue 3, p. 367-418, 2008.

Multi-Level Judicial Trade Governance without Justice? On the Role of Domestic Courts in the WTO Legal and Dispute Settlement System. European University Institute, Department of Law, EUI Working Paper LAW, n. 2006/44.

- Multilevel Judicial Governance of International Trade Requires a Common Conception of Rule of Law and Justice. Journal of International Economic Law, vol. 10, p. 529-551, 2007.

- The Future of the WTO: From Authoritarian Mercantilism to Multilevel Governance for the Benefit of Citizens. Asian Journal of WTO \& International Health Law and Policy, vol. 6, issue 1, p. 45-80, mar/2011.

The WTO Constitution and Human Rights. Journal of International Economic Law, vol. 3, p. 19-25, 2000.

PHAM, Hansel T. Developing Countries and the WTO: The Need for More Mediation in the DSU. Harvard Negotiation Law Review, vol. 9, p. 331-390, 2004.

QI, Tong. China's First Decade Experience in the WTO Dispute Settlement System: Practice and Prospect. Asian Journal of WTO \& International Health Law \& Policy, vol. 7, p. 143-180, 2012.

QUEIROZ, Adriana de. Brasil está à beira de uma "revolução do internacionalismo". CEBRI Textos. 2013. Disponível em: <http://www.cebri.org/portal/publicacoes/cebritextos/revolucao-do-internacionalismo> Acesso em: 10 fev. 2014.

RAMOS, André de Carvalho. Tratados Internacionais: Novos espaços de atuação do Ministério Público. Boletim Científico da ESMPU, n. 7, a. II, p. 81-100, abr.jun. 2003.

RAMOS, Guilherme Cantarino da Costa. IBI - the institute of brazilian business \& public management issues. Minerva program - spring 2010. CAMEX and USTR: an institutional analysis of the conduct of trade policy in brazil and the U.S. Elliot School 
of International Affairs. George Washington University. Washington DC, April 2010. Disponível em: < http://www.gwu.edu/ ibi/minerva/Spring2010/Ramos.pdf $>$ Acesso em: 10 jul. 2014.

REYNOLDS, Kara M. Why Are So Many WTO Disputes Abandoned? American University. Department of Economics Working Paper Series, n. 2007-05, jun. 2007. Disponível em: $\quad<$ http://aladinrc.wrlc.org/bitstream/handle/1961/4988/200705.pdf? sequence $=1>$ Acesso em: 12 mai. 2014.

ROMANO, Cesare. A Taxonomy of International Rule of Law Institutions. Journal of International Dispute Settlement, vol. 2, n. 1, p. 241-277, 2011.

ROSAS, Allan. Implementation and Enforcement of WTO Dispute Settlement Findings: An EU Perspective. Journal of International Economic Law, vol. 4, p. 131-144, 2001.

SALIBA, Aziz Tuffi; AUGUSTIN, Bruno Herwig Rocha. Comentários ao Artigo 46. In: SALIBA, Aziz Tuffi (Org.) Direito dos Tratados: Comentários à Convenção de Viena sobre o Direito dos Tratados (1969). Belo Horizonte: Arraes Editores, 2011. p. 372-404.

SANCHEZ, Michelle Ratton et al. Política Externa Como Política Pública: Uma Análise pela Regulamentação Constitucional Brasileira. (1967-1988) Revista de Sociologia e Política, vol. 27, p. 125-143, nov. 2006.

SCHNEPF, Randy. Status of the WTO Brazil-U.S. Cotton Case. Washington, DC: Congressional Research Service, dez. 2013. Disponível em: < http://fas.org/sgp/crs/row/R43336.pdf> Acesso em: 10 mar. 2014.

SCHWARTZ, Warren.; SYKES, Alan 0. The Economic Structure of Renegotiation and Dispute Resolution in the World Trade Organization. Journal of Legal Studies, vol. 31, 179-204, 2002.

SEAWRIGHT, Jason.; GERRING, John. Case Selection Techniques in Case Study Research: A Menu of Qualitative and Quantitative. Political Research Quarterly, vol. 61, n. 2, p. 294-308, jun. 2008.

SERDAREVIC, Asja. European Union and Its Member States as a Collective Actor in WTO Decision-Making Process. American Consortium on European Union Studies (ACES). EU Center of Excellence Washington. ACES Cases, n. 2010.3. Disponível em: $<$ http://transatlantic.sais-

jhu.edu/ACES/ACES_Cases/2010.3_ACES_Cases_Serdarevic.pdf>. Acesso em: 05 mar. 2014. 
SHAFFER, Gregory; RATTON SANCHEZ, Michelle; ROSENBERG, Barbara. The Trials of Winning at the WTO: What Lies Behind Brazil's Success. Cornell International Law Journal, vol. 41, issue 2, p. 383-501, 2008.

SILVA, Elaini Cristina Gonzaga da. SPÉCIE, Priscila. VITALE, Denise. Um novo arranjo institucional para a política externa brasileira. Brasília: CEPAL. Escritório do Brasil/IPEA, 2010. Textos para discussão CEPAL/ IPEA. (Texto para Discussão CEPAL-IDEA, 3).

SLAUGHTER, Anne-Marie. BURKE-WHITE, William. Future of International Law Is Domestic (or, the European Way of Law). Harvard International Law Journal, vol. 47, p. 327-352, 2006.

SOUZA, Celina. Políticas Públicas: uma revisão da literatura. Sociologias, ano 8, n. 16, p. 20-45, jul/dez 2006. p. 24-25.

SPAIN, Anna. Integration Matters: Rethinking The Architecture Of International Dispute Resolution. University of Pennsylvania Journal of International Law, vol. 32, p. 1-56, 2010-2011.

STEINBERGER, Eva. The WTO Treaty as a Mixed Agreement: Problems with the EC's and the EC Member States' Membership of the WTO. European Journal of International Law, vol. 17 n.4, p. 837-862, 2006.

TANCREDI, Antonello. EC Practice in the WTO: How Wide is the 'Scope for Manoeuvre'? European Journal of International Law, vol. 15, n. 5, p. 933-961, 2004.

TANIGUCHI, Yasuhei. WTO Dispute Settlement as Seen by a Proceduralist. Cornell International Law Journal, vol. 42, p. 1-21, 2009.

TARULLO, Daniel. K. The Hidden Costs of International Dispute Settlement: WTO Review of Domestic Anti-Dumping Decisions. Law \& Policy in International Business. vol. 34, p. 109-181, 2002-2003. p. 178.

THEILER, Eduardo. Os direitos e deveres internacionais dos Estados. Boletim da Sociedade Brasileira de Direito Internacional, 1948. N. 8, p. 57-69.

TRACHTMAN, Joel P. Bananas, Direct Effect and Compliance. European Journal of International Law, vol 10, n. 4, p. 655-678, 1999. 
The Constitutions of the WTO. European Journal of International Law, vol.

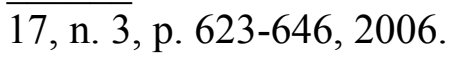
$\overline{167,2007 .}$

The WTO Cathedral. Standford Journal of International Law, vol. 43, p. 127 -

VAN AAKEN, Anne. Defragmentation of Public International Law Through Interpretation: A Methodological Proposal. Indiana Journal of Global Legal Studies, vol. 16, pp. 483-ss, 2009.

VAN DER BORGHT, Kim. The Review of the WTO Understanding on Dispute Settlement: Some Reflections on the Current Debate. American University International Law Review, vol. 14, p. 1223-1243, 1998.

VAZQUEZ, Carlos Manuel. The Four Doctrines of Self-Executing Treaties. American Journal of International Law, vol. 89, p. 695- 723, 1995.

VENTURA, Deisy. ONUKI, Janina. MEDEIROS, Marcelo et alli. Internalização das normas do MERCOSUL. Serie Pensando o Direito, vol. 45. Brasília: Ministério da Justiça, 2012.

VIDIGAL, Geraldo. Re-assessing WTO Remedies: The Prospective and the Retrospective. Journal of International Economic Law, vol. 16, issue 3, 505-534, jul. 2013.

VILLALPANDO, Santiago. The Legal Dimension of the International Community: How Community Interests Are Protected in International Law? European Journal of International Law, vol. 21, n. 2, p. 387-419, 2010.

WWF, World Wide Fund For Nature. A League of Gentlemen: Who really runs EU Trade Decision-Making? nov. $2003 . \quad$ Disponível em: $<$ http://www.google.com.br/url?sa=t\&rct $=\mathrm{j} \& \mathrm{q}=\&$ esrc $=$ s\&source=web\&cd $=1 \&$ ved $=0 \mathrm{CC} 8$ QFjAA>. Acesso em: 6 mar. 2014.

XIULI, Han. China's First Ten Years in WTO Dispute Settlement. Journal of World Investment \& Trade, vol. 12, p. 49-64, 2011.

YAMANE, Hiroko. The WTO Dispute Settlement Mechanism and Japanese Traders. Journal of International Economic Law, vol. 1, p. 683-689, 1998. 
YUJI, Iasawa. Effectuation of International Law in the Municipal Legal Order of Japan. SIK, Ko Swan; SYATAUW J. J. G., PINTO M. C. W. (Eds.) Asian Yearbook of International Law, vol. 4, p. 143-169, 1995.

ZIMMERMANN, Claus D. Toleration of Temporary Non-Compliance: The Systematic Safety Valve of WTO Dispute Settlement Revisited. Trade, Law \& Developmentm, vol. 3, p. 382-406, 2011.

ZHANG, Naigen. Implementation of WTO Dispute Settlement. Manchester Journal of International Economic Law, vol. 5, issue 2, p.111-125, 2008.

ZHANG, Xin. Domestic Effect of the WTO Agreement in China: Trends and Implications. The Journal of World Investment, vol. 3, p. 912-937, 2002.

Implementation of the WTO Agreements: Framework and Reform. Northwestern Journal of International Law \& Business, vol. 23, p. 383-432, 2002-2003.

ZONNEKEYN, Geert A. EC Liability for the Non-Implementation of WTO Dispute Settlement Decisions - Advocate General Alber Proposes a 'Copernican Innovation' in the Case Law of the ECJ. Journal of International Economic Law, vol. 6, p. 761-769, 2003.

. The Latest on Indirect Efect of WTO Law in the legal order: The Nakajima Case Law Misjudged? Journal of International Economic Law, vol. 4, p. 597-608, 2001.

. The legal status of WTO panel reports in the EC legal order: Some reflections on the opinion of advocate general Mischo in the Atlanta case. Journal of International Economic Law, vol. 2, p. 713-722, 1999.

Teses e Dissertações

CLODOVIL, Leonor Augusta Giovine. O Interesse Público no Antidumping. 2009. 345 f. Tese (Doutorado em Direito) - Faculdade de Direito, Universidade de São Paulo, São Paulo. 
DUARTE, Mônica. Execução de Decisões de Organismos Internacionais de Proteção de Direitos Humanos no Ordenamento Jurídico Brasileiro. 2010. 133 p. Dissertação (Mestrado em Ciência Jurídica), Centro de Educação de Ciências Sociais e Jurídicas, Universidade do Vale do Itajaí, Itajaí.

FARIAS, Rogério de Souza. Industriais, Economistas e Diplomatas: O Brasil e as negociações comerciais multilaterais (1946 - 1967). 2012. 480 p. Tese (Doutorado em Relações Internacionais) - Instituto de Relações Internacionais, Universidade de Brasília.

FERNANDES, Ivan Filipe de Almeida Lopes. Burocracia e Política: a construção institucional da política comercial brasileira pós - abertura económica. 2010. 172 p. Dissertação (Mestrado em Ciência Política) - Faculdade de Filosofia, Letras e Ciências Humanas, Universidade de São Paulo, São Paulo.

JUNQUEIRA, Carla Amaral de Andrade. A Técnica Interpretativa do Órgão de Apelação da Organização Mundial do Comércio. 2010. 268 f. Tese (Doutorado em Direito) - Faculdade de Direito, Universidade de São Paulo, São Paulo.

MENEZES, Wagner. A Jurisdicionalização do Direito Internacional: Conflitos de Competência entre Tribunais Internacionais, sua prevenção e resolução. $2011.513 \mathrm{f}$. Tese (Livre Docência em Direito) - Faculdade de Direito, Universidade de São Paulo, São Paulo.

OLIVEIRA, João Paulo de. Adjudicação e Comércio Internacional - o Caso dos Pneus Reformados. 2012. 152 p. Dissertação (Mestrado), Programa de Pós-Graduação em Integração da América Latina, Universidade de São Paulo, São Paulo.

PANNUNZIO, Eduardo. A judicialização das relações internacionais no Brasil em face do principio constitucional da prevalência dos direitos humanos. 2012. 257 p. Tese (Doutorado em Direito) - Faculdade de Direito, Universidade de São Paulo, São Paulo.

PETRY, Mariana Simões. A política de comércio exterior brasileira de 1995 a 1998: a política comercial estratégica e o caso Embraer. 2006. 139 p. Dissertação (Mestrado em Relações Internacionais) - Instituto de Filosofia e Ciências Humanas, Universidade Federal do Rio Grande do Sul, Porto Alegre.

POLIDO, Fabrício Bertini Pasquot. Contribuições ao Estudo do Direito Internacional da Propriedade Intelectual na Era Pós-Organização Mundial do Comércio: Fronteiras da Proteção, Composição do Equilíbrio e Expansão do Domínio Publico. 2010. 535 p. Tese (Doutorado em Direito) - Faculdade de Direito, Universidade de São Paulo, São Paulo. 
RAMANZINI JÚNIOR, Haroldo. O Brasil e as Negociações no Sistema GATT/OMC: Uma Análise da Rodada Uruguai e da Rodada Doha. 2012. 137 p. Tese (Doutorado em Ciência Política) - Faculdade De Filosofia, Letras E Ciências Humanas, Universidade De São Paulo, São Paulo.

RAMOS, Guilherme Cantarino da Costa Ramos. Comércio Internacional, Política Comercial Brasileira e a Atuação da Câmara da Comércio Exterior (CAMEX) na Condução das Políticas para o Setor. 2008. 312 p. Dissertação (Mestrado em Administração) - Escola Brasileira de Administração Pública e de Empresas, Fundação Getúlio Vargas, Rio de Janeiro.

SILVA, Elaini Cristina Gonzaga da. Juridicização das Relações Internacionais e Solução de Controvérsias: Análise do Sistema Multilateral de Comércio. 2007. 225 f. Dissertação (Mestrado em Direito) - Faculdade de Direito, Universidade de São Paulo, São Paulo, 2007.

SPÉCIE, Priscila. Política Externa e Democracia: Reflexões sobre o acesso à informação na política externa brasileira a partir da inserção da temática ambiental no caso dos pneus entre o Mercosul e a OMC. 2008. 111p. Dissertação (Mestrado em Ciência Política) - Faculdade de Filosofia, Letras e Ciências Humanas da Universidade de São Paulo, São Paulo.

\section{Lista Cronológica de Casos de Tribunais Nacionais}

\section{Brasil}

BRASIL. Supremo Tribunal Federal. Agravo Regimental em Carta Rogatória, CR 8279 AgR / AT - ARGENTINA. Relator: Min. Celso de Mello. Brasília, 17 jun. 1998.

BRASIL. Superior Tribunal de Justiça. Recurso Especial, REsp 661536 / RJ (2004/0068155-5), Relator: Min. Carlos Alberto Menezes Direito, Órgão Julgador Terceira Turma. Brasília, 7 abr. 2005. DJ 30 maio 2005.

BRASIL. Superior Tribunal de Justiça. Recurso Especial, REsp 667025 / RJ (2004/0086618-6), Relator: Min. Castro Filho, Órgão Julgador Terceira Turma. Brasília, 14 dez. 2006. DJ 12 fev. 2007. 
BRASIL. Superior Tribunal de Justiça. Sentença Estrangeira Contestada, SEC 2707 / NL (SEC 2007/02568161). Relator: Min. Francisco Falcão. Órgão julgador Corte Especial. Brasília, 3 dez. 2008. DJE 19 fev. 2009.

BRASIL. Superior Tribunal de Justiça. Voto da Relatora. Recurso Especial, REsp 960728 / RJ (2007/0134388-8). Relatora: Min. Nancy Andrighi, Órgão Julgador Terceira Turma. Brasília, 17 mar. 2009. DJE 15 abr. 2009.

BRASIL. Supremo Tribunal Federal. Recurso Extraordinário, RE 474132 / SC. Relator: Min. Gilmar Mendes. Brasília, 12 ago. 2010. DJE 1 dez. 2010.

BRASIL. Supremo Tribunal Federal. Recurso Extraordinário, RE 564413 / SC. Relator: Min. Marco Aurélio. Brasília, 12 ago. 2010. DJE 6 dez. 2010.

BRASIL. Supremo Tribunal Federal. Repercussão Geral no Recurso Extraordinário, RE 627280 RG / RJ. Relator: Min. Joaquim Barbosa. Brasília, 17 nov. 2011. DJE 23 fev. 2012.

BRASIL. Superior Tribunal de Justiça. Recurso Especial, REsp 1205393 / RJ (2010/0138530-1). Relator: Min. Mauro Campbell Marques, Órgão Julgador Segunda Turma. Brasília, 9 abr. 2013. DJE 16 abr. 2013.

\section{Estados Unidos da América}

Murray v. The Schooner Charming Betsy, 6. U.S. (2 Cranch) 64 (1804)

Chevron, U.S.A., Inc. v. Natural Res. Def. Council, Inc., 467 U.S. 837 (1984)

Allegheny Ludlum Corp. vs. United States, 367 E3d 1348 (Fed. Cir. 2004)

Corus Staal, BV v. Department of Commerce, 395 E3d 1343, 1349 (Fed. Cir. 2005)

Earth Island Institute v. Hogarth 494 F.3d 757 (9th Cir. 2007) 


\section{Lista Cronológica de Casos do TJUE/TJCE}

Van Gend en Loos v. Administratie der Belastingen (Rec.1963, p.1), Case 26/62, 05 fev. 1963.

Costa / E.N.E.L. (Rec.1964, p.585) Case 6/64, 15 jul. 1964.

International Fruit Company and others / Produktschap voor Groenten en Fruit (Rec.1972,p.1219), Case 21/72, 12 dez. 1972.

Schlüter / Hauptzollamt Lörrach (Rec.1973,p.1135), Case 9/73, 24 out. 1973.

Haegemann v. Belgian State (Rec.1974,p.449), Case 181/73, 30 abr. 1974.

Bresciani v. Amministrazione delle finanze dello Stato (Rec.1976,p.129), Case 87/75, 5 fev. 1976.

SIOT / Ministero delle finanze (Rec.1983, p.731), Case 266/81, 16 mar. 1983.

Amministrazione delle finanze dello Stato / SPI and SAMI (Rec.1983, p.801), Case 267/81, 16 mar. 1983.

Demirel / Stadt Schwäbisch Gmünd (Rec.1987,p.3719), Case 12/86, 30 out. 1987.

Fédération de l'industrie de l'huilerie de la CEE (Fediol) v. Commission of the European Communities. (Rec.1989, p. 1-1781), Case C-70/87, 22 jun. 1989.

Nakajima All Precision Co. Ltd v Council of the European Communities (Rec.1991, p. 12069), Case C-69/89, 7 maio 1991.

Opinion 1/91, Draft agreement relating to the creation of the European Economic Area (Rec. 1991, p. 1-6079), 14 dez. 1991. 
Germany / Council (Rec.1994, p.I-4973), Case 280/93, 5 out. 1994.

Opinion 1/94 (Rec.1994, p.I-5267), 15 nov. 1994.

Opinion of Mr Advocate General Mischo delivered on 6 May 1999. Atlanta AG and others $v$ Commission of the European Communities and Council of the European Union (Rec.1999, p.I-06983), Case C-104/97, 14 out. 1999.

Portugal v. Council (Rec.1999, p.I-8395), Case C-149/96, 23 nov. 1999.

Opinion of Advocate General Alber, ltablissements Biret et Cie SA v. Council (Rec.2003, p. I-10565), Case C-94/02, 15 maio 2003.

ltablissements Biret et Cie SA v. Council, (Rec.2003, p. I-10565). Case C-94/02, 30 set. 2003.

Chiquita Brands International, Inc. and Others v. Commission (Rec.2005, p. 11-315), Case T-19/01, 3 fev. 2005.

Lon Van Parys NV v. Belgisch Interventie-en Restitutiebureau (BIRB) (Rec. 2005, p. 11465), Case C-377/02, 1 mar. 2005.

Ikea Wholesale Ltd v. Comm'rs of Customs \& Excise (Rec.2007, p. 1-7723), Case C351/04, 27 set. 2007.

Fabbrica Italiana Accumulatori Motocarri Montecchio SpA v. Council (Rec.2008, p. 16513, 23-24, 30), Joined Cases C-120/06P \& C-121/06P, 9 set. 2008.

\section{Lista Cronológica de Casos da CIJ}

CIJ. United States Diplomatic and Consular Staff in Tehran. 24 maio 1980. 


\section{Lista Cronológica de Casos da CIDH}

CIDH. Caso Gomes Lund e Outros ("Guerrilha Do Araguaia”) vs. Brasil. 24 nov. 2010.

CIDH. Caso Ximenes Lopes vs Brasil. 4 jul. 2006.

CIDH. Caso García Prieto vs. El Salvador. Voto concurrente del Juez García Ramírez. 20 nov. 2007.

Lista cronológica de Casos do Mecanismo de Solução de Controvérsias do MERCOSUL

MERCOSUL. Tribunal Arbitral Ad Hoc. Laudo VI, 01/2002. 09 jan. 2002.

\section{Lista Cronológica de Casos do Sistema de Solução de Controvérsias da OMC}

United States-Standards for Reformulated and Conventional Gasoline (DS2, DS4)

Brazil - Measures Affecting Desiccated Coconut (DS22)

United States - Restrictions on Imports of Cotton and Man-made Fibre Underwear (DS24)

European Communities - Measures Concerning Meat and Meat Products (Hormones) (DS26, DS48)

European Communities - Regime for the Importation, Sale and Distribution of Bananas (Bananas III) (DS27) 
Brazil - Countervailing Duties on Imports of Desiccated Coconut and Coconut Milk Powder from Sri Lanka (DS30)

Brazil - Export Financing Programme for Aircraft (DS46)

India - Patent Protection for Pharmaceutical and Agricultural Chemical Products (DS50)

Brazil - Certain Measures Affecting Trade and Investment in the Automotive Sector (DS51, DS52, DS65, DS81)

Argentina - Measures Affecting Imports of Footwear, Textiles, Apparel and Other Items (DS56)

United States - Import Prohibition of Certain Shrimp and Shrimp Products (DS58)

Guatemala - Anti-Dumping Investigation Regarding Portland Cement from Mexico (DS60)

European Communities - Customs Classification of Certain Computer Equipment (DS62, DS67, DS68)

European Communities - Measures Affecting Importation of Certain Poultry Products (DS69)

Canada - Measures Affecting the Export of Civilian Aircraft (DS70, DS71)

Japan - Measures Affecting Agricultural Products (DS76)

Chile - Taxes on Alcoholic Beverages (DS87, DS110)

United States - Tax Treatment for "Foreign Sales Corporations" (DS108)

Peru - Countervailing Duty Investigation against Imports of Buses from Brazil (DS112) 
Canada - Patent Protection of Pharmaceutical Products (DS114)

Brazil - Measures Affecting Payment Terms for Imports (DS116)

European Communities — Measures Affecting Asbestos and Products Containing Asbestos (DS135)

United States - Imposition of Countervailing Duties on Certain Hot-Rolled Lead and Bismuth Carbon Steel Products Originating in the United Kingdom (DS138)

United States - Sections 301-310 of the Trade Act of 1974 (DS152)

European Communities - Measures Affecting Differential and Favourable Treatment of Coffee (DS154)

Argentina - Measures Affecting the Export of Bovine Hides and Import of Finished Leather (DS155)

United States- Section 110(5) of the U.S. Copyright Act (DS160)

United States-Import Measures on Certain Products from the European Communities. (DS165)

European Communities - Protection of Trademarks and Geographical Indications for Agricultural Products and Foodstuffs, Complaint by the United States (DS174)

United States - Anti-Dumping Measures on Stainless Steel Plate in Coils and Stainless Steel Sheet and Strip from Korea (DS179)

Brazil - Measures on Import Licensing and Minimum Import Prices (DS183)

United States - Anti-Dumping Measures on Certain Hot-Rolled Steel Products from Japan (DS184)

Argentina - Transitional Safeguard Measures on Certain Imports of Woven Fabric Products of Cotton and Cotton Mixtures Originating in Brazil (DS190) 
United States - Transitional Safeguard Measure on Combed Cotton Yarn from Pakistan (DS192)

Brazil — Measures on Minimum Import Prices (DS197)

Brazil - Measures Affecting Patent Protection (DS199)

United States - Definitive Safeguard Measures on Imports of Circular Welded Carbon Quality Line Pipe from Korea (DS202)

Mexico - Measures Affecting Telecommunications Services (DS204)

Chile - Price Band System and Safeguard Measures Relating to Certain Agricultural Products (DS207)

Turkey - Anti-Dumping Duty on Steel and Iron Pipe Fittings (DS208)

European Communities - Measures Affecting Soluble Coffee (DS209)

United States - Countervailing Measures Concerning Certain Products from the European Communities (DS212)

Mexico - Provisional Anti-Dumping Measure on Electric Transformers (DS216)

United States - Continued Dumping and Subsidy Offset Act of 2000 (DS217, DS234)

United States - Countervailing Duties on Certain Carbon Steel Products from Brazil (DS218)

European Communities - Anti-Dumping Duties on Malleable Cast Iron Tube or Pipe Fittings from Brazil (DS219)

Canada - Export Credits and Loan Guarantees for Regional Aircraft (DS222)

United States - US Patents Code (DS224) 
Brazil - Anti-Dumping Duties on Jute Bags from India (DS229)

European Communities - Trade Description of Sardines (DS231)

United States — Anti-Dumping Duties on Silicon Metal from Brazil (DS239)

Argentina - Definitive Anti-Dumping Duties on Poultry from Brazil (DS241)

United States - Sunset Review of Anti-Dumping Duties on Corrosion-Resistant Carbon Steel Flat Products from Japan (DS244)

Japan - Measures Affecting the Importation of Apples (DS245)

European Communities - Conditions for the Granting of Tariff Preferences to Developing Countries (DS246)

United States - Definitive Safeguard Measures on Imports of Certain Steel Products (DS248, DS249, DS251, DS252, DS253, DS254, DS258, DS259)

United States - Equalizing Excise Tax Imposed by Florida on Processed Orange and Grapefruit Products (DS250)

United States - Final Dumping Determination on Softwood Lumber from Canada (Softwood Lumber V) (DS264)

European Communities - Export Subsidies on Sugar (DS265, DS266, DS283)

European Communities - Export Subsidies on Sugar (DS266)

United States - Subsidies on Upland Cotton (DS267)

United States - Sunset Reviews of Anti-Dumping Measures on Oil Country Tubular Goods from Argentina (DS268) 
European Communities - Customs Classification of Frozen Boneless Chicken Cuts (DS269, DS286)

European Communities - Protection of Trademarks and Geographical Indications for Agricultural Products and Foodstuffs (DS290)

European Communities - Measures Affecting the Approval and Marketing of Biotech Products (DS292, DS293)

United States - Laws, Regulations and Methodology for Calculating Dumping Margins (Zeroing) (DS294)

United States - Countervailing Duty Investigation on Dynamic Random Access Memory Semiconductors (DRAMS) from Korea (DS296)

Korea - Anti Dumping Duties on Imports of Certain Paper from Indonesia (DS312)

European Communities - Selected Customs Matters (DS315)

European Communities - Measures Affecting Trade in Large Civil Aircraft (DS316, DS317)

United States - Continued Suspension of Obligations in the EC - Hormones Dispute (DS320)

Canada-Continued Suspension of Obligations in the EC - Hormones Dispute (DS321)

United States - Measures Relating to Zeroing and Sunset Reviews (DS322)

Mexico - Anti-Dumping Duties on Steel Pipes and Tubes from Guatemala (DS331)

Brazil-Measures Affecting Imports of Retreaded Tyres (DS332)

United States - Anti-Dumping Measure on Shrimp from Ecuador (DS335) 
Japan - Countervailing Duties on Dynamic Random Access Memories from Korea (DS336)

China - Measures Affecting Imports of Automobile Parts (DS339, DS340, DS342)

United States- Measures Relating to Shrimp from Thailand (DS343)

United States — Final Anti-Dumping Measures on Stainless Steel from Mexico (DS344)

United States - Customs Bond Directive for Merchandise Subject to AntiDumping/Countervailing Duties (DS345)

European Communities and Certain Member States - Measures Affecting Trade in Large Civil Aircraft (Second Complaint) (DS347)

United States - Continued Existence and Application of Zeroing Methodology (DS350)

United States - Measures Affecting Trade in Large Civil Aircraft - Second Complaint (DS353)

Brazil - Anti-dumping Measures on Imports of Certain Resins from Argentina (DS355)

China - Measures Affecting the Protection and Enforcement of Intellectual Property Rights (DS362)

China - Measures Affecting Trading Rights and Distribution Services for Certain Publications and Audiovisual Entertainment Products (DS363)

United States - Domestic Support and Export Credit Guarantees for Agricultural Product (DS365)

Colombia - Indicative Prices and Restrictions on Ports of Entry (DS366)

European Communities and its Member States - Tariff Treatment of Certain Information Technology Products (DS375, DS376, DS377) 
United States - Definitive Anti-Dumping and Countervailing Duties on Certain Products from China (DS379)

United States - Measures Concerning the Importation, Marketing and Sale of Tuna and Tuna Products (DS381)

United States - Anti-Dumping Administrative Reviews and Other Measures Related to Imports of Certain Orange Juice from Brazil (DS382)

United States - Certain Country of Origin Labelling (COOL) Requirements (DS384, DS386)

Korea - Measures Affecting the Importation of Bovine Meat and Meat Products from Canada (DS391)

United States - Certain Measures Affecting Imports of Poultry from China (DS392)

European Communities - Definitive Anti-Dumping Measures on Certain Iron or Steel Fasteners from China (DS397)

China - Measures Related to the Exportation of Various Raw Materials (DS394, DS395, DS398)

European Union and a Member State - Seizure of Generic Drugs in Transit (DS409)

Canada - Certain Measures Affecting the Renewable Energy Generation Sector (DS412)

United States - Anti-dumping measures on corrosion-resistant carbon steel flat products from Korea (DS420)

Canada - Measures Relating to the Feed-in Tariff Program (DS426)

India - Measures Concerning the Importation of Certain Agricultural Products from the United States (DS430)

China - Measures Related to the Exportation of Rare Earths, Tungsten and Molybdenum (DS431, DS432, DS433) 
Australia - Certain Measures Concerning Trademarks and Other Plain Packaging Requirements Applicable to Tobacco Products and Packaging (DS434, DS435, DS441)

United States - Countervailing Duty Measures on Certain Products from China (DS437)

South Africa - Anti-Dumping Duties on Frozen Meat of Fowls from Brazil (DS439)

United States - Measures Affecting the Importation of Animals, Meat and Other Animal Products from Argentina (DS447)

Argentina - Measures Relating to Trade in Goods and Services (DS453)

India - Certain Measures Relating to Solar Cells and Solar Modules (DS456)

Peru - Additional Duty on Imports of Certain Agricultural Products (DS457)

Australia - Certain Measures Concerning Trademarks, Geographical Indications and Other Plain Packaging Requirements Applicable to Tobacco Products and Packaging (DS458, DS467)

Russian federation — Recycling Fee on Motor Vehicles (DS462)

United States - Anti-dumping and Countervailing Measures on large residential washers from Korea (DS464)

European Union - Measures on Atlanto-Scandian Herring (DS469)

United States - Certain Methodologies and their Application to Anti-Dumping Proceedings Involving China (DS471)

Brazil - Certain Measures Concerning Taxation and Charges (DS472) 


\section{Bases de Dados e Páginas Eletrônicas}

BRASIL. Câmara de Comércio Exterior. Disponível em: <http://www.camex.gov.br>. Acesso em: 15 jul. 2014.

BRASIL. Câmara dos Deputados. Projetos de lei. <http://www2.camara.leg.br>. Acesso em: 15 jul. 2014.

BRASIL. Ministério do Desenvolvimento, Indústria e Comércio. Disponível em: $<$ http://www.mdic.gov.br>

BRASIL. Presidência da República. Portal da Legislação. Leis e Decretos. Disponível em: $<$ http://www4.planalto.gov.br/legislacao>. Acesso em: 15 jul. 2014.

BRASIL. Senado Federal. Projetos de lei. $<$ http://www.senado.gov.br $>$. Acesso em: 15 jul. 2014.

BRASIL. Superior Tribunal de Justiça. Jurisprudência. Disponível em: $<$ http://www.stj.jus.br/portal_stj/>. Acesso em: 15 jul. 2014.

BRASIL. Supremo Tribunal Federal. Jurisprudência. Disponível em: $<$ http://www.stf.jus.br/portal/principal/principal.asp>. Acesso em: 15 jul. 2014.

CIDH. Jurisprudência. Disponível em: $<$ http://www.corteidh.or.cr>. Acesso em: 15 jul. 2014.

EUA. U. S. Government Printing Office. Legislação e decisões dos EUA. Disponível em: $<$ http://www.gpo.gov>. Acesso em: 15 jul. 2014.

Heinonline. Base de dados de artigos jurídicos. Disponível em: $<\mathrm{http}$ //home.heinonline.org $>$. Acesso em: 15 jul. 2014.

MERCOSUL. Documentos e decisões. Disponível em: <www.mercosur.int> Acesso em: 15 jul. 2014.

OMC. Acordos e Documentos. Disponível em: <www.wto.org>. Acesso em: 15 jul. 2014. 
OMC. Base de dados sobre solução de controvérsias. Disponível em: < http://www.wto.org/english/tratop_e/dispu_e/dispu_e.htm>. Acesso em: 15 jul. 2014.

OMC. Legal Affairs Division. WTO analytical index: Guide to WTO Law and Practice. Disponível em:

$<$ http://www.wto.org/english/res_e/booksp_e/analytic_index_e/analytic_index_e.htm>. Acesso em: 15 jul. 2014.

UE/CE. Eur-Lex. Portal de Acesso ao Direito da União Europeia. Disponível em: $<$ http://eur-lex.europa.eu>. Acesso em: 15 jul. 2014.

UE/CE. Site oficial da União Europeia. Disponível em: <http://europa.eu>. Acesso em: 15 jul. 2014.

UE/CE. Tribunal de Justiça da União Europeia (TJUE/TJCE). Jurisprudência. Disponível em: $<$ http://curia.europa.eu>. Acesso em: 15 jul. 2014.

World Trade Law Net. Artigos sobre comércio internacional. Disponível em: < http://www.worldtradelaw.net>. Acesso em: 15 jul. 2014. 


\section{APÊNDICE A}

TABELA 1. PARTICIPAÇÃO DO BRASIL COMO DEMANDADO NO SISTEMA DE SOLUÇÃO DE CONTROVÉRSIAS DA OMC

\begin{tabular}{|c|c|c|c|c|c|c|}
\hline Fase & Subsídios & $\begin{array}{l}\text { Medidas } \\
\text { Antidumping }\end{array}$ & $\begin{array}{l}\text { Medidas } \\
\text { Sanitárias e } \\
\text { fitossanitárias }\end{array}$ & $\begin{array}{l}\text { Barreiras } \\
\text { técnicas }\end{array}$ & $\begin{array}{l}\text { Propriedade } \\
\text { Intelectual }\end{array}$ & Outros \\
\hline $\begin{array}{ll}\text { Fase } & \text { de } \\
\text { consultas } & \end{array}$ & $\begin{array}{l}\text { DS30, } \\
\text { DS51, } \\
\text { DS52, } \\
\text { DS65, } \\
\text { DS81, } \\
\text { DS472 }\end{array}$ & DS229 & & & & $\begin{array}{l}\text { DS116, } \\
\text { DS183, } \\
\text { DS197 }\end{array}$ \\
\hline \multicolumn{7}{|l|}{ Fase do painel } \\
\hline $\begin{array}{ll}\text { Fase } & \text { da } \\
\text { apelação } & \\
\end{array}$ & & & & & & \\
\hline $\begin{array}{ll}\text { Relatório } & \\
\text { adotado, } & \text { sem } \\
\text { necessidade } & \text { de } \\
\begin{array}{l}\text { conduta } \\
\text { demandado }\end{array} & \text { do } \\
\end{array}$ & DS22 & & & & & \\
\hline $\begin{array}{l}\text { Relatório } \\
\text { adotado, com } \\
\text { recomendação }\end{array}$ & & & & & & \\
\hline $\begin{array}{l}\text { Implementação } \\
\text { notificada pelo } \\
\text { demandado }\end{array}$ & & & & & & DS332 \\
\hline $\begin{array}{l}\text { Solução } \\
\text { mutuamente } \\
\text { acordada para } \\
\text { implementação }\end{array}$ & & & & & & \\
\hline $\begin{array}{ll}\text { Painel } & \text { de } \\
\text { verificação de } & \text { de } \\
\text { cumprimento }\end{array}$ & & & & & & \\
\hline \begin{tabular}{l}
\multicolumn{2}{l}{ Verificação } \\
com conclusão \\
de re não \\
cumprimento
\end{tabular} & & & & & & \\
\hline $\begin{array}{l}\text { Verificação } \\
\text { com conclusão } \\
\text { de } \\
\text { cumprimento }\end{array}$ & DS46 & & & & & \\
\hline $\begin{array}{l}\text { Autorização } \\
\text { para retaliar }\end{array}$ & & & & & & \\
\hline $\begin{array}{l}\text { Autoridade do } \\
\text { painel caducou }\end{array}$ & & DS335 & & & & \\
\hline $\begin{array}{l}\text { Desistência ou } \\
\text { solução } \\
\text { mutuamente } \\
\text { acordada }\end{array}$ & & & & & DS199 & \\
\hline
\end{tabular}




\begin{tabular}{|c|c|c|c|c|c|c|}
\hline Fase & Subsídios & $\begin{array}{l}\text { Medidas } \\
\text { Antidumping }\end{array}$ & $\begin{array}{l}\text { Medidas } \\
\text { Sanitárias e } \\
\text { fitossanitárias }\end{array}$ & $\begin{array}{l}\text { Barreiras } \\
\text { técnicas }\end{array}$ & $\begin{array}{l}\text { Propriedade } \\
\text { Intelectual }\end{array}$ & Outros \\
\hline $\begin{array}{l}\text { durante o } \\
\text { procedimento }\end{array}$ & & & & & & \\
\hline
\end{tabular}

Obs. 1: As áreas destacadas da tabela demonstram o foco de nossa análise, as fases em que considera-se haver implementação da decisão. As fases anteriores são agrupadas de modo geral, sem pretensão de abordagem detalhada.

Obs. 2: A separação dos casos segundo as categorias expressadas no sentido horizontal se deu conforme a preponderância numérica dos dispositivos citados na argumentação do demandante e/ou segundo a natureza da medida. Muitos casos poderiam ter sido incluídos em mais de uma classe temática, mas esse procedimento foi evitado na constituição desta tabela. Nota-se, contudo, que há uma natural coincidência temática entre os casos que envolvem simultaneamente subsídios e antidumping, bem como aqueles que envolvem simultaneamente barreiras técnicas e medidas sanitárias e fitossanitárias. Para uma visão mais detalhada dos acordos citados nos casos, confira o apêndice B. 


\title{
APÊNDICE B
}

\author{
BREVE DESCRIÇÃO DOS CASOS EM QUE O BRASIL ATUOU COMO \\ DEMANDADO NO SISTEMA DE SOLUÇÃO DE CONTROVÉRSIAS DA OMC
}

\begin{tabular}{|c|c|}
\hline $\begin{array}{l}\text { NÚMERO } \\
\text { DO CASO }\end{array}$ & BREVE DESCRIÇÃO DO CASO \\
\hline DS22 & $\begin{array}{l}\text { O caso DS22, Brazil - Measures Affecting Desiccated Coconut, foi suscitado pelas } \\
\text { Filipinas em face do Brasil, e contou com Canadá, UE/CE, EUA, Indonésia, Malásia, e Sri } \\
\text { Lanka como terceiras partes. O pedido de consultas foi recebido em } 30 \text { de novembro de } \\
\text { 1995, o relatório do painel circulou em } 17 \text { de outubro de } 1996 \text { e o relatório do Órgão de } \\
\text { Apelação foi divulgado em } 21 \text { de fevereiro de } 1997 \text {. As consultas foram iniciadas sob a } \\
\text { alegação das Filipinas de que contramedidas impostas pelo Brasil, em } 18 \text { de agosto de } \\
\text { 1995, sob a exportação de coco desidratado e leite de coco estariam em violação aos } \\
\text { artigos VI:3, VI:6 do GATT } 1994 \text { e ao artigo } 13 \text { do Acordo de Agricultura. Em seu } \\
\text { relatório, o painel chegou à constatação de que os dispositivos alegados pelo membro } \\
\text { demandante não seriam aplicáveis à controvérsia, em razão da limitação rationae tempore } \\
\text { dos acordos da OMC. Isto pois a medida desafiada foi resultado de procedimento iniciado } \\
\text { em } 21 \text { de junho de } 1994 \text {, e portanto antes de } 1 \text { de janeiro de } 1995 \text {, data da entrada em vigor } \\
\text { dos Acordos da OMC para o Brasil. Houve a apelação das Filipinas, mas o relatório do } \\
\text { Orgão de Apelação confirmou a interpretação feita pelo painel. O Relatório do OA foi } \\
\text { aprovado pelo DSB em } 20 \text { de março de } 1997 \text {, mas como não houve o reconhecimento de } \\
\text { desconformidade, não havia ação a ser tomada por parte do membro demandado. Os dados } \\
\text { deste caso foram retirados da base de dados de solução de controvérsias da OMC: } \\
\text { <http://www.wto.org/english/tratop_e/dispu_e/cases_e/ds22_e.htm> Acesso em: } 22 \text { jan. } \\
\text { 2014. }\end{array}$ \\
\hline DS30 & $\begin{array}{l}\text { O caso DS30, Brazil - Countervailing Duties on Imports of Desiccated Coconut and } \\
\text { Coconut Milk Powder from Sri Lanka, foi uma demanda iniciada pelo Sri Lanka, em } \\
\text { relação à direitos compensatórios correlatos aos questionados pelo caso DS22. Em } 23 \text { de } \\
\text { fevereiro de 1996, e portanto antes da divulgação do Relatório do painel no caso DS22, o } \\
\text { Sri Lanka havia formulado um pedido de consultas em relação à imposição de direitos } \\
\text { compensatórios em } 21 \text { de agosto de } 1995 \text {, sob a exportação de coco desidratado e leite de } \\
\text { coco em pó, sob alegação de que a medida brasileira seria excessiva e inconsistente com os } \\
\text { artigos I, II e VI do GATT } 1994 \text { e com o artigo } 13 \text { (a) do Acordo de Agricultura. Contudo, } \\
\text { em face da decisão do caso DS22, com substrato fático-normativo correlato, o } \\
\text { procedimento não teve continuidade, vez que o mecanismo de solução de controvérsias já } \\
\text { havia rechaçado a aplicação dos dispositivos à investigações de contramedidas iniciadas } \\
\text { antes da entrada em vigor dos Acordos da OMC. Os dados deste caso foram retirados da } \\
\text { base de dados de solução de controvérsias da OMC: } \\
\text { <http://www.wto.org/english/tratop_e/dispu_e/cases_e/ds30_e.htm> Acesso em: } 15 \text { jan. } \\
\text { 2014. }\end{array}$ \\
\hline DS46 & $\begin{array}{l}\text { O caso DS46, Brazil - Export Financing Programme for Aircraft, é analisado no subitem } \\
\text { 3.4.3. }\end{array}$ \\
\hline DS51 & 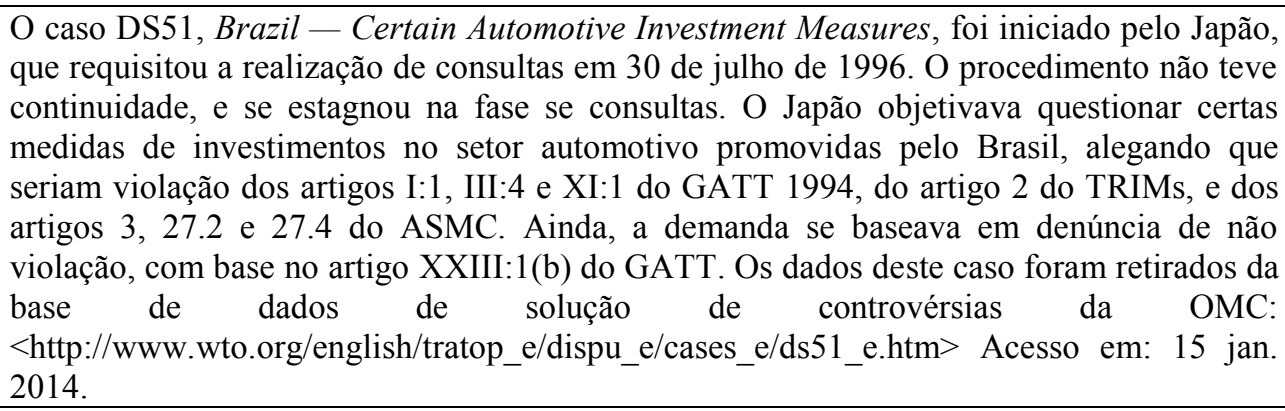 \\
\hline 52 & as questionadas no procedimento DS51, o caso DS52, \\
\hline
\end{tabular}




\begin{tabular}{|c|c|}
\hline & $\begin{array}{l}\text { - Certain Measures Affecting Trade and Investment in the Automotive Sector, foi iniciado } \\
\text { pelos EUA, que requisitaram a realização de consultas em } 9 \text { de agosto de 1996. O } \\
\text { procedimento não teve continuidade, e se estagnou na fase se consultas. Os EUA } \\
\text { entendiam que medidas de investimento no setor automotivo promovidas pelo Brasil } \\
\text { estariam em desconformidade com a normativa multilateral. A demanda se baseou na } \\
\text { alegação de que as medidas seriam violação dos artigos I:1, II, III:4 do GATT, do artigo } 2 \\
\text { do TRIMs, e dos artigos } 3 \text { e } 27.4 \text { do ASMC. Ainda, a demanda se baseava em denúncia de } \\
\text { não violação, com base no artigo XXIII:1(b) do GATT 1994. Os dados deste caso foram } \\
\text { retirados da base de dados de solução de controvérsias da OMC: } \\
<\text { http://www.wto.org/english/tratop_e/dispu_e/cases_e/ds52_e.htm> Acesso em: } 15 \text { jan. } \\
2014 \text {. }\end{array}$ \\
\hline DS65 & $\begin{array}{l}\text { O caso DS65, Brazil - Certain Measures Affecting Trade and Investment in the } \\
\text { Automotive Sector, foi iniciado pelos EUA, que requisitaram a realização de consultas em } \\
10 \text { de janeiro de 1997. O procedimento não teve continuidade, e se estagnou na fase se } \\
\text { consultas. Os EUA questionavam, de modo geral, as medidas objeto do DS52, } \\
\text { investimentos no setor automotivo promovidas pelo Brasil. O objeto deste procedimento } \\
\text { incluía, contudo, outras medidas adotadas pelo governo brasileiro após as consultas } \\
\text { desenvolvidas no âmbito do caso DS52, que abarcavam inclusive medidas concedendo } \\
\text { benefícios a certas empresas localizadas na União Europeia, República da Coréia e Japão. } \\
\text { A demanda se baseou na alegação de que as medidas seriam violação dos artigos I:1, III:4 } \\
\text { do GATT, do artigo } 2 \text { do TRIMs, e dos artigos } 3 \text { e } 27.4 \text { do ASMC. Se baseava também em } \\
\text { denúncia de não violação, com base no artigo XXIII:1(b) do GATT 1994. Os dados deste } \\
\text { caso foram retirados da base de dados de solução de controvérsias da OMC: } \\
<\text { http://www.wto.org/english/tratop_e/dispu_e/cases_e/ds65_e.htm> Acesso em: } 15 \text { jan. } \\
\text { 2014. }\end{array}$ \\
\hline DS81 & $\begin{array}{l}\text { De modo correlato às demandas DS51, DS52 e DS65, o caso DS81, Brazil - Measures } \\
\text { Affecting Trade and Investment in the Automotive Sector, foi instaurado pela UE/CE, em } \\
\text { requisição de consultas datada de } 7 \text { de maio de 1997. O procedimento não teve } \\
\text { continuidade, e se estagnou na fase se consultas. A requisição de consultas com o Brasil } \\
\text { dizia respeito à diversas medidas de investimento no setor automobilístico, em especial a } \\
\text { Leis 9440/1997, a Lei 9449/1997 e o Decreto 1987/1996. Segundo a demandante, tais } \\
\text { medidas violavam os artigos I:1 e III:4 do GATT 1994, os artigos 3, } 5 \text { e } 27.4 \text { do ASMC e o } \\
\text { artigo } 2 \text { do Acordo TRIMs. Adicionalmente, a demandante se baseava em denúncia de não } \\
\text { violação. Os dados deste caso foram retirados da base de dados de solução de } \\
\text { controvérsias } \\
<\text { http://www.wto.org/english/tratop_e/dispu_e/cases_e/ds81_e.htm> Acesso em: } 15 \text { jan. } \\
\text { 2014. }\end{array}$ \\
\hline DS116 & $\begin{array}{l}\text { O caso DS116, Brazil-Measures Affecting Payment Terms for Imports, foi iniciado pela } \\
\text { UE/CE, mediante a requisição de consultas em } 8 \text { de janeiro de 1998. A demanda dizia } \\
\text { respeito à medidas relacionadas a termos de pagamento para importação introduzidos pelo } \\
\text { Banco Central do Brasil. A demandante alegava que essas medidas consistiam numa } \\
\text { violação dos artigos } 3 \text { e } 5 \text { do Acordo sobre Procedimentos para o Licenciamento de } \\
\text { Importações e dos artigos II, X, XI, XV do GATT 1994. O procedimento não teve } \\
\text { continuidade, e se estagnou na fase se consultas. Os dados deste caso foram retirados da } \\
\text { base de dados de solução de controvérsias da OMC: } \\
<\text { http://www.wto.org/english/tratop_e/dispu_e/cases_e/ds116_e.htm> Acesso em: } 15 \text { jan. } \\
2014 \text {. }\end{array}$ \\
\hline DS183 & $\begin{array}{l}\text { O caso DS183, Brazil - Measures on Import Licensing and Minimum Import Prices, } \\
\text { consistiu numa demanda iniciada pela UE/CE, mediante requisição de consultas, em } 14 \text { de } \\
\text { outubro de } 1999 \text {. A demanda se baseava na alegação de que diversas medidas brasileiras, } \\
\text { em particular o sistema de licenciamento não automático e a prática de tabelamento de } \\
\text { preços, estariam supostamente restringindo a exportação da UE, afetando especialmente } \\
\text { produtos têxteis Sorbitol e Carboxymethylcellulose (CMC). Na interpretação da } \\
\text { demandante, estas medidas seriam violação de diversas regras dos Acordos da OMC, quais } \\
\text { sejam: os artigos II, VIII, X e XI do GATT 1994, os artigos } 4.2 \text { do Acordo sobre } \\
\text { Agricultura, artigos } 1,3,5 \text { e } 8 \text { do Acordo sobre Procedimentos para o Licenciamento de } \\
\text { Importações e artigos } 1,2,3,4,5,6 \text { e } 7 \text { do Acordo sobre Valoração Aduaneira. O } \\
\text { procedimento não teve continuidade, e se estagnou na fase se consultas. Os dados deste } \\
\text { caso foram retirados da base de dados de solução de controvérsias da OMC: } \\
<\text { http://www.wto.org/english/tratop e/dispu e/cases e/ds } 183 \text { e.htm> Acesso em: } 15 \text { jan. }\end{array}$ \\
\hline
\end{tabular}




\begin{tabular}{|c|c|}
\hline & 2014. \\
\hline DS197 & $\begin{array}{l}\text { O caso DS197, Brazil - Measures on Minimum Import Prices, foi instaurado pelos EUA, } \\
\text { por meio da requisição de consultas, em } 30 \text { de maio de } 2000 \text {. O procedimento tinha como } \\
\text { objeto a prática de preços mínimos de importação para fins de valoração aduaneira, } \\
\text { mesmas medidas questionadas pelo caso DS183. A medida questionava se tratava do } \\
\text { Decreto } 2.498 / 98 \text { e outras leis e Regulamentos. Segundo o demandante, as medidas } \\
\text { brasileiras seriam inconsistentes com os artigos II e XI do GATT 1994, com os artigos } 1 \text { a } \\
7,12 \text { e anexo } 1 \text { do Acordo sobre Valoração Aduaneira, com os artigos } 1 \text { e } 3 \text { do sobre } \\
\text { Procedimentos para o Licenciamento de Importações, com os artigos } 2 \text { e } 7 \text { do Acordo } \\
\text { sobre Têxteis e Vestuário, e finalmente com o artigo } 4.2 \text { do Acordo sobre Agricultura. O } \\
\text { procedimento não teve continuidade, e se estagnou na fase se consultas. Os dados deste } \\
\text { caso foram retirados da base de dados de solução de controvérsias da OMC: } \\
<\text { http://www.wto.org/english/tratop_e/dispu_e/cases_e/ds197_e.htm> Acesso em: } 20 \text { jan. } \\
2014 \text {. }\end{array}$ \\
\hline DS199 & 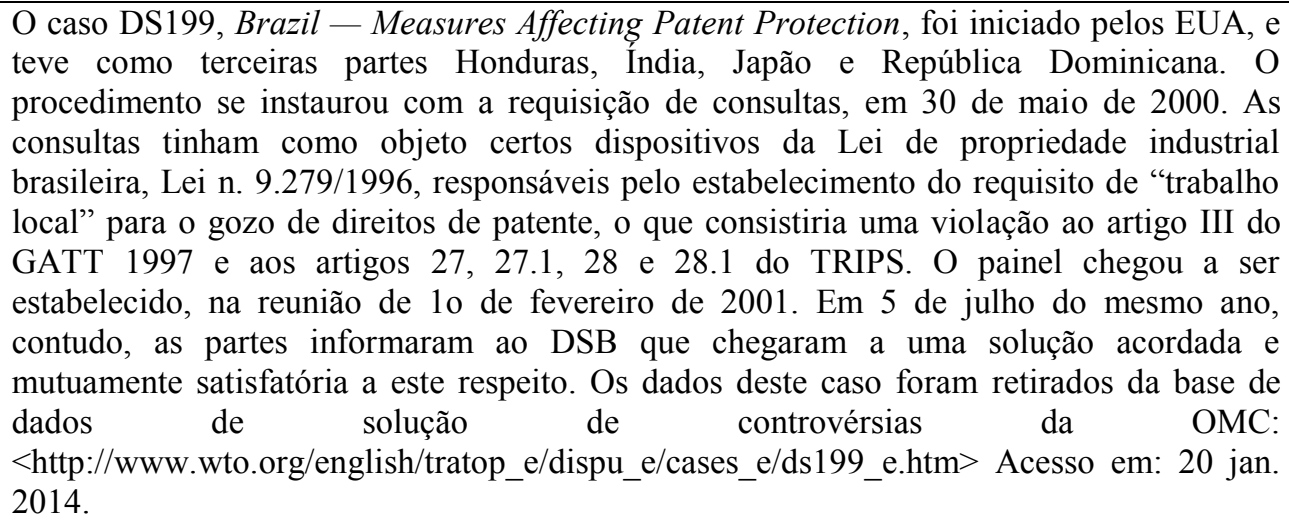 \\
\hline DS229 & $\begin{array}{l}\text { O caso DS229, Brazil - Anti-Dumping Duties on Jute Bags from India, iniciou-se com a } \\
\text { requisição de consultas pela Índia, em } 9 \text { de abril de } 2001 \text {. A demanda da Índia se baseava } \\
\text { nos artigos VI e X do GATT 1994, no artigo XVI do Acordo constitutivo da OMC e nos } \\
\text { artigos } 1,2,3,5,6,11,12,17.6(\mathrm{i}), 18.3 \text { e } 18.4 \text { do Acordo sobre Antidumping. Segundo a } \\
\text { demandante, a conduta brasileira consistiria numa violação dos referidos dispositivos da } \\
\text { normativa multilateral, em especial pelo artigo } 58 \text { do Decreto n. 1.602/1995. A } \\
\text { demandante questionava, portanto, a aplicação de medidas antidumping pelo governo } \\
\text { brasileiro aos sacos feitos de juta importados da Índia e sua recusa na reconsideração da } \\
\text { decisão. O procedimento não teve continuidade, e estagnou-se na fase de consultas. Os } \\
\text { dados deste caso foram retirados da base de dados de solução de controvérsias da OMC: } \\
<\text { http://www.wto.org/english/tratop_e/dispu_e/cases_e/ds229_e.htm> Acesso em: } 20 \text { jan. } \\
\text { 2014. }\end{array}$ \\
\hline DS332 & $\begin{array}{l}\text { O caso DS332, Brazil - Measures Affecting Imports of Retreaded Tyres, é analisado no } \\
\text { subitem 3.4.3. }\end{array}$ \\
\hline DS355 & $\begin{array}{l}\text { O caso DS355, Brazil - Anti-dumping Measures on Imports of Certain Resins from } \\
\text { Argentina, foi iniciado com o pedido de consultas, em } 26 \text { de dezembro de 2006. A } \\
\text { demanda tinha como parte demandante a Argentina, e como terceiras partes UE/CE, EUA, } \\
\text { Japão e Taiwan (Taipé chinês). Segundo a demandante, as investigações de antidumping } \\
\text { realizada pelo governo brasileiro e as medidas impostas sob a importação de certas resinas } \\
\text { PET oriundas da Argentina seriam inconsistentes com diversos dispositivos da normativa } \\
\text { multilateral, dentre os quais: o artigo XVI:4 do Acordo constitutivo da OMC, os artigos } \\
\text { VI, X, X:1, X:3 do GATT } 1994 \text { e os artigos } 2.2 .1,2.2 .1 .1,2.2 .2,2.4,3.1,3.2,3.4,3.5,6 \text {, } \\
6.1,6.2,6.4,6.6,6.8,6.9,6.14,8,8.3,9,10,10.1,12,12.1,12.1 .1,12.2,12.2 .2,18.4 \text { e } \\
\text { Anexo II do Acordo sobre Antidumping. Em particular, a Argentina contestava o Decreto } \\
4732 / 2003 \text { e o Decreto } 1602 / 1995 \text {. A demandante requisitou a formação de um painel em } \\
7 \text { de junho de } 2007 \text {, o que foi deferido na reunião de } 24 \text { de junho de } 2007 \text { do DSB. O } \\
\text { painel foi composto, em } 28 \text { de setembro de } 2007 \text {, e iniciou seus trabalhos. Em } 4 \text { de } \\
\text { fevereiro de } 2008 \text {, a Argentina pediu a suspensão dos trabalhos do painel (artigo } 12.12 \\
\text { ESC), uma vez que a CAMEX do Brasil havia decidido suspender a aplicação das medidas } \\
\text { antidumping objeto da controvérsia ( decisão de } 29 \text { de janeiro de } 2008 \text { ). Uma vez } \\
\text { suspensos os trabalhos do painel, e não tendo sido provocado a retomar sua função, a } \\
\text { autoridade do painel se esvaiu em } 5 \text { de fevereiro de } 2009 \text {. Os dados deste caso foram } \\
\text { retirados da base de dados de solução de controvérsias da OMC: }\end{array}$ \\
\hline
\end{tabular}




\begin{tabular}{|c|c|}
\hline & $\begin{array}{l}<\text { http://www.wto.org/english/tratop_e/dispu_e/cases_e/ds355_e.htm> Acesso em: } 22 \text { jan. } \\
\text { 2014. }\end{array}$ \\
\hline DS472 & 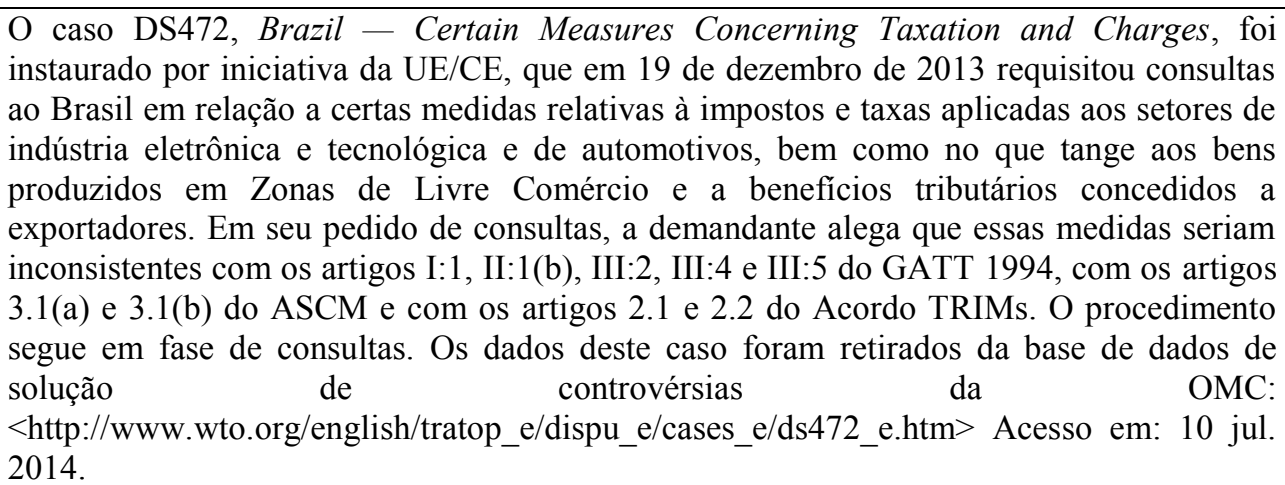 \\
\hline
\end{tabular}




\section{APÊNDICE C}

TABELA 2. PARTICIPAÇÃO DO BRASIL COMO DEMANDANTE NO SISTEMA DE SOLUÇÃO DE CONTROVÉRSIAS DA OMC

\begin{tabular}{|c|c|c|c|c|c|c|}
\hline $\begin{array}{l}\text { Tema } \\
\text { Principal }\end{array}$ & Subsídios & $\begin{array}{l}\text { Medidas } \\
\text { Antidumping }\end{array}$ & $\begin{array}{l}\text { Medidas } \\
\text { Sanitárias e } \\
\text { fitossanitárias }\end{array}$ & $\begin{array}{l}\text { Barreiras } \\
\text { técnicas }\end{array}$ & $\begin{array}{l}\text { Propriedade } \\
\text { Intelectual }\end{array}$ & Outros \\
\hline $\begin{array}{ll}\text { Fase } & \text { de } \\
\text { consultas } & \end{array}$ & $\begin{array}{l}\text { DS71, } \\
\text { DS112, } \\
\text { DS218 }\end{array}$ & $\begin{array}{l}\text { DS208, } \\
\text { DS216, } \\
\text { DS239, } \\
\text { DS439 }\end{array}$ & & & $\begin{array}{l}\text { DS224, } \\
\text { DS409 }\end{array}$ & $\begin{array}{l}\text { DS154, } \\
\text { DS209 }\end{array}$ \\
\hline Fase do painel & DS365 & & & & & \\
\hline $\begin{array}{ll}\begin{array}{l}\text { Fase } \\
\text { apelação }\end{array} & \text { da } \\
\end{array}$ & & & & & & \\
\hline $\begin{array}{l}\text { Relatório } \\
\text { adotado, sem } \\
\text { necessidade de } \\
\text { conduta do } \\
\text { demandado }\end{array}$ & & & & & & DS259 \\
\hline $\begin{array}{l}\text { Relatório } \\
\text { adotado, com } \\
\text { recomendação }\end{array}$ & DS266 & DS241 & & & & DS69 \\
\hline $\begin{array}{l}\text { Implementação } \\
\text { notificada pelo } \\
\text { demandado }\end{array}$ & & DS219 & & DS4 & & DS269 \\
\hline $\begin{array}{l}\text { Solução } \\
\text { mutuamente } \\
\text { acordada para } \\
\text { implementação }\end{array}$ & & DS382 & & & & \\
\hline $\begin{array}{ll}\text { Painel } & \text { de } \\
\text { verificação } & \text { de } \\
\text { cumprimento }\end{array}$ & & & & & & \\
\hline \begin{tabular}{l}
\multicolumn{2}{l}{ Verificação } \\
com conclusão \\
der não \\
cumprimento
\end{tabular} & DS70 & & & & & \\
\hline $\begin{array}{l}\text { Verificação } \\
\text { com conclusão } \\
\text { de } \\
\text { cumprimento }\end{array}$ & & & & & & \\
\hline $\begin{array}{l}\text { Autorização } \\
\text { para retaliar }\end{array}$ & $\begin{array}{l}\text { DS222, } \\
\text { DS267 }\end{array}$ & DS217 & & & & \\
\hline $\begin{array}{l}\text { Autoridade do } \\
\text { painel caducou }\end{array}$ & & & & & & \\
\hline $\begin{array}{l}\text { Desistência ou } \\
\text { solução } \\
\text { mutuamente }\end{array}$ & & & & & & $\begin{array}{l}\text { DS190 } \\
\text { DS250 }\end{array}$ \\
\hline
\end{tabular}




\begin{tabular}{|l|l|l|l|l|l|l|}
\hline $\begin{array}{c}\text { Tema } \\
\text { Principal }\end{array}$ & Subsídios & $\begin{array}{l}\text { Medidas } \\
\text { Antidumping }\end{array}$ & $\begin{array}{l}\text { Medidas } \\
\text { Sanitárias e } \\
\text { fitossanitárias }\end{array}$ & $\begin{array}{l}\text { Barreiras } \\
\text { técnicas }\end{array}$ & $\begin{array}{l}\text { Propriedade } \\
\text { Intelectual }\end{array}$ & Outros \\
\hline $\begin{array}{l}\text { acordada } \\
\text { durante o } \\
\text { procedimento }\end{array}$ & & & & & & \\
\hline
\end{tabular}

Obs. 1: As áreas destacadas da tabela demonstram o foco de nossa análise, as fases em que considera-se haver implementação da decisão. As fases anteriores são agrupadas de modo geral, sem pretensão de abordagem detalhada.

Obs. 2: A separação dos casos segundo as categorias expressadas no sentido horizontal se deu conforme a preponderância numérica dos dispositivos citados na argumentação do demandante e/ou segundo a natureza da medida. Muitos casos poderiam ter sido incluídos em mais de uma classe temática, mas esse procedimento foi evitado na constituição desta tabela. Nota-se, contudo, que há uma natural coincidência temática entre os casos que envolvem simultaneamente subsídios e antidumping, bem como aqueles que envolvem simultaneamente barreiras técnicas e medidas sanitárias e fitossanitárias. Para uma visão mais detalhada dos acordos citados nos casos, remete-se ao apêndice D. 


\section{APÊNDICE D}

\section{BREVE DESCRIÇÃO DOS CASOS EM QUE O BRASIL ATUOU COMO DEMANDANTE NO SISTEMA DE SOLUÇÃO DE CONTROVÉRSIAS DA OMC}

\begin{tabular}{|c|c|}
\hline $\begin{array}{l}\text { NÚMERO } \\
\text { DO CASO }\end{array}$ & BREVE DESCRIÇÃO DO CASO \\
\hline DS4 & 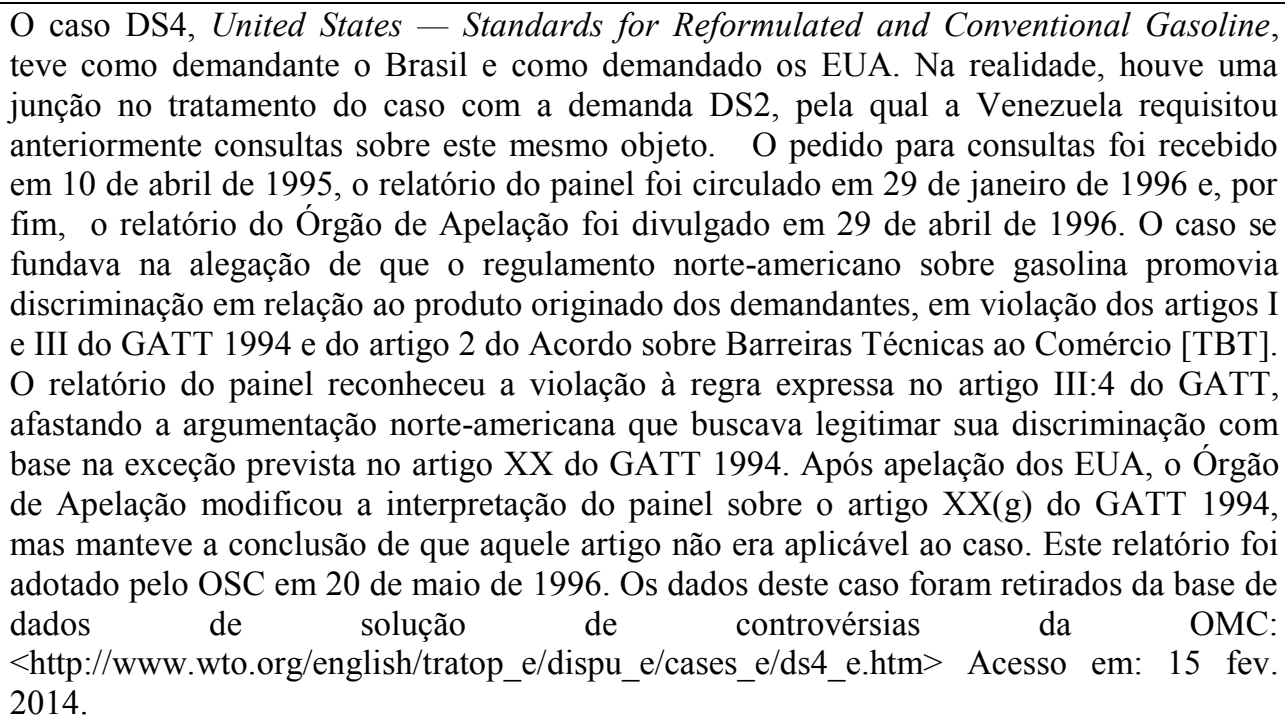 \\
\hline DS69 & 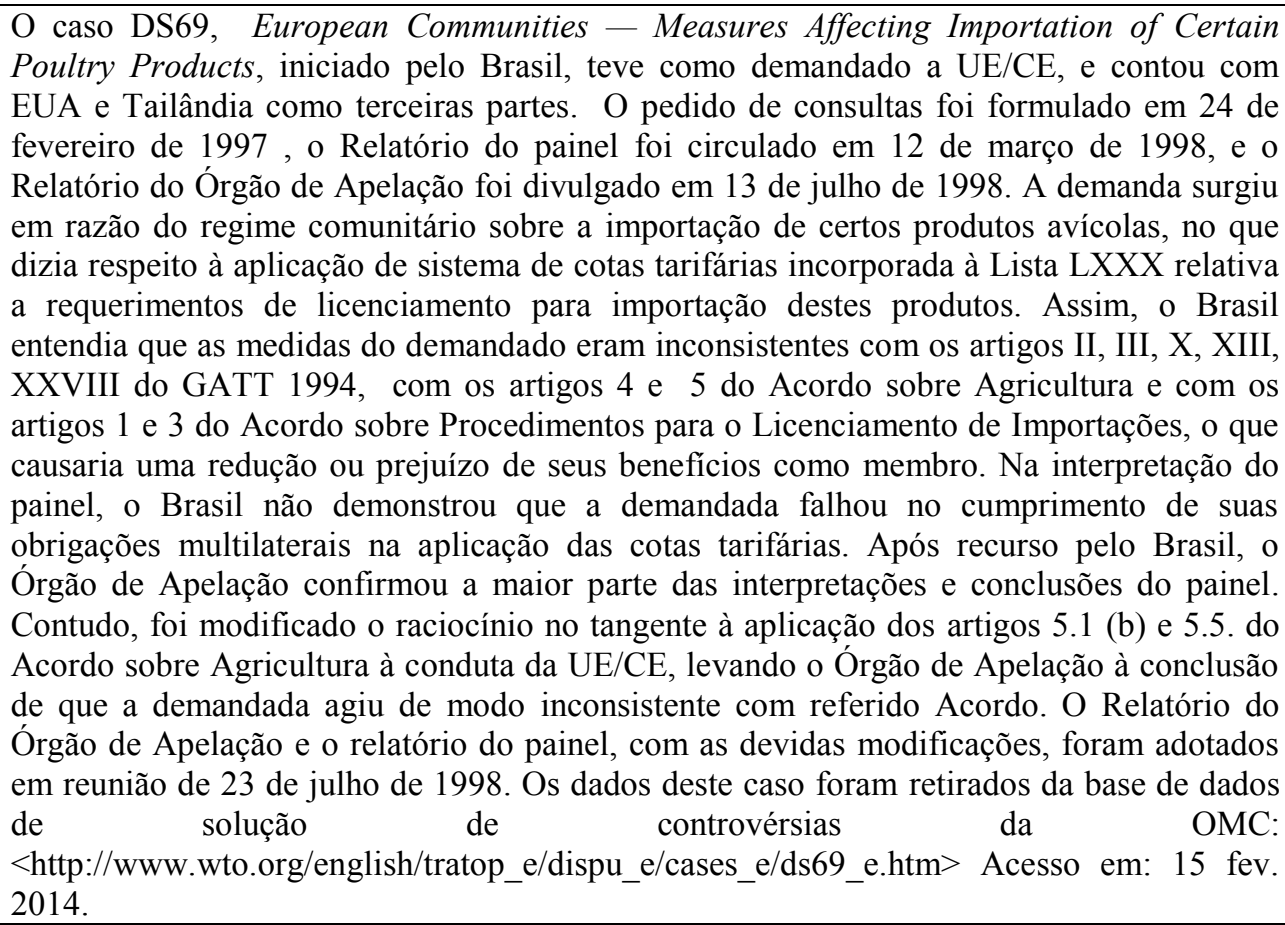 \\
\hline DS70 & $\begin{array}{l}\text { O caso DS70, Canada-Measures Affecting the Export of Civilian Aircraft, insere-se no } \\
\text { contexto da controvérsia entre Brasil e Canadá sobre os subsídios à aeronaves. O caso em } \\
\text { questão iniciou-se de pedido de consultas, em } 10 \text { de março de 1997, instaurado pelo Brasil } \\
\text { em face do Canadá. Segundo o Brasil, os subsídios canadenses concedidos à Bombardier } \\
\text { consistiam numa violação aos artigos } 3,3.1 \text { (a), } 3.2 \text { do ASMC. UE/CE e EUA reservaram } \\
\text { seus direitos como terceiras partes. O painel foi estabelecido em } 23 \text { de Julho de } 1998 \text {, e seu } \\
\text { relatório foi exarado aos membros em } 14 \text { de abril de } 1999 \text {. O relatório reconhecia que os }\end{array}$ \\
\hline
\end{tabular}




\begin{tabular}{|c|c|}
\hline & 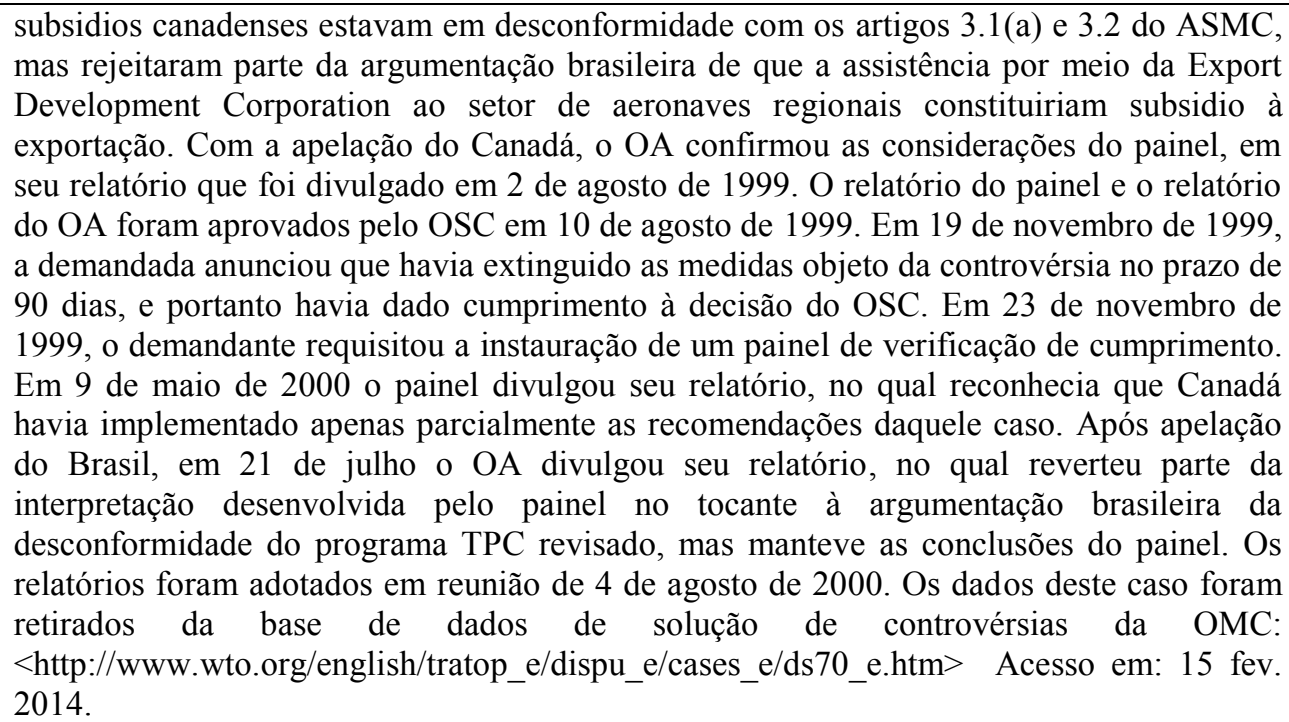 \\
\hline DS71 & $\begin{array}{l}\text { O caso DS71, Canada - Measures Affecting the Export of Civilian Aircraft, foi iniciado } \\
\text { pelo Brasil com pedido de consultas com o Canadá, em } 10 \text { de março de } 1997 \text {. A demanda } \\
\text { questionava as mesmas medidas objeto do caso DS70, mas com base em dispositivos } \\
\text { diversos. Referido procedimento se embasava no artigo } 7 \text { do Acordo de subsídios, } \\
\text { relativos aos subsídios acionáveis (Parte III do Acordo), e portanto com efeitos diversos. O } \\
\text { procedimento restou congelado na fase de consultas, não tendo sido dado andamento } \\
\text { formal posterior a este procedimento. Os dados deste caso foram retirados da base de } \\
\text { dados de colução de de controvérsias } \quad \text { da } \\
<\text { http://www.wto.org/english/tratop_e/dispu_e/cases_e/ds71_e.htm> Acesso em: } 2 \text { fev. } \\
2014\end{array}$ \\
\hline DS112 & $\begin{array}{l}\text { O caso DS112, Peru - Countervailing Duty Investigation against Imports of Buses from } \\
\text { Brazil, foi iniciado com o pedido de consultas, recebido em } 23 \text { de dezembro de } 1997 . \\
\text { Tratava-se de questionamento em função de uma investigação de direitos compensatórios } \\
\text { realizada pelo Peru em face de importação de ônibus do Brasil, que segundo o demandante } \\
\text { havia sido iniciada em desconformidade com os artigos } 11 \text { e } 13.1 \text { do ASMC. O } \\
\text { procedimento, contudo, não avançou, tendo se estagnado na fase de consultas. Os dados } \\
\text { deste caso foram retirados da base de dados de solução de controvérsias da OMC: } \\
<\text { http://www.wto.org/english/tratop_e/dispu_e/cases_e/ds112_e.htm> Acesso em: } 2 \text { fev. } \\
2014 \text {. }\end{array}$ \\
\hline DS154 & $\begin{array}{l}\text { O caso DS154, European Communities - Measures Affecting Differential and Favourable } \\
\text { Treatment of Coffee, foi iniciado pelo Brasil em } 7 \text { de dezembro de } 1998 \text {, com o pedido de } \\
\text { consultas em face da UE/CE. Neste procedimento, o Brasil questionava o Sistema Geral de } \\
\text { Preferências (SGP) da UE/CE, em sua aplicação ao café solúvel, como expresso na } \\
\text { Resolução do Conselho n. 1256/96, que garantia aos beneficiários livre acesso ao mercado } \\
\text { da comunidade europeia. Na medida em que este tratamento afeta negativamente a } \\
\text { importação de seu produto ao mercado da demandada, o Brasil alegava que o tratamento } \\
\text { era inconsistente com o princípio da nação mais favorecida, como insculpido no Art. I do } \\
\text { GATT 1994, causando ainda a redução de seus benefícios. O procedimento restou } \\
\text { congelado na fase de consultas, não tendo sido dado andamento formal posterior. Os dados } \\
\text { deste caso foram retirados da base de dados de solução de controvérsias da OMC: } \\
<\text { http://www.wto.org/english/tratop_e/dispu_e/cases_e/ds154_e.htm> Acesso em: } 2 \text { fev. } \\
\text { 2014. }\end{array}$ \\
\hline DS190 & $\begin{array}{l}\text { O caso DS190, Argentina - Transitional Safeguard Measures on Certain Imports of } \\
\text { Woven Fabric Products of Cotton and Cotton Mixtures Originating in Brazil, foi } \\
\text { instaurado com o pedido de consultas formulado pelo Brasil em } 11 \text { de fevereiro de 2000, } \\
\text { tendo o Paquistão, o Paraguai e os EUA como terceiras partes. O procedimento se referia a } \\
\text { medidas de salvaguarda transitória aplicadas pela Argentina contra certas importações de } \\
\text { tecidos de algodão e misturas de algodão oriundas do Brasil. Por força do comando } \\
\text { específico do Acordo de Têxteis, o Brasil havia submetido a medida à revisão do Órgão de } \\
\text { Supervisão de Têxteis, e este havia recomendado a retirada da salvaguarda em questão. Em } \\
\text { face da não adoção da recomendação expressa pelo OST, e a continuidade da medida, o } \\
\text { Brasil iniciou o procedimento alegando que referidas salvaguardas transitórias seriam }\end{array}$ \\
\hline
\end{tabular}




\begin{tabular}{|c|c|}
\hline & $\begin{array}{l}\text { inconsistentes com os artigos } 2.4,6.1,6.2,6.3,6.4,6.7,6.8,6.11,8.9 \text { e } 8.10 \text { do Acordo } \\
\text { sobre Têxteis. O painel havia sido estabelecido pelo OSC em } 20 \text { de março de } 2000 \text {, mas as } \\
\text { partes notificaram uma solução mutuamente acordada em comunicado conjunto datado de } \\
30 \text { de junho de } 2000 \text {. Os dados deste caso foram retirados da base de dados de solução de } \\
\text { controvérsias } \\
<\text { http://www.wto.org/english/tratop_e/dispu_e/cases_e/ds190_e.htm> Acesso em: } 10 \text { fev. } \\
2014 \text {. }\end{array}$ \\
\hline DS208 & $\begin{array}{l}\text { O caso DS208, Turkey - Anti-Dumping Duty on Steel and Iron Pipe Fittings, foi iniciado } \\
\text { em } 9 \text { de Outubro de } 2000 \text {, com o pedido do Brasil para a realização de consultas com a } \\
\text { Turquia relativas a investigações de antidumping sob acessórios para tubos de ferro e aço } \\
\text { do Brasil. O demandante entendia que o procedimento estaria em desconformidade com } \\
\text { diversos elementos da disciplina normativa multilateral, em especial haveria violação dos } \\
\text { artigos } 2,3,5,6,12 \text { e } 15 \text { do Acordo sobre Anti-Dumping e do artigo VI do GATT } 1994 \text {. } \\
\text { O procedimento restou congelado na fase de consultas, não tendo sido dado andamento } \\
\text { formal posterior. Os dados deste caso foram retirados da base de dados de solução de } \\
\text { controvérsias } \\
<\text { http://www.wto.org/english/tratop_e/dispu_e/cases_e/ds208_e.htm> Acesso em: } 2 \text { fev. } \\
\text { 2014. }\end{array}$ \\
\hline DS209 & $\begin{array}{l}\text { O caso DS209, European Communities — Measures Affecting Soluble Coffee, foi } \\
\text { instaurado por pedido do Brasil, em } 12 \text { de outubro de } 2000 \text {, para a realização de consultas } \\
\text { com a UE/CE, sobre medidas relativas ao Sistema Geral de Preferências (SGP), em sua } \\
\text { aplicação ao café solúvel. A medida questionada se tratava do mecanismo denominado } \\
\text { "graduação", que reduz ou elimina preferencias concedidas sob certos produtos ou países } \\
\text { incluídos no SGP. O demandante também questionava a medida denominada "regime de } \\
\text { drogas", que conferia tratamento preferencial a produtos originados de países andinos e } \\
\text { centro-americanos que implementassem campanha de combate aos entorpecentes. Por } \\
\text { causarem um efeito adverso na importação de café solúvel originário do Brasil, as } \\
\text { normativas comunitárias que previam estes mecanismo seriam inconsistentes com a } \\
\text { Cláusula de Habilitação, bem como com o artigo I do GATT 1994. O procedimento } \\
\text { permaneceu na fase de consultas, não tendo sido dado andamento formal posterior. Os } \\
\text { dados deste caso foram retirados da base de dados de solução de controvérsias da OMC: } \\
<\text { http://www.wto.org/english/tratop_e/dispu_e/cases_e/ds209_e.htm> Acesso em: } 4 \text { fev. } \\
2014\end{array}$ \\
\hline DS216 & 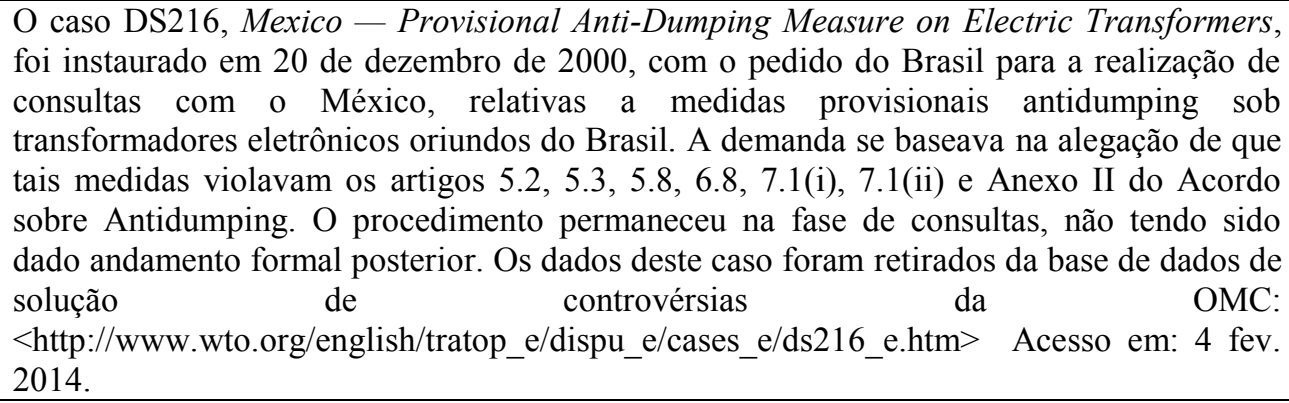 \\
\hline DS217 & $\begin{array}{l}\text { O caso DS217, United States - Continued Dumping and Subsidy Offset Act of 2000, foi } \\
\text { iniciado pelo Brasil, juntamente com Austrália, Chile, UE/CE, İndia, Indonésia, Japão, } \\
\text { República da Coreia, e Tailândia em face dos Estados Unidos, e contou com Argentina, } \\
\text { Canadá, China, Costa Rica, Hong Kong, Israel, México e Noruega como terceiras partes. } \\
\text { O pedido de consultas foi formulado em } 21 \text { de dezembro de } 2000 \text {, o Relatório do painel foi } \\
\text { circulado em } 16 \text { de setembro de 2002, e o Relatório do Órgão de Apelação foi divulgado } \\
\text { em } 16 \text { de janeiro de } 2003 \text {. A demanda surgiu em razão de emendas relativas à legislação } \\
\text { norte-americana de dumping ("the Byrd Amendment"), que no entendimento dos } \\
\text { demandantes violavam diversas obrigações multilaterais, em especial os artigos VI:3, X:3, } \\
\text { XXIII:1 e VI:2 do GATT 1994, os artigos } 1,5.4,8,18.1 \text { e } 18.4 \text { do Acordo sobre } \\
\text { Antidumping, e os artigos } 4.10,7.9,10,11.4,18,32.1 \text { e } 32.5 \text { do ASMC. Na interpretação } \\
\text { do painel, a medida questionada estava em desconformidade com alguns dos dispositivos } \\
\text { citados. Após o recurso do demandado, o Orrgão de Apelação confirmou a maior parte das } \\
\text { interpretações e conclusões do painel sobre a desconformidade da medida com certos } \\
\text { dispositivos do Acordo sobre Antidumping, do ASMC e do GATT 1994, embora tenha } \\
\text { revertido parcialmente determinados entendimentos do painel. O Relatório do Órgão de } \\
\text { Apelação, bem como do painel, com as devidas modificações, foi adotado em reunião de }\end{array}$ \\
\hline
\end{tabular}




\begin{tabular}{|c|c|}
\hline & $\begin{array}{l}27 \text { de janeiro de 2003. Em seguida, os demandantes requisitaram a arbitragem do artigo } \\
\text { 21.3. (c) do ESC, que determinou que o tempo razoável para a implementação seria de } 11 \\
\text { meses. Em } 15 \text { de janeiro de 2004, Brasil, Canadá, UE/CE, Chile, Coréia, Índia, Japão e } \\
\text { México requereram ao OSC autorização para suspender as concessões, tendo em vista a } \\
\text { falha na implementação pela demandante. Uma vez estabelecida arbitragem com base no } \\
\text { artigo } 22.6 \text { do ESC, o laudo arbitral fixou limite máximo para a suspensão. A suspensão de } \\
\text { direitos - autorização para retaliar - foi concedida em } 26 \text { de novembro de } 2004 \text {. Em } 17 \text { de } \\
\text { fevereiro de } 2006 \text { os EUA aprovaram modificação legislativa nesta seara, mas a maior } \\
\text { parte dos demandantes discordou que o demandante havia implementado suas obrigações. } \\
\text { Os dados deste caso foram retirados da base de dados de solução de controvérsias da } \\
\text { OMC: <http://www.wto.org/english/tratop_e/dispu_e/cases_e/ds217_e.htm> Acesso em: } \\
18 \text { fev. } 2014 \text {. }\end{array}$ \\
\hline DS218 & $\begin{array}{l}\text { O caso DS218, United States - Countervailing Duties on Certain Carbon Steel Products } \\
\text { from Brazil, foi iniciado em } 21 \text { de dezembro de } 2000 \text {, a pedido do Brazil, que requereu } \\
\text { consultas com os EUA acerca de aspectos da prática de imposição medidas } \\
\text { compensatórias sob certos produtos de aço carbono oriundos do Brasil. A prática } \\
\text { questionada dizia respeito à aplicação destas medidas à empresas privatizadas sob } \\
\text { benefícios relativos à subsídios anteriores à sua privatização, o que violaria os artigos } \\
1.1(\text { b), } 10,11.9,14,19 \text { e } 21 \text { do ASMC. Segundo a argumentação do demandante, a prática } \\
\text { já havia sido declarada inconsistente no caso DS138 US - Lead and Bismuth II. O } \\
\text { procedimento permaneceu na fase de consultas, não tendo sido dado andamento formal } \\
\text { posterior. Os dados deste caso foram retirados da base de dados de solução de } \\
\text { controvérsias } \\
\text { <http://www.wto.org/english/tratop_e/dispu_e/cases_e/ds218_e.htm> Acesso em: } 10 \text { fev. } \\
2014 \text {. }\end{array}$ \\
\hline DS219 & $\begin{array}{l}\text { O caso DS219, European Communities - Anti-Dumping Duties on Malleable Cast Iron } \\
\text { Tube or Pipe Fittings from Brazil, será analisado no subitem 3.5.2. }\end{array}$ \\
\hline DS222 & $\begin{array}{l}\text { O caso DS222, Canada - Export Credits and Loan Guarantees for Regional Aircraft, foi } \\
\text { iniciado pelo Brasil, em face do Canadá, e contou com Austrália, UE/CE, EUA e India } \\
\text { como terceiras partes. O pedido de consultas foi feito em } 22 \text { de janeiro de 2001, relativo a } \\
\text { subsídios concedidos ao setor de aeronaves regionais. Segundo o Brasil diversas medidas } \\
\text { de apoio concedidas pelo governo canadense consistiam em violação aos artigos } 1 \text { e } 3 \text {, e ao } \\
\text { Anexo I (j) e (k) do ASMC. O painel foi estabelecido em } 12 \text { de março de } 2001 \text {, e divulgou } \\
\text { seu relatório em } 28 \text { de janeiro de } 2002 \text {. O relatório do painel rejeitou a maior parte das } \\
\text { reclamações brasileiras, acolhendo, contudo, a alegação de que financiamentos por meio } \\
\text { da Export Development Corporation (EDC) consistiam em subsidies proibidos à } \\
\text { exportação. O relatório foi adotado em } 19 \text { de fevereiro de } 2002 \text {. Em } 23 \text { de maio de } 2002 \text {, } \\
\text { embasando-se na alegação de que o Canadá não havia implementado as recomendações do } \\
\text { painel no prazo de } 90 \text { dias, o demandante requereu autorização para suspender concessões, } \\
\text { por força do artigo } 22.2 \text { do ESC. Em } 24 \text { de junho de } 2002 \text { brasil retomou a requisição para } \\
\text { suspender as concessões no valor de US } \$ 3.36 \text { bilhões. Como houve discordância por parte } \\
\text { do Canadá, a questão foi levada à arbitragem prevista no artigo } 22.6 \text { do ESC. O laudo do } \\
\text { árbitro foi exarado em } 17 \text { de fevereiro de } 2003 \text {, quantificando em US\$247,797,000 o valor } \\
\text { apropriado de contramedidas. Em } 18 \text { de março de } 2003 \text {, o OSC autorizou a suspensão das } \\
\text { concessões. Tais medidas, contudo, não chegaram a ser aplicadas pois as partes chegaram } \\
\text { a um acordo. Os dados deste caso foram retirados da base de dados de solução de } \\
\text { controvérsias da } \\
\text { <http://www.wto.org/english/tratop_e/dispu_e/cases_e/ds } 222 \text { e.html> Acesso em: } 20 \text { fev. } \\
2014 \text {. }\end{array}$ \\
\hline DS224 & $\begin{array}{l}\text { O caso DS224, United States - US Patents Code, foi instaurado por pedido do Brasil, em } \\
31 \text { de janeiro de } 2001 \text {, para o estabelecimento de consultas com os EUA relativas a } \\
\text { aspectos de sua legislação de proteção da propriedade intelectual por meio de patentes, o } \\
\text { "US Patents Code". Segundo o demandante, o capítulo 18, em especial, continha diversos } \\
\text { elementos discriminatórios, em violação às obrigações assumidas nos artigos } 27 \text { e } 28 \text { do } \\
\text { TRIPS, bem como no artigo } 2 \text { do TRIMs e artigos III e XI do GATT 1994. O } \\
\text { procedimento permaneceu na fase de consultas, não tendo sido dado andamento formal } \\
\text { posterior. Os dados deste caso foram retirados da base de dados de solução de } \\
\text { controvérsias } \\
\text { <http://www.wto.org/english/tratop_e/dispu_e/cases_e/ds224_e.htm> Acesso em: } 10 \text { fev. } \\
2014 \text {. }\end{array}$ \\
\hline
\end{tabular}




\begin{tabular}{|c|c|}
\hline DS239 & $\begin{array}{l}\text { O caso DS239, United States - Anti-Dumping Duties on Silicon Metal from Brazil, } \\
\text { originou-se de demanda do Brasil, em } 17 \text { de setembro de } 2001 \text {, para a realização de } \\
\text { consultas com os EUA. O pedido de consultas formulado foi substituído por uma nova } \\
\text { requisição em } 01 \text { de novembro de } 2001 \text {, na qual o demandante questionava medidas } \\
\text { antidumping impostas sob a importação de silício metálico do Brasil, mediante aplicação } \\
\text { da metodologia do "zeroing". Segundo o demandante, a metodologia aplicada era } \\
\text { inconsistente com diversos artigos do Acordo sobre Anti-Dumping, em especial com os } \\
\text { artigos } 2.4 .2,5.8,9.3,11.1,11.2 \text { e } 18.3 \text {. UE/CE e Tailândia pediram para juntar-se às } \\
\text { consultas. O procedimento permaneceu na fase de consultas, não tendo sido dado } \\
\text { andamento formal posterior. Os dados deste caso foram retirados da base de dados de } \\
\text { solução de controvérsias } \\
<\text { http://www.wto.org/english/tratop_e/dispu_e/cases_e/ds239_e.htm> Acesso em: } 10 \text { fev. } \\
\text { 2014. }\end{array}$ \\
\hline DS241 & $\begin{array}{l}\text { O caso DS241, Argentina - Definitive Anti-Dumping Duties on Poultry from Brazil, foi } \\
\text { iniciado pelo Brasil, em face da Argentina, e contou com Canadá, UE/CE, Chile, EUA, } \\
\text { Guatemala e Paraguai como terceiras partes. O pedido de consultas foi formulado em } 7 \text { de } \\
\text { dezembro de } 2001 \text { e o Relatório do painel foi circulado em } 22 \text { de Abril de } 2003 \text {. A } \\
\text { demanda surgiu em razão de direitos antidumping impostos pela Argentina ao frango } \\
\text { oriundo do Brasil, que no entendimento do demandante violava diversas obrigações } \\
\text { multilaterais, em especial o artigo VI do GATT } 1994 \text {, os artigos } 1,2,3,4,5,6,9,12 \text { e } \\
\text { Anexo II do Acordo sobre Antidumping, os artigos } 1 \text { e } 7 \text { do Acordo sobre Valoração } \\
\text { aduaneira. Na interpretação do painel, a medida questionada estava em desconformidade } \\
\text { com os artigos } 2.4,2.4 .2,3.1,3.2,3.3,3.4,3.5,5.1,5.8,6.1 .1,6.1 .3,6.8 \text { e Anexo II, } 6.10 \text { e } \\
12.1 \text { do Acordo sobre Anti-Dumping. O Relatório do Orgão de Apelação foi adotado em } \\
\text { reunião de } 19 \text { de maio de } 2003 \text {. Os dados deste caso foram retirados da base de dados de } \\
\text { solução } \\
\text { <http://www.wto.org/english/tratop_e/dispu_e/cases_e/ds241_e.html> Acesso em: } 20 \text { fev. } \\
\text { 2014. } \\
\text { de controvérsias }\end{array}$ \\
\hline DS250 & $\begin{array}{l}\text { O caso DS250, United States - Equalizing Excise Tax Imposed by Florida on Processed } \\
\text { Orange and Grapefruit Products, originou-se de demanda do Brasil, em } 20 \text { de março de } \\
\text { 2002, para a realização de consultas com os EUA, relativas à medida "Equalizing Excise } \\
\text { Tax", imposta pelo Estado da Florida sob produtos processados de laranja e toranja. } \\
\text { Segundo o demandante, este tributo tem sido imposto sob tais produtos, excepcionando de } \\
\text { sua incidência aqueles produzidos nos EUA, em violação aos artigos II:1(a), III.1 e III:2 do } \\
\text { GATT 1994. Considerando que sucos cítricos era um dos produtos mais significativos de } \\
\text { exportação do Brasil no comércio com os EUA, tratava-se também de demanda de não- } \\
\text { violação. O estabelecimento do painel foi autorizado pelo OSC em 1o de Outubro de } 2002 \text {. } \\
\text { UE/CE, Chile, México e Paraguai reservaram seus direitos como terceiras partes no } \\
\text { procedimento. Contudo, em } 28 \text { de maio de } 2004 \text {, as partes da controvérsia informaram ao } \\
\text { OSC que haviam chegado a uma solução mutuamente acordada, no sentido do Artigo } 3.6 \\
\text { do ESC. Os dados deste caso foram retirados da base de dados de solução de controvérsias } \\
\text { da OMC: <http://www.wto.org/english/tratop_e/dispu_e/cases_e/ds } 250 \text { e.htm> Acesso } \\
\text { em: } 15 \text { fev. } 2014 \text {. }\end{array}$ \\
\hline DS259 & $\begin{array}{l}\text { O caso DS259, United States - Definitive Safeguard Measures on Imports of Certain } \\
\text { Steel Products, originou-se de demanda do Brasil, em } 21 \text { de maio de } 2002 \text {, para a } \\
\text { realização de consultas com os EUA, relativas a medidas de salvaguarda impostas pelo } \\
\text { demandado sob diversos produtos de aço. Segundo o demandante, estas medidas seriam } \\
\text { inconsistentes com as obrigações expressas nos artigos I, I:1, X:3, XIX e XIX:1 do GATT } \\
\text { 1994, nos artigos } 2,2.1,2.2,3,4 \text { e } 5 \text { do Acordo de Salvaguardas, e no artigo XVI do } \\
\text { Acordo que institui a OMC. Os casos DS248, DS249, DS251, DS252, DS253, DS254 e } \\
\text { DS258 tratavam das mesmas medidas, e portanto foi estabelecido um mesmo painel para } \\
\text { as demandas. Canadá, Cuba, México, Tailândia, Taiwan (Taipé Chinês), Turquia e } \\
\text { Venezuela reservaram seus direitos como terceiras partes neste procedimento. O Relatório } \\
\text { do painel, divulgado em } 11 \text { de julho de } 2003 \text {, concluiu que as salvaguardas impostas } \\
\text { estavam em desconformidade com diversos pré-requisitos estabelecidos dos Acordos. } \\
\text { Após apelação dos EUA, em } 10 \text { de novembro de } 2003 \text { o relatório do Órgão de Apelação } \\
\text { modificou algumas interpretações do painel, mas manteve a sua conclusão de } \\
\text { desconformidade das medidas questionadas. O Relatório do OA e o relatório do painel, } \\
\text { com as devidas modificações, foram adotados na reunião do OSC de } 10 \text { de dezembro de } \\
\text { 2003, contudo a adoção se deu sem necessidade de conduta corretiva pelo demandado, }\end{array}$ \\
\hline
\end{tabular}




\begin{tabular}{|c|c|}
\hline & 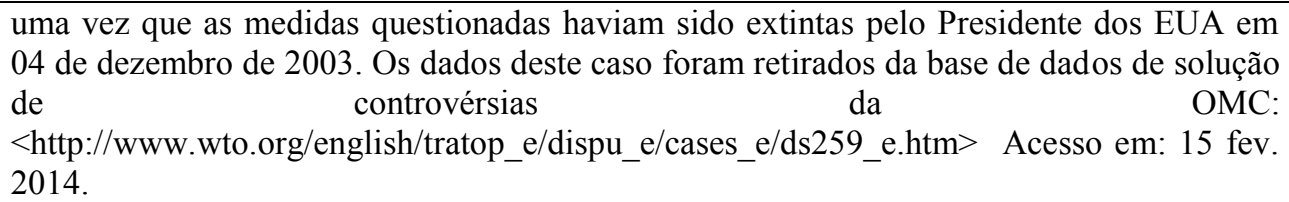 \\
\hline DS266 & 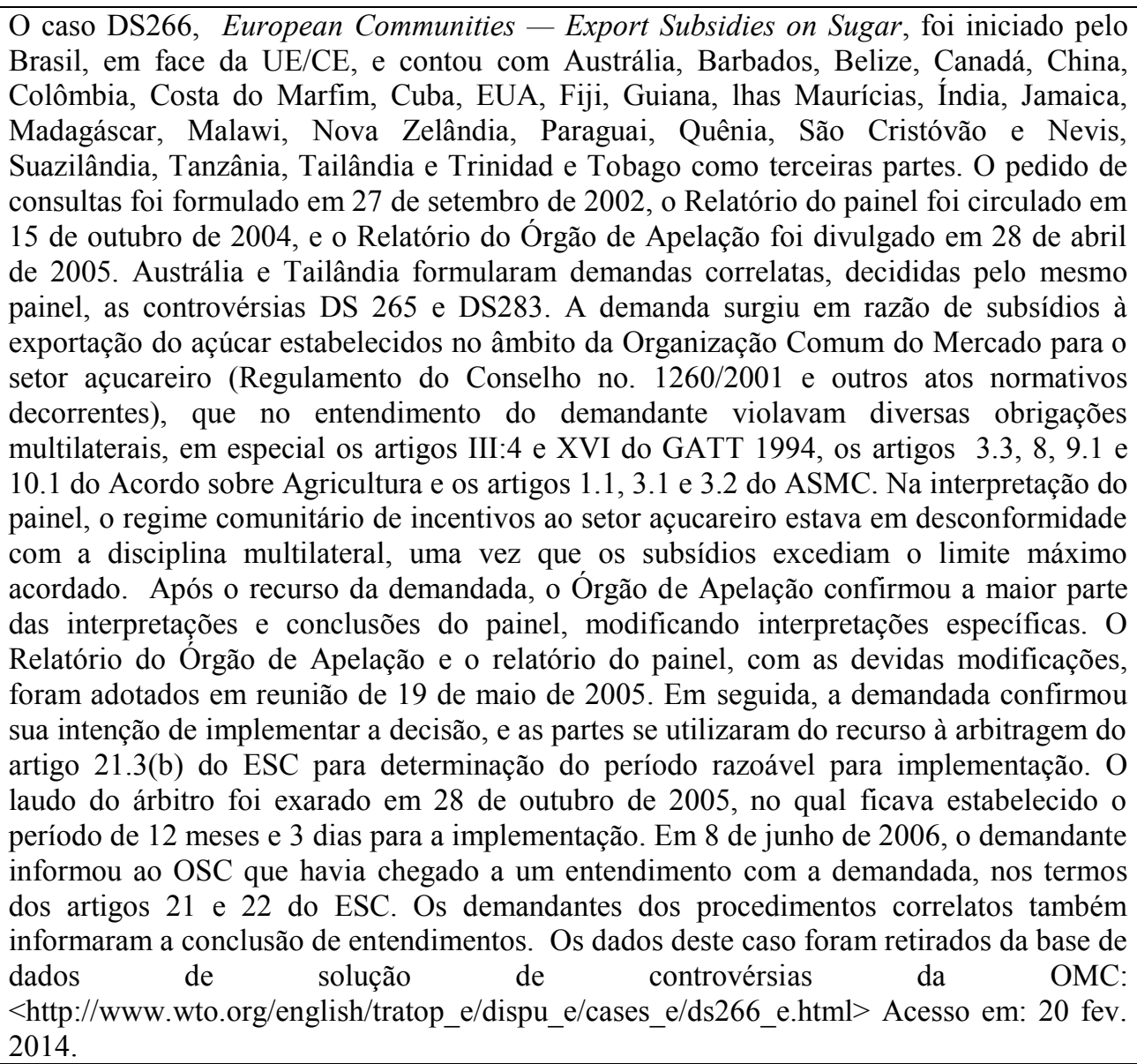 \\
\hline DS267 & $\begin{array}{l}\text { O caso DS267, United States - Subsidies on Upland Cotton, foi iniciado pelo Brasil, em } \\
\text { face dos Estados Unidos, e contou com Argentina, Austrália, Benin, Canadá, Chade, } \\
\text { China, UE/CE, Índia, Japão, Nova Zelândia, Paquistão, Paraguai, Taiwan (Taipei chinês), } \\
\text { Tailândia e Venezuela como terceiras partes. O pedido de consultas foi formulado em } 27 \\
\text { de setembro de 2002, o Relatório do painel foi circulado em } 8 \text { de setembro de } 2004 \text {, e o } \\
\text { Relatório do Órgão de Apelação foi divulgado em } 3 \text { de março de } 2005 \text {. A demanda surgiu } \\
\text { em razão de subsídios proibidos e acionáveis concedidos à indústria de algodão } \\
\text { (produtores, usuários e exportadores), que no entendimento do demandante violavam } \\
\text { diversas obrigações multilaterais, em especial os artigos III:4 e XVI do GATT 1994, os } \\
\text { artigos } 3.3,8,9.1 \text { e } 10.1 \text { do Acordo sobre Agricultura e os artigos } 1.1,3.1 \text { e } 3.2 \text { do ASMC. } \\
\text { Na interpretação do painel, as medidas em questão se tratavam de subsídios à exportação } \\
\text { proibidos, que estando sujeitos à disciplina multilateral de subsídios à exportação, estariam } \\
\text { excluídos da proteção da chamada "cláusula da paz" do Acordo sobre Agricultura. Os } \\
\text { acordos de apoio interno dos EUA, portanto, resultavam em graves prejuízos ao } \\
\text { demandante por meio da supressão do preço do produto do mercado mundial, estando em } \\
\text { desconformidade com as normas multilaterais. Após o recurso da demandada, o Órgão de } \\
\text { Apelação confirmou a maior parte das interpretações e conclusões do painel, modificando } \\
\text { certos raciocínios e interpretações específicas. O Relatório do Órgão de Apelação, bem } \\
\text { como do painel, com as devidas modificações, foi adotado em reunião de } 21 \text { de março de } \\
\text { 2005. A decisão do OSC neste caso incluiu a recomendação de que o demandante retirasse } \\
\text { os subsidies inconsistentes, no prazo de seis meses. O Brasil requisitou a formação de um } \\
\text { painel de verificação do cumprimento, que em } 18 \text { de dezembro de } 2007 \text { exarou seu } \\
\text { relatório, reconheceu a inconsistência da conduta norte-americana, que falhou ao cumprir a } \\
\text { obrigação do artigo } 7.8 \text { do ASMC, que fixa a obrigação de remoção dos subsidies e de } \\
\text { seus efeitos. Após recurso de ambas as partes, o relatório foi objeto de revisão pelo Órgão }\end{array}$ \\
\hline
\end{tabular}




\begin{tabular}{|c|c|}
\hline & $\begin{array}{l}\text { de Apelação, que em } 2 \text { de junho de } 2008 \text { divulgou seu relatório, confirmando a maior parte } \\
\text { das interpretações e conclusões do painel, modificando certos raciocínios e interpretações } \\
\text { específicas. O Relatório do Órgão de Apelação e o relatório do painel, com as devidas } \\
\text { modificações, foram adotados em reunião de } 20 \text { de Junho de } 2008 \text {. Em } 4 \text { de julho de } 2005 \text {, } \\
\text { antes do procedimento de verificação da implementação, o Brasil havia requisitado } \\
\text { autorização para aplicar contramedidas com base no artigo } 4.10 \text { do Acordo SCM e } \\
\text { suspender concessões ou outras obrigações, com base no artigo } 22.2 \text { do ESC. A requisição } \\
\text { do Brasil objetivava autorização para retaliação cruzada, isto é, suspensão de obrigações } \\
\text { do TRIPS e do GATS. A arbitragem do artigo } 22.2 \text { fixou que em relação aos subsídios } \\
\text { proibidos o limite seria de USD } 147.4 \text { milhões, e atingido um gatilho seria possível a } \\
\text { restrição relativa ao TRIPS e/ou GATS. Em relação aos subsidies acionáveis, de modo } \\
\text { correlato, restou estabelecido o nível máximo de USD } 147.3 \text { milhões anuais e atingido um } \\
\text { gatilho seria possível a restrição relativa ao TRIPS e/ou GATS. O OSC autorizou a } \\
\text { retaliação em relação aos subsídios proibidos e subsídios acionáveis em 19 de novembro } \\
\text { de } 2009 \text {. Em } 25 \text { de agosto de } 2010 \text {, as partes informaram ao OSC que haviam concluído } \\
\text { um Quadro para uma solução mutuamente acordada para a disputa, que embora não } \\
\text { constituísse uma solução mutuamente acordada, fixava parâmetros para a discussão e } \\
\text { negociação de solução, com a previsão de consultas periódicas. O Brasil iniciou } \\
\text { procedimentos internos para concretizar a retaliação autorizada, mas antes que fosse } \\
\text { iniciada conclui negociações com os EUA para suspender tais medidas enquanto não fosse } \\
\text { aprovada a nova Farm Bill norte-americana. Tais procedimentos foram retomados em } \\
2014 \text {. Os dados deste caso foram retirados da base de dados de solução de controvérsias da } \\
\text { OMC: <http://www.wto.org/english/tratop_e/dispu_e/cases_e/ds267_e.html> Acesso em: } \\
10 \text { jul. } 2014 \text {. }\end{array}$ \\
\hline DS269 & $\begin{array}{l}\text { O caso DS269, European Communities - Customs Classification of Frozen Boneless } \\
\text { Chicken Cuts, será analisado no subitem 3.5.3. }\end{array}$ \\
\hline DS365 & $\begin{array}{l}\text { O caso DS365, United States - Domestic Support and Export Credit Guarantees for } \\
\text { Agricultural Products, instaurou-se com o pedido de consultas formulado em } 11 \text { de julho } \\
\text { de } 2007 \text { pelo Brasil em face dos EUA. O procedimento questiona medidas também objeto } \\
\text { do prévio procedimento DS357, surgido do pedido de consultas formulado em 08 de } \\
\text { Janeiro de } 2007 \text { pelo Canadá. A medida questionada em ambos os casos consiste em } \\
\text { subsídios a produtos agrícolas, e no caso DS357 há o questionamento especial destes } \\
\text { subsidios na produção e industrialização do milho. A demanda DS365 questiona, pois, } \\
\text { medidas de apoio interno aos produtos agrícolas e garantias de crédito para a exportação } \\
\text { dos produtos agrícolas. Segundo o demandante, as medidas violariam os artigos 3.3, } 8,9.1 \\
\text { e } 10.1 \text { do Acordo sobre Agricultura, e os artigos 3.1(a) e } 3.2 \text { do ASMC. Canadá e Brasil } \\
\text { requisitaram a formação de um painel, e em } 17 \text { de dezembro de } 2007 \text {, foi autorizada a } \\
\text { realização do painel. Os seguintes membros constam como terceiras-partes: África do Sul, } \\
\text { Argentina, Austrália, Chile, China, UE/CE, Índia, Japão, México, Nova Zelândia, } \\
\text { Nicarágua, Taiwan, Tailândia, Turquia e Uruguai. Os dados deste caso foram retirados da } \\
\text { base de dados de solução de controvérsias da OMC: } \\
<\text { http://www.wto.org/english/tratop_e/dispu_e/cases_e/ds365_e.htm> Acesso em: } 10 \text { fev. } \\
\text { 2014. }\end{array}$ \\
\hline DS382 & $\begin{array}{l}\text { O caso DS382, United States - Anti-Dumping Administrative Reviews and Other } \\
\text { Measures Related to Imports of Certain Orange Juice from Brazil, foi iniciado pelo Brasil, } \\
\text { em face dos EUA, e contou com Argentina, UE/CE, Coreia, Japão, México, Taiwan } \\
\text { (Taipei chinesa) e Tailândia como terceiras partes. O pedido de consultas foi formulado } \\
\text { em } 27 \text { de novembro de } 2008 \text {, o Relatório do painel foi circulado em } 25 \text { de Março de } 2011 . \\
\text { A demanda surgiu em razão de certas decisões do Departamento de Comércio norte- } \\
\text { americano relativas à revisão de aplicação de direitos antidumping sobre a importação de } \\
\text { sucos de laranja oriundos do Brasil, que se caracterizam pelo uso contínuo da metodologia } \\
\text { de "zeroing", que no entendimento do demandante violava diversas obrigações } \\
\text { multilaterais, em especial as constantes dos artigos II, II:1, VI: } 1 \text { e VI:2 do GATT 1994, e } \\
\text { dos artigos } 1,2,2.1,2.4,2.4 .2,9.1,9.3,11.2 \text {, } 18.4 \text { do Acordo sobre Anti-Dumping. Na } \\
\text { interpretação do painel, os EUA agiram em desconformidade com o Acordo de Anti- } \\
\text { Dumping pela continua utilização da metodologia "zeroing", o zeramento para determinar } \\
\text { as margens de dumping. O painel avaliou que a medida questionada era muito similar, } \\
\text { senão idêntica, à conduta continuada objeto da demanda US - Continued Zeroing, e } \\
\text { havendo expectativa de sua continuidade é susceptível de ser levada à apreciação da } \\
\text { solução de controvérsias da OMC. O Relatório do painel foi adotado na reunião de } 19 \text { de }\end{array}$ \\
\hline
\end{tabular}




\begin{tabular}{|c|c|}
\hline & $\begin{array}{l}\text { junho de } 2011 \text {. Em seguida, as partes informaram que haviam acordado que o período } \\
\text { razoável para implementação seria de } 9 \text { meses. Em seguida, o demandado informou sobre } \\
\text { medidas internas de modificação da metodologia do cálculo de direitos antidumping, e } \\
\text { sobre a revogação de decisões sobre a aplicação de direitos antidumping sobre o suco de } \\
\text { laranja. Em } 3 \text { de abril de } 2012 \text {, as partes informaram ao OSC que haviam chegado a um } \\
\text { entendimento, nos termos dos artigos } 21 \text { e } 22 \text { do ESC. Em } 14 \text { de fevereiro de } 2013 \text {, a } \\
\text { partes informaram que haviam concluído uma solução mutuamente satisfatória para a } \\
\text { controvérsia, e esclareceram que em seu entendimento anterior haviam concordado em } \\
\text { estabelecer consultas no sentido de atingir solução para a controvérsia. Os dados deste } \\
\text { caso foram retirados da base de dados de solução de controvérsias da OMC: } \\
\text { <http://www.wto.org/english/tratop_e/dispu_e/cases_e/ds382_e.html> Acesso em: } 20 \text { fev. } \\
2014 \text {. }\end{array}$ \\
\hline DS409 & $\begin{array}{l}\text { O caso DS409, European Union and a Member State - Seizure of Generic Drugs in } \\
\text { Transit, instaurou-se com o pedido de consultas formulado pelo Brasil em face da UE/CE } \\
\text { e Países Baixos, em } 12 \text { de maio de } 2010 \text {. A consulta tratava da prática de apreensões de } \\
\text { medicamentos genéricos originados da India e outros, em trânsito nos portos holandeses, } \\
\text { para o Brasil e outros destinos. Segundo o demandante, as medidas violariam os artigos V } \\
\text { e X do GATT 1994, bem como o artigo XVI:4 do Acordo que cria a OMC, e diversos } \\
\text { dispositivos do TRIPS. Após o requerimento, e a aceitação pelo demandante, os membros } \\
\text { Canadá, China, Equador, India, Japão e Turquia se juntaram às consultas. Os dados deste } \\
\text { caso foram retirados da base de dados de solução de controvérsias da OMC: } \\
\text { <http://www.wto.org/english/tratop_e/dispu_e/cases_e/ds409_e.htm> Acesso em: } 10 \text { fev. } \\
2014\end{array}$ \\
\hline DS439 & $\begin{array}{l}\text { O caso DS439, South Africa - Anti-Dumping Duties on Frozen Meat of Fowls from } \\
\text { Brazil, foi iniciado pelo Brasil, com pedido de consultas com a África do Sul, formulado } \\
\text { em } 27 \text { de junho de } 2012 \text {. O pedido se relacionava a imposição de medidas antidumping } \\
\text { pela África do Sul à carne congelada de Aves importadas do Brasil. Segundo o } \\
\text { demandante, a medida violava os artigos } 2.4,2.4 .2,3.1,3.2,3.4,3.5,4.1,5.2,5.3,5.8,6.1 \text {, } \\
6.1 .2,6.2,6.4,6.5 .1,6.5 .2,6.7,6.8,6.9,6.10,7.1 \text { e } 12.2 .1 \text { do Acordo sobre Antidumping, } \\
\text { bem como os parágrafos } 7 \text { e } 8 \text { do Anexo I; e os parágrafos } 1,3,5,6 \text { e } 7 \text { do Anexo II do } \\
\text { mesmo Acordo. O procedimento segue na fase de consultas. Os dados deste caso foram } \\
\text { retirados da base de dados de solução de controvérsias da OMC: } \\
<\text { http://www.wto.org/english/tratop_e/dispu_e/cases_e/ds439_e.htm> Acesso em: } 10 \text { jul. } \\
2014 \text {. }\end{array}$ \\
\hline
\end{tabular}




\section{APÊNDICE E}

\section{TABELA 3. PARTICIPAÇÃO DO BRASIL COMO TERCEIRA PARTE NO SISTEMA DE SOLUÇÃO DE CONTROVÉRSIAS DA OMC}

\begin{tabular}{|c|c|c|c|c|c|c|}
\hline $\begin{array}{l}\text { Tema } \\
\text { Principal }\end{array}$ & Subsídios & $\begin{array}{l}\text { Medidas } \\
\text { Antidumping }\end{array}$ & $\begin{array}{l}\text { Medidas } \\
\text { Sanitárias e } \\
\text { fitossanitárias }\end{array}$ & $\begin{array}{l}\text { Barreiras } \\
\text { técnicas }\end{array}$ & $\begin{array}{l}\text { Propriedade } \\
\text { Intelectual }\end{array}$ & Outros \\
\hline \multicolumn{7}{|l|}{$\begin{array}{ll}\text { Fase } & \text { de } \\
\text { consultas } & \end{array}$} \\
\hline Fase do painel & $\begin{array}{l}\text { DS437, } \\
\text { DS456 }\end{array}$ & $\begin{array}{l}\text { DS420, } \\
\text { DS464, } \\
\text { DS471 }\end{array}$ & $\begin{array}{l}\text { DS430, } \\
\text { DS447 }\end{array}$ & & $\begin{array}{l}\text { DS434, } \\
\text { DS435, } \\
\text { DS441, } \\
\text { DS458, } \\
\text { DS467 }\end{array}$ & $\begin{array}{l}\text { DS453, } \\
\text { DS457, } \\
\text { DS462, } \\
\text { DS469 }\end{array}$ \\
\hline $\begin{array}{ll}\begin{array}{l}\text { Fase } \\
\text { apelação }\end{array} & \mathrm{da} \\
\end{array}$ & & & & & & $\begin{array}{l}\text { DS431, } \\
\text { DS432, } \\
\text { DS433 }\end{array}$ \\
\hline $\begin{array}{l}\text { Relatório } \\
\text { adotado, sem } \\
\text { necessidade de } \\
\text { conduta do } \\
\text { demandado }\end{array}$ & & DS244 & $\begin{array}{l}\text { DS135, } \\
\text { DS392 }\end{array}$ & & & $\begin{array}{l}\text { DS152, } \\
\text { DS248, } \\
\text { DS249, } \\
\text { DS251, } \\
\text { DS252, } \\
\text { DS253, } \\
\text { DS254, } \\
\text { DS258, } \\
\text { DS320, } \\
\text { DS321 }\end{array}$ \\
\hline $\begin{array}{l}\text { Relatório } \\
\text { adotado, com } \\
\text { recomendação }\end{array}$ & $\begin{array}{l}\text { DS265, } \\
\text { DS283 }\end{array}$ & $\begin{array}{l}\text { DS184, } \\
\text { DS350 }\end{array}$ & & & & \\
\hline $\begin{array}{l}\text { Implementação } \\
\text { notificada pelo } \\
\text { demandado }\end{array}$ & $\begin{array}{l}\text { DS138, } \\
\text { DS212, } \\
\text { DS339, } \\
\text { DS340, } \\
\text { DS342, } \\
\text { DS412, } \\
\text { DS426 }\end{array}$ & $\begin{array}{l}\text { DS335, } \\
\text { DS343, } \\
\text { DS345, } \\
\text { DS379, } \\
\text { DS405 }\end{array}$ & & & $\begin{array}{l}\text { DS114, } \\
\text { DS174, } \\
\text { DS290, } \\
\text { DS362 }\end{array}$ & $\begin{array}{l}\text { DS121, } \\
\text { DS204, } \\
\text { DS246, } \\
\text { DS286, } \\
\text { DS315, } \\
\text { DS375, } \\
\text { DS376, } \\
\text { DS377, } \\
\text { DS394, } \\
\text { DS395, } \\
\text { DS398 }\end{array}$ \\
\hline $\begin{array}{l}\text { Solução } \\
\text { mutuamente } \\
\text { acordada para } \\
\text { implementação }\end{array}$ & DS108 & & $\begin{array}{l}\text { DS76, } \\
\text { DS245 }\end{array}$ & & & \\
\hline $\begin{array}{ll}\text { Painel } & \text { de } \\
\text { verificação } & \text { de }\end{array}$ & $\begin{array}{l}\text { DS316, } \\
\text { DS317, }\end{array}$ & DS397 & $\begin{array}{l}\text { DS384, } \\
\text { DS386 }\end{array}$ & DS381 & & \\
\hline
\end{tabular}




\begin{tabular}{|c|c|c|c|c|c|c|}
\hline $\begin{array}{l}\text { Tema } \\
\text { Principal }\end{array}$ & Subsídios & $\begin{array}{l}\text { Medidas } \\
\text { Antidumping }\end{array}$ & $\begin{array}{l}\text { Medidas } \\
\text { Sanitárias e } \\
\text { fitossanitárias }\end{array}$ & $\begin{array}{l}\text { Barreiras } \\
\text { técnicas }\end{array}$ & $\begin{array}{l}\text { Propriedade } \\
\text { Intelectual }\end{array}$ & Outros \\
\hline cumprimento & DS353 & & & & & \\
\hline $\begin{array}{l}\text { Painel de } \\
\text { verificação } \\
\text { com conclusão } \\
\text { de não } \\
\text { cumprimento }\end{array}$ & & DS294 & & & & $\overline{\mathrm{DS} 207}$ \\
\hline $\begin{array}{l}\text { Painel de } \\
\text { verificação } \\
\text { com conclusão } \\
\text { de } \\
\text { cumprimento }\end{array}$ & & & & & & \\
\hline $\begin{array}{l}\text { Autorização } \\
\text { para retaliar }\end{array}$ & DS234 & & DS291 & DS406 & DS160 & \\
\hline $\begin{array}{l}\text { Autoridade do } \\
\text { painel caducou }\end{array}$ & DS347 & & & & & \\
\hline $\begin{array}{l}\text { Desistência ou } \\
\text { solução } \\
\text { mutuamente } \\
\text { acordada } \\
\text { durante o } \\
\text { procedimento }\end{array}$ & & DS344 & $\begin{array}{l}\text { DS292, } \\
\text { DS293, } \\
\text { DS391 }\end{array}$ & & & DS27 \\
\hline
\end{tabular}

Obs. 1: As áreas destacadas da tabela demonstram o foco de nossa análise, as fases em que considera-se haver implementação da decisão. As fases anteriores são agrupadas de modo geral, sem pretensão de abordagem detalhada.

Obs. 2: A separação dos casos segundo as categorias expressadas no sentido horizontal se deu conforme a preponderância numérica dos dispositivos citados na argumentação do demandante e/ou segundo a natureza da medida. Muitos casos poderiam ter sido incluídos em mais de uma classe temática, mas esse procedimento foi evitado na constituição desta tabela. Nota-se, contudo, que há uma natural coincidência temática entre os casos que envolvem simultaneamente subsídios e antidumping, bem como aqueles que envolvem simultaneamente barreiras técnicas e medidas sanitárias e fitossanitárias. Para uma visão mais detalhada dos acordos citados nos casos, remete-se ao apêndice $F$. 


\section{APÊNDICE F}

\section{BREVE DESCRIÇÃO DOS CASOS EM QUE O BRASIL ATUOU COMO TERCEIRA PARTE NO SISTEMA DE SOLUÇÃO DE CONTROVÉRSIAS DA OMC}

\begin{tabular}{|c|c|}
\hline $\begin{array}{l}\text { NÚMERO } \\
\text { DO CASO }\end{array}$ & BREVE DESCRIÇÃO DO CASO \\
\hline DS27 & $\begin{array}{l}\text { O caso DS27, European Communities - Regime for the Importation, Sale and } \\
\text { Distribution of Bananas (Bananas III), foi iniciado com o pedido de consultas formulado } \\
\text { por Equador, EUA, Guatemala, Honduras e México, em } 5 \text { de fevereiro de } 1996 \text {. Os } \\
\text { demandantes questionavam as mesmas medidas objeto do DS16, relativas ao regime de } \\
\text { importação, venda e distribuição de bananas. Segundo os demandantes, tal regime estaria } \\
\text { em desconformidade com os artigos I, II, III, X, XI e XIII do GATT 1994, com o artigo } 19 \\
\text { do Acordo sobre Agricultura, com os artigos II, IV, XVI, XVII do GATS, com os artigos } \\
2 \text { e } 5 \text { do TRIMs e com os artigos } 1 \text { e } 2 \text { do Acordo sobre Licenciamento de Importação. } \\
\text { Belize, Brasil, Camarões, Canadá, Colômbia, Costa Rica, Costa do Marfim, Dominica, } \\
\text { Filipinas, Gana, Granada, Índia, Jamaica, Japão, Mauricio, Madagascar, Nicarágua, } \\
\text { Panamá, República Dominicana, Santa Lúcia, São Vicente e Granadinas, Senegal e } \\
\text { Suriname atuaram como terceiras-partes nesta controvérsia. Em } 22 \text { de maio de } 1997 \text { o } \\
\text { painel emitiu seu relatório em } 27 \text { de Outubro de } 1998 \text {. Em } 9 \text { de Setembro de } 1997 \text { o Órgão } \\
\text { de Apelação emitiu seu relatório em exame de revisão. Após diversos procedimentos do } \\
\text { artigo } 21.5 \text {, que perduraram por mais de } 10 \text { anos, em } 8 \text { de Novembro de } 2012 \text {, as partes } \\
\text { notificaram o OSC que haviam chegado a uma solução mutuamente acordada, com base } \\
\text { no artigo } 3.6 \text { do ESC. Os dados deste caso foram retirados da base de dados de solução de } \\
\text { controvérsias } \\
<\text { http://www.wto.org/english/tratop_e/dispu_e/cases_e/ds27_e.htm> Acesso em: } 10 \text { de jun. } \\
\text { 2014. }\end{array}$ \\
\hline DS76 & 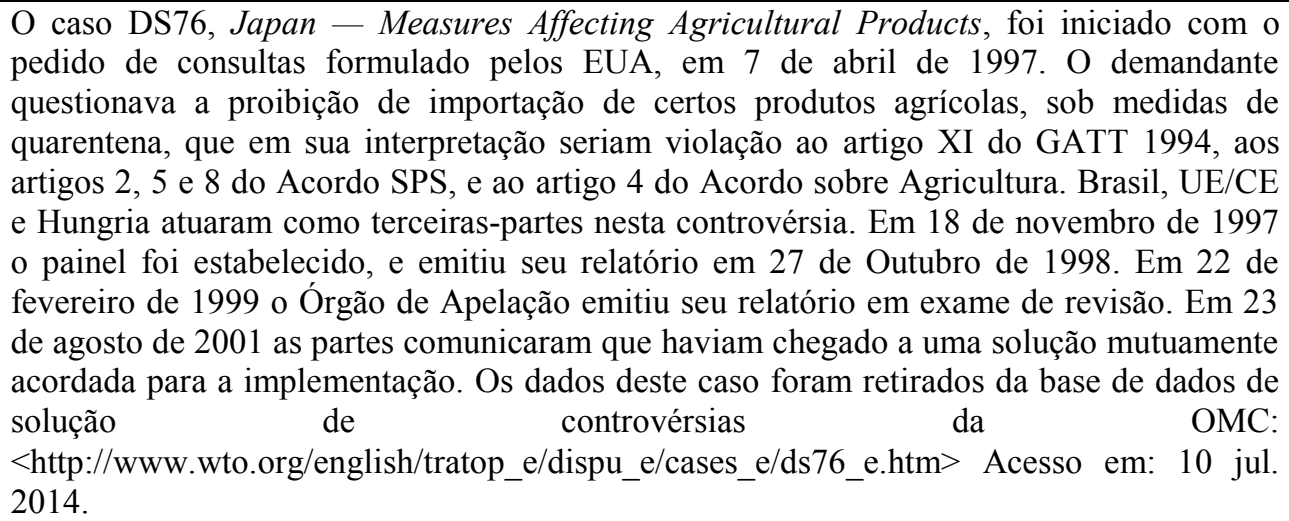 \\
\hline DS108 & $\begin{array}{l}\text { O caso DS108, United States - Tax Treatment for "Foreign Sales Corporations", } \\
\text { originou-se de demanda da UE/CE, em } 18 \text { de novembro de 1997, para a realização de } \\
\text { consultas com os EUA, sobre legislações e medidas que estabelecem um tratamento } \\
\text { tributário especial para "Foreign Sales Corporations". Segundo a demandante, as medidas } \\
\text { questionadas seriam violação aos artigos III:4 e XVI do GATT 1994, aos artigos } 1,3,8,9 \\
\text { e } 10 \text { do Acordo sobre Agricultura e aos artigos } 3.1 \text { (a) e } 3.1(\text { b)do ASMC. O OSC } \\
\text { estabeleceu o painel para analisar a controvérsia em } 22 \text { de setembro de } 2008 \text {. Austrália, } \\
\text { Barbados, Brasil, Canadá, China, Índia, Jamaica e Japão reservaram seus direitos como } \\
\text { terceiras partes no procedimento. O relatório do painel, divulgado em } 8 \text { de outubro de } \\
\text { 1999, reconhecia que o esquema em análise era violação ao ASMC. Com apelação dos } \\
\text { EUA, em } 24 \text { de fevereiro de } 2000 \text { o Órgão de Apelação emitiu seu relatório, confirmando } \\
\text { as conclusões do painel, embora tenha modificado algumas interpretações, e reconhecendo } \\
\text { a desconformidade da conduta norte-americana. O Relatório do Órgão de Apelação e o }\end{array}$ \\
\hline
\end{tabular}




\begin{tabular}{|c|c|}
\hline & 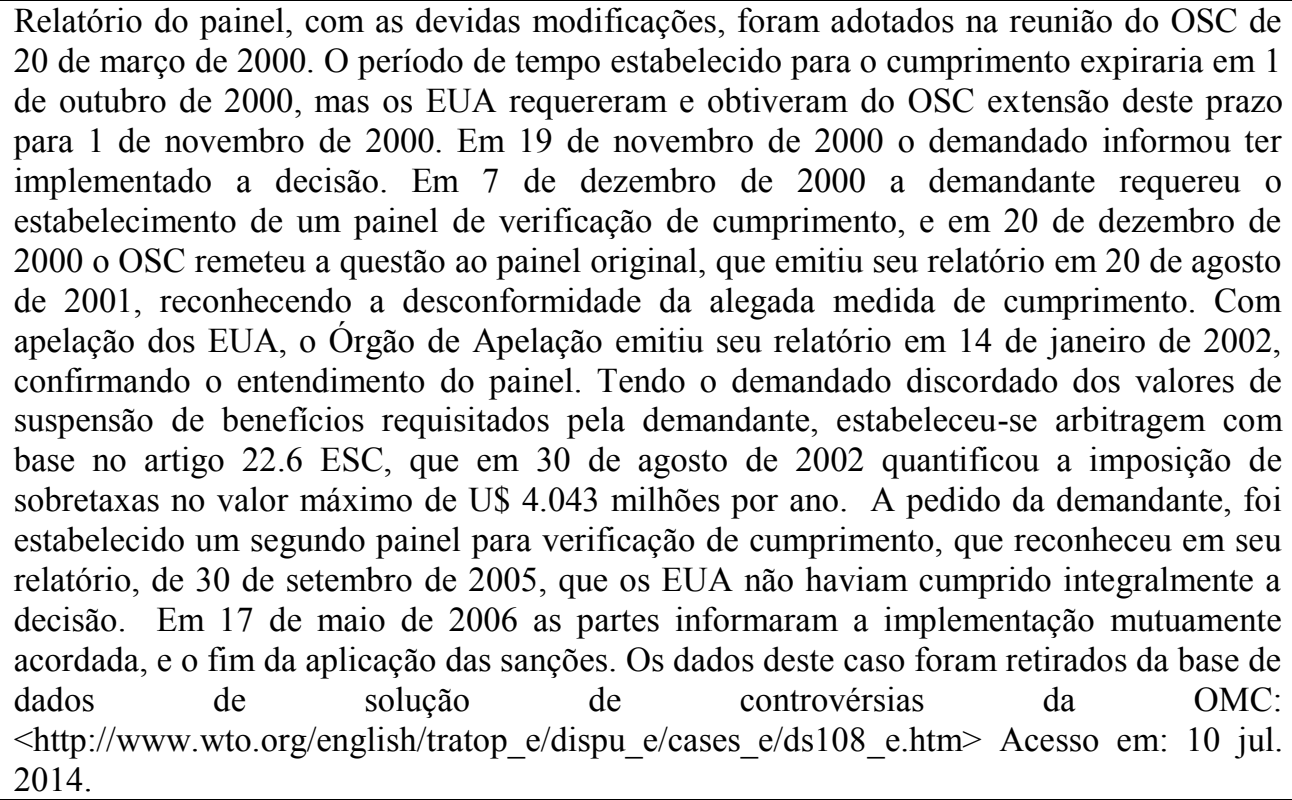 \\
\hline DS135 & $\begin{array}{l}\text { O caso DS135, European Communities - Measures Affecting Asbestos and Products } \\
\text { Containing Asbestos, originou-se de demanda do Canadá, em } 28 \text { de maio de } 1998 \text {, para a } \\
\text { realização de consultas com a UE/CE, relativas à medidas impostas pela França, relativas a } \\
\text { proibição de asbestos e produtos contendo este elemento. Segundo o demandante, estas } \\
\text { medidas violariam os artigos III, XI e XIII do GATT 1994, bem como os artigos } 2,3 \text { e } 5 \\
\text { do Acordo SPS, e o artigo } 2 \text { do Acordo TBT. O estabelecimento do painel foi autorizado } \\
\text { pelo OSC em } 21 \text { de Outubro de } 1998 \text {. O Brasil, os EUA e o Zimbabwe reservaram seus } \\
\text { direitos como terceiras partes no procedimento. O Relatório do painel, de } 18 \text { de setembro } \\
\text { de } 2000 \text {, concluía que a medida estava em conformidade com os Acordos, com exceção do } \\
\text { artigo III:4 do GATT. Com a apelação do Canadá, o Órgão de Apelação emitiu seu } \\
\text { Relatório em } 12 \text { de março de } 2001 \text {, revertendo alguns entendimentos do painel, e } \\
\text { reconhecendo que não havia desconformidade da conduta da UE/CE, uma vez que a } \\
\text { medida era justificada com base no artigo XX(b) do GATT. O Relatório do Órgão da } \\
\text { Apelação e o Relatório do painel com as devidas modificações foram adotados em } 5 \text { de } \\
\text { abril de } 2001 \text {. Os dados deste caso foram retirados da base de dados de solução de } \\
\text { controvérsias } \\
\text { <http://www.wto.org/english/tratop_e/dispu_e/cases_e/ds135_e.htm> Acesso em: } 10 \text { jul. } \\
\text { 2014. }\end{array}$ \\
\hline DS114 & 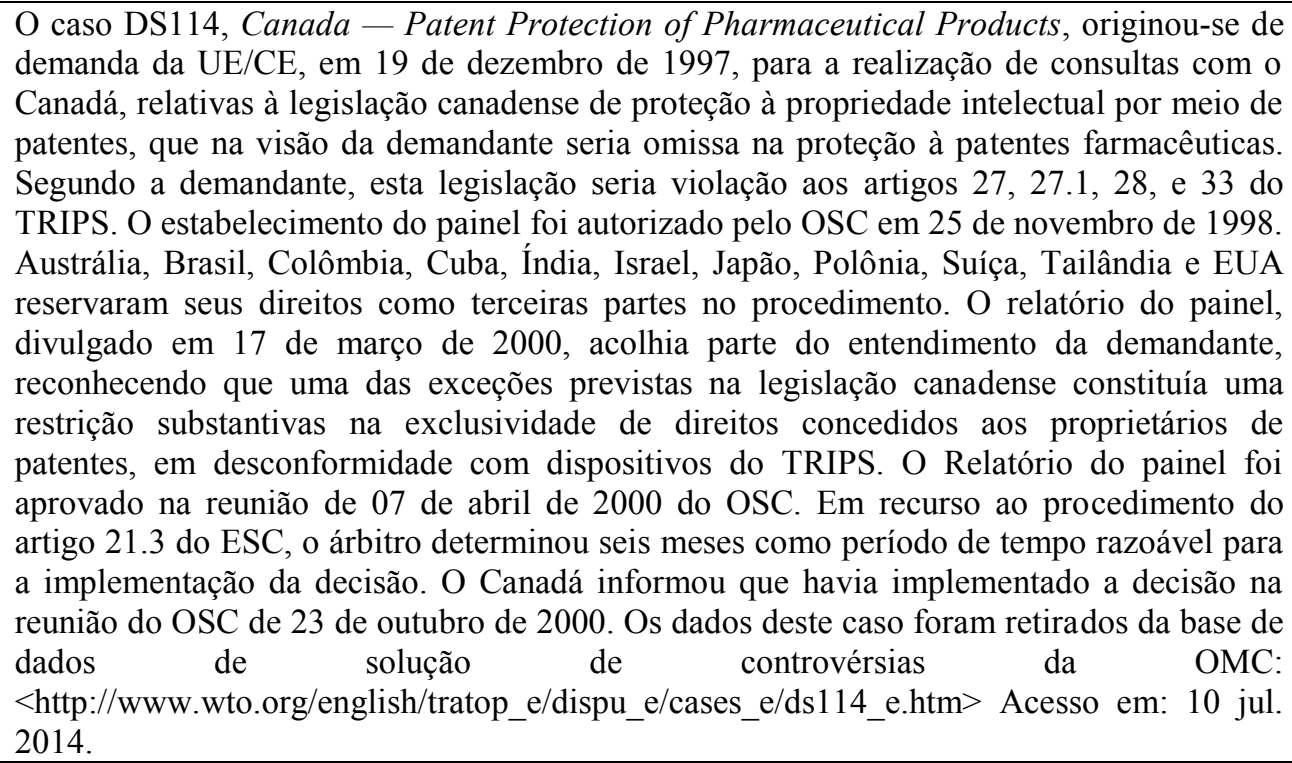 \\
\hline DS121 & $\begin{array}{l}\text { O caso DS121, Argentina - Safeguard Measures on Imports of Footwear, originou-se de } \\
\text { demanda da UE/CE, em } 6 \text { de abril de } 1998 \text {, para a realização de consultas com a } \\
\text { Argentina, relativas à aplicação de medidas de salvaguarda provisórias e definitivas sob a }\end{array}$ \\
\hline
\end{tabular}




\begin{tabular}{|c|c|}
\hline & $\begin{array}{l}\text { importação de calçados. Segundo a demandante, estas medidas seriam violação ao artigo } \\
\text { XIX do GATT } 1994 \text { e aos artigos } 2,4,5,6 \text { e } 12 \text { do Acordo sobre Salvaguardas. O } \\
\text { estabelecimento do painel foi autorizado pelo OSC em } 22 \text { de junho de } 1998 \text {. Brasil, EUA, } \\
\text { Indonésia, Paraguai e Uruguai reservaram seus direitos como terceiras partes no } \\
\text { procedimento. O relatório do painel, divulgado em } 22 \text { de junho de } 1999 \text {, reconhecia a } \\
\text { desconformidade da conduta argentina com os artigos } 2 \text { e } 4 \text { do Acordo de Salvaguardas. } \\
\text { Com a apelação da Argentina, o Órgão de Apelação emitiu relatório em } 14 \text { de dezembro } \\
\text { de } 1999 \text {, mantendo as conclusões do painel sobre a desconformidade da conduta da } \\
\text { demandada, embora tenha modificado algumas interpretações. O Relatório do Órgão de } \\
\text { Apelação e o relatório do painel com as respectivas modificações foram aprovados na } \\
\text { reunião do OSC de } 12 \text { de janeiro de } 2000 \text {. A Argentina informou que havia implementado } \\
\text { a decisão na reunião do OSC de } 11 \text { de fevereiro de } 2000 \text {. Os dados deste caso foram } \\
\text { retirados da base de dados de solução de controvérsias da OMC: } \\
<\text { http://www.wto.org/english/tratop_e/dispu_e/cases_e/ds121_e.htm> Acesso em: } 10 \text { jul. } \\
2014 \text {. }\end{array}$ \\
\hline DS138 & $\begin{array}{l}\text { O caso DS138, United States - Imposition of Countervailing Duties on Certain Hot- } \\
\text { Rolled Lead and Bismuth Carbon Steel Products Originating in the United Kingdom, } \\
\text { originou-se de demanda da UE/CE, em } 12 \text { de junho de } 1998 \text {, para a realização de consultas } \\
\text { com os EUA, relativas à imposição de contramedidas aplicadas à certos produtos de } \\
\text { chumbo laminados a quente e certos produtos de aço-carbono-bismuto originários do } \\
\text { Reino Unido, tendo como base para o cálculo subsídios concedidos a empresas estatais } \\
\text { antes de sua privatização. Segundo a demandante, estas medidas seria violação dos artigos } \\
\text { 1.1(b), 10, } 14 \text { e } 19.4 \text { do ASMC. O estabelecimento do painel foi autorizado pelo OSC em } 1 \\
\text { de fevereiro de } 1999 \text {. Brasil e México reservaram seus direitos como terceiras partes no } \\
\text { procedimento. O relatório do painel, divulgado em } 23 \text { de dezembro de } 1999 \text {, reconhecia a } \\
\text { desconformidade da conduta norte-americana com o artigo } 10 \text { do ASMC. Com a apelação } \\
\text { dos EUA, o Órgão de Apelação emitiu relatório em } 27 \text { de janeiro de } 2000 \text {, mantendo as } \\
\text { conclusões do painel sobre a desconformidade da conduta da demandada, embora tenha } \\
\text { modificado algumas interpretações do painel. O Relatório do Órgão de Apelação e o } \\
\text { relatório do painel com as respectivas modificações foram aprovados na reunião do OSC } \\
\text { de } 7 \text { de junho de } 2000 \text {. Em recurso ao procedimento do artigo } 21.3 \text { do ESC, o árbitro } \\
\text { determinou seis meses como período de tempo razoável para a implementação da decisão. } \\
\text { O demandante informou que havia implementado a decisão na reunião do OSC de } 5 \text { de } \\
\text { julho de } 2000 \text {. A respeito desta mesma metodologia para o cálculo de contramedidas, a } \\
\text { UE/CE ingressou com uma nova demanda no caso DS212. Os dados deste caso foram } \\
\text { retirados da base de dados de solução de controvérsias da OMC: } \\
<\text { http://www.wto.org/english/tratop_e/dispu_eases_e/ds138_e.htm> Acesso em: 10 jul. } \\
\text { 2014. }\end{array}$ \\
\hline DS152 & $\begin{array}{l}\text { O caso DS152, United States - Sections } 301-310 \text { of the Trade Act 1974, originou-se de } \\
\text { demanda da UE/CE, em } 25 \text { de novembro de 1998, para a realização de consultas com os } \\
\text { EUA, relativas a alguns dispositivos do US Trade Act de } 1974 \text { (Título III, capítulo 1, em } \\
\text { especial sessões } 301 \text { a } 310 \text { ). Segundo o demandante, estas medidas seriam inconsistentes } \\
\text { com as obrigações expressas nos artigos } 3,21,22 \text { e } 23 \text { do ESC, nos artigos I, II, III, VIII e } \\
\text { Xi do GATT. O estabelecimento do painel foi autorizado pelo OSC em } 17 \text { de fevereiro de } \\
\text { 1999. Brasil, Canadá, Colômbia, Costa Rica, Cuba, Dominica, República Dominicana, } \\
\text { Equador, Hong Kong, China, Índia, Israel, Jamaica, Japão, República da Coréia, Santa } \\
\text { Lucia, e Tailândia reservaram seus direitos como terceiras partes no procedimento. O } \\
\text { Relatório do painel, de } 22 \text { de dezembro de } 1999 \text {, concluía que a lei em questão não estava } \\
\text { em desconformidade com a disciplina multilateral, uma vez que dispositivos do } \\
\text { "Statement of Administrative Action" aprovado na oportunidade da incorporação da } \\
\text { Rodada do Uruguai garantiam a possibilidade de realização dos procedimentos do ESC. O } \\
\text { Relatório painel foi adotado em } 27 \text { de janeiro de } 2000 \text {. Os dados deste caso foram retirados } \\
\text { da base de dados de solução de controvérsias da OMC: } \\
<\text { http://www.wto.org/english/tratop_e/dispu_e/cases_e/ds152_e.htm> Acesso em: } 10 \text { jul. } \\
\text { 2014. }\end{array}$ \\
\hline DS174 & $\begin{array}{l}\text { O caso DS174, European Communities - Protection of Trademarks and Geographical } \\
\text { Indications for Agricultural Products and Foodstuffs, originou-se de demanda dos EUA, } \\
\text { em } 1 \text { de junho de 1999, para a realização de consultas com a UE/CE, relativas ao } \\
\text { Regulamento do Conselho n. 2081/91, que seria omisso na proteção de marcas e } \\
\text { indicações geográficas referentes a produtos agrícolas e alimentícios. Segundo o }\end{array}$ \\
\hline
\end{tabular}




\begin{tabular}{|c|c|}
\hline & $\begin{array}{l}\text { demandante, o Regulamento seria violação dos artigos I e III:4 do GATT, bem como dos } \\
\text { artigos } 1.1,2,2.1,3,3.1,4,16,16.1,20,22,22.1,22.2,24,24.5,41.1,41.2,41.4,42,44.1 \text {, } \\
63,63.1,63.3,65,65.1 \text { do TRIPS. Em } 4 \text { de Abril de } 2003 \text {, o demandante formulou um } \\
\text { requerimento para consultas complementar ao inicialmente apresentado. A Austrália } \\
\text { requisitou a abertura de procedimento questionando as mesmas medidas no caso DS290, e } \\
\text { em } 2 \text { de outubro de } 2003 \text { foi estabelecido o mesmo painel para apreciar ambos os casos. } \\
\text { Argentina, Austrália, Brasil, Canadá, China, Colômbia, Guatemala, Índia, México, Nova } \\
\text { Zelândia, Taiwan (Taipé chinês) e Turquia reservaram seus direitos como terceiras partes } \\
\text { no procedimento. O relatório do painel, divulgado em } 15 \text { de março de } 2005 \text {, reconhecia a } \\
\text { desconformidade da conduta comunitária, uma vez que o Regulamento não respeita o } \\
\text { comando do tratamento nacional na proteção de marcas e indicações geográficas referentes } \\
\text { a produtos agrícolas e alimentícios. O Relatório do painel foi aprovado na reunião do OSC } \\
\text { de } 20 \text { de Abril de } 2005 \text {. As partes chegaram a um acordo sobre o período razoável para } \\
\text { implementação, que seria de } 11 \text { meses e duas semanas. Em } 21 \text { de Abril de } 2006 \text {, a UE/CE } \\
\text { afirmou que havia implementado a decisão, com a edição de um novo Regulamento sobre } \\
\text { a matéria, que entrou em vigor em } 31 \text { de Março de } 2006 \text {. Os dados deste caso foram } \\
\text { retirados da base de dados de solução de controvérsias da OMC: } \\
\text { <http://www.wto.org/english/tratop_e/dispu_e/cases_e/ds174_e.htm> Acesso em: 10 jul. } \\
\text { 2014. }\end{array}$ \\
\hline DS184 & 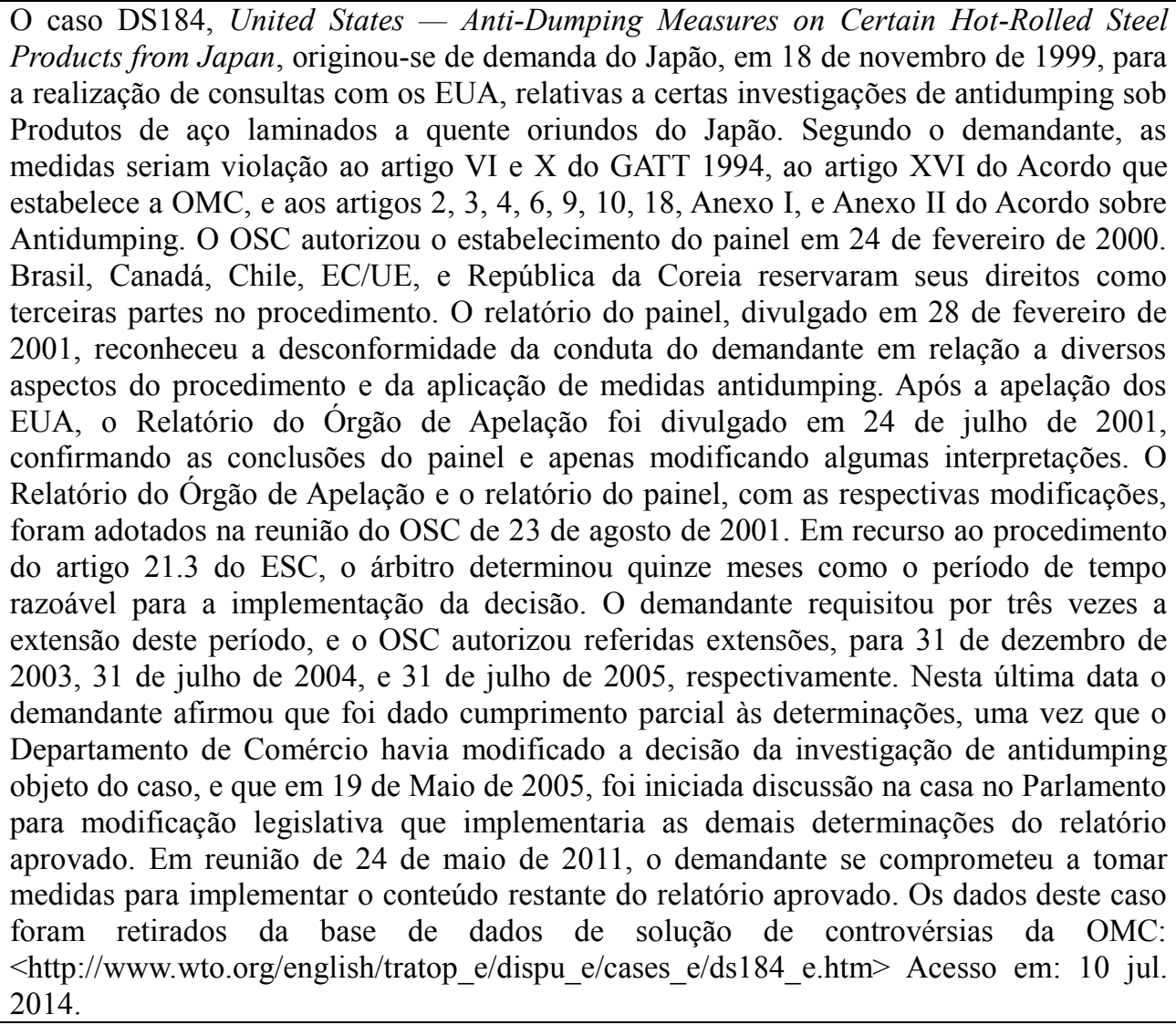 \\
\hline DS204 & $\begin{array}{l}\text { O caso DS204, Mexico - Measures Affecting Telecommunications Services, originou-se } \\
\text { de demanda dos EUA, em } 27 \text { de agosto de } 2000 \text {, para a realização de consultas com o } \\
\text { México, a respeito de diversas medidas regulatórias no serviço de telecomunicações. } \\
\text { Segundo o demandante, as medidas seriam violação aos Artigos VI, VI:1, XVI, XVI:1, } \\
\text { XVI:2, XVII, XVII:1, XVII:2, XVII:3, XVIII, e VI:5 do GATS. O OSC autorizou o } \\
\text { estabelecimento do painel em } 8 \text { de março de } 2002 \text {. Austrália, Brasil, Canadá, UE/CE, } \\
\text { Cuba, Guatemala, Honduras, India, Japão e Nicarágua reservaram seus direitos como } \\
\text { terceiras partes no procedimento. O relatório do painel, divulgado em } 2 \text { de abril de } 2004 \text {, } \\
\text { reconheceu a desconformidade da conduta do demandante em relação a alguns dispositivos } \\
\text { do GATS. O Relatório do Órgão de foi adotado na reunião do OSC de } 1 \text { de junho de } 2004 \text {. } \\
\text { As partes chegaram a um acordo sobre o período razoável, que seria de } 13 \text { meses. Em } 31 \\
\text { de agosto de 2005, México anunciou que havia cumprido a decisão do caso, com a } \\
\text { publicação de novos regulamentos para o setor. Os dados deste caso foram retirados da }\end{array}$ \\
\hline
\end{tabular}




\begin{tabular}{|c|c|}
\hline & 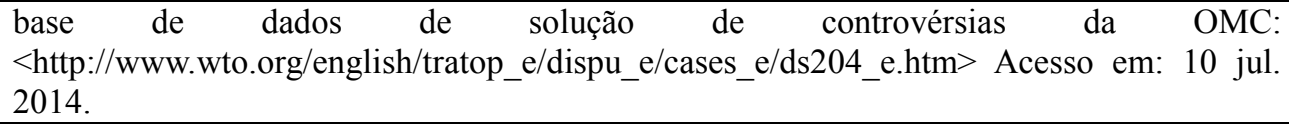 \\
\hline DS207 & 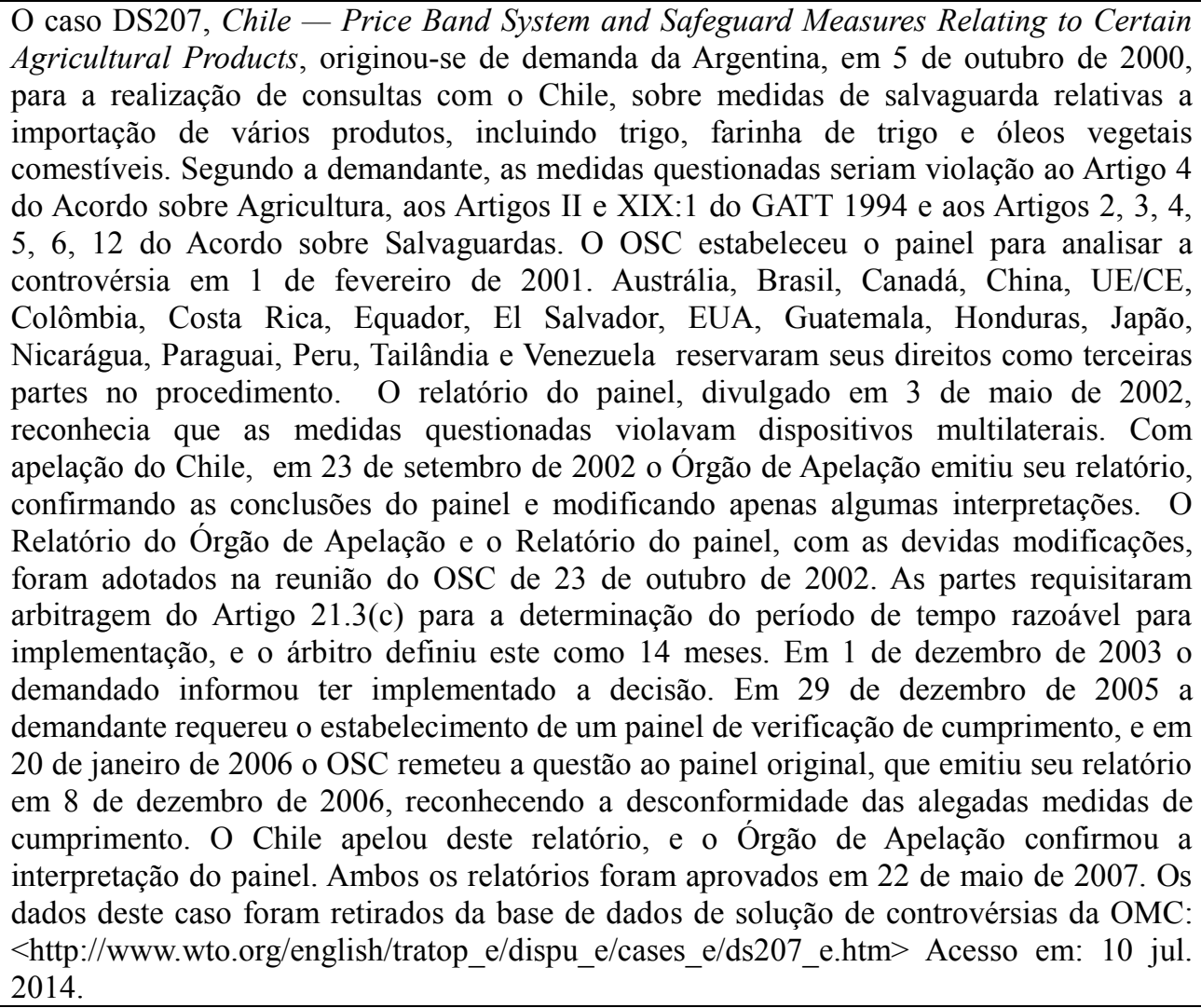 \\
\hline DS212 & $\begin{array}{l}\text { O caso DS212, United States - Countervailing Measures Concerning Certain Products } \\
\text { from the European Communities, originou-se de demanda da UE/CE, em } 10 \text { de novembro } \\
\text { de } 2000 \text {, para a realização de consultas com os EUA, a respeito da aplicação de continuada } \\
\text { de medidas compensatórias, com base em uma metodologia denominada "same person". } \\
\text { Segundo a demandante, as medidas seriam violação ao Artigo VI:3 do GATT 1994, ao } \\
\text { Artigo XVI:4 do Acordo que estabelece a OMC, e aos Artigos } 1,1.1,10,14,19,19.1 \text {, } \\
\text { 19.3, } 19.4,21,21.1,21.2,21.3 \text { e } 32.5 \text { do ASMC. O OSC autorizou o estabelecimento do } \\
\text { painel em } 8 \text { de março de } 2002 \text {. Brasil, China, Índia, República da Coréia e México } \\
\text { reservaram seus direitos como terceiras partes no procedimento. O relatório do painel, } \\
\text { divulgado em } 31 \text { de julho de } 2002 \text {, reconhecia a desconformidade dos doze procedimentos } \\
\text { questionados, bem como da legislação que prevê a metodologia. Após a apelação dos } \\
\text { EUA, o Relatório do Órgão de Apelação foi divulgado em } 9 \text { de dezembro de } 2002 \text {, } \\
\text { confirmando a maioria das conclusões do painel e modificando algumas interpretações. O } \\
\text { Relatório do Órgão de Apelação e o relatório do painel, com as respectivas modificações, } \\
\text { foram adotados na reunião do OSC de } 8 \text { de janeiro de } 2003 \text {. As partes chegaram a um } \\
\text { acordo sobre o período razoável, que seria de } 10 \text { meses. Tendo anunciado que promoveria } \\
\text { à implementação, os EUA revisaram oito dos doze procedimentos. Não satisfeita com a } \\
\text { conduta do demandado, em } 16 \text { de setembro de } 2004 \text { a UE/CE requisitou um painel para } \\
\text { verificação de cumprimento. O painel foi estabelecido em } 27 \text { de setembro de } 2004 \text {, e em } \\
17 \text { de agosto de } 2005 \text { o seu relatório foi divulgado, reconhecendo apenas algumas das } \\
\text { diversas alegações da demandante. Em } 27 \text { de setembro de } 2005 \text { o relatório foi adotado, e } \\
\text { em } 19 \text { de junho de } 2006 \text { os EUA notificaram sua implementação. Os dados deste caso } \\
\text { foram retirados da base de dados de solução de controvérsias da OMC: } \\
\text { <http://www.wto.org/english/tratop_e/dispu_e/cases_e/ds212_e.htm> Acesso em: 10 jul. } \\
2014 \text {. }\end{array}$ \\
\hline DS244 & $\begin{array}{l}\text { O caso DS244, United States - Sunset Review of Anti-Dumping Duties on Corrosion- } \\
\text { Resistant Carbon Steel Flat Products from Japan, originou-se de demanda do Japão, em } \\
30 \text { de janeiro de 2002, para a realização de consultas com os EUA, relativas direitos } \\
\text { antidumping impostos sob a importação de produtos planos de aço-carbono resistentes à } \\
\text { corrosão originários do Japão. Segundo o demandante, estas medidas seriam inconsistentes }\end{array}$ \\
\hline
\end{tabular}




\begin{tabular}{|c|c|}
\hline & $\begin{array}{l}\text { com as obrigações expressas nos artigos VI e X do GATT 1994, nos artigos 2, 3, 5, 6, 11, } \\
\text { 12, 18.3, 18.4 e Anexo II do Acordo de Antidumping, e no Artigo XVI:4 no Acordo que } \\
\text { estabelece a OMC. O estabelecimento do painel foi autorizado pelo OSC em } 17 \text { de abril de } \\
\text { 2002. Brasil, Canadá, Chile, UE/CE, Índia, República da Coréia e Noruega reservaram } \\
\text { seus direitos como terceiras partes no procedimento. O Relatório do painel, divulgado em } \\
22 \text { de maio de } 2003 \text {, rejeitou as acusações do demandante, não fazendo portanto nenhuma } \\
\text { recomendação. Após apelação do Japão, o Órgão de Apelação emitiu relatório em } 15 \text { de } \\
\text { dezembro de } 2003 \text {, confirmando as conclusões do painel, mas revertendo algumas de suas } \\
\text { interpretações. O Relatório do Órgão de Apelação e o Relatório do painel, com as devidas } \\
\text { modificações, foram adotados em } 9 \text { de janeiro de 2004. Os dados deste caso foram } \\
\text { retirados da base de dados de solução de controvérsias da OMC: } \\
<\text { http://www.wto.org/english/tratop_e/dispu_e/cases_e/ds244_e.htm> Acesso: 10 jul. } \\
\text { 2014. }\end{array}$ \\
\hline DS245 & 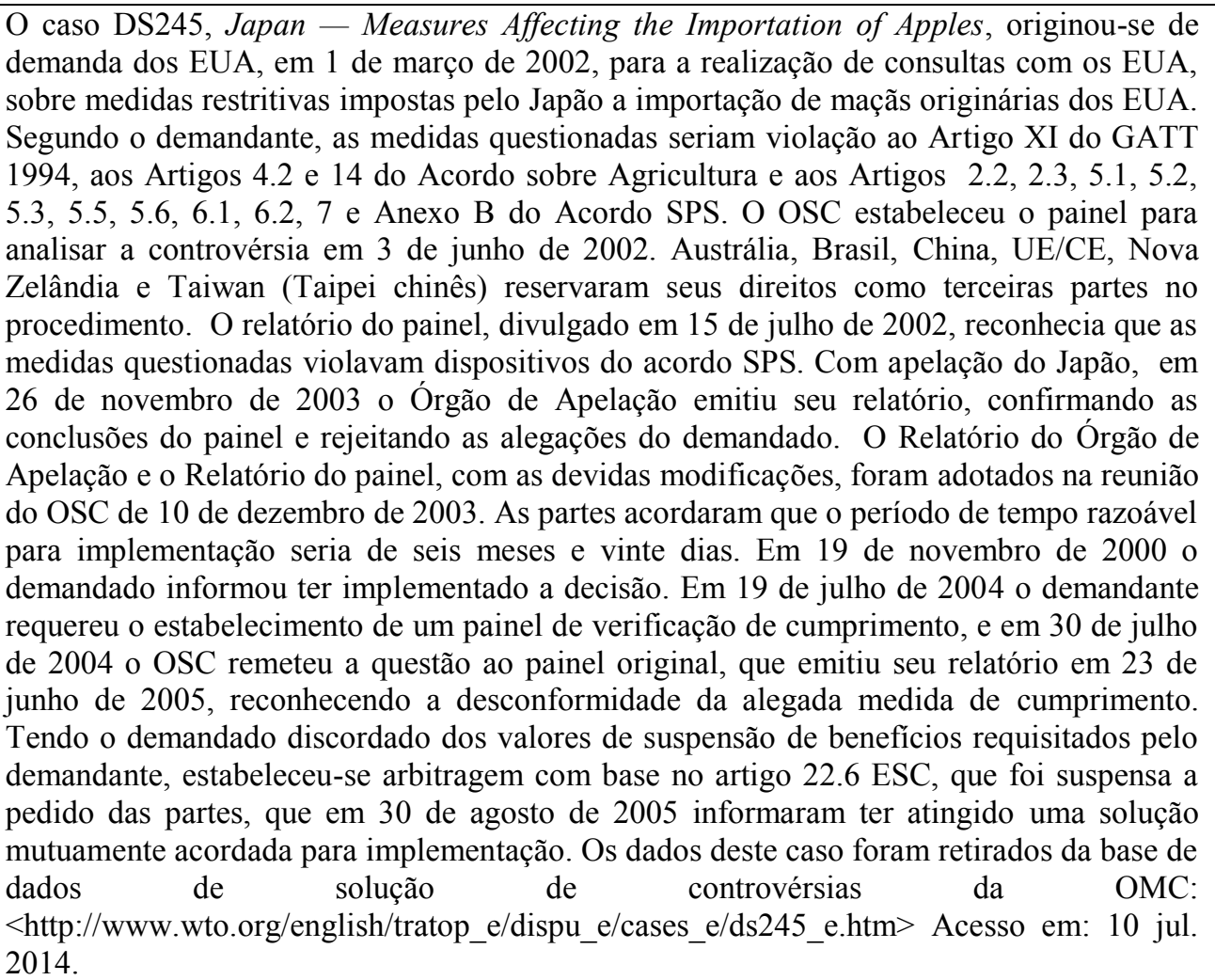 \\
\hline DS246 & $\begin{array}{l}\text { O caso DS246, European Communities - Conditions for the Granting of Tariff } \\
\text { Preferences to Developing Countries, originou-se de demanda da Índia, em } 5 \text { de março de } \\
2002 \text {, para a realização de consultas com a UE/CE, a respeito de preferências concedidas a } \\
\text { países em desenvolvimento por meio do esquema do GSP (tarifas preferenciais } \\
\text { generalizadas). Segundo a demandante, as medidas seriam violação ao Artigo I:1 do } \\
\text { GATT 1994. O OSC autorizou o estabelecimento do painel em } 19 \text { de dezembro de } 2002 \text {. } \\
\text { Bolívia, Brasil, Colômbia, Costa Rica, Cuba, Equador, El Salvador, EUA, Guatemala, } \\
\text { Honduras, Mauricio, Nicarágua, Paquistão, Panamá, Paraguai, Peru, Sri Lanka e } \\
\text { Venezuela reservaram seus direitos como terceiras partes no procedimento. O relatório do } \\
\text { painel, divulgado em } 1 \text { de dezembro de } 2003 \text {, reconhecia a desconformidade da conduta } \\
\text { comunitária com o dispositivo basilar do GATT. Após a apelação da UE/CE, o Relatório } \\
\text { do Órgão de Apelação foi divulgado em } 7 \text { de abril de } 2004 \text {, confirmando algumas } \\
\text { conclusões do painel e modificando certas interpretações. O Relatório do Órgão de } \\
\text { Apelação e o relatório do painel, com as respectivas modificações, foram adotados na } \\
\text { reunião do OSC de } 20 \text { de abril de } 2004 \text {. Em recurso ao procedimento do Artigo } 21.3 \text { do } \\
\text { ESC, o árbitro determinou que o período de tempo razoável para a implementação da } \\
\text { decisão se esgotaria em } 1 \text { de julho de } 2005 \text {. A UE/CE informou que naquela data o } \\
\text { regulamento desconforme havia sido substituído por um outro já em vigor, notificando a } \\
\text { implementação. Os dados deste caso foram retirados da base de dados de solução de } \\
\text { controvérsias } \\
\text { <http://www.wto.org/english/tratop_e/dispu_e/cases_e/ds246_e.htm> Acesso em: OMC: } 10 \text { jul. }\end{array}$ \\
\hline
\end{tabular}




\begin{tabular}{|c|c|}
\hline & 2014 \\
\hline DS248 & $\begin{array}{l}\text { O caso DS248, United States - Definitive Safeguard Measures on Imports of Certain } \\
\text { Steel Products, originou-se de demanda da UE/CE, em } 7 \text { de março de 2002, para a } \\
\text { realização de consultas com os EUA, relativas a medidas de salvaguarda impostas pelo } \\
\text { demandado sob diversos produtos de aço. Segundo o demandante, estas medidas seriam } \\
\text { inconsistentes com as obrigações expressas nos artigos I:1, XIII e XIX:1 do GATT } 1994 \text { e } \\
\text { nos artigos } 2.1,2.2,3.1,3.2,4.1,4.2,5.1,5.2,7.1 \text { e } 9.1 \text { do Acordo de Salvaguardas. Os } \\
\text { casos DS249, DS251, DS252, DS253, DS254, DS258 e DS } 259 \text { tratavam das mesmas } \\
\text { medidas, e portanto foi estabelecido um mesmo painel para as demandas. Brasil, Canadá, } \\
\text { China, Taipé chinês, Cuba, Japão, República da Coréia, Nova Zelândia, Noruega, Suíça, } \\
\text { Tailândia, Turquia, Venezuela reservaram seus direitos como terceiras partes neste } \\
\text { procedimento. O Relatório do painel, divulgado em } 11 \text { de julho de } 2003 \text {, concluiu que as } \\
\text { salvaguardas impostas estavam em desconformidade com diversos pré-requisitos } \\
\text { estabelecidos dos Acordos. Após apelação dos EUA, em } 10 \text { de novembro de } 2003 \text { o } \\
\text { relatório do Orgão de Apelação modificou algumas interpretações do painel, mas manteve } \\
\text { a sua conclusão de desconformidade das medidas questionadas. O Relatório do OA e o } \\
\text { relatório do painel, com as devidas modificações, foram adotados na reunião do OSC de } \\
10 \text { de dezembro de } 2003 \text {, contudo a adoção se deu sem necessidade de conduta corretiva } \\
\text { pelo demandado, uma vez que as medidas questionadas haviam sido extintas pelo } \\
\text { Presidente dos EUA em } 04 \text { de dezembro de } 2003 \text {. Os dados deste caso foram retirados da } \\
\text { base de dados de solução de controvérsias da OMC: } \\
<\text { http://www.wto.org/english/tratop_e/dispu_e/cases_e/ds248_e.htm> Acesso em: } 10 \text { jul. } \\
\text { 2014. }\end{array}$ \\
\hline DS249 & 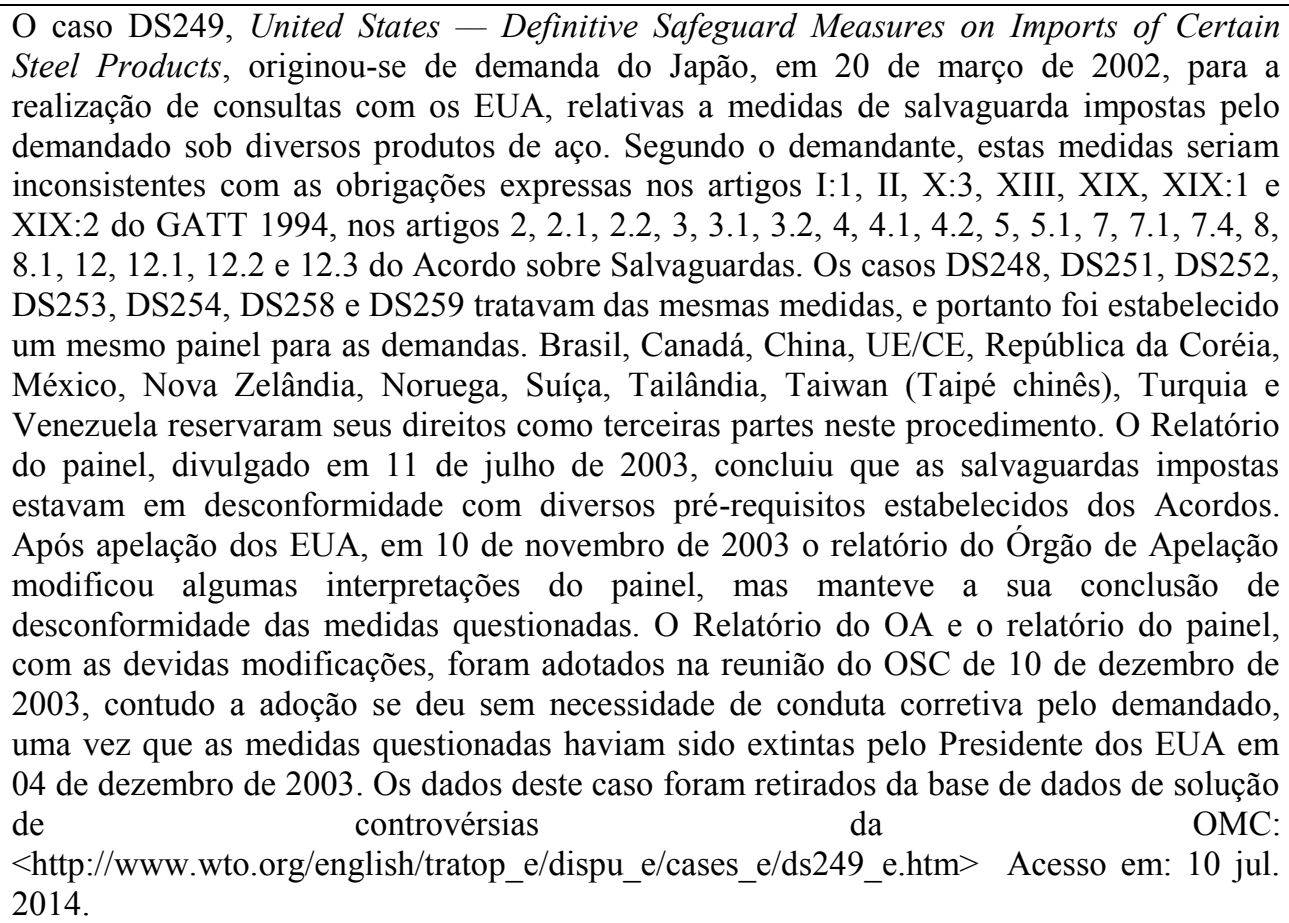 \\
\hline DS251 & $\begin{array}{l}\text { O caso DS251, United States - Definitive Safeguard Measures on Imports of Certain } \\
\text { Steel Products, originou-se de demanda da Coreia, em } 20 \text { de março de } 2002 \text {, para a } \\
\text { realização de consultas com os EUA, relativas a medidas de salvaguarda impostas pelo } \\
\text { demandado sob diversos produtos de aço. Segundo o demandante, estas medidas seriam } \\
\text { inconsistentes com as obrigações expressas nos artigos I, X:3, XIII, XIX, XIX:1 do GATT } \\
\text { 1994, nos artigos } 2,2.1,2.2,3,4,4.2,5,7.1,7.4,8.1,9.1 \text { e } 12 \text { do Acordo sobre } \\
\text { Salvaguardas, e no artigo XVI:4 do Acordo que estabelece a OMC. Os casos DS248, } \\
\text { DS249, DS252, DS253, DS254, DS258 e DS } 259 \text { tratavam das mesmas medidas, e portanto } \\
\text { foi estabelecido um mesmo painel para as demandas. Brasil, Canadá, China, CE/EU, } \\
\text { Japão, México, Nova Zelândia, Noruega, Suíça, Tailândia, Taiwan (Taipé chinês), Turquia } \\
\text { e Venezuela reservaram seus direitos como terceiras partes neste procedimento. O } \\
\text { Relatório do painel, divulgado em } 11 \text { de julho de } 2003 \text {, concluiu que as salvaguardas } \\
\text { impostas estavam em desconformidade com diversos pré-requisitos estabelecidos dos } \\
\text { Acordos. Após apelação dos EUA, em } 10 \text { de novembro de } 2003 \text { o relatório do Órgão de }\end{array}$ \\
\hline
\end{tabular}




\begin{tabular}{|c|c|}
\hline & $\begin{array}{l}\text { Apelação modificou algumas interpretações do painel, mas manteve a sua conclusão de } \\
\text { desconformidade das medidas questionadas. O Relatório do OA e o relatório do painel, } \\
\text { com as devidas modificações, foram adotados na reunião do OSC de } 10 \text { de dezembro de } \\
\text { 2003, contudo a adoção se deu sem necessidade de conduta corretiva pelo demandado, } \\
\text { uma vez que as medidas questionadas haviam sido extintas pelo Presidente dos EUA em } \\
04 \text { de dezembro de 2003. Os dados deste caso foram retirados da base de dados de solução } \\
\text { de controvérsias } \\
<\text { http://www.wto.org/english/tratop_e/dispu_e/cases_e/ds251_e.htm> Acesso em: } 10 \text { jul. } \\
2014 \text {. }\end{array}$ \\
\hline DS252 & $\begin{array}{l}\text { O caso DS252, United States - Definitive Safeguard Measures on Imports of Certain } \\
\text { Steel Products, originou-se de demanda da China, em } 26 \text { de março de } 2002 \text {, para a } \\
\text { realização de consultas com os EUA, relativas a medidas de salvaguarda impostas pelo } \\
\text { demandado sob diversos produtos de aço. Segundo o demandante, estas medidas seriam } \\
\text { inconsistentes com as obrigações expressas nos artigos I:1, II, X:3, XIII, XIX:1 e XIX:2 do } \\
\text { GATT } 1994 \text { e nos artigos } 2,2.1,2.2,3,3.1,3.2,4,4.1,4.2,5,5.1,5.2,7,7.1,8,8.1,9,9.1 \\
\text { e } 12 \text { do Acordo de Salvaguardas. Os casos DS248, DS249, DS251, DS } 253 \text {, DS254, DS258 } \\
\text { e DS259 tratavam das mesmas medidas, e portanto foi estabelecido um mesmo painel para } \\
\text { as demandas. Brasil, Canadá, UE/CE, Coréia, Japão, México, Nova Zelândia, Noruega, } \\
\text { Suíça, Tailândia, Taiwan (Taipé chinês), Turquia e Venezuela reservaram seus direitos } \\
\text { como terceiras partes neste procedimento. O Relatório do painel, divulgado em } 11 \text { de julho } \\
\text { de } 2003 \text {, concluiu que as salvaguardas impostas estavam em desconformidade com } \\
\text { diversos pré-requisitos estabelecidos dos Acordos. Após apelação dos EUA, em } 10 \text { de } \\
\text { novembro de } 2003 \text { o relatório do Órgão de Apelação modificou algumas interpretações do } \\
\text { painel, mas manteve a sua conclusão de desconformidade das medidas questionadas. O } \\
\text { Relatório do OA e o relatório do painel, com as devidas modificações, foram adotados na } \\
\text { reunião do OSC de } 10 \text { de dezembro de } 2003 \text {, contudo a adoção se deu sem necessidade de } \\
\text { conduta corretiva pelo demandado, uma vez que as medidas questionadas haviam sido } \\
\text { extintas pelo Presidente dos EUA em } 04 \text { de dezembro de } 2003 \text {. Os dados deste caso foram } \\
\text { retirados da base de dados de solução de controvérsias da OMC: } \\
\text { <http://www.wto.org/english/tratop_e/dispu_e/cases_e/ds252_e.htm> Acesso em: } 10 \text { jul. } \\
\text { 2014. }\end{array}$ \\
\hline DS253 & $\begin{array}{l}\text { O caso DS253, United States - Definitive Safeguard Measures on Imports of Certain } \\
\text { Steel Products, originou-se de demanda da Suíça, em } 3 \text { de abril de 2002, para a realização } \\
\text { de consultas com os EUA, relativas a medidas de salvaguarda impostas pelo demandado } \\
\text { sob diversos produtos de aço. Segundo o demandante, estas medidas seriam inconsistentes } \\
\text { com as obrigações expressas nos artigos I:1 e XIX:1 do GATT } 1994 \text { e nos artigos . 2.1, } \\
2.2,3,3.1,4,4.1,4.2,5.1,7.1,8.1 \text { e } 12 \text { do Acordo de Salvaguardas. Os casos DS248, } \\
\text { DS249, DS251, DS252, DS254, DS258 e DS259 tratavam das mesmas medidas, e portanto } \\
\text { foi estabelecido um mesmo painel para as demandas. Brasil, Canadá, UE/CE, China, } \\
\text { Coréia, Cuba, Japão, Nova Zelândia, Noruega, Tailândia, Taiwan (Taipé chinês), Turquia, } \\
\text { Venezuela reservaram seus direitos como terceiras partes neste procedimento. O Relatório } \\
\text { do painel, divulgado em } 11 \text { de julho de } 2003 \text {, concluiu que as salvaguardas impostas } \\
\text { estavam em desconformidade com diversos pré-requisitos estabelecidos dos Acordos. } \\
\text { Após apelação dos EUA, em } 10 \text { de novembro de } 2003 \text { o relatório do Orgão de Apelação } \\
\text { modificou algumas interpretações do painel, mas manteve a sua conclusão de } \\
\text { desconformidade das medidas questionadas. O Relatório do OA e o relatório do painel, } \\
\text { com as devidas modificações, foram adotados na reunião do OSC de } 10 \text { de dezembro de } \\
2003 \text {, contudo a adoção se deu sem necessidade de conduta corretiva pelo demandado, } \\
\text { uma vez que as medidas questionadas haviam sido extintas pelo Presidente dos EUA em } \\
04 \text { de dezembro de 2003. Os dados deste caso foram retirados da base de dados de solução } \\
\text { de controvérsias } \\
\text { <http://www.wto.org/english/tratop_e/dispu_e/cases_e/ds253_e.htm> Acesso em: 10 jul. } \\
\text { 2014. }\end{array}$ \\
\hline DS254 & $\begin{array}{l}\text { O caso DS254, United States - Definitive Safeguard Measures on Imports of Certain Steel } \\
\text { Products, originou-se de demanda da Noruega, em } 4 \text { de abril de } 2002 \text {, para a realização de } \\
\text { consultas com os EUA, relativas a medidas de salvaguarda impostas pelo demandado sob } \\
\text { diversos produtos de aço. Segundo o demandante, estas medidas seriam inconsistentes com } \\
\text { as obrigações expressas nos artigos I:1, II, X:3, XIX, XIX:1 e X:3(a) do GATT 1994, e nos } \\
\text { artigos } 2,2.1,2.2,3,4,4.1,4.2,5.1,7,7.1,8.1,9,9.1 \text { e } 12 \text { do Acordo de Salvaguardas. Os } \\
\text { casos DS248, DS249, DS251, DS252, DS253, DS258 e DS259 tratavam das mesmas }\end{array}$ \\
\hline
\end{tabular}




\begin{tabular}{|c|c|}
\hline & $\begin{array}{l}\text { medidas, e portanto foi estabelecido um mesmo painel para as demandas. Brasil, Canadá, } \\
\text { China, UE/CE, Coréia, Cuba, Japão, México, Nova Zelândia, Suíça, Tailândia, Taiwan } \\
\text { (Taipé chinês), Turquia e Venezuela reservaram seus direitos como terceiras partes neste } \\
\text { procedimento. O Relatório do painel, divulgado em } 11 \text { de julho de } 2003 \text {, concluiu que as } \\
\text { salvaguardas impostas estavam em desconformidade com diversos pré-requisitos } \\
\text { estabelecidos dos Acordos. Após apelação dos EUA, em } 10 \text { de novembro de } 2003 \text { o } \\
\text { relatório do Órgão de Apelação modificou algumas interpretações do painel, mas manteve } \\
\text { a sua conclusão de desconformidade das medidas questionadas. O Relatório do OA e o } \\
\text { relatório do painel, com as devidas modificações, foram adotados na reunião do OSC de } \\
10 \text { de dezembro de } 2003 \text {, contudo a adoção se deu sem necessidade de conduta corretiva } \\
\text { pelo demandado, uma vez que as medidas questionadas haviam sido extintas pelo } \\
\text { Presidente dos EUA em } 04 \text { de dezembro de } 2003 \text {. Os dados deste caso foram retirados da } \\
\text { base de dados de solução de controvérsias da OMC: } \\
<\text { http://www.wto.org/english/tratop_e/dispu_e/cases_e/ds254_e.htm> Acesso em: } 10 \text { jul. } \\
2014 \text {. }\end{array}$ \\
\hline DS258 & 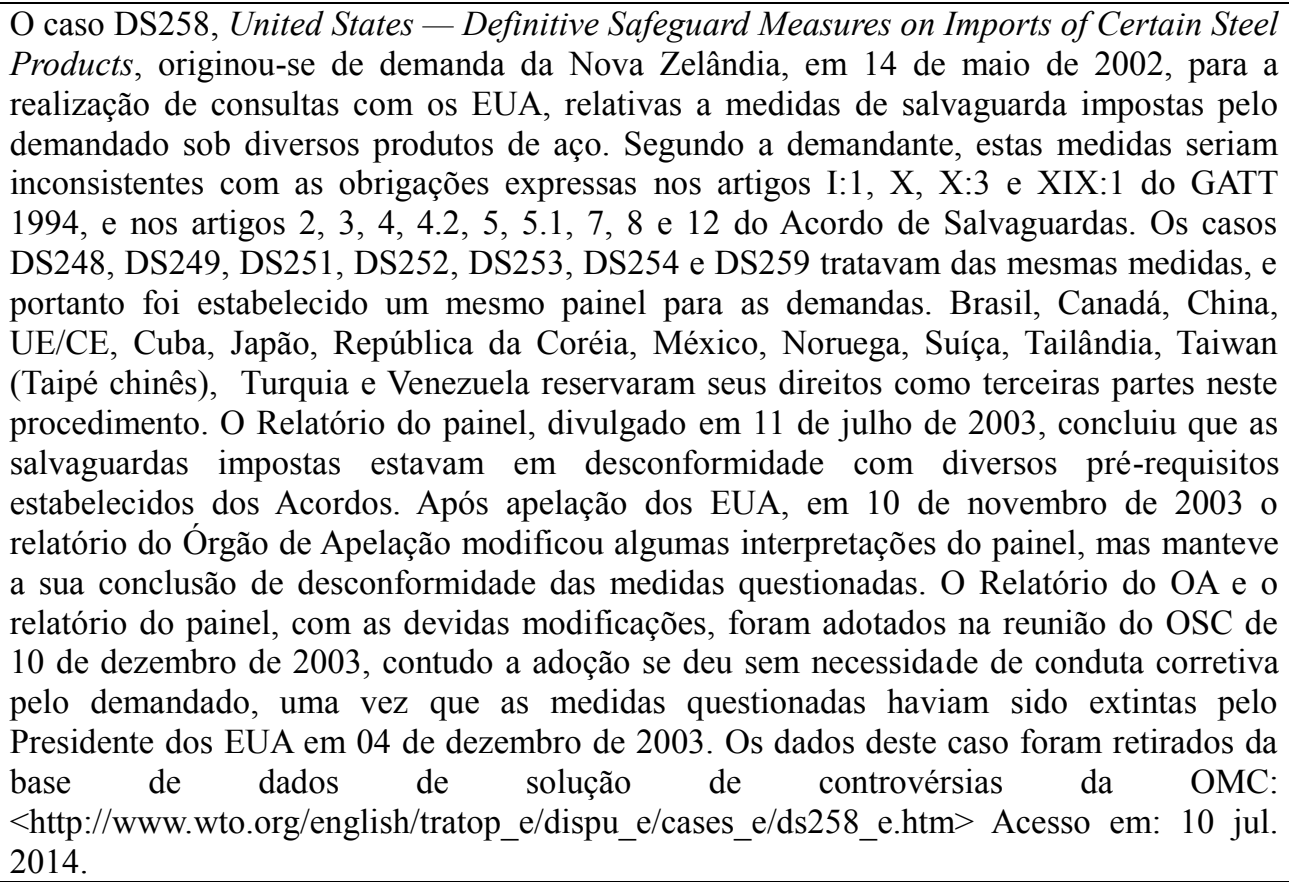 \\
\hline DS265 & $\begin{array}{l}\text { O caso DS265, European Communities - Export Subsidies on Sugar, foi iniciado pela } \\
\text { Austrália, em face da EC/UE, e contou com Barbados, Belize, Brasil, Canadá, China, } \\
\text { Colômbia, Costa do Marfim, Cuba, EUA, Fiji, Guiana, Índia, Jamaica, Quênia, } \\
\text { Madagascar, Malawi, Mauricio, Nova Zelândia, Paraguai, Saint Kitts and Nevis, Suíça, } \\
\text { Tanzânia, Tailândia e Trinidad e Tobago como terceiras partes. O pedido de consultas foi } \\
\text { formulado em } 27 \text { de setembro de } 2002 \text {, o Relatório do painel foi circulado em } 15 \text { de } \\
\text { Outubro de } 2004 \text {, e o Relatório do Órgão de Apelação foi divulgado em } 28 \text { de abril de } \\
\text { 2005. Brasil e Tailândia formularam demandas correlatas, decididas pelo mesmo painel, } \\
\text { nas controvérsias DS266 e DS283. A demanda surgiu em razão de subsídios à exportação } \\
\text { do açúcar estabelecidos no âmbito da Organização Comum do Mercado para o setor } \\
\text { açucareiro (Regulamento do Conselho no. 1260/2001 e outros atos normativos } \\
\text { decorrentes), que no entendimento do demandante violavam diversas obrigações } \\
\text { multilaterais, em especial os Artigos III:4 e XVI do GATT, os Artigos } 3.3 \text {, 8, } 9.1 \text {, 10.1 e } 11 \\
\text { do Acordo sobre Agricultura e os Artigos } 3.1 \text { (a) e } 3.2 \text { do ASMC. Na interpretação do } \\
\text { painel, o regime comunitário de incentivos ao setor açucareiro estava em desconformidade } \\
\text { com a disciplina multilateral, uma vez que os subsídios excediam o limite máximo } \\
\text { acordado. Após o recurso da demandada, o Órgão de Apelação confirmou a maior parte } \\
\text { das interpretações e conclusões do painel, modificando interpretações específicas. O } \\
\text { Relatório do Orgão de Apelação, bem como do painel, com as devidas modificações, foi } \\
\text { adotado em reunião de } 19 \text { de maio de } 2005 \text {. Em seguida, a demandada confirmou sua } \\
\text { intenção de implementar a decisão, e as partes se utilizaram do recurso à arbitragem do } \\
\text { Artigo 21.3(b) do ESC para determinação do período razoável para implementação. O } \\
\text { laudo do árbitro foi exarado em } 28 \text { de Outubro de } 2005 \text {, no qual ficava estabelecido o }\end{array}$ \\
\hline
\end{tabular}




\begin{tabular}{|c|c|}
\hline & 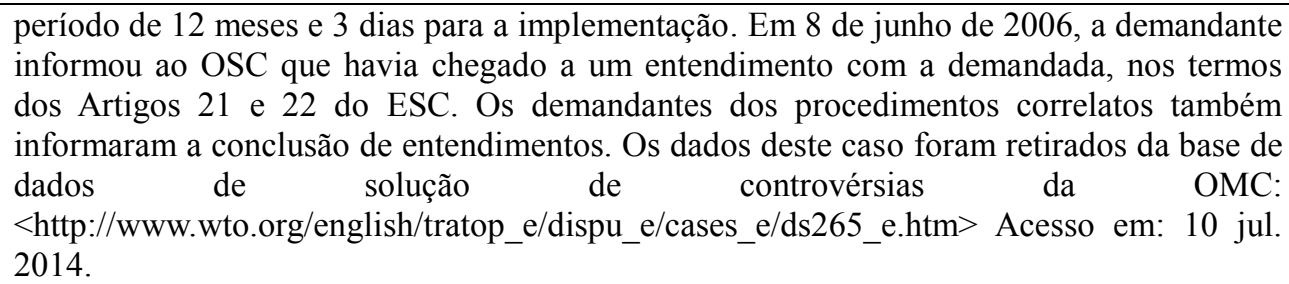 \\
\hline DS283 & 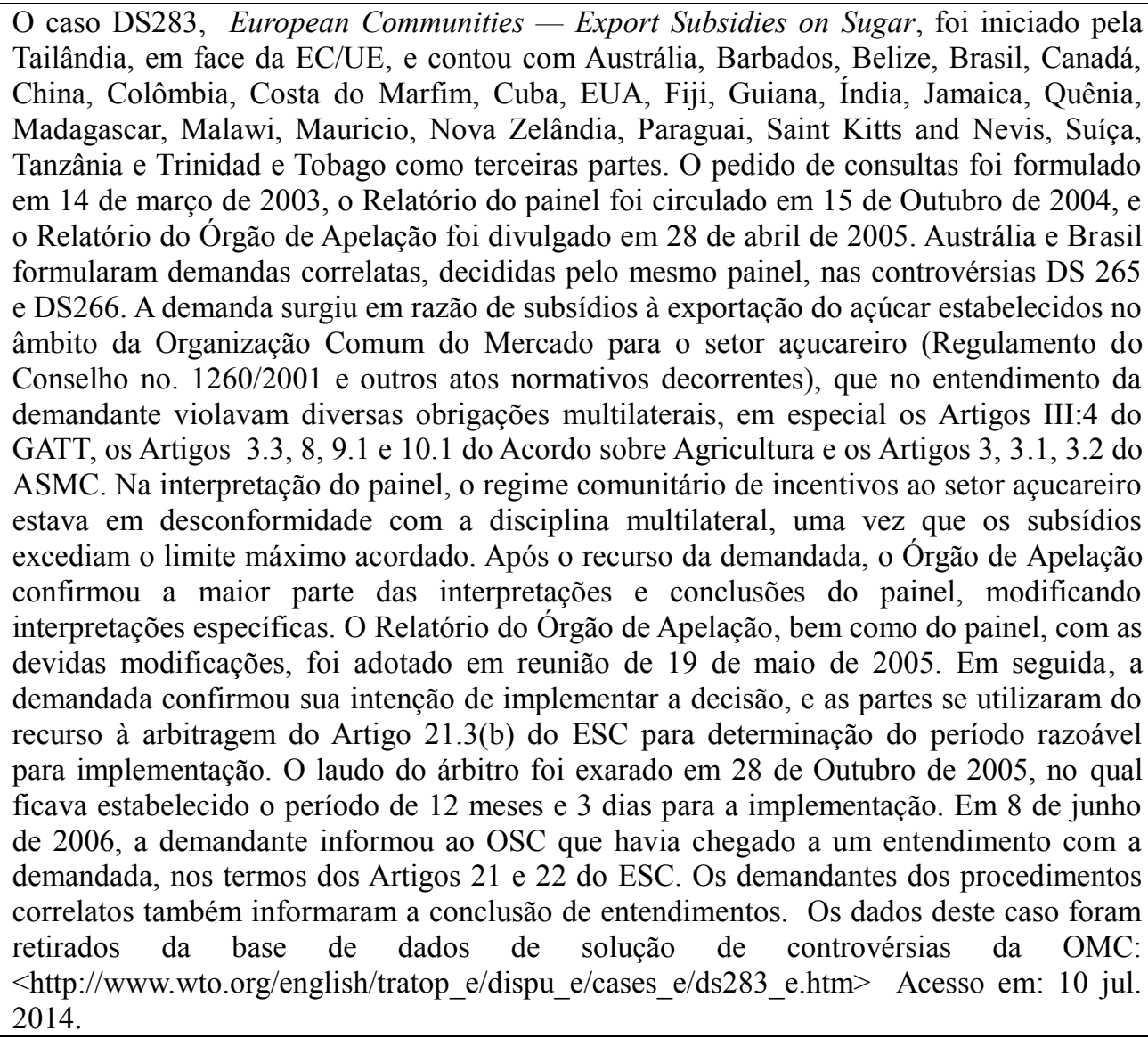 \\
\hline DS286 & $\begin{array}{l}\text { O caso DS286, European Communities - Customs Classification of Frozen Boneless } \\
\text { Chicken Cuts, originou-se de demanda da Tailândia, em } 25 \text { de março de } 2003 \text {, para a } \\
\text { realização de consultas com a UE/CE, a respeito do Regulamento da Comissão N. } \\
1223 / 2002 \text {, que fixava uma nova descrição dos cortes de frango congelado sem osso } \\
\text { dentro da nomenclatura da Comunidade, que no entendimento da demandante violava } \\
\text { obrigações multilaterais constantes dos Artigos II e XXII do GATT. O OSC autorizou o } \\
\text { estabelecimento de um único painel para as controvérsias DS269 e DS286, em } 21 \text { de } \\
\text { novembro de } 2003 \text {. Brasil, China e EUA reservaram seus direitos como terceiras partes } \\
\text { neste procedimento. O relatório do painel, divulgado em } 30 \text { de Maio de } 2005 \text {, reconhecia } \\
\text { que a medida era inconsistente com as obrigações da demandante constante do GATT } \\
\text { 1994, uma vez que os produtos afetados pela medida estavam inseridos em uma concessão } \\
\text { feita pela demandante. Após o recurso de ambas as partes, o Órgão de Apelação confirmou } \\
\text { as conclusões do painel, embora tenha se apoiado em diferente argumentação. O Relatório } \\
\text { do Órgão de Apelação, bem como do painel, com as devidas modificações, foi adotado em } \\
\text { reunião de } 27 \text { de setembro de } 2005 \text {. Em seguida, a demandada confirmou sua intenção de } \\
\text { implementar a decisão, e as partes se utilizaram do recurso à arbitragem do Artigo } 21.3 \text { (b) } \\
\text { do ESC para determinação do período razoável para implementação. O laudo do árbitro foi } \\
\text { exarado em } 20 \text { de fevereiro de } 2006 \text {, no qual ficava estabelecido o período de } 9 \text { meses para } \\
\text { a implementação. A demandante informou na reunião do OSC de } 19 \text { de Julho de } 2006 \text {, que } \\
\text { havia implementado em sua totalidade as recomendações do OSC com a adoção do } \\
\text { Regulamento da Comissão n. } 949 / 2006 \text {. Em } 26 \text { de julho de } 2006 \text {, as partes informaram ao } \\
\text { OSC que haviam chegado a um entendimento, nos termos dos Artigos } 21 \text { e } 22 \text { do ESC. Os } \\
\text { dados deste caso foram retirados da base de dados de solução de controvérsias da OMC: } \\
<\text { http://www.wto.org/english/tratop e/dispu e/cases e/ds269 e.htm> Acesso em: } 10 \text { jul. }\end{array}$ \\
\hline
\end{tabular}




\begin{tabular}{|c|c|}
\hline & 14. \\
\hline DS290 & $\begin{array}{l}\text { O caso DS290, European Communities - Protection of Trademarks and Geographical } \\
\text { Indications for Agricultural Products and Foodstuffs, originou-se de demanda da } \\
\text { Austrália, em } 17 \text { de abril de } 2003 \text {, para a realização de consultas com a UE/CE, relativas } \\
\text { ao Regulamento do Conselho n. 2081/91, que seria omisso na proteção de marcas e } \\
\text { indicações geográficas referentes a produtos agrícolas e alimentícios. Segundo a } \\
\text { demandante, o Regulamento seria violação aos Artigos I, I:1, III, III:4 do GATT, ao Artigo } \\
\text { XVI:4 do Acordo que estabelece a OMC, aos Artigos } 1,2,3,4,10,16,20,22,22.2,24 \text {, } \\
24.5,41,42,63,63.1,63.3,65 \text { e } 65.1 \text { do TRIPS, e aos Artigos } 2,2.1,2.2 \text { e Anexo } 1 \text { do } \\
\text { TBT. Em } 2 \text { de outubro de } 2003 \text { foi estabelecido o mesmo painel para apreciar a demanda } \\
\text { em conjunto com o caso DS174. Argentina, Brasil, Canadá, China, Colômbia, Guatemala, } \\
\text { Îndia, México, Nova Zelândia, Taiwan (Taipé chinês) e Turquia reservaram seus direitos } \\
\text { como terceiras partes no procedimento. O relatório do painel, divulgado em } 15 \text { de março } \\
\text { de } 2005 \text {, reconhecia a desconformidade da conduta comunitária, uma vez que o } \\
\text { Regulamento não respeita o comando do tratamento nacional na proteção de marcas e } \\
\text { indicações geográficas referentes a produtos agrícolas e alimentícios. O Relatório do } \\
\text { painel foi aprovado na reunião do OSC de } 20 \text { de Abril de } 2005 \text {. As partes chegaram a um } \\
\text { acordo sobre o período razoável para implementação, que seria de } 11 \text { meses e duas } \\
\text { semanas. Em } 21 \text { de Abril de } 2006 \text {, a EC/UE afirmou que havia implementado a decisão, } \\
\text { com a edição de um novo Regulamento sobre a matéria, que entrou em vigor em } 31 \text { de } \\
\text { Março de } 2006 \text {. Os dados deste caso foram retirados da base de dados de solução de } \\
\text { controvérsias } \\
\text { <http://www.wto.org/english/tratop_e/dispu_e/cases_e/ds290_e.htm> Acesso em: } 10 \text { jul. } \\
\text { 2014. }\end{array}$ \\
\hline DS292 & 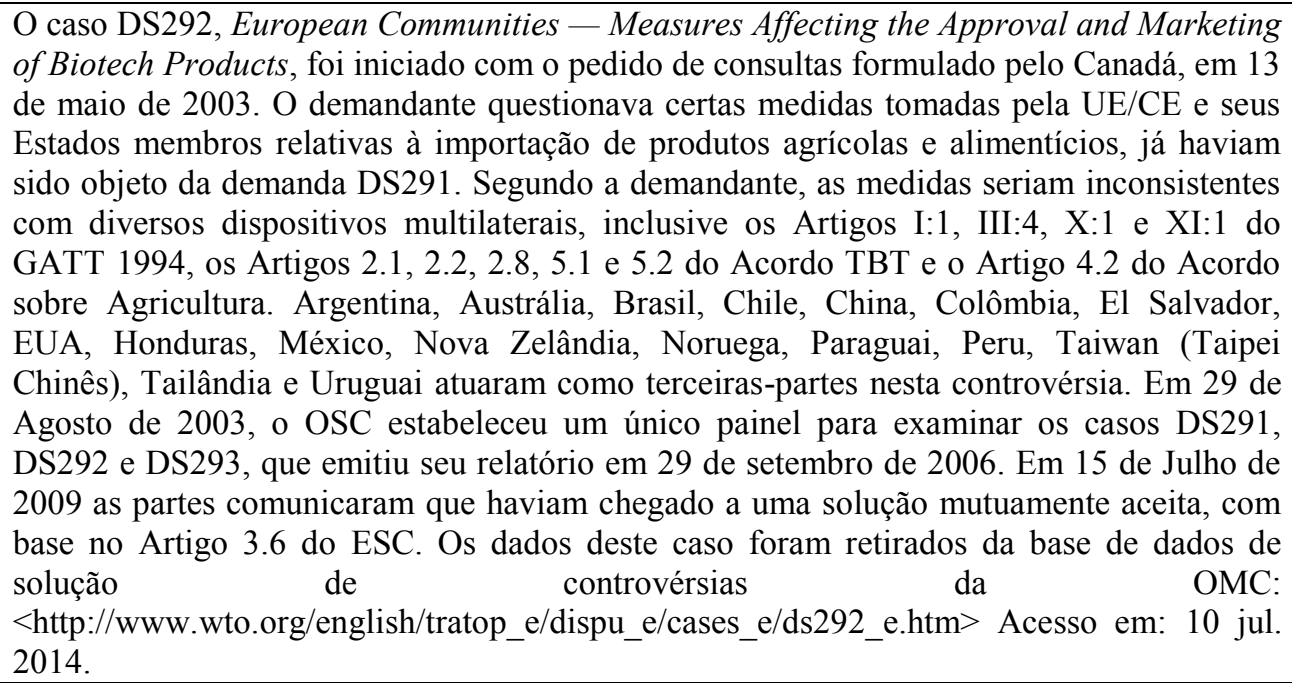 \\
\hline DS293 & 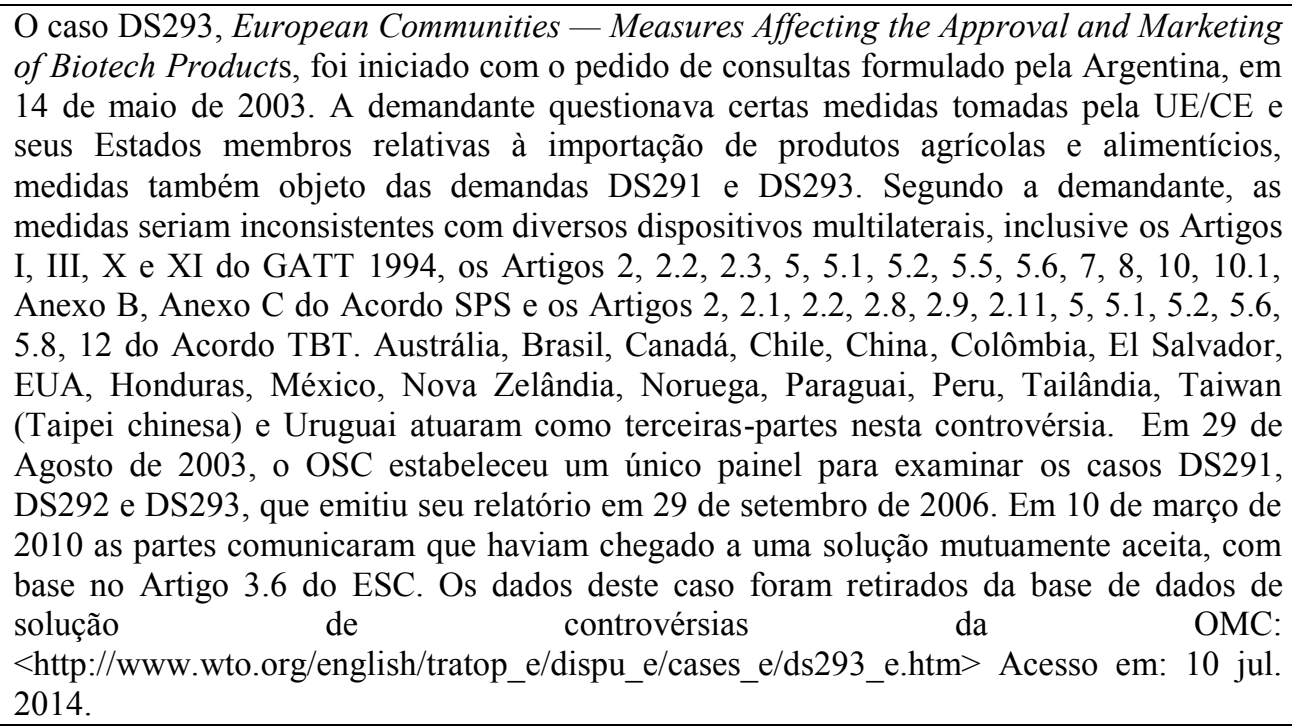 \\
\hline DS294 & O caso DS294, United States - Laws, Regulations and Methodology for Calculating \\
\hline
\end{tabular}




\begin{tabular}{|c|c|}
\hline & 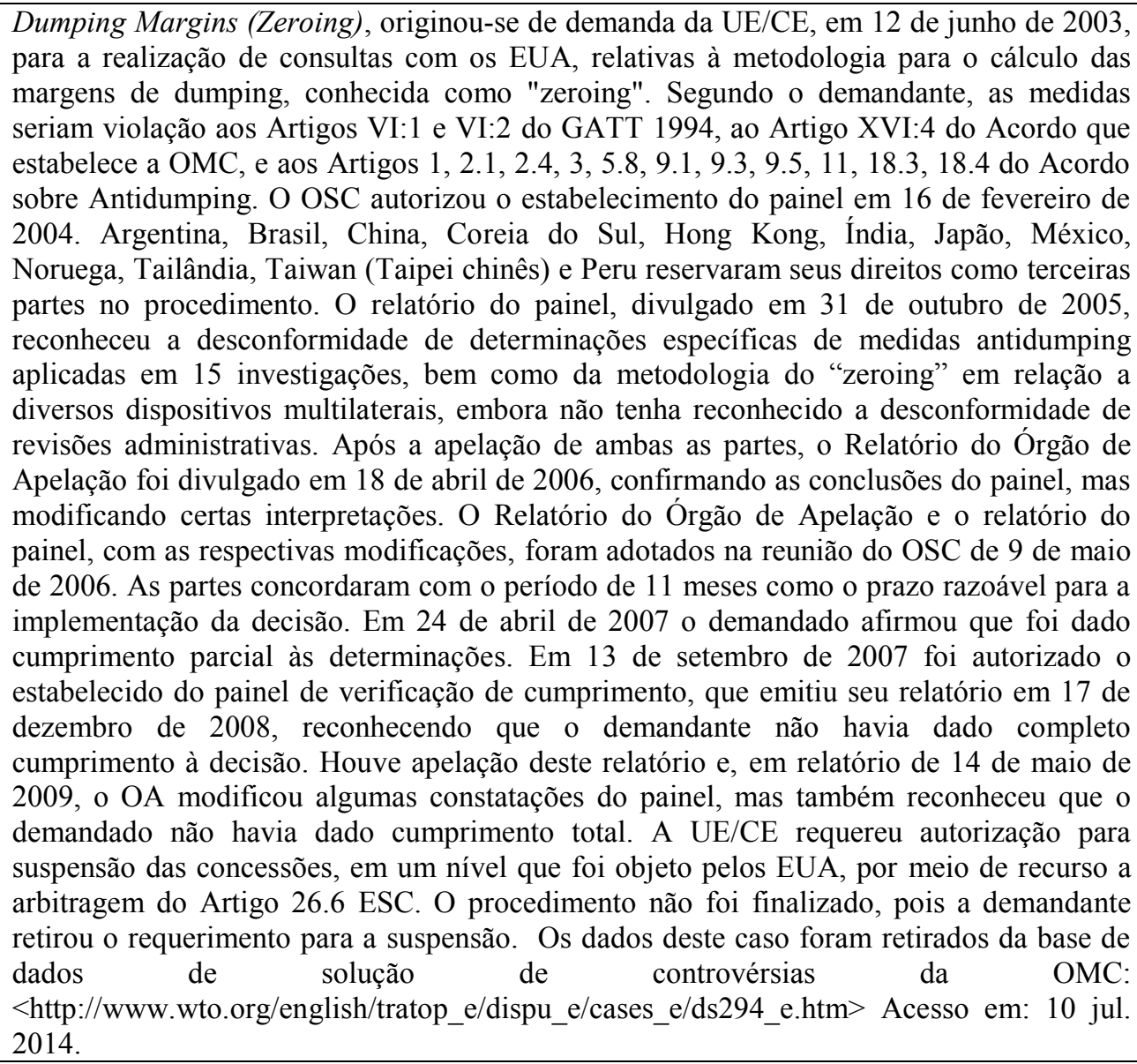 \\
\hline DS315 & $\begin{array}{l}\text { O caso DS315, European Communities - Selected Customs Matters, originou-se de } \\
\text { demanda dos EUA, em } 21 \text { de setembro de 2004, para a realização de consultas com os } \\
\text { EUA, relativas à leis e regulamentos de classificação e avaliação de produtos para fins } \\
\text { aduaneiros e na ausência de procedimentos para revisão de atos administrativos em } \\
\text { matéria aduaneira. Segundo o demandante, as medidas seriam violação aos Artigos X:1, } \\
\text { X:3(a) e X:3(b) do GATT 1994. O OSC estabeleceu o painel em } 21 \text { de março de } 2005 \text {. } \\
\text { Argentina, Austrália, Brasil, Coreia, China, Hong Kong, Índia, Japão e Taiwan (Taipei } \\
\text { Chinês) reservaram seus direitos como terceiras partes no procedimento. O relatório do } \\
\text { painel, divulgado em } 16 \text { de junho de } 2006 \text {, reconheceu a desconformidade da conduta } \\
\text { comunitária com o artigo X:3(a) do GATT 1994. Após a apelação dos EUA, o Relatório } \\
\text { do Órgão de Apelação foi divulgado em } 13 \text { de novembro de } 2006 \text {, modificando certas } \\
\text { conclusões e confirmando algumas interpretações do painel. O Relatório do Órgão de } \\
\text { Apelação e o relatório do painel, com as respectivas modificações, foram adotados na } \\
\text { reunião do OSC de } 11 \text { de dezembro de 2006, quando a demandada informou ter } \\
\text { implementado a decisão. Os dados deste caso foram retirados da base de dados de solução } \\
\text { de controvérsias } \\
\text { <http://www.wto.org/english/tratop_e/dispu_e/cases_e/ds315_e.htm> Acesso em: } 10 \text { jul. } \\
\text { 2014. }\end{array}$ \\
\hline DS316 & $\begin{array}{l}\text { O caso DS316, European Communities - Measures Affecting Trade in Large Civil } \\
\text { Aircraft, originou-se de demanda dos EUA, em } 6 \text { de outubro de 2004, para a realização de } \\
\text { consultas com a EC/UE e alguns de seus Estados membros (Alemanha, França, Espanha e } \\
\text { Reino Unido), quanto a medidas que afetam o comércio de grandes aeronaves civis. } \\
\text { Segundo o demandante, as medidas questionadas seriam violação aos Artigos III:4, XVI:1 } \\
\text { e XXIII: } 1 \text { do GATT } 1994 \text { e aos Artigos } 1,2,3.1,3.2,5,6.3 \text { e } 6.4 \text { do ASMC. O OSC } \\
\text { estabeleceu o painel para analisar a controvérsia em } 20 \text { de julho de } 2005 \text {. Austrália, Brasil, } \\
\text { Canadá, China, Coreia e Japão reservaram seus direitos como terceiras partes no } \\
\text { procedimento. O relatório do painel, divulgado em } 30 \text { de junho de 2010, reconhecia } \\
\text { violações nas medidas questionadas por meio de subsídios proibidos. Com apelação da } \\
\text { UE/CE, em } 18 \text { de maio de } 2011 \text { o Órgão de Apelação emitiu seu relatório, confirmando as } \\
\text { conclusões do painel, embora tenha modificado algumas interpretações. O Relatório do }\end{array}$ \\
\hline
\end{tabular}




\begin{tabular}{|c|c|}
\hline & $\begin{array}{l}\text { Órgão de Apelação e o Relatório do painel, com as devidas modificações, foram adotados } \\
\text { na reunião do OSC de } 1 \text { de junho de } 2011 \text {. Em } 1 \text { de dezembro de } 2011 \text { a demandada } \\
\text { informou ter implementado a decisão. Em } 30 \text { de março de } 2012 \text { o demandante requereu o } \\
\text { estabelecimento de um painel de verificação de cumprimento, e em } 13 \text { de abril de } 2013 \text { o } \\
\text { OSC remeteu a questão ao painel original, que espera concluir a sua análise até o fim de } \\
2014 \text {. Os dados deste caso foram retirados da base de dados de solução de controvérsias da } \\
\text { OMC: <http://www.wto.org/english/tratop_e/dispu_e/cases_e/ds316_e.htm> Acesso em: } \\
10 \text { jul. } 2014 \text {. }\end{array}$ \\
\hline DS317 & $\begin{array}{l}\text { O caso DS317, European Communities - Measures Affecting Trade in Large Civil } \\
\text { Aircraft, originou-se de demanda da UE/CE, em } 6 \text { de outubro de 2004, para a realização de } \\
\text { consultas com os EUA, sobre subsídios proibidos e acionáveis concedidos aos produtores } \\
\text { norte-americanos de grandes aeronaves civis e em particular, à empresa Boeing. Segundo } \\
\text { o demandante, as medidas questionadas seriam violação aos Artigos III:4 do GATT } 1994 \text { e } \\
\text { aos Artigos } 3.1,3.2,5,6.3 \text { do ASMC. O OSC estabeleceu o painel para analisar a } \\
\text { controvérsia em } 20 \text { de julho de } 2005 \text {. Austrália, Brasil, Canadá, China, Coreia e Japão } \\
\text { reservaram seus direitos como terceiras partes no procedimento. Não foi dada continuidade } \\
\text { formal a esta demanda, tendo em vista que seu objeto foi absorvido pela segunda } \\
\text { controvérsia, DS353. Os dados deste caso foram retirados da base de dados de solução de } \\
\text { controvérsias } \\
\text { <http://www.wto.org/english/tratop_e/dispu_e/cases_e/ds317_e.htm> Acesso em: } 10 \text { jul. } \\
\text { 2014. }\end{array}$ \\
\hline DS320 & 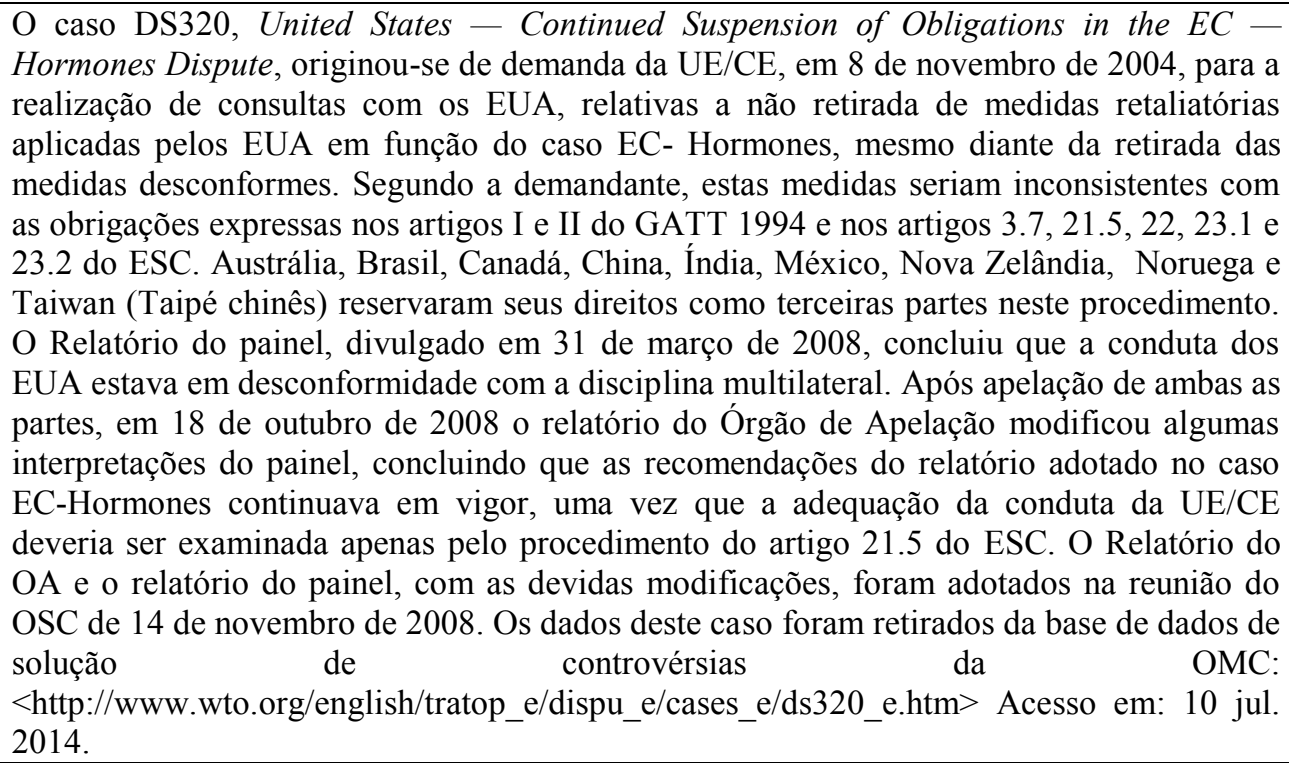 \\
\hline DS321 & $\begin{array}{l}\text { O caso DS321, Canada - Continued Suspension of Obligations in the EC - Hormones } \\
\text { Dispute, originou-se de demanda da UE/CE, em } 8 \text { de novembro de } 2004 \text {, para a realização } \\
\text { de consultas com o Canadá, relativas a não retirada de medidas retaliatórias aplicadas pelo } \\
\text { Canadá em função do caso EC- Hormones, mesmo diante da retirada das medidas } \\
\text { desconformes. Segundo a demandante, estas medidas seriam inconsistentes com as } \\
\text { obrigações expressas nos artigos I e II do GATT } 1994 \text { e nos artigos } 3.7,21.5,22,23.1 \text { e } \\
23.2 \text { do ESC. Austrália, Brasil, China, EUA, Taipé chinês, Índia, México, Nova Zelândia } \\
\text { e Noruega reservaram seus direitos como terceiras partes neste procedimento. O Relatório } \\
\text { do painel, divulgado em } 31 \text { de março de } 2008 \text {, concluiu que a conduta do Canadá estava } \\
\text { em desconformidade com a disciplina multilateral. Após apelação de ambas as partes, em } \\
16 \text { de outubro de } 2008 \text { o relatório do Órgão de Apelação modificou algumas interpretações } \\
\text { do painel, concluindo que as recomendações do relatório adotado no caso EC-Hormones } \\
\text { continuava em vigor, uma vez que a adequação da conduta da UE/CE deveria ser } \\
\text { examinada apenas pelo procedimento do artigo } 21.5 \text { do ESC. O Relatório do OA e o } \\
\text { relatório do painel, com as devidas modificações, foram adotados na reunião do OSC de } \\
14 \text { de novembro de 2008. Os dados deste caso foram retirados da base de dados de solução } \\
\text { de controvérsias } \\
\text { <http://www.wto.org/english/tratop_e/dispu_e/cases_e/ds321_e.htm> Acesso em: } 10 \text { jul. } \\
\text { 2014. }\end{array}$ \\
\hline DS335 & O caso DS335, United States - Anti-Dumping Measure on Shrimp from Ecuador, \\
\hline
\end{tabular}




\begin{tabular}{|c|c|}
\hline & $\begin{array}{l}\text { originou-se de demanda do Equador, em } 17 \text { de novembro de } 2005 \text {, para a realização de } \\
\text { consultas com os EUA, relativas a determinação de medidas antidumping pelo } \\
\text { Departamento de Comércio dos Estados Unidos (DOC) sob camarão oriundo do Equador, } \\
\text { em especial no tocante à metodologia "zeroing". Segundo o demandante, as medidas } \\
\text { seriam violação ao Artigo VI do GATT 1994, e aos Artigos } 1,2.1,2.4,2.4 .2,5.8,6.10 \text {, } \\
\text { 9.2, 9.3, } 9.4 \text { e } 18.1 \text { do Acordo sobre Anti-Dumping. O OSC estabeleceu o painel em } 16 \text { de } \\
\text { julho de } 2006 \text {. Brasil, UE/CE, Chile, China, Coreia, China, Índia, Japão. México e } \\
\text { Tailândia reservaram seus direitos como terceiras partes no procedimento. O relatório do } \\
\text { painel, divulgado em } 30 \text { de janeiro de } 2007 \text {, reconheceu a desconformidade da conduta do } \\
\text { Departamento de Comércio com o artigo } 2.4 .2 \text { do Acordo sobre Anti-Dumping. O } \\
\text { Relatório do painel foi adotado na reunião do OSC de } 20 \text { de fevereiro de } 2007 \text {. As partes } \\
\text { acordaram que } 6 \text { meses seria o período de tempo razoável para a implementação, e em } 31 \\
\text { de agosto de } 2007 \text { o demandado informou ter implementado a decisão. Os dados deste } \\
\text { caso foram retirados da base de dados de solução de controvérsias da OMC: } \\
<\text { http://www.wto.org/english/tratop_e/dispu_e/cases_e/ds335_e.htm> Acesso em: } 10 \text { jul. } \\
2014\end{array}$ \\
\hline DS339 & $\begin{array}{l}\text { O caso DS339, China - Measures Affecting Imports of Automobile Parts, originou-se de } \\
\text { demanda da UE/CE, em } 30 \text { de março de } 2006 \text {, para a realização de consultas com a China, } \\
\text { relativas a imposição de uma série de medidas que afetam negativamente as exportações } \\
\text { de peças de automóveis originárias da UE/CE. Segundo a demandante, as medidas seriam } \\
\text { violação aos Artigos II:1, III:1, III:2, III:4, III:5, XI e XIII:1 do GATT 1994, aos Artigos } \\
2.1,2.2 \text { do TRIMs, ao Artigo } 3 \text { do ASMC e à parte I (para. 1.2, 7.2, e 7.3) do Protocolo de } \\
\text { Acessão. O OSC estabeleceu, em } 26 \text { de outubro de } 2006 \text {, um painel para analisar esta e as } \\
\text { controvérsias DS340 e DS342. Argentina, Austrália, Brasil, Japão, México, Tailândia e } \\
\text { Taiwan (Taipei Chinês) reservaram seus direitos como terceiras partes no procedimento. O } \\
\text { relatório do painel, divulgado em } 18 \text { de janeiro de } 2008 \text {, reconheceu a desconformidade da } \\
\text { conduta chinesa com diversos dispositivos do GATT 1994, exercendo economia judicial } \\
\text { em relação à análise da violação dos demais dispositivos. Com a apelação da China, o } \\
\text { Órgão de Apelação emitiu seu relatório em } 15 \text { de dezembro de } 2008 \text {, confirmando a maior } \\
\text { parte das interpretações e conclusões do painel. O Relatório do Órgão de Apelação e o } \\
\text { relatório do painel, com as devidas modificações, foram adotados na reunião do OSC de } \\
11 \text { de fevereiro de } 2009 \text {. As partes acordaram que } 7 \text { meses e } 20 \text { dias seria o período de } \\
\text { tempo razoável para a implementação, e em } 31 \text { de agosto de } 2009 \text { a demandado informou } \\
\text { ter implementado a decisão, por meio de decreto modificador das medidas. Os dados deste } \\
\text { caso foram retirados da base de dados de solução de controvérsias da OMC: } \\
<\text { http://www.wto.org/english/tratop_e/dispu_e/cases_e/ds339_e.htm> Acesso em: 10 jul. } \\
\text { 2014. }\end{array}$ \\
\hline DS340 & $\begin{array}{l}\text { O caso DS340, China - Measures Affecting Imports of Automobile Parts, originou-se de } \\
\text { demanda dos EUA, em } 30 \text { de março de } 2006 \text {, para a realização de consultas com a China, } \\
\text { relativas a imposição de uma série de medidas que afetam negativamente as exportações } \\
\text { de peças de automóveis originárias dos EUA. Segundo a demandante, as medidas seriam } \\
\text { violação aos Artigos II, II:1, III, III:2, III:4, III:5 e XI:1 do GATT 1994, aos Artigos } 2 \text { e } \\
2.1 \text { do TRIMs, aos Artigos } 3,3.1 \text { (b) e } 3.2 \text { do ASMC e à parte I (para. 1.2, 7.2, e } 7.3 \text { ) do } \\
\text { Protocolo de Acessão. O OSC estabeleceu, em } 26 \text { de outubro de } 2006 \text {, um painel para } \\
\text { analisar esta e as controvérsias DS339 e DS342. Argentina, Austrália, Brasil, Japão, } \\
\text { México, Tailândia e Taiwan (Taipei Chinês) reservaram seus direitos como terceiras partes } \\
\text { no procedimento. O relatório do painel, divulgado em } 18 \text { de janeiro de } 2008 \text {, reconheceu a } \\
\text { desconformidade da conduta chinesa com diversos dispositivos do GATT 1994, exercendo } \\
\text { economia judicial em relação à análise da violação dos demais dispositivos. Com a } \\
\text { apelação da China, o Órgão de Apelação emitiu seu relatório em } 15 \text { de dezembro de } 2008 \text {, } \\
\text { confirmando a maior parte das interpretações e conclusões do painel. O Relatório do } \\
\text { Orgão de Apelação e o relatório do painel, com as devidas modificações, foram adotados } \\
\text { na reunião do OSC de } 11 \text { de fevereiro de } 2009 \text {. As partes acordaram que } 7 \text { meses e } 20 \text { dias } \\
\text { seria o período de tempo razoável para a implementação, e em } 31 \text { de agosto de } 2009 \text { a } \\
\text { demandado informou ter implementado a decisão, por meio de decreto modificador das } \\
\text { medidas. Os dados deste caso foram retirados da base de dados de solução de controvérsias } \\
\text { da OMC: <http://www.wto.org/english/tratop_e/dispu_e/cases_e/ds340_e.htm> Acesso } \\
\text { em: } 10 \text { jul. 2014. }\end{array}$ \\
\hline DS342 & $\begin{array}{l}\text { O caso DS342, China - Measures Affecting Imports of Automobile Parts, originou-se de } \\
\text { demanda do Canadá, em } 30 \text { de março de } 2006 \text {, para a realização de consultas com a China, }\end{array}$ \\
\hline
\end{tabular}




\begin{tabular}{|c|c|}
\hline & $\begin{array}{l}\text { relativas a imposição de uma série de medidas que afetam negativamente as exportações } \\
\text { de peças de automóveis oriundas do Canadá. Segundo a demandante, as medidas seriam } \\
\text { violação aos Artigos II, II:1, III:1, III:2, III:4, III:5, X:1 e X:3 do GATT 1994, aos Artigos } \\
2 \text { e } 2.1 \text { do TRIMs, aos Artigos 3, 3.1(b) e 3.2 do ASMC e à parte I (para. 1.2, 7.2 e 7.3) do } \\
\text { Protocolo de Acessão. O OSC estabeleceu, em } 26 \text { de outubro de 2006, um painel para } \\
\text { analisar esta e as controvérsias DS339 e DS340. Argentina, Austrália, Brasil, Japão, } \\
\text { México, Tailândia e Taiwan (Taipei Chinês) reservaram seus direitos como terceiras partes } \\
\text { no procedimento. O relatório do painel, divulgado em } 18 \text { de janeiro de 2008, reconheceu a } \\
\text { desconformidade da conduta chinesa com diversos dispositivos do GATT 1994, exercendo } \\
\text { economia judicial em relação à análise da violação dos demais dispositivos. Com a } \\
\text { apelação da China, o Órgão de Apelação emitiu seu relatório em } 15 \text { de dezembro de } 2008 \text {, } \\
\text { confirmando a maior parte das interpretações e conclusões do painel. O Relatório do } \\
\text { Órgão de Apelação e o relatório do painel, com as devidas modificações, foram adotados } \\
\text { na reunião do OSC de } 11 \text { de fevereiro de } 2009 \text {. As partes acordaram que } 7 \text { meses e } 20 \text { dias } \\
\text { seria o período de tempo razoável para a implementação, e em } 31 \text { de agosto de } 2009 \text { a } \\
\text { demandado informou ter implementado a decisão, por meio de decreto modificador das } \\
\text { medidas. Os dados deste caso foram retirados da base de dados de solução de } \\
\text { controvérsias } \\
\text { Chttp://www.wto.org/english/tratop_e/dispu_e/cases_e/ds342_e.htm> Acesso em: } 10 \text { jul. } \\
\text { 2014. }\end{array}$ \\
\hline DS343 & $\begin{array}{l}\text { O caso DS343, United States- Measures Relating to Shrimp from Thailand, originou-se de } \\
\text { demanda da Tailândia, em } 24 \text { de abril de } 2006 \text {, para a realização de consultas com os } \\
\text { EUA, relativas a determinação de medidas antidumping pelo Departamento de Comércio } \\
\text { dos Estados Unidos (DOC) sob camarão oriundo da Tailândia, em especial no tocante à } \\
\text { metodologia "zeroing". Segundo a demandante, as medidas seriam violação aos Artigos } \\
\text { I:1, II, II:1, III, VI, XI:1, XIII:1, XX, X:3(a), VI:2 do GATT 1994, e aos Artigos } 1,2,2.1 \text {, } \\
\text { 2.4, 2.4.2, 3.1, 3.2, 3.4, 3.5, 5.8, 7, 7.1, 7.2, 7.4, } 9.2,9.3,9.4 \text { e } 18.1 \text { do Acordo sobre Anti- } \\
\text { Dumping. O OSC estabeleceu o painel em } 26 \text { de outubro de } 2006 \text {. Brasil, UE/CE, Chile, } \\
\text { China, Coreia, China, Índia, Japão, México e Vietnam reservaram seus direitos como } \\
\text { terceiras partes no procedimento. O relatório do painel, divulgado em } 29 \text { de fevereiro de } \\
\text { 2008, reconheceu a desconformidade da conduta do Departamento de Comércio com } \\
\text { alguns dispositivos do GATT } 1994 \text { e do Acordo sobre Anti-Dumping. Com apelação de } \\
\text { ambas as partes, o Órgão de Apelação emitiu seu relatório em } 16 \text { de julho de } 2008 \text {, } \\
\text { confirmando as recomendações do painel. O Relatório do Órgão de Apelação e o relatório } \\
\text { do painel, com as devidas modificações, foi adotado na reunião do OSC de } 1 \text { de agosto de } \\
\text { 2008. As partes acordaram que } 8 \text { meses seria o período de tempo razoável para a } \\
\text { implementação, e em } 20 \text { de abril de } 2007 \text { o demandado informou ter implementado a } \\
\text { decisão. Os dados deste caso foram retirados da base de dados de solução de controvérsias } \\
\text { da OMC: <http://www.wto.org/english/tratop_e/dispu_e/cases_e/ds343_e.htm> Acesso } \\
\text { em: } 10 \text { jul. } 2014 \text {. }\end{array}$ \\
\hline DS344 & $\begin{array}{l}\text { O caso DS344, United States - Final Anti-Dumping Measures on Stainless Steel from } \\
\text { Mexico, foi iniciado com o pedido de consultas formulado pelo México, em } 31 \text { de janeiro } \\
\text { de } 2006 \text {. O demandante questionava diversas determinações de antidumping aplicadas pelo } \\
\text { Departamento de Comércio norte-americano, incluída a metodologia de zeroing, que } \\
\text { seriam inconsistentes com diversos dispositivos multilaterais, inclusive os Artigos VI:1 e } \\
\text { VI:2 do GATT 1994, o Artigo XVI:4 do Acordo que estabelece a OMC es os Artigos } 1,2.1 \text {, } \\
\text { 2.4, 2.4.2, 5, 6.10, 9, } 11 \text { e } 18 \text { do Acordo sobre Anti-Dumping. Brasil, Chile, China, EC, } \\
\text { Japão, República da Coreia e Tailândia atuaram como terceiras-partes nesta controvérsia. } \\
\text { Em } 09 \text { de maio de } 2006 \text { foi estabelecido o painel para examinar a controvérsia, e foi } \\
\text { composto em } 17 \text { de julho de } 2006 \text {. Em } 26 \text { de outubro de } 2006 \text { o painel foi estabelecido, e } \\
\text { emitiu seu relatório em } 20 \text { de dezembro de } 2007 \text {. Em } 30 \text { de abril de } 2008 \text { circulou o } \\
\text { Relatório do Órgão de Apelação, e na pendência do exame do painel de verificação do } \\
\text { cumprimento (Artigo } 21.3(c) \text { ESC), as partes comunicaram que haviam chegado a uma } \\
\text { solução mutuamente aceita, com base no Artigo } 3.6 \text { do ESC. Os dados deste caso foram } \\
\text { retirados da base de dados de solução de controvérsias da OMC: } \\
\text { <http://www.wto.org/english/tratop_e/dispu_e/cases_e/ds344_e.htm> Acesso em: } 10 \text { jul. } \\
2014 \text {. }\end{array}$ \\
\hline DS345 & $\begin{array}{l}\text { O caso DS345, United States - Customs Bond Directive for Merchandise Subject to Anti- } \\
\text { Dumping/Countervailing Duties, originou-se de demanda da Índia, em } 6 \text { de junho de } 2006 \text {, } \\
\text { para a realização de consultas com os EUA, relativas a medidas normativas de exigência }\end{array}$ \\
\hline
\end{tabular}




\begin{tabular}{|c|c|}
\hline & 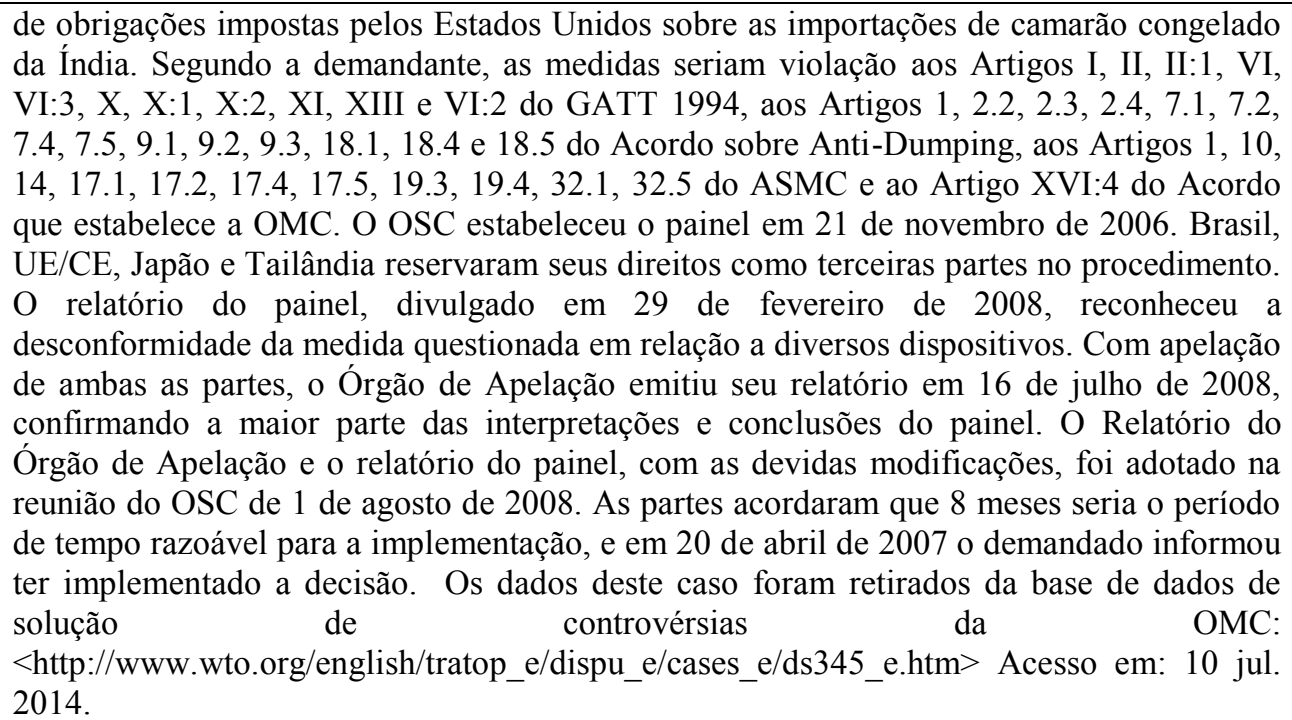 \\
\hline DS347 & $\begin{array}{l}\text { O caso DS347, European Communities and Certain Member States - Measures Affecting } \\
\text { Trade in Large Civil Aircraft (Second Complaint), foi iniciado com o pedido de consultas } \\
\text { formulado pelos EUA, em } 31 \text { de janeiro de 2006, em face da UE/CE e de seus seguintes } \\
\text { Estados membros: Alemanha, Espanha, França e Reino Unido. O demandante questionava } \\
\text { supostos subsídios (medidas também questionadas no caso DS316) que seriam } \\
\text { inconsistentes com os Artigos III:4 e XVI:1 do GATT 1994 e com os Artigos 3.1(a), } \\
3.1(\text { b), } 3.2,5(a), 5(c) \text { ), 6.3(a), 6.3(b) e 6.3(c) do ASCM. Austrália, Brasil, Canadá, China, } \\
\text { Japão e República da Coréia atuavam como terceiras-partes nesta controvérsia. Em } 09 \text { de } \\
\text { maio de } 2006 \text { foi estabelecido o painel para examinar a controvérsia, e foi composto em } 17 \\
\text { de julho de 2006. Em } 9 \text { de outubro de 2006, o demandante requisitou a suspensão dos } \\
\text { trabalhos do painel, que não tendo sido retomado, caducou sua autoridade em } 7 \text { de outubro } \\
\text { de } 2007 \text {. Os dados deste caso foram retirados da base de dados de solução de controvérsias } \\
\text { da OMC: <http://www.wto.org/english/tratop_e/dispu_e/cases_e/ds347_e.htm> Acesso } \\
\text { em: } 10 \text { jul. } 2014 \text {. }\end{array}$ \\
\hline DS350 & 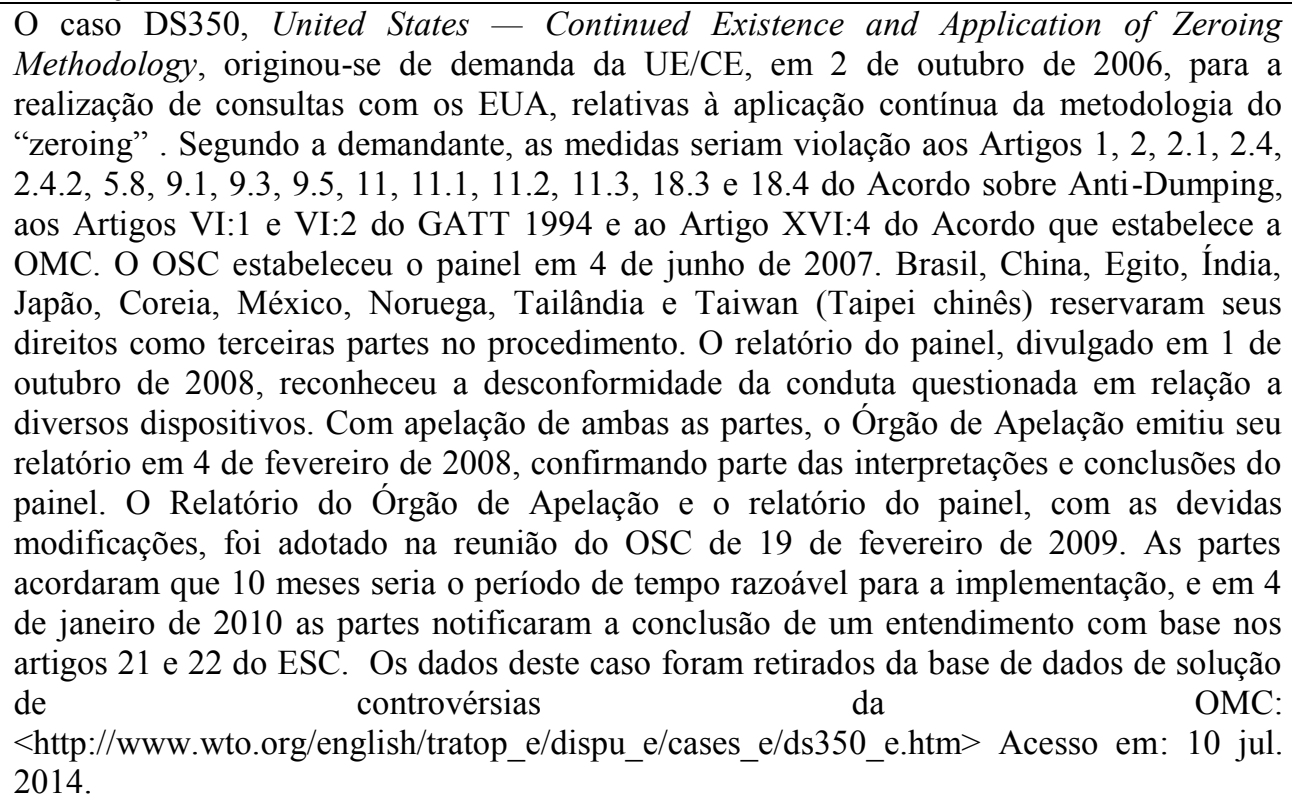 \\
\hline DS353 & $\begin{array}{l}\text { O caso DS353, United States - Measures Affecting Trade in Large Civil Aircraft - } \\
\text { Second Complaint, originou-se de demanda da UE/CE, em } 27 \text { de junho de } 2005 \text {, para a } \\
\text { realização de consultas com os EUA, sobre subsídios proibidos e acionáveis concedidos } \\
\text { aos produtores norte-americanos de grandes aeronaves civis. Segundo a demandante, as } \\
\text { medidas questionadas seriam violação aos Artigos III:4 do GATT 1994, ao Artigo } 23 \text { do } \\
\text { ESC e aos } 1.1,2,3.1,3.2,5,6.3 \text { e } 32 \text { do ASMC. O OSC estabeleceu o painel para analisar } \\
\text { a controvérsia em } 17 \text { de fevereiro de } 2006 \text {. Austrália, Brasil, Canadá, China, Coreia e } \\
\text { Japão reservaram seus direitos como terceiras partes no procedimento. O relatório do }\end{array}$ \\
\hline
\end{tabular}




\begin{tabular}{|c|c|}
\hline & $\begin{array}{l}\text { painel, divulgado em } 31 \text { de março de } 2011 \text {, reconhecia violações em algumas das medidas } \\
\text { questionadas. Com apelação de ambas as partes, em } 12 \text { de março de } 2012 \text { o Órgão de } \\
\text { Apelação emitiu seu relatório, confirmando as conclusões do painel, embora tenha } \\
\text { modificado algumas interpretações. O Relatório do Órgão de Apelação e o Relatório do } \\
\text { painel, com as devidas modificações, foram adotados na reunião do OSC de } 23 \text { de março } \\
\text { de } 2012 \text {. Em } 23 \text { de setembro de } 2012 \text { o demandado informou ter implementado a decisão. } \\
\text { Em } 11 \text { outubro de } 2012 \text { a demandante requereu o estabelecimento de um painel de } \\
\text { verificação de cumprimento, e em } 23 \text { de outubro de } 2012 \text { o OSC remeteu a questão ao } \\
\text { painel original, que espera concluir a sua análise até o meio de } 2015 \text {. Os dados deste caso } \\
\text { foram retirados da base de dados de solução de controvérsias da OMC: } \\
<\text { http://www.wto.org/english/tratop_e/dispu_e/cases_e/ds353_e.htm> Acesso em: } 10 \text { jul. } \\
2014 \text {. }\end{array}$ \\
\hline DS362 & $\begin{array}{l}\text { O caso DS362, China - Measures Affecting the Protection and Enforcement of } \\
\text { Intellectual Property Rights, será analisado no subitem 3.6.2. }\end{array}$ \\
\hline DS375 & $\begin{array}{l}\text { O caso DS375, European Communities and its Member States - Tariff Treatment of } \\
\text { Certain Information Technology Products, originou-se de demanda dos EUA, em } 28 \text { de } \\
\text { maio de } 2008 \text {, para a realização de consultas com UE/CE, relativas ao tratamento tarifário } \\
\text { de certos produtos de tecnologia da informação. Segundo o demandante, as medidas } \\
\text { seriam violação aos Artigos II:1, X:1, X:2 e XXII do GATT 1994. O OSC estabeleceu, em } \\
23 \text { de setembro de } 2010 \text {, um painel para analisar esta e as controvérsias DS376 e DS377. } \\
\text { Austrália, Brasil, China, Costa Rica, Hong Kong, China, Índia, Japão, Coreia, Filipinas, } \\
\text { Cingapura, Tailândia, Taiwan (Taipei Chinês), Peru e Vietnam reservaram seus direitos } \\
\text { como terceiras partes no procedimento. O relatório do painel, divulgado em } 16 \text { de agosto } \\
\text { de } 2010 \text {, reconheceu a desconformidade da conduta questionada em relação a diversos } \\
\text { dispositivos. O Relatório do painel foi adotado na reunião do OSC de } 21 \text { de setembro de } \\
\text { 2010. As partes acordaram que } 9 \text { meses e } 9 \text { dias seria o período de tempo razoável para a } \\
\text { implementação, e em } 20 \text { de julho de } 2011 \text { a demandada notificou a implementação. Os } \\
\text { dados deste caso foram retirados da base de dados de solução de controvérsias da OMC: } \\
<\text { http://www.wto.org/english/tratop_e/dispu_e/cases_e/ds375_e.htm> Acesso em: } 10 \text { jul. } \\
\text { 2014. }\end{array}$ \\
\hline DS376 & $\begin{array}{l}\text { O caso DS376, European Communities and its Member States - Tariff Treatment of } \\
\text { Certain Information Technology Products, originou-se de demanda do Japão, em } 28 \text { de } \\
\text { maio de 2008, para a realização de consultas com a UE/CE, relativas ao tratamento } \\
\text { tarifário de certos produtos de tecnologia da informação. Segundo o demandante, as } \\
\text { medidas seriam violação aos Artigos II, II:1, X:1, X:2, XXIII e XXIII:1 do GATT 1994. O } \\
\text { OSC estabeleceu, em } 23 \text { de setembro de 2010, um painel para analisar esta e as } \\
\text { controvérsias DS375 e DS377. Austrália, Brasil, China, Costa Rica, EUA, Hong Kong, } \\
\text { China, Índia, Coreia, Filipinas, Cingapura, Tailândia, Taiwan (Taipei Chinês), Peru e } \\
\text { Vietnam reservaram seus direitos como terceiras partes no procedimento. O relatório do } \\
\text { painel, divulgado em } 16 \text { de agosto de } 2010 \text {, reconheceu a desconformidade da conduta } \\
\text { questionada em relação a diversos dispositivos. O Relatório do painel foi adotado na } \\
\text { reunião do OSC de } 21 \text { de setembro de } 2010 \text {. As partes acordaram que } 9 \text { meses e } 9 \text { dias } \\
\text { seria o período de tempo razoável para a implementação, e em } 20 \text { de julho de } 2011 \text { a } \\
\text { demandada notificou a implementação. Os dados deste caso foram retirados da base de } \\
\text { dados de de controvérsias } \\
<\text { http://www.wto.org/english/tratop_e/dispu_e/cases_e/ds376_e.htm> Acesso em: } 10 \text { jul. } \\
\text { 2014. }\end{array}$ \\
\hline DS377 & $\begin{array}{l}\text { O caso DS377, European Communities and its Member States - Tariff Treatment of } \\
\text { Certain Information Technology Products, originou-se de demanda de Taiwan (Taipei } \\
\text { chinês, em } 28 \text { de maio de } 2008 \text {, para a realização de consultas com a UE/CE, relativas ao } \\
\text { tratamento tarifário de certos produtos de tecnologia da informação. Segundo o } \\
\text { demandante, as medidas seriam violação aos Artigos II:1, X:1, X:2, XXIII e XXIII:1 do } \\
\text { GATT 1994. O OSC estabeleceu, em } 23 \text { de setembro de } 2010 \text {, um painel para analisar esta } \\
\text { e as controvérsias DS375 e DS376. Austrália, Brasil, China, Costa Rica, EUA, Hong } \\
\text { Kong, China, Índia, Coreia, Filipinas, Cingapura, Tailândia, Peru e Vietnam reservaram } \\
\text { seus direitos como terceiras partes no procedimento. O relatório do painel, divulgado em } \\
16 \text { de agosto de } 2010 \text {, reconheceu a desconformidade da conduta questionada em relação a } \\
\text { diversos dispositivos. O Relatório do painel foi adotado na reunião do OSC de } 21 \text { de } \\
\text { setembro de } 2010 \text {. As partes acordaram que } 9 \text { meses e } 9 \text { dias seria o período de tempo } \\
\text { razoável para a implementação, e em } 20 \text { de julho de } 2011 \text { a demandada notificou a }\end{array}$ \\
\hline
\end{tabular}




\begin{tabular}{|c|c|}
\hline & $\begin{array}{l}\begin{array}{l}\text { implementação. Os dados deste caso foram retirados da base de dados de solução de } \\
\text { controvérsias }\end{array} \\
\text { <http://www.wto.org/english/tratop_e/dispu_e/cases_e/ds377_e.htm> Acesso em: } 10 \text { jul. } \\
2014 \text {. }\end{array}$ \\
\hline DS379 & 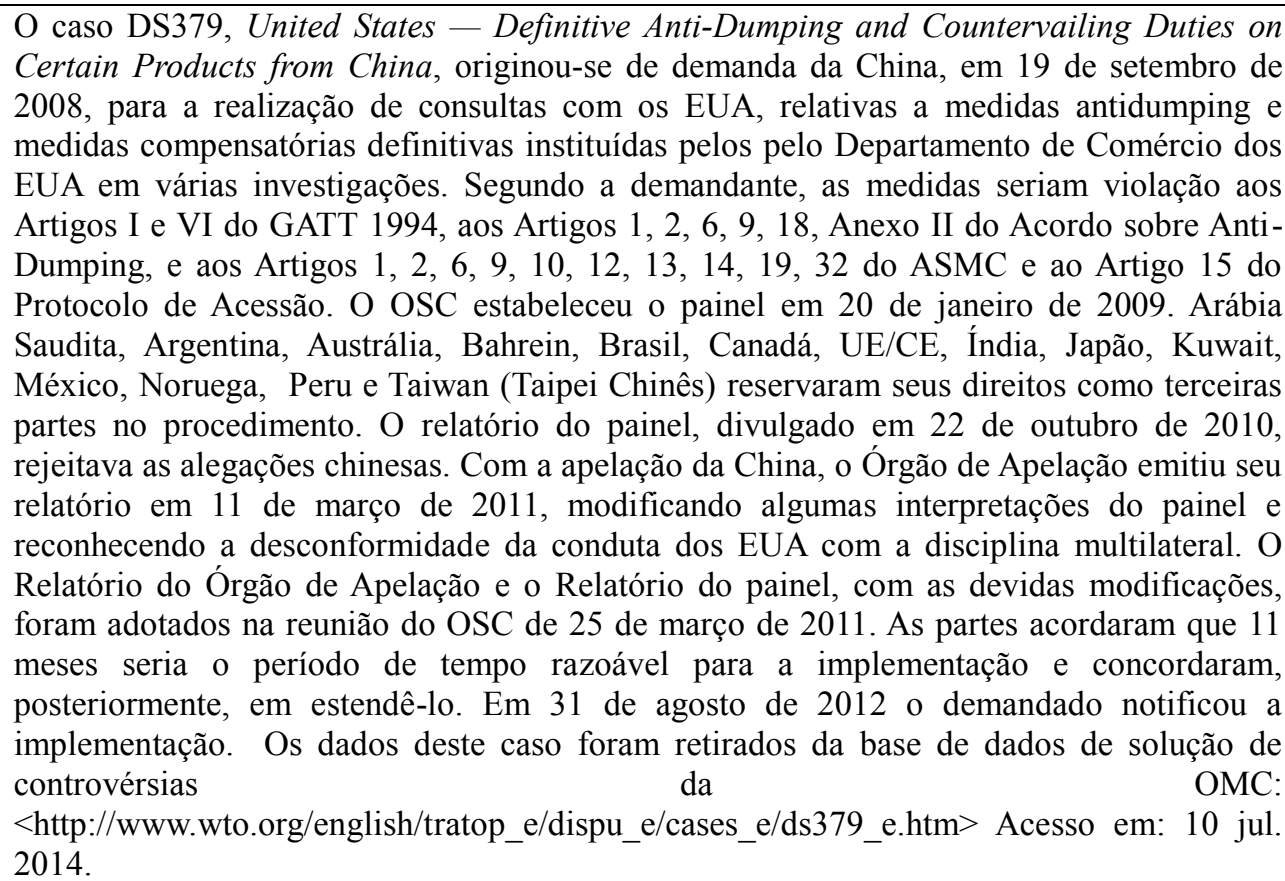 \\
\hline DS381 & $\begin{array}{l}\text { O caso DS381, United States - Measures Concerning the Importation, Marketing and } \\
\text { Sale of Tuna and Tuna Products, será analisado no subitem 3.6.3. }\end{array}$ \\
\hline DS384 & 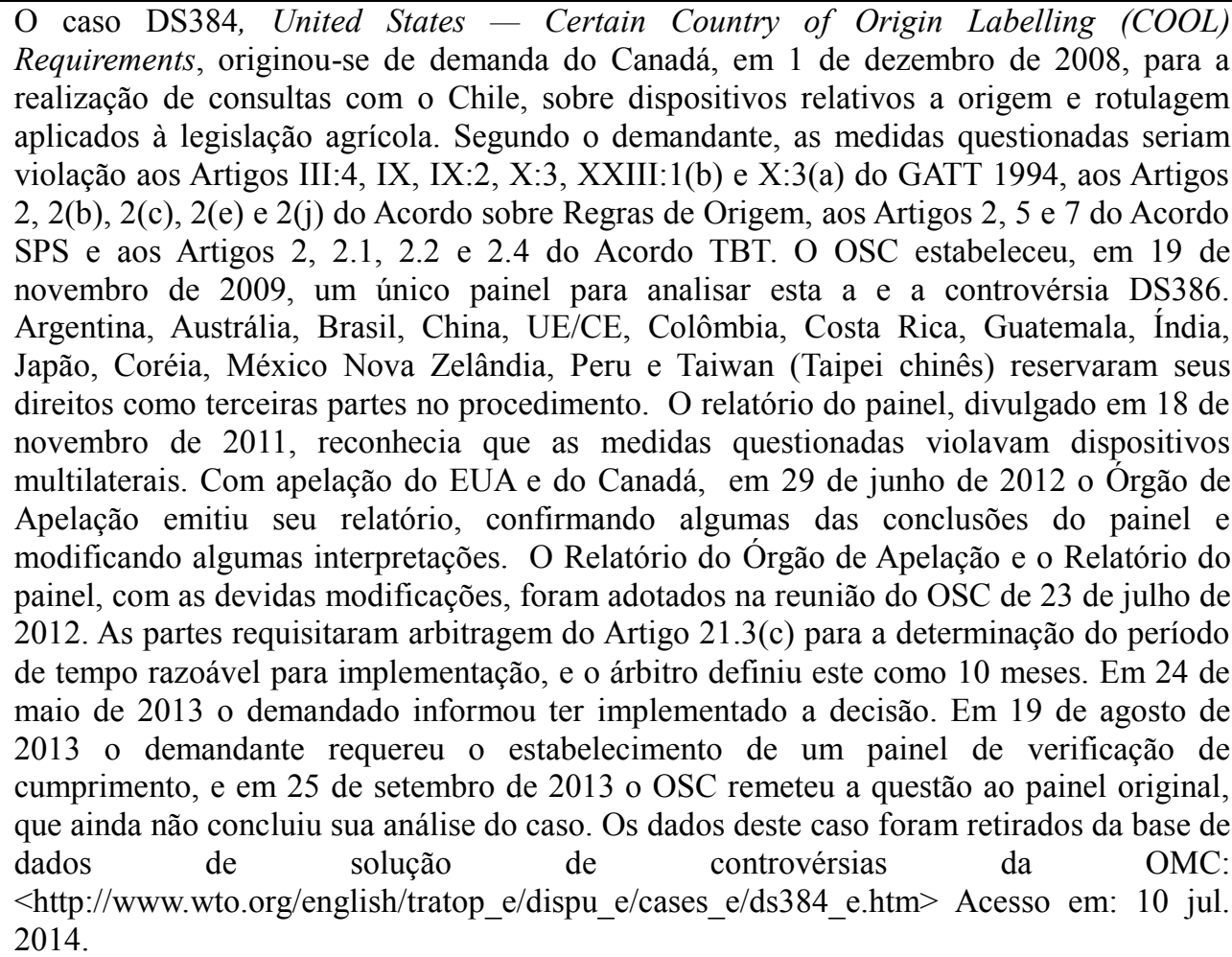 \\
\hline DS386 & $\begin{array}{l}\text { O caso DS386, United States - Certain Country of Origin Labelling (COOL) } \\
\text { Requirements, originou-se de demanda do México, em } 17 \text { de dezembro de 2008, para a } \\
\text { realização de consultas com o Chile, sobre dispositivos relativos a origem e rotulagem } \\
\text { aplicados à legislação agrícola. Segundo o demandante, as medidas questionadas seriam } \\
\text { violação aos Artigos III, IX, X e X:3(a) do GATT 1994, ao Artigos } 2 \text { do Acordo sobre } \\
\text { Regras de Origem, aos Artigos } 2,5 \text { e } 7 \text { do Acordo SPS e aos Artigos } 2 \text { e } 12 \text { do Acordo } \\
\text { TBT. O OSC estabeleceu, em } 19 \text { de novembro de 2009, um único painel para analisar esta }\end{array}$ \\
\hline
\end{tabular}




\begin{tabular}{|c|c|}
\hline & 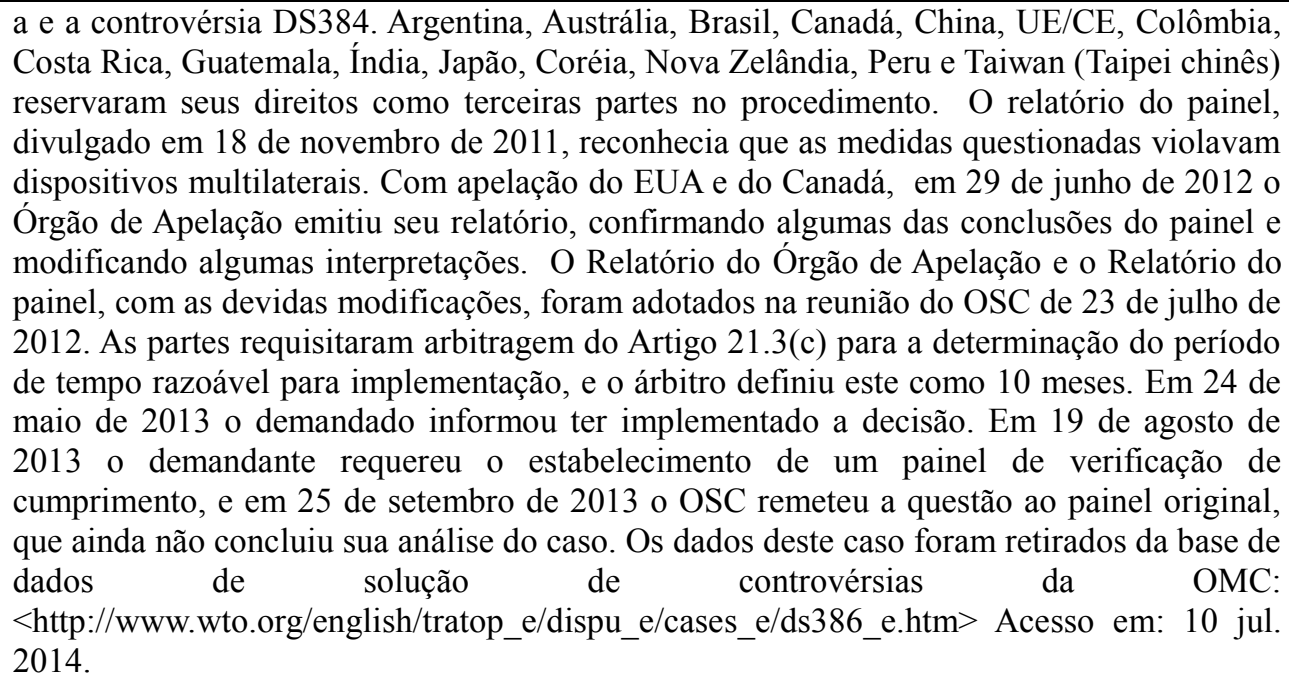 \\
\hline DS391 & $\begin{array}{l}\text { O caso DS391, Korea - Measures Affecting the Importation of Bovine Meat and Meat } \\
\text { Products from Canada, originou-se de demanda do Canadá, em } 9 \text { de abril de } 2009 \text {, para a } \\
\text { realização de consultas com a Coreia, relativas a medidas que afetem a importação de } \\
\text { carne e produtos de carne bovina oriundos do Canadá. Segundo a demandante, as medidas } \\
\text { questionadas seriam violação aos Artigos I:1, III:4 e XI:1 do GATT } 1994 \text { e aos Artigos } \\
2.2,2.3,3.1,3.3,5.1,5.5,5.6,5.7,6.1,8 \text { e Anexo C do Acordo SPS. O OSC estabeleceu o } \\
\text { painel para analisar a controvérsia em } 31 \text { de agosto de } 2009 \text {. Argentina, Brasil, UE/CE, } \\
\text { China, EUA, Índia, Japão e Taiwan (Taipei Chinês) reservaram seus direitos como } \\
\text { terceiras partes no procedimento. Em } 19 \text { junho de 2012, as partes notificaram que haviam } \\
\text { chegado a uma solução mutuamente acordada no âmbito do artigo } 3.6 \text { do DSU. De acordo } \\
\text { com esta solução mutuamente acordada, e o relatório explicitando a descrição do caso e a } \\
\text { solução acordada foi emitido em } 3 \text { de julho de } 2012 \text {. Os dados deste caso foram retirados } \\
\text { da base de dados de solução de controvérsias da OMC: } \\
<\text { http://www.wto.org/english/tratop_e/dispu_e/cases_e/ds391_e.htm> Acesso em: } 10 \text { jul. } \\
2014 \text {. }\end{array}$ \\
\hline DS392 & $\begin{array}{l}\text { O caso DS392, United States - Certain Measures Affecting Imports of Poultry from } \\
\text { China, originou-se de demanda da China, em } 17 \text { de abril de } 2009 \text {, para a realização de } \\
\text { consultas com os EUA, relativas a certas medidas norte-americanas que afetam a } \\
\text { importação de produtos avícolas da oriundos da China. Segundo a demandante, as medidas } \\
\text { questionadas seriam violação aos Artigos I:1 e XI:1 do GATT 1994, ao Artigo } 4.2 \text { e aos } \\
\text { Artigos } 2.1,2.2,2.3,3.1,3.3,5.1,5.2,5.3,5.4,5.5,5.6,5.7 \text { e } 8 \text { do Acordo SPS. O OSC } \\
\text { estabeleceu o painel para analisar a controvérsia em } 31 \text { de julho de } 2009 \text {. Brasil, UE/CE, } \\
\text { Guatemala, Coreia, Taiwan (Taipei Chinês) e Turquia reservaram seus direitos como } \\
\text { terceiras partes no procedimento. O relatório do painel, divulgado em } 22 \text { de outubro de } \\
2010 \text {, reconhecia várias violações nas medidas analisadas, mas não estabelecia nenhuma } \\
\text { recomendação pois as medidas em questão já tinham expirado. Os dados deste caso foram } \\
\text { retirados da base de dados de solução de controvérsias da OMC: } \\
<\text { http://www.wto.org/english/tratop_e/dispu_e/cases_e/ds392_e.htm> Acesso em: } 10 \text { jul. } \\
2014 \text {. }\end{array}$ \\
\hline DS394 & $\begin{array}{l}\text { O caso DS394, China - Measures Related to the Exportation of Various Raw Materials, } \\
\text { originou-se de demanda dos EUA, em } 23 \text { de junho de } 2009 \text {, para a realização de consultas } \\
\text { com a China, relativas a imposição de restrições sobre a exportação da China de várias } \\
\text { formas de matérias-primas (várias formas de bauxita, coque, fluorite, magnésio, manganês, } \\
\text { carboneto de silício, silício metálico, fósforo amarelo e zinco). Segundo o demandante, } \\
\text { haveria medidas adicionais não publicadas, e as medidas questionadas seriam violação aos } \\
\text { Artigos Art. VIII, VIII:1, VIII:4, X, X:1, X:3, XI e XI:1 do GATT } 1994 \text { e aos parágrafos } \\
\text { 1.2, } 5.1,5.2,8.2 \text { e } 11.3 \text { da Parte I do Protocolo de Acessão. O OSC estabeleceu, em } 21 \text { de } \\
\text { dezembro de } 2009 \text {, um painel para analisar esta e as controvérsias DS395 e DS398. Arábia } \\
\text { Saudita, Argentina, Brasil, Canadá, UE/CE, Chile, Colômbia, Coreia, Equador, Î́ndia, } \\
\text { Japão, México, Noruega, Taiwan (Taipei Chinês) e Turquia reservaram seus direitos como } \\
\text { terceiras partes no procedimento. O relatório do painel, divulgado em } 5 \text { de julho de } 2011 \text {, } \\
\text { reconheceu a desconformidade da conduta chinesa com diversos dispositivos multilaterais. } \\
\text { Com a apelação de ambas as partes, o Órgão de Apelação emitiu seu relatório em } 30 \text { de }\end{array}$ \\
\hline
\end{tabular}




\begin{tabular}{|c|c|}
\hline & $\begin{array}{l}\text { janeiro de } 2012 \text {, confirmando a maior parte das interpretações e conclusões do painel. O } \\
\text { Relatório do Órgão de Apelação e o relatório do painel, com as devidas modificações, } \\
\text { foram adotados na reunião do OSC de } 23 \text { de março de } 2012 \text {. As partes acordaram que } 10 \\
\text { meses e } 9 \text { dias seria o período de tempo razoável para a implementação, e em } 28 \text { de janeiro } \\
\text { de } 2013 \text { a demandada informou ter implementado a decisão, por meio de medidas } \\
\text { administrativas. Os dados deste caso foram retirados da base de dados de solução de } \\
\text { controvérsias } \\
<\text { http://www.wto.org/english/tratop_e/dispu_e/cases_e/ds394_e.htm> Acesso em: } 10 \text { jul. } \\
\text { 2014. }\end{array}$ \\
\hline DS395 & $\begin{array}{l}\text { O caso DS395, China - Measures Related to the Exportation of Various Raw Materials, } \\
\text { originou-se de demanda da UE/CE, em } 23 \text { de junho de } 2009 \text {, para a realização de consultas } \\
\text { com a China, relativas a imposição de restrições sobre a exportação da China de várias } \\
\text { formas de matérias-primas (várias formas de bauxita, coque, fluorite, magnésio, manganês, } \\
\text { carboneto de silício, silício metálico, fósforo amarelo e zinco). Segundo o demandante, } \\
\text { haveria medidas adicionais não publicadas, e as medidas questionadas seriam violação aos } \\
\text { Artigos Art. VIII, VIII:1, VIII:4, X, X:1, X:3, XI e XI:1 do GATT } 1994 \text { e aos parágrafos } \\
1.2,5.1,5.2,8.2 \text { e } 11.3 \text { da Parte I do Protocolo de Acessão. O OSC estabeleceu, em } 21 \text { de } \\
\text { dezembro de } 2009 \text {, um painel para analisar esta e as controvérsias DS394 e DS398. Arábia } \\
\text { Saudita, Argentina, Brasil, Canadá, Chile, Colômbia, Coreia, Equador, EUA, Índia, Japão, } \\
\text { México, Noruega, Taiwan (Taipei Chinês) e Turquia reservaram seus direitos como } \\
\text { terceiras partes no procedimento. O relatório do painel, divulgado em } 5 \text { de julho de } 2011 \text {, } \\
\text { reconheceu a desconformidade da conduta chinesa com diversos dispositivos multilaterais. } \\
\text { Com a apelação de ambas as partes, o Órgão de Apelação emitiu seu relatório em } 30 \text { de } \\
\text { janeiro de } 2012 \text {, confirmando a maior parte das interpretações e conclusões do painel. O } \\
\text { Relatório do Órgão de Apelação e o relatório do painel, com as devidas modificações, } \\
\text { foram adotados na reunião do OSC de } 23 \text { de março de } 2012 \text {. As partes acordaram que } 10 \\
\text { meses e } 9 \text { dias seria o período de tempo razoável para a implementação, e em } 28 \text { de janeiro } \\
\text { de } 2013 \text { a demandada informou ter implementado a decisão, por meio de medidas } \\
\text { administrativas. Os dados deste caso foram retirados da base de dados de solução de } \\
\text { controvérsias } \\
<\text { http://www.wto.org/english/tratop_e/dispu_e/cases_e/ds395_e.htm> Acesso em: } 10 \text { jul. } \\
\text { 2014. }\end{array}$ \\
\hline DS397 & 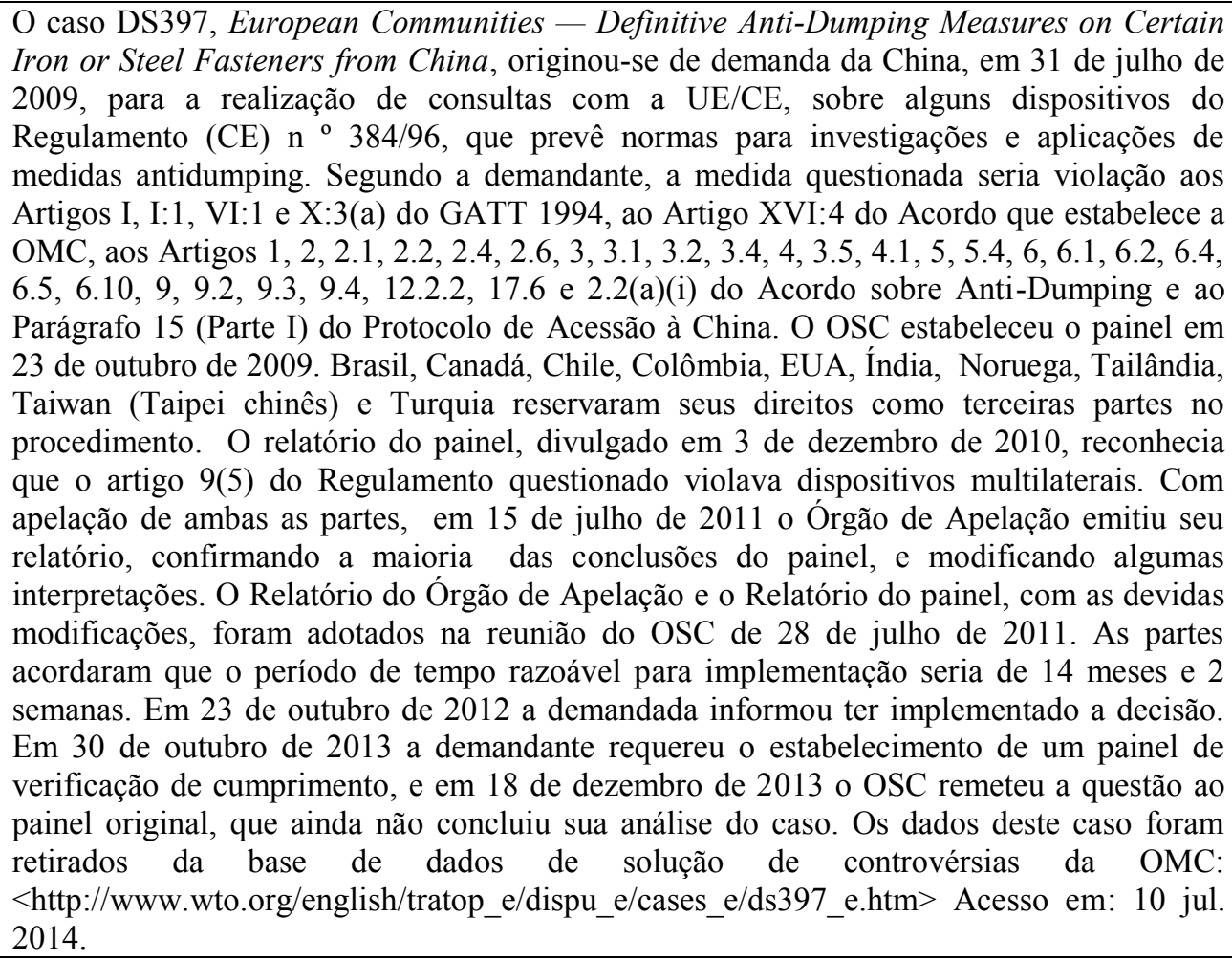 \\
\hline DS398 & $\begin{array}{l}\text { O caso DS398, China - Measures Related to the Exportation of Various Raw Materials, } \\
\text { originou-se de demanda do México, em } 21 \text { de agosto de } 2009 \text {, para a realização de } \\
\text { consultas com a China, relativas a imposição de restrições sobre a exportação da China de }\end{array}$ \\
\hline
\end{tabular}




\begin{tabular}{|c|c|}
\hline & $\begin{array}{l}\text { várias formas de matérias-primas (várias formas de bauxita, coque, fluorite, magnésio, } \\
\text { manganês, carboneto de silício, silício metálico, fósforo amarelo e zinco). Segundo o } \\
\text { demandante, haveria medidas adicionais não publicadas, e as medidas questionadas } \\
\text { seriam violação aos Artigos Art. VIII, VIII:1, VIII:4, X, X:1, X:3, XI e XI:1 do GATT } \\
1994 \text { e aos parágrafos } 1.2,5.1,5.2,8.2 \text { e } 11.3 \text { da Parte I do Protocolo de Acessão. O OSC } \\
\text { estabeleceu, em } 21 \text { de dezembro de } 2009 \text {, um painel para analisar esta e as controvérsias } \\
\text { DS395 e DS398. Arábia Saudita, Argentina, Brasil, Canadá, UE/CE, Chile, Colômbia, } \\
\text { Coreia, Equador, EUA, Índia, Japão, Noruega, Taiwan (Taipei Chinês) e Turquia } \\
\text { reservaram seus direitos como terceiras partes no procedimento. O relatório do painel, } \\
\text { divulgado em } 5 \text { de julho de } 2011 \text {, reconheceu a desconformidade da conduta chinesa com } \\
\text { diversos dispositivos multilaterais. Com a apelação de ambas as partes, o Órgão de } \\
\text { Apelação emitiu seu relatório em } 30 \text { de janeiro de } 2012 \text {, confirmando a maior parte das } \\
\text { interpretações e conclusões do painel. O Relatório do Órgão de Apelação e o relatório do } \\
\text { painel, com as devidas modificações, foram adotados na reunião do OSC de } 23 \text { de março } \\
\text { de } 2012 \text {. As partes acordaram que } 10 \text { meses e } 9 \text { dias seria o período de tempo razoável } \\
\text { para a implementação, e em } 28 \text { de janeiro de } 2013 \text { a demandada informou ter } \\
\text { implementado a decisão, por meio de medidas administrativas. Os dados deste caso foram } \\
\text { retirados da base de dados de solução de controvérsias da OMC: } \\
<\text { htttp://www.wto.org/english/tratop_e/dispu_e/cases_e/ds398_e.htm> Acesso em: } 10 \text { jul. } \\
2014 \text {. }\end{array}$ \\
\hline DS405 & 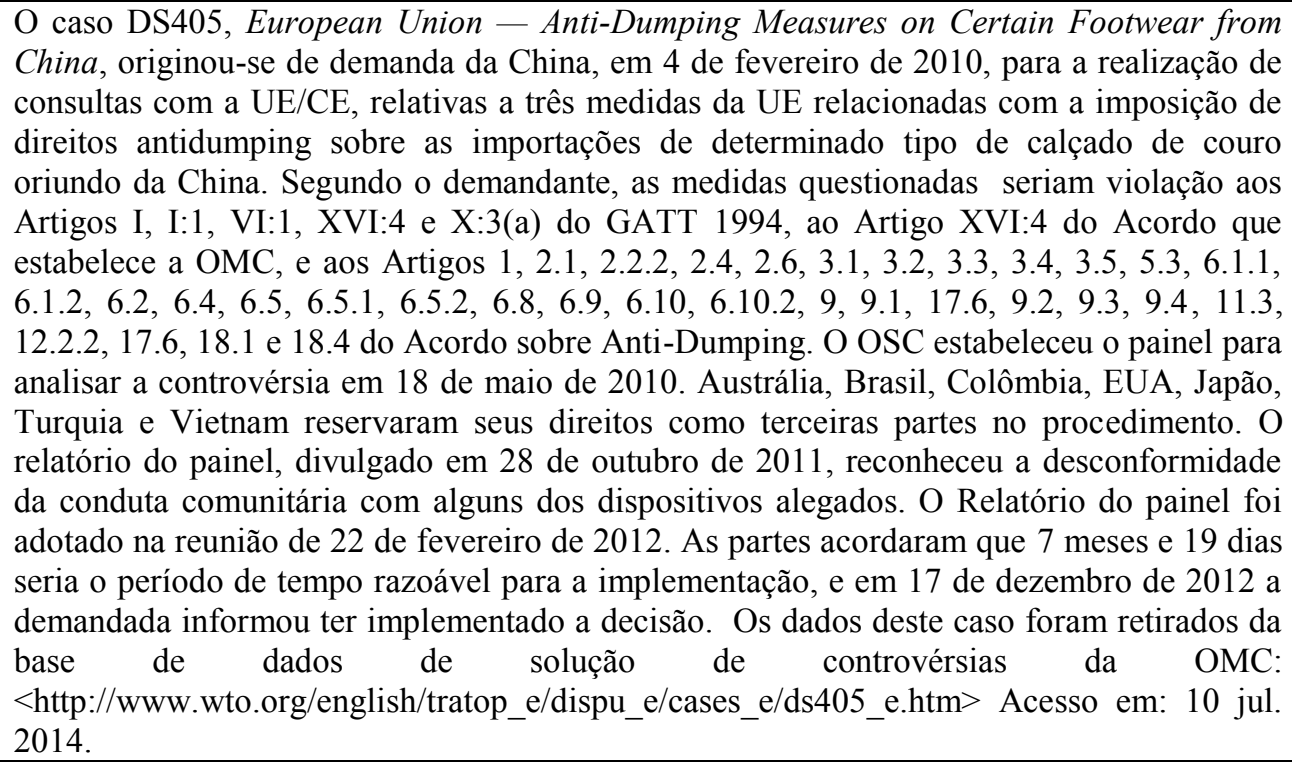 \\
\hline DS412 & 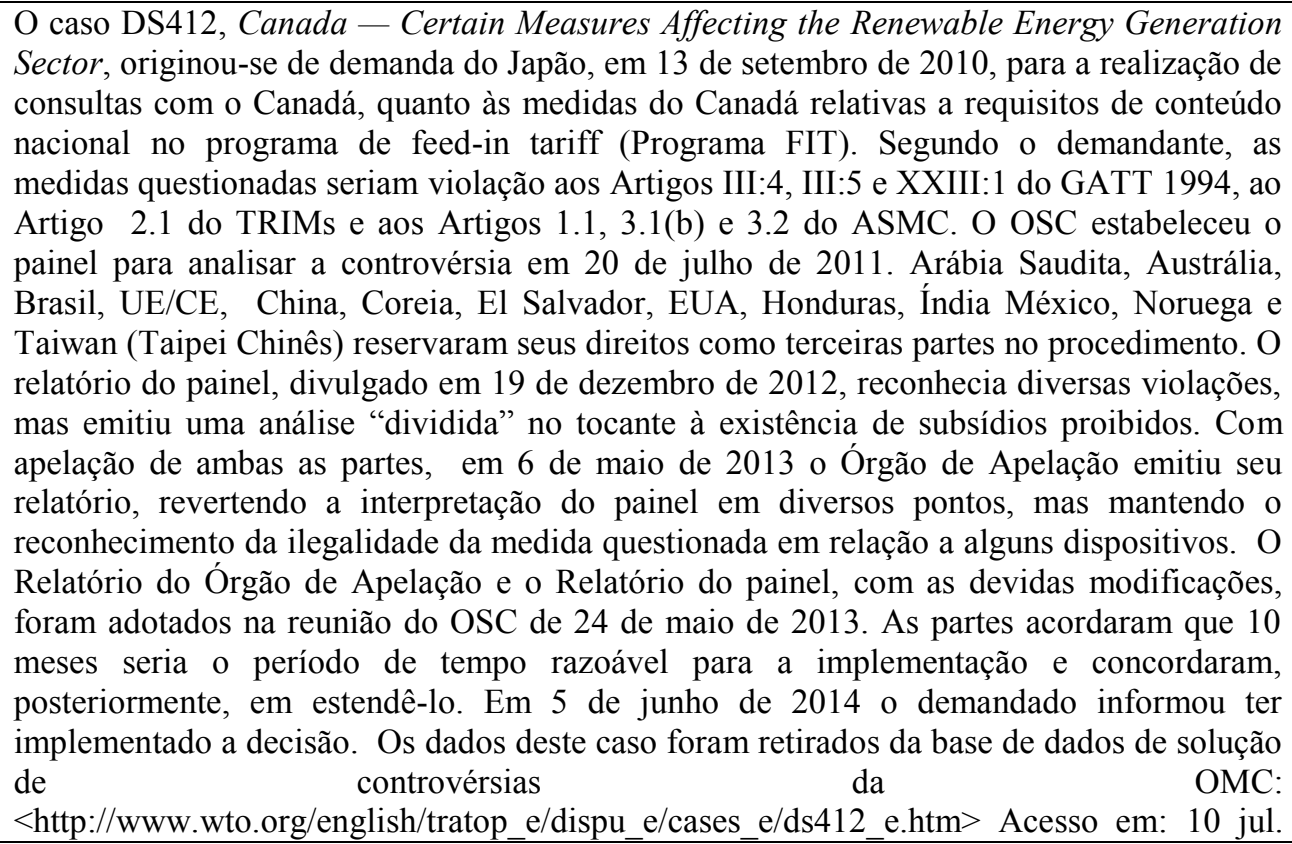 \\
\hline
\end{tabular}




\begin{tabular}{|c|c|}
\hline & 2014. \\
\hline DS420 & $\begin{array}{l}\text { O caso DS420, United States - Anti-dumping measures on corrosion-resistant carbon } \\
\text { steel flat products from Korea, foi iniciado com o pedido de consultas formulado pela } \\
\text { República da Coréia, recebido em } 30 \text { de janeiro de } 2011 \text {. Trata-se de questionamento de } \\
\text { diversas medidas antidumping sobre produtos planos de aço carbono resistentes à corrosão } \\
\text { originados da Coréia, em especial no que tange à metodologia do zeroing. Segundo o } \\
\text { demandante, as medidas são contrárias aos Artigos VI:1 e VI:2 do GATT 1994, a diversos } \\
\text { dispositivos do Acordo sobre Anti-Dumping, e ao Artigo XVI:4 do Acordo que estabelece } \\
\text { a OMC. Brasil, UE/CE, China, Japão, México, Noruega e Tailândia atuam como terceiras- } \\
\text { partes nesta controvérsia. Em } 22 \text { de fevereiro de } 2012 \text { houve autorização para o } \\
\text { estabelecimento do painel, mas este não foi composto, pois a demandante requereu a } \\
\text { suspensão do procedimento (com base no Artigo } 12.12 \text { do ESC). Os dados deste caso } \\
\text { foram retirados da base de dados de solução de controvérsias da OMC: } \\
<\text { http://www.wto.org/english/tratop_e/dispu_e/cases_e/ds420_e.html> Acesso em: } 10 \text { jul. } \\
2014 \text {. }\end{array}$ \\
\hline DS430 & $\begin{array}{l}\text { O caso DS430, India - Measures Concerning the Importation of Certain Agricultural } \\
\text { Products from the United States, foi iniciado com o pedido de consultas formulado pelos } \\
\text { EUA, recebido em } 06 \text { de março de } 2012 \text {. Trata-se de questionamento em função de } \\
\text { proibições impostas pela Índia à importação de diversos produtos agrícolas originários dos } \\
\text { EUA, supostamente motivadas pela gripe aviária. Segundo a demandante, as medidas são } \\
\text { contrárias aos Artigos I e XI do GATT 1994, bem como aos Artigos } 2.2,2.3,3.1,5.1,5.2 \text {, } \\
\text { 5.5, 5.6, 5.7, 6.1, 6.2, 7, e Anexo B (parágrafos 2, } 5 \text { e 6) do Acordo sobre Medidas } \\
\text { Sanitárias e Fitossanitárias. Argentina, Austrália, Brasil, UE/CE, China, Colômbia, } \\
\text { Equador, Guatemala, Japão e Vietnam atuam como terceiras-partes nesta controvérsia. O } \\
\text { painel foi composto em } 18 \text { de fevereiro de } 2013 \text {, e esperava emitir o seu relatório em } \\
\text { meados de junho de } 2014 \text {. Os dados deste caso foram retirados da base de dados de } \\
\text { solução de controvérsias } \\
<\text { http://www.wto.org/english/tratop_e/dispu_e/cases_e/ds430_e.htm> Acesso em: } 10 \text { jul. } \\
2014 \text {. }\end{array}$ \\
\hline DS431 & 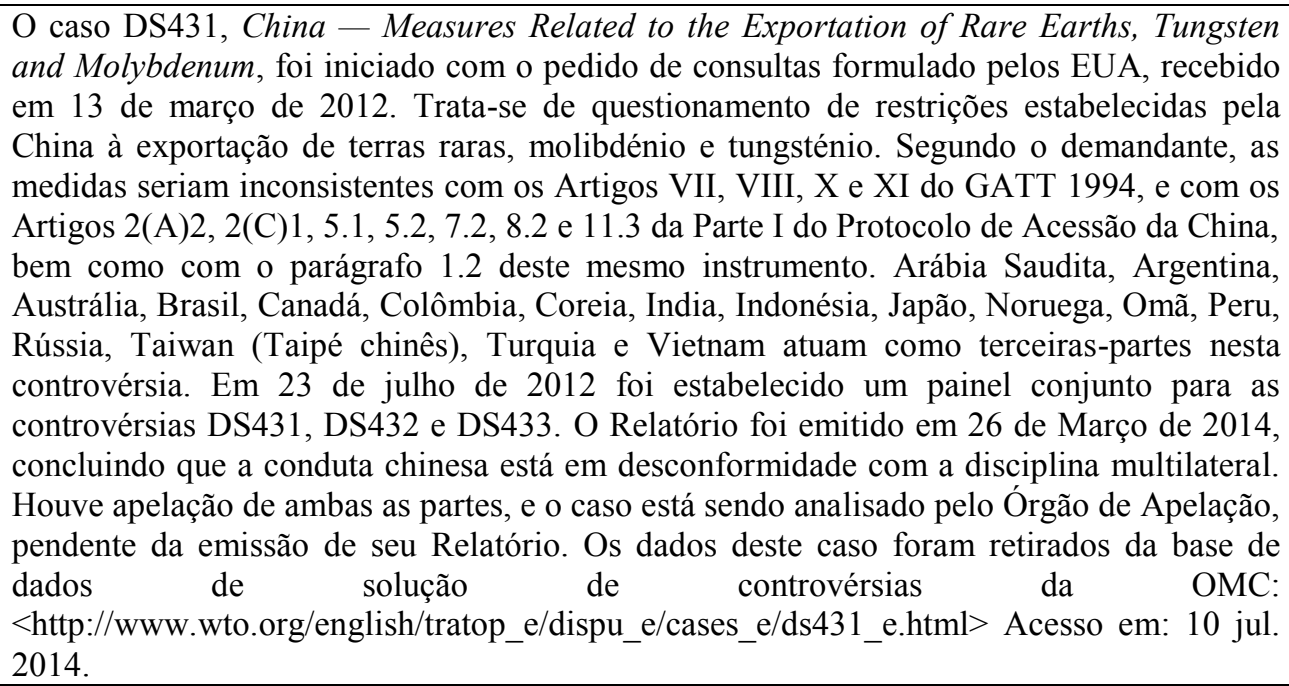 \\
\hline DS432 & $\begin{array}{l}\text { O caso DS432, China - Measures Related to the Exportation of Rare Earths, Tungsten } \\
\text { and Molybdenum, foi iniciado com o pedido de consultas formulado pela UE/CE, recebido } \\
\text { em } 13 \text { de março de 2012. Trata-se de questionamento das mesmas medidas objeto das } \\
\text { controvérsias DS431 e DS433, restrições estabelecidas pela China à exportação de terras } \\
\text { raras, molibdénio e tungsténio. Segundo o demandante, as medidas seriam inconsistentes } \\
\text { com os Artigos VII, VIII, X, XI, XI:1, e X:3(a) do GATT 1994, bem como com os } \\
\text { Parágrafos 1.2, 5.2, 5.1, 7.2, } 8.2 \text { e 11.3, da Parte I do Protocolo de Acessão da China. } \\
\text { Arábia Saudita, Argentina, Austrália, Brasil, Canadá, Colômbia, Coreia, Índia, Indonésia, } \\
\text { Japão, Noruega, Omã, Peru, Rússia, Taiwan (Taipé chinês), Turquia e Vietnam atuam } \\
\text { como terceiras-partes nesta controvérsia. Em } 23 \text { de julho de } 2012 \text { foi estabelecido um } \\
\text { painel conjunto para as controvérsias DS } 431 \text {, DS432 e DS433. O Relatório foi emitido em } \\
26 \text { de Março de 2014, e concluía que a conduta chinesa está em desconformidade com a } \\
\text { disciplina multilateral. Houve apelação de ambas as partes, e o caso está sendo analisado } \\
\text { pelo Orgão de Apelação, pendente da emissão de seu Relatório. Os dados deste caso foram }\end{array}$ \\
\hline
\end{tabular}




\begin{tabular}{|c|c|}
\hline & $\begin{array}{l}\text { retirados da base de dados de solução de controvérsias da } \text { OMC: } \\
<\text { http://www.wto.org/english/tratop_e/dispu_e/cases_e/ds432_e.html }>\text { Acesso em: } 10 \text { jul. } \\
\text { 2014. }\end{array}$ \\
\hline DS433 & $\begin{array}{l}\text { O caso DS433, China - Measures Related to the Exportation of Rare Earths, Tungsten } \\
\text { and Molybdenum, foi iniciado com o pedido de consultas formulado pelo Japão, recebido } \\
\text { em } 13 \text { de março de } 2012 \text {. Trata-se de questionamento das mesmas medidas objeto das } \\
\text { controvérsias DS431 e DS432, restrições estabelecidas pela China à exportação de terras } \\
\text { raras, molibdénio e tungsténio. Segundo o demandante, as medidas seriam inconsistentes } \\
\text { com os Artigos VII, VIII, X, XI, XI:1, e X:3(a) do GATT 1994, bem como com os } \\
\text { Parágrafos 1.2, 5.1, 5.2, 7.2, } 8.2 \text { e } 11.3 \text { da Parte I do Protocolo de Acessão da China. } \\
\text { Arábia Saudita, Argentina, Austrália, Brasil, Canadá, Coreia, Colômbia, India, Indonésia, } \\
\text { Japão, Noruega, Omã, Peru, Rússia, Taiwan (Taipé chinês), Turquia e Vietnam atuam } \\
\text { como terceiras-partes nesta controvérsia. Em } 23 \text { de julho de } 2012 \text { foi estabelecido um } \\
\text { painel conjunto para as controvérsias DS } 431 \text {, DS432 e DS433. O Relatório foi emitido em } \\
26 \text { de Março de 2014, e concluía que a conduta chinesa está em desconformidade com a } \\
\text { disciplina multilateral. Houve apelação de ambas as partes, e o caso está sendo analisado } \\
\text { pelo Órgão de Apelação, pendente da emissão de seu Relatório. Os dados deste caso foram } \\
\text { retirados da base de dados de solução de controvérsias da OMC: } \\
<\text { http://www.wto.org/english/tratop_e/dispu_e/cases_e/ds433_e.htm> Acesso em: } 10 \text { jul. } \\
2014 \text {. }\end{array}$ \\
\hline DS434 & $\begin{array}{l}\text { O caso DS434, Australia - Certain Measures Concerning Trademarks and Other Plain } \\
\text { Packaging Requirements Applicable to Tobacco Products and Packaging, foi iniciado com } \\
\text { o pedido de consultas formulado pela Ucrânia, recebido em } 13 \text { de março de } 2012 \text {. Trata-se } \\
\text { de questionamento de certas leis e regulamentos australianos que impunham restrições de } \\
\text { marca e requerimentos relativos à embalagem de produtos de tabaco. Segundo o } \\
\text { demandante, as medidas seriam inconsistentes com os Artigos I e III:4 do GATT 1994, } \\
\text { com os Artigos } 1,1.1,2.1,3.1,15,15.1,15.4,16,16.1,16.3,20 \text { e } 27 \text { do TRIPS, bem como } \\
\text { com os Artigos } 2.1 \text { e } 2.2 \text { do Acordo TBT. Argentina, Brasil, Canadá, UE/CE, China, Chile, } \\
\text { Coréia, Cuba Egito, Equador, EUA, Filipinas, Guatemala, Honduras, India, Indonésia, } \\
\text { Japão, Malásia, Malawi, México, Nicarágua, Nigéria, Nova Zelândia, Noruega, Omâ, } \\
\text { Peru, República Dominicana, República da Moldávia, Singapura, Taiwan (Taipei Chinês), } \\
\text { Tailândia, Turquia, Uruguai, Zâmbia e Zimbabwe como terceiras-partes nesta } \\
\text { controvérsia. Em } 28 \text { de setembro de } 2012 \text { foi estabelecido o painel para examinar a } \\
\text { controvérsia. O painel foi composto em } 5 \text { de maio de } 2014 \text {. Os dados deste caso foram } \\
\text { retirados da base de dados de solução de controvérsias da OMC: } \\
<\text { http://www.wto.org/english/tratop_e/dispu_eases_e/ds434_e.htm> Acesso em: 10 jul. } \\
\text { 2014. }\end{array}$ \\
\hline DS435 & $\begin{array}{l}\text { O caso DS435, Australia - Certain Measures Concerning Trademarks and Other Plain } \\
\text { Packaging Requirements Applicable to Tobacco Products and Packaging, foi iniciado com } \\
\text { o pedido de consultas formulado por Honduras, recebido em } 4 \text { de abril de } 2012 \text {. Tratava-se } \\
\text { de questionamento das mesmas medidas questionadas nos casos DS434, DS441, DS458 e } \\
\text { DS467. Segundo o demandante, as medidas seriam inconsistentes com o Artigo III:4 do } \\
\text { GATT 1994, com o Artigos, } 2.1,3.1,15.4,16.1,22.2(\text { b) e } 24.3 \text { do TRIPS, bem como com } \\
\text { os Artigos } 2.1 \text { e } 2.2 \text { do Acordo TBT. Argentina, África do Sul, Brasil, Canadá, UE/CE, } \\
\text { China, Chile, Coréia, Cuba Egito, Equador, EUA, Filipinas, Guatemala, India, Indonésia, } \\
\text { Japão, Malásia, Malawi, México, Nicarágua, Nigéria, Nova Zelândia, Noruega, Omã, } \\
\text { Peru, República Dominicana, República da Moldávia, Singapura, Taiwan (Taipei Chinês), } \\
\text { Tailândia, Turquia, Uruguai, Zâmbia e Zimbabwe atuam como terceiras-partes nesta } \\
\text { controvérsia. Em } 25 \text { de setembro de } 2013 \text { foi estabelecido o painel para examinar a } \\
\text { controvérsia. O painel foi composto em } 5 \text { de maio de } 2014 \text {. Os dados deste caso foram } \\
\text { retirados da base de dados de solução de controvérsias da OMC: } \\
<\text { http://www.wto.org/english/tratop_e/dispu_e/cases_e/ds435_e.htm> Acesso em: } 10 \text { jul. } \\
\text { 2014. }\end{array}$ \\
\hline DS437 & $\begin{array}{l}\text { O caso DS437, United States - Countervailing Duty Measures on Certain Products from } \\
\text { China, foi iniciado com o pedido de consultas formulado pela China, recebido em } 25 \text { de } \\
\text { maio de } 2012 \text {. Trata-se de questionamento da imposição de medidas compensatórias sob } \\
\text { certos produtos originários da China. Segundo o demandante, as medidas seriam } \\
\text { inconsistentes com o Artigo VI do GATT 1994, com os Artigos } 1.1,2,11.1,11.2,11.3 \text {, } \\
12.7 \text { e } 14(\text { d) do ASMC, bem como com o Artigo } 15 \text { do Protocolo de Acessão da China à } \\
\text { OMC. Arábia Saudita, Austrália, Brasil, Canadá, UE/CE, Coreia, Índia, Japão, Noruega, }\end{array}$ \\
\hline
\end{tabular}




\begin{tabular}{|c|c|}
\hline & $\begin{array}{l}\text { Rússia, Turquia e Vietnam atuam como terceiras-partes nesta controvérsia. Em } 28 \text { de } \\
\text { setembro de } 2012 \text { foi estabelecido o painel para examinar a controvérsia, e o mesmo foi } \\
\text { composto em } 26 \text { de novembro de } 2012 \text {. O painel esperava emitir o seu relatório em } \\
\text { meados de maio de } 2014 \text {. Os dados deste caso foram retirados da base de dados de solução } \\
\text { de controvérsias } \\
\text { <http://www.wto.org/english/tratop_e/dispu_e/cases_e/ds437_e.htm> Acesso em: } 10 \text { jul. } \\
2014\end{array}$ \\
\hline DS441 & 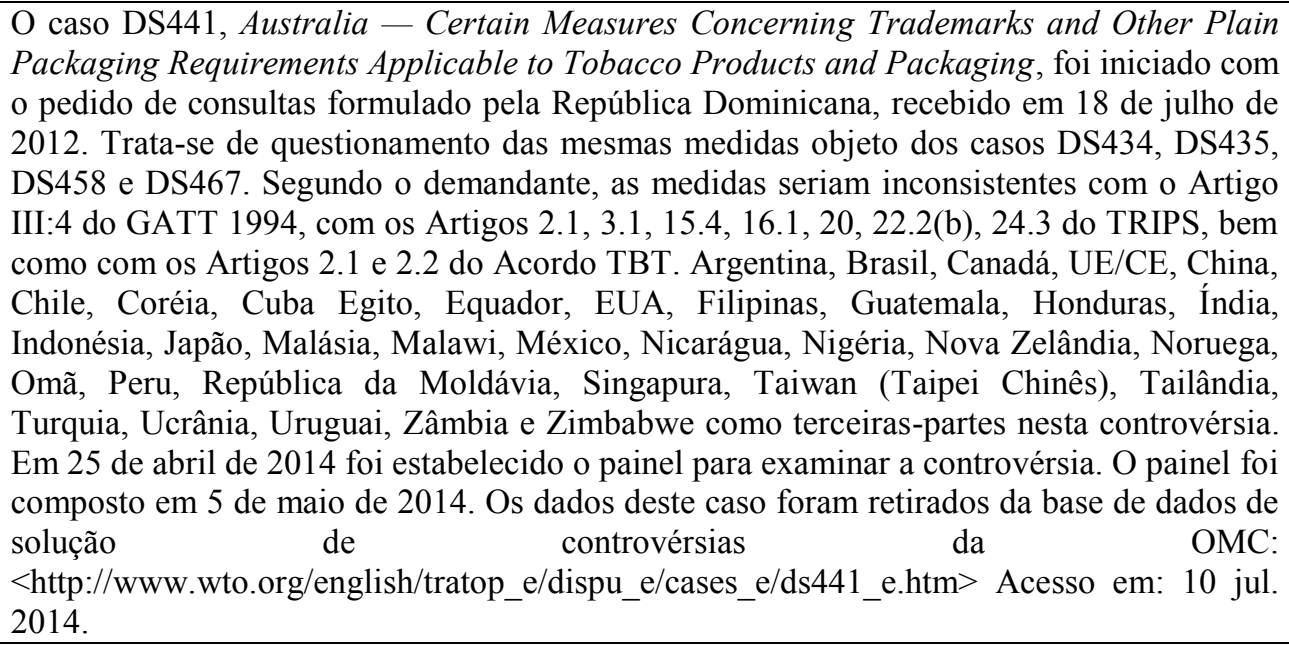 \\
\hline DS447 & $\begin{array}{l}\text { O caso DS447, United States - Measures Affecting the Importation of Animals, Meat and } \\
\text { Other Animal Products from Argentina, foi iniciado com o pedido de consultas formulado } \\
\text { pela Argentina, recebido em } 30 \text { de agosto de } 2012 \text {. Trata-se de questionamento de certas } \\
\text { medidas relativas à importação de animais, carne e outros produtos derivados de animais } \\
\text { oriundos da Argentina. Segundo a demandante, as medidas seriam inconsistentes com o } \\
\text { Artigo XVI:4 do Acordo da OMC, com os Artigos I:1, III:4 e XI:1 do GATT 1994, bem } \\
\text { como com os Artigos } 1.1,2.2,2.3,3.1,3.3,5.1,5.2,5.4,5.6,6.1,6.2,8 \text { e Anexo C.1, e } \\
10.1 \text { do Acordo SPS. Austrália, Brasil, UE/CE, China, Coreia e India atuam como } \\
\text { terceiras-partes nesta controvérsia. Em } 28 \text { de janeiro de } 2013 \text { foi estabelecido o painel para } \\
\text { examinar a controvérsia, e este foi composto em } 20 \text { de agosto de } 2013 \text {. Os dados deste } \\
\text { caso foram retirados da base de dados de solução de controvérsias da OMC: } \\
<\text { http://www.wto.org/english/tratop_e/dispu_e/cases_e/ds447_e.htm> Acesso em: } 10 \text { jul. } \\
2014 \text {. }\end{array}$ \\
\hline DS453 & 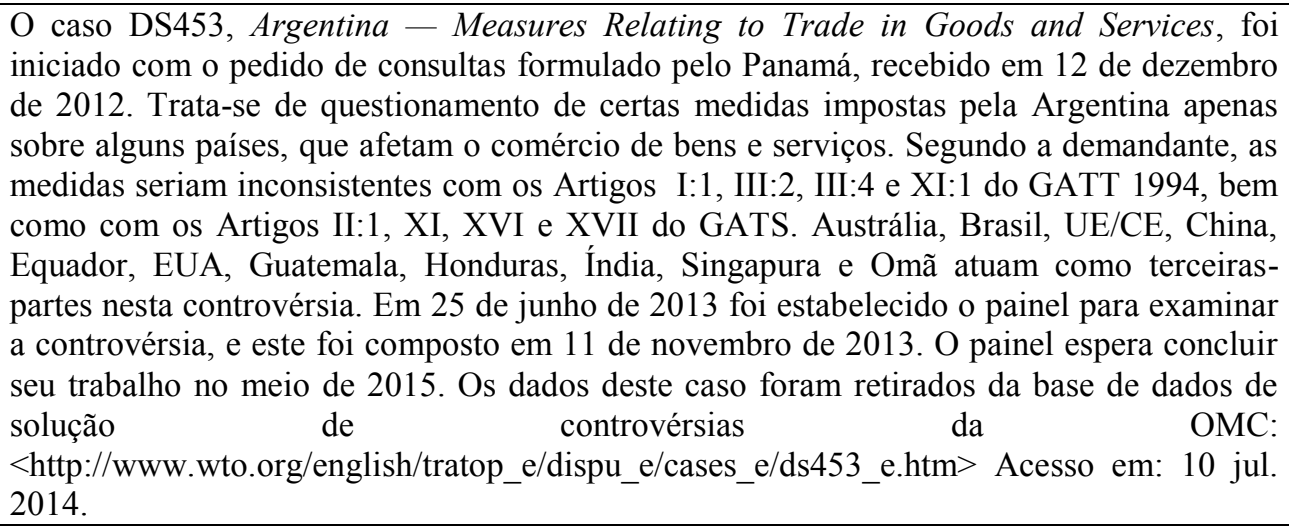 \\
\hline DS456 & $\begin{array}{l}\text { O caso DS456, India - Certain Measures Relating to Solar Cells and Solar Modules, foi } \\
\text { iniciado com o pedido de consultas formulado pelos EUA, recebido em } 6 \text { de fevereiro de } \\
\text { 2013. Trata-se de questionamento de certas medidas da Índia relativas a requisitos de } \\
\text { conteúdo nacional no âmbito da Missão Solar Nacional Jawaharlal Nehru para células } \\
\text { solares e módulos solares. Segundo o demandante, as medidas seriam inconsistentes com } \\
\text { os Artigo III:4 do GATT 1994, com o Artigo } 2.1 \text { do TRIMs e com os Artigos 3.1(b), 3.2, } \\
\text { 5(c), 6.3(a), 6.3(c) e } 25 \text { do ASMC. Brasil, Canadá, UE/CE, China, Japão, Coreia do Sul, } \\
\text { Malásia, Noruega, Peru e Rússia atuam como terceiras-partes nesta controvérsia. Em } 23 \text { de } \\
\text { maio de } 2014 \text { foi estabelecido o painel para examinar a controvérsia, mas este ainda não } \\
\text { foi composto. Os dados deste caso foram retirados da base de dados de solução de } \\
\text { controvérsias } \\
\text { da }\end{array}$ \\
\hline
\end{tabular}




\begin{tabular}{|c|c|}
\hline & $\begin{array}{l}<\text { http://www.wto.org/english/tratop_e/dispu_e/cases_e/ds456_e.htm }>\text { Acesso em: } 10 \text { jul. } \\
\text { 2014. }\end{array}$ \\
\hline DS457 & $\begin{array}{l}\text { O caso DS457, Peru - Additional Duty on Imports of Certain Agricultural Products, foi } \\
\text { iniciado com o pedido de consultas formulado pela Guatemala, recebido em } 12 \text { de abril de } \\
\text { 2013. Tratava-se da imposição de impostos adicionais sob certos produtos agrícolas. } \\
\text { Segundo a demandante, a medida seria inconsistentes com os Artigos II:1(a), II:1(b), X:1, } \\
\text { X:3(a), XI e XI:1 do GATT 1994, e com o Artigo } 4.2 \text { do Acordo sobre Agricultura, bem } \\
\text { como com os Artigos } 1,2,3,5,6 \text { e } 7 \text { do Acordo sobre valoração aduaneira. Argentina, } \\
\text { Brasil, UE/CE, Colômbia, Coreia, China, El Salvador, Equador, EUA, Índia e Honduras } \\
\text { atuam como terceiras-partes nesta controvérsia. Em } 23 \text { de julho de } 2013 \text { foi estabelecido o } \\
\text { painel para examinar a controvérsia, e composto em } 19 \text { de setembro de } 2013 \text {. O painel } \\
\text { espera concluir o seu trabalho em setembro de } 2014 \text {. Os dados deste caso foram retirados } \\
\text { da base de dados de solução de controvérsias da OMC: } \\
<\text { http://www.wto.org/english/tratop_e/dispu_e/cases_e/ds457_e.htm> Acesso em: } 10 \text { jul. } \\
\text { 2014. }\end{array}$ \\
\hline DS458 & $\begin{array}{l}\text { O caso DS458, Australia - Certain Measures Concerning Trademarks, Geographical } \\
\text { Indications and Other Plain Packaging Requirements Applicable to Tobacco Products and } \\
\text { Packaging, foi iniciado com o pedido de consultas formulado por Cuba, recebido em } 3 \text { de } \\
\text { maio de 2013. Trata-se de questionamento das mesmas medidas objeto dos casos DS434, } \\
\text { DS435, DS441 e DS467. Segundo o demandante, as medidas seriam inconsistentes com os } \\
\text { Artigos III:4 e IX do GATT 1994, com os Artigos 3.1, 15.4, 16.1, 20, 22.2(b), e } 24.3 \text { do } \\
\text { TRIPS, bem como com os Artigos } 2.1 \text { e } 2.2 \text { do Acordo TBT. Argentina, Brasil, Canadá, } \\
\text { UE/CE, China, Chile, Coréia, Egito, Equador, EUA, Filipinas, Guatemala, Honduras, } \\
\text { Índia, Indonésia, Japão, Malásia, Malawi, México, Nicarágua, Nigéria, Nova Zelândia, } \\
\text { Noruega, Omã, Peru, República Dominicana, República da Moldávia, Singapura, Taiwan } \\
\text { (Taipei Chinês), Tailândia, Turquia, Ucrânia, Uruguai, Zâmbia e Zimbabwe como } \\
\text { terceiras-partes nesta controvérsia. Em } 25 \text { de abril de } 2014 \text { foi estabelecido o painel para } \\
\text { examinar a controvérsia. O painel foi composto em } 5 \text { de maio de } 2014 \text {. Os dados deste } \\
\text { caso foram retirados da base de dados de solução de controvérsias da OMC: } \\
<\text { http://www.wto.org/english/tratop_e/dispu_e/cases_e/ds458_e.htm> Acesso em: } 10 \text { jul. } \\
\text { 2014. }\end{array}$ \\
\hline DS462 & $\begin{array}{l}\text { O caso DS462, Russian federation - Recycling Fee on Motor Vehicles, foi iniciado com o } \\
\text { pedido de consultas formulado pela UE/CE, recebido em } 9 \text { de julho de } 2013 \text {. Tratava-se de } \\
\text { questionamento de medidas russas relativas a uma taxa imposta sob veículos motorizados } \\
\text { importados. Segundo a demandante, as medidas seriam inconsistentes com os Artigos I:1, } \\
\text { II:1(a), II:1(b), III:2 e III:4 do GATT 1994, e com os Artigos } 2.1 \text { e } 2.2 \text { do Acordo TRIMs. } \\
\text { Brasil, Coreia, China, EUA, Índia, Japão, Noruega, Turquia e Ucrânia atuam como } \\
\text { terceiras-partes nesta controvérsia. Em } 25 \text { de novembro de } 2013 \text { foi estabelecido o painel } \\
\text { para examinar a controvérsia, mas ainda não foi composto. Os dados deste caso foram } \\
\text { retirados da base de dados de solução de controvérsias da OMC: } \\
<\text { http://www.wto.org/english/tratop_e/dispu_e/cases_e/ds462_e.htm> Acesso em: } 10 \text { jul. } \\
2014 \text {. }\end{array}$ \\
\hline DS464 & $\begin{array}{l}\text { O caso DS464, United States - Anti-dumping and Countervailing Measures on large } \\
\text { residential washers from Korea, foi iniciado com o pedido de consultas formulado pela } \\
\text { Coreia, recebido em } 29 \text { de agosto de } 2013 \text {. Trata-se de questionamento de medidas } \\
\text { antidumping e medidas compensatórias relativas a grandes lavadoras residenciais oriundas } \\
\text { da Coréia. Segundo o demandante, as medidas seriam inconsistentes com os Artigos VI:1, } \\
\text { VI:2, VI, VI:3 do GATT 1994, com o Artigo XVI:4 do Acordo que estabelece a OMC, } \\
\text { com os Artigos } 1,2,2.1,2.4,2.4 .2,5.8,9.3,9.4,9.5,11,11.2,11.3 \text { e } 18.4 \text { do Acordo sobre } \\
\text { Antidumping, com os Artigos } 1.1,1.2,2.1,2.2,10,14 \text { e } 19.4 \text { do ASMC. Arábia Saudita, } \\
\text { Brasil, Canadá, UE/CE, China, União Europeia, Índia, Noruega, Peru, Tailândia e Vietnam } \\
\text { atuam como terceiras-partes nesta controvérsia. Em } 22 \text { de janeiro de } 2014 \text { foi estabelecido } \\
\text { o painel para examinar a controvérsia, e este foi composto em } 20 \text { de junho de } 2014 \text {. Os } \\
\text { dados deste caso foram retirados da base de dados de solução de controvérsias da OMC: } \\
<\text { http://www.wto.org/english/tratop_e/dispu_e/cases_e/ds464_e.htm> Acesso em: } 10 \text { jul. } \\
\text { 2014. }\end{array}$ \\
\hline DS467 & $\begin{array}{l}\text { O caso DS467, Australia - Certain Measures Concerning Trademarks, Geographical } \\
\text { Indications and Other Plain Packaging Requirements Applicable to Tobacco Products and } \\
\text { Packaging, foi iniciado com o pedido de consultas formulado pela Indonésia, recebido em } \\
18 \text { de julho de } 2012 \text {. Trata-se de questionamento das mesmas medidas objeto dos casos }\end{array}$ \\
\hline
\end{tabular}




\begin{tabular}{|c|c|}
\hline & $\begin{array}{l}\text { DS434, DS435, DS441 e DS458. Segundo a demandante, as medidas seriam inconsistentes } \\
\text { com o Artigo III:4 do GATT 1994, com os Artigos 2.1, 3.1, 15.4, 16.1, 20, 22.2(b) e } 24.3 \\
\text { do TRIPS, bem como com os Artigos } 2.1 \text { e 2.2 do Acordo TBT. Argentina, Brasil, Canadá, } \\
\text { UE/CE, China, Chile, Coréia, Cuba Egito, Equador, EUA, Filipinas, Guatemala, } \\
\text { Honduras, Índia, Japão, Malásia, Malawi, México, Nicarágua, Nigéria, Nova Zelândia, } \\
\text { Noruega, Omã, Peru, República Dominicana, República da Moldávia, Singapura, Taiwan } \\
\text { (Taipei Chinês), Tailândia, Turquia, Ucrânia, Uruguai, Zâmbia e Zimbabwe atuaram como } \\
\text { terceiras-partes nesta controvérsia. Em } 25 \text { de abril de } 2014 \text { foi estabelecido o painel para } \\
\text { examinar a controvérsia. O painel foi composto em } 5 \text { de maio de 2014. Os dados deste } \\
\text { caso foram retirados da base de dados de solução de controvérsias da OMC: } \\
\text { <http://www.wto.org/english/tratop_e/dispu_e/cases_e/ds467_e.htm> Acesso em: } 10 \text { jul. } \\
\text { 2014. }\end{array}$ \\
\hline DS469 & $\begin{array}{l}\text { O caso DS469, European Union - Measures on Atlanto-Scandian Herring, foi iniciado } \\
\text { com o pedido de consultas formulado pela Dinamarca, recebido em } 4 \text { de novembro de } \\
\text { 2013. Trata-se de questionamento do uso de medidas econômicas coercitivas por parte da } \\
\text { União Europeia em relativas às Ilhas Faroé. Segundo a demandante, as medidas seriam } \\
\text { inconsistentes com os Artigos I:1, V:2 e XI:1 do GATT 1994. Austrália, Brasil, China, } \\
\text { Guatemala, Honduras; Islândia; Îndia; Japão; Nova Zelândia; Panamá; Federação da } \\
\text { Rússia; Taipei chinês; peru; Estados Unidos; Argentina; México; Noruega; Peru; Tailândia } \\
\text { atuaram como terceiras-partes nesta controvérsia. Em } 26 \text { de fevereiro de } 2014 \text { foi } \\
\text { estabelecido o painel para examinar a controvérsia, mas este ainda não foi composto. Os } \\
\text { dados deste caso foram retirados da base de dados de solução de controvérsias da OMC: } \\
\text { <http://www.wto.org/english/tratop_e/dispu_e/cases_e/ds469_e.htm> Acesso em: } 10 \text { jul. } \\
\text { 2014 }\end{array}$ \\
\hline DS471 & $\begin{array}{l}\text { O caso DS471, United States - Certain Methodologies and their Application to Anti- } \\
\text { Dumping Proceedings Involving China, foi iniciado com o pedido de consultas formulado } \\
\text { pela China, recebido em } 3 \text { de dezembro de } 2013 \text {. Trata-se de questionamento do uso de } \\
\text { certas metodologias em investigações antidumping envolvendo produtos chineses. } \\
\text { Segundo a demandante, as medidas seriam inconsistentes com o Artigo VI:2 do GATT } \\
1994 \text { e com os Artigos Art. } 2.4 .2,6.1,6.8,6.10,9.2,9.3,9.4 \text {, e Anexo II do Acordo sobre } \\
\text { Antidumping. Arábia Saudita, Brasil, Canadá, UE/CE, Coreia do Sul, Índia, Japão, } \\
\text { Noruega, Peru, Rússia, Taiwan (taipei chinês), Ucrânia e Vietnam atuaram como terceiras- } \\
\text { partes nesta controvérsia. Em } 26 \text { de março de } 2014 \text { foi estabelecido o painel para examinar } \\
\text { a controvérsia, mas este ainda não foi composto. Os dados deste caso foram retirados da } \\
\text { base de dados de solução de controvérsias da OMC: } \\
\text { <http://www.wto.org/english/tratop_e/dispu_e/cases_e/ds471_e.htm> Acesso em: } 10 \text { jul. } \\
2014 \text {. }\end{array}$ \\
\hline
\end{tabular}

